\title{
La voz de los cuerpos que callan.
}

\section{Las crónicas de Pedro Lemebel: entre la literatura y la historia}

\section{ÍNDICE}

\section{INTRODUCCIÓN}

Objeto material y objeto formal de la presente tesis

Presentación resumida de las hipótesis y del corpus textual abordado en el desarrollo de cada una 15

Presentación general del marco teórico-metodológico

I. LA CRÓNICA EN CUESTIÓN. DIÁLOGOS Y DEBATES TEÓRICO-CRÍTICOS EN TORNO A LEMEBEL

I. 1. Crítica periodística sobre la crónica de Pedro Lemebel

I. 2. Crítica académica sobre la crónica de Lemebel y sobre los ejes problemáticos de la investigación

I. 3. Problemáticas teórico-críticas acerca del género crónica

I. 4. Problemáticas teórico-críticas acerca del género: lo camp y lo queer

II. HISTORIA, CRÓNICA, LITERATURA.

PROBLEMAS EPISTEMOLÓGICOS Y TEÓRICOS

EN TORNO AL GÉNERO

II. 1. Genealogía de los discursos de la historia

[1] Las crónicas y su relación problemática con las series histórica y literaria 
[2] Friedrich Nietzsche: contra el "sujeto puro del conocimiento"

[3] Hayden White: las formas de la figuración histórica y el estatuto cognitivo del relato 164

[4] Michel de Certeau: las voces y las materias en la escritura de la historia $\quad 170$

[5] Michel Foucault: el orden del discurso y los dispositivos de exclusión

II. 2. Genealogía de la crónica latinoamericana: continuidades y rupturas

[1] La crónica de Indias. Lemebel contra los neocolonialismos del presente 180

[2] La crónica modernista. Lemebel/Martí o la recuperación de la memoria colectiva 192

[3] La crónica de Pedro Lemebel en el contexto latinoamericano 212

3.1. Lemebel/Monsiváis: la distancia con el cronista intelectual-letrado 215

3.2. Lemebel/Perlongher: una genealogía neobarroca 221

3.3. Lemebel/Poniatowska: la crónica y la novela de testimonio 232

\section{LA CRÓNICA DE PEDRO LEMEBEL COMO INTERVENCIÓN POLÉMICA EN EL UNIVERSO DE LOS DISCURSOS DE LA HISTORIA

III. 1. Procedimiento literario-historiográfico: el trabajo con el punto de vista

III. 2. Lemebel y la ambigüedad constitutiva de la práctica histórica

III. 3. Lemebel y su inscripción política en las estéticas neobarrocas

III. 4. Lemebel y la historia reciente de Chile

III. 5. Hacia una nueva alianza entre la escritura y la historia

IV. LA CRÓNICA DE PEDRO LEMEBEL: CUERPO Y VOZ DE IDENTIDADES MINORITARIAS

IV. 1. La tensión historia-ficción

IV. 2. La tensión crónica-poesía

IV. 3. La tensión escritura-oralidad

IV. 4. Tensiones y discontinuidades. El discurso lemebeliano

y la heterogeneidad cultural 


\section{INTRODUCCIÓN}

$\underline{\text { Objeto material y objeto formal de la presente tesis }}$

En esta introducción me propongo delimitar el objeto de mi estudio, anticipar de manera sumaria mis hipótesis y determinar el enfoque teórico y metodológico de la investigación.

En primer lugar el objeto material de la presente tesis es la obra de un autor, concretamente la obra cronística de Pedro Lemebel, quien ha publicado hasta el momento siete volúmenes de crónicas: La esquina es mi corazón (1995); Loco afán. Crónicas de Sidario (1996); De perlas y cicatrices (1998); Zanjón de la Aguada (2003); Adiós mariquita linda (2004); Serenata cafiola (2008) y Háblame de amores (2012). También ha publicado dos libros de ficción: Incontables (relatos, 1986), y Tengo miedo torero (novela, 2001). Tres de sus libros han sido reeditados hasta el momento: Loco afán. Crónicas de Sidario fue reeditado, con algunos cambios, por el sello barcelonés Anagrama en mayo del año 2000. La esquina es mi corazón y De perlas y cicatrices fueron reeditados por Seix Barral Chile en 2004 y 2010 respectivamente.

Pedro Lemebel nació en Santiago de Chile en 1955. Es escritor, artista plástico y performer. Junto a Francisco Casas fundó el colectivo de arte "Yeguas del Apocalipsis" (1987-1995) en cuyas presentaciones combinaron la actuación, la fotografía, el video y la instalación ${ }^{1}$. A las mencionadas formas de expresión (que testimonian la posición de

\footnotetext{
${ }^{1}$ La cronología de obras de "Yeguas del Apocalipsis" es la siguiente: "Refundación Universidad de Chile", intervención, Facultad de Arte, Universidad de Chile (1988); "Tiananmen", performance, Sala de Arte Garage Matucana, Santiago (1989); “¿De qué se ríe Presidente?”, intervención en espacio público (sobre la proclamación presidencial, Sala Carlos Cariola, Santiago, 1989); "La conquista de América", instalación y performance, baile nacional descalzo en mapa y vidrios, Comisión Chilena de Derechos Humanos, Santiago (1989); "Lo que el sida se llevó", instalación, fotografía y performance, Instituto
} 
borde de nuestro autor en el universo de las disciplinas artísticas) se le suma la crónica radial, práctica periodística en la que ha trabajado entre 1996 y 1998 inclusive $^{2}$. Sus crónicas orales han sido trasladadas por el autor al registro gráfico en numerosos suplementos periodísticos y revistas santiaguinas ${ }^{3}$. El viaje desde la oralidad radial a la escritura periodística, y de esta al libro da cuenta de la singular ductilidad de la producción de Lemebel y de su heterogeneidad formal.

Chileno-francés de Cultura (1989); "Estrellada", intervención de espacio público, zona de prostitución, calle San Camilo, Santiago (1989); "Suda América", instalación y performance en la Obra Gruesa del Hospital del Trabajador, Proyecto de salud pública del gobierno de Salvador Allende, Santiago (1989); "Cuerpos contingentes", performance y exposición colectiva, Galeria de Arte CESOC, Santiago (1990); "Las dos Fridas", Instalación performance, Galería Bucci, Santiago (1990); "Museo abierto", exposición colectiva, instalación y performance, Museo Nacional de Bellas Artes (1990); "De la nostalgia", instalación y performance, Cine Arte Normandí, Santiago (1991); "Homenaje por Sebastián Acevedo", instalación, video y performance, Facultad de Periodismo, Universidad de Concepción (1993); "Tu dolor dice minado", instalación, video y performance, Facultad de Periodismo, Universidad de Chile (1993); "La mirada oculta", exposición colectiva, fotografía, Museo de Arte Contemporáneo, Universidad de Chile, Santiago (1994); "N.N.", instalación y video, Universidad de Talca (1995); "Yeguas del Apocalipsis", Bienal de la Habana (mayo, 1997).

${ }^{2}$ El micro-programa radial "Cancionero", de diez minutos de duración, conducido por Pedro Lemebel y transmitido por la emisora Radio Tierra de lunes a viernes dos veces al día durante dos años, se caracterizó por la lectura al aire de las crónicas del autor, reunidas luego en el volumen De perlas y cicatrices (1998), y por la selección de temas musicales de corte netamente popular, como el bolero, la balada latinoamericana y española junto a otros géneros de circulación masiva como el corrido mejicano y el tango.

${ }^{3}$ En el Estado de la Cuestión realizaré un detallado relevamiento de las revistas que publicaron sus crónicas, no obstante considero oportuno adelantar aquí la cronología del desempeño cultural y -aunque informalmente- académico de nuestro autor.

Pedro Lemebel ganó el primer premio de cuento en el Concurso Nacional Javier Carrera (1982). Sus relatos aparecieron en la Antología Incontables (Santiago, Editorial Ergo Sum, 1986). En 1992 dictó el seminario "Eva dice a Adán" en la Universidad Católica de Valparaíso. En 1992 publicó sus primeras crónicas en la Revista Página abierta (hoy existe sólo en formato digital) y al año siguiente fue editor de esa revista. Hizo la presentación de Carlos Monsiváis en el Seminario "Utopías" que tuvo lugar en Santiago de Chile en 1993. Participó del Festival Cultural Stonewall, Nueva York, en 1994. Ese mismo año empezó a publicar crónicas en el diario La Nación de Santiago. Participó de la Escuela de Verano de la Universidad de Concepción en 1996, y dictó el seminario sobre Crónica urbana de la Universidad Playa Ancha de Valparaíso. Ese año colaboró en la revista Lamda News y comenzó su programa radial "Cancionero" en Radio Tierra. Ha dictado talleres de crónica en la Facultad de Filosofía y Letras de la Universidad de Chile y recibió la beca Fondart en dos oportunidades, lo que le permitió publicar su segundo y tercer libro de crónicas: Loco Afán. Crónicas de Sidario (1996) y De Perlas y Cicatrices (1998). Ha participado del seminario "Crossing and Sexual Borders" en New York University en 1996. $\mathrm{Al}$ año siguiente viajó a La Habana para intervenir en la Bienal de Arte, viaje del cual dejó testimonio en su volumen de crónicas: Adiós mariquita linda (2004). Desde 1998 es cronista de la revista Punto Final. Ese mismo año vieron la luz las primeras traducciones de sus crónicas al inglés en las revistas Grand Street y Nacla Report. Su novela Tengo miedo torero (2001) fue adaptada para su representación teatral y llevada a la escena en la ciudad de Buenos Aires en enero de 2010; ha sido traducida al inglés y al francés.

El autor participa habitualmente en presentaciones de libros, exposiciones y conferencias. En los últimos dos años su participación pública se ha visto reducida por razones de salud. Reside en la ciudad de Santiago de Chile. En 2013 abrió una cuenta en la red social Facebook, a través de la cual se comunica con sus numerosos seguidores y en la que publica crónicas ya editadas. 
En el marco del Chile de la transición, (es decir, durante los últimos años de la dictadura de Pinochet que coinciden con los tres primeros de las "Yeguas del Apocalipsis" y durante los gobiernos de la Concertación, desde 1990 hasta 2005 sobre todo) sus intervenciones públicas fueron un modo de resistencia contra la discriminación de género y de otras minorías y un reclamo por la vigencia plena de los derechos humanos y las libertades democráticas para todos los chilenos. En términos artísticos, esa experiencia resultó singular por lo renovadora e irreverente en un paisaje cultural dominado por el statu quo inercial que caracterizó los primeros años de la posdictadura chilena. La última presentación pública de las "Yeguas del Apocalipsis" tuvo lugar en 1995, año de publicación del primer volumen de crónicas de Lemebel.

Un rasgo que caracteriza su discurso, distinguiéndolo de sus contemporáneos $-\mathrm{y}$ que será analizado detenidamente en esta tesis- es la condición vocal de su escritura. Las crónicas de Lemebel se producen en la tensión escritura-oralidad, generada por el registro de voces que incorporan sus relatos y por la musicalidad que con frecuencia los atraviesa. Su escritura disuelve, además, otra dicotomía: aquella que se presupone entre la fícción y la crónica histórica o periodística. En la obra de Lemebel, un hecho de ficción puede convertirse en el núcleo de una crónica, por cuanto nos ofrece un cuidadoso relevamiento de datos históricos, sociales, políticos y aun geográficos del contexto del episodio historiado. De este modo instaura en el texto una travesía: crónica en el corazón de la ficción, ficción como principio activo de la crónica.

Otro elemento central que hace a su singularidad está dado por la condición poética de su escritura, rasgo que lo vincula a algunos autores considerados neobarrocos (categoría que será analizada durante la investigación), particularmente Néstor Perlongher, a quien el chileno considera clave en su propio desarrollo como escritor ${ }^{4}$.

\footnotetext{
${ }^{4}$ A propósito es muy significativo que su primer libro de crónicas, La esquina es mi corazón (1995) tenga un epígrafe de Néstor Perlongher, y que su texto final: "Las amapolas también tienen espinas" retome un
} 
También en cuanto a la reivindicación de la homosexualidad y, en general, de todas las minorías que luchan por la dignidad de su diferencia, Lemebel enlaza su escritura con la del poeta argentino, quien fuera cronista y cartógrafo de los suburbios de Buenos Aires y San Pablo, y en cuyas crónicas y ensayos se postula una concepción itinerante y móvil de la sexualidad a la que el escritor chileno adscribe. Este modo de concebir y practicar la sexualidad como nomadismo será analizado en vínculo dialéctico con algunos rasgos de su escritura en el primer capítulo de la presente tesis, a propósito de Lemebel y las teorías queer.

La heterogeneidad de los textos de Pedro Lemebel se hace evidente en la complejidad de líneas divergentes propia de su universo intertextual (el ya mencionado Perlongher; Manuel Puig; José Lezama Lima; todo el cancionero popular, desde el bolero hasta la balada española y latinoamericana, el son cubano, los poemas y canciones de Violeta Parra y Víctor Jara, entre muchos otros). También nuestro autor incursiona en el discurso académico filosófico contemporáneo, especialmente con su empleo de las nociones de devenir (término que precisaré al final de este mismo capítulo introductorio) y de territorialización / desterritorialización de Gilles Deleuze y Félix Guattari, cruzándolas en sus historias con los materiales de la canción popular, el refranero y la visión del mundo de los sectores alejados de la "catedral cultural". Esta operación no tiene como propósito postular una nueva categorización del margen. Daré cuenta de este cruce decisivo y absolutamente original del autor a lo largo de la investigación.

Las características consignadas muestran la condición distintiva de su producción: una escritura orientada hacia el acontecimiento singular y minoritario, a

tópico instalado por el poeta argentino en el campo problemático de la violencia de género con su ensayocrónica: "Matan a una marica" (Perlongher 1997: 35-40). Tal como señalan Christian Ferrer y Osvaldo Baigorria en la nota a esa edición, este ensayo de Perlongher acerca de la violencia contra los homosexuales se publicó en la revista Fin de Siglo $\mathrm{N}^{\circ} 16$, en octubre de 1988 y también en Comunicaçoes do ISER, año 9, №35, Río de Janeiro, 1990. 
contrapelo de cualquier "posición global”, eludiendo las dicotomías del tipo: izquierda/ derecha; femenino/ masculino; centro/ periferia; culto/ popular, entre otras, así como evita las oposiciones excluyentes crónica/ ficción, literatura/ historia, narración/ poesía, escritura/oralidad integrándolas en un compuesto discursivo que rehúye las clasificaciones establecidas y rechaza la categorización paralizante.

Las crónicas de Lemebel promueven lo fragmentario, lo discontinuo, lo inconcluso, lo minoritario, optando por el caso singular con el propósito de historiar el suceso. Su mirada asume desde un punto de vista particular la dimensión social y política del acontecimiento. Por ejemplo, la experiencia doliente, pero también asumida con humor, del cuerpo "sarcomido" por la sombra, la plaga, la peste, el misterio (nombres y figuras para el SIDA, nuevo mal del siglo) está entramada con otras experiencias de una historia personal. Pero en ese registro se cruzan consideraciones de orden político y social, relevamiento de datos muy precisos del contexto histórico y cultural del infectado o el grupo de infectados, lo cual permite trascender el plano individual, convirtiendo la crónica en historia y transformando la historia en discurso literario. La simultaneidad de estos procesos justifica el empleo de la categoría filosófica de devenir en la presente investigación.

Las multiplicidades y tensiones de la obra lemebeliana dan lugar a una escritura que acompaña la móvil territorialidad del espacio callejero. Su punto de vista ubicuo y la discontinuidad de los sucesos narrados desde una experiencia itinerante, trazan la cartografía inestable de la ciudad y configuran un saber histórico en proceso ${ }^{5}$, a partir de gestos, rostros (colectivos o individuales, que muestran la orfandad social, la

\footnotetext{
${ }^{5}$ La expresión "en proceso" que será empleada más de una vez en el desarrollo de la tesis, se define como aquello que está siendo expresado narrativa y poéticamente en el devenir de su constitución; esta, a su vez, no es completa ni acabada, sino incesante y por lo tanto, siempre inconclusa. Este término envía a un conjunto de teorizaciones que establecen entre ellas un productivo diálogo interno, a saber: El espacio literario, El diálogo inconcluso, y El paso (no) más allá, de Maurice Blanchot (1955; 1969; 1973). "Una productividad denominada texto" y "El sujeto en proceso", de Julia Kristeva (1967; 1974). "Escribir la lectura", "De la obra al texto" y El grado cero de la escritura, de Roland Barthes (1970b; 1971; 1972).
} 
persecución o la indiferencia del poder político que los elimina o los silencia), ruinas (lo que queda de la gesta revolucionaria, como el esqueleto de la $\mathrm{UNCTAD}^{6}$ o del Bar 777, lugares emblemáticos de la Unidad Popular que funcionan como restos de una ilusión perdida), los cuerpos marcados, las huellas de la violencia en los rostros o en las calles, los deseos silenciados u ocultos (como el encuentro furtivo de las parejas homosexuales en el Parque Forestal, protagonistas de la primera crónica de La esquina es mi corazón) que dejan su huella casi invisible o inobservable. Estos y otros muchos elementos particulares, constituyen materiales devaluados o ignorados por el saber historiográfico.

Ahora bien, como toda investigación, la mía presenta un objeto formal apelando a la antigua terminología aristotélica- determinado por el tratamiento de aquel objeto material. Entonces, tanto como la obra de un autor ${ }^{7}$, me propongo indagar en el conjunto de operaciones que tienen lugar en el campo discursivo complejo y heterogéneo en el que esa obra se produce y circula, campo en permanente proceso de transformación.

La crónica es un registro discursivo que verifica una notable continuidad en América Latina desde el período colonial hasta nuestros días. En su prolongado desarrollo histórico podemos identificar claramente tres momentos: las crónicas de Indias, las crónicas modernistas y las crónicas contemporáneas latinoamericanas (con este último término me refiero a la producción del género que ha tenido lugar durante las dos últimas décadas del siglo XX y la primera década del siglo XXI). Ahora bien, en los términos de las dos afirmaciones precedentes habita una enorme complejidad y un grado de heterogeneidad que merecen mayor detenimiento.

\footnotetext{
${ }^{6}$ La III Conferencia de las Naciones Unidas sobre Comercio y Desarrollo (UNCTaD por sus siglas en inglés: United Nations Conference on Trade and Development) inauguró su edificio en Santiago de Chile durante la presidencia de Salvador Allende. Fue durante ese período un lugar de reunión de los trabajadores y un ícono de la Unidad Popular. Contaba con comedores y patios de esparcimiento, entre otros servicios.

${ }^{7}$ Empleo ambos términos (obra y autor) consciente de su complejidad, la cual será analizada durante el desarrollo de la tesis.
} 
En efecto, "registro discursivo" es una expresión técnica que alberga las enormes diferencias que entraña el género "crónica". Asimismo el uso del sustantivo "género" $" 8$ obliga a realizar una cantidad de precisiones teóricas y metodológicas que integran el segundo capítulo de la presente tesis. Los intensos debates que la noción de “texto" ha generado en el campo académico desde la década de $1960^{9}$ me permiten capitalizar una concepción abierta y dinámica del texto literario, la cual tiene el valor epistemológico de tratar la vinculación entre serie literaria y serie social no como una dicotomía sino como una interacción y, de hecho, un modo de cooperación que produce saberes y productos nuevos en ambas series. Por ello he incluido en la presente tesis la noción de “intervención”. El texto así entendido, participa no sólo de la serie literaria a la que sin ninguna duda pertenece, sino también -para decirlo en términos de Iuri Tinianov- de la configuración de las "series vecinas", en este caso: los discursos de la historia y el campo híbrido y complejo de los llamados "géneros no ficcionales", cuya constitución misma plantea la inconsistencia de la división clásica entre géneros literarios.

Julia Kristeva plantea (en la estela del pensamiento de Mijaíl Bajtín, de quien se considera continuadora) que la verosimilitud (ley interna y condición de posibilidad de todo texto) se produce como un efecto entre discursos (Kristeva 1967:12). Esta idea indaga en la naturaleza misma del discurso literario y pone en primer plano su decisiva vinculación con los discursos sociales. Esta teoría es tributaria $-\mathrm{y}$ su autora así lo reconoce- de la noción bajtiniana de bivocalidad. En efecto, según Bajtín, todo discurso es un enunciado que encarna la cosmovisión del héroe o del autor (la posición-autor) en

\footnotetext{
${ }^{8}$ Me refiero tanto al género literario como al género en el sentido de gender, término que precisaré en el Capítulo I: "La crónica en cuestión", en relación con otros términos asociados (camp y queer) y su sentido en la obra de Pedro Lemebel.

${ }^{9}$ Me refiero al trabajo crítico de figuras como Roland Barthes y Julia Kristeva, cuyas tesis han dejado establecida la noción de texto como productividad. Ver especialmente: Crítica y verdad (1966), y los ya citados en la nota 5: "De la obra al texto" y El grado cero de la escritura, de Roland Barthes; "Una productividad denominada texto", de Julia Kristeva, entre otros ensayos.
} 
vínculo dialógico con las ideas y los discursos de la época y la comunidad a la que pertenece. No hay para el célebre teórico ruso ningún discurso humano que no sea bivocal; en este sentido vehiculiza un diálogo (o contrapunto dialógico) entre los discursos sociales e ideológicos de la comunidad del "hablante" (héroe o autor), lo que

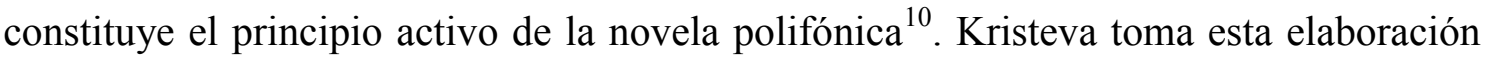
teórica de su maestro y postula una crítica a los modelos semióticos vigentes en las discusiones académicas de los años sesenta. “Así vemos en la actualidad -afirma Kristeva- cómo el texto se convierte en el terreno en que se juega, se practica y se presenta la refundición epistemológica, social y política" (1968a: 19). Esta manera de concebir el texto literario es perfectamente compatible con las hipótesis del teórico checo Ian Mukařovský, cuyo modelo dialéctico será tomado por Susana Rotker en su consideración de la crónica modernista. Me referiré a esta cuestión en el segundo capítulo, a propósito de las continuidades y rupturas en la historia de la crónica latinoamericana.

Lemebel ha producido textos en el sentido preciso que acabo de referir. Sus crónicas se presentan como una práctica compleja, como "lo que se deja leer" en el heterogéneo entramado de significados sociales y líneas de fuerza en tensión que podemos llamar "la historia", y en este caso desde luego, la historia reciente de Chile: las huellas de la dictadura pinochetista y de la prolongada transición democrática (o pseudo-democrática según muchos analistas ${ }^{11}$ ), en vínculo problemático con una gran cantidad de situaciones particulares de orden político que atravesó la sociedad chilena

\footnotetext{
${ }^{10}$ Este concepto aparece reelaborado a lo largo de toda la obra de Bajtín. Ver, en orden cronológico: Teoría de la novela (1938a), Problemas de la poética de Dostoievsky (1963, aunque la primera versión en ruso de este texto, más breve y nunca traducida, data de 1929) y Estética de la creación verbal (publicado póstumamente en 1977). En relación con los problemas analizados en estos tratados, Kristeva escribe: "La palabra, el diálogo, la novela" (1966), "Una productividad denominada texto" (1967), "El texto y su ciencia" (1968a), entre otros artículos reunidos en los dos tomos de su obra: Semiótica, Madrid, Fundamentos, 1981.

${ }^{11}$ Esos puntos de vista serán considerados en el Estado de la Cuestión (Capítulo I) y en el apartado: "Lemebel y la historia reciente de Chile", incluido en el Capítulo III.
} 
durante las dos últimas décadas del siglo XX y la primera del siglo XXI. En dichas situaciones se encuentran involucrados diversos grupos o individuos que protagonizaron episodios de la vida política y social de aquellos años; algunos anónimos, otros identificados con su nombre; figuras populares ligadas al mundo de la farándula o al de la música; y sobre todo personajes que "representan" minorías sexuales y étnicas o grupos excluidos. En todos los casos las crónicas de Lemebel registran un punto presente de esa historia ${ }^{12}$ en la que persiste una multitud diferenciada de determinaciones: el texto las despliega, las expresa, las vocaliza, las hace cuerpo y materia. Por esta razón sus crónicas se configuran como travesías (Barthes 1971), es decir, se encuentran atravesadas por formas y significaciones no estabilizadas, no configuradas según las reglas de ningún género convencional; esa condición nómade las hace circular transformándose y transformando las series comprometidas en su producción.

Estoy utilizando aquí el conocido concepto de "géneros discursivos" acuñado por Mijaíl Bajtín (1977), quien los define como "tipos relativamente estables de enunciados" reconocibles o identificables como formaciones discursivas que prosperan en el intercambio social y que corresponden a determinadas esferas de la actividad humana (registro periodístico, texto académico, carta formal o informal, texto científico, relato oral tradicional, géneros literarios, etc.). Las crónicas de Lemebel hacen oír voces y recogen materiales y significaciones que remiten a registros discursivos muy diversos, configurando en sus textos una composición discursiva heterogénea.

Al mismo tiempo, los textos de Pedro Lemebel les dan cuerpo y voz a individuos particulares y a sectores sociales silenciados y por lo tanto ausentes en esos registros

\footnotetext{
12 Escribo aquí "historia" con minúscula, dado que en el transcurso de la tesis se reservará el término Historia, con mayúscula, para hacer referencia -en la estela del pensamiento foucaultiano- a la disciplina histórica (o historiografía) ligada a la ideología positivista. Es esta ideología la que será desfondada por los textos de Lemebel, al construir un discurso histórico que se postula como una "hermenéutica del otro" (de Certeau).
} 
discursivos establecidos. Por ejemplo, la denuncia de la persecución homofóbica, que marca y determina tanto sus libros como su figura pública y aun mediática; las voces de individuos o sectores sociales marginados, caídos de la cartografía urbana, perseguidos por las fuerzas del orden e ignorados por la indiferencia social que no los reconoce (porque permanecen invisibilizados aun después de la dictadura). Esas voces se hacen audibles en un registro discursivo que es eminentemente poético, procedimiento que determina la singularidad de Lemebel: las voces que no tenían discurso son vehiculizadas en sus crónicas, pero a condición de no estar "representadas" como una posición fija e individualizada, personal o socialmente determinada. Este particular tratamiento de la voz será justificado en el desarrollo del cuarto capítulo.

La investigación dará cuenta, a partir de la obra de Lemebel, del estatuto problemático de los géneros no ficcionales sin eludir las dificultades de un género que se produce en la tensión entre discurso literario y discurso historiográfico, por un lado, y en las tensiones historia/ ficción, crónica/ poesía y escritura/ oralidad, por otro, reconociendo la necesidad de elaborar dispositivos teóricos que permitan pensar y registrar los nuevos modos de producción literaria. En este caso, procuraré establecer algunas distinciones útiles para la observación crítica de las líneas de fuerza que atraviesan, complejizan y dan vida al campo literario.

No obstante la condición inestable y por lo tanto indefinible que acabo de señalar, propia de la producción lemebeliana, conviene puntualizar algunas condiciones de enunciación que considero específicas del género, y en ellas, el sesgo particular que presenta la escritura de Pedro Lemebel.

$1^{\circ}$. La conciencia de ser una mirada, y al mismo tiempo un registro de los acontecimientos vividos en un lugar particular y un tiempo acotado de la historia reciente de nuestros pueblos latinoamericanos. Pedro Lemebel participa de esa 
conciencia, y se propone vehiculizar, como se ha dicho, la experiencia de los hechos. Para ello no basta narrar acentuando los rasgos de un entorno natural y social particular. Lemebel satura el texto de imágenes que materializan el discurso y vehiculizan sensaciones irreductibles a una idea; satura el texto de voces que reponen el "aquí y ahora" del registro oral y provocan la sensación de presente al cancelar la distancia entre el narrar y lo narrado, propia de la representación narrativa convencional.

$2^{\circ}$. La crónica latinoamericana contemporánea tiene como protagonistas a individuos o grupos que pertenecen a distintas minorías sociales, políticas, étnicas o de género (este rasgo vincula al género con las novelas de testimonio. En dichas novelas, la marca minoritaria de los protagonistas suele ser doble o triple en un mismo individuo, como en la figura de Jesusa Palancares ${ }^{13}$ o en el protagonista de la célebre biografía de Miguel Barnet $\left.{ }^{14}\right)$. En todos los casos, el género se posiciona como una práctica discursiva apta para poner en escena la alteridad. Lemebel construye una nueva posición de autor: él es "el otro" que toma la palabra, y a través de su escritura vocalizada, hace audibles las voces de muchos "otros", identidades negadas o silenciadas que no tenían discurso.

$3^{\circ}$. Los aspectos antes considerados (la conciencia de ser una mirada y el registro de acontecimientos vividos por individuos pertenecientes a minorías sociales, étnicas o de género) se erigen en la crónica latinoamericana actual como posición crítica, y también como denuncia de situaciones políticas, sociales o institucionales de injusticia, desamparo y discriminación. La obra cronística de Lemebel no desconoce ni se aparta de este carácter testimonial y de denuncia propio del género; de hecho sus

\footnotetext{
${ }^{13}$ Protagonista exclusiva de Hasta no verte Jesús mío (1969), de Elena Poniatowska, única voz de la narración. Ella es mujer, analfabeta, pobre y está presa, entre otras determinaciones del "margen". Esa novela será objeto de análisis en el Capítulo IV, por considerarla un antecedente ineludible de la tensión oralidad-escritura en la obra de Lemebel.

${ }^{14}$ Biografía de un cimarrón. El cimarrón es un esclavo negro fugitivo. Esteban Montejo nació esclavo en el ingenio de Santa Teresa, Cuba, en 1860, y se fugó siendo un niño. Vivió muchos años solo en el monte hasta que tomó la decisión de luchar en la guerra de independencia. Miguel Barnet lo inmortalizó en su biografía publicada en 1966 y considerada la primera novela-testimonio latinoamericana.
} 
crónicas evocan cada situación de vida asumiendo su propia lógica, relatando con conocimiento directo su mundo privado y siendo parte de su posición en el campo social. Ahora bien, lo singular está dado por el tratamiento del lenguaje y del sujeto de la enunciación. En las crónicas de Pedro Lemebel escritas en primera persona (casi todas) encontramos la especificidad del discurso poético. Las crónicas comunican el dolor intransferible de las madres que no encuentran a sus hijos; la visión y la experiencia de los perseguidos por la dictadura militar; las huellas del maltrato en la carne, en los rostros, en la mirada de las víctimas, también las huellas del olvido y de la exclusión. La comunicación de la experiencia, en estos términos, exige su transposición al discurso poético en virtud de su materialidad y su conexión directa con el orden pulsional (las experiencias no pueden ser representadas según el verosímil de la narrativa realista o del relato testimonial, sino solo transpuestas a otro orden material, ligado a la energía de los cuerpos: el registro poético).

$4^{\circ}$. La observación crítica y el análisis minucioso del objeto o suceso narrado acerca las crónicas a otros discursos no literarios, como la historia, el periodismo, la etnografía, la filología, el ensayo y la crítica literaria. Lemebel reescribe su historia contemporánea atravesando con su crónica los discursos que acabo de enumerar. Interviene en el discurso historiográfico desbaratando el postulado implícito inherente a él en su vertiente positivista, clásica y moderna: la neutralidad del sujeto y las consecuentes objetividad y condición totalizadora del sentido en el relato de la Historia. Interviene en el discurso etnográfico al elaborar sus descripciones desde la oralidad del pueblo chileno, con sus términos y su modulación, "incrustando" la voz popular y haciéndola audible e inteligible. Dado su singular registro heterogéneo, hace un uso de 
la imagen literaria que podemos calificar de historiográfico ${ }^{15}$, por cuanto transmite el acontecimiento en su particularidad material, física, sonora, olfativa, plástica y visual.

Todos estos procedimientos, característicos de su escritura, demuestran la singularidad de la obra lemebeliana en el contexto de la producción del género crónica en el continente.

\section{Presentación resumida de las hipótesis y del corpus textual abordado en el desarrollo de cada una}

I.

Hechas las necesarias consideraciones que acabo de puntualizar, surgidas del análisis de la crítica académica y periodística de la obra del autor que detallaré en el Capítulo I y desde luego de mi propia lectura de la producción lemebeliana, formulo a continuación la primera hipótesis de esta investigación, la cual consiste en considerar las crónicas de Pedro Lemebel como intervenciones transgresoras en el universo de los discursos de la historia.

Los textos de Pedro Lemebel se vinculan con la crónica entendida como discurso histórico desechado por la voluntad de saber (Foucault 1966; 1969; 1970) de la historiografía moderna, dentro de la episteme positivista. La diferencia cualitativa establecida por Hayden White $(1973 ; 1987)$ entre “anales” y “crónica”, operará como punto de partida de esta indagación, por cuanto esa diferencia específica -que fue la razón del rechazo de las crónicas medievales por parte de los editores del siglo XIXexplica en alguna medida la opción por la crónica como dispositivo textual que privilegia lo particular, lo fragmentario, lo menor como objeto de observación.

\footnotetext{
${ }^{15}$ En el sentido preciso de la "operación historiográfica" postulada por Michel de Certeau. Este concepto será explicado en el segundo capítulo y utilizado en el desarrollo de las hipótesis.
} 
La economía libidinal no está en la agenda de la política global ni es objeto de la historiografía clásica. Lemebel realiza la cartografía de otros territorios "no historiados" por el discurso oficial. Las crónicas de nuestro autor configuran un nuevo saber y un lugar diferenciado de enunciación: hacen hablar al cuerpo, narran desde una experiencia particular que no tenía discurso. Esta práctica discursiva, entonces, no se opone a la Historia como disciplina, sino precisamente constituye un saber-otro, que pone en discurso aquellos aspectos de la vida social que la Historia no ha documentado ni ha recortado como objeto.

La primera hipótesis presenta un pliegue: el discurso de la crónica se postula como vehículo para lograr una experiencia de la historia, para "hacer hablar al cuerpo que calla" en los términos de Michel de Certeau (1978: 16). ${ }^{16}$ Las crónicas de Pedro Lemebel provocan una relación dialéctica entre el discurso histórico y la economía de los cuerpos, en la medida en que recuperan e integran los materiales, los fragmentos, los detalles, también las posiciones particulares, los testimonios de experiencias subjetivas y otros elementos que tanto la historiografía moderna como las políticas de control de la

\footnotetext{
${ }^{16}$ Michel de Certeau analiza los discursos etnológicos del siglo XVI, en particular la Historia de un viaje hecho a la tierra del Brasil, de Jean de Léry (1578). En su estudio, que ocupa la tercera parte del libro ya citado: La escritura de la historia (201-269) postula un "cuadrilátero etnológico" (203) que se reconoce siempre, a pesar de las múltiples transformaciones operadas desde entonces. Las cuatro nociones que organizan ese campo científico - cuya condición se fija en el siglo XVIII y es bautizada por Ampère como "etnología"- son: la oralidad, la espacialidad, la alteridad y la inconsciencia. Esas cuatro categorías están destinadas a entender lo diferente de las culturas conquistadas y, al mismo tiempo, a ajustar la eficacia del poder colonial. La crónica de la conquista procede a lo que de Certeau llama "la invención del Salvaje", por cuanto el relato reconoce la alteridad pero al interpretarla, la "trae de regreso" al universo comprensible y escrito de la Historia (regreso a la mismidad, la escritura, la temporalidad y la identidad, el por-acá del pensamiento occidental, que se opone en espejo a las cuatro categorías etnológicas mencionadas que representan el por-allá del Salvaje, garantizando la separación). De ese modo la voz del salvaje -del "otro"- es irrecuperable, "está limitada al círculo evanescente de su audición" (211). Por lo tanto, la Historia "relata" gracias a su organización, su escritura, su temporalidad, operando el regreso de la alteridad por la vía de la interpretación. En el modo histórico de la crónica (crónicas de la conquista, crónicas de viajes) cada episodio modula lo extraño, lo representa al producirse en un movimiento simultáneo de progreso hacia la alteridad y regreso hacia la mismidad por el camino de la hermenéutica. A Lemebel no le hace falta esa doble operación; en sus crónicas la separación no se desvanece ni se disimula, el texto la supone y la atraviesa porque está escrito por ese mismo otro que habla ahora, desde su propio deseo, desde la experiencia de su propio cuerpo enfermo, estigmatizado por la exclusión, la persecución homofóbica, el control político-policial, la indiferencia cómplice, y se propone como discurso de un saber que no había sido oído, o había sido oído bajo la estructura de la separación que lo representa, lo interpreta y lo exotiza.
} 
posdictadura chilena descartan. En esta primera hipótesis se considerará la inscripción de la obra del autor en las estéticas neobarrocas ya señaladas por la crítica temprana a la obra de Lemebel. ${ }^{17}$ La escritura lemebeliana presenta rasgos que lo vinculan al universo que Severo Sarduy (1987) designó con el problemático pero muy productivo concepto de "Neobarroco". Esta opción es tanto estética como ideológica, por ser la condición de posibilidad para vehiculizar la mencionada experiencia de la historia. En todos los casos las crónicas de Lemebel registran un punto presente de una historia particular en la que persiste una multiplicidad diferenciada: el texto las confronta, las despliega, las expresa, las vocaliza, las hace palpables. Por ello resulta operativo el aporte del pensamiento de Michel de Certeau, quien se interesa por consignar las prácticas de hombres y mujeres que en determinada época y lugar se apropian de objetos, códigos y saberes existentes para dar lugar a prácticas nuevas (nuevos modos de subjetividad y de sociabilidad). La historia así entendida es un discurso apto para poner en escena la alteridad, cartografiando los cambios y la redistribución de los espacios (físicos y simbólicos, sociales y subjetivos) que aquellas prácticas provocan, y asimismo los nuevos saberes, objetos y códigos que producen. Lemebel interviene en los discursos de la serie literaria y de la serie histórica por cuanto narra una historia de Chile que no ha sido contada por el saber oficial, y ha sido negada por los "neo-oficialismos del consenso" (Richard). Esto último aparece de manera explícita a lo largo de toda su producción.

Postulo que las crónicas de Pedro Lemebel, por las cuestiones que acabo de señalar, se leen como una línea de fuerza que atraviesa la separación generada por el discurso historiográfico y sus estrategias representativas. En las crónicas del escritor chileno no hay distancia con el "otro" que garantice la interpretación, por cuanto Lemebel es el otro que toma la palabra y hace audibles las voces y los cuerpos

\footnotetext{
${ }^{17}$ Ver al respecto Capítulo I: “La crónica en cuestión”, el comentario acerca de los artículos de Soledad Bianchi, Yanko González y Carlos Monsiváis.
} 
silenciados. Tampoco encontramos la temporalidad clásica del discurso historiográfico que produce el corte y se separa del pasado; las crónicas re-escriben $s u$ pasado en vínculo dialógico con el presente, y se producen en una temporalidad sincrónica (Aníbal González) con los hechos o acontecimientos narrados.

Tal como desarrollaremos más adelante, a la luz de los ineludibles trabajos de $\mathrm{H}$. White, las crónicas no son "historias imperfectas", sino "productos particulares de posibles concepciones de la realidad histórica, concepciones que constituyen alternativas, más que anticipaciones fallidas del discurso histórico consumado que supuestamente encarna la historia moderna”. (White 1978: 21-22). No existe por parte del autor la voluntad de narrativizar los hechos con el fin de hacerlos significativos dentro de una secuencia ordenada y teleológica. Para nosotros, el texto de Lemebel opera según otro principio, otra regla de construcción del significado. Se propone leer en los pliegues del acontecimiento, y construir un saber del contenido invisibilizado.

El corpus que será analizado en relación con estas problemáticas está constituido por textos de los siguientes libros: La esquina es mi corazón (1995); Loco afán. Crónicas de Sidario (1996); De perlas y cicatrices (1998); Zanjón de la Aguada (2003); Serenata Cafiola (2008). No obstante, en el desarrollo de la primera hipótesis -que ocupa el tercer capítulo de la tesis- se pondrá el acento en los dos primeros volúmenes publicados por el autor: La esquina es mi corazón y Loco afán. Crónicas de Sidario, por cuanto en ellos predominan textos que registran episodios históricos de violencia política y de género, los cuales representan la continuidad de los métodos autoritarios en las estrategias de control urbano durante la transición. Lemebel denuncia la persecución homofóbica a pesar de la recuperación democrática ("Anacondas en el parque"); narra el anonimato y el desnudo indefenso de una mujer transgresora, inocente y sin nombre, primera desaparecida-exiliada en democracia ("La Babilonia de Horcón”); las 
violaciones en cárceles masculinas ("Encajes de acero para una almohada penitencial”), entre otros textos que testimonian la vigencia del aparato político-policial aun en tiempos de la "Concertación para la democracia”. En síntesis, las crónicas de estas dos primeras colecciones dan cuenta de historias particulares y minoritarias que no tenían espacio en las voces oficiales de la dictadura, pero que tampoco encuentran su lugar durante la apertura democrática de los noventa, dado el carácter ambiguo de la transición, lo que el autor llama el "reconciliado sopor" o "una oscura negociación".

II.

Después de recorrer las crónicas de Lemebel y reflexionar acerca de ellas en la perspectiva dada por nuestra primera hipótesis, según la cual su prosa registra un punto presente de historias particulares en las que se despliegan multiplicidades diferenciadas, estamos en condiciones de formular la segunda hipótesis, la cual consiste en sostener que las crónicas de Lemebel dan cuerpo y voz a identidades silenciadas, discontinuas, "minoritarias" en el sentido preciso que le da a este término la filosofía de Gilles Deleuze y Félix Guattari. Este es un término dinámico que señala en el objeto o fenómeno observado un proceso de resistencia a la estructura o sistema dominante. Una lengua minoritaria, por ejemplo, no es aquella que habla una minoría por cuanto lo minoritario no remite a una determinación cuantitativa. Una lengua minoritaria es aquella que opone su resistencia a las estructuras estandarizadas de la lengua dominante, dentro del propio sistema; su fuerza transgresora produce cambios incesantes y, por ello, este concepto vehiculiza una poderosa crítica ontológica hacia el interior de los sistemas conceptuales y disciplinares de nuestra cultura occidental. Este concepto, y su correlativo: “devenir", nos permitirá desarrollar una idea compleja pero sumamente productiva, que tomamos de Deleuze, Derrida, Foucault y Kristeva, a saber, que el 
proceso identitario no remite a la fijeza ni a una esencia inmutable platónicamente entendida, sino, por el contrario, a la movilidad continua que da lugar a entes singulares (“singularidades" en términos deleuzeanos) heterogéneos e incategorizables. Para poder cartografiar esas identidades discontinuas, que no se dejan "leer" bajo el dispositivo privilegiado de la razón moderna: la oposición binaria, siempre jerárquica y excluyente, Lemebel produce sus textos en el cruce de múltiples sistemas de heterogeneidad: objetivo/ subjetivo; historia/ ficción; discurso histórico/ discurso literario; crónica/ poesía; oralidad/ escritura. Pero hay que tener en cuenta que los términos no son opositivos ni excluyentes, sino que se vinculan según lo que Maurice Blanchot llamó "intermitencia"18 y "ambigüedad" como principios activos de "la dialéctica de la obra" (1955: 209-221): entre el acontecimiento ficcional y el propósito de registro; entre el dato demográfico, histórico-político y etnográfico y la prosa poética rica en imágenes plásticas y musicales, propias de una estética neobarroca; entre el punto de vista

${ }^{18}$ En el segundo apartado del capítulo 7: "La literatura y la experiencia original" (1955: 197-236) Blanchot destaca el valor de la obra como "alianza de los contrarios": "La obra no es la unidad mitigada de un reposo. Es la intimidad y la violencia de movimientos contrarios que nunca se concilian ni se apaciguan mientras la obra es obra. Esta intimidad donde se afronta la contradicción de antagonismos que son inconciliables pero que, sin embargo, sólo tienen plenitud en la oposición que los opone, esta intimidad desgarrada es la obra [...] en la violencia que la hace una, [la obra] realiza como el acontecimiento único de una discordia esencial en el corazón de la cual sólo lo que está en lucha puede aprehenderse y calificarse.” (213-214. Énfasis mío). Esta consideración de la obra literaria anima particularmente el último capítulo de mi tesis: las tres tensiones que vibran en la escritura de Pedro Lemebel (historia/ ficción, crónica/ poesía, escritura/ oralidad) conviven sin resolverse y le otorgan su dinamismo y su carácter de acontecimiento. Se explica así por qué Blanchot, siguiendo a Mallarmé, afirma que "el punto central" de la obra "es la ambigüedad misma" (Blanchot 1955: 38). Por un lado, la obra es presencia, realización y afirmación de sí misma, ("no tiene que admitir más luminosa evidencia que la de existir"); por otro lado, por ser alianza de los contrarios, la obra es puro movimiento, tensión, potencia, y por lo tanto, más allá de su "luminosa evidencia", se configura como "lo inasible en movimiento": "Donde creemos tener palabras, nos atraviesa 'un virtual reguero de fuego', una prontitud, una exaltación centelleante [...] Entonces todo se hace suspenso, disposición fragmentaria con alternancia y enfrentamiento." (38-39). Subrayo que las afirmaciones de Maurice Blanchot no se limitan en ningún momento exclusivamente al género poético tradicionalmente entendido, sino que sus hipótesis se refieren al campo de la literatura y del arte, como lo indican claramente sus títulos ("La literatura y la experiencia original", "El futuro y la cuestión del arte", "Los caracteres de la obra de arte", entre otros) y también sus constantes referencias a Kafka. Otro elemento ineludible de la reflexión blanchotiana que la hace productiva para leer a Lemebel es su análisis de la posición de quien lee y escucha la obra. En ese espacio ("el espacio violentamente desplegado por el enfrentamiento mutuo el poder de decir y del poder de oír", Blanchot 1955: 31) se produce la intermitencia de la obra, que la hace perceptible. Quien escribe, el "creador", no podrá expresar la obra si ésta no "se convierte en la intimidad abierta de alguien que la escribe y de alguien que la lee". Quien la "oyó" también la escribe: "quien la oyó como palabra penetró en su comprensión, se sostuvo en su exigencia [...] la interrumpió, y en esa intermitencia la hizo perceptible, la pronunció" (31). 
particular subjetivo y la observación que da cuenta de un estado de cosas en el plano social y político; entre la literatura vocalizada y el silencio escriturario. He aquí la razón del título de la presente tesis: "La voz de los cuerpos que callan. Las crónicas de Pedro Lemebel: entre la literatura y la historia", enunciado que despliega el problema de la intimidad y la violencia de movimientos contrarios que configuran la obra del chileno, antagonismos inconciliables (voz y silencio, olvido y memoria) "pero que, sin embargo, sólo tienen plenitud en la oposición que los opone" al decir de Blanchot (1955: 213). La intimidad desgarrada es la crónica lemebeliana. ${ }^{19}$ El múltiple deslizamiento de los contrarios constituye la condición previa y necesaria para el despliegue de procedimientos poéticos que caracterizan su prosa y es la condición de posibilidad de un enunciado literario que interviene en los discursos de la historia reciente de su país.

La crónica será considerada aquí una textualidad cuya naturaleza está dada por los mencionados cruces -que no son fáciles de cartografiar, de allí la dificultad crítica que hemos registrado y que la presente investigación no elude- en los que se operan devenires que serán tratados en sus distintos niveles de consideración: el punto de vista, la condición ficcional e histórica del discurso, su naturaleza poética. Estos devenires habilitan el discurso para expresar identidades en deriva: "narrar la multiculturalidad" (García Canclini 2005) y rehuir el riesgo de las "subalternidades" en términos de Nelly Richard. Las crónicas de Lemebel se configuran como espacios donde habla el otro. Este término, tomado de Michel de Certeau, debe ser precisado en el caso Lemebel: me refiero con él a las identidades que no tenían discurso, y por lo tanto no existían en el espacio simbólico de la historia y la cultura chilenas. Lemebel las hace audibles pero sin caer en la trampa de la mitificación, o de la "épica de la Resistencia" como la llama Richard: "el fundamentalismo mesiánico y redentor de las utopías; la re-mitificación de

\footnotetext{
${ }^{19}$ En el Capítulo III me voy a detener en la crónica que inaugura La esquina es mi corazón, su primera colección, la cual puede leerse como una metáfora de esta intimidad desgarrada.
} 
lo nacional-popular [...] la re-trascendentalización de la Historia como monumento a los caídos y gesta redentora" (1991: 41). En las historias de Lemebel no hay héroes ni figuras idealizadas, sino más bien todo lo contrario. La historia reciente de Chile se narra a escala humana, sin ninguna operación que promueva la trascendentalización de los seres que protagonizan las crónicas; no se pretende sustituir una mitificación por otra, sino echar luz sobre los intersticios de la historia.

Uno de los rasgos que caracteriza a las crónicas hispanoamericanas contemporáneas y que permite tender líneas genealógicas tanto con las crónicas de Indias como con la crónica modernista, es la clara conciencia autoral de ser mirada, pensamiento, escritura, consecuencia directa de la posición del observador. Afirmo que todos los discursos de la historia lo son, pero el sujeto de la crónica lo sabe. En otros términos: el discurso historiográfico y otros que se vinculan estrechamente con la historia reciente, como el periodismo narrativo y la novela no ficcional, son el resultado de una posición particular del observador, desde la cual se ajusta el verosímil del relato: ser un punto de emisión de la voz que registra y da testimonio, borrando o minimizando las marcas de la enunciación. De ese modo los hechos parecen "narrarse solos" (Barthes $1970^{a}$ ) aunque sabemos que cualquier lector atento advertirá que se trata de un relato y que su punto de vista es inherente a él. En Lemebel el discurso narrativo -lejos de disimular u omitir las particularidades de la enunciación y de su emisor-capitaliza su punto de observación y su identidad india o mestiza, loca o coliza, gay o marica, cronista, escritor y periodista radial, pobre o proleta. Por esta razón, postulamos en esta segunda hipótesis que la identidad no está fijada ni establecida, todos esos términos funcionan en simultaneidad incesante y producen, como trataremos de probar, un discurso que conoce y narra cada historia en su propia particularidad incategorizable; un discurso que expresa el lugar, el tiempo, la voz, el paisaje como condensación de 
sentido lo cual permite al lector acceder a una experiencia de los sucesos narrados y no a un conocimiento abstracto del acontecer histórico.

Para formular esta hipótesis de manera completa y no dejar de lado aspectos técnicos que son absolutamente indispensables para la producción del sentido, debemos tener en cuenta que en la crónica de Lemebel (a la luz del tratamiento del sujeto que acabo de señalar) se construye "una temporalidad sincrónica" (o, como la llama Aníbal González, ubicándose en la estela del pensamiento foucaultiano: una arqueología del presente). "Tipos", “escenas" o "cuadros", siempre en presente, en vínculo necesario con lo que hemos observado antes: la importancia de la posición del observador. La visión de quien escribe el artículo costumbrista es "fragmentaria, dividida en compartimientos, de ahí que sean piezas breves carentes de la ilación narrativa que es normal en el discurso histórico" (68). "La crónica se ocupa de eventos, de sucesos que quiebran la rutina del acontecer cotidiano. La crónica subdivide la progresión temporal en una multitud de instantes discretos, en una pululación de eventos que es necesario historiar." (73). Dicha temporalidad sincrónica no se observa en otras discursividades a las que se les asigna el indeterminado rótulo de "no ficcionales", las cuales (como se verá en los análisis pertinentes) organizan su desarrollo según una secuencia lógica que se inscribe en los modelos más convencionales de la temporalidad narrativa propia del realismo decimonónico.

Ahora bien, Lemebel potencia ese procedimiento propio de la crónica por cuanto su registro del momento presente está dado en clave subjetiva-emocional, articulado en registro poético y atravesado por las voces (el habla popular) y la música (el cancionero que conocen sus lectores), de modo que el espacio deja de ser una categoría del relato: el paisaje deja de ser escenario de los hechos y se convierte en vehículo del sentido. El basural, la esquina, el sauna, el Zanjón, el parque forestal, el departamento de la Regine 
o la calle constituyen en cada caso una unidad de sentido entramada con la condición material-sensorial del momento presente y con la audición de las voces que lo narran. Ese compuesto heterogéneo es la condición misma de su escritura.

Las crónicas de Lemebel recogen y hacen oír voces, materiales y significaciones que remiten a registros discursivos muy diversos. Se escucha en ellos la polifonía propia del discurso social y cultural de la modernidad latinoamericana y se perciben las particularidades y contrastes de la experiencia urbana que ya habían registrado las crónicas modernistas. Las "locas", los "rotos", los "indios", los "proletas", los perseguidos por el régimen militar y por los forzados consensos de la transición, toda una diferenciada galería de seres minoritarios e invisibles excluidos de todos los registros discursivos: ausentes en el discurso histórico, en el periodístico, en el político oficial, en el discurso de las clases dominantes; ausentes en el género literario más encumbrado en el sistema literario chileno: la poesía (dominada, según Lemebel, por las “próstatas locales"); ausentes en el discurso académico y en el discurso etnográfico.

El corpus que será analizado en relación con estas problemáticas está constituido por textos que pertenecen a los siguientes libros: Loco afán. Crónicas de Sidario (1996). De perlas y cicatrices (1998). Zanjón de la Aguada (2003). Adiós mariquita linda (2004). Serenata cafiola (2008). No obstante, en el desarrollo de esta segunda hipótesis -que ocupa el cuarto capítulo de la tesis- se pondrá el acento en los siguientes libros: De perlas y cicatrices (1998). Zanjón de la Aguada (2003), Adiós mariquita linda (2004) y Serenata cafiola (2008), por cuanto en ellos se pone en evidencia la triple tensión (historia/ ficción; crónica/ poesía; escritura/ oralidad) que atraviesa toda su obra y que articulará el desarrollo de la hipótesis. De perlas y cicatrices hace explícito un desafío: "la documentación letrada" que es este libro no puede contener la experiencia radial del espacio "Cancionero" emitido por Radio Tierra ("el goteo oral de su 
musicalizado relato"). No obstante, las crónicas de esta colección asumen ese desafío por cuanto son literatura vocalizada. Me refiero con este concepto -que será desarrollado en el cuerpo del correspondiente capítulo- a aquellos textos que (por su origen radial, su vínculo con la oralidad y su poder comunicativo, también por su condición performática, fragua del discurso lemebeliano) asumen un carácter instantáneo, tienden a la inmediatez, a la espontaneidad y a la transparencia, dotando de musicalidad, ritmo y energía vital a la palabra. Esto se observa claramente en la mayoría de los textos que integran los libros De perlas y cicatrices, Adiós mariquita linda y Serenata cafiola. Crónicas como "El Informe Rettig” y "Corpus Christi (o la noche de los alacranes)", entre otros, me permitirán avanzar en la descripción de la tensión crónica-poesía. El relato "Solos en la madrugada (o el pequeño delincuente que soñaba ser feliz)" nos pone al tanto de un saber y nos hace participar de una experiencia. La fuerza de estos textos, su potencia, está dada por procedimientos literarios -narrativos y poéticos- que permiten historiar el suceso. Por su parte, el eje articulador de Serenata cafiola está dado por las diferentes canciones que evoca en consonancia con una situación personal o histórica. La segunda condición de este "cancionero" es su clave metonímica. El fin de la ilusión democrática se enlaza con la pérdida de la madre configurando un desplazamiento que da la clave semántica del libro: la pérdida de la madre - la pérdida de la patria.

\section{$\underline{\text { Presentación general del marco teórico-metodológico }}$}

En atención a lo postulado en mi primera hipótesis, resulta operativo y necesario el aporte del pensamiento de Michel de Certeau y su concepto de "operación historiográfica". De Certeau recupera la "función crítica" de la historia, en el marco de 
una concepción no ortodoxa del trabajo del historiador. Tal como él lo concibe, el historiador sale a la calle y sus observaciones se producen "en tránsito" del estudio monumental a la sociedad presente; indaga en los márgenes y las fronteras (incluidas las de su propio hacer), y orienta sus actividades técnicas con el fin de captar la importancia de lo singular, la excepción, aquello que configura las "particularidades" entrevistas en los vagabundeos del hombre preocupado por el hacer historiográfico.

El objeto privilegiado de su estudio -al que le dedicó toda su vida- será la excepción o la alteridad (el "otro", cuando se lo nombra desde la perspectiva dominante). Estas son las mencionadas "particularidades" entrevistas por el historiador alejado (o más bien diríamos: “alejándose”, sin desentenderse de la institución a la que pertenece) “del estudio monumental que lo clasificará entre sus pares” (1978: 68). Michel de Certeau se interesa por consignar las prácticas de hombres y mujeres que en determinada época y lugar se apropian de objetos, códigos y saberes existentes para dar lugar a prácticas nuevas.

Por ello la historia, así entendida, es una ciencia apta para poner en escena la alteridad y mostrar la relación intensa e incesante entre la historia y los actores sociales, cartografiando los cambios y la redistribución de los espacios (físicos y simbólicos, sociales y subjetivos) que aquellas prácticas provocan, y asimismo los nuevos saberes, objetos y códigos que producen. Y por ello Lemebel interviene en los discursos de la serie literaria y de la serie histórica, tanto en su país como en la región, y como consecuencia, genera redistribuciones y transformaciones en las categorías de la serie literaria. Para de Certeau tanto la historia moderna como la medicina son heterologías (discursos sobre el "otro") en tanto "se construyen en función de una separación entre el saber que provoca el discurso y el cuerpo mudo que lo supone" (1978: 17). En Occidente, el discurso de la Historia implica una doble separación: pasado/ presente y 
discurso/ cuerpo social. Supone una distancia entre la realidad opaca y silenciosa y el discurso que se refiere a ella; también separa su propio presente del pasado que observa, repitiendo el gesto de dividir el tiempo cronológico, organizándolo en una estructura. En ese gesto se realiza la voluntad de ser otro con respecto al pasado: dejar de ser lo que se ha sido hasta entonces; de esa voluntad surgen los grandes cortes que son a un tiempo el procedimiento y el objeto del trabajo historiográfico: Edad Media, Renacimiento, Barroco, etc. etc., una formulación abstracta del tiempo, "separada", impersonal. A propósito Michel de Certeau señala:

Una estructura propia de la cultura occidental moderna se indica sin duda en este tipo de historiografía: La inteligibilidad se establece en relación al "otro", se desplaza (o "progresa") al modificar lo que constituye su "otro" -el salvaje, el pasado, el pueblo, el loco, el niño, el tercer mundo. A través de variantes, heterónomas entre ellas -etnología, historia, psiquiatría, pedagogía, etcétera-, se desarrolla una problemática que elabora un "saber decir" todo lo que el otro calla, y que garantiza el trabajo interpretativo de una ciencia ("humana") (de Certeau 17, énfasis del autor).

La historiografía moderna nace con dos exigencias que forman parte de su estructura: a) el privilegio de la génesis (la importancia decisiva de saber "lo que está antes") y b) la formación de series que impone al historiador la tarea obsesiva de llenar las lagunas, a fin de postular una estructura, la cual, por definición, debe ser exhaustiva y minuciosa. Estos son dos imperativos epistemológicos que determinan su estructura disciplinar. Según de Certeau la temporalidad de la historiografía clásica satisface esta doble demanda: responde formalmente a la pregunta por el comienzo y a la exigencia de un orden. Por lo tanto, la temporalidad no es tanto el resultado de la investigación como su condición: "es la trama que trazan a priori los dos hilos sobre los que avanza el tejido histórico" (26, énfasis del autor). 
Hemos de plantear aquí una cuestión central que dominará nuestra reflexión sobre la obra de Pedro Lemebel. La historiografía procede imponiendo la muerte, es decir, procura detener el devenir incesante de la historia. La muerte o el detenimiento son absolutamente indispensables para producir el discurso historiográfico según las exigencias que acabamos de señalar. Esa distancia mortífera ${ }^{20}$ que separa al discurso de su objeto, también garantiza su posibilidad al concederle al presente el privilegio de recapitular e interpretar el pasado convirtiéndolo en el objeto de un saber. Paradójica y simultáneamente -señala de Certeau- es un trabajo "contra la muerte", por cuanto intenta rescatar el pasado, y es un "trabajo de la muerte" (19) en la medida en que exige el detenimiento, la quietud, la cancelación del devenir histórico.

Ahora bien, tanto el privilegio de la génesis como la formulación de series completas que dan brillo a una estructura y a un sentido totalizador, satisfactorio para el pensamiento racional, caen o se van fisurando progresivamente conforme avanza lo que Tzvetan Todorov ha llamado "consciencia del lenguaje" (1970b: 11). Por eso el objeto de la presente tesis exige el análisis de la escritura. Esto es: la intervención de Pedro Lemebel en el discurso de la historia reciente de Chile (que implica operar a contrapelo del dispositivo ideológico-argumentativo que es la Historia y su voluntad de verdad) requiere indispensablemente el análisis de su obra como discurso. Ese es el sentido de la segunda hipótesis, la cual está en estrecha relación con la primera y la complementa.

La aparición en Occidente (tanto en el campo de las ciencias sociales como en el de la producción de los discursos) de la noción de escritura, trae consigo la reformulación de otras nociones fundamentales para la crítica de la cultura y, más

\footnotetext{
${ }^{20}$ Empleo este adjetivo en el sentido bajtiniano de "lazo mortífero" que la voz ajena le impone a la consciencia del héroe. Cuando el héroe es visto y representado como objeto en el contexto de la novela monológica, la voz ajena funciona como agente de la conclusividad del personaje, cancelando las "condiciones de la enunciación dialógica", es decir, la posibilidad para los héroes de ser consciencias ideológicamente autónomas. Su resultado, según el teórico ruso, es convertir a los personajes en "psiques objetivadas" en lugar de ser las "posiciones plenas de sentido" propias de la polifonía.
} 
específicamente, para el hacer historiográfico. Se trata -nada menos- que de la noción de verdad y el estatuto discursivo del presente. Estos tres conceptos fundamentales y sus transformaciones en la escena epistemológica contemporánea serán objeto de análisis y acompañarán todo el desarrollo de la presente investigación.

En el segundo capítulo analizaremos detenidamente los aportes de Michel Foucault en relación con esta compleja trama de problemas que comienza a ocupar el centro de los debates epistemológicos hacia fines de los años sesenta. Sus ideas, desarrolladas en La arqueología del saber (1969) y en El orden del discurso (1970) constituyen un análisis de los orígenes de los discursos disciplinares enfocando el momento en que la verdad cambia de condición, y pasa de ser lo que se manifiesta o puede manifestarse (puede ser conocida, representada y aun comprobada) a ser lo que se produce. Sus desarrollos elaboran y actualizan el concepto nietzscheano de Voluntad de Verdad. Para ambos filósofos la verdad es una construcción, y su aceptación y legitimidad dependen, como afirma Nietzsche, de muchas generaciones de seres humanos cuyos hábitos milenarios han "petrificado" un concepto o sistema de conceptos de tal manera que resulta incuestionable. ${ }^{21}$

El filósofo alemán postula el perspectivismo como cualidad inherente a todo género de conocimiento, aun tratándose de una disciplina formal; en esa configuración perspectivista del saber se jugará la suerte, también, de la temporalidad del discurso. En otros términos, el carácter de producción de la verdad está indisolublemente ligado al cambio en la función del presente en la escritura de la historia. El presente deja de ser la posición de privilegio desde la cual se podía conocer, recapturar y comprender el

\footnotetext{
${ }^{21}$ En Verdad y mentira en sentido extramoral (1873), texto anticipador y en cierto sentido preparatorio de su Genealogía de la moral (1887), Nietzsche afirma: "No sabemos todavía de dónde procede el impulso hacia la verdad, pues hasta ahora solamente hemos prestado atención al compromiso que la sociedad establece para existir: la de ser veraz, es decir, usar las metáforas habituales [...] Ciertamente, el hombre se olvida de que su situación es ésta, por tanto, miente inconscientemente de la manera que hemos indicado y en virtud de hábitos milenarios $-\mathrm{y}$ precisamente en virtud de esta inconsciencia, precisamente en virtud de este olvido- adquiere el sentimiento de la verdad" (1873: 20).
} 
pasado, su sentido histórico, sus causas y consecuencias. Ahora el presente no es más que el tiempo de la escritura que produce una verdad desde un punto de vista particular y con arreglo a una voluntad.

Señala Hayden White que esas dos condiciones (la voluntad de verdad y la separación pasado-presente en el discurso que acabamos de comentar) generan la concepción de la historia como una trama ajustada a un proyecto moral: "Sugiero que la exigencia de cierre en el relato histórico es una demanda de significación moral, una demanda de valorar las secuencias de acontecimientos reales en cuanto a su significación como elementos de un drama moral" (White 1987: 35). De algún modo lo que White llama la "exigencia de cierre" y de Certeau define como "estructura" es un procedimiento supeditado siempre a un impulso moralizante o bien a una voluntad de verdad: otorgar a lo narrado un "sentido histórico" totalizador, siempre ideológico y al que White considera, además, de naturaleza imaginaria:

El discurso narrativizante tiene la finalidad de formular juicios moralizantes. [...] Lo que he intentado sugerir es que este valor atribuido a la narratividad en la representación de acontecimientos reales surge del deseo de que los acontecimientos reales revelen la coherencia, integridad, plenitud y cierre de una imagen de la vida que es y sólo puede ser imaginaria. (White 1987: 38).

Michel Foucault coincide en estos aspectos centrales de la cuestión. Me refiero a las condiciones que determinan el cambio de paradigma en la producción del discurso histórico que estoy señalando sumariamente en estas líneas. En efecto, en los artículos de Microfísica del poder ${ }^{22}$ el pensador francés analiza particularmente las dos exigencias de la historiografía moderna, a saber: el desarrollo continuo y la necesidad ideal. Sus análisis (en los que me voy a detener en el Capítulo II) lo llevan a una

\footnotetext{
${ }^{22}$ Libro que puede leerse como el "precipitado" de su Arqueología del saber, publicado dos años antes.
} 
conclusión, la cual me servirá de punto de partida para mi lectura de la obra de Lemebel:

La historia será efectiva en la medida en que introduzca lo discontinuo en nuestro ser [...] Hay toda una tradición de la historia (teológica o racionalista) que tiende a disolver el suceso singular en una continuidad ideal al movimiento teleológico o encadenamiento natural. La historia "efectiva" hace resurgir el suceso en lo que puede tener de único, de cortante (Foucault 1971: 20).

Pedro Lemebel rechaza en su discurso la continuidad ideal de una historia teleológica y providencial, para producir textos capaces de vehiculizar y provocar una experiencia de la historia. Desde esta perspectiva puede entenderse su incursión en la performance como una apuesta contestataria que instaura visibilidad. Con las Yeguas del Apocalipsis, colectivo de arte que integró con Francisco Casas entre 1987 y 1995, participó en el espacio público dominado o controlado por el orden policial-político de los 90 generando, como decíamos, un espacio de visibilidad para lo que se conoce como "homosexualidad" 23 y será proclamado -por este colectivo de arte primero y por sus crónicas después- como una identidad de género ${ }^{24}$. Su condición de gay (o "loca" como prefiere autodenominarse) será exhibida como producto artístico en las calles. Indudablemente, con la experiencia de las Yeguas del Apocalipsis Lemebel participa activamente en las estrategias del camp y su "nueva visibilidad":

\footnotetext{
${ }^{23}$ Empleo la perífrasis "lo que se conoce como..." para no pasar por alto un hecho histórico y cultural decisivo vinculado a esta problemática: el concepto de homosexualidad "es un constructo, originado en la mentalidad criminalizante del positivismo que lo creó" (Amícola 2000: 176), idea señalada por todos los estudiosos de la cuestión gender.

${ }^{24}$ Empleo aquí el término "género" en el sentido de gender. Judith Butler, en su ensayo "Gender Trouble, Feminist Theory, and Psychoanalytic Discourse", en Feminist/Postmodernism, Linda Nicholson ed., New York and London, Routledge, 1990. (Versión castellana: "Problemas de los géneros, teoría feminista y discurso psicoanalítico", en: Linda Nicholson (comp.) Feminismo/Posmodernismo, Buenos Aires, Feminaria Editora, 1992. Págs. 75-95) ineludible a la hora de considerar la cuestión gender y los debates a ella asociados, señala la asimetría entre género y sexo biológico. Las diferencias de género son múltiples, de número indeterminado, por cuanto constituyen una marca social y cultural que se construye sobre la determinación biológica. Esta cuestión es analizada por la ensayista en el marco de la crisis del sujeto unívoco de la Modernidad (también denominada en otros contextos teóricos como el Pensamiento o la Episteme de lo Uno). Estas cuestiones serán retomadas en el primer capítulo de esta tesis: "La crónica en cuestión".
} 
En cuanto a la función del camp en el nuevo marco de la visibilidad gay, podemos decir que el camp funciona (como la risa carnavalesca) desconstructivamente, significando una intervención en el concierto de los discursos sociales: la estética kitsch puede tornarse camp justamente en base a las crisis de identificación que están en los fundamentos de la homosexualidad (Amícola 2000: 182).

En efecto, la asociación señalada por Amícola entre camp y risa carnavalesca (Bajtín 1938b) será muy evidente en las crónicas de Lemebel, particularmente en dos que serán analizadas en el decurso de la investigación ${ }^{25}$. Por lo tanto vemos una interesante continuidad entre su experiencia como performer y su producción como cronista a través del acto o gesto camp, mascarada exhibicionista y provocadora que proyecta su acción en dos sentidos: por un lado, como hemos dicho, genera la visibilidad de las identidades sexuales silenciadas o excluidas de la escena urbana, a contrapelo de las prácticas y la persecución homofóbicas de las que fueron objeto durante décadas; y por otro, realiza un cruce -también altamente productivo- entre la alta y la baja cultura.

La obra de nuestro autor será considerada en el complejo entramado de discursos heterogéneos propio de su producción discursiva y en el marco de su intervención en campos disciplinares diversos. En otros términos, sus crónicas se producen, circulan y son recibidas (desde 1995 hasta la fecha, tanto en su país de origen como en el resto de América Latina) en el cruce de varios universos en interacción: el de la producción de los discursos (literarios, periodísticos, historiográficos), el de la configuración de nuevos espacios urbanos y nuevos modos de sociabilidad a partir de la apertura de espacios de visibilidad para sectores sociales que durante décadas permanecieron en la sombra o fueron invisibilizadas por las políticas hegemónicas pinochetistas y post-

\footnotetext{
${ }^{25}$ Me refiero a "La noche de los visones (o la última fiesta de la Unidad Popular)" y "El último beso de Loba Lamar", ambos incluidos en Loco afán. Crónicas de Sidario. También encontramos el procedimiento desconstructivo de la risa carnavalesca en otros textos, como: "Son quince, son veinte, son treinta" o "Quién mató a Víctor Jara", incluidos en Serenata cafiola.
} 
pinochetistas. Desde luego, la intervención de estas crónicas no modifica mágicamente las determinaciones sociales y políticas existentes, por lo tanto la configuración del "nuevo mapa" es un fenómeno lento que por su complejidad y su naturaleza permanece en proceso. Pero, además, es indispensable señalar aquí un elemento central y distintivo de su estética y de su intervención cultural: nuestro autor pone en primer plano las contradicciones y las ambigüedades del campo social. Las identidades culturales son reconocidas como plurales, divergentes y dinámicas, según una mirada que asume su continua transformación y su historicidad. Por lo tanto, el campo problemático al que me estoy refiriendo incluye necesariamente el problema de la identidad. Esta cuestión es compleja y excede el marco de la presente investigación, pero también es ineludible porque la escritura del chileno pone en discusión el concepto mismo de "identidad cultural" como un todo acabado y preciso, homogéneo y definido. Su posición es siempre reactiva a las estrategias de identificación que operan dogmáticamente. Como señala Michel Foucault: "El proyecto de una historia global es el que trata de restituir la forma de conjunto de una civilización, el principio -material o espiritual- de una sociedad, la significación común a todos los fenómenos de un período" (1969: 15). Lemebel pone en evidencia y a la vez postula que en la historia reciente de Chile no hay grupos, ni ghettos, no hay identidades fijas ni establecidas en la ciudad, escenario multicultural por excelencia. Se produce en la escritura de Lemebel una auténtica "hermenéutica del otro", en términos de Michel de Certeau, por ser reactivo a cualquier posición identitaria que se proponga como fija, verdadera y homogénea, es decir, claramente "distinta" de otras que funcionarían como su negativo especular o su término opositivo.

En esta línea han reflexionado y generado interesantes debates los críticos culturales: Néstor García Canclini, Jesús Martín Barbero y Nelly Richard. A lo largo de 
la investigación iremos estableciendo las relaciones pertinentes entre esas reflexiones y

la producción cronística de Lemebel y de los escritores contemporáneos que he considerado en el corpus de esta tesis. Las identidades que configuran el universo multicultural latinoamericano son concebidas y reconocidas en la obra de nuestro autor como puntos intensivos en un flujo siempre desterritorializado, lejos del propósito de “muchos movimientos sociales y políticos" señalado por García Canclini, los cuales:

[...] absolutizan el encuadre territorial originario de las etnias y naciones, afirman dogmáticamente los rasgos biológicos y telúricos asociados a ese origen, como si fueran ajenos a las peripecias históricas y a los cambios contemporáneos. En los conflictos interétnicos e internacionales, de Bosnia a Perú, de Argelia a Alemania, encontramos tendencias obstinadas en concebir cada identidad como un núcleo duro y compacto de resistencia; por eso, exigen lealtades absolutas a los miembros de cada grupo y satanizan a los que ejercen la crítica o la disidencia. La defensa de la pureza se impone en muchos países a las corrientes modernas que buscan relativizar lo específico de cada etnia y nación a fin de construir formas democráticas de convivencia, complementación y gobernabilidad multicultural. (García Canclini 1995: 10).

Estas tendencias dogmáticas en relación con los estudios antropológicos y etnográficos se replican en cierto "romanticismo folclórico y nacionalismo político" que sentó las bases para una concepción rígida de las relaciones entre espacio y cultura. En este sentido afirma el autor:

Se estableció que los habitantes de un cierto espacio debían pertenecer a una sola cultura homogénea y tener por lo tanto una única identidad distintiva y coherente. La cultura propia se formaría en relación con un territorio y se organizaría conceptual y prácticamente gracias a la formación de colecciones de objetos, textos y rituales, con los que se afirmarían y reproducirían los signos que distinguen a cada grupo. (ibidem)

Coincido con García Canclini en que la conceptualización dogmática de los estudios antropológicos y culturales se está agrietando de la mano de los artistas y como 
consecuencia de la difusión de sus obras: "un sector cada vez más extenso de la creación, la difusión y la recepción del arte se realiza hoy de un modo desterritorializado" (1995: 11). La cuestión no es negar las etnias, las identidades culturales o las determinaciones sociales que desde luego siguen existiendo, sino entender cómo se constituyen y cómo se expresan en su vida cotidiana y en sus prácticas, en sus modos de sociabilidad y en sus saberes, en su relación con la tierra y en las formas de circulación y ocupación de los espacios urbanos. Por todo esto comparto plenamente la pregunta que se formula el ensayista y la hago propia en esta investigación:

Si concebimos las naciones como escenarios multideterminados, donde diversos sistemas simbólicos se intersectan e interpenetran, la pregunta es qué tipos de literatura, cine y televisión pueden narrar la heterogeneidad y la coexistencia de varios códigos en un mismo grupo y hasta en un mismo sujeto. (García Canclini 1995: 13)

En efecto, afirmo con el autor: ésa es la pregunta. A esa pregunta responden, entre otras expresiones desde luego, las crónicas de Pedro Lemebel. Y ello explica la opción del autor chileno por este género, un discurso que efectúa la "desterritorialización fabulosa" que Néstor Perlongher le atribuyera a la estética neobarroca: entre la oralidad y la escritura, entre la literatura y la historia, entre la narración y el ensayo, entre el periodismo y la ficción, inestabilidad del género “crónica" que lo hace apto para "narrar la multiculturalidad", en términos de García Canclini, pero también para hacer audibles las voces no asumidas por los discursos oficiales, disciplinares, periodísticos y literarios. También para "hacer hablar al cuerpo que calla”, en términos de Michel de Certeau, aspecto que las crónicas de Lemebel ponen en primer plano en su discurso plástico, musical, de una materialidad que lo liga a las estéticas neobarrocas de sus contemporáneos. 
Opción discursiva eficaz para generar también una intervención sensible en el campo académico, donde provoca interrogaciones y polémicas en relación con sus protocolos de investigación y sus elecciones de objeto. A propósito del papel renovador que jugaron los estudios culturales en el ámbito académico, Nelly Richard afirma que éstos favorecieron "el libre ingreso universitario de saberes que cruzan las construcciones de objetos con las formaciones de sujetos: el 'adentro' de la máquina de enseñanza con 'afueras' múltiples que des-bordan el texto académico (sus archivos y bibliotecas)" (Richard 2005:189). Lemebel toma parte en esos desbordes de manera consciente y eficaz problematizando las series de lo que Foucault ha llamado "el proyecto de la historia global". Tampoco se trata de abolir la posibilidad del orden disciplinar para estudiar la historia, sino de revisar sus cortes y su presuposición constitutiva: la que sostiene que entre todos los fenómenos se debe poder establecer un sistema de relaciones homogéneas, una red de causalidad y de analogías, de oposiciones y semejanzas; una ley que dé cuenta de su supuesta cohesión, y describa o devele el "rostro" de una época. Las crónicas de Pedro Lemebel hacen saltar las diferencias que se despliegan en un espacio de dispersión y de alteridad.

Como vemos, las relaciones entre discurso literario y discurso historiográfico son de carácter dialéctico, vale decir que ambos registros discursivos se producen en interacción incesante, sin alcanzar una instancia única y sintetizadora. Dicho carácter ha dado lugar a numerosos géneros discursivos que, a su vez, establecen relaciones problemáticas entre sí: la crónica (como acabo de señalar, aparece asociada a las disciplinas históricas, a la literatura y al periodismo, con frecuencia de modo tan cercano y de fronteras difusas que debemos emplear adjetivos dobles tales como: histórico-literaria, o periodístico-literaria), el artículo de costumbres, la crónica de viajes, el ensayo, la narrativa autobiográfica y la novela de no-ficción. Entre ellos, como 
queda señalado, abordaré el estudio de la crónica habida cuenta de su particular dinamismo formal y su dificultad de definición, sin intentar "legislar" acerca de su naturaleza y configuración por cuanto la presente tesis no se postula como una normativa del género. Al contrario, mi propósito es, al decir de Michel de Certeau, cartografiar las múltiples alianzas posibles entre la escritura literaria y la historia, explorando sus modos de articulación sin afán sintetizador. Para ello he recurrido a la noción nietzscheana-deleuzeana de devenir, por cuanto constituye un dispositivo teórico eficaz para eludir el exceso clasificatorio que, sin ninguna duda, es uno de los riesgos en los que suele caer la reflexión académica sobre el discurso literario.

Deudora del pensamiento de Baruch Spinoza, la noción de devenir se opone radicalmente a la concepción sustancialista de la metafísica occidental clásica y moderna (y por lo tanto al pensamiento hegemónico de raíz platónica cuyo representante paradigmático es René Descartes). Este concepto fue elaborado por Nietzsche en el siglo XIX y reelaborado por Gilles Deleuze en el siglo XX. Me propongo realizar un empleo productivo de esta noción cuya potente crítica ontológica me permitirá justificar el carácter híbrido de esta textualidad desde una perspectiva también filosófica. La producción del género se caracteriza por su impronta interdisciplinaria: se encuentran involucradas en ella, además de la filosofía, la epistemología, la teoría literaria, la crítica cultural y desde luego la historiografía. Estos aspectos de la investigación serán especificados adecuadamente en el segundo capítulo, referido al marco teórico y metodológico de la tesis.

En cuanto a la genealogía del género, he titulado ese apartado: "Continuidades y rupturas en la crónica latinoamericana", por cuanto además de las similitudes, serán relevadas aquellas diferencias cualitativas que dan cuenta de la evolución del género. Las crónicas de Indias no solo constituyen el antecedente histórico de la crónica actual, 
sino su matriz discursiva. Para dar cuenta de ello, me voy a detener en algunos aspectos generales de las crónicas del período colonial que considero pertinentes para esta investigación, y en los relatos de dos cronistas destacados del siglo XVI (Bernal Díaz del Castillo y Gonzalo Fernández de Oviedo) a fin de establecer las continuidades y diferencias específicas con la obra de nuestro autor. Otro tanto ocurre con las crónicas modernistas, entre las que he seleccionado un corpus limitado pero representativo, dando cuenta de sus puntos de contacto y sus elementos diferenciadores con la obra cronística de Lemebel. En este sentido tomaré como eje de mi reflexión el vínculo problemático entre la obra del chileno y algunas crónicas de José Martí. Mis análisis estarán centrados en establecer el punto de contacto más relevante, dado por el valor poético de sus respectivas prosas y por los procedimientos de ficcionalización del suceso historiado; al mismo tiempo serán analizadas las diferencias más significativas entre la figura de Lemebel y la función social del autor cubano, habida cuenta de la condición de héroe y aun "apóstol" que reviste en la conciencia y en la tradición de su pueblo. En cuanto al lugar de Lemebel en el contexto latinoamericano actual, su obra cronística será confrontada con un segundo recorte textual, formado por: Hasta no verte Jesús mío (1969) y Fuerte es el silencio (1980) de Elena Poniatowska (nacida en París en 1933, radicada en México desde su infancia); Los rituales del caos (1995) y Amor perdido (1978) de Carlos Monsiváis (México, 1938-2010); Prosa plebeya (1997) y Papeles insumisos (póstumo, 2004), ambos de Néstor Perlongher (Buenos Aires, 1949 San Pablo, 1992). En cada caso las crónicas de Pedro Lemebel establecen vínculos problemáticos -de identificación y diferencia simultáneas- que serán analizados detenidamente en tres apartados. Con el poeta argentino, nuestro autor tiene un claro y explícito vínculo genealógico, además de una posición equivalente respecto de la sexualidad como identidad itinerante, móvil. Frente a la obra cronística de Lemebel, el 
ensayista y cronista mexicano pone en evidencia la distancia letrada que lo separa del suceso narrado. Con Elena Poniatowska el vínculo está dado por la interesante y particular articulación entre oralidad y escritura. La mención de la obra testimonial de Poniatowska me permite el abordaje de uno de los puntos cruciales de la crónica de Lemebel que es la recuperación de su resonancia vocal. La crónica radial deriva en la crónica escrita y de ese modo se constituye un circuito que podríamos condensar así: de la oralidad a la escritura vocalizada. Un circuito que siempre ha estado latente en la crónica latinoamericana, desde las crónicas de Indias y la crónica modernista a las crónicas del presente. En este prolongado desarrollo histórico será considerado el caso particular de Elena Poniatowska, por cuanto su escritura constituye un punto de inflexión singular, un salto cualitativo en la evolución de la escritura cronística, testimonial y denunciativa (sobre todo en materia de procedimientos y elaboración artística de la voz que enuncia). Lemebel tiene en cuenta, a la hora de escribir sus crónicas, la tradición latinoamericana y la lección de Poniatowska -también la de otros cronistas latinoamericanos que voy a trabajar en esta tesis- que le permiten recuperar la voz de los cuerpos que callan y no escriben, como tantas Jesusas Palancares de nuestra América. 


\section{La crónica en cuestión. Diálogos y debates teórico-}

\section{críticos en torno a Lemebel}

La hibridez discursiva señalada ${ }^{26}$ en la obra del escritor chileno (texto históricoperiodístico / texto literario) genera como consecuencia directa una doble vertiente de producción crítica: por una parte, la crítica periodística que circula en diarios y revistas, suplementos o dossier, y también en páginas web, todos ellos de circulación masiva; y por otra, la crítica académica cuya circulación se da en congresos de especialistas (en su mayoría docentes e investigadores dependientes de universidades o academias nacionales, o bien de centros de investigación oficial), revistas especializadas o libros de estudios académicos. En cada una de dichas vertientes el interés por la obra de Pedro Lemebel se enfoca en distintos aspectos de su obra, por lo tanto se analizarán por separado.

Sumariamente señalo aquí que en las publicaciones periodísticas, tanto artículos como entrevistas, el interés está exclusivamente centrado en la denuncia social y la defensa de las minorías que los textos del escritor ejercen. Para una consideración crítica más justa con el valor literario y la originalidad que la obra del escritor chileno demuestra en materia de técnicas narrativas, lenguaje, transgresión y renovación de géneros, entre otros rasgos eminentemente artísticos (sin minimizar el valor innegable de la denuncia social que sus crónicas vehiculizan), es necesario indagar en la producción crítica que tiene lugar en el campo académico. En ambos registros, el interés

\footnotetext{
${ }^{26}$ Por ser uno de los puntos de partida de la presente investigación, esta cualidad heterogénea de la prosa lemebeliana articula el presente Capítulo I, está tratada en el desarrollo de mis hipótesis (Capítulos III y IV) y será retomada en las Conclusiones.
} 
por la obra de Pedro Lemebel es creciente y verifica una continuidad sin fisuras desde 1995 hasta la fecha.

\section{I.1. Crítica periodística sobre la obra de Pedro Lemebel ${ }^{27}$}

La primera crónica de Pedro Lemebel fue publicada en 1992 en la revista -ya desaparecida-Página Abierta, de Santiago de Chile, y la mayor parte de su obra fue publicada en medios periodísticos gráficos y radiales antes de su transposición al libro.

Para comprender la participación de nuestro autor en los medios gráficos chilenos de la posdictadura es indispensable ponerla en contexto, y ese contexto está dado por la peculiar relación que se dio entre los sucesivos gobiernos de la Concertación (tomaré en cuenta el período 1990-2010) y los medios gráficos de comunicación.

Juan Pablo Cárdenas Squella (docente universitario, Premio Nacional de Periodismo 2005 y director de la Radio Universidad de Chile hasta hoy) es una figura central en la lucha por la libertad de expresión durante y después de la dictadura del general Pinochet. ${ }^{28}$

Un dato curioso es que una de las revistas más combativas, Análisis, creada y dirigida por Cárdenas, circuló durante el período 1973-1991, es decir, duró exactamente lo mismo que el régimen al cual combatía, y se vio obligada a cerrar sus puertas en 1991 por razones económicas. Resulta paradojal que el ahogo financiero de la revista se haya

\footnotetext{
${ }^{27}$ Los artículos y entrevistas citados en este capítulo que no presentan la referencia bibliográfica convencional, pertenecen al Proyecto Patrimonio (http://www.letras.s5.com/archivolemebel.htm). Todas las referencias tomadas de esta fuente se consignarán en adelante como PP.

${ }^{28}$ Cárdenas fue redactor y director de la revista Debate Universitario de la Universidad Católica de Chile entre los años 1971 y 1973. Ese año fundó la revista Análisis, publicación que dirigió hasta 1991. Posteriormente, fundó y dirigió la revista Los Tiempos (1992-93) y el diario electrónico Primera Línea. Entre 1994 y 1999 se desempeñó como Agregado de Prensa de la Embajada de Chile en México. Es colaborador frecuente del diario El País, en España y ha sido columnista del Helsinky Sannomat, de Finlandia; también de los diarios chilenos La Época y La Nación. Actualmente es el director de Radio Universidad de Chile, (la cual funciona como emisora FM online y Diario Electrónico) y colabora en la revista El Periodista y en el diario electrónico Clarín Digital.
} 
producido precisamente con la recuperación del sistema democrático en Chile. Dicha contradicción se comprende cuando indagamos un poco más en la circulación de este tipo de medios gráficos durante los años de la Concertación.

En el período 1990-2005, es decir, durante los primeros 15 años de la transición democrática en los que gobernó el país la centroizquierda, se cerraron más medios de los que se crearon. El cierre de la revista Rocinante, ${ }^{29}$ en octubre de 2005 y del semanario Plan $B$ en el mismo mes, representan un punto de inflexión dado que determinaron la consolidación de la concentración informativa por parte de la cadena $E l$ Mercurio (la cual obtuvo en ese año -según registros oficiales- el 62,7 \% de los 500 millones de dólares que las empresas estatales destinaron a la publicidad). Corrieron la misma suerte los diarios La Época, Fortín Mapocho y las revistas Cauce y Apsi, todos ellos surgidos durante el régimen pinochetista, medios que no pudieron sostenerse durante los gobiernos democráticos de la Concertación. También tuvieron una vida efímera el diario El Metropolitano y las revistas Página Abierta (donde publicó Lemebel su primera crónica) y Los Tiempos, esta última también dirigida por Cárdenas.

Una de las pocas revistas independientes que se sobrepuso a la asfixia económica fue El Periodista, dirigida por Francisco Martorell, quien ha denunciado públicamente la situación de la prensa libre en Chile en numerosas oportunidades. "No hay voluntad por parte de los gobiernos de la Concertación para producir equilibrios dentro del sistema informativo nacional, pero tampoco hay creencia de que ello es importante", manifiesta Martorell en una entrevista concedida al medio periodístico digital IPS del 19 de octubre de 2005, a propósito del cierre de la revista Rocinante.

\footnotetext{
${ }^{29}$ Rocinante fue considerada "la mejor revista cultural" por el Círculo de Críticos de Arte de Chile, en tanto la Sociedad de Escritores la reconoció "por su contribución a la cultura y la difusión de libros en el país". Por su parte, la consultora Ipso Search Marketing comprobó en un estudio que era el medio más demandado en cuanto a número de lectores por ejemplar.
} 
Los críticos a la gestión comunicacional de la presidencia de Ricardo Lagos y de sus antecesores, Patricio Aylwin (1990-1994) y Eduardo Frei Ruiz-Tagle (1994-2000), sostienen que se ha reforzado un duopolio en la prensa escrita, donde comparten la hegemonía las cadenas El Mercurio y Copesa (Consorcio Periodístico S.A.).

Lo significativo de la situación señalada es que pone de manifiesto una característica del período posdictatorial unánimemente repudiada por los intelectuales y periodistas independientes y a la que parece aludir el nombre de la coalición gobernante. Este colectivo político no significó un corte ni una separación radical respecto del período anterior. Más bien la "Concertación para la Democracia"30 ha sido una transición complaciente y hasta cómplice con los protagonistas de la dictadura militar de los años setenta y ochenta, consolidando algunas de sus prácticas. Esta continuidad se manifiesta en muchos planos de la vida social y política de la nación y ha sido tema de intensos debates.

En el campo cultural, Nelly Richard caracteriza este período como marcado por un "neo-oficialismo del consenso", y señala en él diversidad de prácticas dadas en el universo cultural contestatario; esas prácticas implican diversidad de lenguajes y de operaciones. Algunas “eligen plegarse al convenio del discurso institucional [...] otras buscan desacomodar sus pliegues más sumisos haciendo valer un saber táctico de la

\footnotetext{
${ }^{30}$ Considero necesaria una breve precisión histórica respecto de este colectivo político. La "Concertación de Partidos por la Democracia" (conocida simplemente como "Concertación") es una coalición de partidos de centro-izquierda, la cual ha gobernado Chile desde el 11 de marzo de 1990 hasta la misma fecha de 2010. Nacida para enfrentar políticamente a la dictadura de Augusto Pinochet, aglutinó a la oposición y ganó el plebiscito nacional del 5 de octubre de 1988 como "Concertación de Partidos por el No". Se mantuvo unida y triunfó en todas las elecciones presidenciales desde 1989 hasta 2005. Su símbolo, el arcoiris, representa la variedad de agrupaciones que la conforman, entre las que se destacan el Partido Demócrata Cristiano (PDC), el Partido Socialista (PS), el Partido Por la Democracia (PPD), y el Partido Radical Social Demócrata (PRSD). A estos se suman el Partido Democrático de Izquierda (PDI), el MAPU Obrero Campesino, el Partido Liberal y otros movimientos civiles hoy desaparecidos o fusionados en otros partidos. Los presidentes que llegaron al poder por la Concertación han sido cuatro: $1^{\circ}$ : Patricio Aylwin (PDC), entre 1990 y 1994; $2^{\circ}$ : Eduardo Frei (PDC), entre 1994 y 2000; 3: Ricardo Lagos (PPD-PS), entre 2000 y 2006; 4: Michelle Bachelet (PS), entre 2006 y 2010. El 11 de marzo de 2010 asumió la presidencia el empresario Sebastián Piñera.
} 
disensión capaz de interferir críticamente con los neo-oficialismos del consenso" (Richard 1991: 43).

Cito a Richard y pongo su voz en diálogo con la situación de los medios periodísticos independientes durante los gobiernos posdictatoriales, porque ese ha sido el contexto de las primeras crónicas publicadas por nuestro autor. Pedro Lemebel y su obra cronística han jugado y juegan hoy un papel muy importante en el campo altamente problemático de la difícil recuperación de las instituciones democráticas en Chile, sobre todo en dos aspectos. Primero, como cronista que observa, registra y denuncia situaciones de opresión y de discriminación que la recuperación democrática no ha modificado; y segundo, generando él mismo a través de sus micro-programas en Radio Tierra y sus intervenciones públicas (tanto callejeras, con las Yeguas del Apocalipsis, como en eventos culturales: Ferias del Libro, conferencias, presentaciones, etc.) un espacio de debate y concientización respecto de los derechos no recuperados aún por los ciudadanos.

Numerosas crónicas de Lemebel hacen referencia directa a esta situación, en la cual el pueblo chileno parece no querer despertar del letargo al que se vio sometido durante los años de la dictadura militar: "Al llegar los noventa se fueron los milicos, y la democracia hizo como que llegó pero nos dejó a todos con los crespos hechos, esperando" (Lemebel 1998: 34). Es paradigmática en este sentido, la crónica "La mesa de diálogo. (O el mantel blanco de una oscura negociación)", incluida en Zanjón de la Aguada (Lemebel 2003: 283-286), que será analizada en el capítulo IV. En ella el autor hace resonar las palabras que aparecen silenciadas en el documento ${ }^{31}$ y en el discurso presidencial: impunidad, impunidad, impunidad (tres veces), crímenes, cadáver, olvido: "La palabra impunidad aunque no se diga se asoma y juguetea en la boca irónica de los

\footnotetext{
${ }^{31}$ Me refiero al Documento Final de la Mesa de Diálogo, presentado ante la Presidencia de la Nación y dado a conocer por los medios masivos de comunicación a la comunidad chilena, resultado de uno de los últimos intentos de reconciliación y pacificación política a cargo del presidente Ricardo Lagos.
} 
generales. Es más, la palabra impunidad, aunque no ${ }^{32}$ se diga, es la única que resuena en los ecos de este diálogo conciliador.” (Lemebel 2003: 285)

Nuestro autor participa activamente de la vida pública de su país, concede entrevistas e integra mesas redondas y paneles en las actividades culturales para las que es convocado. Este perfil lo ubica en un plano de actualidad y de permanente exposición pública y determina una fuerte interacción dialógica con la crítica acerca de su obra.

Se observa en la producción crítica de circulación masiva (es decir, en medios periodísticos gráficos y electrónicos), una marcada inclinación a subrayar el contenido de denuncia social de las crónicas de Pedro Lemebel, siempre a favor de las minorías que siguen siendo objeto de discriminación en Chile, como así también la actitud y las opiniones del autor en relación con la actualidad política y social de su país.

En efecto, los artículos publicados en la revista Rocinante desde 1998 hasta su cierre en 2005 verifican esta tendencia; entre ellos: "Un mapa de la denuncia", por Patricia Espinoza, artículo de diciembre de 1998. En él la autora establece una distinción entre el volumen que está reseñando (De perlas y cicatrices, que acababa de aparecer en Chile) y los dos libros anteriores, al señalar que éste

[...] impone un desplazamiento del sitio en el cual se ubica el cronista. La escritura de Pedro Lemebel habría (de algún modo) posibilitado su encasillamiento en el fichero bibliotecario de las literaturas gays. Su discurso imponía la voz crítica de la loca letrada, la loca sabia y no intervenida. El maravilloso "ojo coliza" se nos imponía como una entidad irreductible e inacotable, del mismo modo que su tránsito genérico no dejaba de oscilar desde la crónica al microcuento o el lirismo. En De perlas y cicatrices se ha producido un cambio. Estamos ahora, ante una crónica más "pura", que parece pretender deshacerse de toda connotación ficcional y que, además, se autoconstruye a partir de un ligero entreparéntesis o deslizamiento de la diferencia sexual del enunciante. Así, sólo en contados sitios nos encontramos con un sujeto que alude a su homosexualidad o que la

\footnotetext{
${ }^{32}$ Corrijo la errata de la versión que aparece en el volumen de Seix-Barral, pág. 285 (allí se omite el “no"), y sigo la versión original aparecida en la Revista Punto Final del 1 de octubre de 1999: "La palabra impunidad se asoma y juguetea en la boca irónica de los generales. Es más, la palabra impunidad, aunque no se diga, es la única que resuena en los ecos de este diálogo conciliador”.
} 
privilegia en su observación del mundo. Pese a ello, la mirada y el animus no dejan de ser los mismos, ya que aún así logran nuevamente armar el territorio desde donde surge una interrogación poderosa a nuestro fin de siglo. (Espinoza: 15)

Es cierto que en este volumen de crónicas, al compararlo con los dos anteriores, se evidencia una mayor atención al contexto social, político y cultural de las historias narradas, ajustando el propósito crítico de los gobiernos de la transición al poner en evidencia sus contradicciones y ambigüedades. Ahora bien, de ningún modo acuerdo con la autora de la nota en que este libro presente "una crónica más 'pura', que parece pretender deshacerse de toda connotación ficcional". Como se observará en mis análisis textuales, la composición crónica-ficción es una constante de su obra y no puede entenderse en términos de renuncia al "realismo" o "verosimilitud" ingenuamente concebidos, ni en términos de distancia/cercanía con los hechos narrados. Como será sostenido y argumentado en el desarrollo de la investigación el compuesto crónicaficción en Lemebel responde a una necesidad inherente al relato histórico.

El estatuto cognitivo y el valor histórico de la narración de Lemebel no se da $a$ pesar sino a causa de su configuración literaria y su "contaminación" con lo ficcional. Los hechos no cuentan su propia historia, el pasado no es un relato que espera a un relator; las crónicas de Pedro Lemebel son una operación literaria, productora de ficción, y eso de ningún modo atenta contra su condición de relato histórico sino que es necesario para lograr refamiliarizarnos, a nosotros los lectores, con sucesos desconocidos, olvidados o desechados por el saber oficial. La autora de este artículo señala un "retroceso" de la ficción en De perlas y cicatrices que de ningún modo aparece corroborado por los textos. Y entendemos que no podría ser así, dada la opción consciente de Lemebel por la configuración literaria de su discurso histórico, necesidad inherente al relato del pasado para hacerlo eficaz, para familiarizar al lector con una 
visión silenciada de los episodios narrados, para otorgarle a los hechos y situaciones, figuras y rostros evocados un sentido histórico que había sido invisibilizado. Lemebel interviene deliberadamente en el espacio discursivo dominado por un registro impersonal, en el que no parece haber lugar para la ambigüedad o para la tensión entre juicios críticos divergentes, desplegando su escritura que enlaza la poesía y la ficción con el relato de los hechos. Como afirma Hayden White: "Para poder ser considerado histórico, un hecho debe ser susceptible de, al menos, dos narraciones que registren su existencia" (1978: 34). Citaré más adelante in extenso a este autor y su concepción del relato histórico, pero me parece necesario puntualizar aquí esta cuestión central para comprender el sentido que tiene en Lemebel el recurso a la ficción y la elaboración literaria de las historias que narra. La autora de este artículo señala, además, un elemento decisivo que será analizado en el desarrollo de esta investigación: las problemáticas relaciones entre la escritura, la memoria y la verdad. Ellas son elementos en conflicto que la crónica de Lemebel no se propone disciplinar ni resolver:

Loco afán, La esquina es mi corazón y el recientemente aparecido De perlas y cicatrices han sido subtitulados "crónicas". Textos que se ubican dentro de la intencionalidad manifiesta de redimensionar el tiempo desde la perspectiva de un narrador en primera persona que intenta recrear la escena de lo real-originalverdadero. La crónica resulta de tal modo una escritura en la cual ocupan un sitio privilegiado tanto la memoria como la verdad. Pero Lemebel pareciera repulsar de la grandilocuencia de la memoria y la verdad, para convertirlas en recuerdos particulares y en verdades oblicuas, haciendo emerger con ello lo infinito de lo intrahistórico. (Espinoza: 14).

Esta reseña periodística señala dos elementos constitutivos de la tradición del género en la que el chileno opera una transformación: el tratamiento particular del tiempo y la importancia de la perspectiva del narrador. Ambos aspectos serán abordados detenidamente en la presente tesis doctoral, por considerar que Lemebel construye una 
subjetividad nueva para el análisis histórico y social, que tiene en cuenta al deseo como fuerza configuradora de la realidad, y por lo tanto, abre un nuevo espacio para el registro de los acontecimientos históricos: las políticas del deseo.

Otra dominante de la producción crítica periodística que bordea la obra lemebeliana es la constante proliferación de entrevistas, que no cesan de aparecer en medios masivos de comunicación, especialmente chilenos y argentinos. Por ejemplo: "La Yegua silenciada", entrevista realizada por Maureen Schaffer en Revista HOY, N 1.072, del 9 al 15 de febrero de 1998. El punto sobresaliente del diálogo, como lo indica el título de la publicación, es la reciente censura de la que fuera objeto el escritor en una entrevista filmada para el canal 5 de Valparaíso, y que nunca salió al aire. Luego de comentar el episodio, la entrevistadora insiste en "la defensa de las minorías", haciendo foco exclusivamente en ese perfil del escritor. No obstante, ante la pregunta acerca del carácter "vivencial" o autobiográfico de sus crónicas, Lemebel da una respuesta de sumo interés para nuestra investigación:

La biografía de un hombre pobre, sudaca y "aindiado" siempre pasa por un gesto de confesión. Yo evito el testimonio real, porque me desagradan los confesionarios y esa objetividad eclesiástica del periodismo acusete. Pero tampoco podría negar mi origen y lo evoco en la escritura, travestido, multiplicado en un tornasol engañador. (Schaffer: PP)

Según su autor, las crónicas no son "testimonio real"; tampoco niegan ni silencian los rasgos de identidad biográfica: la ambivalencia del yo en la escritura de Lemebel es de naturaleza poética. Esta problemática, ligada específicamente a las teorías del sujeto poético, ocupa un lugar importante en el desarrollo de la presente tesis, por cuanto es uno de los ejes de la primera hipótesis la cual, como ya he señalado, se centra en las relaciones entre la literatura y la historia articuladas en la obra de Lemebel. El autor expresa en esta entrevista su experiencia de otredad ("lo evoco en la escritura, 
travestido, multiplicado en un tornasol engañador”). Es una simplificación inaceptable sostener que el "yo" de la escritura responde de manera simple y directa al yo autoral; sería igualmente torpe negar las relaciones evidentes entre la biografía o las circunstancias históricas del autor real y las determinaciones del sujeto textual en estas crónicas. La ambivalencia no se resuelve; es una idea problemática en sentido filosófico, por cuanto ninguna respuesta cancela ni detiene la capacidad productiva de la pregunta. J'est un autre ha dicho Rimbaud sin resolver el problema, sólo planteándolo en términos poéticos. La presente tesis dará cuenta de los efectos de esta problemática en la escritura de Pedro Lemebel.

En las publicaciones periodísticas, tanto en los artículos como en las entrevistas, el interés está centrado de manera casi unánime en la denuncia social y la defensa de las minorías que los textos del escritor ejercen. Presentan esta característica las entrevistas y reseñas aparecidas en Las Últimas Noticias, El Mercurio, La Tercera, Primera línea y Cultura Urbana, (además de la ya mencionada Rocinante), todas publicaciones santiaguinas, particularmente las publicadas durante los años 2000 y 2001.

En una entrevista realizada por Iván Quezada en La Tercera, Santiago de Chile, el 6 de julio de 2000, titulada: "El baile de máscaras de Pedro Lemebel” el autor afirma su voluntad de trasladar ("contrabandear", en sus términos) contenidos de la alta cultural intelectual a los sectores menos favorecidos de la sociedad:

Mi inquietud cultural es hacer el contrabando de contenidos culturales a la periferia y llevar a ésta a la catedral cultural. Las crónicas de Loco Afán, que acaba de sacar una editorial tan prestigiosa como Anagrama, antes pasaron por revistas y diarios al alcance de todos, como The Clinic. Y en Radio Tierra mi proyecto es llegar a hogares donde los libros son inalcanzables. He visto, de todos modos, que mis publicaciones tienen llegada en el pueblo. Hablo de sus cosas elaboradamente, con un poco de aparatosa literatura, pero porque creo que la supuesta identidad chilena es más compleja que la imagen simplona y atontada que nos da el rating televisivo. (PP) 
Esta voluntad de mostrar la complejidad del campo cultural chileno, y al mismo tiempo de "horizontalizar" o democratizar los contenidos de la "catedral cultural" llevándolos a la periferia, volverá a ser tema de interés en más de una entrevista realizada en el ámbito académico, lo analizaré en la segunda parte de este capítulo y es objeto de mi investigación como se verá en el desarrollo del capítulo IV a propósito de los fenómenos de territorialización que dinamizan el campo cultural. Como sabemos, la referida transposición es uno de los tópicos de los estudios culturales en la actualidad y Lemebel se presenta también en este aspecto como un escritor singular. Su capacidad para señalar el dinamismo de las energías internas del campo cultural queda demostrada una vez más. En las declaraciones que acabo de transcribir el autor no está usando despreocupadamente la frase verbal: "hacer el contrabando". Su proyecto es atravesar fronteras sin que ese procedimiento esté "legalizado". Por ello muestra la complejidad del campo social utilizando teorías y metáforas epistemológicas como el "rizoma" y la “desterritorialización”, provenientes del campo académico, para pensar los flujos y reflujos de la dinámica social, o la móvil territorialidad del espacio callejero. Cito como ejemplo su crónica "Gloria Benavides (o 'era una gotita en la C.N.I.')" (Lemebel 1998: 21-23) -texto que será analizado en el capítulo IV a propósito de las identidades y su particular tratamiento en la obra de Lemebel- en la que el autor demuestra potencia y eficacia a la hora de señalar complejidad allí donde por razones ideológicas o por desatención e indiferencia el ojo popular simplifica y consume -legitimandoestereotipos falsos y descalificadores.

En una entrevista realizada por Andrés Gómez B. a propósito de la reedición, en 2001, de La esquina es mi corazón, Lemebel es interrogado acerca del papel que juega el deseo en su visión de la sociedad chilena, a lo cual responde: 
En una ciudad alambrada de prejuicios, acartonada, vigilada, el deseo burla la vigilancia. Anida en lugares de penumbra, como parques, algunos cines, los baños turcos. El deseo es necesario para que respire la ciudad. Hay que soltar algunas perversiones y obscenidades, para sobrevivir. Llenos de cámaras, de micrófonos, de policías a caballo y en moto, aun así se permean deseos subterráneos, que la ciudad necesita y merece para resistir el estrés paranoico del neoliberalismo. (PP)

Esta reedición de su primer libro de crónicas se produce en 2001, durante el gobierno de Lagos, tercero de la Concertación. Y como lo veremos más adelante en el análisis de la primera crónica de este libro, “Anacondas en el parque”, el cronista revela y denuncia la continuidad del control oficial sobre el deseo - sexual y social- de liberación. Lemebel sostiene la potencia del deseo como configuradora del orden social, resistiendo las normas del orden político-policial; la coloca en primer plano, muestra su poder territorial, es decir, su capacidad de modificar los espacios urbanos y de atravesar las férreas divisiones de la escala social. Esa historia de Chile no había sido contada; los homosexuales, las mujeres y otras minorías de género, como así también los pobres, los indios, los rotos, los proletas, habían sido -a lo sumo- señalados como los marginales del tejido social, y -en el mejor de los casos- se les habían "concedido" algunas libertades y derechos. Como dirá Lemebel respecto de sus colegas escritores: "me aceptan con una risa torcida [...] me toleran con una náusea educada" (Costa: 7), pero ni las clases populares ni las clases medias ni las acomodadas han aceptado la condición mestiza del pueblo chileno ni el carácter cambiante, fuertemente dinámico de las determinaciones sociales. ${ }^{33}$ El binarismo ellos/nosotros funciona como presupuesto indiscutido (además de implícito, lo que lo hace operativamente "indiscutible") y determina la organización de los espacios en la vida cultural chilena de los últimos treinta años. La obra de Lemebel, desde las Yeguas del Apocalipsis hasta su último

\footnotetext{
${ }^{33}$ Esta cuestión será desarrollada en el apartado "Lemebel y la historia reciente de Chile", al final del tercer capítulo.
} 
libro de crónicas, trabaja a contrapelo de ese statu quo inercial, denunciando la persecución, especialmente la discriminación homofóbica, y haciendo visible la intrincada trama de los mecanismos de control que operan a su favor.

A partir de 2003, aparecen artículos periodísticos en los diarios Página/12 de Buenos Aires (entrevista “La rabia”, por Andi Nachón, en Página/12 del 25 de octubre 2003) y en el Suplemento $\tilde{N}$ del Diario Clarín de Buenos Aires ("La rabia es la tinta de mi escritura", por Flavia Costa, Suplemento Ñ Diario Clarín de Buenos Aires, sábado 14 de agosto de 2004, páginas 6-9). Como sus títulos lo indican, la dominante de los textos periodísticos sobre las crónicas lemebelianas es, también en la Argentina, su contenido de denuncia social y defensa de las minorías oprimidas, especialmente por cuestiones de género. En la primera de las dos entrevistas nombradas (la de Página/12, realizada por Andi Nachón) destaco dos temas que tendrán particular interés en el desarrollo de esta tesis: el vínculo de su escritura con la poesía y la cuestión de la sexualidad sin determinación de identidad. Lemebel afirma:

La poesía a su manera sigue existiendo, sigue respirando en algunos textos. Con bastante vitalidad. Textos de mujeres jóvenes, muy fuertes. Pero también está la mirada de eso como exotismo. Que habita como exotismo y está escenificada como exotismo. Y se le da un lugar preferencial, para homenajearla, pero como a una señora vieja, latera, lírica y latera. Hay esa falta de respeto con la poesía. [...] una tradición literaria tan masculina... Todos los próceres de la poesía chilena son falos coronados con laureles, por los laureles de la academia literaria. Quizás por eso, a lo mejor, yo hice el doblez. No me dediqué a la poesía porque era un territorio mucho más difícil para un homosexual evidente. No digo declarado, ni tan militante, ni tan fanático. En el fondo, una parada sexual que puede cambiar también. En el amplio abanico de las sexualidades, me tocó ésta en este momento. No sé en el futuro. El futuro puede venir mujer. Puede venir tantas cosas. Tantas sexualidades como personas conozca. (PP)

Con admirable capacidad de condensación, Lemebel plantea aquí dos cuestiones decisivas en su manera de concebir y de producir sus textos. Por un lado, rechaza el 
tratamiento de la poesía como una "señora latera" que debe ser homenajeada (no abona la "separación" que implica siempre un rechazo, aunque utilice la vía del homenaje, como ha explicado Michel Foucault en su ineludible conferencia El orden del discurso). La poesía en su obra es una fuerza que la territorializa, la atraviesa y la potencia con su musicalidad, con sus metáforas y su poder de significación. Por eso rechaza la estrategia de homenajearla y considerarla como "exotismo"; esa separación la habilita como territorio a conquistar, en este caso, conquistado por los "falos coronados de laureles". En el desarrollo de esta tesis se verá cómo en Lemebel la poesía es un "flujo desterritorializado" (Perlongher) cuya naturaleza determina agenciamientos y compuestos discursivos; en este caso su composición con la crónica produce una discursividad nueva y poderosa. ${ }^{34}$

Del mismo modo, la sexualidad no es para el autor una identidad atribuida y mucho menos definitiva. En este campo problemático Lemebel también sigue a su admirado poeta y cronista Néstor Perlongher, quien ha argumentado con gran consistencia teórica y filosófica acerca de esta cuestión en sus ensayos. ${ }^{35}$

A propósito de su "parada sexual" como la llama Lemebel y los devenires que entraña, mi investigación indaga en los actuales debates propuestos por la teoría queer y su concepción de la sexualidad como algo móvil, ambiguo, siempre cambiante, ligada al contexto histórico. En otros términos, la teoría queer ${ }^{36}$ se presenta y funciona como una

\footnotetext{
${ }^{34}$ Este aspecto de la obra de Pedro Lemebel será extensamente analizado en el desarrollo de la segunda hipótesis, en el cuarto capítulo de la tesis, a propósito de las tensiones que dominan su escritura, transformándola en un compuesto heterogéneo.

${ }^{35}$ En especial: "Avatares de los muchachos de la noche": "Lo impropio de esa denominación ['gueto gay', que el autor opone a las 'bocas' de San Pablo] se constata de inmediato: [...] se trata de áreas de circulación [...] focos de emisión de flujos [...] 'bocas' manifiesta por añadidura cierta relación de contigüidad entre las marginalidades sexuales (que atentan contra el orden de la reproducción sexual) y económicas (que atentan contra el orden de la producción social). [...] Se van delineando los personajes de esta red de tránsitos. Es preciso evitar la tentación de pensarlos en tanto "identidades", para verlos en cambio como puntos de calcificación de las redes de flujos (de las trayectorias y los devenires del margen)." (Perlongher 1997: 46-47).

${ }^{36}$ Los ineludibles análisis de: Martínez 2008; Kaminsky 2008; Epps 2008; Blanco 2006; Amícola, 2000; Sinfield 1994, serán tratados en este primer capítulo de la investigación.
} 
práctica crítica desconstructiva que pone de relieve la condición inestable de toda identidad sexual, haciendo visible el carácter jerárquico y excluyente de los binarismos que fundan las identidades modernas.

Como se verá en el desarrollo y justificación textual de mi segunda hipótesis, la condición poética del discurso lemebeliano funciona como un dispositivo necesario a su poder de intervención en la historia, está entramada con él, le es inherente. Lo que quiero subrayar -Pedro Lemebel lo ha dicho claramente en el fragmento de la entrevista que acabo de citar- es que la composición crónica-poesía en su escritura es decisiva para la intervención que opera en el relato de la historia de Chile. El discurso que tiene como imperativo epistemológico la asepsia positivista y la exigencia de objetividad y neutralidad en el relato de "los hechos" no puede narrar la historia que Lemebel quiere contar. No tendría ninguna posibilidad de dar cuenta de la irreductible complejidad de las identidades minoritarias, que siempre están "en menos" respecto de los modelos aceptados de conductas y sociabilidad "regular" o "normal". Lemebel registra los acontecimientos y narra las transformaciones que generan el deseo como fuerza social y el devenir como dinámica ontológica. Ambos desconfiguran la "identidad" normalizada y reconocida por los discursos técnicos y disciplinares (historiografía; etnología; modos del discurso "épico" revolucionario, que trascendentalizan los sujetos históricos y mitifican lo nacional-popular; tendencias dogmáticas de los movimientos sociales que afirman "lo telúrico" como un absoluto a-histórico que define las etnias según el enclave territorial; incluso algunas teorías del género -ya superadas por los estudios queer-que caen en la trampa de la esencialización de los sujetos, y que Lemebel -como lo hiciera Perlongher- no cesa de combatir, deconstruyendo sus binarismos excluyentes). 
En la segunda entrevista mencionada, ("La rabia es la tinta de mi escritura", por Flavia Costa, Suplemento N, Diario Clarín de Buenos Aires) que es acompañada por una importante muestra fotográfica, la periodista realiza una presentación general del escritor -recordemos que es una de las primeras notas que aparecen sobre Pedro Lemebel en un medio argentino- presentando sus crónicas como "amalgama de literatura y periodismo" (7). Aunque Lemebel se encarga de señalar que su prosa y su actividad artística exceden los límites de esa definición, es muy significativo que la crítica repita unánimemente este aserto. Salvo muy pocas excepciones, que señalaré en cada caso, los periodistas, críticos culturales y también los investigadores y críticos literarios especializados ubican la prosa de Lemebel entre la literatura y el periodismo, cuando es muy evidente que interviene también en el campo de los discursos históricos (eje de nuestra primera hipótesis), en el campo académico, como ya hemos señalado y justificaremos en el desarrollo de la investigación, y desde luego en el campo social (por su mirada siempre desconstructiva en relación con las identidades de género, su compromiso con las voces silenciadas durante la dictadura y durante el largo proceso de transición a la democracia y su desconfianza respecto de algunos movimientos que surgieron como espacios de resistencia y terminaron acomodados en el status de la legalización). En la misma nota la periodista lo interroga acerca de los géneros literarios que aborda (la entrevista es de 2004, dos años posterior a la publicación de su única novela: Tengo miedo torero), a lo que Lemebel contesta:

-Mira: la novela Tengo miedo torero fue un desafío, un ejercicio de provocación frente al protagonismo mesiánico de los novelistas machos. Y me resultó, ni trascendental ni como proyecto de mundo, apenas una balada guerrillera y romanticona como un eco trasnochado de la obra de Puig. Nunca escribí poesía, en Chile era un género colonizado por las próstatas locales, y aunque Bolaño dijo que yo era el mejor poeta de mi generación sin ser poeta, su noble intención me significó la envidia de los faunos líricos nacionales. (Costa: 7). 
Estas declaraciones echan luz sobre su opción por el género crónica. Tanto la novela como la poesía son consideradas por el autor como géneros "colonizados" ("protagonismo mesiánico de los novelistas machos"; "próstatas locales" o "falos coronados con laureles" de la poesía chilena). La crónica, como se verá en el desarrollo y justificación de mis hipótesis, constituye un género apto para responder a esa distribución sexista de los géneros literarios. La ficción y la poesía habitan la crónica y la configuran como un género en devenir, por el que transitan diversos modos de textualidad y en el que - no casualmente- se reconoce y se postula la sexualidad como devenir y trayectoria, no como identidad fija. Lemebel es interrogado al respecto en este reportaje. La periodista le pregunta si él alguna vez había pensado "que ser gay o ser travesti podían ser en sí mismas formas de resistencia”, a lo cual Lemebel responde:

-Te aclaro que lo gay no es sinónimo de travesti, marica, trolo, camiona, marimacho o transgénero. Estos últimos flujos del desbande sexual aparecen encintados como multitudes "queer" (raras) después de que lo gay obtuvo su conservador reconocimiento. Quizá son estas categorías las que pueden alterar el itinerario de los azahares gay tan cómodos en el status de la legalización (Costa: 8).

Lemebel realiza una precisión teórica importante al advertir y señalar que la periodista emplea el sustantivo "gay" en un sentido abarcador que -sea por intención normativa o por desatención a las diferencias- uniformiza las identidades sexuales en un universal abstracto, cuyo uso "natural" conspira contra la des-categorización sexual, textual y social que Lemebel propone desde sus crónicas. ${ }^{37}$ Asimismo nuestro autor aprovecha la pregunta para señalar que ninguna transgresión al orden establecido puede

\footnotetext{
${ }^{37}$ Esta es una de las cuestiones que abordan los estudios lésbico-gays y queer latinoamericanos en la actualidad, al concebir la sexualidad como algo móvil, ambivalente, con variantes ligadas a los contextos históricos, sociales y culturales. Señala a propósito Luciano Martínez: "El objetivo es deconstruir las bases ontológicas con las que operan [las categorías de normatividad y desviación] y poner de relieve cómo se construye lo que se considera "normal", "natural" o "esencial" en un momento dado. (2008: 863)
} 
instalarse en "su conservador reconocimiento" sin perder eficacia, riesgo latente para cualquier colectivo que busque la legalización.

Al ser interrogado acerca del lugar de las minorías sexuales ("mujeres, homosexuales, travestis", puntualiza la entrevistadora) en el campo cultural y literario latinoamericano, Lemebel responde: “[...] mientras los maricas poeticemos la maricada está todo bien, en el rincón que le asigna la democracia oficial. Pero cuando se opina sobre etnias, aborto, derechos reproductivos, libertad de culto o políticas económicas, la licencia freak queda cancelada" (Costa: 8). Me interesa esta afirmación por cuanto queda explícita su voluntad de intervenir en otros campos más allá del lugar que "le asigna la democracia oficial" y esto lo dice en relación con el campo cultural y literario en América Latina. Por ello, el autor reconoce y reivindica como una necesidad vital para su escritura la condición marginal:

Con respecto a Chile, la catedral literaria se yergue sobre las plumas de closet; a mí me aceptan con una risa torcida, debe ser porque la crónica marucha no compite con los géneros sacralizados por el canon literario. Me toleran con una náusea educada [...] También no se puede desconocer que hay una calentura mercantil por estos temas, donde cierta morbosidad de lo políticamente correcto mete su espéculo curioso. Uno no deja de ser un polizón en la nave de las letras, pero hay que entrar y salir sin que se sepa por dónde y cuidar que no suenen las alarmas. (Costa: 7)

En muy pocas líneas y con singular lucidez Lemebel plantea su posición en el campo cultural chileno determinado por las líneas de fuerza dominantes que expulsan o intentan colocar al margen su proyecto. Dicha posición marginal es resistida, de modo que su producción se perfila como "lo que hay que aceptar". En esa compleja trama de tensiones Lemebel detecta la garra de lo "políticamente correcto" que disimula el mecanismo de exclusión sin compromiso real con la renovación artística. Por ello 
distingue entre la legítima dinámica del campo y la "calentura mercantil”, señalando la hipocresía del mercado que enmascara su carácter conservador.

La insistencia de la crítica periodística en el carácter combativo de las crónicas lemebelianas no se modifica con la aparición de Zanjón de la Aguada, como lo demuestra la reseña del escritor chileno Alejandro Zambra en Las Últimas Noticias, del miércoles 30 de julio de 2003, titulada "El unicornio de Pedro Lemebel”, de la que transcribo un fragmento:

Como cronista, Pedro Lemebel rara vez desentona. Zanjón de la Aguada, su más reciente recopilación de artículos (Seix Barral, 298 páginas), es la mejor demostración de que con unas pocas pero fervientes obsesiones es posible construir una obra importante o, mejor dicho, una manera de hacer literatura sumamente personal y, sobre todo, profundamente inimitable.

Si en sus libros anteriores el autor había dado buena cuenta de la postergación del mundo gay (antes, durante y después de la dictadura), esta vez se aboca, con su habitual y saludable desmesura, al paisaje social de Santiago. Así, la Plaza Italia y el barrio Dieciocho, el indiferente interior de un mall o el desalentado fanatismo de los hinchas de las barras bravas se reúnen y se confunden en un solo y desolador cuadro de costumbres, boceteado con esa sintaxis intuitiva y arrebatada que ya se ha convertido en una especie de marca de fábrica de Lemebel. (PP)

Si bien la reseña es breve y sin pretensiones de exhaustividad, su afirmación de que "con unas pocas pero fervientes obsesiones es posible construir una obra importante o, mejor dicho, una manera de hacer literatura sumamente personal" no le hace justicia al conjunto de la obra de Lemebel ni al volumen reseñado, Zanjón de la Aguada. Sí acuerdo con Zambra en que este libro enfoca más en el "paisaje social de Santiago" que los anteriores, y le da menos espacio a "la postergación del mundo gay". No obstante, la simplificación que entraña la frase "mundo gay" resulta poco menos que inaceptable en un escritor reconocido y lector atento de la literatura de su país. 
En una entrevista realizada por Sonia Budassi, cuyo título es una frase del escritor: "Me interesa el clandestinaje", publicada en el Suplemento Cultural del semanario Perfil del domingo 27 de agosto de 2006, página 7, Lemebel reafirma su vocación por el margen. Ante una pregunta de la periodista acerca de la difusión de su obra por parte de instituciones culturales, el autor señala los riesgos de cristalizar su posición en una inmovilidad que termina por contradecir la noción misma de "artista marginal": "más bien te colocan allí y te inmovilizan con esa piedad cristiana del pobrecito marica cronista. Me interesa más el clandestinaje, cruzar fronteras, sin que se sepa por dónde" (7). Me detengo en esta respuesta del autor -jerarquizada por Budassi al emplearla como título de la nota- porque roza una cuestión que desarrollaré en el trámite de la presente tesis. Se trata, precisamente, del problemático calificativo de “artista marginal”. Lemebel rechaza esa caracterización como emblema, es decir, se resiste a ser definido por una posición que debe ser móvil por naturaleza. Por ello declara (también lo ha hecho en entrevistas anteriores) la condición dinámica, itinerante, siempre en fuga que orienta su opción por la crónica, su militancia de género y su apuesta estético-ideológica. Por esta razón cita a su amigo Manu Chao, quien afirma de él: "Cuando llega, ya se ha ido".

Otro elemento importante que quiero destacar en esta nota es la declarada admiración de Lemebel por el poeta argentino Néstor Perlongher, que ya fuera señalada en entrevistas anteriores: "Cuando leí a Perlongher me trastornó, lo copié con dulce amargura" (ibidem). Como justificaré más adelante, en el capítulo III, a propósito de su genealogía como escritor, Perlongher juega y ha jugado un papel decisivo, tanto en términos estéticos como en cuanto a su política de género.

Asimismo subraya su resistencia a cualquier género de categorización que lo "fiche" o intente inmovilizarlo como autor y como personaje público. Al ser interrogado 
por la incidencia del mercado en sus gestos políticos, Lemebel responde: “-La fiebre mercantil a veces produce otros comercios paralelos, incita la piratería, la copia no autorizada, el plagio, la reventa. Y quien nunca entró en una librería me encuentra a módico precio tirado en la vereda" (Budassi 7). Sin pasar por alto la poeticidad de la última frase, señalo el tono complaciente del autor respecto de la comercialización pirata de sus textos, actitud amigablemente cómplice con el comerciante informal, enfrentándose así al interés económico que rige la vida del mercado editorial. Esto es corroborado en la misma entrevista por una observación crítica del autor a la editorial Planeta: "En editorial Planeta de Argentina no me quieren reeditar porque me encuentran muy local. Como loca, pero con "ele"' (ibidem). En el mismo sentido elogia el "proyecto cartonero" de Washington Cucurto ${ }^{38}$ quien también ha publicado algunas de sus crónicas.

La tensión mercado editorial-posición marginal es el eje de la reflexión crítica de Henri Billard en su último artículo: "Y la mariquita le dijo al torero... Pedro Lemebel, figura de resistencia cultural" (15-25), en el libro compilado por María A. Semilla Durán: L'écriture de Pedro Lemebel. Nouvelles pratiques identitaires et scripturales, publicado en 2012 por la Universidad de Saint-Étienne. Me ocuparé del libro en su totalidad -está integrado por diez artículos más una Introducción de la compiladorapero me detengo aquí en la colaboración de Billard porque aborda la misma cuestión problemática de la entrevista de Sonia Budassi. El autor, investigador de género en la Universidad de Poitiers, Francia, analiza la "tensión entre la influencia cultural procedente de los países del Norte y los códigos culturales del Sur” y en ese contexto ubica a Lemebel, a quien considera una voz disonante frente "a la hipocresía masculina

\footnotetext{
${ }^{38}$ Se refiere a la editorial Eloísa Cartonera, iniciativa del autor argentino, cuya producción artesanal y su modalidad cooperativa han tenido muy buena recepción, configurando una estrategia editorial paralela y a contrapelo de las grandes empresas cuyos intereses no contemplan la llegada del libro a las capas más desfavorecidas de la sociedad.
} 
y a las contradicciones de la clase política”. El autor subraya la posición marginal de Lemebel en la sociedad chilena otorgándole un valor determinante para su producción: "Desde y gracias a su marginalidad, Lemebel ha dado oxígeno literario a la figura del travesti local como una forma de resistencia a la del gay urbano, socialmente integrado y políticamente correcto" (Billard 15, énfasis mío). Billard destaca el valor de sus performances que resisten "el modelo cosmopolita del gay proveniente de los Estados Unidos" (18), y traza una oposición interesante y poco explorada entre la expresión artística lemebeliana y la llamada Generación $\mathrm{McOndo}^{39}$, cuya intención, según el autor, fue "hacer desaparecer los estereotipos exóticos de la literatura latinoamericana para ofrecer una literatura cosmopolita sin marcas locales y próxima a los Estados Unidos” (23). Sin polemizar con el ensayista acerca de los propósitos de la generación liderada por el peruano Jaime Bayly, señalo en esta afirmación una tendencia a simplificar la problemática generada por aquella tensión que, en efecto, atraviesa el campo literario y artístico latinoamericano, y en cuyo entramado de fuerzas juega un papel protagónico Pedro Lemebel, sobre todo en el contexto chileno. Esta tendencia a la simplificación termina malogrando en alguna medida el artículo de Billard, por cuanto en la última página y sin mediar justificación alguna, afirma:

\footnotetext{
${ }^{39}$ Billard se refiere a un conjunto de autores latinoamericanos reunidos en la publicación colectiva prologada y compilada por el chileno Alberto Fuguet: McOndo, Barcelona, Grijalbo-Mondadori, 1996. Algunos de sus integrantes son: Jaime Bayly, el más visible y mediático del grupo, el escritor boliviano José Edmundo Paz Soldán, los colombianos Juan Gabriel Vásquez y Andrés Caicedo (este último prematuramente desaparecido en 1977), los chilenos Alberto Fuguet y Alejandro Zambra, los argentinos Juan Forn y Rodrigo Fresán, el ecuatoriano Leonardo Valencia, entre otros. El nombre de la generación está vinculado, como es obvio, a la novela Cien años de soledad, paradigma del realismo mágico, que por su enorme popularidad y difusión internacional generó una imagen de América Latina en el mundo a partir de los años setenta, e influyó sobre la producción literaria de numerosos autores. Estos escritores sostienen que esa determinación no siempre ha sido positiva, y por ello rechazan la pretensión foránea de algunos editores y lectores- de que toda la literatura de la región sea homogénea y obedezca a los estándares "canónicos" y mundialmente celebrados del realismo mágico. Por ello rechazan el exotismo latinoamericanista y los excesos de folclorismo y de "color local". Gran parte de la narrativa de McOndo está ambientada en un contexto urbano, a menudo en las periferias empobrecidas de las grandes ciudades latinoamericanas, con marcas de la cultura urbana actual (libertad sexual, violencia, prostitución, delincuencia común, narcotráfico). Un rasgo notable de esta generación -y que también la aleja de los autores del boom - es la ausencia de ideología política específica. La antología incluyó a tres autores españoles (Ray Loriga, José Ángel Mañas y Martín Casariego), aunque poco o nada tuvieran que ver con la batalla cultural que protagonizaba el grupo.
} 
Con el título de su última obra, Adiós mariquita linda, Lemebel pareciera despedirse de sus crónicas anteriores porque a su pesar él también se ha globalizado y la mirada del cronista ahora va más allá de los barrios populares de Santiago. Además, su último libro incluye un glosario. La fama y el éxito lo han llevado a otros países y sus pétalos bordados florecen en otras lenguas. [...] El mercado-torero aplaude y legitima hoy la voz del que lo denuncia. ¿Quién vencerá? ¿El torero o la mariquita? (Billard 24).

Que Lemebel sea traducido a otras lenguas, publique sus últimas colecciones en editoriales multinacionales y se haya mudado de barrio no me parece justificación crítica suficiente para sostener que haya perdido potencia contra-cultural ni mucho menos eficacia en su intervención literaria (y, según mi hipótesis, historiográfica). Nuestro autor conjura con éxito los riesgos de "domesticación" cultural propios del sistema y mantiene su posición marginal en términos sexuales, sociales y políticos. Esos riesgos no se combaten ingenuamente rechazando la publicación en editoriales importantes (además el autor, como ya señalé, ha permitido y aun promovido la distribución "pirata" y la venta informal de su obra, también ha permitido la publicación de Serenata cafiola en Internet simultáneamente con su salida en el mercado del libro), sino renovando las condiciones de producción de los discursos históricos y literarios, denunciando incansablemente la falsa reconciliación y los forzados consensos de la Concertación, la hipocresía del mercado que lucra con la enfermedad y la sensibilidad de los ciudadanos, rechazando los intentos de "legalización" de las agrupaciones gay, que él considera una búsqueda de reconocimiento aburguesada, cómoda y, en última instancia, conservadora. Lemebel ha preferido siempre los "flujos del desbande sexual" o la adhesión a las "multitudes queer" como posición resistente a la domesticación social. En lo que a mi investigación se refiere, sostengo que nuestro autor provoca una transformación radical en las condiciones de posibilidad del discurso histórico y literario, con su original y poderosa combinación de crónica y poesía. 
ADN Cultura, la revista semanal del diario La Nación de Buenos Aires publica en su edición del sábado 13 de marzo de 2010, páginas 10-11, una entrevista concedida en ocasión de la visita del autor a nuestro país a propósito del estreno de la versión teatral de su novela Tengo miedo torero. El periodista, Martín Lojo, titula la nota con una frase del autor: "Mi escritura es un género bastardo". En efecto, a propósito de ello Lemebel afirma:

-Mi crónica no es la que hacen los cronistas latinoamericanos ahora. Los periodistas dicen que hago literatura y los literatos, que hago crónica. En ese intermedio se mueven mis letras y aparentemente se mueven bien. Mi escritura es una mezcla de estilos, un género bastardo, un pastiche de la canción popular, la biografía, el testimonio, la entrevista, las voces y los susurros de la calle. Con esos materiales, literarios o no, me muevo. (Lojo: 11)

Claramente el autor no se deja encasillar en un género establecido ni se considera dentro del sistema literario sin mostrar, por lo menos, una fisura que le permita conservar su posición de borde, su política del margen. Por eso afirma su diferencia con los cronistas latinoamericanos contemporáneos. Si releemos la respuesta que acabo de transcribir, la ambivalencia periodismo-literatura que le atribuyen es lo que justifica el rotundo "no" de la primera afirmación. Su singularidad radica en que sus crónicas no pueden ser clasificadas dentro de los géneros periodísticos sin considerar su naturaleza literaria y su hibridez constitutiva.

En esta entrevista se plantean otros temas importantes como la recepción de sus performances $^{40}$ en los primeros años de la democracia y su reivindicación del folletín en Tengo miedo torero, por ello la retomaremos más adelante.

\footnotetext{
${ }^{40}$ El término performance proviene de las artes plásticas y originalmente (por su etimología inglesa: performance art) significa "arte en vivo". Está íntimamente relacionado con el happening, el body art y, en general, el arte conceptual. El término comenzó a ser utilizado a fines de los años sesenta para definir ciertas manifestaciones artísticas en las que un individuo o un grupo representa una situación particular, empleando vestuario, maquillaje y otros elementos teatrales -usualmente la performance no tiene textoen un lugar determinado y durante un tiempo concreto. Tiene similitudes evidentes con otras expresiones artísticas como la acción poética, la poesía visual, el llamado live art y las intervenciones. Una
} 
En diciembre de 2012 Lemebel presentó su último libro de crónicas: Háblame de amores, en la Sala de Las artes de la Estación Mapocho, en Santiago. Allí lo entrevistó Carolina Rojas para el Suplemento Ñ del Diario Clarín de Buenos Aires que salió a la luz el sábado 15 de diciembre de 2012, en páginas 20-21. La periodista emplea en su nota algunos procedimientos de la crónica: comenta las alternativas de la presentación, describe al público agolpándose en la terraza para verlo, los "fans" que gritan: “¡Te amo, Pedro!” y algunas otras notas de color, para retomar luego temas ya transitados en otras entrevistas, como el papel de lo confesional y autobiográfico en su escritura. Una vez más, como lo hiciera en la nota realizada por Maureen Schaffer para la Revista Hoy en febrero de 1998, citada en este capítulo, Lemebel rechaza la confesión como procedimiento: “-Jamás hay confesión en mis textos. Eso es católico. Mi crónica es un espejeo donde lo que cuento 'puede ser sólo el viento sobre la nieve'”. (Rojas 19)

Del mismo modo vuelve al tema de la indefinición y la hibridez genérica, rasgo inconfundible de su producción, y afirma:

-Siempre en mi crónica conviven incestuosamente la biografía y lo contingente. Además, por qué hay que definir un libro. Háblame de amores es como un rompecabezas o una máquina desarmable y rearmable de panfletos, dibujos, cartas, cuentos, fotos... [...] son afectaciones y complicidades sensibles y políticas, siempre estuve ahí, no tendría por qué estar en otro lugar. (Rojas: 20)

En esta entrevista, la más reciente de las publicadas en un medio argentino, el autor se expresa en relación con el gobierno de Sebastián Piñera (quien asumió la presidencia en marzo de 2010) y el consecuente y definitivo cierre del diario La Nación de Santiago, medio en el que Lemebel publicara muchas de sus crónicas y del que era

característica - aunque debo señalar que sus posibilidades son variadísimas- es su espontaneidad, su claro propósito transgresor, en ocasiones crítico, y su valoración de lo provocador y sorprendente. Todo ello genera una intensa aunque efímera relación con el público. Sus raíces, como es evidente, están en las acciones en vivo inauguradas por movimientos de Vanguardia como el Dadaísmo, el Surrealismo y el Futurismo. Volveré a este concepto a propósito de la oralidad en la escritura de Pedro Lemebel, en el cuarto capítulo de la tesis. 
colaborador habitual. La nota puntualiza en dos momentos de la presidencia de Piñera: el primero, la realización de una cena en homenaje al torturador Miguel Krassnoff ${ }^{41}$ realizada el 20 de noviembre del año 2011 en la comuna de Providencia. La Agrupación de Familiares de Detenidos Desaparecidos realizó una "funa", esto es una protesta pacífica, acompañada por algunos integrantes del campo cultural chileno, Pedro Lemebel entre ellos. El segundo momento recordado en la entrevista fue el asesinato de Daniel Zamudio, joven gay asesinado brutalmente por una pandilla neonazi. A propósito de este crimen, la periodista le pregunta:

-Después del asesinato de Daniel Zamudio [...] hubo conflictos entre fundaciones y rostros que se apropiaron de este incidente. ¿Hay un nuevo prototipo de homosexualidad que se instaló con el discurso de derecha?

-Desde antes, el movimiento homosexual chileno se aburguesó "cerdamente" en la obsesión eunuca de su "matrimonia" gay. Se emparejó con la derecha chilena en sus tibias demandas liberales. Y el repudiable asesinato de este chico lo instaló como el mártir preciso que necesitaba la derecha homo para reforzar sus peticiones legales. Era joven y lindo, un Sebastián gay del neoliberalismo. Si hubiera sido una "trava" vieja no les hubiera importado. (Rojas: 21)

Como vemos Lemebel detecta y señala sin vacilaciones el complejo entramado de la sociedad chilena donde no funcionan los binarismos simplificadores. Critica las "tibias demandas liberales" de lo que para él es un movimiento homosexual aburguesado, y denuncia su elitismo neoliberal que juega el mismo juego de la derecha homofóbica y clasista. Esta concepción de la sexualidad está perfectamente alineada con los debates actuales de los estudios queer, los cuales -como ya he señalado en la nota 37 y será analizado al final del presente capítulo- proponen la sexualidad y sus prácticas

\footnotetext{
${ }^{41}$ Participó como miembro del Ejército en el Golpe de Estado de 1973 y posteriormente, en diversas misiones como miembro designado de la policía secreta Dirección de Inteligencia Nacional (DINA) durante la dictadura militar de Augusto Pinochet (1973-1990). Ha sido acusado y condenado en numerosos casos de secuestro y desaparición de personas, cometidos principalmente en el período entre 1974 y 1976. Krassnoff es uno de los agentes de la represión con más condenas ratificadas por la Corte Suprema de Chile las que suman 144 años de cárcel.
} 
como condiciones dinámicas, sujetas a múltiples cambios, y cuestionan los esencialismos, que tarde o temprano provocan categorizaciones paralizantes $\mathrm{y}$ jerárquicas, reinstalando mecanismos de sujeción y opresión.

Como hemos podido observar, la atención que el periodismo ha dedicado a la obra del chileno desde 1998 a 2012 enfoca principal o exclusivamente, según los casos, en la carga de denuncia y demanda social que presenta tanto la obra narrativa como cronística del autor. Particularmente su defensa de las minorías de género, y su rechazo a la constitución de una identidad homosexual cristalizada o fija, y por ello, reinscripta en el orden social vigente. Esto puede parecer contradictorio a simple vista pero más bien devela la radicalidad del autor respecto de lo que antes he llamado su política del margen. Su obra, y solidariamente su figura social e intelectual, resisten las clasificaciones y sobre todo, la identificación simple: Lemebel no quiere "ser" definitivamente, ni gay ni cronista ni literato ni representante de ninguna minoría. Rechaza enérgicamente cualquiera de esas identificaciones con el fin explícito de rehuir la inmovilidad.

Veremos a continuación, a propósito de la crítica que se desarrolla en el campo académico, que el autor se declara admirador del pensamiento que celebra el devenir como el modo de ser de la multiplicidad, y por lo tanto, una manera de ejercer sus prácticas artísticas con un marcado sesgo contra-hegemónico. Ahora bien, me parece decisivo señalar que en ese universo contestatario también se producen multitud de diálogos y contrapuntos. El campo cultural es heterogéneo y no se deja definir unívocamente. Lemebel es perfectamente consciente de ello y su discurso se sustrae a la fraseología revolucionaria y lo que podríamos llamar el "dogma militante”. Desconfía de las posiciones totalizadores o fuertemente unívocas. Con ese criterio he seleccionado 
las intervenciones en medios periodísticos que transcribí en las páginas precedentes. Lemebel realiza un esfuerzo crítico y artístico para sostener una posición reactiva en el campo cultural, libre de las determinaciones del "gueto" homosexual o de cualquier otro dogma militante.

En la entrevista que presentaré en el próximo apartado, realizada por Juan G. Gelpí y Fernando Blanco para la Revista Nómada, el autor se afirma en una posición siempre inestable, inscripta en las ontologías del devenir, en la estela del pensamiento de Gilles Deleuze y Félix Guattari, a su vez ligados filosóficamente a Friedrich Nietzsche y Baruch Spinoza: "Los pobladores, las barriadas cariocas, los cinturones periféricos, los travestis callejeros saben lo que es el devenir. Lo practican a diario [...] experimentan conceptos como transformar, alterar, metamorfosear, transfigurar”. (Gelpí y Blanco 1997: 96. Énfasis mío.) He subrayado los verbos “practicar” y “experimentar” en la cita precedente por cuanto Lemebel subraya en sus crónicas la capacidad de los habitantes del margen de llevar a la experiencia los conceptos teorizados en la academia; de algún modo ellos encarnan, es decir, prueban la existencia real de esas ideas en su callejero deambular y en su resistencia a la clasificación formal.

De este modo Lemebel deconstruye las dicotomías jerárquicas propias de los modos de clasificación positivistas (adoptando, ciertamente, paradigmas filosóficos del siglo XX que ponen en duda el sistema clásico de pensamiento y clasificación, la metafísica sustancialista occidental y cristiana), demuestra su eficacia ontológica al pensar desde esa perspectiva las nuevas "grupalidades" 42 del fin de siglo XX y

\footnotetext{
${ }^{42}$ Empleo este término porque su especificidad está ligada a la problemática planteada en esta tesis. En la topología de la grupalidad postulada por Sigmund Freud (1927) los lazos de pertenencia que constituyen a los individuos grupalizados no pueden funcionar sino tomando en cuenta aquello exterior-diferenciado con respecto al "nosotros" de la consciencia grupal; en otros términos: la identidad de un grupo no se puede afirmar sino en relación con una alteridad que permite instaurar la diferencia. El aporte de la perspectiva psicoanalítica a la cuestión de las identidades colectivas consiste en que no todo puede explicarse por las condiciones de existencia social, puesto que entre las dos series (identidad colectiva y condiciones de existencia) no es posible establecer relaciones de causalidad simple. La clave de esta idea es el poder de la "ilusión" (el ensayo al que me estoy refiriendo se titula: El porvenir de una ilusión y es
} 
comienzos del XXI en Chile, y al mismo tiempo reescribe un capítulo muy importante de la historia contemporánea de su país.

\section{I.2. Crítica académica sobre la obra de Pedro Lemebel y sobre los ejes problemáticos planteados}

Se ha registrado un interés creciente en las crónicas de Pedro Lemebel en los Congresos, Jornadas, Coloquios y reuniones académicas, sobre todo durante los últimos diez años. Pero ya en 1997, cuando el autor había publicado sólo dos volúmenes de crónicas (La esquina es mi corazón y Loco afán. Crónicas de Sidario) encontramos un texto académico que ubica al escritor en la trama -todavía en debate- del "Neobarroco", emparentándolo con Lezama Lima y Néstor Perlongher, por la vía de la reflexión teórica insoslayable de Severo Sarduy.

Se trata de la comunicación titulada: "Un guante de áspero terciopelo. La escritura de Pedro Lemebel", de Soledad Bianchi, Departamento de Literatura, Universidad de Chile. (Trabajo leído en la Mesa Redonda: “Travestismo: la infidelidad del disfraz", en el marco del Ciclo de Género, Educación y Cultura: Conjurando lo perverso. Lo femenino: presencia, supervivencia, realizado los días 19 y 29 de junio de 1997 en la Universidad Metropolitana de Ciencias de la Educación).

Transcribo a continuación un fragmento:

\footnotetext{
posterior a la Psicología de las masas, publicado en 1921), en virtud de la cual los iguales se vuelven "equivalentes" y los otros, "exteriores", son percibidos como diferentes al nos grupal. Dicho brevemente: el imaginario funciona en la percepción de las posiciones sociales. La acción del imaginario grupal tiende a generar una violenta "compresión" que borra las diferencias -imaginariamente claro está- con el fin de construir el "exterior", el otro, habitado por un índice de negatividad que lo aleja, lo "cercena" de la grupalidad reconocida como propia. Como veremos en el desarrollo de la investigación, Lemebel acorta la distancia no por fusión o indiferenciación, sino porque no cree en las identidades fijas, considera las dicotomías como dispositivos de poder y por lo tanto no reclama legalización, "inclusión" ni reconocimiento; su diferencia se mantiene como condición itinerante y marginal, posición necesaria para llevar adelante su proyecto artístico-político transformador.
} 
Abundan en sus crónicas estos -que yo llamo- deslizamientos o desplazamientos que siento son las mismas "sustituciones" que Sarduy considera un procedimiento propio del Barroco y del NeoBarroco (y así lo afirma en su artículo homónimo), máscaras -las del Barroco y Neo-Barroco- que Pedro ha querido utilizar para enmascarar su voz y desenmascarar; velos -los del Barroco y NeoBarroco- tras los cuales se ha ocultado una mirada mirona, una mirada de voyeur que se expone a exhibir, mostrar, dejar ver en textos nombrados más de una vez como "crónica[s] voyeur". Disfraces, finalmente, que lo ligarían con cierta tradición dándole, tal vez mayor seguridad a ese "imaginario frágil de sus tacoaltos" (Esquina, 28); confiriéndole, quizás, mayor repercusión a su palabra, a su lenguaje, a su escritura. Porque al contemplar, acercarse y juguetear con esos autores, Pedro Lemebel ha optado por cierta genealogía -nada de arbórea, por supuesto-- O, mejor dicho: su obra podría considerarse una raicilla más de una red entre cuyos nudos pueden reconocerse a Lezama Lima, Sarduy, Perlongher: cada uno a su modo, con sus particularidades, en sus escenarios, en sus territorios, pero todos espejeando, reflejando y haciendo reflejar, provocando y acogiendo ecos, deslizándose desde Cuba, La Habana-París, a Buenos Aires y, en su navegación, atracar con las santiaguinas orillas del Mapocho; delineando un mapa otro, diferente y de la diferencia. Fluyendo del Barroco, al Neo-Barroco (americano ya), al Neobarroso rioplatense, al Neobarrocho. (PP)

Como vemos, la autora integra los textos de Pedro Lemebel en la "red" del Neobarroco, y subraya la condición de "mirada mirona" o "crónica-voyeur" de los textos lemebelianos, en coincidencia con uno de los rasgos discursivos del género que hemos señalado en la Introducción. Pero lo que más me interesa destacar en esta comunicación es el carácter del vínculo que la ensayista establece entre Lemebel y los autores que nombra; al tiempo que contextualiza la obra del chileno describe sus vínculos con metáforas lo suficientemente móviles e indeterminadas (red, raicilla, nudos, espejos y reflejos, ecos) como para no caer en una terminología propia de las estructuras rígidas o los sistemas cerrados la cual resultaría contradictoria con los deslizamientos y las resonancias que conectan estas escrituras: "todos espejeando, reflejando y haciendo reflejar, provocando y acogiendo ecos, deslizándose desde Cuba, 
La Habana-París, a Buenos Aires y, en su navegación, atracar con las santiaguinas orillas del Mapocho".

Comparo este acierto de Bianchi con lo que considero una limitación evidente en uno de los textos más citados y celebrados sobre la obra de Pedro Lemebel. Carlos Monsiváis prologa en 2001 la reedición de La esquina es mi corazón, primer libro de Lemebel, originalmente publicado en 1995. Este prólogo se titula "El amargo, relamido y brillante frenesí"; fue leído por Monsiváis en la presentación oficial del libro, la cual tuvo lugar el 2 de noviembre de 2001 en el marco de la XXI Feria Internacional del Libro de Santiago, celebrada entre el 23 de octubre y el 4 de noviembre en la Estación Mapocho; fue retomado por el propio Monsiváis en 2007 en un artículo que será comentado más adelante ("Lemebel o el barroco desclosetado"), y ha sido citado en numerosas referencias al autor chileno, tanto en textos académicos como en publicaciones periodísticas.

Destaco la admirable cultura letrada de Monsiváis que pone en contexto las crónicas del chileno con una serie de reconocidos y muy valorados escritores latinoamericanos pero también, quiéralo o no el ensayista, determina la existencia de un "gueto" en el que resulta incluido Lemebel. Citaré tres fragmentos y realizaré a continuación mis observaciones:

Pienso ahora entre otros en el argentino Néstor Perlongher, el mexicano Joaquín Hurtado y, un tanto más a distancia, los cubanos Severo Sarduy y Reinaldo Arenas y el argentino Manuel Puig. Se trata de una literatura de la ira reinvidicatoria (Perlongher, Arenas, Hurtado), de la experimentación radical (Sarduy), de la incorporación festiva y victoriosa de la sensibilidad proscrita (Puig). En todos ellos lo gay no es la identidad artística, sino la actitud que al abordar con valor, insistencia y calidad un tema se deja ver como el movimiento de las conciencias que por valores compartidos y acumulación de obras dibuja una tendencia cultural. No hay literatura gay, sino una sensibilidad proscrita que ha de persistir mientras continúe la homofobia, y estos autores al asumir con talento y vehemencia sus 
voces únicas, le añaden una dimensión cultural y social a la América Latina. (PP)

Desde luego que "la sensibilidad proscrita" de la que habla Monsiváis está presente en las crónicas lemebelianas y también, por cierto, "la ira reivindicatoria”, pero me parece absolutamente insuficiente reducir el impacto y la originalidad de la obra del chileno a estas características que lo adscriben al gueto homosexual o gay. El propio Lemebel no se cansa de rechazar esa clasificación que lo inmoviliza y lo convierte en una "voz representativa"; nada más lejos de la sensibilidad reactiva y la rebeldía radical del escritor nacido en Santiago. Monsiváis emplea en dos oportunidades (sin ironía ni propósito crítico) el sustantivo "gueto":

Un poeta muy apreciado por Lemebel, Néstor Perlongher, describe el gueto: "Novedades de noche: satín terciopelo, modelando con flecos la moldura del anca, flatulencia de flujo, oscuro brillo. Resplandor respingado, caracoles de nylon que le esmaltaban de lamé el flaco de las orlas... Perdida en burlas, de macramé, lo que pendía en esas naderías, ruleros colibrí, lábil orzuelo, era el revuelvo de un codazo artero, en las calcomanías del satín, comido (masticación de flutes, de bollidos)". (PP. Énfasis mío)

Con la referencia a Perlongher anticipa la relación que establecerá entre Lemebel y los poetas neobarrocos:

Estas mismas atmósferas lezamianas, transmitidas por Lemebel, son algo similar y muy opuesto. En Lemebel la intencionalidad barroca es menos drástica, menos enamorada de sus propios laberintos, igualmente vitriólica y compleja, igualmente abominadora del vacío, pero menos centrada en el deslumbramiento del vocabulario que en la forma exhaustiva. Así, Lemebel describe la intromisión del gueto en la ciudad, las reverberaciones de lo prohibido en lo permitido exactamente en el momento en que los absolutos se desintegran: "La calle sudaca y sus relumbres derribistas de neón neoyorquino se hermanan en la fiebre homoerótica que en su zigzagueo voluptuoso replantea el destino de su continuo güeviar. La maricada gitanea la vereda y deviene gesto, deviene beso, deviene ave, aletear de pestaña, ojeada nerviosa por el causeo de cuerpos masculinos, expuestos, marmoleados por la rigidez del sexo en la 
mezclilla que contiene sus presas. La ciudad, si no existe, la inventa el bambolear homosexuado que en el flirteo del amor erecto amapola su vicio. El plano de la city puede ser su página, su bitácora ardiente que en el callejear acezante se hace texto, testimonio documental, apunte iletrado que el tráfago consume" (de Loco afán). (PP. Énfasis mío)

Monsiváis vincula aquí, como lo hiciera antes Soledad Bianchi, la obra de Lemebel con el universo del Neobarroco latinoamericano, hipótesis que comparto y que será justificada en el desarrollo de la presente tesis. ${ }^{43}$ Ahora bien, si acordamos con el ensayista mexicano que es propio de la "intencionalidad barroca" describir "las reverberaciones de lo prohibido en lo permitido exactamente en el momento en que los absolutos se desintegran", resulta paradójico que el mismo Monsiváis señale reiteradamente el "gueto" homosexual como marco de visibilidad y contención en el cual la voz del chileno se expresa y se reconoce. La sensibilidad barroca deconstruye o pulveriza los absolutos como polos de una dicotomía irreductible, pero no para configurar nuevos absolutos, en este caso y en términos de Monsiváis, el "gueto gay". Lemebel, como hemos señalado exhaustivamente en este capítulo, y como lo hiciera Perlongher en sus ensayos -también citados en esta tesis- se encarga de rechazar una y otra vez esa determinación que falsea el movimiento incesante de su escritura. Esa intención, además, está explícita precisamente en el fragmento que el propio Monsiváis cita: "la fiebre homoerótica que en su zigzagueo voluptuoso replantea el destino de su continuo güeviar” (el énfasis es mío). Volveremos a esta problemática en el desarrollo de las hipótesis a fin de subrayar el propósito del autor de permanecer en el margen, ajeno a los intentos de aceptación y legalización de la homosexualidad.

El poeta y antropólogo chileno Yanko González publica en 1997 el que hasta ese momento era, según sus propias palabras, "uno de los pocos trabajos en las lateras

\footnotetext{
${ }^{43}$ Ver en el Capítulo III la inscripción de Lemebel en las estéticas neobarrocas, en vínculo con el poeta argentino Néstor Perlongher y los cubanos Lezama Lima y Severo Sarduy.
} 
revistas 'científicas' universitarias sobre la obra de Lemebel” (González 2007). A él se refiere el 14 de setiembre de 2005, a propósito de la presentación de: Adiós mariquita linda. En dicho acto -celebrado en la Universidad ARCIS- lee un texto titulado: "Lemebel o el poder cognitivo de la metáfora", en el que hace referencia a ese trabajo de 1997:

Los caprichos de Lemebel han hecho posible que hoy me guarde como poeta y salga del armario como antropólogo. Por lo mismo, sé que Pedro, esta vez, espera más que un par de gárgaras lingüísticas, sino, la suspensión -que no supresión- de alguna duda sobre su propio ejercicio escritural. El año 1997, escribí lo que hasta ese momento, era uno de los pocos trabajos en las lateras revistas "científicas" universitarias sobre la obra de Lemebel. El artículo, titulado "Loco Afán: una bella etnografía sobre el dolor marica", tenía la particularidad juguetona de imitar la escritura de Pedro, acercándose lo más posible a lo que me parecía un grueso aporte estético inscrito al interior de la crónica en Chile: la construcción de un nuevo alfabeto a partir de la adjetivación enrarecida, el hipérbaton, cientos de neologismos "emic" y una lucha frontal en contra de la economía del lenguaje. Aunque esta paráfrasis estética (o mimesis crítica) para hablar sobre el texto resultó una golosina para la criticona revisteril de la academia apoltronada -en esa onda iba el papers - la promesa del título se cumplió apenas. (PP)

El autor se propone aquí completar el programa inconcluso de su artículo anterior, y para ello reenvía a sus observaciones de $1997^{44}$ en las que ya consideraba a Lemebel el constructor "de un nuevo alfabeto a partir de la adjetivación enrarecida, el hipérbaton, cientos de neologismos 'emic' ${ }^{45}$ y una lucha frontal en contra de la economía del lenguaje". Aunque no cita a Sarduy ni nombra al Neobarroco, alude a un conjunto de rasgos que según el célebre escritor cubano desaparecido en 1993, serían

\footnotetext{
${ }^{44}$ Desafortunadamente, el trabajo de 1997 del Dr. Yanko González es absolutamente inhallable. Me he comunicado personalmente con él, y afirma no haber conservado ninguna separata, ni copia del artículo ni de sus borradores.

${ }^{45}$ La distinción emic/etic se usa en las ciencias sociales y las ciencias del comportamiento para referirse a dos tipos diferentes de descripción relacionadas con la conducta y la interpretación de los agentes involucrados. Una descripción emic, o émica, es una descripción en términos significativos para el agente que las realiza. Así por ejemplo una descripción emic de cierta costumbre de los habitantes de un lugar estaría basada en cómo explican los miembros de esa sociedad el significado y los motivos de esa costumbre. Una descripción etic es una descripción de hechos visibles para cualquier observador, tenga o no el propósito de descubrir el significado que los agentes involucrados le dan. (Fuente: Pike, Kenneth Lee. Language in relation to a unified theory of structure of human behavior, The Hague: Mouton, 1967).
} 
centrales en esa estética (recordemos que fue Severo Sarduy quien acuñó el término "Neobarroco" e intentó si no definirlo, bordearlo por primera vez). Dibujando un arco que va de 1997 a 2005, la crítica -con mayor o menor distancia del universo académico- parece unívoca a la hora de vincular la estética lemebeliana al “árbol Lezama" según la entrañable metáfora de Sarduy.

El trabajo de Yanko González de 1997 (calificado por el propio autor como "paráfrasis estética o mimesis crítica") es el primero en el campo académico que señala la relevancia de las crónicas de Pedro Lemebel en vínculo con otras disciplinas humanísticas como la etnografía y la antropología. La hipótesis del profesor González se encuentra más desarrollada en el artículo titulado: "Etnografía persistente: Pedro Lemebel o el poder cognifivo de la metáfora", publicado en 2007 en la revista Atenea, Concepción, Chile, número 496, págs. 161-165. Me voy a detener en ese artículo porque destaca la importancia de Lemebel no sólo en el campo de la literatura sino específicamente en el de las ciencias sociales.

González parte de un aserto caro a la antropología, según el cual: “reconocemos una buena descripción cuando la vemos". Según el especialista, uno de los problemas que enfrenta la antropología es determinar qué distingue y valida esa descripción, qué autoridad tiene para describir al "otro". Según González, el "entuerto" se ha resuelto con heridos graves (entendemos: para la pretensión positivista), dado que "la descripción etnográfica es un género literario y, lo que es peor para nuestro gremio, es un género contrahecho, tributario de otros, especialmente de la crónica y, en América Latina, del muy castizo "costumbrismo"' (2007: 162). El autor revela que la antropología chilena no ha sido capaz de producir un conjunto sistemático de textos sobre "sus otros" que "puedan tener la eficacia comunicativa y cognitiva de Biografía de un cimarrón de Miguel Barnet (1968) o El zorro de arriba y el zorro de abajo (1971) 
de José María Arguedas” (2007: 162). De allí la importancia antropológica de la obra de Pedro Lemebel, por ello afirma que

[...] hay algo en la obra y la escritura de Lemebel que constituye una anomalía, tanto en la tradición literaria costumbrista del siglo XIX, en la cronística del siglo XX, como en la escueta etnografía escrita en Chile: su condición de actor social gay, urbano-popular e ilustrado; nativo a la vez que observador. Todo ello convierte sus escritos en documentos excepcionales, no sólo como "fuentes" (datos secundarios), sino también como trabajos analíticos de primer orden. (Y. González 2007: 163).

Como vemos, González le atribuye a Lemebel la capacidad de producir textos específicamente etnográficos dada la calidad de sus descripciones, y destaca su singularidad al constituirse en productor de un trabajo analítico de primer orden por su punto de observación privilegiado: "actor social gay, urbano-popular e ilustrado; nativo a la vez que observador”. Esta posición de Lemebel determina su lugar de enunciación y será tenida en cuenta en el desarrollo de la presente tesis, como así también la vecindad entre su obra y las disciplinas sociales, destacada por un especialista perteneciente a ese campo, el cual considera que los textos del chileno constituyen un corpus eficaz además de singular- para el conocimiento de "las distintas alteridades que se han articulado" en Chile. Para concluir mi referencia a este texto, voy a citar un último párrafo que revela el valor cognitivo de la metáfora -el autor explica con precisión qué entiende por él- y la singular eficacia de la intervención de Lemebel en la ciencia social:

Quizás, la particularidad etnográfica de Lemebel en este libro [Adiós mariquita linda] es su desplazamiento hacia la síntesis: la descripción de la mano con un plan hermenéutico trazado. Varios corpus están teñidos de este sincretismo, no sólo en "El alfabeto iletrado...", sino también y maravillosamente en "La momia del cerro El Plomo". Esta pieza constituye, sin duda, un ejercicio metodológico para la arqueología, a cuya meta - "sacarle el habla" a las materialidades pasadas- mis colegas llegan con la misma dosis de imaginación, pero con sopor y escasa eficacia comunicativa. Si el 
autor no hubiera cifrado a pie de página que la crónica era una interpretación libre de los hechos -sino, una especulación esclava de los mismos- y le hubiese agregado una batería de referencias bibliográficas a modo de "joyas pedantes", el texto es un artículo de divulgación científica a lo menos, singular. He ahí el poder cognitivo de la metáfora. (Y. González 2007: 163)

González destaca el "plan hermenéutico" que él sabe leer en la obra de Lemebel. Los textos que cita tomados del libro Adiós mariquita linda constituyen ejercicios de arqueología, en tanto y en cuanto esa disciplina busca "sacarle el habla" a las piedras, a las ruinas, a los restos del pasado, propósito que cumplen este conjunto de crónicas lemebelianas. Volveré a este artículo de Yanko González en el desarrollo de las hipótesis a propósito del rescate de la oralidad en los textos del chileno.

Párrafo aparte merece la temprana entrevista realizada en Santiago de Chile por Fernando Blanco y Juan G. Gelpí entre enero de 1996 y enero de 1997 para la revista Nómada, de San Juan de Puerto Rico, y publicada en el número 3, correspondiente al mes de junio de 1997. Cabe aclarar que tanto la revista como los entrevistadores pertenecen al campo académico y los temas abordados responden a la agenda literaria y cultural del Chile de la posdictadura. Las preguntas giran en torno a la opción de Lemebel por la crónica como género y su papel en el campo intelectual. Además, el autor esboza cierta trayectoria autobiográfica, señalando su paso del cuento a la crónica. En ese traslado destaca un punto de inflexión determinante que tuvo lugar en 1990:

La crónica fue un desdoblamiento escritural que se gestó cuando los medios periodísticos opositores me dieron cabida en el año 90. [...] Creo que pasé a la crónica en la urgencia periodística de la militancia. Fue un gesto político, hacer grafitti en el diario, "cuentar", sacar cuentas sobre una realidad ausente, sumergida por el cambiante acontecer de la paranoia urbana. (Blanco y Gelpí: 93)

Dos temas abordados en esta entrevista son dignos de destacar porque determinan la posición de Pedro Lemebel en el campo cultural-intelectual y su 
relevancia en la renovación de las formas literarias. El autor es consciente de su nomadismo y de la productividad de su obra dentro de un sistema en permanente cambio. Ante la pregunta de Juan G. Gelpí acerca de su concepción de la crónica, Lemebel responde:

Digo crónica por decir algo, por la urgencia de nombrar de alguna forma lo que uno hace [...] cierto afán escritural embarrado de contingencia. Te digo crónica como podría decirte apuntes al margen, croquis, anotación de sucesos. (Blanco y Gelpí: 93).

Además de elegir un registro de escritura "embarrado de contingencia", deliberadamente la fragua de sus textos es la radio y los medios gráficos de comunicación, por cuanto su trabajo reclama una transmisión no ligada a los medios convencionales de consagración literaria o cultural, y más cercana al desequilibrio formal y el nomadismo inherente a la comunicación cotidiana y efímera propia del hecho periodístico, particularmente en el medio radial. Al mismo tiempo y en consonancia con lo que acabo de señalar, rechaza explícitamente la "postura doctrinaria sobre el saber", razón por la cual "mis escritos pasan siempre por medios masivos antes de transformarse en libros” (Blanco y Gelpí: 94, énfasis mío).

Si bien la entrevista también releva su alianza con las minorías, se recorta claramente del panorama de la crítica no especializada al abordar otro tema digno de ser destacado: su inscripción en las ontologías del devenir, particularmente los desarrollos teóricos de Gilles Deleuze y Félix Guattari, con quien el escritor ha entablado una relación intelectual-afectiva de la que da cuenta brevemente, en un pasaje muy lúcido de la entrevista. Lemebel afirma que para él es muy fácil entender el devenir:

Los pobladores, las barriadas cariocas, los cinturones periféricos, los travestis callejeros saben lo que es el devenir. Lo practican a diario... pasar por el ojo de una aguja sin ser rico ni camello, deslizarse de un momento espinudo a otro [...] ellos manejan 
los códigos tránsfugas del devenir, experimentan conceptos como transformar, alterar, metamorfosear, transfigurar. (Blanco y Gelpí: 96)

La mención de las minorías itinerantes y su errancia, configurando cartografías del margen, evoca poderosamente la figura de Néstor Perlongher quien es nombrado en la entrevista bajo la metáfora de otro devenir: "alambres transplatinos", en alusión al libro de poemas del autor argentino, Alambres, y el ensayo publicado en 1992 como "Neobarroco transplatino" 46 , en cuya "desterritorialización fabulosa" se inscribe el escritor chileno. Como se verá en el desarrollo del Capítulo II, en el que analizaré el contexto de producción de su obra, la escritura de Lemebel reformula los procedimientos del Barroco áureo transformándolos: el claroscuro, la proliferación indefinida, el pliegue, el desplazamiento del foco, la reelaboración de la picaresca, entre otros procedimientos que serán analizados especialmente en su segundo libro, Loco afán. Crónicas de Sidario.

Ángeles Mateo del Pino publica en 1998 un artículo breve titulado: “Chile mar y cueca... arréglate Juana Rosa que llega Pedro Lemebel", en el $\mathrm{N}^{\circ} 4$ de Espejo de paciencia, Revista de literatura y arte de la Universidad de Las Palmas de Gran Canaria. Si bien hasta ese momento el autor había publicado solo dos libros de crónicas y tenía el tercero en preparación, la autora del artículo percibe y expresa con lucidez las grandes líneas de fuerza de la obra cronística de Lemebel, ligada a la memoria colectiva:

Sus textos se convierten así en testimonio, documento y memoria de los desmemoriados, de aquéllos a los que se les negó la posibilidad de pronunciarse, al ser relegados a una oralidad en baja voz por temor a ser escuchados; pero, también de esos otros que perdieron el habla y el derecho a la palabra al optar por el silencio y el olvido. (Mateo del Pino 1998a: 92)

\footnotetext{
${ }^{46}$ Este ensayo fue en su primera versión el prólogo a Caribe Transplatino. Poesía neobarroca cubana e rioplatense, selección de poemas realizada por Néstor Perlongher y publicada por la editorial Illuminiras de San Pablo, Brasil, en 1991.
} 
También acierta Mateo del Pino en la descripción del sujeto textual de estas crónicas, el cual establece un vínculo físico entre el territorio y la escritura, provocando en el lector una experiencia particular del recorrido urbano. Si bien, como se verá en el desarrollo de mis hipótesis, no me parece del todo afortunada la selección de los términos "simbiosis", "metamorfosis", "identificación", por su matiz sintetizador o conclusivo, me parece acertada la percepción de un vínculo poderoso y material entre el discurso, el cuerpo y la ciudad:

[...] en las crónicas asistimos a una suerte de simbiosis entre el narrador y lo narrado, entre lo que se cuenta y el cómo se cuenta, entre el texto y la realidad. Un proceso de metamorfosis en el cual el registro discursivo se traviste e identifica con la voz de la urbe santiaguina. (Mateo del Pino 1998a: 92-93).

Esa intuición se ajusta y cobra precisión sobre el final del artículo, con el que coincido plenamente, y al que volveré en el desarrollo de la investigación:

Un ojo deseante y deseado que recorre con lascivia la ciudad de Santiago. Urbe que en la pupila del narrador-testigo-cronista se convierte en un gran soma que se desnuda, se disfraza, se colorea y se traviste a su ant-ojo. Cuerpo-ciudad que en manos de Pedro Lemebel se transforma en cuerpo-textual, cartografía de las fantasías sexuales y las apetencias eróticas de los ciudadanos. Discurso que apuesta por el poder subversivo del deseo y la función revolucionaria del erotismo: el placer no sólo como explosión corporal sino como crítica moral y política de la sociedad. Escritura que responde al tráfico constante de cuerpo-ciudad-texto, cuyo fin es siempre revelar el "otro lado" —el oscuro, el silenciado. (Mateo del Pino 1998a: 95).

En efecto, Lemebel "apuesta por el poder subversivo del deseo" en tanto y en cuanto ese poder configura nuevos recorridos y actores sociales que no habían sido incluidos en ningún discurso. Lemebel pone en la escena textual ese deseo narrando una historia de Chile desde el punto de vista móvil y plural propio del cartógrafo deseante. 
En el mismo año, la autora publica "Chile, una loca geografía o las crónicas de Pedro Lemebel", en el $\mathrm{N}^{\circ} 80 / 81$ de la Revista Hispamérica. El título hace referencia al conocido ensayo de Benjamín Subercaseaux publicado en 1940: Chile, una loca geografía; la autora subraya una de las tesis fuertes del libro -citado en el epígrafe- a saber: la originalidad de Santiago, su condición de "ciudad contradictoria por esencia", cuya diversidad desalienta a los que pretenden fijarla. En este artículo vuelve a una de las hipótesis del trabajo anterior a propósito del valor testimonial de las crónicas lemebelianas, su intento de "rescatar del olvido hechos o personajes de la historia" conjugando ese valor con la fuerza de la imaginación:

Memoria, historia, imaginación que en el caso de la crónica se aunan para evidenciar la escritura como espacio de reflexión. Así, el narrador como sujeto del discurso arma un texto -acaso un pre-texto, medio o vehículo- para preguntarse a sí y a los otros, para analizar, dudar, recordar... sobrevivir. [...] Este poder evocador y sugerente del cronista que vive y experimenta lo relatado es lo que, sin lugar a dudas, vivifica la materia narrativa y nos devuelve un discurso íntimo, a medio camino entre la poesía y la prosa. (Mateo del Pino 1998b: 18)

Destaco la condición de compuesto discursivo -en mis términos- que presenta la prosa de Lemebel, señalada aquí por la ensayista, quien postula la múltiple condición de su escritura: historia e imaginación que "vivifica la materia narrativa", y poesía / prosa, que la hace "íntima". La presente tesis tomará dicha hibridez como un rasgo singular de este cronista, sobre todo en el desarrollo del Capítulo IV en el que planteo las conexiones heterogéneas (historia/ ficción, crónica/ poesía, escritura/ oralidad) como rasgo peculiar de su escritura y vehículo de las identidades negadas por los discursos políticos y disciplinares reconocidos u oficiales. En este mismo campo (me refiero a las operaciones que conectan la crónica lemebeliana con otros discursos y aun con otras materialidades) Mateo del Pino señala en los artículos citados la importancia de la oralidad (la autora se enfoca en el libro: De perlas y cicatrices): "al leer los textos de 
Pedro Lemebel se escuchan siempre voces de muchos otros que juguetean entre las líneas y vociferan entre las páginas" (1998b: 22).

Destaco, finalmente, una observación que considero muy importante en la obra de Lemebel: el tratamiento del "margen chileno", señalado por Mateo del Pino aunque posiblemente por la brevedad del artículo- es una idea que no desarrolla:

Estas crónicas no tratan tan sólo de identificar el 'margen chileno', sino más bien de diferenciarlo, no buscan categorizarlo sino propiciar la discusión en torno a él. Es la cara de esa otra realidad chilena que no forma parte de los tópicos, ni de los lugares comunes. (Mateo del Pino 1998b: 26)

En efecto, Lemebel no busca categorizar sino todo lo contrario: sus textos son una poderosa estrategia de deconstrucción de las categorizaciones paralizantes surgidas de algunos discursos políticos, sociales y aun académicos. Este también será un problema a desarrollar en el Capítulo IV de la presente investigación, a propósito de las identidades latinoamericanas y la crítica al sesgo fundamentalista de algunos marcos disciplinares (García Canclini 1995: 14).

En: "Cronista y malabarista. Entrevista a Pedro Lemebel", realizada por la misma autora, publicada en Revista Cyber Humanitatis, $\mathrm{N}^{\circ}$ 20, primavera de 2001, Lemebel se refiere a su experiencia "performática" $" 47$ anterior a la publicación de su primer libro de crónicas en los siguientes términos:

Aun así evoco a las Yeguas como un imaginario delirante que intentaba contener algunos lugares minoritarios que no estaban contemplados en el proyecto de la futura democracia que se peleaba en esos años. Creo que hoy esos lugares por los que batallamos las

\footnotetext{
${ }^{47}$ Es muy importante este aspecto en la obra de Pedro Lemebel. No sólo por su formación artística vinculada a las artes plásticas- o porque el origen de su carrera esté en las performances y las instalaciones del colectivo de arte "Yeguas del Apocalipsis" que integró junto a Francisco Casas, sino fundamentalmente porque toda su producción como cronista pone en evidencia la importancia de la performance también en su escritura. Esta consideración ocupa un lugar central del Capítulo IV por cuanto el texto lemebeliano está configurado no sólo por palabras, sino también por sonoridades, ritmos, elementos visuales, esto es, abarca los factores de la performance (cfr. Zumthor 1983: 83-84).
} 
Yeguas siguen más ausentes que nunca coartados o simplemente invisibilizados por esta farsa democrática que añora al tirano.

Lo de Yeguas tiene que ver con cierta reivindicación de palabras duras y fuertes que ofenden a la mujer. En Chile la palabra yegua es sinónimo de libertina, de mala mujer como perra, puerca, etc. Nosotros al usar este adjetivo con glamour lo descargamos de misoginia. Pero también el nombre completo citaba los jinetes del Apocalipsis metaforizados en una gran ópera sobre el Sida. También es un nombre rutilante como de película hollywoodense del 50, en suma el nombre fue un artificio más de nuestro desnutrido y sudaca ajuar travesti. (Mateo del Pino 2001: online)

Subrayo en esta respuesta del autor la orientación crítica y conceptual del colectivo de arte "Yeguas del Apocalipsis", que "intentaba contener algunos lugares minoritarios" no contemplados ni en el proyecto de la futura democracia por el que se peleaba en los años ochenta, ni en el presente (la entrevista es del año 2001) en el cual "siguen más ausentes que nunca coartados o simplemente invisibilizados por esta farsa democrática que añora al tirano". Esta última afirmación es tan contundente como sus crónicas que, a más de diez años de la recuperación democrática, denuncian la red de complicidades y la vigencia de los mecanismos de exclusión de las minorías durante el gobierno de Lagos.

Interrogado acerca de su opción por las crónicas como género, y en consonancia con respuestas dadas en otras entrevistas (Blanco y Gelpí 1997; Jeftanovic 2000), el autor responde: "Yo digo crónica por decir algo, quizás porque no quiero enmarcar o alambrar mis retazos escriturales con una receta que pueda inmovilizar mi pluma o signarla en alguna categoría literaria”. Una vez más Lemebel rehúye la categorización de su discurso, rechazando los marcos convencionales de la literatura que puedan “inmovilizar” su producción. Por eso concluye su respuesta:

Puedo tratar de definir lo que hago como un calidoscopio oscilante, donde caben todos los géneros o subgéneros que posibiliten una estrategia de escritura, así la biografía, la carta, el testimonio, la canción popular, la oralidad, etc. Creo que escogí esta escritura por las 
distintas posibilidades que me ofrece o que puedo inventar, para decirlo en lenguaje travesti es como tener el ropero de Lady D. en el computador. (Mateo del Pino 2001: online)

Rescato los términos "estrategia de escritura", por cuanto en ellos hace explícita su intención de escribir e intervenir en el campo de los discursos literarios. Eso está en relación directa con una de mis hipótesis, a saber: la escritura de Pedro Lemebel como una intervención activa y poderosa en universos discursivos atravesados por la convención y sus normas como la literatura y la historia. En esos universos Lemebel participa, interviene y obliga a cuestionar los moldes estatuidos ante la audaz provocación y la compleja elaboración que implican sus composiciones heterogéneas: historia y ficción, crónica y poesía, oralidad popular y refinadísima escritura literaria.

Por último, cito esta entrevista en relación con la conciencia de singularidad que caracteriza al escritor chileno:

- ¿Crees que existen diferencias notables -formales o de contenidoentre tus crónicas y las de Carlos Monsiváis, Edgardo Rodríguez Juliá o José Joaquín Blanco?

- Muchas, tantas como los kilómetros que separan las distintas territorialidades que se escriben en el formato crónica. Son voces y saberes que, más allá de practicar el mismo género, se colorean distinto según la instancia política que las genera, aunque el afán por testificar un tiempo, un continente y muchos deseos contenidos tal vez aúnen en los bordes cierta alianza crítica y movilizadora de otros imaginarios y agredidas subjetividades. (Mateo del Pino 2001: online)

Nuevamente me detengo en una expresión significativa empleada por el autor: "voces y saberes". Como quedará demostrado en el desarrollo de la presente tesis, las crónicas de Pedro Lemebel, con su singular carga de oralidad y su originalísimo empleo del registro poético, vehiculizan un saber y se constituyen como discurso disciplinar-no- 
disciplinado. Otros dos trabajos de la autora bordean cuestiones ya planteadas en las referencias a los artículos $\operatorname{citados}^{48}$. Por ejemplo:

Lemebel fuerza a recordar y para ello hurga en esa cicatriz abierta que sigue siendo el Chile de nuestros días. Escritura que acaso cartografía algunos mapas de ese largo país con una loca geografia, tal como lo describiera Benjamín Subercaseaux, o parte de ese "cuerpo" o "bulto patrio", como lo denominara Gabriela Mistral. Pero lo que nunca pretende es devolvernos esa otra visión idílica que convierte a Chile en "la copia feliz del Edén". (Mateo del Pino 2009: 242)

O bien:

[...] si algo caracteriza el registro literario de Pedro Lemebel es el carácter ácido, a la vez que apasionado, de una escritura que se resiste constantemente a ese "blanqueo de Chile" que, como advierte Tomás Moulian, se materializa en la "compulsión al olvido" y el "bloqueo de la memoria". [...] De perlas y cicatrices se erige en la constatación de un "delito", el delito que conlleva implícito el olvido, porque será precisamente la fragilidad de la memoria la que imposibilite la integración del pasado y el presente chilenos. Éste es, pues, el instrumento crítico del que se vale Pedro Lemebel para trazar límites, para diferenciar, pero, sobre todo, para remarcar lo que la historia y la cultura chilenas han excluido. (Mateo del Pino 2009: 243-244)

En "Pedro Lemebel: El Cronista de los Márgenes", entrevista realizada por Andrea Jeftanovic para la Revista Lucero, de la Universidad de California, Berkeley, año 2000, la entrevistadora también señala como rasgo distintivo de Lemebel la convivencia en su escritura de dos universos distantes: el de la crítica cultural (ella la llama "élite intelectual") y el mundo marginal, proletario, permanentemente evocado en su escritura. Ante la pregunta por cómo resuelve Lemebel esta convivencia, el escritor da una respuesta que se encuentra, obviamente, en la misma línea de la que les diera tres años antes a Blanco y a Gelpí:

\footnotetext{
${ }^{48}$ Ver: Mateo del Pino 2004 y 2009. Como puede observarse por los fragmentos citados, la autora remarca el propósito político de Lemebel: desmentir la postal idílica de Chile que cierto discurso complaciente con los poderes hegemónicos se encarga de mantener vigente durante los gobiernos de la Concertación.
} 
Eso depende justamente del lugar de donde escribes. En mi caso, es desde una territorialidad movediza, también tránsfuga; de alguna manera lo que hacen mis textos es piratear contenidos que tienen una raigambre más popular para hacerlos transitar en otros medios donde el libro es un producto sofisticado. Así por ejemplo mis crónicas antes de ser publicadas en libros, son difundidas en revistas o en diarios. Era lo que antes hacía en Página Abierta que era un medio con una llegada bastante masiva. Lo mismo hago en la radio, de alguna forma "panfleteo" estos contenidos a través de la oralidad para que no tengan esa difusión tan sectaria, tan propia de la llamada crítica cultural o de los ámbitos académicos. (PP)

Si bien el resto de la entrevista discurre por los lugares comunes de la defensa de las minorías de género, destaco la pregunta de la entrevistadora que relaciona las crónicas de Lemebel con el pensamiento de Foucault, Derrida o Deleuze, dado que Lemebel la aprovecha para hacer explícito su propósito de "panfletear", es decir, de llevar a su auditorio masivo (los oyentes de su programa de radio o los lectores de las revistas en las que publica) ideas que se originan en un campo mucho más restringido y -en sus términos- sectarios, dando lugar a un procedimiento de transposición de contenidos filosóficos de alta complejidad a un registro popular de consumo masivo.

En el año 2003 la editorial Corregidor publica: La fugitiva contemporaneidad. Narrativa latinoamericana 1990-2000, con edición a cargo de Celina Manzoni. El libro reúne diez artículos que enfocan la obra de diez autores latinoamericanos contemporáneos cuyos recorridos constituyen, según la editora: “desplazamientos simbólicos que recuperan a su vez tradiciones diversas (la del flâneur, la de la bohemia, la del exilio y la del nomadismo) en el mismo momento en que las trascienden" (Manzoni 2003: 12). Advertimos entonces que los autores del volumen se proponen evitar los criterios de canonización literaria y abordar sus análisis desde una perspectiva permeable al cambio, la diversidad y la inestabilidad formal que la editora señala como sesgo particular del corpus seleccionado. 
El estudio dedicado a Pedro Lemebel es de Andrea Ostrov, se titula: "Las crónicas de Pedro Lemebel. Un mapa de las diferencias" y sostiene dos hipótesis enlazadas: "La confluencia de la periferia y de lo marginal o minoritario [...] en la escritura de la crónica urbana propone un mapa otro de la ciudad"; y: "la posición definitivamente crítica de estos textos frente a la supuesta homogeneidad del mundo homosexual" (106). Para la autora, Lemebel activa su crítica fulminante a los sistemas de categorización unívoca de la identidad normativa, aun dentro del "ghetto" homosexual, promoviendo un nuevo mapa de la ciudad con su desterritorialización nómade. Destaco el cuidadoso y muy completo relevamiento teórico de la ensayista en relación con las perspectivas de género, que incluye desde textos canónicos e ineludibles como los de Judith Butler, Susan Sontag o Nelly Richard hasta ensayos recientes y aun inéditos (Diana Palaversich, Lucía Guerra o María Julia Daroqui, entre otros). Me interesa este aporte de Andrea Ostrov particularmente por su atención al propósito deconstructivo de la obra lemebeliana respecto de la noción -ya comentadade "ghetto" homosexual. Como se verá en el desarrollo de esta tesis, el autor chileno está al tanto de los desarrollos teóricos de los llamados estudios queer, y realiza una transposición muy productiva de esas nociones al campo literario, al tiempo que inscribe esa transposición en su proyecto creador. Ese proyecto, como he remarcado antes y voy a sostener en mi trabajo, se propone como operación historiográfica instaurando voz y visibilidad en "lugares minoritarios" -en sus términos- donde sólo había silencio y marginalidad. Pero insistiendo siempre en que esa instauración de voz y de visibilidad no se orienta a la configuración de nuevos ghettos ni reedita la pulsión clasificatoria del pensamiento positivista, con sus taxonomías jerárquicas y excluyentes. $\mathrm{Su}$ propósito es el de cartografiar -como señala Ostrov- agenciamientos colectivos móviles y heterogéneos que no tenían discurso. 
En el año 2004 la editorial chilena LOM publica el primer libro de crítica académica dedicado a la obra del escritor: Reinas de otro cielo. Modernidad y autoritarismo en la obra de Pedro Lemebel, texto integrado por cuatro artículos cuyos autores son: Jean Franco, Bernardita Llanos, Fernando Blanco (editor del volumen) y Héctor Domínguez. Excepto el último artículo, que está dedicado a la faceta lemebeliana de artista visual y performer, los otros tres se centran exclusivamente en la figura de Lemebel como un artista-militante.

En las primeras líneas de su artículo: "Encajes de acero. La libertad bajo vigilancia", Jean Franco refiere su primer encuentro con el escritor, y señala las características particulares de ese momento que fecha en 1995: "En aquel momento se percibía un cambio tanto en el trabajo intelectual y creativo de escritoras, poetas y artistas como en los movimientos que militaban contra las prohibiciones del aborto, el divorcio y la sodomía" (Franco 2004: 11). A lo largo de su estudio la ensayista hace un rápido recorrido por las crónicas de Lemebel publicadas hasta el momento, a saber: $L a$ esquina es mi corazón, Loco afán. Crónicas de Sidario, De perlas y cicatrices y Zanjón de la Aguada, sin apartarse en ningún momento de la perspectiva que ha asumido en las primeras líneas: reconocer la trayectoria del escritor como un militante de género, tanto durante los años duros de la dictadura pinochetista como durante los años de la transición. En el artículo encontramos numerosas citas de textos de Lemebel que se van hilvanando sin una estructura conceptual que las contenga. Lo que podemos decir es que el artículo insiste en temas vinculados exclusivamente al proceso de liberación sexual tanto de las mujeres como de los homosexuales- y su abrupta culminación con la epidemia del SIDA. También la autora señala los residuos de control de la dictadura durante los años de la transición democrática conocida como posdictadura, que marcan la necesaria continuidad de la resistencia política, social y cultural, de la que Pedro 
Lemebel es un protagonista. Hacia el final del artículo, puntualiza que el autor chileno critica tanto a los militantes de izquierda como a los militares por representar ambos un modelo de masculinidad convencional y concluye inesperadamente señalando que Lemebel ha renovado la crónica más allá de sus modelos. Digo que la conclusión es inesperada, porque en ningún momento del artículo la ensayista se detiene a analizar los procedimientos del autor, o sus estrategias discursivas o su estética; tampoco se detiene en ningún aspecto, digamos, compositivo de la obra, dado que su crítica es exclusivamente de carácter temático y sólo aborda la relevancia del escritor en su lucha contra la discriminación de género y a favor de las minorías silenciadas. Jean Franco no justifica su afirmación final -que aparece como una conclusión pero no lo es- de que Lemebel ha renovado la crónica o que ha superado a su modelo Carlos Monsiváis (tampoco justifica por qué Monsiváis sería el modelo, por cuanto en el desarrollo del artículo la autora no ha trabajado sobre ese punto).

El artículo de Fernando Blanco, quien es además editor del volumen, titulado: “Comunicación política y memoria en la escritura de Pedro Lemebel” analiza las operaciones de los medios de comunicación masiva durante la dictadura militar, sus mecanismos de control y el papel intelectual de Lemebel como artista y performer primero, y como cronista urbano después, especialmente durante el período de la transición. Subraya el repertorio lingüístico y temático del autor tomado de la cultura popular, mestiza, proletaria y homosexual, y su protagonismo en la resistencia a los controles de la posdictadura, fundamental en el proceso -todavía incompleto según Blanco- de la democratización del espacio público en Chile. Es inevitable coincidir con Fernando Blanco en estas observaciones, por cuanto resultan absolutamente obvias para cualquier lector de las crónicas de Pedro Lemebel. 
El artículo de Bernardita Llanos: "Masculinidad, Estado y violencia en la ciudad neoliberal" es, como indica su título, una lectura de la racionalidad patriarcal institucionalizada por la dictadura y favorecida por la posdictadura chilena. La perspectiva de género seleccionada vehiculiza un debate sobre los conflictos de las identidades minoritarias dentro del discurso hegemónico ("heteronormativo", dice la autora) de la modernidad y del régimen militar.

Por último, el artículo de Héctor Domínguez: "La Yegua de Troya. Pedro Lemebel, los medios y la performance", enfoca en la participación del escritor en la actividad radial y teatral, y analiza las estrategias de Lemebel para resistir los intentos de asimilación del sistema mediático neoliberal. También destaca su actividad militante en la recuperación democrática del espacio mediático, dando voz a las minorías silenciadas.

Como vemos, el primer libro dedicado íntegramente a la obra de Pedro Lemebel -si bien se trata de una compilación de artículos- analiza su obra desde una doble perspectiva que lo considera como un artista-militante: la que aborda la obra como instrumento de lucha intelectual a favor de los derechos sociales durante la dictadura y la posdictadura chilenas; y la perspectiva de género, que analiza su participación decisiva y protagónica en la defensa de los derechos de las minorías sexuales y, en general, de toda minoría invisibilizada y silenciada. Si bien esta consideración de la obra lemebeliana es ineludible y se encuentra en primer plano, me parece reductiva. Lemebel es mucho más que un artista-militante. Es un escritor que renueva todas las convenciones literarias en las que incursiona, operando transformaciones inéditas como la composición crónica-poesía o la presencia no "redimida" de una oralidad irreductible a su escritura. Por otro lado, su opción por la crónica no habilita la homologación directa con otros cronistas latinoamericanos contemporáneos por ser él mismo "el otro" 
que toma la palabra (a diferencia de Carlos Monsiváis, José Joaquín Blanco, Edgardo Rodríguez Juliá o Juan Villoro). Lemebel no se convierte "en la voz de los que no tienen voz” según reza el lugar común. Él es la voz mestiza, quiltra, pobre o proleta, rota, marginal, pelienta, loca, gay, coliza, marica, travesti y un largo etcétera. Al mismo tiempo y sin desmedro de lo antedicho, la de Lemebel es una prosa que deslumbra por su poder desautomatizador, que permite ver y realizar con el narrador un recorrido desconocido por las calles de Santiago (o un paseo por el Santiago invisibilizado e ignorado). De este modo y con procedimientos literarios ligados a las estéticas neobarrocas, Lemebel realiza su intervención en el fosilizado discurso historiográfico convencional, y un aporte etnográfico único reconocido por científicos de esa especialidad. ${ }^{49} \mathrm{Al}$ mismo tiempo atraviesa límites que parecían infranqueables, por cuanto promueve el tránsito entre el universo letrado y su itinerario callejero. Como hemos apuntado antes, "contrabandea" conceptos filosóficos y epistemológicos del campo académico y demuestra su operatividad en el campo social ("prueba" la existencia y nos permite a los lectores tener la experiencia de los devenires minoritarios que plantearan Deleuze y Guattari. Del mismo modo realiza la demostración de la idea derrideana del monolingüismo del otro) ${ }^{50}$.

Entre el 21 y el 24 de noviembre de 2006 se realiza en la sede de la Casa de las Américas, en La Habana, la tradicional Semana de Autor, en este caso dedicada a Pedro Lemebel. El número 246 de la revista, correspondiente al período enero-marzo de 2007, publica los textos leídos en esa oportunidad: de Jorge Fornet: "Un escritor que se expone"; de Jorge Ruffinelli: "Lemebel después de Lemebel”; de Norge Espinosa Mendoza: "Puig, Paz, Lemebel: la sexualidad como revolución"; de Fernando Blanco:

\footnotetext{
${ }^{49}$ Me refiero a las consideraciones del etnógrafo Yanko González respecto del aporte etnográfico de la obra lemebeliana, como hemos visto en sus artículos de 1997, 2005 y 2007, citados en páginas precedentes de este mismo capítulo.

${ }_{50}^{50}$ Acerca de esta noción ver nota 105.
} 
“La crónica urbana de Pedro Lemebel: Discurso cultural y construcción de lazo social en los modelos neoliberales"; de Luis Cárcamo-Huechante: "Las perlas de los ‘mercados persas' o la poética del mercadeo popular en las crónicas de Pedro Lemebel”; y de Roberto Zurbano: "Pedro Lemebel o el triángulo del deseo iletrado". Voy a realizar un rápido relevamiento de las hipótesis planteadas, para detenerme luego en aquellas que considero más originales y relevantes.

El texto de Fornet es una brevísima presentación del dossier, y sólo señala la importancia de la obra del autor (la "Semana de Pedro Lemebel” que se está celebrando constituye un explícito reconocimiento), al tiempo que considera su obra ubicada en un lugar extraño y excéntrico en la cartografía literaria del continente.

El texto de Espinosa Mendoza enfoca en la única novela del chileno, Tengo miedo torero y su lectura reconoce en ella la herencia de Puig y del cubano Senel Paz, tomando como eje articulador del análisis su concepto de "ser en revolución"; Espinosa le atribuye dicho estatuto al homosexual latinoamericano a partir de los dos textos narrativos analizados: El beso de la mujer araña, de Manuel Puig y "El lobo, el bosque y el hombre nuevo" de Senel Paz (relato que inspirara la celebrada película "Fresa y chocolate" dirigida por Tomás Gutiérrez Alea y Juan Carlos Tabío, con guión del propio Senel Paz). La novela de Lemebel se ubicaría en esta trayectoria al inscribirse según el ensayista- en la "breve pero intensa galería de homosexuales que la literatura del Continente ha podido ir sumando a partir de la reorganización de su propia prehistoria, en lo tocante a sus juegos de representación articulados desde el género" (Espinosa Mendoza 81). La comunicación tiene un inocultable matiz romántico y su categoría del "ser en revolución” constituye un caso más de lo que Nelly Richard ha llamado "épica revolucionaria" con la consabida carga de mitificación, poco consistente con el propósito de registro de la diversidad cultural y de las identidades heterogéneas 
que las crónicas de Lemebel demuestran. Estas operaciones desmitificadoras de la obra de Lemebel serán analizadas en los Capítulos III y IV de esta tesis, a propósito del rechazo de nuestro autor a las nuevas "re-categorizaciones del margen".

El artículo de Fernando Blanco enfoca en los procesos de transformación por los que atravesaba Chile en el momento de la comunicación, después de quince años de "gobiernos de transición seudo-democrática". La producción de Lemebel ha sido, según su punto de vista, "particularmente efectiva a la hora de explorar las contradicciones del liberalismo económico y político", y su eficacia reside en otorgarle visibilidad a los sujetos pertenecientes a las capas medias y populares, el proletariado urbano homosexual y la pauperizada clase media trabajadora. Lo más relevante, a mi juicio, de los análisis de Blanco, está dado por su reflexión acerca de la oralidad en la práctica discursiva de Lemebel, la cual funciona como articuladora del lazo social, entendida como sostén de la subjetividad amenazada. Remitiendo al discurso lacaniano, postula que las crónicas lemebelianas posibilitan la reconstrucción de sistemas de identificación colectiva e intersubjetiva que les devuelven a los sujetos excluidos del sistema social visible (homosexuales, indígenas, mujeres, familiares de detenidos desaparecidos, seropositivos) la posibilidad de

[...] reestablecer el lazo social que les permitirá recuperar un lugar desde el cual volver a vivir una vida subjetiva [...] en una identidad recuperada que se vuelve resistente a los modos mercantiles disponibles para la sobrevivencia: drogas buenas, consumos ordenados, políticas consensuadas de reparación. (Blanco 2007: 92).

Según Blanco, las estrategias discursivas de Lemebel, al unir la política de la diferencia sexual a la política de la memoria, reponen un lugar para el sujeto disidente, resignificando la noción de lazo social dentro de la red simbólica y generando nuevas 
agrupaciones "contra la mediación natural que el Estado busca en la familia funcional del Estado-nación” (Blanco 2007: 94).

Las hipótesis de Fernando Blanco son centrales en toda reflexión que aborde la obra de Lemebel como dispositivo de resistencia contra-cultural. Está claro que los discursos de la transición democrática buscaron forzar los consensos y en ese proyecto promovieron lo que Blanco llama con acierto: "los modos mercantiles disponibles para la sobrevivencia: drogas buenas, consumos ordenados, políticas consensuadas de reparación.” (Blanco 2007: 92). Lemebel denuncia con insistencia estas operaciones que replican la marginación, la mercantilizan al tiempo que la silencian, invisibilizando los mecanismos de exclusión y control. Por eso el autor chileno es reactivo a la "legalización homosexual", proyecto que califica de neoconservador, y propone una marginalidad itinerante, siempre en deriva, capaz de neutralizar la garra del mercado y los dispositivos de opresión enmascarados bajo el pretendido propósito de restablecer el lazo social.

El trabajo de Luis Cárcamo-Huechante, por su parte, retoma la categoría de "residual" en el sentido que le da al término Raymond Williams en Marxismo y Literatura, para ubicar a Lemebel como agente de una cultura económica de formas residuales, favoreciendo formas alternativas ("rituales", según el autor) de consumo e intercambio. Según el ensayista, lo que Lemebel registra en sus crónicas a partir de escenarios como "el mercado persa o la feria callejera, es un deseo político y social por enunciar y poner en circulación ciudadanías económicas, sociales y culturales de raigambre popular" (Cárcamo-Huechante 2007: 96). El ensayista se refiere a la celebración lemebeliana del "comercio cuneta que atrae multitudes" (97) en la medida en que éste abre posibilidades a modos informales de transacción popular al margen del circuito neocapitalista. El ensayo establece una analogía entre "el juego de mezclas 
entre economías formales e informales" y "el ensamblaje híbrido de la propia crónica, como una especie de mercado persa en que operan variados y disparatados códigos de lenguaje". Por ello propone "que la crónica urbana de Lemebel constituye, en su propia economía interna, una estética de "mercado persa"” (97). Bajo la orientación general de esta línea interpretativa, Cárcamo-Huechante hace una breve historia de los mercados populares en Chile, y señala una imagen orientalista del mercado popular en el imaginario social:

En el contexto chileno, la figura del "mercado persa" ha sido incorporada al imaginario nacional, y más específicamente capitalino, para denominar las ferias o los mercados populares. El discurso criollo chileno pone así en relieve su visión exotizante de lo popular y lo marginal. (Cárcamo-Huechante 98-99)

El ensayista atribuye al imaginario nacional chileno esta visión exotizante de lo popular. Lemebel celebra el comercio "cuneta" y -como ha sido señalado en páginas precedentes- comprende al comerciante informal forzado por la "fiebre mercantil" a traficar su mercadería pirata: “-La fiebre mercantil a veces produce otros comercios paralelos, incita la piratería, la copia no autorizada, el plagio, la reventa. Y quien nunca entró en una librería me encuentra a módico precio tirado en la vereda" (Budassi 7). El artículo insiste en la mencionada analogía entre el mercado persa y la crónica de Lemebel "en el plano de los lenguajes y los códigos [...] en que cohabitan injertos retóricos provenientes del habla coloquial popular con otros giros de estilizado aliento lírico" (Cárcamo-Huechante: 101). Esta analogía conduce a la conclusión de "que la crónica urbana de Lemebel constituye, en su propia economía interna, una estética de 'mercado persa'”. En efecto, como señala el autor, la crónica de Lemebel "celebra el colapso del orden disciplinante de la economía formal de la sociedad hegemónica" y pone de relieve "el juego de mezclas entre economías formales e informales". Dicho 
juego no se da sólo a nivel temático, sino que "sobre todo, caracteriza el ensamblaje híbrido de la propia crónica" (97). En este mismo sentido, el ensayista señala un procedimiento de "barrialización" del discurso letrado chileno. A propósito de este concepto, coincido con él en su consideración de la mirada de Lemebel sobre ese espacio híbrido y sensual del comercio popular:

De ahí que su mirada sobre el mundo popular marginal del principal mercado persa santiaguino no sea la del turista que exotiza al "otro", sino la de un intelectual de origen popular que decide registrar las imágenes de su territorio barrial para reinventarlo en el espacio del discurso letrado. Al mismo tiempo, en ese proceso, el ámbito de la letra es reformado y transformado como efecto de su inmersión en las hablas y los escenarios de los mercados populares santiaguinos, barrializando así la tradición de la literatura, y en particular la de la crónica, en el contexto letrado chileno. [...] En este paroxismo de las mezclas, el "mercado persa" se desorientaliza y se relocaliza, travestizándose en la imagen sudamericana y caribeña del "mambo callejero". (Cárcamo-Huechante 99).

A propósito del procedimiento de "barrialización" del discurso letrado chileno, coincido con Cárcamo-Huechante en su consideración de la mirada de Lemebel sobre ese espacio híbrido y sensual del comercio popular como una estrategia que des-exotiza al "otro", desarticulando la separación establecida en la autoconsciencia de la clase media chilena.

El texto de Roberto Zurbano ("Pedro Lemebel o el triángulo del deseo iletrado") señala que la homosexualidad no termina de legitimarse como una sexualidad más, sino que sigue siendo vista como una disidencia, como un acto transgresor. Sin poder abandonar el plano de lo obvio, Zurbano postula que Lemebel y su obra operan en un espacio triangular, cuyos lados son: la homosexualidad como lugar de resistencia y contra-discurso; las operaciones artístico-literarias marcadas por el barroquismo; y los presupuestos políticos de su obra. 
El artículo de Jorge Ruffinelli, sin dejar de lado la consideración de Lemebel como artista transgresor, cuyo discurso contra-hegemónico denuncia la injusticia social que la transición democrática -o seudodemocrática, en términos de Blanco- tolera y aun profundiza, señala como rasgo central el hecho de que Lemebel

[...] ha conseguido realizar una nueva cartografía de Chile, y especialmente de Santiago, modificando radicalmente la existente y dominante. [...] Hay un Chile anterior y otro posterior a Lemebel, en cuanto a esta cartografía se refiere. Después de leer sus crónicas, la imagen (y la realidad) de Santiago es otra: descubrimos otros barrios que habían sido borrados o censurados o aplastados por la cartografía oficial y clasista en el imaginario nacional. (Ruffinelli 74).

La hipótesis del artículo es que las crónicas de Lemebel configuran un nuevo mapa, en línea con los desarrollos teóricos de Nelly Richard (1993) a los que Ruffinelli envía. Ahora bien, en este nuevo mapa hace su aparición una nueva ciudadanía; se trata de ciudadanos anónimos, de la calle, del barrio, de la esquina, a quienes Lemebel da identidad y realidad con sus nombres propios o "travestidos", y como consecuencia les otorga "un lugar en el mundo" (77). El ensayista señala la capacidad de Lemebel para "moldear y cambiar nuestra visión de Chile; no trabaja solamente sobre hechos externos y sociales, ayuda a procesarlos, a cambiarlos, a hacerlos inteligibles gracias a su poderosa imaginación verbal" (ibidem). Establecido su punto de vista, a saber: la capacidad de la literatura de efectuar transformaciones en lo real, termina su comunicación rechazando la "trampa funesta" que representa

[...] leer a Lemebel exclusivamente desde el costado o la perspectiva de la corriente de los estudios de la sexualidad queer o gay [...] porque esa visión, si es única, constituye un encierro, significa colocar a la literatura de Lemebel en lo que él mismo denomina "el gueto homosexual". (Ruffinelli 78, énfasis mío). 
Esta observación de Ruffinelli merece algún detenimiento. Por un lado, el ensayista se refiere a "los estudios de la sexualidad queer o gay" como si estos dos últimos términos fueran sinónimos, y está muy claro hoy tanto para las teorías de género como para el propio Lemebel que no lo son. Cito al respecto un fragmento de la introducción al dossier: "Los estudios lésbico-gays y queer latinoamericanos", a cargo de Luciano Martínez:

Si los estudios lésbico-gays se ubican un paso más adelante de la crítica feminista al examinar la diferencia sexual más allá de las diferencias de género, la teoría queer pasa a concebir la sexualidad como algo móvil, ambiguo y ambivalente, siempre mutable de acuerdo al contexto histórico-cultural. A partir de dos categorías de análisis particulares (normatividad y desviación), el énfasis se corre del estudio de la construcción histórica de las identidades homosexuales para ocuparse, no sólo ya de la homosexualidad, sino también de otras conductas sociales. El objetivo es desconstruir las bases ontológicas con las que operan y poner de relieve cómo se construye lo que se considera "normal", "natural" o "esencial" en un momento dado. Al socavarse las nociones de continuidad, estabilidad e integridad que fundan lo identitario se está cuestionando también la identidad homosexual y los binarismos que la rigen. (Martínez 2008: 863-864)

En idéntico sentido, Lemebel le aclara a uno de sus entrevistadores -entrevista ya citada en el presente estado de la cuestión:

Te aclaro que lo gay no es sinónimo de travesti, marica, trolo, camiona, marimacho o transgénero. Estos últimos flujos del desbande sexual aparecen encintados como multitudes "queer" (raras) después de que lo gay obtuvo su conservador reconocimiento. Quizá son estas categorías las que pueden alterar el itinerario de los azahares gay tan cómodos en el status de la legalización (Costa: 8)

No obstante la necesaria corrección que acabamos de hacer, es aceptable la advertencia de Ruffinelli por cuanto hemos observado que algunos críticos -tanto en el campo académico como en el periodístico- encuadran de un modo absoluto y 
excluyente las crónicas de Lemebel en la "trinchera" de la militancia de género, visión que considero - como ya he señalado- muy reductiva.

Antes de abandonar este dossier, es necesario señalar su importancia y sus diferencias internas. Los artículos de Fernando Blanco y de Luis Cárcamo-Huechante iluminan dos aspectos muy importantes de la obra del chileno. El primero, su resistencia a lo que Blanco llama "modos mercantiles disponibles para la sobrevivencia: drogas buenas, consumos ordenados, políticas consensuadas de reparación". Lemebel no negocia con las buenas intenciones de los gobiernos seudo-democráticos de la transición. Como he señalado en la Introducción de esta tesis y demostraré en el Capítulo IV, sus crónicas denuncian no sólo la pervivencia del autoritarismo en las instituciones y los modos de sociabilidad en el Santiago de los 90, sino sobre todo las estrategias de (falsa) reparación, que ofenden la memoria de los exiliados y de los que sufrieron en carne propia la crueldad de la dictadura pinochetista. Como se verá en la lectura crítica de las crónicas que realizaremos en el desarrollo de la presente investigación, Lemebel señala, justifica y denuncia el riesgo de negociar con la memoria, ajustando mecanismos de control avalados por la complicidad y/o complacencia de las políticas de la Concertación. El segundo aspecto, analizado por Luis Cárcamo-Huechante, enfoca en la crónica de Lemebel como estrategia que deconstruye la mirada que exotiza al "otro" en el contexto del mercado persa santiaguino. Como justificaré en el desarrollo de la investigación, Lemebel desanda el camino de la dicotomía excluyente al elaborar una crítica de las identidades como posiciones fijas según el rígido esquema del sustancialismo filosófico tradicional, de raíz platónica. Por su parte, el artículo de Ruffinelli enfoca en un aspecto relevante de la obra lemebeliana: su actitud contestataria también respecto de los intentos de disciplinar su discurso integrándolo a la perspectiva única del colectivo-gay. En muchas entrevistas 
y numerosas crónicas Pedro Lemebel se encarga de desalentar ese malentendido: no es un artista-militante, no se considera exclusivamente "gay" aunque su identidad sexual es y ha sido levantada como bandera y gesto de provocación ante la pacatería reinante. Lo que señala Ruffinelli es que esa perspectiva, si es única, corre el riesgo de desconocer la singularidad y eficacia de este artista que ha renovado la escena literaria chilena de fines del siglo XX y comienzos del XXI, por su intervención poderosa en los sistemas discursivos (literario, histórico, periodístico, etnográfico y político).

Carlos Monsiváis retoma su consideración de la obra de Pedro Lemebel seis años después de aquel prólogo a la reedición de La esquina... que ya hemos comentado. En su artículo: "El Barroco desclosetado", en: Revista de la Universidad de México, UNAM, Número 42, año 2007, el escritor mexicano despliega su concepción de la obra de Lemebel en una perspectiva de género (cayendo, tal vez, en la "trampa funesta" sobre la que advertía Ruffinelli).

Claramente Monsiváis declara al chileno un autor gay o de tema homosexual, quien tiene además el valor agregado de una prosa intensa en la que brillan "las reverberaciones de lo prohibido" (11). Lemebel se inscribe, para Monsiváis, en la tradición latinoamericana de "las expresiones literarias del deseo otro". Para él "escribir sobre la cuestión gay o lésbica, equivale [...] a una declaración de principios" (7). Sin hacer distinciones entre los volúmenes de crónicas (el artículo se ubica temporalmente entre Adiós mariquita linda y Serenata cafiola), homologa la escritura lemebeliana a los géneros confesionales y considera que su registro es el de la autobiografía. Al mismo tiempo, lo incluye dentro de una genealogía muy precisa, absolutamente vinculada a los temas homofílicos y, particularmente, al drama del Sida:

A la tradición de Lemebel pertenecen, entre otros muchos, el argentino Néstor Perlongher, el mexicano Joaquín Hurtado, el puertorriqueño Manuel Ramos Otero, el cubano Reynaldo Arenas, y, 
un tanto más a distancia, el cubano Severo Sarduy y el argentino Manuel Puig. (El común denominador: el Sida). Es una literatura de la indignación moral (Perlongher, Ramos Otero, Arenas, Hurtado), de la experimentación radical (Sarduy), de la incorporación festiva $\mathrm{y}$ victoriosa de la sensibilidad proscrita (Puig). En todos ellos lo gay no es la identidad artística sino la actitud contigua que afirma una tendencia cultural y un movimiento de conciencia. No hay literatura gay, sino la sensibilidad ignorada que ha de persistir mientras continúe la homofobia, y mientras no se acepte que, en materia de literatura, la excelencia puede corresponder a temas varios. (Monsiváis 2007: 12)

Un artículo que marca su diferencia respecto de la perspectiva mayoritaria (me refiero a las perspectivas de género y la mirada sociológica que fija el "lugar Lemebel" en los discursos políticos contestatarios) es el trabajo de Juan Pablo Neyret titulado: "Postal de La Habana: lugares y no lugares en Adiós mariquita linda de Pedro Lemebel", publicado en el № 34 de la Revista de estudios literarios Espéculo, Madrid, Universidad Complutense, correspondiente a noviembre 2006-febrero 2007. En su trabajo Neyret parte del concepto de "no lugar" acuñado por el antropólogo francés Marc Augé, caracterizado por las experiencias del espacio, el tiempo y la individualidad propias de nuestra época, que Augé califica de "sobremoderna". La definición del no lugar está dada, para Augé, "por oposición al lugar antropológico tradicional de la modernidad, el cual posee tres características distintivas: ser identitario, relacional e histórico" (Neyret 2006).

El ensayista hace pie en esta oposición (moderno/sobremoderno; lugar/no lugar; presencia/ausencia de la dimensión histórica) para sostener su hipótesis, según la cual Lemebel opera en su texto la transformación de uno de los no lugares típicos de la sobremodernidad -el avión- en un lugar cargado de elementos históricos relativos al destino de ese viaje: la isla de Cuba. Me parece oportuno señalar, a propósito de este artículo, uno de los rasgos que el propio Lemebel le atribuye a su crónica: sucesos "embarrados de contingencia". A la asepsia e impersonalidad del no lugar 
sobremoderno de Augé que toma Neyret como punto de partida para su reflexión, opone Lemebel la caracterización del vuelo sin fronteras de Cubana de Aviación como un itinerario plagado de contingencia histórica: el habla cubana de las azafatas quienes son llamadas por su nombre de pila, la ausencia de primera clase, asientos vips, música funcional y televisión, entre otros rasgos que "historizan" el vuelo.

Jody Parys, académica perteneciente al departamento de Español de la Universidad de Wisconsin-Whitewater, es $\mathrm{PhD}$ en Literatura Latinoamericana Contemporánea, y su área de investigación incluye la intersección del deseo y la literatura, enfocando especialmente en la epidemia del SIDA. En su trabajo de 2007: "La creación de (com)unidad mediante la hibridez", en: Memoria histórica, Género e Interdisciplinariedad: Los Estudios Culturales Hispánicos en el siglo XXI, se detiene exclusivamente en el libro Loco afán. Crónicas de Sidario, e interpreta el texto de Lemebel como un intento de escribir un concepto de nación desde una perspectiva marginal. Los personajes de Lemebel, según la autora, son un grupo de individuos marginados por su tendencia sexual y por el SIDA, y la crónica es un discurso utilizado para dar "un retrato detallado" de ellos. La hipótesis de Parys parte de los conceptos de "liminalidad" e "hibridez" de Homi Bhabha en Locations of Culture (New York, Routledge, 1994). Según este autor, es en los “intersticios” o "espacios liminales" donde se operan los movimientos, traslados, negociaciones y cambios, convergencias o divergencias en el orden cultural, con la meta final de contrarrestar la hegemonía. Según la autora de este artículo, Lemebel usa esos espacios intersticiales e híbridos para iluminar los personajes que los habitan y "dar voz a sus historias", personajes "tres veces marginados: por su sexualidad, por su travestismo y por su enfermedad" [...] "El autor abraza y celebra el margen intersticial, acentuando las hibrideces múltiples que se desarrollan dentro de él” (114). Su proyecto, según Parys, es “inscribir la comunidad 
travestida en la historia literaria de Chile". Es decir que Lemebel aprovecharía estos espacios intersticiales para producir una anti-narrativa contra-cultural. Para ello, siempre según la ensayista, elige en primer lugar un género híbrido: la crónica. Parys sostiene que a través de esta estrategia discursiva, Pedro Lemebel

[...] se desvía considerablemente de los textos tradicionales, los cuales básicamente servían para apuntar y atestiguar acontecimientos históricos, políticos o culturales importantes. Esencialmente Lemebel ha tomado una forma histórica típicamente reservada para conmemorar las vidas y hazañas de personas importantes (Parys 116).

Se equivoca la autora al olvidar que la crónica latinoamericana, como lo han demostrado sólidamente Aníbal González y Susana Rotker, tiene sus antecedentes en la crónica parisiense y en el artículo de costumbres dieciochesco inglés, los que constituían cuadros casi siempre breves, algunos anclados en el pasado, otros preñados de urgente actualidad, en los que el cronista registraba personajes comunes y acontecimientos propios de la vida cotidiana, a veces en los márgenes de la gran ciudad. Aníbal González reflexiona y se interroga: "No es difícil entender por qué la crítica apenas se ha ocupado de la crónica modernista. [...] ¿cómo tomar en serio textos que desde un principio parecían destinados a una existencia tan efímera como la de sus temas?” (1983: 61). Vale decir que la crónica es y ha sido un cuerpo heterogéneo, en el que se abordan temas "importantes" - como señala Parys- y también efímeros y cotidianos. El propio Mariano José de Larra los llama "ligeros cuadros de costumbres". 51

Por esta razón -y en desacuerdo con la autora- afirmo que Lemebel, en efecto, opera una transformación radical en los modos de historiar la vida de los sectores marginados del espacio público e institucional, político y discursivo de Santiago de

\footnotetext{
${ }^{51}$ Citado por Aníbal González: Mariano José de Larra, "Fígaro", en Artículos, edición, introducción y notas de Carlos Seco Serrano, Barcelona, Ed. Planeta, 1964. Págs. 1013-1014.
} 
Chile, pero para ello dispone de un instrumento de larga y fecunda tradición latinoamericana, la crónica, que le permitirá intervenir en la construcción de nuevos espacios institucionales y discursivos, y al mismo tiempo ahondar en una de las características distintivas del género: ser el registro de historias particulares que darán cuenta -siempre fragmentariamente- de una experiencia social y colectiva que no tenía espacio en los discursos historiográficos regidos por la asepsia positivista y alejados de toda "contaminación" literaria o subjetiva. Tanto la mirada, como la voz y la experiencia singular de los personajes menores que habían sido "representados" pero no oídos (Lemebel ha logrado "sacarle el habla" a las materialidades pasadas, dice Yanko González) en los textos académicos históricos y etnográficos, han constituido el nervio de la crónica desde que se tiene registro de ella en América Latina. Podemos decir que este género ha acompañado y al mismo tiempo registrado el desarrollo de la autonomización desigual de nuestro continente latinoamericano (Ramos) y de su abigarrada complejidad cultural.

En la última parte del breve tratado, Jody Parys cita y sigue las conocidas reflexiones de Judith Butler en su obra de 1990 para considerar que "el texto de Lemebel tiene como eje central el travestismo, definido por su pluralidad y ambivalencia”. (118). Este muy breve artículo no logra superar los lugares comunes que insisten alrededor de la obra de Pedro Lemebel, destacando su militancia de género y su propósito (para esta autora exclusivo y sin fisuras) de dar voz a las minorías sexuales marginadas del espacio institucional.

Kulawik Krzysztof, en: “Travestir para reclamar espacios: la simulación sex/text-ual de Pedro Lemebel y Francisco Casas en la urbe chilena”, publicado en ALPHA No 26, Julio de 2008, aborda los textos narrativos de Pedro Lemebel y Francisco Casas, (como se ha señalado en esta tesis, integrantes del colectivo de arte "Yeguas del 
Apocalipsis" entre 1987 y 1995). Según el ensayista, estos escritores "emplean el motivo del travestismo como arma para parodiar y criticar el sistema de valores que determinan el proceso de formación de la identidad, sea individual o social". Kulawik Krzysztof sostiene que los autores emplean "el lenguaje exuberante y ornamentado del estilo neobarroco" para destacar la figura del travesti, y proponen a través de ella "una nueva perspectiva hacia las categorías tradicionales de lo masculino, femenino, blanco, mestizo" (101). El autor vincula el artificio lingüístico neobarroco (sin explicar en ningún momento por qué incluye a Lemebel y a Casas en esa estética) “con la simulación, una técnica artística y discursiva empleada como una máscara que desenmascara la convencionalidad de las categorías que rigen la sociedad patriarcal, masculina-heterosexual y occidental" (101). Este breve artículo reitera desde las primeras líneas hasta las últimas la misma idea -que acabo de transcribir del resumenreformulándola una y otra vez. El resultado es un artículo circular, reiterativo, que no despliega los términos del problema ni justifica ninguna hipótesis. Dicho rasgo es muy evidente y para justificar mi observación transcribo a continuación algunas líneas:

Pedro Lemebel y Francisco Casas en sus crónicas y novelas simulan las distinciones convencionales de los géneros, tanto sexuales como artísticos. Con un lenguaje experimental y ambiguos personajes travestis, han perturbado el orden estético establecido por el canon neoliberal-burgués y por su discurso normativo (102).

El texto de Casas conforma una serie de contrastes, típicos de todas las urbes latinoamericanas: con imágenes excesivamente ornamentadas y, a la vez, abyectas; con un vocabulario rebuscado, y a la vez, vulgar; con una sintaxis elaborada y artificiosa, combinada con otra simple, oral y callejera (105).

El elaborado lenguaje poético de los textos analizados está en disonancia con el crudo contenido de estas obras que exponen la situación socioeconómica de Santiago de Chile, una ciudad llena de contrastes. (111)

En La esquina es mi corazón de Lemebel y en Yo, yegua de Casas, el travestismo se adopta como una estrategia formativa de una 
identidad descentrada e híbrida con toda la transitividad de atributos masculinos y femeninos inestables [...] Es una exploración consciente de las posibilidades discursivas de construir una identidad sexual transitiva y múltiple, alternativa al binarismo heterosexual impuesto por el canon cultural occidental. (112).

Con todo, las obras de Lemebel y Casas constituyen una propuesta crítica para la inclusión de voces marginales y descentralizadoras en la discusión postmoderna sobre las relaciones entre la identidad sexual, el poder político y la expresión cultural en el contexto latinoamericano de los comienzos del siglo XXI. (114)

Desde luego acuerdo con las afirmaciones precedentes a propósito del carácter perturbador de los textos y las performances de Lemebel y Casas, y el obvio carácter crítico de su propuesta estética en relación con el orden patriarcal; no obstante observo en el artículo una falta abrumadora de argumentación al respecto. La crítica literaria y cultural tiene la obligación insoslayable de ser consistente, y para ello es indispensable argumentar las hipótesis, no solo repetirlas o reformularlas una y otra vez.

El libro de reciente aparición: L'écriture de Pedro Lemebel. Nouvelles pratiques identitaires et scripturales. (La escritura de Pedro Lemebel. Nuevas prácticas identitarias y escriturales), Saint-Étienne: Publications de l’Université de Saint-Étienne, publicado en marzo del año 2012, y compilado por María A. Semilla Durán (Profesora de Literatura Latinoamericana en la Universidad Lumière Lyon 2) reúne diez trabajos de investigadores interesados en los fenómenos culturales y literarios que caracterizan las últimas décadas de la producción latinoamericana. Los artículos (de los cuales tres están escritos en francés y siete en castellano) enfocan la obra de Pedro Lemebel desde diversas perspectivas, con el objetivo común de hacer inteligibles algunos procesos como la emergencia de las minorías que buscan su propia voz, o bien los gestos políticos y las nuevas prácticas de escritura que dan cuenta de una profunda transformación de los imaginarios sociales y culturales. El artículo de Henri Billard, que 
abre el volumen y que ya fuera comentado en este capítulo ${ }^{52}$ postula a Lemebel como un protagonista en las estrategias de transformación cultural en Chile por presentar "la figura del travesti local como una forma de resistencia a la del gay urbano, socialmente integrado y políticamente correcto”. Subraya, además, el vínculo con la poética de Néstor Perlongher en su apuesta por una sexualidad nómade, en contra de las políticas de "normalización" de la homosexualidad. Esta problemática está presente en mi investigación por cuanto coincido con el autor en considerar a Perlongher una figura central en la genealogía lemebeliana, no sólo en su estética sino particularmente en su concepción de la sexualidad como devenir. Asimismo Billard destaca el papel del colectivo de arte "Yeguas del Apocalipsis" que -como ha sido señalado en reiteradas oportunidades- Lemebel integró junto a Francisco Casas, promoviendo la figura de la "loca" contra el modelo gay importado cuya piel blanca y "aséptica envoltura" es la marca de su identidad foránea.

El segundo artículo del libro, "Culture populaire et 'neobarrocho' dans le’écriture lémébélienne" de Isabelle López García, estudia los rasgos neobarrocos (o "neobarrochos", haciendo uso del neologismo acuñado por Soledad Bianchi en el artículo citado al comienzo de este capítulo) de la escritura lemebeliana y para dar cuenta de ello subraya la intertextualidad con el cancionero popular, los homenajes a figuras emblemáticas de la resistencia (Gladys Marín, Sola Sierra, Carmen Soria y Carmen Gloria Quintana) y otros procedimientos tendientes a deconstruir los géneros, lo cual le otorga a la obra de Lemebel su condición transformadora y al mismo tiempo errante (la autora emplea el término francés l'errance en su doble sentido de "vagabundeo" y "traslado") desde el medio radial o periodístico al libro. Coincido con

\footnotetext{
${ }^{52}$ Ver páginas 55 y 56 , en las que hago explícitas mis diferencias con lo sostenido por el autor acerca de su última obra, Adiós mariquita linda. Según Billard: "Lemebel pareciera despedirse de sus crónicas anteriores porque a su pesar él también se ha globalizado y la mirada del cronista ahora va más allá de los barrios populares de Santiago. Además, su último libro incluye un glosario. La fama y el éxito lo han llevado a otros países y sus pétalos bordados florecen en otras lenguas." (24)
} 
López García tanto en la inscripción neobarroca de nuestro autor, aspecto que desarrollaré en el Capítulo IV de la presente tesis, como en la condición itinerante y transformadora de su escritura. Este es, como queda señalado, uno de los ejes de mi investigación. El tercer artículo, de Milagros Ezquerro, aborda la única novela publicada por Lemebel hasta el momento, Tengo miedo torero, observando detenidamente una de las escenas en la que el autor realiza ciertos desplazamientos simbólicos que hacen coincidir la figura de "la loca" con la de la madre, puesto que "seduce a los hombres no substituyendo la imagen de la mujer que ellos podrían amar, sino adoptando la función de la buena madre, que alimenta, cuida, mima, da ternura, escucha y consuela" (Ezquerro: 48). Todo conduce, según la autora, a ajustar esos desplazamientos: el léxico, las metáforas, la elipsis y la perspectiva del relato. El trabajo de Mónica Zapata, "Barroco, grotesco y deconstrucción de los géneros" (51-59), considera la combinación de lo barroco y lo grotesco en los textos que componen Loco afán. Enumera características generales atribuidas al barroco español y las ejemplifica en la obra, poniendo el acento en lo feo y lo grotesco así como en la expresión de oposiciones o el empleo de la sátira, la ironía y la parodia. Considero acertado por parte de la autora el tomar como objeto de estudio el segundo libro del autor para analizar su vínculo con el Barroco español, habida cuenta de que es el que más claramente recupera, reelaborándolos, los procedimientos del siglo de oro español. Este vínculo productivo con el Barroco áureo será objeto de mi análisis en el Capítulo III de esta tesis doctoral.

La segunda parte de la presente compilación de estudios críticos se titula: “Crónicas” y está formada por tres ensayos. El primero de ellos, de Ángeles Mateo del Pino, "Ética y estética de la pasión. Pedro Lemebel camino del sidario" (63-77) postula que Lemebel pone en conexión tres realidades: enfermedad, dictadura y neoliberalismo. Esta relación se desarrolla en la escritura gracias a una teatralidad que convierte las 
crónicas, al igual que ocurriera con los textos de Copi, en una Comedia de la muerte (Copi 1993). Tanto el cuerpo sidado de la "loca" como el cuerpo sitiado del país sufren el asedio de un sarcoma, y los cuerpos desaparecidos por la dictadura "significan" el país desmembrado por la epidemia. Todos esos cuerpos están en el centro de la escena discursiva aunando tragedia y humor para articular la memoria colectiva a través de un juego de contrastes, en los que las imágenes barrocas y las metáforas violentas conviven con lo coloquial y lo marginal. En la presente investigación también haré referencia al humor en las crónicas del autor chileno, haciendo hincapié en su vínculo genealógico con los géneros cómico-serios de la antigüedad, procedimiento que carnavaliza el drama sin banalizarlo. El artículo de Carolina Navarrete, "Restos y restas de una memoria fotográfica” (79-91), analiza las imágenes incluidas en Zanjón de la Aguada. Bajo el título "Porquería visual", el autor chileno le concede a su voz el poder de crear y fijar imágenes en una colección fotográfica que se nos abre como un álbum familiar. Lemebel funda un territorio donde las imágenes son fragua de la relación que el escritor posee con el saber. La construcción de este álbum le da cabida al pasado y al presente, enlazando los diferentes territorios por los que deambula y por los cuales hace circular también al lector. Según Navarrete estas "porquerías" son parte de la idiosincrasia y de la historia del país, y al insertarlas entre las páginas del libro se convierten en imágenes parlantes de un pasado excluido del discurso, razón por la cual configuran un paseo territorial. Si bien el material visual y fotográfico incluido por Lemebel en sus crónicas no será el objeto de mi estudio, sí lo es, y en ello coincido con la autora, el vínculo productivo y singular entre la escritura de nuestro autor y el pasado excluido de los discursos oficiales.

El trabajo de María A. Semilla Durán: "Las travesías del imaginario: la poética del des-borde en la obra de Pedro Lemebel" (93-108) cierra la segunda parte del 
volumen y sostiene que la obra de Lemebel se construye a partir del principio de la transgresión, lo cual le permitirá desplegar su hipótesis del des-borde como procedimiento central en la obra del chileno. El des-borde se plantea en diversos planos: el discursivo (en términos de género literario y de registro lingüístico), el espacial (la loca conquista un espacio que el urbanismo reglamentado no había previsto) y el sexual (la condición de homosexual y de travesti sitúa al autor en otro lugar, fuera del cuadriculado organizador de géneros). Lemebel desafía las retóricas oficiales no sólo nombrando lo que no se debe nombrar, sino mostrándolo bajo una lente de aumento, magnificándolo hasta hacer que toda percepción de su universo pase por el abismo-ojo de la analidad. Según la autora, Lemebel habla y mira no desde una subalternidad bienpensante, sino desde "el sitio de lo evacuado", instaurando una retórica anal. En este sentido Semilla Durán señala la designación repetitiva del orificio censurado como una multiplicación barroca de juegos y alusiones. A través de esta retórica de la analidad, Lemebel rescata a sus personajes no por la vía de una redención estética, sino por un reconocimiento sentimental, una entrañable complicidad. El des-borde, en este caso, no se entiende ya como un derrame, sino como una estrategia de erosión que recrea un espacio sin bordes. Por lo tanto la transferencia de lo sexual a lo político no configura una acción sectorial, ni un discurso ideológico disponible; la retórica lemebeliana es siempre oblicua y reactiva a las categorizaciones: "Reticentes a la violencia del disciplinamiento impuesto por la dictadura, aún invisibles en su peripecia cotidiana de desechos sociales unánimemente expulsados más allá de los bordes de lo enunciable, los cuerpos martirizados de las locas son objeto, como las cavidades anales, de una focalización extrema que los convierte en alegorías de un colectivo inestable" (98). La obra de Lemebel reafirma una pertenencia múltiple, hecha de identidades fragmentarias que "se arraigan y se desarraigan en función de los flujos de deseo o del 
intercambio monetario, construyendo un discurso compuesto de figuras migrantes" (100). Como se verá en el desarrollo de mi investigación, coincido con la autora en la condición reactiva de Lemebel a todo disciplinamiento (discursivo, sexual, político y social) y por lo tanto, coherente con la condición incategorizable de su escritura y de su identidad. La reflexión de Anne-Claire Huby “Tengo miedo torero, de Pedro Lemebel: Variations" (111-118) y el trabajo de Fernando Moreno, "Bordar la historia desde los bordes: Tengo miedo torero" (119-128) abordan la novela de Lemebel desde distintas perspectivas. Huby analiza su sistema de analogías, de ecos y de temporalidades. Según la autora, el texto puede leerse como una transposición constante de situaciones, cambios de ritmo, reiteración de motivos, multiplicación de puntos de vista y de voces que asumen el relato y su melodía como el despliegue de un arte del contrapunto. Moreno propone una lectura de la novela como escritura que "borda la Historia" al realizar una ficcionalización del atentado contra el general Pinochet desde una perspectiva doblemente marginal: la mirada de la loca del Frente y la del revolucionario. La relación metafórica entre el bordado del mantel que ocupa a la protagonista y la escritura de la Historia "desde los bordes" es el eje central del artículo a partir del cual el autor analiza los procedimientos escriturales que se despliegan en la novela. El artículo de Pedro Araya "La política y el ruido" (129-139) que cierra el volumen expone su reflexión en once parágrafos que se acercan a la obra de Lemebel desde distintos puntos de abordaje: la escritura subversiva respecto de los modelos de género, tanto literario como sexual; su condición de indio que subvierte todas las determinaciones sociales y lo coloca en un espacio exterior a la civilidad propio del salvaje; su escritura como vehículo de voces desautorizadas; el Sida como síntoma de una corrosiva enfermedad social y la vecindad entre política y procedimiento, artificio orientado a darle intensidad a una escritura que jaquea nuestras certezas. Si bien mi investigación 
aborda un campo problemático común con los últimos artículos de esta compilación (el vínculo entre historia y ficción, la deconstrucción del género literario y la vecindad entre política y procedimiento) mis argumentaciones justificarán la condición radicalmente reactiva del autor a dejarse categorizar en una identidad fija y determinada (más que indio, Lemebel se considera mestizo; más que gay, homosexual o marica, Lemebel se inscribe en una "parada sexual" que podría cambiar mañana, según sus propias declaraciones; más que ubicarse en un espacio exterior a la civilidad, Lemebel realiza una cartografía deseante que visibiliza espacios e identidades que habían sido negados -silenciados, invisibilizados, excluidos- del mapa urbano. A partir de su escritura nuestro autor otorga espacio, voz y visibilidad a esas identidades minoritarias.

Para finalizar haré una breve referencia a mis contribuciones al estudio de la obra cronística de Lemebel. En mi artículo "Retazos de la historia. Acerca de las crónicas de Pedro Lemebel" (en: Cristina Piña comp. Literatura y (pos)modernidad. Teorías y lecturas críticas, Buenos Aires, Biblos, 2008) estudio algunas transformaciones operadas en los discursos historiográficos durante la segunda mitad del siglo XX, y analizo una de las relaciones intertextuales que considero ineludibles en la obra de Lemebel: la obra poética y ensayística de Néstor Perlongher, autor ya estudiado por mí en trabajos publicados con anterioridad. Entiendo que Lemebel lleva a cabo el proyecto perlongheriano de provocar en la escritura una línea de fuga “entre el deseo y la historia, entre el deseo y lo social" (Perlongher 1997: 312). En cuanto a su desfondamiento de las estrategias de verosimilitud propias del pensamiento moderno y en ese universo, del historicismo occidental, vinculo las estrategias lemebelianas con la desustancialización operada en algunos relatos de Jorge Luis Borges y en una novela de Luis Gusmán. El artículo tiene como sustrato teórico la perspectiva de Walter Benjamin, particularmente en su Tesis sobre Filosofía de la Historia, (1967) y su artículo: "El 
narrador. Consideraciones sobre la obra de Nikolai Leskov" en: Para una crítica de la violencia y otros ensayos, (1991). Este trabajo da cuenta de una investigación en el campo de las transformaciones epistemológicas que determinaron profundos cambios en la disciplina historiográfica y sus consecuencias en la producción de los discursos asociados a ella. Dicha investigación ha operado como punto de partida de las reflexiones teóricas que dan comienzo al Capítulo II de esta tesis. Mi segundo trabajo publicado sobre Lemebel: "Crónicas neobarrocas: la construcción de una experiencia de la historia" (Revista de Crítica Literaria Latinoamericana, Lima-Hanover, $\mathrm{N}^{\circ} 68$, correspondiente al segundo semestre 2008) es un primer acercamiento a la relación -que estableceré con mayor precisión en el desarrollo de la presente tesis doctoral- entre la estética neobarroca y la construcción de una experiencia de la historia. El sustrato teórico de este trabajo está dado por Michel de Certeau en La escritura de la historia y algunos artículos de Michel Foucault que integran la colección Microfísica del Poder. Por último, en mis comunicaciones en reuniones científicas, ${ }^{53}$ abordé la escritura de Pedro Lemebel como un caso particular dentro de la producción de discursos autobiográficos y no ficcionales, actualmente muy intensa. Se trata de una voz en

53 En el II Congreso Internacional de Literatura CELEHIS: "Reinvención de un género: las crónicas de Pedro Lemebel”. Mar del Plata, del 25 al 27 de noviembre de 2004. En el I Congreso Regional del Instituto Internacional de Literatura Iberoamericana: Nuevas cartografías críticas. Problemas actuales de la Literatura Iberoamericana: "Hacer hablar al cuerpo que calla: las crónicas de Pedro Lemebel". Rosario, 23, 24 y 25 de junio de 2005. En el VI Congreso Internacional Orbis Tertius de Teoría y Crítica Literaria: Las tradiciones críticas: "Crónicas: producto literario/ discurso histórico. Un compuesto discursivo heterogéneo". Universidad Nacional de La Plata, 10 al 12 de mayo de 2006. En el Congreso Internacional Cuestiones críticas: "Crónicas neobarrocas. Una línea de fuga entre el deseo y la historia", Universidad Nacional de Rosario, Facultad de Humanidades y Artes. 17, 18 y 19 de octubre de 2007. Actas en línea. En el III Congreso Internacional de Literatura CELEHIS: "Bordes problemáticos: autobiografía/ crónicas/ no ficción", Universidad Nacional de Mar del Plata. 7, 8 y 9 de abril de 2008. Actas en soporte electrónico. En el II Coloquio Internacional Escrituras del yo organizado por el Centro de Estudios de Teoría y Crítica Literaria de la Universidad Nacional de Rosario, Facultad de Humanidades y Artes: "El giro autobiográfico en la obra de Pedro Lemebel". Rosario, 18, 19 y 20 de agosto de 2010. Publicada en Actas en línea. Expositora en el IV Congreso Internacional CELEHIS de Literatura: "Procedimientos del barroco áureo en la poética de Pedro Lemebel", Facultad de Humanidades, Universidad Nacional de Mar del Plata, 7 al 9 de noviembre de 2011. En las V Jornadas de intercambio académico en el área de docencia e investigación de la literatura y de la cultura latinoamericanas, organizadas por la Red Académica de Docencia e Investigación en Literatura latinoamericana Katatay: "Poesía y crónica. El género como travesía en la poética de Pedro Lemebel", Valle Hermoso, Córdoba. 9 al 11 de diciembre de 2011. 
deriva, cuyo propósito de registro de la experiencia colectiva lo vincula a la mejor tradición de la crónica hispanoamericana a través de un sujeto itinerante que le otorga a la ficción autobiográfica una marca excéntrica y una condición nómade. Estos trabajos, cuyas fases previas de investigación me acercaron a las problemáticas relaciones entre la escritura y la historia, y a su particular modulación en el registro de la crónica latinoamericana, me permitieron advertir la singularidad de la obra de Pedro Lemebel y fueron la fragua de mis hipótesis. Me refiero específicamente a la condición transgresora y polémica de Lemebel respecto de los discursos establecidos, y su propósito de narrar la historia de su país desde la perspectiva de los seres minoritarios, caídos de la escena política y discursiva de los noventa.

\section{I.3. Problemáticas teórico-críticas acerca del género crónica}

En cuanto a las problemáticas críticas planteadas por las crónicas se advierte un interés creciente, manifestado en las reuniones científicas de los últimos años, a las que he aludido antes, como en las revistas especializadas en teoría y crítica literarias. Entre los cronistas contemporáneos más transitados por la crítica académica en los últimos años, pueden reconocerse dos generaciones, o bien dos grupos que presentan una sensible diferencia de edad. La primera generación estaría integrada por: Elena Poniatowska, Miguel Barnet, Edgardo Rodríguez Juliá, Néstor Perlongher, Carlos Monsivás y Pedro Lemebel. La segunda es mucho más difícil de determinar, dada la intensa productividad que registra el género actualmente, pero me atrevo a dar algunos nombres: Juan Villoro, Martín Caparrós y María Moreno. ${ }^{54}$

\footnotetext{
54 No obstante la señalada dificultad, cito a los autores que han sido recogidos en las recientes compilaciones del género: Leila Guerriero; Fabricio Mejía Madrid; Josefina Licitra; Roberto Navia Gabriel; Hernán Casciari; Álvaro Sierra; Toño Angulo Daneri; Cristian Alarcón; Alejandro Zambra; Juan Pablo Meneses; José Navia; Jaime Bedoya; Juan Forn; Julio Villanueva Chang; Alberto Salcedo Ramos;
} 
Si bien es obvio que muchos otros autores han publicado textos que pueden ser considerados crónicas, Poniatowska, Barnet, Rodríguez Juliá y Monsiváis, entre los más reconocidos por la crítica, publican crónicas desde la década de 1970 o primeros años de la década de 1980. Por esta razón, sus obras pueden ser consideradas un corpus establecido que opera como referente necesario para la consideración crítica y teórica del género.

Un ensayo que dentro del campo académico aborda tempranamente la problemática de los textos no ficcionales es el de Ana María Amar Sánchez: El relato de los hechos. Rodolfo Walsh: testimonio y escritura, Rosario, Beatriz Viterbo, 1992 (reeditado por Ediciones de la Flor, 2008). El trabajo comienza señalando la tensión como característica del género, y para ello hace alusión al nombre de no-ficción dado por Truman Capote. Según la ensayista, ese nombre se mantiene por convención, y por ello propone uno más preciso: "relato documental o testimonial" (13). En el primer capítulo ubica los orígenes del género en la década de 1960, en la que se registra la aparición de los primeros textos de no-ficción, e insiste en que la hibridez, la dicotomía o el contrapunto han dominado las observaciones de los críticos, y por ello "no han definido su especificidad" (14). Según la autora: "Es justamente en el espacio de la literatura misma donde las fricciones, los roces entre lo real y lo ficcional señalan la existencia de una relación compleja que pone al descubierto la no-ficción y que no se resuelve en términos de oposiciones" (18).

Si bien Amar Sánchez rechaza la hibridez, el contrapunto, la dicotomía o cualquier otro tipo de oposición como rasgo distintivo del género, no logra superar en el ensayo esos mismos términos que parecen detener la reflexión teórica precisamente

(en la compilación de Jaramillo Agudelo: 2010), a los que se agregan: Jordi Costa; Alberto Fuguet; Maye Primera; Rodrigo Fresán; Edgardo Cozarinsky; Juan Gabriel Vásquez; Guillem Martínez y Gabriela Wiener (en la compilación de Jorge Carrión: 2012). 
cuando se pretende eliminarlos. El momento más lúcido de su reflexión, a mi juicio, lo alcanza cuando asume la imposibilidad de toda síntesis como rasgo peculiar del género:

El género se juega en el cruce de dos imposibilidades: la de mostrarse como ficción, puesto que los hechos ocurrieron y el lector lo sabe y, por otra parte, la imposibilidad de mostrarse como un espejo fiel de esos hechos. Lo real no es describible "tal cual es" porque el lenguaje es otra realidad e impone sus leyes: de algún modo recorta, organiza y ficcionaliza. El relato de no-ficción se distancia tanto del realismo ingenuo como de la pretendida "objetividad" periodística, produciendo simultáneamente la destrucción de la ilusión ficcional (en la medida en que mantiene un compromiso de "fidelidad" con los hechos) y de la creencia en el reflejo exacto e imparcial de los sucesos, al utilizar formas con un fuerte verosímil interno como es el caso de la novela policial. (Amar Sánchez: 19)

Ahora bien, después de esta interesante observación, que le hace justicia a la hibridez irreductible del género, la ensayista afirma que ha encontrado la clave para resolver las dicotomías y por lo tanto se dispone a definir la especificidad del género:

Lo específico del género está en el modo en que el relato de no-ficción resuelve la tensión entre lo "ficcional" y lo "real". El encuentro de ambos términos no da como resultado una mezcla [...] sino que surge una construcción nueva cuya particularidad está dada con la constitución de un espacio intersticial donde se fusionan y destruyen al mismo tiempo los límites entre distintos géneros. (Amar Sánchez: 19)

Llama la atención que en la misma página se den dos párrafos, uno tan lúcido y otro tan inconsistente. En la última cita observamos que "un espacio intersticial donde se fusionan y destruyen al mismo tiempo los límites..." no quiere decir absolutamente nada. No puede afirmarse con consistencia primero que la no-ficción sea el resultado de una doble imposibilidad por aquello que la filosofía del lenguaje ha tratado desde los estoicos: la irreductible diferencia entre las palabras y las cosas, entre el lenguaje y lo real, y afirmar después que esa irreductibilidad puede superarse mágicamente a través de una "fusión” y una “destrucción” que la ensayista no explica. 
Lo que advertimos en el género crónica (y postulo: en todos los géneros rozados por la hibridez y el contrapunto entre realidad y ficción), y es una de las líneas de reflexión que los textos de Pedro Lemebel provoca, es un incesante y múltiple juego de desplazamientos. El espacio intersticial del que habla Amar Sánchez, lejos de ser superado o resuelto a través de una fusión o desaparición inexplicable, no es ni será llenado u obturado, sino que funciona como el principio mismo o motor de los desplazamientos. Por ello las crónicas de Pedro Lemebel se oponen a una filosofía de la claridad y de las luces, pues en ella la opacidad, la incertidumbre y la contradicción se encuentran interdictas. En las crónicas latinoamericanas contemporáneas y particularmente en las del autor chileno, se promueve la diferencia (la rareza de la joya, al decir de Néstor Perlongher) como un valor y una positividad. Una diferencia que no será salvada ni superada, sino reconocida y valorada como positividad, no sólo en el plano ideológico y políticamente correcto, sino como principio activo de los movimientos internos al campo literario e historiográfico. La memoria ligada no solo al documento: también a la pérdida. La escritura retirada del ámbito solitario y silencioso para ser territorializada por los sonidos y las voces de la calle. La escritura que remonta la abstracción e inmaterialidad del mandato racionalista para ser atravesada por la materialidad del cuerpo y la experiencia del sujeto itinerante, que camina y se deja “arrastrar por lo que llega”.

Luego la autora vuelve a demostrar una aguda comprensión de los cambios y reposicionamientos en la serie literaria, cuando afirma que después de la segunda guerra mundial se inicia un período de "intensa experimentación en literatura", y afirma que más tarde, en los años sesenta, se observa la "presión de lo real de la que no podían hacerse cargo formas ya desgastadas como el realismo" (Amar Sánchez: 23). Ello explica el proyecto de una "literatura fáctica", ligado a interesantes discusiones teóricas 
(la ensayista nombra a Lukács, a Brecht y a Benjamin como sus protagonistas). Tanto Brecht como Benjamin sostienen la historicidad de las formas: los nuevos temas exigen formas nuevas que se valgan de la evolución de los medios técnicos. Según Amar Sánchez, “el proyecto de los autores alemanes recién a partir de la década del '60 se configura y toma fuerza en el relato de no-ficción” (26). Hasta el momento la autora no ha hecho ninguna diferencia entre no-ficción (considerada un sinónimo de Nuevo Periodismo) y crónica. Pero sí establece una diferencia con el periodismo a secas:

[...] los textos [periodísticos] investigan y trabajan con las evidencias, las pruebas, los testimonios comprobables. [...] El texto de no-ficción es una versión que enfrenta otras versiones de los mismos hechos, sólo que trabaja sin omitir testimonios, grabaciones y discursos que las otras silencian. (Amar Sánchez: 34)

Cuando se refiere específicamente a la crónica (en referencia a un texto de Rodríguez Juliá: El entierro de Cortijo), señala que su especificidad está dada por la ficcionalización del cronista:

[...] en la medida en que todo el relato pasa por él, por su posición de sujeto que escribe, por su perspectiva en la que cobran importancia los gestos, las actitudes y los recuerdos de los otros sujetos. De este modo el texto, lejos de ser un informe escueto, objetivo, lleva al lector al centro de lo ocurrido (Amar Sánchez: 51).

Luego se refiere a Biografía de un cimarrón, de Barnet, y lo llama "crónica", pero lo considera, sin más, dentro de los textos de no-ficción (52). Por lo tanto, el propósito de establecer claras distinciones -declarado en el primer capítulo del ensayono se cumple.

En 2006 la misma editorial -dedicada, como sabemos, a estudios académicospublica: Cristoff, María Sonia (comp.): Idea crónica. Literatura de no ficción iberoamericana, Buenos Aires, Beatriz Viterbo, 2006. En ese volumen, que reúne 
producciones de quince autores (casi todos hispanoamericanos con las excepciones de la escritora estadounidense Anna Kazumi Stahl y el periodista español Jorge Carrión) encontré un conjunto muy variado de textos, muchos de los cuales, a mi juicio, no justifican su condición de crónicas, por mucha buena voluntad que el lector ponga en ello. Mi sorpresa deriva de que el propósito del libro - puesto de manifiesto por la compiladora en el título y en la contratapa, y por Mónica Bernabé en el prólogo- no es otro que explorar las condiciones del género:

Los críticos que estudian la amplia gama de formas que va del nuevo periodismo hasta la narrativa documental trabajan con un corpus difuso, en donde la crónica se confunde con el testimonio y el testimonio no logra distinguirse de la novela de no-ficción [...]. Asimismo, la mayoría reconoce que ese impreciso espacio textual encuentra su precedente más remoto en el testimonio de los cronistas de Indias y las relaciones de la Conquista (Bernabé 2006: 7-8).

Ahora bien, la selección de textos agrega material a la confusión que señala la ensayista. Por ejemplo, el texto de Alan Pauls ${ }^{55}$ incluido en la colección, es, a todas luces, un texto de ficción. Es decir, no sólo no presenta ninguno de los rasgos que he señalado como distintivos de la crónica, sino que tampoco puede ser considerado un texto que se proponga o señale una relación de correferencia con lo real. "Mi vida como hombre" (tal el título) es lisa y llanamente un relato que podría perfectamente incluirse en un libro de cuentos del autor, o en una antología de narrativa de ficción. El texto de María Moreno ("No, mi ama") es una entrevista; también hay diarios de viaje (como el texto de Luis Chitarroni titulado "Cinco días") y textos mucho más cercanos al diario íntimo, como "Los pájaros cantaron de noche", de Jacinta Escudos. También encuentro en la compilación tres características muy significativas. La primera es que casi todos los textos (diez) fueron escritos ad hoc, es decir, para ser publicados en el volumen,

\footnotetext{
${ }^{55}$ Pauls, Alan: “Mi vida como hombre”, en: Cristoff, María Sonia, op. cit., págs. 101-116.
} 
configurando una especie de contradicción -a mi juicio- con la expectativa del lector que espera un recorrido por las producciones más destacadas o representativas del género dado que es ése el único criterio homogeneizador del libro. La segunda es que la gran mayoría de los autores convocados son escritores de ficción o de ensayo, y -salvo Monsiváis y Rodríguez Juliá- no tienen una producción importante en el terreno de la crónica (en algunos casos curiosamente no han escrito crónica nunca antes). La tercera está dada por las inconcebibles ausencias de Elena Poniatowska, Miguel Barnet y Pedro Lemebel. En los dos primeros casos por tratarse de autores insoslayables, tanto por su papel en la constitución del género tal como lo entendemos hoy, es decir, en su desarrollo posterior al Modernismo, como por la abundante producción que registran desde 1966 hasta la actualidad. En el caso de Lemebel, por tratarse de un autor que ha publicado seis volúmenes de crónicas entre 1995 y 2008, que registra muy poca producción literaria en otro género (una novela y un muy temprano libro de cuentos), y que es el único escritor nacido durante la segunda mitad del siglo XX en América Latina cuya obra, como hemos dicho aquí, está siendo intensamente observada por la crítica especializada en el género "crónica".

Desde luego, debo decir que hay muchas otras ausencias cuestionables o por lo menos llamativas; y también es justo reconocer que toda antología es incompleta; sólo he señalado las ausencias y las inconsistencias que me parecen inadmisibles en un libro que se propone explorar las condiciones del género. Al menos eso parece indicar el prólogo de Mónica Bernabé, que ilustra al lector acerca de las cuestiones problemáticas más debatidas hoy a propósito de esta nueva discursividad de "fronteras abiertas y funciones variables". Nuestro propósito es despejar en la medida de nuestras posibilidades y de las posibilidades del género, las confusiones y las imprecisiones que 
cita Bernabé, a fin de cartografiar las "múltiples alianzas posibles", al decir de Michel de Certeau, entre la escritura y la historia.

La ensayista ecuatoriana Cecilia Lanza Lobo publica en diciembre de 2004 su ensayo: Crónicas de identidad, Ediciones Abya-Yala, Corporación Editora Nacional, Quito. En él aborda un libro del reconocido poeta boliviano Jaime Sáenz: Imágenes paceñas (1979), uno de Carlos Monsiváis: Los rituales del caos (1995) y uno de Pedro Lemebel: La esquina es mi corazón (1995). Pero antes de abordar esas escrituras, la autora desarrolla en dos capítulos sus puntos de vista sobre la crónica como género. A propósito Lanza Lobo considera que

La crónica es un género situado por fuera del espacio normado -digamos en los márgenes de la institución literaria y periodísticadebido a su particular tratamiento de las categorías de ficción y no ficción. La crónica es así una "textualidad discordante" cuya marginalidad le ha permitido señalar, precisamente desde allí, su lugar de enunciación al asumir la vida como relato.

Porque ubicada en los márgenes, la crónica ha optado por narrar el reverso de la realidad extendiendo el horizonte de los "temas poetizables" hacia la cotidianidad como un espacio atravesado, de manera fundamental, por relatos y sentidos. (Lanza Lobo: 9. Énfasis en el original).

En la línea de Susana Rotker -a quien cita con cierta insistencia- podemos reconocer una idea que aparecerá también en el desarrollo de esta tesis, por otra parte ineludible dada su obviedad: la crónica como género marginal, "textualidad discordante" o, como dirá Lanza a continuación, género "anfibio":

La apuesta de este texto entonces es doble: afirmar a la crónica como relato anfibio capaz de aprehender una realidad tan caótica como ella misma (en tanto género "impuro", constituido a modo de collage de formas y categorías narrativas) y, por lo mismo, ubicar a la crónica como el relato capaz de dar cuenta de las identidades contemporáneas constituidas hoy en el espacio mediático. (Lanza Lobo: 10) 
También acuerda con Rotker en situar a la crónica entre la literatura y el periodismo y postula que:

Ningún otro texto propone mirar y empaparse del espacio que la rodea tanto como la crónica porque ningún otro texto resume/asume toda la impregnación (contaminación) de géneros tanto como la crónica, señalando de esta manera un rasgo particular de dos fines de siglo, XIX y XX. (Lanza Lobo: 13)

La autora ecuatoriana señala en el desarrollo de su ensayo que la crónica surge como un género apto para representar y dar cuenta de las identidades heterogéneas ("pluriculturales") del ámbito latinoamericano, al tiempo que la ubica en un espacio de crisis y tensiones propio de los dos períodos finiseculares que analiza: fin de siglo XIX y fin de siglo XX, en los cuales la incertidumbre es "el telón de fondo" (19). Esto le permite dar cuenta de un tránsito: de la ciudad letrada a la ciudad mediática, desplazamiento convergente -para la autora- con el paso de la modernidad a la posmodernidad. En un intento de síntesis algo simplificador, Lanza Lobo afirma:

Los escenarios de representación de la crónica, entonces, van de la conciencia racional, normativa y totalizadora de la modernidad a la conciencia individual, heterogénea, dispersa y "plurimulti" de la posmodernidad. (Lanza Lobo: 17)

En este contexto abordará -en la última parte de su tratado- el volumen de Lemebel de 1995 como una obra posmoderna. Con respecto al vínculo entre crónica y marginalidad, reconoce un elemento paradójico:

[...] la crónica es capaz de articular tres discursos: el concierto polifónico de las voces de la alteridad que no caben sino en la crónica; la centralidad de los márgenes que -paradójicamente- la crónica hace posible extendiendo, al mismo tiempo, el espacio de circulación de sentidos, cuestionando a su vez el logos pretendido de la propia literatura y finalmente, la mitificación de la vida cotidiana a partir de la articulación del discurso paradójico de la vida asumida como relato. (Lanza Lobo: 10). 
Una vez más advierto en la crítica acerca del género la casi obsesiva necesidad de resolver y “domesticar” las tensiones y contradicciones que la crónica testimonia y al mismo tiempo sostiene en su propia materialidad híbrida de propósitos y técnicas divergentes. Lanza Lobo sostiene que el género en cuestión (por su tendencia, ya apuntada, a "la mitificación de la vida cotidiana") resolvería las tensiones construyendo espacios y personajes míticos:

Las tensiones, entonces, se resuelven ficcionalizando los mitos, haciendo de ellos historias más próximas mediante relatos que se le parezcan, modificando o acomodando -por qué no- el propio mito a nuestro relato. De qué otra manera si no se construyen los personajes míticos, de qué otra manera si no podemos aspirar a la trascendencia, al lugar donde habita la eternidad en la que finalmente somos solo Uno. (Lanza Lobo: 23)

Cabe aclarar que esta última derivación del ensayo me parece por completo desacertada, y profundamente incoherente con lo que sostiene en la introducción y en buena parte de su desarrollo. Si postulamos que la crónica es una espacio de tensiones que da cuenta de identidades heterogéneas propias del ámbito latinoamericano, y que la incertidumbre de los períodos finiseculares ha hecho resurgir, promoviendo la hibridez genérica como algo positivo habida cuenta de su ductilidad formal y su posibilidad de dar centralidad a las marginalidades de la historia cultural latinoamericana, entonces no puede sostenerse al mismo tiempo que la crónica resuelva esas tensiones y abandone su lugar ambivalente e híbrido por la vía de la mitificación trascendente. Más incoherente aún teniendo en cuenta que la autora cita a Michel Foucault y a Michel de Certeau para abonar sus dos primeras hipótesis (primera: el concierto polifónico de las voces de la alteridad "que no caben sino en la crónica"; y segunda: "la centralidad de los márgenes" extendiendo el espacio de circulación de sentidos y cuestionando el 
pretendido logocentrismo de los discursos establecidos) y para justificar la tercera (la mitificación de la vida cotidiana) remite a Marc Augé, en su artículo: "La vida como relato", cuyos desarrollos reniegan y descalifican la mirada filosófica que los autores antes mencionados sostienen acerca de la irreductible diferencia entre el orden del discurso y el incapturable orden real. Paradoja irresoluble que los discursos bordean y problematizan -a la vez que son problematizados por ella- sin poder eludir, resolver ni remontar jamás.

Recurro una vez más a la lucidez de Severo Sarduy, quien ha criticado la "violenta pulsión de unificación" que parece dominar el pensamiento ensayístico y crítico sobre la literatura. ¿Qué sentido puede tener -volviendo al ensayo de Lanza Lobo- la nostalgia de trascendencia que nos llevaría a una "mitificación de la vida cotidiana" que permita "aspirar a la trascendencia, al lugar donde habita la eternidad en la que finalmente somos solo Uno" [sic], dando por hecho que esta aspiración sería generalizada y positiva, aplanando las tan mentadas identidades heterogéneas que habían sido felizmente recuperadas por la crónica?

Lanza Lobo reitera sus hipótesis en la conclusión del trabajo, y afirma que

[...] en tanto relato, al narrar la vida, la crónica va dotándole de sentido, otorgando a lo (re)presentado una cualidad distinta, una significación propia que lo singulariza y lo eleva a una condición mítica. Este proceso de mitificación se logra, asimismo, al fundir la crónica la representación con lo representado, porque entonces el sujeto se reconoce -épicamente- en el relato y se construye como personaje de su propia historia (Lanza Lobo: 120. Énfasis en el original).

Claramente, de la mano de la mitificación, la autora trae a su discurso las nociones de fusión, reconocimiento e identificación, todas tributarias de una epistemología clásica, deudora del pensamiento de lo Uno, y poco o nada consistente con el propósito de registro de la diversidad cultural y el relevamiento de las identidades 
heterogéneas del amplio campo multicultural latinoamericano. También poco consistente con la hibridez y la condición "anfibia" y marginal que la propia ensayista había señalado como rasgo distintivo del género.

Párrafo aparte merecen las tres importantes antologías de crónicas latinoamericanas contemporáneas de reciente aparición.

La primera, compilada por Darío Jaramillo Agudelo y publicada en 2010 por el sello Alfaguara comienza con una extensa introducción del editor, titulada "Collage sobre la crónica latinoamericana del siglo veintiuno" (11-47). En ella Jaramillo Agudelo propone la hipótesis de que la crónica podría ser el "nuevo boom" de la literatura latinoamericana, en obvia alusión al auge de la novela en nuestro continente que protagonizaran Rulfo, Fuentes, García Márquez, Vargas Llosa, Onetti, Cortázar, Carpentier, Roa Bastos, entre otros, durante los años sesenta (o mediados de los cincuenta teniendo en cuenta a Rulfo) y cuya declinación se dio a comienzos de los setenta. Según el compilador, hubo algunos ensayos para forzar un nuevo auge, pero no pasaron de la etapa de "plan de mercadeo" (11); la clave para que se produjera este nuevo auge ha sido -siempre según Jaramillo- "que no se pareciera en nada el fenómeno de hace cincuenta años: que cambiara el modelo de lector, que cambiara el arquetipo de la escritura y, por lo tanto, que las técnicas de los escritores fueran diferentes. Tal cosa parece estar ocurriendo con la crónica en nuestro continente” (11). Creo que las tres afirmaciones (modelo de lector, arquetipo de escritura y técnicas de escritores) presentan un grado de generalidad tan intratable que no permiten ni siquiera intentar discutir con ellas. No obstante, podemos aceptar que, en efecto, la crónica reviste hoy un interés por parte de editores, lectores, críticos y autores que merece la comparación con el celebrado boom. 
Un rasgo a destacar en esta introducción, es que el autor habla siempre de "periodismo narrativo" para referirse a este tipo de discurso. No tengo objeciones fuertes al respecto, simplemente señalo que esa denominación subraya la condición del autor (ser periodista) que, como sabemos, no es absolutamente indispensable para ser cronista. Prueba de ello es el autor que me ocupa en la presente tesis doctoral: Pedro Lemebel no es ni ha sido nunca periodista. (Tampoco Elena Poniatowska -aunque ha ejercido el periodismo, como sabemos- podría ser definida profesionalmente como "periodista". Tampoco Néstor Perlongher, poeta y ensayista argentino que juega un papel preponderante en la genealogía autoral de Lemebel, puede ser considerado un periodista: nunca lo fue. Y podríamos seguir citando ejemplos, pero estos tres me parecen suficientes).

Jaramillo Agudelo aborda la historia del género, y nombra en primer lugar a Carlos Monsiváis; cita su definición de crónica y lo declara "uno de los padres fundadores del periodismo narrativo latinoamericano del siglo veintiuno" (12). A continuación se refiere muy brevemente a las etapas de la historia del género, mencionando las crónicas de los conquistadores, los cuadros de costumbres del siglo diecinueve, y -sin dar precisiones temporales- las crónicas de los modernistas. Siempre según el compilador, después de ellas hubo una época "en que la noticia escueta y la prisa informativa se convierten en dogma excluyente del periodismo" (12). Finalmente (“decenios después", seguimos sin encontrar precisiones de orden temporal) la crónica "renace a través de libros y de la publicación fragmentada en varias entregas en periódicos y revistas" (como vemos la imprecisión marca el estilo de esta introducción). El siguiente párrafo sorprende al afirmar:

Es en ese momento [no sabemos a qué momento se refiere Jaramillo Agudelo] cuando aparecen los clásicos modernos de la narrativa periodística latinoamericana de hoy. García Márquez, Tomás 
Eloy Martínez, Elena Poniatowska, Carlos Monsiváis forman parte de ese parnaso de padres (iy madres!) fundadores reconocidos en todo el continente (Jaramillo Agudelo: 13).

Todos los que nos hemos acercado con interés epistemológico al género conocemos las dificultades de intentar cercar el fenómeno, y sobre todo, de elaborar una lista o conjunto completo de autores. Tal cosa es materialmente imposible, y así lo reconoce Jaramillo Agudelo. En el intento, comete el error de incluir -de la mano de Tomás Eloy Martínez- a Jorge Luis Borges (Historia universal de la infamia y Otras inquisiciones son los títulos enunciados) en la lista de los autores consagrados del género. Me pregunto qué ha llevado a Tomás Eloy Martínez, y a Jaramillo Agudelo siguiéndolo, a considerar al autor de Ficciones como cronista, pero no hay en la introducción ningún elemento de juicio que permita discutir esa inclusión. Simplemente se lo consigna junto a Sarmiento, Mansilla, José Hernández, Cané, Payró, Arlt y Cortázar. También sorprende la referencia al Martín Fierro como un texto de crónica, pero, de nuevo, no hay justificación alguna en el texto de la introducción que dé lugar a una discusión crítica al respecto.

Un apartado particularmente interesante de la introducción que estoy analizando -dado el interés que comparte con mi investigación- es el dedicado al concepto y las características de la crónica. Tiene la virtud de reunir definiciones muy interesantes y completas, siempre de autores reconocidos: a la ya citada de Carlos Monsiváis, se suma la muy literaria de Juan Villoro; dos muy breves de García Márquez y de Toño Angulo Danieri, y una de Martín Caparrós que subraya su vínculo filosófico con el tiempo. Luego Jaramillo cita extensamente el prólogo de Los periodistas literarios (o el arte del reportaje personal), de Normas Sims. El resto de la introducción está absolutamente teñido y consustanciado con ese prólogo, lo cual no le impide citar también a otros 
autores, como el peruano Marcos Avilés y Alberto Chillón quien cita a su vez a José María Valverde.

A propósito señalo lo que es a las claras uno de los errores más reiterados en esta introducción: la fuente indirecta. Jaramillo Agudelo hace uso (y abuso a mi criterio) de la cita indirecta, lo cual conspira contra el interés del lector que no encuentra las referencias bibliográficas de las citas de autoridad. Esto me parece grave por tratarse de un libro que se presenta con un propósito de análisis exhaustivo y como una indagación acerca de las regularidades del género, como lo indican claramente algunos subtítulos: “¿De qué estoy hablando cuando digo ‘crónica'?” (14) o bien: “Características de la crónica: Wolf, Sims y otros" (17).

La antología se divide en dos partes. La primera parte se titula "Los cronistas escriben crónicas", y es la que tiene mayor desarrollo (Jaramillo Agudelo 49-573), y la segunda: "Los cronistas escriben sobre la crónica" (575-635). Esta última parte es muy interesante para los estudiosos del género, pues presenta una buena selección de textos en la que los propios autores reflexionan sobre este tipo de discurso dinámico, híbrido y complejo, dando cuenta de su interés como objeto de reflexión crítica y, al mismo tiempo, de su dificultad de definición. La antología, además de la profusión de fuentes indirectas, carece absolutamente de bibliografía. Esa omisión resulta muy limitante para quienes nos acercamos con interés epistemológico a las múltiples cuestiones que nos plantea hoy la crónica y sus vínculos con los discursos literarios, periodísticos e historiográficos en nuestro continente.

La editorial Eterna Cadencia ha iniciado en 2010 la publicación de una serie de volúmenes de crónicas al cuidado de María Moreno. La colección, titulada Nuestra América, da cuenta una vez más del interés que reviste el género en nuestro continente, de su vigencia y su productividad. Los tres tomos aparecidos hasta el momento 
demuestran que la crónica no reconoce límites temáticos (a diferencia de lo que Jaramillo Agudelo postula en su apartado "Los temas" al que apenas dedica dos páginas de su extensa introducción, ya comentada).

El primer tomo, a cargo de Beatriz Colombi, se titula: Cosmópolis. Del flâneur al globe-trotter y reúne cuarenta y dos textos de veintiocho autores latinoamericanos, cuya producción se ubica mayoritariamente durante las últimas décadas del siglo XIX y las primeras del XX. Los textos compilados son crónicas de viaje en las que el narrador invita a su lector a realizar el recorrido. Así, el género convoca, recorta y de algún modo construye a su destinatario, a través de una sintaxis digresiva: el eje del itinerario se encuentra a menudo interrumpido por la anécdota insólita, el suceso inesperado, el encuentro casual. Como señala Colombi en el prólogo, este tipo textual se desarrolla en nuestro continente al calor del proyecto emancipador. El hispanoamericano se inicia como viajero con los preparativos de la independencia, movido por el interés que despiertan en él los modelos de organización política de las naciones europeas y de los Estados Unidos. En sus desplazamientos los cronistas llevan diarios y producen anotaciones, artículos, notas de costumbres, los cuales inauguran un corpus textual vasto y diverso, que se va acrecentando con el correr de los años y se convierte en un patrimonio de singular valor tanto para el estudioso del género como para el lector interesado en la complejidad política y social de nuestra historia americana.

El volumen da cuenta de la cercanía entre crónica de viaje y crónica periodística, y también de la hibridez constitutiva del género. La ambigüedad se efectúa en varias dimensiones textuales. En principio, está dada por la interacción entre la propiedad verificable de lo dicho y el estatuto ficcional que permea la narración. Así el verosímil de este género se construye en virtud de una relación dialéctica entre la verdad de los hechos narrados y de los espacios recorridos, y la ficción que sostiene el interés del 
lector y ajusta el efecto de realidad. De allí que ficción y veridicción potencien recíprocamente su valor cognitivo (algunas "notas" de Lucio V. López por ejemplo, pueden ser leídas como cuentos). Así como la ficción y el testimonio se dan la mano, también conviven en este género la intimidad y el interés social y político, como se observa en la reflexión de Martí sobre la idiosincrasia del pueblo norteamericano; del mismo modo se amalgaman la narración y la descripción, el propósito de registro y el despreocupado "vaguear" (término con el que Sarmiento intenta traducir el verbo francés flâner).

La diversidad de estilos y de intereses de los autores que se hace patente en este libro, permite comprender por qué las definiciones que intentan fijar los rasgos del género resultan, más temprano que tarde, inoperantes. El volumen que nos ocupa tiene también el mérito de explorar las variantes históricas de esta discursividad heterogénea. A partir de la primera mitad del siglo XIX, la crónica se aparta de la tutela de la ciencia y se afirma dentro del campo literario; este primer avatar está representado por el cuadro y el artículo de costumbres, con su construcción de tipos y descripción de paisajes y escenarios regionales, lo que podemos llamar "relato costumbrista" (este devenir será analizado en el primer capítulo de la presente tesis). Dicha condición se destaca tanto en los Viajes de Sarmiento como en los Paseos de Flora Tristán; y permanece en las descripciones de Enrique Gómez Carrillo y en las crónicas de José Martí.

Durante el transcurso del siglo XIX y con el desarrollo de la industria gráfica, la crónica se acerca a la noticia, y el viajero se convierte en corresponsal (lo que explica la conocida frase de Gutiérrez Nájera: "La crónica, señores y señoritas, es, en los días que corren, un anacronismo [...] ha muerto a manos del reporter ${ }^{, 56}$ ). Pero la crónica no muere ni pierde nunca su estatuto literario, y se distingue de los imperativos

\footnotetext{
${ }^{56}$ Citado por José Ismael Gutiérrez: "La crónica, género de transición. La confluencia periodismo literatura", en Manuel Gutiérrez Nájera y sus cuentos. De la crónica periodística al relato de ficción, Peter Lang Publishing, New York, 1999, pp. 91-92.
} 
racionalistas y "objetivos" de la prensa. La experiencia del enunciador es decisiva, y por ella, el relato de espacio transforma los lugares observados en espacios recorridos. Algunos, como Miguel Cané, viajan en misión oficial, otros, como Lucio V. Mansilla, representan la mirada del viajero goloso, consciente de su posición privilegiada y sus prerrogativas de clase. No falta la mirada femenina en las voces de Eduarda Mansilla, Clorinda Matto de Turner, Teresa de la Parra y la ya nombrada Flora Tristán.

Muchos otros célebres escritores se dan cita en este volumen, como César Vallejo, Alfonso Reyes, Ricardo Palma, Pablo Neruda, Amado Nervo, Salvador Novo, Eduardo Wilde. El libro traza un recorrido histórico que abarca aproximadamente un siglo, entre los años 40 del siglo XIX y la década del 30 del siglo XX, con dos excepciones: la primera crónica es de 1783 y la última, de Cabrera Infante, es de 1999, como recordando a los lectores que esta tradición de escritura se extiende en ambas direcciones del tiempo cronológico, y desde luego, no ha perdido su vigencia.

El segundo tomo de esta colección dirigida por María Moreno, en este caso a cargo de Ariela Schnirmajer, se titula ;Arriba las manos! Crónicas de crímenes, "filo misho" y otros cuentos del tío, y aborda los modos de narrar el delito en América Latina entre 1880 y 1930 . En su mayoría, estas crónicas se publicaron en los diarios, y por ello dan cuenta de un doble proceso: las transformaciones en el oficio del cronista y los cambios en los públicos lectores, cuyo crecimiento y diversificación determinaron en buena medida las variantes de esta especie particular del género.

El fin de siglo asiste al surgimiento de la llamada prensa popular, que responde a la demanda de grandes masas de lectores recién incorporados a la alfabetización. Esos periódicos se orientan al entretenimiento, y surge en ellos un tipo de crónica policial, de grandes titulares y profusamente ilustrada (cuyo representante más destacado en Buenos Aires fue la célebre Caras y Caretas, fundada en 1898 y dirigida por José S. Álvarez, 
más conocido como Fray Mocho). Algunas de esas crónicas de corte sensacionalista, conviven en este volumen con otra vertiente ligada a los grandes diarios prestigiosos, como La Nación de Buenos Aires, O Estado de Saõ Paulo de Brasil, o El Imparcial de México, que en respuesta al deseo de actualidad y novedad de sus lectores, introducen crónicas de "casos célebres" o "ladrones famosos", y con ellos, una riquísima pluralidad de estilos literarios y opciones retóricas. Por ejemplo, Rubén Darío escribe en La Nación sobre el caso de una famosa actriz ahogada en el Rhin ("La novela de Lantelme") y con absoluta consciencia de estar escribiendo un texto literario, produce un drama romántico (“melodrama romántico-bovarista”, según Ariela Schnirmajer) en el que reflexiona sobre la figura del artista y sus relaciones conflictivas con el mercado en las primeras décadas del siglo XX.

Abundan en estas crónicas multitud de procedimientos literarios, desde el naturalismo de los bajos fondos y la creación de atmósferas inquietantes (Laurentino Mejías o Adolfo Bátiz), hasta la esmerada y muy ingenua erudición filológica del comisario-escritor Manuel Barrés, que nos ilustra sobre el "caló" o argot porteño y acerca del "filo misho", una de las variantes del "cuento del tío" que consiste en engañar a algún ingenuo acaudalado con una falsa máquina de falsificación de billetes. Este último texto registra un fenómeno decisivo en las transformaciones del fin de siglo latinoamericano, y que Schnirmajer consigna al comienzo de su prólogo: los cambios vertiginosos en la composición poblacional, producto de la economía en crecimiento y la consecuente esperanza de ascenso social que atraen hacia los grandes centros urbanos a multitudes de inmigrantes. "En su mayoría - narra Barrés- estos delincuentes son extranjeros; abundando el polaco, ruso, checo-eslovaco, italiano y muy escasamente el español o argentino.” (230). 
En algunas crónicas se observa la impronta de Edgar Allan Poe, especialmente cuando el policía se transforma en detective y la estructura narrativa sigue el modelo tripartito de la novela de enigma, donde el método hipotético-deductivo se impone, su racionalidad sin fisuras diluye el misterio inicial y conduce a la resolución del caso. Mención especial merece el texto del colombiano Francisco de Paula Muñoz, pionero del periodismo de investigación, quien escribe un temprano relato de no-ficción, "El crimen de Aguacatal", texto de 1874 que sorprende por su ajustada fidelidad a los hechos y su atención al detalle, rasgos que provocan un efecto de realidad muy eficaz y tiene en vilo al lector hasta la última línea, en una audaz y original elaboración del legado de Poe -la tensión hacia el efecto- anticipándose en un siglo al nuevo género fundado por Capote.

También en este volumen, como lo señaláramos a propósito del primero, se observa el feliz matrimonio entre el registro fidedigno de los hechos y la creación ficcional. Una vez más queda demostrado que las intensas contradicciones y ambigüedades que constituyen la crónica determinan el valor y la potencia de una paradoja que no debemos (y no podemos) resolver: la distancia entre la expectativa de verdad y la libertad ficcional es un requerimiento del verosímil del género, y su única garantía de eficacia narrativa. En otros términos: hay que mentir bien la verdad.

El tercer volumen de la colección está a cargo de José Quiroga y se titula Mapa callejero. Crónicas sobre lo gay desde América latina. Es el último aparecido hasta la fecha $\mathrm{y}$, sin ninguna duda, el más heterogéneo y el menos ajustado a la expectativa creada por el término "crónica" consignado en el título. Veintidós de los treinta y siete textos incluidos en la compilación no aceptarían ese rótulo. Uso deliberadamente el término "rótulo" porque con él me refiero al gesto siempre reductivo y racionalista de la unificación categorial. No obstante, en una compilación dirigida al público en general, o 
bien al lector interesado pero no especializado, y teniendo en cuenta, además, que está precedido por dos volúmenes que son, sin discusión, compilaciones de crónicas, se espera encontrar un conjunto de textos que remitan a una historia o relato de hechos sucedidos, con un punto de vista particular -el del cronista- y una construcción ficcional y literaria que dé cuenta de los acontecimientos y tienda a lograr el efecto de realidad que la dialéctica historia-ficción produce, condición ambivalente y paradojal propia del género.

En la sucesión de textos reunidos aquí por el compilador, encontramos una amplia variedad de géneros y aun de textualidades que en primera instancia no consideraríamos literarias, por ejemplo: un artículo de Historia Natural de 1813, titulado "Descripción de un hermafrodita"; un largo y muy interesante artículo de medicina legal, con todas las características discursivas y formales de esa disciplina, titulado "La pederastia en Cuba", publicado en La Habana en 1890; un extracto de los Archivos de Psiquiatría, Criminología y Ciencias afines, de Francisco de Veyga (1903), titulado: "La inversión sexual adquirida". Entre los textos literarios, se destacan un largo y hermoso poema rimado de Teófilo Pedroza (1897) y otro poema popular anónimo de 1901. También abundan los géneros de la intimidad, como memorias, cartas o fragmentos de cartas y diarios íntimos. No falta el blog, la noticia periodística, el ensayo, un fragmento de novela y varios cuentos. Desde luego, también hay crónicas. El elemento común que le da profunda unidad de sentido a este volumen es, desde luego, la experiencia de la homosexualidad y en muchos casos, de la discriminación y la persecución homofóbicas. Los protagonistas de estos textos, a veces sujetos de su propia escritura, a veces objetos de una fría descripción científica como en los textos de Montané o de Veyga, son siempre masculinos. No hay registro de homosexualidad femenina (excepto la evocación de Martha Strada, escrita por un hombre: Norge 
Espinosa) lo cual nos lleva a preguntarnos si se trata de una ausencia en el interés del compilador o de un silencio que habla a gritos en las siempre dudosas instancias de legitimación del sistema literario.

El libro presenta "lo gay” en América latina en vínculo con el espacio callejero. Quiroga afirma en el prólogo que "una nueva sociología en primera persona, participativa en muchos casos, ha reclamado su lugar" (13). Atendiendo a esa definición, los autores o enunciadores de los textos reunidos aquí se asoman a "la ventana de la crónica para ver, para entender, la calle", asumiendo un "gesto de ruptura [...] dentro de una realidad codificada" (14). Es decir que los cronistas contemporáneos (como antes el Inca Garcilaso, como Bernal Díaz del Castillo) "están fuera": fuera del orden social e institucional que los discrimina y los rechaza, fuera del mapa urbano que ignora sus itinerarios, y aun fuera del orden contracultural, valga la paradoja, que desconfía de "las locas" a la hora de sentar las bases de una nueva sociedad.

La multiplicidad es la condición de este libro. Multiplicidad sin centro y sin estructura jerárquica, cuyos desplazamientos y conexiones heterogéneas evocan los desplazamientos callejeros y el trazado de nuevos mapas de la ciudad, realizando también dentro de la serie literaria- el proyecto de Néstor Perlongher: una cartografía deseante. Resultan llamativas algunas ausencias, como la del chileno Pedro Lemebel y el mexicano recientemente desaparecido Carlos Monsiváis, pero están los ineludibles: Julián del Casal, Enrique Gómez Carrillo, José Enrique Rodó, José Lezama Lima, Salvador Novo y Néstor Perlongher, entre otros. Me permito destacar la bella evocación de García Lorca, por Salvador Novo, y el relato de la última hora de Julián del Casal, excelente y conmovedor relato de Francisco Morán.

La más reciente antología, aparecida en España en marzo y en Argentina en julio del año 2012, publicada por el sello Anagrama, está editada por el periodista español 
Jorge Carrión, y se titula: Mejor que ficción. Crónicas ejemplares. Destaco en primer lugar su prolija referencia a las fuentes de las crónicas que componen la antología, consignadas en las dos primeras páginas del volumen, y la presencia -a diferencia de lo hecho por Jaramillo Agudelo- de la "Bibliografía consultada" (Carrión 41-43) que aparece después del Prólogo, vale decir, en un lugar muy destacado de la edición. También resulta interesante y útil el "Diccionario abreviado de cronistas hispanoamericanos", de María Angulo, Jorge Carrión, Marco A. Cervantes y Diajanida Hernández que aparece al final del volumen (405-432) como así también el “Apéndice: Antologías consultadas" (432-434) que ofrece al lector una valiosa guía para profundizar el estudio del género o bien disfrutar de su lectura. Al mismo tiempo ofrece un registro de la intensa productividad que registra este tipo de discurso en América Latina.

En cuanto al caso particular de Pedro Lemebel, el relevamiento y análisis que acabo de realizar en el presente Estado de la Cuestión, tanto en el campo de la crítica académica como en el de la menos especializada (publicada en medios de comunicación masiva), demuestra que -salvo pocas excepciones- la perspectiva desde la que se observa y analiza la obra del chileno es casi unánimemente de base socio-institucional, y en muchos casos ese punto de vista se limita aún más dando como único rasgo distintivo del autor la reivindicación de las minorías, particularmente sexuales. Esta mirada, si se la postula como única, resulta sumamente reductiva, y deja fuera de consideración elementos de la obra de este autor que interesan por su capacidad de transformación tanto en el campo literario como en el campo historiográfico.

En cuanto a su condición de borde con los discursos académicos, su obra puede ser considerada como un caso excepcional de transposición literaria de nociones filosóficas contemporáneas como: “devenir", “territorialización” y "nomadismo”, tal 
vez sólo comparable a la que se opera en los textos de Néstor Perlongher. En cuanto a su condición de obra historiográfica, constituye un caso igualmente excepcional de intervención transgresora en la asepsia positivista, clave en las estrategias de verosimilitud del discurso de la Historia.

En cuanto a su condición de homosexual militante, es obvio que nuestro autor "habla por su diferencia", parafraseando el título de su conocida intervención de 1986. Pero también es evidente que la academia y el interés periodístico no estarían dedicándole tanta atención si el punto saliente de su obra se agotara en la militancia a favor de los derechos de las minorías sexuales. La obra cronística de Pedro Lemebel despliega una multitud de estrategias que intervienen en la transformación discursiva dada en diversos campos: a) literario, en varios registros: como renovador de formas literarias y como integrante del "árbol Lezama", es decir, partícipe de una práctica discursiva transformadora: la del neobarroco latinoamericano; b) historiográfico, por su intervención poderosa e inteligente en el universo de los discursos de la historia; también en este caso acelerando una renovación de los registros discursivos que “cuentan" la historia chilena ${ }^{57}$; c) periodístico, recuperando la oralidad radial para la memoria colectiva; y d) en el campo de los géneros discursivos, rescatando la oralidad popular y su repertorio verbal para la recuperación del plurilingüismo (Bajtín) amenazado por el "logocentrismo" escrito.

Por ello sostengo que la obra de Pedro Lemebel puede abordarse desde múltiples perspectivas teóricas, y si bien está claro que ninguna agotará la siempre proliferante obra del chileno, me parece oportuno subrayar la necesidad de abrir las posibilidades de

\footnotetext{
${ }^{57}$ Recordemos lo que Lemebel responde en una de las entrevistas citadas: "pasé a la crónica en la urgencia periodística de la militancia. Fue un gesto político, hacer grafitti en el diario, 'cuentar', sacar cuentas sobre una realidad ausente, sumergida por el cambiante acontecer de la paranoia urbana" (Gelpí y Blanco 1997: 93. Énfasis mío).
} 
lectura de una obra plural (una verdadera multiplicidad maquínica) que resiste y seguirá resistiendo los embates de la pulsión clasificatoria.

\section{I.4. Problemáticas teórico-críticas acerca del género: lo camp y lo queer}

Si bien, como ha sido señalado, el objeto específico de la presente investigación es el conjunto de la obra cronística de Pedro Lemebel y sus relaciones con otros discursos, particularmente con el discurso de la historia, no puede eludirse la cuestión del género, no ya literario, sino sexual, tratándose de un autor cuya sexualidad es puesta en primer plano en su discurso, en sus performances y en sus participaciones públicas.

En primer término debemos aclarar -aunque ya está muy claro desde los años sesenta por lo menos- la diferencia específica entre los términos "sexo" y "género". En el primer caso hablamos inequívocamente de una determinación biológica, y en el segundo -aunque sabemos que es un primer deslinde provisional- se trata de una determinación cultural.

Esta primera y muy general distinción tiene implícita una afirmación elemental: el género de un individuo no está "atado" a su determinación biológica, y por lo tanto, dentro del universo de los hombres y de las mujeres, entendidos como campos biológicos claramente determinados, existe una multitud de identidades de género cuyas diferencias cualitativas son difíciles de establecer, o imposible desde una perspectiva epistemológica clásica, la cual deriva siempre más temprano que tarde en taxonomías rígidas que dejan fuera de consideración, precisamente, lo que ellas mismas regulan y determinan como marginal o excluido. Esta cuestión, de gran complejidad y creciente 
interés teórico en campos disciplinares muy diversos, ha generado apasionantes debates, y uno de ellos está dado por las problemáticas relaciones entre subjetividad y escritura.

Las relaciones entre género y escritura comienzan a estudiarse en el seno de los movimientos académicos feministas durante la década del sesenta del siglo XX, cuya importancia no radica, como señala José Amícola, “en haber reclamado la especificidad de la sexualidad de la mujer, sino en haber ocasionado una ruptura dentro del dispositivo total de la sexualidad" (2000: 189). Por ello voy a resumir brevemente los orígenes de la crítica a ese dispositivo, partiendo necesariamente -por las razones históricas apuntadas- de las teorías feministas, para llegar a la estética camp, las teorías queer y las relaciones de estas dos últimas con la obra de Pedro Lemebel.

En sus orígenes, y al abordar el posible sesgo diferencial que identificaría a la escritura de mujeres (el concepto de "escritura femenina" de Hélène Cixious por ejemplo) las teorías femenistas caían en un problema teórico que no se resolvía, a mi juicio, satisfactoriamente. Del mismo modo, muchas teóricas y críticas de la literatura lo habían percibido y habían escrito lúcidamente al respecto. Entre ellas, Julia Kristeva ${ }^{58}$, Elaine Showalter ${ }^{59}$, Judith Butler ${ }^{60}$, Emilce Dio-Bleichmar ${ }^{61}$, Celia Amorós y Rosa María Rodríguez Magda ${ }^{62}$, Ana María Fernández ${ }^{63}$ y Cristina Piña ${ }^{64}$, por nombrar sólo

\footnotetext{
58 "La femme, ce n'est jamais ça", en: Polylogue, París, Seuil-Tel Quel, 1977.

59 "Feminist Criticism in the Wilderness", en Critical Inquiry, VIII, 2, invierno de 1981. Versión castellana: "La crítica feminista en el desierto", en: Otramente: lectura y escritura feministas, México, Fondo de Cultura Económica, 1999. Págs. 75-111.

60 "Gender Trouble, Feminist Theory, and Psychoanalytic Discourse" en: Feminist/Postmodernism, Linda Nicholson ed., New York and London, Routledge, 1990. Versión castellana: "Problemas de los géneros, teoría feminista y discurso psicoanalítico", en: Linda Nicholson (comp.) Feminismo/Posmodernismo, Buenos Aires, Feminaria Editora, 1992. Págs. 75-95.

61 "Los pies de la ley en el deseo femenino", en: Ana María Fernández (comp.), Las mujeres en la imaginación colectiva. Una historia de discriminación y resistencias, Buenos Aires, Paidós, 1993. Págs. 136-146.

${ }^{62}$ Celia Amorós (coord.), Historia de la teoría feminista, Madrid, Instituto de Investigaciones Feministas de la Unversidad Complutense de Madrid, 1994.

${ }^{63}$ La mujer de la ilusión. Pactos y contratos entre hombres y mujeres, Buenos Aires, Paidós, 1994.

64 "Las mujeres y la escritura: el gato de Cheshire", en: Cristina Piña (comp.), Mujeres que escriben sobre mujeres (que escriben), Buenos Aires, Biblos, 1997. Págs. 15-48.
} 
aquellas que, a mi juicio, analizan con mayor exhaustividad y rigor la cuestión, por cierto altamente resbaladiza y compleja.

Dice Elaine Showalter en su artículo de 1981: "Hasta fecha reciente, la crítica feminista carecía de bases teóricas; una huérfana empírica en la tormenta de la teoría” (76). Había sí, variadas metodologías, estrategias de lectura y presupuestos ideológicos que se denominaban a sí mismos lectura o escritura feministas, pero no un sistema teórico que pudiera dar cuenta de su objeto y articular sus criterios de verdad. Más aún, un sector de la crítica feminista fue renuente a ajustarse a un marco teórico que justificara sus hipótesis (Virginia Woolf, Adrienne Rich, Marguerite Duras, entre otras). Esta resistencia a los sistemas teóricos y a las codificaciones académicas fue más una etapa en la evolución del feminismo crítico que una constante. Según Showalter:

Si vemos nuestro trabajo crítico como una labor de interpretación y reinterpretación, debemos conformarnos con el pluralismo como nuestra posición crítica. Pero si deseamos plantear preguntas sobre el proceso y los contextos de la escritura, si deseamos, genuinamente, definirnos ante los no iniciados, no podremos descartar la perspectiva de un consenso teórico en esta etapa inicial [...] [ $\mathrm{La}$ crítica feminista] Debe encontrar su propio objeto de estudio, su propio sistema, su propia teoría y su propia voz. (Showalter: 81-82)

Así, durante la década de los setenta del siglo XX, se inició el largo proceso de intentar definir la diferencia femenina, su posible especificidad. Los esfuerzos por cercar las rasgos distintivos de la práctica literaria femenina derivaron en la búsqueda de aquel aspecto de la experiencia femenina que sería "el responsable" o la "causa eficiente" de la huidiza diferencia. Casi como consecuencia lógica de una búsqueda planteada en estos términos, los resultados fueron filosóficamente esencializantes y teóricamente débiles. A propósito de esta etapa, el trabajo de Elaine Showalter resulta muy didáctico. La autora señala cuatro caminos:

a) la crítica orgánica o biológica 
b) las teorías lingüísticas sobre la escritura femenina

c) la crítica literaria feminista de orientación psicoanalítica

d) (presentándola como su propuesta) una teoría basada en un modelo de cultura femenina

Si bien Showalter no califica abiertamente los niveles de eficacia de cada una, señala las enormes dificultades teóricas de las tres primeras, por el riesgo esencialista que implican. Particularmente la perspectiva biologista, según la cual -para Showalteranatomía es textualidad (85), puede ser altamente prescriptiva y teóricamente muy vulnerable. Asimismo, el concepto de lenguaje femenino está plagado de dificultades (93) por cuanto no existen lenguajes de género que difieran significativamente de la lengua dominante.

Elaine Showalter considera que es la última de las perspectivas analizadas la más eficaz (si bien no la considera excluyente) de los cuatro caminos críticos que se proponen aislar y analizar la condición femenina de un discurso:

La primera tarea de una crítica ginocéntrica debe ser la de delinear el lugar cultural preciso de la identidad literaria femenina, y la de describir las fuerzas que intersectan el campo cultural de la escritora. Una crítica ginocéntrica ubicaría también a la mujer en relación con las variables de la cultura literaria, tales como los modos de producción y distribución, las relaciones entre autora y el público, las relaciones entre la alta cultura y la popular, y las jerarquías de género literario. (Showalter: 107. Énfasis mío)

Resulta muy sensible el enfoque que sutilmente se filtra en las palabras: “escritora” y "autora” están dichas aquí en sentido empírico, en consonancia con el propósito de delinear el lugar cultural preciso de la identidad literaria femenina.

Un ensayo posterior de Judith Butler viene a complicar el optimismo culturalista de Showalter, por cuanto considera que aun esta perspectiva presenta graves problemas teóricos y políticos. En el intento de determinar el lugar cultural de la identidad 
femenina ha descollado Judith Butler, quien en su famoso ensayo de 1990 desconfía de la "categoría mujer" y su papel en el avance teórico en el campo de las relaciones entre condición femenina y escritura. Enuncia dos problemas básicos: "reconocer la intersección del género con la raza, la clase, la etnicidad, la edad, la sexualidad...” (76) por un lado, y por otro, lo que ella llama los "efectos de exclusión de la categoría":

Cuando se entiende esa categoría como la representación de un grupo de valores o disposiciones, se vuelve normativa en cuanto a su carácter y, por lo tanto, en principio, excluyente. Este movimiento ha creado un problema teórico y uno político: una variedad de mujeres de varias posiciones culturales se han negado a reconocerse como "mujeres" en términos articulados por la teoría feminista, con el resultado de que esas mujeres quedan fuera de la categoría y se ven forzadas a suponer que o 1) no son mujeres como habían creído hasta ese momento o 2) esta categoría refleja la localización restringida de sus teóricas y por lo tanto, fracasa en su intento por reconocer la intersección del género con la raza, la clase, la etnicidad, la edad, la sexualidad y otras corrientes que contribuyen a la formación de la (no)identidad cultural. (Butler 1990: 76).

En esta línea, Butler cita a Gayatri Spivak $(1985)^{65}$ : cuando hablamos de mujer, hablamos de "el conjunto de seres corpóreos que se encuentran en la posición cultural de mujeres". Por razones estratégicas, como dice Spivak, es una categoría necesaria para avanzar políticamente. En otros términos: la política feminista se inscribe en el orden de las luchas históricas y en el universo de la distribución de espacios sociales y subjetivos, es decir, en el eje poder/opresión. Todo esto nos enfrentaría en apariencia con un atolladero teórico: parece que la crítica feminista estuviera condenada a no contar con un discurso teórico o un conjunto de codificaciones (formalizadas académicamente, dependientes de una teoría de objeto general) que le permita superar la condición que Showalter retratara con la imagen de huérfana empírica en la tormenta de la teoría. Claro que dicho atolladero, sólo lo es si las expectativas teóricas del

\footnotetext{
${ }^{65}$ Citada por J. Butler: Remarks, Center for the Humanities, Wesleyan University, Primavera, 1985.
} 
feminismo -y de todas las escuelas y corrientes de pensamiento que encuentran en él su genealogía- están calcadas de las exigencias disciplinares de la epistemología clásica. Esto es, si esperamos de todo sistema teórico que como gesto inaugural establezca con absoluta certeza y determinación cuál es su objeto. Dichas "certeza” y “determinación” hoy son cuestionadas aun en el seno de las ciencias tradicionalmente consideradas "duras", como la ciencia experimental por antonomasia: la física. Aun en el contexto de las disciplinas científicas, sabemos que las exigencias de certeza y determinación han caído o, por lo menos, han sufrido un desplazamiento importante a partir de la teoría de la relatividad de Einstein y de los físicos posteriores a él.

Está claro que la noción de género, como bien lo señala Mabel Burín ${ }^{66}$ en su referencia al origen del término y los comienzos de los “estudios de género", está en vínculo indisociable con "las construcciones sociales que aluden a características culturales y psicológicas asignadas de manera diferenciada a mujeres y hombres" (2). Es decir, la de género es una categoría del mundo empírico, determinada por los múltiples condicionamientos de la vida en sociedad:

Desde este criterio, el género se define como la red de creencias, rasgos de personalidad, actitudes, sentimientos, valores, conductas y actividades que diferencian a mujeres y varones. Tal diferenciación es producto de un largo proceso histórico de construcción social, que no sólo genera diferencias entre los géneros femenino y masculino, sino que, a la vez, esas diferencias implican desigualdades y jerarquías entre ambos. Cuando realizamos estudios de género, ponemos énfasis en analizar las relaciones de poder que se dan entre varones y mujeres. (Burín 2)

Por muy variadas y distantes que sean las perspectivas respecto de la categoría de género, está claro que se refieren a "sujetos" empíricamente entendidos. Desde

\footnotetext{
66 Burín, Mabel. “Género y psicoanálisis: subjetividades femeninas vulnerables”, en: Actualidad psicológica, año XIX, número 210, Junio de 1994, pp. 2-8.
} 
luego, dicha categoría no será nunca totalizadora, y vale citar la aclaración de Burín en este sentido:

La noción de género suele ofrecer dificultades, en particular cuando se lo toma como un concepto totalizador, que invisibiliza la variedad de determinaciones con las que nos construimos como sujetos: raza, religión, clase social, nivel educativo, etc. Todos estos son factores que se entrecruzan en la construcción de la subjetividad [...] el género jamás aparece en su forma pura, sino entrecruzado con otros aspectos determinantes de la vida de las personas: su historia familiar, sus oportunidades educativas, etc. (Burín 3)

Los estudios culturales, y en ese gran campo teórico y metodológico, los estudios de género, constituyen una fuente de reflexión y análisis insoslayable al momento de considerar escrituras en las que el autor, con todas sus determinaciones individuales, sociales y culturales, se hace presente y asume posicionamientos políticos concretos, es decir, históricos, anclados a una problemática social contemporánea.

En el caso de las crónicas lemebelianas, el autor asume su sexualidad como una posición política, vale decir que su escritura es también un instrumento de acción. De hecho, los numerosos episodios de censura homofóbica de los que ha sido víctima, dejan en claro que sus textos remiten a un posicionamiento ideológico combativo en el campo de fuerzas políticas, siempre móvil, que se intersectan con un lugar y una comunidad, en un eje de reivindicación que puede proyectarse, incluso, a nivel continental y aun planetario: las minorías sexuales y cualquier minoría excluida del sistema social.

Señalada la genealogía feminista de los estudios de género, hoy podemos considerar que este campo se ha ampliado y complejizado. Está claro que lo que Butler señaló, en las postrimerías del siglo XX, como el fracaso de la "categoría mujer" por sus efectos paralizantes a nivel teórico y excluyentes en la práctica social, se replica en cualquier intento de "categorización" de género por la impronta esencializante común a 
toda definición. En otros términos, el género no es una "identidad" que deba ser determinada, ni siquiera con la saludable intención de aceptar la diversidad. Puesto que esa diversidad no se deja capturar en esquemas clasificatorios establecidos. La noción de género debe ser comprendida en un marco filosófico y epistemológico liberado de los presupuestos sustancialistas (subordinados al principio de identidad) de la metafísica occidental. Las categorizaciones reponen siempre la noción de identidad, por exceso o por defecto, por similitud o por oposición.

En su reflexión sobre la prostitución viril y su multiplicidad de figuras, Néstor Perlongher advierte que la proliferación de nomenclaturas que denominan las mil variaciones posibles entre los polos michê/travesti ${ }^{67}$ no fija ni puede fijar identidades, sólo alude a "pasajes intensivos", en un plano de consistencia sin jerarquía y sin profundidad. De este modo Perlongher concibe la multiplicidad de figuras en el circuito de la baja prostitución paulista como una "red de tránsitos" (1997: 47), irreductible a dos, tres o $n$ determinaciones. Su noción de multiplicidad (que supera la noción sustancialista de identidad y libera al pensamiento de sus efectos paralizantes) deconstruye la concepción tradicional del territorio (y aquí se habla de territorio "real"): no se trata de un campo determinado por espacios fijos y funciones atribuidas, sino de una superficie de circulación de flujos, puntos que no son puntos en el sentido geométrico tradicional, sino puntos paradójicos (Deleuze 1969) que hacen resonar las series en un movimiento incesante. De este modo el territorio es una superficie móvil, atravesada por flujos de deseo.

Pedro Lemebel concibe el territorio y el devenir de la sexualidad en este mismo sentido. En su libro más autobiográfico, Adiós mariquita linda, se pone en juego esta

\footnotetext{
${ }^{67}$ Véase el excelente ensayo "Avatares de los muchachos de la noche", en Prosa plebeya (1997: 45-58). Perlongher analiza la prostitución masculina en la noche de San Pablo haciendo jugar su concepto de "pasajes intensivos" (al que también nombra como "puntos de calcificación de las redes de flujos"), noción que considero altamente productiva para abordar su propia escritura poética y ensayística.
} 
territorialidad nómade que des-configura la noción de género (tanto literario como sexual). Pero ya antes de la publicación de ese volumen, nuestro autor había manifestado su adhesión al concepto de identidad sexual múltiple e itinerante en varias entrevistas (que cito en este capítulo) y también en el texto "Los mil nombres de María Camaleón" (1996: 57-61), en el que me voy a detener brevemente. El texto despliega una idea que está presente a lo largo de su producción:

[...] el zoológico gay pareciera fugarse continuamente de la identidad. No tener un solo nombre ni una geografía precisa donde enmarcar su deseo, su pasión, su clandestina errancia por el calendario callejero donde se encuentran casualmente; donde saludan siempre inventando chapas y sobrenombres que relatan pequeñas crueldades, caricaturas zoomorfas [...] colección de apodos que ocultan el rostro bautismal; esa marca indeleble del padre que lo sacramentó con su macha descendencia. (Lemebel 1996: 57)

En este breve fragmento se condensan las determinaciones que la sexualidad nómade rechaza: identidad fija, geografía precisa, marca paterna y sacramento bautismal. Pero además, claramente, se postula una sexualidad múltiple, itinerante y aun casual, esto es, librada a las fuerzas del azar y del deseo. El posicionamiento de Lemebel respecto de la cultura dominante lo lleva a absorber y reelaborar o reciclar productivamente las contradicciones del campo cultural. Así, su obra se nutre de viejas antinomias que funcionaron durante décadas como oposiciones dicotómicas excluyentes, a saber: historia / literatura; escritura / oralidad; alta cultura dominante blanca / baja cultura popular mestiza; discurso académico / habla vulgar; prosa / poesía, entre otras, y las convierte (por reelaboración artística y como instrumento de intervención política) en pares dialécticos que darán lugar a nuevos discursos, nuevos saberes y nuevas prácticas en el interior del campo cultural. Esta operación compleja y deconstructiva se vincula con la estética -que es también una práctica- del camp. José Amícola subraya el sesgo político del fenómeno. Después de una ineludible y 
completísima historización del concepto "camp", sus orígenes y sus determinaciones específicas, el autor afirma:

La fuerza de la estética camp va a surgir, entonces, como estrategia de producción y de recepción -por ejemplo, de los géneros hollywoodenses clásicos-, que reutiliza y transforma la cultura de masas. En este sentido, dicho reciclaje implica una crítica de la cultura dominante, pero lo singular del fenómeno es que lo hará en los mismos términos de esa cultura. El camp es, entonces, una forma ideológica llevada a sus extremos que contiene contradicciones en su mayor estado de productividad. (Amícola 2000: 52).

Por lo tanto, podemos decir -en la línea de reflexión propuesta por Amícolaque Lemebel generaliza la operación deconstructiva del camp y amplía su campo de operaciones: de la visibilidad del género y de las políticas de liberación de las minorías sexuales, a la disolución de antinomias paralizantes del viejo paradigma cultural. La obra de Pedro Lemebel, en su conjunto, desmiente las representaciones de la homosexualidad naturalizadas en el imaginario cultural $^{68}$. En este aspecto resulta ineludible valorar aquí el aporte de las teorías queer para la justa consideración de la potencia renovadora de la obra lemebeliana. El objetivo de las mencionadas teorías es deconstruir las bases ontológicas con las que opera la construcción histórica y social de las identidades sexuales $-\mathrm{y}$ también de otras conductas sociales- $\mathrm{y}$ poner de relieve cómo se configura lo considerado "normal", "natural", "esencial" y sus opuestos devaluados:

Si los estudios lésbico-gays se ubican un paso más adelante de la crítica feminista al examinar la diferencia sexual más allá de las diferencias de género, la teoría queer pasa a concebir la sexualidad como algo móvil, ambiguo y ambivalente, siempre mutable de

\footnotetext{
${ }^{68}$ A propósito Luciano Martínez, en la Introducción al Dossier: "Los estudios lésbico-gays y queer latinoamericanos", del Número 225 de la Revista Iberoamericana, realiza un recorrido por las antologías publicadas en las últimas décadas sobre estudios de sexualidad y género, en las que comienza a gestarse un nuevo paradigma que busca legitimar la relación entre el campo de las literaturas hispánicas y el de la teoría queer británica, estadounidense y francesa, sin ubicar al primero en una posición subordinada (2008: 861-862).
} 
acuerdo al contexto histórico-cultural. A partir de dos categorías de análisis particulares (normatividad y desviación), el énfasis se corre del estudio de la construcción histórica de las identidades homosexuales para ocuparse, no sólo ya de la homosexualidad, sino también de otras conductas sociales. (Martínez 2008: 863)

La obra de Lemebel socava las bases que fundan lo identitario, esto es: la esencia fija e inmutable, la continuidad, la estabilidad y la integridad de lo existente. Por ello cuestiona también la identidad homosexual y los binarismos que rigen el conjunto de las prácticas sociales. Está claro que, en el contexto latinoamericano, las figuras de Néstor Perlongher y Pedro Lemebel anticipan la profunda transformación que tendrá lugar en el imaginario social y cultural con respecto a las diversidades sexuales. Resulta evidente si tenemos en cuenta que el famoso manifiesto de Lemebel "Hablo por mi diferencia" fue pronunciado en $1986^{69}$ y el primer ensayo de Néstor Perlongher sobre la cuestión: "El sexo de las locas”, es de mayo de $1984^{70}$. Según Luciano Martínez en la Introducción del citado Dossier, la problemática se instala en América Latina cerca del año 2000:

A partir del año 2000 aproximadamente, comienza a registrarse una constelación de fenómenos históricos y culturales que ponen en evidencia una transformación profunda en el imaginario social y cultural latinoamericano en relación con las diversidades sexuales. (Martínez 2008: 865)

Como señala Amy Kaminsky, la práctica queer es un "compromiso con la provisionalidad”. Esta noción está claramente en la línea propuesta por los ensayos y crónicas de Perlongher y Lemebel. El artículo de Kaminsky (2008: 892) concluye citando el rechazo de Lemebel -expresado en una entrevista que cito en el presente

\footnotetext{
${ }^{69}$ Como se consigna al pie de la primera edición de Loco afán publicada por LOM (Lemebel 1996: 90), el manifiesto fue leído como intervención en un acto político de la izquierda en septiembre de 1986, en Santiago de Chile.

${ }^{70}$ El ensayo "El sexo de las locas", recogido en el volumen póstumo Prosa plebeya (Perlongher 1997: 2934), fue originalmente una conferencia dada en el Centro de Estudios y Asistencia Sexual (CEAS) y se publicó en el número 28 de la revista El Porteño en mayo de 1984.
} 
Estado de la Cuestión- a aceptar lo gay como sinónimo de "travesti, marica, trolo, camiona, marimacho o transgénero"71. Como lo afirma inmediatamente después, Lemebel no acepta la búsqueda de reconocimiento y cuestiona los intentos de legalización, es decir que nuestro autor rechaza las estrategias tanto hetero como homonormativas.

El artículo de Diamela Eltit, "La plenitud de la apariencia", (2008: 1077-1082) que integra el volumen cuya Introducción a cargo de Luciano Martínez he comentado, destaca la centralidad de la producción de Pedro Lemebel en las operaciones de selección y jerarquización efectuadas por la crítica literaria. Este rasgo señalado por Eltit queda en evidencia en el Estado de la Cuestión que abre la presente tesis. Lo que la autora propone es entablar un diálogo productivo entre la obra de Lemebel y la de otros autores que han permanecido en un cono de sombras sin otra justificación que la siempre discutible legitimación de la crítica. Por ello hace foco en la obra del chileno Francisco Casas, precisamente el autor y performer conocido por su asociación con Pedro Lemebel en el colectivo de arte Yeguas del Apocalipsis.

Desde luego un tema central a estas problemáticas es también insoslayable en la obra de Lemebel: la violencia normativa que los modos de representación dominantes ejercen y que determinan modos de violencia y exclusión en el orden real. Por eso Pedro Lemebel es tan contundente en su condena al gueto gay y su cómodo recurso a la legalización. También lo gay corre el riesgo de volverse normativo y esencializante. Es precisamente la perspectiva queer la que permite pensar la multiplicidad de identidades que señalan la impotencia crítica de las categorías homogeneizadoras tales como

\footnotetext{
${ }^{71}$ Entrevista realizada por Flavia Costa: "La rabia es la tinta de mi escritura", Suplemento $\tilde{N}$ del Diario Clarín de Buenos Aires, sábado 14 de agosto de 2004, pág. 8. La intervención aparece completa en la página 56 de esta tesis; para facilitar la contextualización de la frase la transcribo a continuación: "-Te aclaro que lo gay no es sinónimo de travesti, marica, trolo, camiona, marimacho o transgénero. Estos últimos flujos del desbande sexual aparecen encintados como multitudes "queer" (raras) después de que lo gay obtuvo su conservador reconocimiento. Quizá son estas categorías las que pueden alterar el itinerario de los azahares gay tan cómodos en el status de la legalización" (Costa: 8).
} 
"homosexual", "gay" o "lesbiana". La representación de la sexualidad siempre será opaca, o por decirlo en términos filosóficos más precisos, en devenir. 


\section{Historia, crónica, literatura. \\ Problemas epistemológicos y teóricos en torno al género}

\section{1. Genealogía de los discursos de la historia}

[1] Las crónicas y su relación problemática con las series histórica y literaria

Este capítulo tiene como objetivo establecer precisiones de orden teórico para el análisis de las crónicas de Pedro Lemebel y su relación problemática con las series ${ }^{72}$ (literaria, histórica, social) en las que intervienen.

La necesidad de establecer dichas precisiones surge, por una parte, ante la muy intensa productividad que el género registra en las últimas décadas del siglo XX y la primera del XXI, y por otra, ante la ausencia de una reflexión teórica que aísle o "despeje" esta textualidad de otras que -por su condición no ficcional- están íntimamente vinculadas a ella. La presente investigación postula que las crónicas hispanoamericanas presentan una especificidad que las distingue de otros discursos, agrupados bajo el rótulo algo difuso y homogeneizador de "textos no ficcionales". Asimismo, el marco teórico me permitirá dar cuenta de la especificidad de Lemebel dentro de los sistemas a los que pertenece y al mismo tiempo modifica.

El género crónica se encuentra desde sus inicios conectado a los discursos de la Historia. Esa conexión -visible desde la morfología del término- es compleja y será analizada teniendo en cuenta los elementos en común (su propósito de registro, su

\footnotetext{
${ }^{72}$ Empleo aquí el término "series" en el sentido preciso que le dio el teórico ruso Iuri Tinianov (1927), artículo que será citado y analizado en el transcurso de la investigación. La correlación de la literatura con las series histórica, lingüística, social es ineludible para pensar su propia naturaleza dado que la literatura es un sistema en permanente tensión: "el estudio de los géneros es imposible fuera del sistema en el cual y con el cual están en correlación. [...] En rigor, no se consideran jamás los fenómenos literarios fuera de sus correlaciones" (1927: 91; 95).
} 
objeto de observación, su dimensión temporal) y la relación dialéctica que las confronta y las constituye. Vale decir que ambos registros discursivos permanecen en una mutua interacción; lo cual genera el dinamismo formal del género y también su dificultad de definición.

Para ubicar históricamente el conjunto de problemáticas dentro del cual se sitúa la obra de Pedro Lemebel y el género al cual pertenece, debemos analizar en primer término el campo epistemológico en el que se encuadra la práctica que hoy llamamos "escribir la historia", campo marcado por su heterogeneidad disciplinaria y por los cambios y desplazamientos sufridos a lo largo del siglo XX.

Si bien las relaciones entre la filosofía del lenguaje y la historia-como "ciencia social"- no son recientes, no fueron objeto de discusión en el ámbito historiográfico hasta bien avanzado el siglo XX. Dicho campo comienza a conmoverse cuando las disciplinas tradicionalmente consideradas "históricas" son rozadas -o atravesadas, según los casos- por la conciencia del lenguaje. ${ }^{73}$ Es decir, cuando los historiadores y los investigadores del campo historiográfico se acercan -en un cruce que será muy productivo- a cuestiones relativas a la filosofía del lenguaje que se encuentran en pleno debate durante los años cincuenta y sesenta. El desarrollo posterior a la indicada inflexión del pensamiento historiográfico occidental, descubre con lucidez inédita los procedimientos y las opciones ideológicas y discursivas de la Modernidad, y en consecuencia, de los discursos historiográficos: sus postulados implícitos, sus modos de producción y de circulación, sus criterios de verdad, sus mecanismos de control internos y externos. A continuación haré un breve recorrido por los comienzos de este debate.

\footnotetext{
${ }^{73} \mathrm{La}$ "consciencia del lenguaje" es un término acuñado por el teórico de origen búlgaro Tzvetan Todorov, quien ha reflexionado desde los años 60 sobre la complejidad del discurso literario. Sus desarrollos se destacan en el ámbito de la teoría literaria por haber señalado tempranamente la polisemia del término "verosímil", el cual alude tanto a la ley interna de cada género literario como a la relación entre éste y el discurso más "general y difuso", según sus términos, que llamamos "opinión corriente" o "sentido común". Vale decir que lo literario no solamente se rige por sus propias leyes internas, sino también por el vínculo complejo con los discursos sociales y lo que en ellos "circula como verdadero" (Todorov 1970: 11-15).
} 
Ya antes de promediar el siglo XX tenía carta de ciudadanía en el mundo académico un saber nuevo, que entrecruzaba cuestiones y objetos de análisis de disciplinas humanas ya existentes. La creación del Journal of the History of Ideas ${ }^{74}$ en 1940, primera revista que se dedicó a estos estudios, puede ser considerada un punto de inflexión que dio comienzo a lo que será llamado, unos veinte años después, el "giro lingüístico". Remontándonos todavía más atrás en el tiempo, es ineludible la mención de Wilhelm Dilthey (1833-1911) quien a fines del siglo XIX y comienzos del XX promovió una ciencia subjetiva de las humanidades (Geisteswissenschaften). Según Dilthey, los estudios humanos subjetivos (que incluyen, por ejemplo, derecho, religión, arte e historia) deberían centrarse en una "realidad histórica-social-humana". Afirmando que el estudio de las ciencias humanas supone la interacción de la experiencia personal y el entendimiento reflexivo de esa experiencia, Dilthey "descubre" y coloca en el centro de la escena epistemológica el fenómeno de la comprensión: en las ciencias humanas el hombre es parte del objeto de estudio, por lo tanto, está comprendido en el fenómeno que observa. ${ }^{75}$

Esa comprensión es decisiva, porque implica la conciencia de que hay un punto de vista en los saberes en general, y en las ciencias humanas en particular. Y lo más revolucionario de este descubrimiento es la consecuencia inmediata: el punto de vista,

\footnotetext{
${ }^{74}$ Publicación que continúa editándose en la actualidad, a cargo de la University of Pennsylvania Press.

${ }^{75}$ Ver el muy esclarecedor ensayo de Walter Mignolo: Teoría del texto e interpretación de textos, especialmente el capítulo primero: "Comprensión hermenéutica y comprensión teórica", México, UNAM, 1986. La primera es una actividad específica de las ciencias humanas y sociales, y su contenido diferencial es que en ella el sujeto del análisis está comprendido en el campo problemático siendo, por lo tanto, parte del objeto estudiado. La comprensión teórica -que se da tanto en el paradigma científico experimental como en el social- implica una tendencia hacia la explanación sin excluir, desde luego, el fenómeno de la comprensión que afecta a todo estudio disciplinar. El desafío al que se enfrentaba Dilthey consistía, por una parte, en no ceder al vértigo del subjetivismo, y por otra en tratar de desembarazarse de las ilusiones del positivismo, sin anular por ello toda idea de verdad y aceptar como una fatalidad la disolución de la razón histórica. Esta reelaboración de Mignolo obedece al hecho de que el dilema planteado por Dilthey entre comprensión (Verstehen) y explanación (Erklären) hoy ya no puede sostenerse por cuanto sabemos que en las ciencias sociales hay explanación y en las ciencias experimentales y naturales o exactas hay también un grado inevitable de comprensión. No obstante, la inquietud de Dilthey permanece vigente en nuestra reflexión epistemológica, por cuanto las operaciones de comprensión y explanación siguen siendo heterogéneas y producen efectos diferenciales en las disciplinas que nos ocupan en esta tesis.
} 
lejos de ser ajeno al objeto de estudio, forma parte de él, es uno de sus aspectos. Las ciencias humanas, por lo tanto, se construyen en una dialéctica de identificación y diferencia del sujeto con el objeto observado.

De este modo comienza a gestarse una verdadera revolución epistemológica que tendrá consecuencias en el método y en el producto de la investigación histórica, porque las condiciones de producción de los discursos pasan a ser objeto del trabajo científico. ${ }^{76}$ Dentro de este campo, y tal vez diríamos mejor, como elemento clave de estas problemáticas, debemos considerar la enorme cuestión de la construcción de la verdad en las disciplinas (humanísticas o exactas, puras o aplicadas). En este terreno, resbaladizo y muy polémico, ha descollado Michel Foucault quien, en la línea de pensamiento inaugurada por Friedrich Nietzsche en el siglo XIX, analiza los postulados de la Historia ("la Historia de los historiadores" en sus términos) en vínculo problemático con la Voluntad de Verdad que esos postulados promueven y al mismo tiempo ocultan, por cuanto la Voluntad de Verdad aparece siempre enmascarada. Este nuevo conjunto de problemas encontrará cauce en un campo disciplinario inédito, que será ejercido en los bordes de la filosofía, la lingüística, la antropología y la historia, campo que tendrá a Michel Foucault como protagonista: la arqueología del saber.

El trabajo arqueológico de Michel Foucault comienza a cristalizar en 1963, con su libro Nacimiento de la clínica, en el que define claramente lo que concentrará su atención: la articulación del lenguaje médico y de su objeto. En el Prefacio, anticipa la gran hipótesis que dominará su investigación: "Ha cambiado la configuración sorda en

\footnotetext{
${ }^{76}$ En esta línea de pensamiento tampoco podemos olvidar a Max Weber, Benedetto Croce, Karl Huizinga, Ernst Cassirer, por nombrar sólo algunos investigadores quienes en las décadas de 1920 y 1930 realizaron sus análisis teóricos mientras creaban esta disciplina que aún no tiene un nombre único, como lo señala Michel de Certeau: Intellectual History en Estados Unidos, Historia de las Mentalidades en Francia, Historia del Pensamiento en lo que fue la URSS. Véase a propósito: de Certeau, Michel (1978): La escritura de la historia, México, Universidad Iberoamericana, $2^{\mathrm{a}}$ edición revisada, 1993. Págs. 42 y ss.
} 
la que se apoya el lenguaje, la relación de situación y de postura, entre el que habla y aquello de lo cual se habla" (1963: 3).

Foucault advierte sobre la falsa separación entre el objeto y el sujeto de un saber. Los discursos disciplinares no son inocentes respecto de la selección y el recorte de aquello que tratan: abordan su objeto desde una perspectiva (toda visión es una visión direccionada, como postulaba Friedrich Nietzsche) y por lo tanto el objeto de un saber es también, en alguna medida por lo menos, objeto producido.

Desde luego, el propósito de la Historia como disciplina no se agota en la referencia al pasado, sino que, según los casos, el discurso que la vehiculiza opera sobre la materia tratada: une y suelda las discontinuidades de los acontecimientos, redistribuye las materialidades que observa; pone aparte, clasifica, traza líneas de temporalidad, ordena o reordena, "aísla" un determinado acontecimiento o conjunto de acontecimientos y los introduce en otro sistema, al que también ha construido. En otros términos, no acepta pasivamente -como algo dado- los datos de la realidad, los crea: son efectos de una mirada particularmente dispuesta, sobre una materialidad técnicamente tratada. La Historia, por lo tanto, es una práctica inseparable de su objeto: "se comprende a sí misma en el conjunto y en la sucesión de producciones, de las cuales ella misma es un efecto" (de Certeau 1978: 59). La Historia, entonces, a mediados del siglo XX comienza a realizar su propia arqueología y su propia genealogía, es decir, comienza a mirarse a sí misma, a observar los principios de construcción de su propio edificio disciplinar, y a indagar sobre sus modos de construcción de verdad.

Foucault advierte que el discurso es un lugar en el que se ejercen poderes (1970): el poder de prohibir, el de excluir, e inversamente, el de permitir y legitimar. Una de las estrategias internas de legitimación de los enunciados, y por lo tanto, de construcción de verdad, está dada por el conjunto de elementos que la disciplina 
propone con el fin de construirse a sí misma: recorte del objeto, decisión del método, proposiciones verdaderas o axiomas, reglas de validación o criterios de verdad, definiciones generales y específicas, técnicas y métodos de trabajo. Con esta poderosa batería de instrumentos, la disciplina ejerce el control de la producción de enunciados "verdaderos". Como señala Foucault, la disciplina "rechaza toda teratología del saber", es decir, no acepta monstruosidades ni rarezas: para ser verdadero, el discurso debe estar en la verdad. Esto significa que, así como los hechos no pueden "narrarse solos" siempre hay un enunciador aunque disimule o borre sus huellas- también hay una construcción de la verdad de acuerdo a criterios que la disciplina hace valer como legitimadores del discurso. Por lo tanto, las disciplinas (es en ellas y en sus discursos donde el pensador francés observa el funcionamiento de la Voluntad de Verdad) son parte de la red institucional que controla, selecciona y distribuye la producción, la circulación y la validación de los discursos. Citemos el ejemplo clásico: Galileo Galilei (Pisa, 1564-Arcetri, 1642) postulaba una verdad, la teoría heliocéntrica concebida por Copérnico, la cual era inaceptable en su momento por enfrentar las afirmaciones de una autoridad indiscutida: Aristóteles, sostenida por una institución poderosa: la Iglesia Católica en los siglos XVI y XVII. Discutir el principio de autoridad (que emanaba del autor, no del análisis de sus desarrollos) era impensable e intolerable, y Galileo Galilei -a pesar de las pruebas que presentaba a su favor-tuvo que callarse y recluirse; no conoció en vida la legitimación de sus comprobaciones experimentales a través del telescopio, ni por lo tanto, logró la validación de la teoría copernicana.

Las problemáticas relaciones entre las prácticas de escritura y el objeto de las disciplinas históricas se encuentran -especialmente a partir de la segunda mitad del siglo XX- ante el desafío ineludible de revisar sus presupuestos, sus criterios de verdad, sus opciones discursivas y la naturaleza de su objeto. Uno de los requisitos disciplinares 
de la historiografía ha sido durante la Modernidad -y en gran medida sigue siendo- la pretensión de objetividad. Podemos decir, empleando términos de Nietzsche en la Genealogía de la moral, que el discurso de la Historia asume el disfraz de la objetividad y la causalidad para tornarse aceptable. Como hemos señalado, a partir del descubrimiento de Dilthey (el fenómeno de la comprensión), el desarrollo de la historia de las mentalidades, el aporte singular de Walter Benjamin, y a partir de los años 60 con el trabajo arqueológico de Michel Foucault que revaloriza y continúa la labor de Friedrich Nietzsche, la comunidad científica comienza a aceptar que la objetividad es más un imperativo epistemológico que una posibilidad del discurso. En esta línea de comprensión del fenómeno histórico y su relación con lo real se encuentran los trabajos ya mencionados de Hayden White y Michel de Certeau, dos intelectuales que se han dedicado exclusivamente a estas problemáticas, y son referencia obligada en cualquier investigación sobre este campo.

A pesar de sus diferencias teóricas y metodológicas, las investigaciones de los autores contemporáneos que abordaremos en esta tesis han generado y continúan generando en el presente amplios e intensos debates, los cuales han tenido un efecto decisivo durante la segunda mitad del siglo XX y las primeras décadas del XXI sobre nuestro objeto de estudio, a saber: las problemáticas relaciones entre la Historia y la Literatura, o -en términos de Tinianov- entre la serie literaria y la serie histórica.

La primera consecuencia de aquellos debates ha sido desnaturalizar (hacer visible) y poner en el centro de la escena epistemológica la separación entre las palabras y las cosas, en los términos de Foucault. Este problema es tan antiguo -al menos- como la filosofía estoica ${ }^{77}$, pero mi indagación se centra en el cruce de esa cuestión filosófica

\footnotetext{
${ }^{77}$ Ver: Deleuze, Gilles: Lógica del sentido (1969), particularmente las seis primeras series, en las que analiza las dimensiones tradicionales de la proposición (expresión, designación, significación) luego de lo cual postula que el sentido sería su instancia genética, no condicionada. Para contextualizar su hipótesis
} 
y la creciente "conciencia del lenguaje" (Todorov 1970) verificada en todas las disciplinas y particularmente en la historiografía a partir de 1940. Este cruce de campos y de problemáticas comienza a cuestionar la concepción convencional de los estudios históricos en relación a su objeto y a sus métodos, y la obliga a examinarse.

Por otra parte, paralelamente a los debates que se dan en el campo académico, la producción de textos históricos $-\mathrm{o}$ de contenido convencionalmente vinculado al saber historiográfico-dentro de la serie literaria genera intersecciones con las series vecinas y provoca una singular movilidad del sistema en términos de géneros y categorías tradicionales. Esta movilidad en parte se explica porque en los mencionados textos (cuya denominación -atendiendo sólo a la producción del siglo $\mathrm{XX}$ - oscila entre: crónicas, nuevo periodismo o periodismo narrativo, novela-testimonio o no-ficción, entre otras posibilidades) se verifica una tensión no resuelta: se trata de un discurso histórico, es decir, aquél que se propone a sí mismo como un relato fidedigno de los hechos, y al mismo tiempo la posición del sujeto y el empleo del lenguaje -que singularizan la materia tratada- lo acercan a la literatura, o más aún, lo incluyen en el sistema literario.

Esta tensión Historia-Literatura no fue reconocida como objeto de análisis con anterioridad al siglo XX. Todos los historiadores y teóricos de la literatura que tomamos como referencias ineludibles (con sus respectivas distancias históricas y disciplinares, me refiero a: Iuri Tinianov, Ian Mukařovský, Mijaíl Bajtín, Walter Benjamin, Hayden White, Michel de Certeau y Michel Foucault) constituyen piedras angulares en este debate y tienen el mérito de haber planteado y desplegado los problemas inherentes a él. Por lo mismo, sus ideas y categorizaciones han sido sumamente productivas para el desarrollo de la presente investigación, la cual se ubica en la estela de una reflexión

dentro de la tradición filosófica occidental, realiza una genealogía del problema desde sus inicios con la separación entre la realidad y el lenguaje observada por los estoicos en la antigüedad. 
epistemológica y cultural que, por cierto, lejos de haber concluido, se encuentra en intensa actividad.

Afirmamos entonces que la crónica es y ha sido desde sus orígenes un discurso atravesado por la hibridez genérica. Algunos autores han reivindicado esa ambigüedad constitutiva como un valor; otros la han considerado un problema a resolver; otros la han negado como si fuera una limitación inaceptable. Pedro Lemebel se encuentra en el primer grupo. Sus siete volúmenes de crónicas resaltan el valor de ser literatura y discurso histórico a la vez. Desde sus inicios en Latinoamérica, el género ha dado lugar a textos que celebran este cruce y lo convierten en la clave de su valor y de su vigencia. Hechas las consideraciones precedentes, de carácter general, a continuación presentaré de manera desarrollada el marco teórico de la investigación.

[2] Friedrich Nietzsche: contra el "sujeto puro del conocimiento".

El marco teórico de la tesis está constituido en primer término por la obra ineludible de Friedrich Nietzsche, especialmente: Genealogía de la moral (1887), El crepúsculo de los ídolos (1888) y la Segunda consideración intempestiva (1873-1876).

En el Tratado Tercero de la Genealogía de la moral, Friedrich Nietzsche analiza el estrecho vínculo entre ideal ascético y filosofía. Según él, “apoyándose en los andadores de ese ideal es como la filosofía aprendió a dar sus primeros pasos”.

La actividad contemplativa tuvo necesidad de disfrazarse durante siglos a fin de tornarse aceptable. A propósito, Nietzsche afirma:

[...] al principio el espíritu filosófico tuvo siempre que disfrazarse y enmascararse en los tipos antes señalados del hombre contemplativo [...] para ser siquiera posible en cierta medida: el ideal ascético le ha servido durante mucho tiempo al filósofo como forma de presentación [...] La actitud apartada de los filósofos, actitud peculiarmente 
negadora del mundo, hostil a la vida, incrédula con respecto a los sentidos, desensualizada, que ha sido mantenida hasta la época más reciente y que por ello casi ha valido como la actitud filosófica en sí, esa actitud es sobre todo una consecuencia de la precariedad de condiciones en que la filosofía nació y existió en general: pues, en efecto, durante un período larguísimo de tiempo la filosofía no hubiera sido en absoluto posible en la tierra sin una cobertura y un disfraz ascéticos, sin una autotergiversación ascética (Nietzsche 1887: 146).

Sobre el final del mismo apartado, el filósofo alemán se pregunta:

¿Se ha modificado realmente esto? Ese policromo y peligroso insecto, ese espíritu que aquella larva encerraba dentro de sí, ¿ha terminado realmente por quedar liberado de su envoltorio y ha podido salir a la luz, gracias a un mundo más soleado, más cálido, más luminoso? ¿Existe ya hoy suficiente orgullo, osadía, valentía, seguridad en sí mismo, voluntad de espíritu, voluntad de responsabilidad, libertad de la voluntad, como para que en adelante el filósofo sea realmente posible en la tierra? (Nietzsche 1887: 150). Subrayados en el original.

Como vemos, el asceta es presentado por Nietzsche en su doble condición: por un lado, como la representación que le ha permitido a la filosofía existir, en un mundo el antiguo- que impugnaba la contemplación y condenaba la pulsión dubitativa, negadora, analítica, indagadora, atrevida (146), a favor de la "eticidad de la costumbre", esto es, la sumisión a lo establecido (la "mutación como lo no-ético y cargado de corrupción!”, 148); y, por otro lado, dicha representación ha impedido el trabajo filosófico genuino cuya actitud es, en el ideal nietzscheano, "la hybris con respecto a cualquier presunta tela de araña de la finalidad y la eticidad situadas por detrás del gran tejido-red de la causalidad [...] hybris es nuestra actitud con respecto a nosotros" (146147). Esta actitud incisiva, indagadora, activa, atrevida y, yo diría, agresiva en el más positivo sentido del término, es para Friedrich Nietzsche la actitud que permite el verdadero comienzo en filosofía, y la que garantiza el trabajo de "las fuerzas activas e interpretativas, que son, sin embargo, las que hacen que ver sea ver-algo" (154). 
El ideal ascético, enemigo, entonces, de la actitud filosófica (hybris moderna)

supone una voluntad de contradicción y de antinaturaleza que "buscará el error allí donde el auténtico instinto de vida coloca la verdad. Así, rebajará la corporalidad [...] a la categoría de una ilusión" (153). Subrayado en el original. Explícitamente Nietzsche postula un nuevo comienzo para la filosofía:

A partir de ahora, señores filósofos, guardémonos mejor, por tanto, de la peligrosa y vieja patraña conceptual que ha creado un 'sujeto puro del conocimiento, sujeto ajeno a la voluntad, al dolor, al tiempo', guardémonos de los tentáculos de conceptos contradictorios, tales como 'razón pura', 'espiritualidad absoluta', 'conocimiento en sí': aquí se nos pide siempre pensar un ojo que de ninguna manera puede ser pensado, un ojo carente en absoluto de toda orientación, en el cual debieran estar entorpecidas y ausentes las fuerzas activas e interpretativas, que son, sin embargo, las que hacen que ver sea veralgo, aquí se nos pide siempre, por tanto, un contrasentido y un noconcepto de ojo. Existe únicamente un ver perspectivista, únicamente un "conocer" perspectivista; y cuanto mayor sea el número de afectos a los que permitamos decir su palabra sobre una cosa, cuanto mayor sea el número de ojos, de ojos distintos que sepamos emplear para ver una misma cosa, tanto más completo será nuestro 'concepto' de ella, tanto más completa será nuestra 'objetividad'. Pero eliminar en absoluto la voluntad, dejar en suspenso la totalidad de los afectos, suponiendo que pudiéramos hacerlo: ¿cómo?, ¿es que no significaría eso castrar el intelecto?... (Nietzsche 1887: 154-155). Subrayados en el original.

Asumiendo como propia la convicción nietzscheana de que existe únicamente "un ver perspectivista", considero necesario y productivo abolir en el trabajo teórico y crítico ante la literatura la supuesta necesidad de "dejar en suspenso la totalidad de los

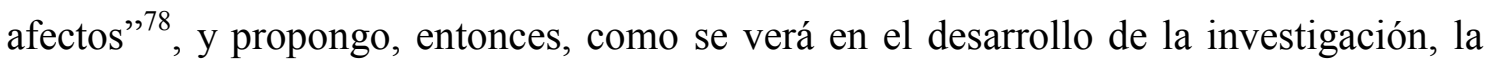
lectura de los textos (lectura crítica, indagación teórica) en el interior de esta actitud

\footnotetext{
${ }^{78}$ Claramente, el término "afectos" tiene en el texto de Nietzsche una reminiscencia spinoziana. Los afectos son, en la Ética de Baruch Spinoza las fuerzas que determinan la constitución de lo existente. En la Proposición II, Parte Tercera de la Ética: "Del origen y naturaleza de los afectos", pp. 171-174, Spinoza promueve al lugar de principio activo regulador de lo existente a los poderes de afección, cuyo dinamismo no está regido por la razón (ni por la razón individual ni por ninguna razón trascendente o divina, por cuanto Dios es para Spinoza sustancia susceptible de infinitos atributos; es decir, un infinito inmanente), e invierte el orden jerárquico de la oposición alma-cuerpo: nadie ha demostrado hasta ahora lo que puede un cuerpo y, según el filósofo, puede más que el alma: hambre, constitución nerviosa, desórdenes de la lengua, apetitos, etc., demuestran que el alma está sometida a los poderes de afección.
} 
filosófica. El trabajo de resistencia que el pensamiento de Nietzsche opone a las representaciones derivadas del ideal ascético opera de manera intensa y decisiva sobre el terreno de la corporalidad, "descoyuntando" la noción platónica, medieval y moderna de "cuerpo". En esa línea, me propongo realizar una lectura resistente a dicha representación del cuerpo, que lo opone -en virtud de una dicotomía jerárquica de raíz platónica- al pensamiento. Muchos textos literarios, teóricos y críticos y, como veremos, también algunos textos históricos, se han encargado de poner en tela de juicio esa dicotomía, y en buena medida, han logrado desfondarla.

Mi trabajo aborda la lectura de crónicas que se proponen como vehículos de una experiencia de la historia, es decir, que establecen un vínculo problemático entre la escritura y el cuerpo, entre el pensamiento y la experiencia, en un intento de abolir "la neutralidad teórica positivista" en términos de Julia Kristeva (1972: 35), o la escritura como actividad de un "sujeto puro del conocimiento" en términos de Friedrich Nietzsche (1887: 154).

Acerca de esta cuestión crucial para la literatura y para el arte en general, otros filósofos y teóricos de la literatura han ampliado y enriquecido el marco teórico de mi indagación, quienes -en la estela del pensamiento nietzscheano- han analizado el carácter heterogéneo de la obra de arte y su calidad de vehículo de la experiencia. Me refiero específicamente al ya clásico ensayo de Maurice Blanchot: El espacio literario (1955), especialmente sus nociones de ambigüedad e intermitencia ${ }^{79}$ como principios

\footnotetext{
${ }^{79}$ Ver nota 18, en la que explico detenidamente esta noción. Blanchot destaca el valor de la obra como "alianza de los contrarios": "La obra no es la unidad mitigada de un reposo. Es la intimidad y la violencia de movimientos contrarios que nunca se concilian ni se apaciguan mientras la obra es obra. Esta intimidad donde se afronta la contradicción de antagonismos que son inconciliables pero que, sin embargo, sólo tienen plenitud en la oposición que los opone, esta intimidad desgarrada es la obra [...] en la violencia que la hace una, [la obra] realiza como el acontecimiento único de una discordia esencial en el corazón de la cual sólo lo que está en lucha puede aprehenderse y calificarse." (1955: 213-214. Énfasis mío). Por ser alianza de los contrarios, la obra es puro movimiento, tensión, potencia, y por lo tanto se configura como "lo inasible en movimiento": "Donde creemos tener palabras, nos atraviesa 'un virtual reguero de fuego', una prontitud, una exaltación centelleante [...] Entonces todo se hace suspenso, disposición fragmentaria con alternancia y enfrentamiento." (38-39). Como he señalado en la nota 18, a la que envío, Blanchot no
} 
productivos de la dialéctica de la obra; al último libro de Gilles Deleuze y Félix Guattari: ¿Qué es la filosofía? (1991), y a la reflexión epistemológica de Julia Kristeva con respecto al enunciado artístico en general y a la poesía en particular, considerada como una práctica significante cuya especificidad está ligada a la crisis del racionalismo moderno. La teoría de Kristeva propone "un nuevo espacio donde se podría pensar la actividad significante: el espacio de la escritura paragramática en el que se eclipsa el sujeto" (1968: 57). Puntualizo al respecto que esta concepción dialéctica de la heterogeneidad del lenguaje y, por lo tanto, de todo género de articulación lingüística, incluida desde luego la literatura (matriz filosófica de Blanchot, Deleuze y Kristeva) está en correlación y de algún modo implica los postulados de Ian Mukařovský que serán muy productivos en el desarrollo de esta investigación.

En segundo término, el marco teórico y metodológico de la presente tesis está integrado por la obra de Hayden White en relación con la especificidad de la crónica y su distancia epistemológica con el discurso de la Historia como "saber oficial": Metahistoria. La imaginación histórica en la Europa del siglo XIX (1973); El contenido de la forma. Narrativa, discurso y representación histórica (1987); El texto histórico como artefacto literario (2003), traducciones de: Tropics of discourse (1978) y de Figural Realism (1999) ${ }^{80}$. Los análisis insoslayables de Hayden White han permitido ya tres décadas de reflexión acerca del discurso historiográfico y su papel en la crisis epistemológica de fin del siglo XIX y principios del XX, la cual se extiende, por cierto, hasta bien avanzada la segunda mitad del XX, y continúa su operatividad en la presente centuria.

se limita exclusivamente al género poético tradicionalmente entendido, sino que sus hipótesis se refieren al campo de la literatura y del arte, como lo indican claramente sus títulos ("La literatura y la experiencia original", "El futuro y la cuestión del arte", "Los caracteres de la obra de arte", entre otros) y también sus constantes referencias a Kafka.

${ }^{80}$ White, Hayden: Metahistoria. La imaginación histórica en la Europa del siglo XIX, México, Fondo de Cultura Económica, 1992 [1973]; El contenido de la forma. Narrativa, discurso y representación histórica, Barcelona, Paidós, 1992 [1987]; El texto histórico como artefacto literario, Barcelona, Paidós, 2003. 
La obra ineludible de Michel Foucault, especialmente: El nacimiento de la clínica (1963); Las palabras y las cosas (1966); La arqueología del saber (1969); El orden del discurso (1970); Microfísica del poder $(1979)^{81}$, constituyen la referencia obligada del propio Hayden White y de cualquier reflexión epistemológica que tome como objeto las complejas relaciones entre el discurso y la Voluntad de Verdad, entre los discursos disciplinares y los mecanismos de control exteriores e interiores a ellos.

En relación más específica con la noción de "experiencia de la historia" y el campo problemático que esta noción genera (oposiciones y tensiones que se dan en el seno de la crisis del historicismo moderno), resultan indispensables los análisis del filósofo e historiador francés Michel de Certeau, particularmente su obra: La escritura de la historia (1978). Como puede observarse por lo expuesto, el propósito críticometodológico es cartografiar las múltiples alianzas posibles entre "lo real” y los discursos, dado que la escritura y los hechos no tienen una única manera de articularse, y que "no son ni han sido nunca un compuesto natural" (de Certeau). Las crónicas de Pedro Lemebel, “nomadizan” la temporalidad lineal y progresiva del idealismo histórico (Hegel, Marx) y del historicismo positivista. Dicha temporalidad ha sido tomada durante siglos como eje de legibilidad de los sucesos según una estructura idealimaginaria que dotaría de un "sentido histórico" al relato. Las crónicas del escritor chileno (y como se ha dicho, de otros escritores contemporáneos que serán tenidos en cuenta) promueven en su escritura la calidad del fragmento, de lo menor o menudo (Benjamin), de las discontinuidades, el tajeado o "lo cortante", en términos de Michel Foucault, con el propósito de hacer una historia "efectiva" escapando al modelo clásico en el que se diluye el suceso singular en una continuidad ideal-imaginaria, la cual obtura

\footnotetext{
${ }^{81}$ Foucault, Michel: El nacimiento de la clínica, Buenos Aires, Siglo XXI, 2004 [1963]; Las palabras y las cosas. Una arqueología de las ciencias humanas, Barcelona, Planeta, 1984 [1966]; La arqueología del saber, México, Siglo XXI, 1978 [1969]; El orden del discurso, Barcelona, Tusquets, 1987 [1970]; Microfisica del poder, Madrid, La piqueta, 1979.
} 
toda posibilidad de provocar una experiencia. Estas ideas implican, como se verá, la noción de "sujeto nómade", de cuño posestructuralista y de productivo desarrollo en la obra de Michel Foucault, Hayden White y Michel de Certeau.

Otros dos teóricos de la literatura han resultado insoslayables en mi análisis textual: Iuri Tinianov, Ian Mukařovský y Mijaíl Bajtín, quienes han teorizado muy productivamente acerca de la transformación de los géneros discursivos y literarios. En el desarrollo iré señalando sus respectivos aportes y en cada caso haré una referencia explícita a sus conceptos y su relación con la obra de Lemebel.

[3] Hayden White: las formas de la figuración histórica y el estatuto cognitivo del relato

El discurso histórico propiamente dicho, según lo que Hayden White llama "la doxa del establishment de la historiografía moderna" (1987: 20), también denominada "la concepción convencional" o "el saber oficial", ha sostenido el siguiente imperativo epistemológico: para que la historia sea "verdadera historia" el relato de los hechos del pasado debe estar dotado de una estructura que organice la secuencia otorgándole significación, representando así un mundo acabado, concluso, no disuelto, no desintegrado. Según Hayden White, en esa representación la realidad lleva la máscara de un significado cuya integridad y plenitud sólo podemos imaginar, no experimentar. Me parece necesario transcribir un fragmento:

El vínculo de la crónica con los anales se percibe en la perseverancia de la cronología como principio organizador del discurso, y esto es lo que hace de la crónica algo menos que una "historia" plenamente desarrollada. Además, la crónica, como los anales pero al contrario que la historia, no concluye sino que simplemente termina; típicamente carece de cierre, de ese sumario del "significado" de la cadena de acontecimientos de que trata, que normalmente esperamos de un relato bien construido. La crónica promete normalmente el cierre pero no lo proporciona -siendo ésta 
una de las razones por las que los editores decimonónicos de las crónicas medievales negaron a éstas la condición de verdaderas "historias" (White 1987: 31).

Tomo la cita de Hayden White para comenzar a establecer el porqué de la opción exclusiva de Lemebel por la crónica. Desde luego, Hayden White no se está refiriendo aquí a las crónicas como las entendemos contemporáneamente, es decir, no se refiere en su estudio a las crónicas que participan claramente de la serie literaria, cuya producción -objeto de la presente tesis- registra una particular productividad en América Latina desde fines del siglo XIX. Pero sí se refiere a este tipo de discurso dando la condición que lo enlaza con nuestro objeto: la crónica no impone a sus materiales y a sus procesos la coherencia formal que le da cierre $y$, en consecuencia, estructura lógica con sentido atribuido. La crónica no muestra un mundo acabado, concluso y por lo tanto dotado de una integridad por fuerza imaginaria, teleológica y providencial en términos de Foucault (o ideológica y moralizante, en términos de White). En ese sentido, las crónicas a las que se refiere Hayden White y las que nos ocupan en la presente investigación participan de otra concepción del presente y de la verdad. Como decíamos en la introducción, la verdad de la crónica no se manifiesta, sino que se produce; el presente no está separado del tiempo de los acontecimientos narrados, sino que instaura una temporalidad sincrónica (A. González) y con ella, disuelve la concepción totalizadora, racionalista y "separada" de la experiencia subjetiva, propia de la Historia monumental (Nietzsche).

La crónica es una textualidad que resulta apta para el acontecimiento singular, sin pretensiones de totalidad. Y sobre todo, para generar una experiencia de los hechos, un saber que no sea sólo intelectual. Para ello hace falta renunciar a aquel mandato de la historia oficial: el de narrar hechos acabados, cuya estructura inmanente les otorgue un significado completo y único. La crónica se presenta como un tipo de enunciado 
especialmente dispuesto para lo fragmentario, lo discontinuo, lo cortado, y también, lo casual o azaroso, me atrevería a decir, lo arbitrario, y desde luego: lo particular y subjetivo. "Toda empresa científica -advierte Michel de Certeau- tiene como características la producción de artefactos lingüísticos autónomos (lenguas y discursos 'propios'), y la capacidad de éstos para transformar las cosas y los cuerpos de los que ya se han separado" (12, énfasis mío).

Está claro que los discursos clásicos o canónicos (que Hayden White llamó el establishment de la historiografía moderna) presentan una estrategia de invisibilización de aquella diferencia. Es decir, operan en un sentido ideológico: borrar las huellas de la enunciación, sus circunstancias, su sesgo individual o subjetivo, y presentar el relato como si fuera la estructura misma de los hechos, "olvidando" la separación.

La Razón Moderna, o más precisamente: la episteme positivista, entre otras verdades aceptadas, ha postulado implícitamente la verdad del método histórico. Dicho en otros términos, durante los siglos XVIII y XIX, los presupuestos epistemológicos de la disciplina histórica excluían la consciencia de que el relato de la Historia fuera lenguaje, artefacto simbólico, atravesado por presupuestos ideológicos, epistemológicos, filosóficos, y aun religiosos. Cuando las verdades universalmente aceptadas de la Razón Moderna comienzan a quebrarse, o por lo menos a ser puestas en duda hacia finales del siglo XIX, también la Historia como discurso objetivo, "vehículo" de los hechos, recibe su cuota de sospecha.

La diferencia cualitativa entre anales y crónica establecida por Hayden White y sus consideraciones acerca del valor de la narrativa en la representación de la realidad, me permitirán establecer el punto de apoyo de mi análisis: los modos que asume la relación específica entre el discurso y los acontecimientos narrados. Cito a propósito un 
fragmento de la Introducción de Verónica Tozzi al último libro de Hayden White (2003):

La configuración de una situación histórica específica, esto es, el darle una trama, explicarla e interpretarla políticamente, es una operación esencialmente discursiva. Los hechos no cuentan su propia historia, el pasado no es un relato que espera a un relator, configurar la Revolución francesa como una estructura con principio, medio y fin es una operación literaria, productora de ficción, que de ninguna manera atenta contra el estatuto cognitivo del relato, sino que es la operación necesaria para lograr refamiliarizarnos, a nosotros los lectores, con sucesos ajenos u olvidados. (Tozzi: 20. Énfasis mío).

Hayden White insiste en afirmar a lo largo de su trayectoria académica que la narrativa es una operación regida por las leyes del discurso, y no por las de la realidad. Aquí resulta pertinente señalar su completa coincidencia con el pensamiento del teórico de origen búlgaro Tzvetan Todorov, quien en su conocida introducción al volumen de la revista Comunicaciones titulada "Lo verosímil" (1970: 11-15), afirma que todos los sentidos evocados por la rica polisemia de ese término remiten a las reglas constitutivas del discurso. ${ }^{82}$

En respuesta a la objeción de Georg Iggers, ${ }^{83}$ White reformula y reafirma la hipótesis inicial de El contenido de la forma (su obra de 1987) en un trabajo posterior: "Hecho y figuración en el discurso histórico", al sostener que

[...] cuando se trata de evaluar las representaciones en competencia y las interpretaciones del significado del mismo acontecimiento proferidas por historiadores de similar erudición y sabiduría, los hechos no pueden ser invocados para decidir la cuestión. Primero,

\footnotetext{
${ }^{82}$ Tzvetan Todorov plantea en el citado texto - con admirable poder de síntesis- un antiguo y complejo problema de la filosofía del lenguaje, que se remonta hasta los estoicos y tiene su punto culminante con la sofística y el origen de la retórica, a saber: la condición irreductible del orden real y del orden simbólico. $\mathrm{Su}$ hipótesis es que todo lo articulado verbalmente se encuentra regido por las leyes del discurso, por lo tanto, el lenguaje no puede dar cuenta de lo real -ni de los sujetos ni de los objetos, ni de las cosas ni de los acontecimientos. Por lo tanto, "lo verosímil" es una categoría del discurso, y se desentiende de la relación lenguaje-objeto. En la misma línea teórica se encuentra el artículo de Julia Kristeva que forma parte del volumen, cuyo título es: "Una productividad denominada texto" (1967).

83 Iggers, Georg (1995): La ciencia histórica en el siglo XX. Las tendencias actuales. Una visión panorámica y crítica del debate internacional. Presentación, adaptación y revisión científica de Fernando Sánchez Marcos, Barcelona, Labor. Las críticas a Hayden White se encuentran en la Segunda Parte, en los capítulos "El retorno de la narrativa” y "El 'giro lingüístico'. ¿El fin de la historia como ciencia?”.
} 
porque lo que está en cuestión entre interpretaciones en competencia no es sólo cuáles son los hechos, sino también qué se ha de considerar como un hecho y qué no. Y, segundo, porque cuando se trata de interpretaciones en conflicto, lo que importa no es la verdad del hecho, sino el significado que ha de atribuirse a los acontecimientos que están en discusión. (White 2003: 55-56. Énfasis mío).

Más allá de la controversia que los estudios de Hayden White han generado especialmente a propósito de las formas de la figuración histórica (su famosa tropología), me interesa rescatar los dos postulados básicos de sus investigaciones, a los que nunca renunció, a saber: primero, que la historiografía no se reduce al trabajo con la evidencia documental y la correlativa necesidad de autentificar sus contenidos; y segundo, su reconocimiento del carácter moralizante, interesado y emotivo de la comunicación de la experiencia del pasado, objetivo primordial de la historización. Ellos explican su indagación en el universo de las teorías literarias y su posición crítica frente a la historiografía de corte positivista. El gran legado de Hayden White para el análisis de las crónicas es precisamente haber postulado y defendido el estatuto cognitivo de la narración no "a pesar" sino a causa de su configuración literaria.

Es justo señalar que la historia de la historiografía le debe a White el haber puesto en el centro de la problemática historiográfica las dudas y las dificultades inherentes a todo género de representación. Para operar en este campo White parte de una distinción básica:

Los acontecimientos ocurren y son atestiguados más o menos adecuadamente por los registros documentales y los rastros monumentales; los hechos son construidos conceptualmente en el pensamiento $\mathrm{y} / \mathrm{o}$ figurativamente en la imaginación y tienen una existencia sólo en el pensamiento, el lenguaje o el discurso. (White 2003: 53).

Esta distinción justifica su hipótesis de que la actividad constitutiva de un objeto específico del saber historiográfico "es tanto una cuestión de imaginación como de 
conocimiento" (White 2003: 32), dándole a la imaginación un estatuto cognitivo equiparable al de la razón. White resume su programa desde Metahistory (1973) hasta Figural Realism (1999) como el intento de revisar las presuposiciones de las “ortodoxias profesionales" autorizadas y corrientes en el campo de los estudios históricos, por cuanto no pueden ser consideradas absolutamente válidas para el estudio del pasado. Consciente de que "la mayor parte de los historiadores modernos no quieren ser considerados escritores de "literatura', entendiendo literatura como 'ficción"” (2003: 61), responde a sus críticos con reelaboraciones de los trabajos publicados en los años 70 y 80 , en los que insiste en su hipótesis central: aunque el propósito de los historiadores sea siempre decir la verdad acerca de sus objetos de estudio, no pueden narrativizar sin recurrir al habla figurativa, en la cual se emplean todas las condensaciones y desplazamientos del discurso literario. Ahora bien, White jamás homologa "literario" a "ficcional", y por lo tanto, historia y literatura no se oponen:

De nuevo, como en el caso de la distinción hecho-ficción, no veo la relación entre la historia y la literatura como una relación de oposición -como Ranke lo hizo cuando opuso su propia noción de historia escrita a las 'novelas románticas' de sir Walter Scott-. Hay muchos críticos que parecen identificar toda la 'literatura' con la ficción, con lo cual no son capaces de reconocer que hay mucha escritura literaria que no es ficcional y mucha escritura ficcional que no es literaria. (White 2003: 57)

Como se verá, esta perspectiva teórico-metodológica jugará un papel central en mis análisis de la crónica lemebeliana, por cuanto nuestro autor recurre a la ficción y a la poesía para narrar la historia reciente de Chile. El recurso a los procedimientos literarios le otorga al texto histórico su capacidad de vehiculizar una experiencia de los hechos que no había sido contada.

[4] Michel de Certeau: las voces y las materias en la escritura de la historia 
En relación más específica con la noción de "experiencia de la historia" y el campo problemático que esta noción genera (oposiciones y tensiones que se dan en el seno de la crisis del historicismo moderno), resultan indispensables los análisis del filósofo e historiador francés Michel de Certeau, particularmente su obra: La escritura de la historia (1978).

Respecto de la heterogeneidad de una escritura que "hace hablar al cuerpo" y comunica un saber que no es puramente intelectual, vale decir, una experiencia de la historia, el análisis textual de las crónicas lemebelianas estará orientado a relevar los procedimientos literarios que develan a) la presencia y operatividad del cuerpo -la materialidad de su escritura- y b) la resonancia de las voces que vinculan al corpus con la etnografía o digamos mejor, lo ubican como objeto de interés etnográfico (Yanko González 1997, 2005 y 2007).

En este campo será clave la propuesta metodológica de Michel de Certeau, quien ha develado para la historiografía contemporánea la condición de la escritura como trazado: los territorios conquistados serán "cuerpo historiado" (1978: 11). Lo que postula es un funcionamiento de la escritura que opera sobre los cuerpos (los conquista o marca en el caso de la empresa colonizadora), y que también los "hace hablar", revirtiendo un proceso de silenciamiento y negación del valor histórico de la experiencia particular y de las fluctuaciones de la oralidad; lo cual implica la recuperación de aquello que la visión historiográfica de matriz positivista había excluido de su campo o bien había configurado como "otro" (los dialectos de las comunidades primitivas, las clases sociales caídas del régimen de producción).

Leeremos las crónicas de Lemebel como un "regreso de la alteridad" (de Certeau) al centro de la escena histórica. En este sentido su construcción de una forma 
literaria híbrida, de difícil clasificación, representa al mismo tiempo un elemento que se integra a ese proceso y lo promueve. Para realizar un relevamiento del mencionado proceso observaré en las crónicas del chileno las estrategias de tratamiento del enunciador, su pluralidad de voces y puntos de vista, la consolidación de una estética neobarroca en la dimensión plástica, musical y material de su escritura y la posible construcción de una fuente para la etnografía y "un ejercicio metodológico para la arqueología cuya meta es sacarle el habla a las materialidades pasadas" (Y. González 2007).

Desde la primera versión de su trabajo "La operación historiográfica", de 1974 (ampliada e incluida luego en La escritura de la historia, libro publicado por Gallimard en 1975), hasta La fábula mística, obra de 1982, el proyecto de Michel de Certeau fue consignar las prácticas mediante las cuales los hombres y las mujeres de determinada época se apropian de objetos, códigos y lugares o bien alteran las convenciones existentes para dar lugar a prácticas nuevas. De allí que la historia sea para él, dentro de las ciencias humanas, la más apta para poner en escena la alteridad. La búsqueda de la palabra del Otro fue su pasión, y en esa búsqueda elaboró una profunda crítica a los modelos disciplinares dentro y fuera de su propio campo. Del cruce entre los múltiples saberes que dominaba (historia, sociología, economía, psicoanálisis) surge su pensamiento y su escritura singulares.

Si bien su reflexión se diferencia de la de su contemporáneo Hayden White, y en reiteradas oportunidades discute con él, no hay entre ellos oposición irreductible. Prueba de ello es que para de Certeau la historia también es un discurso cuyas reglas están dadas por las prácticas de las instituciones de la disciplina. Lo que no comparte con White es su modelo tropológico (el cual, como hemos señalado oportunamente, ha cosechado menos adhesiones que rechazos). No obstante, comparte con su colega 
norteamericano la consideración -central en el desarrollo de mis hipótesis- que la escritura de la historia remite a un yo que la produce, permeable a las determinaciones históricas de su época, su campo y la institución a la que pertenece. También tienen en común la crítica institucional que ya hemos apuntado en ambos autores y que ocupa buena parte de sus respectivas obras.

Tanto Michel de Certeau como su compatriota y contemporáneo Michel Foucault registran en su obra la necesidad de enfrentarse, o al menos de salir al cruce de una nueva corriente historiográfica que tuvo su auge en los comienzos de la década del setenta: la historia cuantitativa, que proponía un nuevo paradigma de la "cientificidad histórica" (Chartier 1996: 53-72; de Certeau 1978: 88-93) ${ }^{84}$. El trabajo cuantitativo (recolección y acumulación de largas series de datos precisos y medibles) oponía a las ambigüedades del discurso, las certidumbres y el rigor de las cifras. No obstante su aspecto cientificista y su entusiasmo renovador, esta escuela no se constituyó como un corte radical, sólo aportó un nuevo instrumento, el tratamiento e interpretación de los datos mediados por el proceso de informatización.

La obra de de Certeau destaca la importancia de lo singular, la excepción, la separación: las "particularidades" entrevistas en los vagabundeos del historiador que frecuenta los márgenes y las fronteras (incluidos los márgenes y las fronteras de su propio hacer):

Interrumpiendo su deambulación erudita por las salas de los archivos, se aleja un momento del estudio monumental que lo clasificará entre sus pares, y saliendo a la calle, se pregunta: ¿De qué se trata en este oficio? Me hago preguntas sobre la relación enigmática que mantengo con la sociedad presente y con la muerte, a través de actividades técnicas. (de Certeau 1978: 68)

\footnotetext{
84 Tanto Chartier como de Certeau citan a François Furet y a Emmanuel Le Roy Ladurie como representantes más destacados de esta corriente.
} 
Esta definición encierra los rasgos particulares del hacer historiográfico, tal como él lo concibe: el historiador saliendo a la calle; en tránsito del estudio monumental a la sociedad presente; enfrentándose al enigma de la muerte; produciendo a través de actividades técnicas. El hacer del historiador, por lo tanto, se produce alejándose del estudio monumental "que lo clasifica entre sus pares", por lo que sostengo, animada por la reflexión de este gran pensador contemporáneo, que Pedro Lemebel opera a través de sus crónicas como un historiador.

Así como nada puede borrar la particularidad del lugar desde donde el historiador habla, ni las del ámbito donde desarrollar su investigación, del mismo modo la práctica histórica depende siempre de la estructura de la sociedad en la que está inserta. Esta convicción es central en el pensamiento y, desde luego, en el legado de Michel de Certeau. De allí que le otorgue un papel central en el marco metodológico de la presente tesis doctoral. Si bien, como es evidente, de Certeau enfoca su análisis en los agentes de la práctica histórica académica, sus desarrollos teóricos nos permiten comprender la estrecha relación, por un lado, entre la historiografía y el conjunto de los discursos que en una sociedad se producen y circulan, y por otro, la íntima e intensa relación entre la historia y los actores sociales, sus prácticas, y la distribución de espacios sociales que esas prácticas provocan, de manera incesante.

En razón de lo que acabo de señalar, la obra de Pedro Lemebel es presentada aquí (y de ello tiene perfecta conciencia nuestro autor) como una obra enraizada en una particularidad social, comprometida con los conflictos sociales que examina, y al mismo tiempo ligada con los procesos de transformación epistemológica que esos conflictos determinan. Las crónicas de Lemebel realizan precisamente lo que Michel de Certeau define como la operación histórica: 
La operación histórica consiste en dividir el dato según una ley presente que se distingue de su "otro" (pasado), en tomar una distancia respecto a una situación adquirida y en señalar con un discurso el cambio efectivo que ha permitido este distanciamiento (de Certeau 1978: 100).

De Certeau recupera la función crítica de la historia, señalando como su operación básica la de distinguir una situación vivida y hacer explícita su distancia con respecto al presente; pero distancia -y ése es su valor para la práctica histórica- que al “simbolizar el límite" hace posible una superación (el pasado conserva, para de Certeau, su valor primitivo de representar lo que hace falta). El autor analiza los discursos etnológicos del siglo XVI, en particular la Historia de un viaje hecho a la tierra del Brasil, de Jean de Léry (1578), relato de una estancia en la bahía de Río durante los años 1556-1558. Esta reflexión sobre uno de los textos fundadores de la etnología (aun previo al surgimiento de esa disciplina, cuyas condiciones se fijan en el siglo XVIII y a la cual Jean-Jacques Ampère bautiza con ese nombre en el $\mathrm{XIX}^{85}$ ) ocupa la tercera parte del libro de de Certeau La escritura de la historia (1978: 201-269). Allí el autor postula un "cuadrilátero etnológico" (203): la oralidad, la espacialidad, la alteridad y la inconsciencia. Esas cuatro categorías están destinadas a entender "lo diferente" de las culturas conquistadas y, al mismo tiempo, a ajustar la eficacia del control colonial. La crónica de la conquista, con estas herramientas, procede según el autor a "la invención del Salvaje", por cuanto el relato reconoce la alteridad y la "trae de regreso" al universo comprensible y escrito de la Historia (regreso a la mismidad, la escritura, la temporalidad y la identidad, el por-acá del pensamiento occidental, que se opone en espejo a las cuatro categorías etnológicas mencionadas que representan el por-allá del Salvaje, garantizando la separación). La Historia "relata" gracias a su organización, su

\footnotetext{
${ }^{85}$ G. de Rohan-Csermak, "La primera aparición del término etnología" en Ethnologia europea. Revue internationale d'ethnologie européene, vol. I, 1967, núm. 4, pp. 170-184. (Citado por Michel de Certeau, pág. 203, nota 1). A Jean-Jacques Ampère (1800-1864), hijo del famoso matemático y físico André-Marie Ampère, se le atribuye unánimemente el nombre de "etnología" dado a esta disciplina.
} 
escritura, su temporalidad, operando el regreso de la alteridad por la vía de la interpretación. La voz del Salvaje queda así "limitada al círculo evanescente de su audición" (211). En el modo histórico de la crónica (crónicas de la conquista, crónicas de viajes) cada episodio modula lo extraño, lo representa al producirse aquel movimiento simultáneo de progreso hacia la alteridad y de regreso hacia la mismidad por el camino de la hermenéutica. A Lemebel no le hace falta esa doble operación; en sus crónicas la separación no se desvanece ni se disimula, el texto la supone y la atraviesa porque está escrito por ese mismo otro que habla ahora, desde su propio deseo, desde la experiencia de su propio cuerpo enfermo, estigmatizado por la exclusión, la persecución homofóbica, el control político-policial, la indiferencia cómplice, y se propone como discurso de un saber que no había sido oído, o había sido oído bajo la estructura de la separación que lo representa, lo interpreta y lo exotiza.

La alteridad y las particularidades son el objeto de una práctica que además de estar enraizada en un lugar (social, político, cultural, siempre colectivo), toma distancia de su objeto, distancia necesaria para toda operación crítica, y al señalar la falta tiende a operar una transformación: "La historia interviene en el modo de realizar una crítica de modelos sociológicos, económicos, psicológicos o culturales" (de Certeau 1978: 94). Ya no tiene la historia la función totalizadora de dar el sentido de las cosas, o de proveer a la sociedad de una representación de su origen, ni tampoco la de determinar las "fuerzas históricas" que determinan las orientaciones en el interior del cuerpo social. La historia indaga en aquellas particularidades y alteridades que interrogan sus "regularidades", y de algún modo cuestionan los modelos vigentes; según de Certeau, "la historia es siempre ambivalente: el lugar que labra en el pasado es al mismo tiempo una manera de abrir el paso a un porvenir" (1978: 100). Lemebel participa de esta concepción de la 
función crítica de la historia, y lleva adelante su cuestionamiento de los modelos vigentes en el Chile de la transición.

[5] Michel Foucault: el orden del discurso y los dispositivos de exclusión

La obra ineludible de Michel Foucault, especialmente: El nacimiento de la clínica (1963); Las palabras y las cosas (1966); La arqueología del saber (1969); El orden del discurso (1970); Microfísica del poder $(1979)^{86}$, constituyen la referencia obligada del propio Hayden White y de cualquier reflexión epistemológica que tome como objeto las complejas relaciones entre el discurso y la Voluntad de Verdad, entre los discursos disciplinares y los mecanismos de control exteriores e interiores a ellos.

Michel Foucault ha reconocido múltiples mecanismos de exclusión que operan en la constitución del orden discursivo occidental desde la antigüedad hasta nuestros días. La hipótesis central de su conferencia inaugural El orden del discurso (1970) es la siguiente:

[...] en toda sociedad la producción del discurso está a la vez controlada, seleccionada y redistribuida por un cierto número de procedimientos que tienen por función conjurar los poderes y peligros, dominar el acontecimiento aleatorio y esquivar su pesada y temible materialidad (Foucault 1970: 11).

El filósofo francés parte de esta hipótesis para analizar luego cada uno de los mecanismos de control que ejercen el poder de producir, valorar, jerarquizar y distribuir los discursos. De los seis procedimientos de exclusión analizados a lo largo de la conferencia, me voy a detener en uno por tratarse del que se encuentra precisamente diluido en la producción de nuestro autor, o diríamos mejor, es el procedimiento contra

\footnotetext{
${ }^{86}$ Foucault, Michel: El nacimiento de la clínica, Buenos Aires, Siglo XXI, 2004 [1963]; Las palabras y las cosas. Una arqueología de las ciencias humanas, Barcelona, Planeta, 1984 [1966]; La arqueología del saber, México, Siglo XXI, 1978 [1969]; El orden del discurso, Barcelona, Tusquets, 1987 [1970]; Microfisica del poder, Madrid, La piqueta, 1979.
} 
el que operan las crónicas de Pedro Lemebel. Me refiero al segundo de los llamados “procedimientos externos": la separación y el rechazo. Foucault toma como ejemplo paradigmático de este procedimiento la palabra del loco, palabra nula y sin valor. No obstante, como lo aclara después, este mecanismo de hecho se aplica a multitud de sujetos a quienes se les niega el derecho y la posibilidad de la palabra. La voz del sujeto señalado (loco, homosexual, travesti, indígena, indigente, salvaje o exótico, extra o contra-cultural) posee un índice de separación que lo hace caer "fuera del logos". Su palabra puede ser considerada -a lo sumo- como razón ingenua o como verdad oculta, y hasta se puede montar a su alrededor "la armazón del saber con la que hoy desciframos esa palabra"; pero aun en este caso la línea de separación no desaparece, al contrario, "mantiene la cesura" (Foucault 1970: 13). El discurso es un lugar donde se ejercen poderes, y la separación es la línea en la que se ejerce el poder de excluir. Este podercomo todos los que se relacionan con el orden del discurso- "se apoya en un soporte institucional [...] tiende a ejercer sobre los otros discursos una especie de presión y como un poder de coacción" (18).

En otros términos, el discurso (su producción, su valor de verdad, su distribución) no es una trama abierta y receptiva a la voluntad de quien desee colaborar en ella, alterar su diseño, hacer oír su voz. Foucault advierte acerca de una densa serie de prácticas que se orientan a excluir de esa trama a los sujetos cuya "cualificación" (gestos, comportamientos, circunstancias) no los habilita a participar o intervenir en ella. Estos sistemas de restricción fijan la eficacia, el valor y la distribución de los lugares simbólicos de la enunciación; en términos de Foucault: determinan "para los sujetos que hablan las propiedades singulares y los papeles convencionales" (1970: 33). Del mismo modo la función de lo que él llama "las sociedades de discursos" es producirlos según sus propios criterios de verdad y conservarlos "pero para hacerlos 
circular en un espacio cerrado, distribuyéndolos nada más que según reglas estrictas y sin que los detentadores sean desposeídos de la función de distribución" (1970: 34).

Lemebel interviene en la densa trama de prácticas que guardan celosamente la producción y distribución de los discursos historiográficos, y levanta el tabú de la separación para hacer oír la voz del otro. En la conjunción del pensamiento de Michel Foucault con el de Michel de Certeau, podemos comprender la importancia epistemológica de lo que este último ha llamado "hermenéutica del otro" y sus efectos en el caso Lemebel: las crónicas del chileno avanzan sobre los sistemas de restricción configurados en el interior de la sociedad de discurso que llamamos "historiografía", y operan una redistribución de sus papeles convencionales, dándole voz y valor de verdad a discursos que habían sido sistemáticamente desoídos, excluidos por las reglas del orden discursivo historiográfico.

Esta conferencia es anterior al volumen de artículos del autor titulado: Microfisica del poder ${ }^{87} \mathrm{y}$, claramente, lo anticipa. En ese volumen, que hemos citado en la Introducción de esta tesis, desarrolla el proyecto de investigación que postula en el final de la conferencia que acabo de reseñar: "temo reconocer una pequeña maquinaria que permite introducir en la misma raíz del pensamiento el azar, lo discontinuo, y la materialidad: triple peligro que una cierta forma de historia pretende conjurar" (1970: 49). En efecto, en los artículos de Microfísica del poder el pensador francés analiza particularmente las dos exigencias de la historiografía moderna, a saber: el desarrollo continuo y la necesidad ideal. Según Foucault, las relaciones de poder determinan

\footnotetext{
${ }^{87}$ La edición castellana que cito reúne doce textos y entrevistas publicados entre 1971 y 1977, y corresponde a Julia Varela y Fernando Álvarez-Uría, Madrid, La Piqueta, 1979. Existe una versión italiana Microfisica del potere, cuya primera edición de 1977 incluye siete textos y fue organizada por Pasquali Pasquino y Alexandre Fontana, Einaudi, Torino. Hay versión portuguesa: Microfisica do Poder, cuya primera edición de 1979 incluye diez textos, y fue organizada por Roberto Machado, Ediçoes Graal, Río de Janeiro.
} 
fenómenos complejos que no obedecen a la forma hegeliana de la dialéctica ${ }^{88}$. De hecho, la idea de la localización única o focalización del poder es falsa, y por lo tanto, también lo es la posibilidad de que la super-estructura se tambalee (en esto reside la crítica de Foucault al marxismo y al neomarxismo, particularmente el de Marcuse). Por ello, afirma que:

[...] una de las primeras cosas que deben comprenderse es que el poder no está localizado en el aparato de Estado, y que nada cambiará en la sociedad si no se transforman los mecanismos de poder que funcionan fuera de los aparatos de Estado, por debajo de ellos, a su lado, de una manera mucho más minuciosa, cotidiana. (Foucault 1979: 108).

El pensamiento estratégico de Foucault considera el espacio del discurso como territorio y encrucijada de prácticas políticas. Dado que no existe un "proyecto global" que presida las políticas discursivas ni organice o coordine sus sistemas de restricción, hace falta observar el entramado de las micro-políticas discursivas, y en él advertir cómo se ensamblan las piezas y cómo se opera -en términos de estrategia- la posibilidad de su transformación.

El marco teórico precedente me permitirá realizar una lectura de la obra de Pedro Lemebel en los términos planteados, es decir, poner en relación su obra cronística con la serie literaria y la serie historiográfica, teniendo en cuenta las transformaciones operadas en ellas a partir de su intervención.

\section{2. Genealogía de la crónica latinoamericana: Continuidades y rupturas}

[1] La crónica de Indias. Lemebel contra los neocolonialismos del presente

\footnotetext{
${ }^{88}$ Como se verá en el desarrollo de la primera hipótesis, esta crítica a la dialéctica hegeliana en relación con la historia aparece reformulada y ajustada a la realidad latinoamericana por José Lezama Lima en su compilación de ensayos: La expresión americana (1969).
} 
Las Crónicas de Indias son antecedentes -remotos pero ineludibles- tanto de la crónica modernista como de la crónica latinoamericana actual. Su análisis resulta necesario por cuanto las crónicas de Pedro Lemebel registran nuevas estrategias de colonización en el presente (últimas décadas del siglo XX, primeras del siglo XXI) al tiempo que ejercen contra ellas una poderosa resistencia en el campo de la producción y la circulación de los discursos. En este apartado me voy a detener en algunos aspectos generales de las crónicas del período colonial que considero pertinentes para esta investigación, y en los relatos de dos cronistas destacados del siglo XVI a fin de establecer las continuidades y diferencias específicas con la obra de nuestro autor.

El análisis de los vínculos complejos y muy significativos que se producen entre los términos: crónica (o corónica); historia; vida (con un significado cercano a "biografía"); gesta y escriptura, en los textos historiográficos de la colonización y la conquista durante los siglos XVI y XVII resulta relevante dada la imbricación de dichos términos y las diferencias que postulan en cuatro ejes: a) la creciente conciencia historiográfica; b) la división de "géneros" que de manera más o menos explícita se da entre los cronistas de Indias; c) la importancia dada al punto de vista de quien enuncia el relato; y d) la jerarquía que progresivamente asume la forma narrativa literaria: el orden, la armonía en la narración y el estilo elevado en las descripciones. Dentro de este aspecto formal es destacable -sobre todo en los textos del Inca Garcilaso- la clara conciencia de la separación entre "historia" y "discurso".

Como consecuencia muy significativa de esta línea genealógica, se observa que la hibridez genérica encuentra sus orígenes en el siglo XVI. Vale decir que existe una matriz discursiva que explica en alguna medida las complejas relaciones que el género reviste en la actualidad con la biografía, la autobiografía, el testimonio, la historiografía, 
el periodismo, el ensayo histórico y la no ficción. Esta es una de las continuidades que podemos señalar en la larga historia del género en nuestro continente.

Walter Mignolo (1987: 57-114) establece tres tipos discursivos en la organización de la prosa narrativa del período colonial, a saber: a) las cartas relatorias, b) las relaciones y c) las crónicas o historias. Lo interesante de esta clasificación propuesta por Mignolo es la posibilidad que nos ofrece de trazar líneas de continuidad entre los primeros discursos considerados historiográficos que se escribieron en nuestro continente y la crónica latinoamericana actual. Por esa razón me voy a detener en ella.

Comencemos por citar las definiciones de estas tres formaciones discursivas:

Por "cartas relatorias" entendemos, como es obvio por el adjetivo, las cartas que relatan con cierto detalle un acontecimiento; distinguiendo así las cartas relatorias, culturalmente marcadas (por ejemplo, Colón, Cortés), del gran cúmulo de cartas que se intercambian entre los conquistadores y representantes de la Corona en Indias. Estas cartas, que tienden más hacia lo documental que hacia lo textual, son portadoras de mensajes, pero estos mensajes no son relatos de los descubrimientos o de las conquistas, [...] sino "comunicaciones" (informes, solicitudes) que reemplazan la inevitable falta de copresencia entre el destinador y el destinatario. (Mignolo 1987: 59)

Como vemos, el enfoque de Mignolo es pragmático. Su clasificación atiende a lo que antes ha definido como tipos y formaciones discursivas que se incluyen en una familia textual, unida por su referente y "ciertas fronteras cronológico-ideológicas" (1987: 58). Por ello la identidad del primer tipo de discurso definido aquí está determinada por su función, es decir, su propósito: la obligación de informar (ésta era una imposición de la Corona) y de solicitar su amparo y sostén. "En segundo lugar prosigue Mignolo- nos ocuparemos de las relaciones marcando, en este caso, la distinción entre la relación como tipo discursivo y el empleo del vocablo 'relación' en contextos en los cuales significa, simplemente relato o informe". (59) 
Como lo explica en el apartado correspondiente (Mignolo 1987: 70-75) la diferencia entre el primero y el segundo tipo de discurso es sutil: las cartas son informes y solicitudes vinculados directamente con el propósito de la conquista; son obligatorios, pero no oficiales. Las relaciones, en cambio, emulando un método habitual en la escolástica y en la metodología española, responden ajustadamente a un cuestionario elaborado por la Corona, dando como resultado un informe oficial. Lo importante y específico de este tipo textual es que

[L]as relaciones no transcriben la observación "libre" de quien escribe, de lo que ve quien escribe, sino que responden, de alguna manera, a los pedidos oficiales. Estas respuestas [...] se oficializan y se codifican en las preguntas del cuestionario a partir de 1574. (Mignolo 71) Cursivas del autor.

El ver del conquistador está condicionado por lo que los reyes quieren saber. Así las relaciones son la respuesta a un texto previo: las instrucciones. Como ejemplo, Mignolo cita uno de los textos recogidos por Jiménez de la Espada. Se trata de una carta de los reyes a Colón fechada en Segovia el 16 de agosto de 1494:

Vimos vuestras letras e memoriales que nos enviastes con Torres. Y visto todo lo que nos escribistes, como quiera que asaz largamente decis todas las cosas de que es mucho gozo y alegría leerlas; pero algo más queríamos que nos escribiésedes, ansí en que sepamos cuántas islas fasta aquí se han fallado, y a las que habéis puesto nombre, qué nombre a cada una; porque, aunque nombráis algunas en vuestras cartas, no son todas, y a las otras los nombres que las llaman los indios; y cuánto hay de una a otra [...]. Y todo nos lo escribáis por nuestro servicio. (Jiménez de Espada, citado por Mignolo 71).

En síntesis, los informes y las solicitudes en las cartas de relación obedecen a la observación del conquistador y responden a sus modelos discursivos y filosóficos que determinan la acción de mirar y de seleccionar lo visto para relatar. Las relaciones, en cambio, son respuestas a demandas precisas volcadas en cuestionarios o textos 
instructivos y por ello, se configuran como formaciones discursivas oficializadas y altamente codificadas.

Un tercer grupo bien diferenciado de textos son las "historias". Historia es un

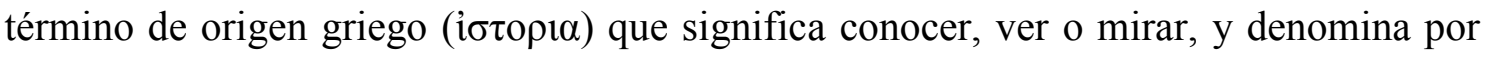
extensión al informe de lo visto o lo aprendido por medio de la formulación de preguntas (al menos en este sentido lo emplea Herodoto). Por su parte Tácito llama anales al informe de lo pasado, y reserva el término historia al informe de los tiempos de los cuales es contemporáneo. Aclara Mignolo que

La ausencia del componente temporal [en el origen del término historia] explica el nombre y el concepto de "historia natural"; y es así como lo encontramos en los siglos XVI y XVII hispánicos. Crónica, por el contrario, es el vocablo para denominar el informe del pasado o la anotación de los acontecimientos del presente, fuertemente estructurados por la secuencia temporal. Más que relato o descripción la crónica, en su sentido medieval, es una "lista" organizada sobre las fechas de los acontecimientos que se desean conservan en la memoria. (Mignolo 75).

Lo cierto es que los términos "historia" y "crónicas" tienden, con el correr de los siglos, a subsumirse en el término "historia" la cual incorpora el elemento temporal y desplaza a la crónica como actividad verbal. De lo cual se sigue que tanto los anales como las crónicas tienden a desaparecer hacia el siglo XVI y son reemplazados por las narraciones históricas del tipo gesta o vitae (antecedente del género biográfico). Cita Mignolo a Jerónimo de San José, quien precisa con detalle el empleo de la voz "crónica" o "corónica" 89 :

Crónica es Historia breve y ceñida, ajustada a los años. La cual también se llama Cronología y especialmente si es narración y averiguación de años y de tiempos, porque Chronos es voz griega que significa tiempo. (Mignolo 1987: 76).

\footnotetext{
89 "Nuestra lengua [...] añade una $o$ en la primera sílaba diciendo Corónica, y de ahí coronista; aunque los muy escrupulosos eruditos siempre retienen la propiedad griega, diciendo crónica y cronista" (Jerónimo de San José, 1651, citado por Mignolo 1987: 76).
} 
Un ejemplo muy importante de la sinonimia de los vocablos crónica e historia en el siglo XVI lo da el propio Bartolomé de las Casas, quien titula su libro: Historia de las Indias y en el Prólogo observa: “¿Dónde va a parar tanto y tan luengo discurso de prólogo [...]? Digo que a poner los fundamentos y asignar las causas de todo lo que en esta Corónica de estas Indias propongo decir”. Del mismo modo Cieza de León, titula Chrónica del Perú a su libro, pero en el Proemio señala: "Y cobrando ánimo, con mayor confianza determiné de gastar algún tiempo de mi vida en escribir historia." (Mignolo 1987: 76-77).

Claramente observamos que la diferencia entre Historia (asimilada aquí al término Crónica) y cartas o relaciones, está dada por la presencia en primer término de la palabra del historiador o cronista. Es su posición frente a lo que ha de narrar (de la que encontramos marcas explícitas, como los pronombres de primera persona y otros deícticos) la que determina esta formación discursiva y le da su especificidad. Esto aparece manifiesto en los Prólogos y Proemios (entre los que se destacan el citado Prólogo del padre de Las Casas a su Historia de las Indias).Vemos la importancia que reviste en este tercer tipo discursivo la conciencia historiográfica. Considero que dicha conciencia es uno de los rasgos configuradores del género, el cual registra una notable continuidad que señalaremos en la obra de Pedro Lemebel.

Planteados los aspectos de las crónicas del período colonial que resultan pertinentes para esta investigación, me voy a detener brevemente en los cronistas que han concitado mayoritariamente el interés de los especialistas. En este apartado, entonces, analizaré exclusivamente aquellos elementos discursivos de dos destacados cronistas de Indias que me permitirán establecer continuidades verificables en este género a lo largo de su evolución, y una diferencia sustancial, por cuanto las crónicas de 
Indias consideradas aquí, a saber: las de Gonzalo Fernández de Oviedo y las de Bernal Díaz del Castillo justifican y acompañan la empresa colonial, mientras que la prosa de Pedro Lemebel se erige como voz que denuncia y resiste los neocolonialismos del presente. Lo que he denominado "conciencia historiográfica" se halla de manera destacada en uno de los más importantes cronistas de Indias: Gonzalo Fernández de Oviedo.

Gonzalo Fernández de Oviedo (1478-1557) 1lamado "el primer cronista del nuevo mundo", escribe sus crónicas alrededor de 1535. Junto con Bernal Díaz del Castillo es el más importante cronista del siglo XVI. La importancia de Fernández de Oviedo para nuestra investigación radica en su carácter de testigo directo de los episodios que narra. Este cronista vivió la mayor parte de su vida en las Indias y es uno de los más prolíficos cronistas de su siglo. Estos rasgos determinan su condición de escritor dedicado enteramente a dar cuenta de los acontecimientos en calidad de testigo presencial y también agente partícipe de los hechos que narra. Otro rasgo fundamental de Fernández de Oviedo es su clara conciencia historiográfica:

Será a lo menos lo que yo escribiera historia verdadera $e$ desviada de todas las fábulas que en este caso otros escriptores, sin verlo, desde España a pie enxuto, han presumido escrebir con elegantes e no comunes letras latinas e vulgares [...] formando historias más allegadas al buen estilo que a la verdad de la cosa que cuentan; porque ni el ciego sabe determinar colores ni el ausente assi testifica estas materias, como quien las mira.

Quiero certificar a V.C.M. que yrán desnudos mis renglones de abundancia de palabras artificiales para convidar a lectores, pero serán muy copiosas de verdad. (Las cursivas son mías). (Disponible online: Biblioteca Virtual Cervantes: 4)

En este fragmento observamos: $1^{\circ}$ ) su propósito de ser fiel a los hechos ("historia verdadera"); $2^{\circ}$ ) su voluntad de diferenciarse de las fábulas de "otros escriptores" que no han estado allí y escriben desde España. $3^{\circ}$ ) el tópico de los 
cronistas de los siglos XVI y XVII de apartarse de la voluntad de estilo para ajustarse a la narración de cosas verdaderas.

Una característica muy destacada en Fernández de Oviedo es su tendencia a detenerse en los detalles de la historia, en apariencia nimios o superfluos, y a recolectar memorias que transcribe en sus crónicas como elementos insustituibles. A este rasgo se refiere precisamente Menéndez y Pelayo como un elemento inapreciable a la hora de escribir la historia:

No hay, entre los primitivos libros sobre América, ninguno tan interesante como éste [...] por lo mismo que acumula todo género de detalles sin elección ni discernimiento, con afán muchas veces nimio y pueril, resulta inapreciable colector de memorias, que otro varón de más letras y más severo gusto hubiera dejado perderse, con grave detrimento de la futura ciencia histórica, que de todo saca partido, y muchas veces encuentra en lo pequeño la revelación de lo grande. (Menéndez Pelayo 1941: 87. Énfasis mío)

Este rasgo (el interés por el detalle que puede parecer menor) propio de los textos de Oviedo, resulta relevante a la luz del desarrollo posterior del género, por cuanto constituye una de las características que anudan la crónica literaria al afán historiográfico o al propósito de registro e instauran la hibridez genérica como rasgo distintivo desde sus orígenes coloniales.

Otro elemento destacable en las crónicas de Oviedo es su interés por las relaciones de conquistadores y navegantes, dando testimonio de sus experiencias en el nuevo mundo, y consignando sus voces en estilo directo. También lo valora en ese sentido Menéndez Pelayo:

Sus descripciones no son las de un naturalista, pero los naturalistas las reconocen como muy exactas. En la historia civil hay que distinguir lo que Oviedo pudo ver por sí durante sus repetidos viajes y estancias en el Nuevo Mundo, y en esto merece todo crédito; y lo que supo por relaciones de conquistadores y navegantes, más o menos fidedignos, como él mismo reconoce, adelantándose al cargo 
que en esto se le pudiera hacer; «y como solo Dios es el que sabe y puede entender a todos, yo, como hombre, podría ser engañado o no tan al propio informado como conviene; pero oyendo a muchos, voy conociendo en partes algunos errores, e assi voy e iré enmendando donde convenga mejor distinguir lo que estuviese dubdoso o desviado de lo derecho». Sobre su imparcialidad se ha disputado mucho; es cierto que escribe generalmente con espíritu favorable a los conquistadores, a cuyo número pertenecía, y cuyas increíbles hazañas ejercían natural prestigio sobre su imaginación. (Menéndez Pelayo 88)

Lo interesante aquí (y pertinente para nuestra investigación) es que Oviedo tiene clara conciencia de estar escribiendo su historia a partir de la experiencia que transmiten los testimonios directos de los protagonistas, y al mismo tiempo, no rehúye -aunque constituya un riesgo para la "verdad" y un desvío respecto de las exigencias discursivas de la corona- la inclusión en estilo directo de otros puntos de vista acerca de los acontecimientos narrados.

Bernal Díaz del Castillo (1492-1584) escribe sus crónicas en 1568, aunque fueron publicadas mucho más tarde. Fue soldado de Hernán Cortés, condición que, desde luego, determina tanto su punto de vista como el interés que anima su testimonio. Su obra, impresa en Madrid en 1632, se titula: "Historia Verdadera de la Conquista de la Nueva España"90. Llegó por primera vez a las Indias en 1514 bajo las órdenes de Pedro Arias de Ávila, pasó a Cuba en 1518 y se instaló en la villa del Espíritu Santo. No sabemos en qué año se radica definitivamente en Guatemala, donde muere en 1584.

En el Capítulo I de su historia, en el que como es de rigor, el cronista se presenta y expone los propósitos de su escritura, se advierten tres características relevantes para nuestra investigación: a) se considera un hombre de acción ("siempre tuve celo de buen soldado", 51), alejado de la "retórica" e ignorante, por lo tanto, de sus convenciones; b) se dirige a los "curiosos lectores" haciéndoles saber su condición y su propósito; esta apelación demuestra su conciencia de escritor más allá de las obligaciones que le

\footnotetext{
${ }^{90}$ Al igual que la de Fernández de Oviedo, su obra completa está disponible en línea: Biblioteca Virtual Cervantes http://www.cervantesvirtual.com aunque aquí cito la edición de Eudeba.
} 
imponen sus jefes políticos y militares; c) además del primer e ineludible propósito de registrar lo que ve, Díaz del Castillo tiene un objetivo literario: "que los curiosos lectores que las leyeren [mis historias] tomen melodía y sabor dellas” (49).

A lo largo de su relato se advierte una tendencia digresiva que el autor insiste en controlar con expresiones como: "Quiero volver a mi materia" o "Volvamos a nuestro cuento" (87). Ese particular "ir y venir" le otorga al texto dinamismo e interés, por cuanto en esas digresiones se narran episodios menores y descripciones de espacio y personajes muy interesantes. Por ejemplo, en el Capítulo XXVI se relata un episodio en el que Cortés libera a un grupo de españoles esclavizados (Díaz del Castillo: 117). En él se narra en detalle un caso de mestizaje. Un soldado español, Gonzalo Guerrero, al recibir el aviso de su rescate de boca de Jerónimo de Aguilar, le contesta:

Hermano Aguilar: yo soy casado y tengo tres hijos, y tiénenme por cacique y capitán cuando hay guerras; idos con Dios, que yo tengo labrada la cara y horadadas las orejas. ¡Qué dirán de mí desde que me vean esos españoles ir de esta manera! Y ya véis estos mis hijitos cuán bonicos son. (Díaz del Castillo: 117)

Nos cuenta Díaz del Castillo que Aguilar no lo pudo convencer, y transcribe (al tiempo que traduce) con mucha gracia el comentario de la esposa del español que ha sido convertido en cacique: "Y asimismo la india mujer del Gonzalo habló a Aguilar en su lengua, muy enojada, y le dijo: 'Mira con qué viene este esclavo a llamar a mi marido; idos, vos y no curéis de más pláticas"” (118). Inmediatamente, sin transición, narra un episodio de robo de tocinos entre los soldados. Hallados los culpables, los hizo azotar. Luego continúa con la historia de Jerónimo de Aguilar y vuelve a referirse a Gonzalo Guerrero (aquel que no quiso ser rescatado).

Lo que me interesa señalar con estas breves referencias es un rasgo del relato de Bernal Díaz del Castillo que sólo se percibe en una detenida lectura: su prosa es llana, 
casi coloquial, y está colmada de referencias a los hábitos de vida cotidiana, tanto de los soldados, como de los jefes militares y de los naturales. Estas referencias incluyen costumbres, modos de sociabilidad, utensilios y vestimenta, hábitos alimenticios y ritos religiosos. Sin olvidar en ningún momento (y por eso reitera las expresiones ya citadas, del tipo: "Quiero volver a mi materia") que el objetivo de su crónica es narrar la conquista "como buen testigo de vista [...] sin torcer a una parte ni a otra [...] y decir $\operatorname{verdad}^{91}$ sin lisonjas" (49). Lo que he llamado "carácter digresivo" de su prosa, atendiendo a las auto-correcciones del autor que se obliga a volver a su "materia" (el relato de la conquista), es precisamente lo que lo hace valioso, por cuanto narra las formas de sociabilidad de conquistadores y conquistados. Este elemento es importante tanto para los historiadores y estudiosos posteriores de la conquista como para nuestro interés: vemos en estos relatos el origen de la crónica en su heterogeneidad discursiva, su pluralidad de propósitos y su atención a las transformaciones que el cronista advierte en el plano de la vida cotidiana (lo que antes he llamado "formas de sociabilidad"). Este rasgo marca una de las más interesantes líneas de continuidad entre los cronistas de Indias, los modernistas y los contemporáneos.

Ahora bien, como he señalado en la introducción de los cronistas coloniales, hay una diferencia ineludible entre estos cronistas de Indias y la obra de Pedro Lemebel, que hace a su especificidad aun entre los autores contemporáneos: la potencia contestataria de su prosa. En los cronistas del siglo XVI cuyas historias he comentado muy sumariamente, observamos a primera vista -más allá de algunas disputas señaladas por Menéndez y Pelayo sobre su imparcialidad- que son soldados de la corona, y como

\footnotetext{
${ }^{91}$ A propósito, son muy reiteradas las referencias a otros cronistas, a quienes cuestiona por apartarse de la verdad objetiva. Todo el capítulo XVIII es una extensa crítica a López de Gómara y al Dr. Illescas, cuyas historias "desde el principio, y medio ni cabo no hablan lo que pasó en la Nueva España [...] en cuanto al número de vecinos tanto se les da poner 80.000 como 8.000 [...] en todo no aciertan. Pues otra cosa peor dicen: que Cortés mandó secretamente barrenar los navíos; no es así [...] En todo escriben muy vicioso" (Díaz del Castillo: 94-95).
} 
tales, participan de la empresa y tienen una opinión general favorable a la conquista. El ojo de Lemebel invierte la mirada colonial, y su voz se opone a todas las formas de neocolonización. Si bien estos aspectos serán analizados puntualmente en el desarrollo de las hipótesis, me parece necesario enumerarlos sumariamente aquí:

1) Para nuestro autor, el Sida es una estrategia de "recolonizaje" por los fluidos corporales, dado que el virus es "importado" por las locas viajadas, que lo traen desde Nueva York. Esta idea es el eje articulador de su segundo libro de crónicas: Loco afán. Crónicas de Sidario, publicado en 1996 y que constituyó un punto de inflexión en su obra por cuanto a partir de esa fecha el escritor experimentó una difusión internacional no conocida por su obra anterior. En este volumen (con su voz poderosa ya reconocida en Chile en virtud de la circulación de sus crónicas en medios masivos y por su obra performática anterior) Lemebel denuncia y ejerce una resistencia eficaz contra la persecución homofóbica que demuestra la continuidad del control político-policial aun en tiempos democráticos. Dicha persecución es activa por parte de las instituciones que presentan intactos los procedimientos de exclusión montados por la dictadura, los cuales cuentan con la eficaz complicidad de la indiferencia social o el prejuicio pacato que "deja hacer" al orden policial; el conjunto de la sociedad se convierte así en un agente de la violencia de género.

2) En este mismo libro el autor señala y justifica que tanto el censo poblacional llevado adelante por el gobierno en 1992 como otras estrategias de control institucional, funcionan como "espéculo curioso" que mete su hocico en la intimidad del ciudadano. El censo es nombrado como "el recolonizaje por la ficha" y es equiparado a las estrategias de la conquista en su voluntad de "vigilar y castigar".

3) La moda "mister-gay", caracterizada por una impostada virilidad o masculinidad homosexual (el "modelo Travolta", Lemebel 1996: 53) representa otra 
modalidad de la garra neo-colonial. A ella se opone la femineidad y la solidaridad de las travestis chilenas (mestizas, ruidosas, desenfadadas, callejeras, arriesgadas, graciosas y solidarias) que protagonizan sus crónicas.

4) Lemebel se opone a la escritura letrada como estrategia de expulsión del habla. En sus crónicas el habla re-territorializa la escritura configurándola como un espacio de circulación de voces. La importancia de la oralidad radial también está relacionada con esta estrategia. Su micro-programa radial "Cancionero"92 es el vehículo de propagación masiva y gratuita de sus crónicas y opera como espacio de resistencia a la colonización musical (sobre todo por bandas de rock de los Estados Unidos cuya producción predominaba en el aire radial y televisivo de los 80 y 90 en Chile) y de recuperación de la cultura oral.

5) Lemebel postula la chilenidad como mestizaje. A lo largo de sus siete volúmenes de crónicas recupera la valoración del componente mestizo, quiltra de la cultura nacional y rechaza la autoconsciencia "blanca" de los discursos sobre la identidad chilena. Esto le permite crear en su escritura un espacio para la emisión de la voz de las identidades minoritarias silenciadas y excluidas de los discursos oficiales o socialmente admitidos. La obra de Lemebel produce y sostiene un habla chilena mestiza y plural, es decir, multicultural.

6) El barroco es para Lemebel -como lo es para Lezama Lima- una estrategia de contra-conquista, pues narra con los procedimientos del barroco áureo los avatares de la condición minoritaria en la periferia de Santiago. Esa condición minoritaria está sobredeterminada: mestiza, infectada por el Sida, excluida por la pobreza, inhabilitada por las drogas, perseguida por la homofobia, silenciada por el discurso oficial que pacta

\footnotetext{
92 Como ha sido señalado, Pedro Lemebel fue creador y conductor del micro-programa radial "Cancionero" emitido por Radio Tierra de Santiago de Chile durante los años 1996 y 1998 inclusive. Era transmitido dos veces por día de lunes a viernes, a las 10 y a las 20 horas, con una duración de diez minutos.
} 
con la impunidad. La parodia y la ironía, la sobredeterminación y la contradicción barroca (oxímoron, antítesis, oposición no excluyente) son procedimientos utilizados en la prosa neo-barroca de Lemebel como estrategia contra-colonial que expresa la condición mestiza y determina una ruptura con la razón imperial, blanca, heterosexualmasculinizante del modelo colonial hegemónico. En el plano ideológico, Lemebel denuncia el pacto de la dictadura con las políticas de consenso forzado de la Concertación y la evidente protección del ex-dictador por parte del Reino Unido. Esto se une en su prosa a la recuperación de la memoria colectiva y la resistencia a los pactos de silencio e impunidad en relación con los crímenes de la dictadura pinochetista.

7) Lemebel gana para su escritura la condición poética, territorio conquistado por las "próstatas locales" y la utiliza como elemento decisivo en los procedimientos de historización de los territorios y sujetos no atendidos y por lo tanto invisibilizados en los discursos oficiales, historiográficos, políticos y sociales.

[2] La crónica modernista.

Lemebel/Martí o la recuperación de la memoria colectiva

No habría poema más triste y hermoso que el que se puede sacar de la historia americana

José Martí, Las ruinas indias

La segunda línea genealógica configurada por los célebres cronistas del Modernismo hispanoamericano ha sido estudiada por Aníbal González, Julio Ramos y Susana Rotker. Los tres ensayistas serán considerados aquí, y -como se veráestableceré algunas hipótesis y controversias a partir de sus lúcidos desarrollos. También serán tenidas en cuenta las hipótesis de Ángel Rama, especialmente sobre la 
obra de Rubén Darío (1970) y sobre la ciudad letrada (1984) junto a las de otros teóricos y críticos que han dedicado buena parte de sus investigaciones a este género.

En el prólogo al "Poema del Niágara" del poeta venezolano Juan Antonio Pérez Bonalde, analizado por Ramos (1989: 7-16), Martí reflexiona sobre los problemas de la producción e interpretación de textos literarios en una sociedad inestable (la sociedad latinoamericana finisecular), en tiempos de fluctuación y crisis de los valores que hasta entonces habían garantizado el sentido de la escritura y su función social. En dicho prólogo queda en evidencia que el flujo, la inestabilidad, parecen ser para Martí la única ley del mundo moderno. Ahora bien, según la lectura de Ramos,

Martí no se entrega a los flujos; propone a la literatura, más bien, como un modo de contenerlos y superarlos. Postula, ante los saberes formales privilegiados por la racionalización moderna, la superioridad del "saber" alternativo del arte, capaz aún de proyectar la armonía futura. Para Martí la autoridad de la literatura moderna radica precisamente en la resistencia que ofrece a los flujos de modernización. (Ramos: 10)

La literatura, en el discurso martiano, recupera y otorga valor a aquello que el impulso modernizador descarta: "palabras, posiciones, experiencias [...] materiales devaluados por las economías utilitarias de la racionalización" (Ramos: 10). Julio Ramos describe un doble movimiento en la obra del célebre autor cubano. Por un lado, en efecto, Martí postula su proyecto de autonomización literaria, es decir, propone un nuevo concepto literario que implica estrategias de legitimación tendientes a consolidar la institucionalidad de la literatura. Pero al mismo tiempo, junto a la exploración de la literatura como un discurso que intenta precisar su campo de autoridad social, se desarrolla "el análisis de las condiciones de imposibilidad de su institucionalización" (12). Julio Ramos llama a este doble movimiento "modernización desigual de la literatura latinoamericana en el período de su emergencia”. Dicha modernización 
desigual problematiza y torna contradictorio el proceso de autonomización literaria en nuestro continente. ${ }^{93}$

A diferencia de la autonomización del arte y la literatura en Europa, donde las condiciones de producción de los discursos en el siglo XIX están en buena medida ordenados por una relativa autonomía del Estado y una clara división del trabajo intelectual, en América Latina el campo literario es un espacio de tensiones cuya complejidad está determinada por los obstáculos de una autonomización difícil o imposible: los escritores no son ya letrados, la función social de la escritura se rige por normas y prácticas discursivas diferentes respecto de la comunicabilidad letrada tradicional, por cuanto la división del trabajo intelectual es muy relativa. En términos de Ramos:

La categoría de la literatura ha sido problemática en América Latina. De ahí que al explorar la voluntad moderna de autonomización, también leamos la heterogeneidad de los presupuestos de la autoridad literaria de Martí y el fin de siglo, no como un hecho aislado y excepcional, sino como una muestra de la relatividad de la separación de roles y funciones discursivas que distingue la producción intelectual latinoamericana, incluso en sus instancias más autónomas o puras. [...] aun en los escritores más politizados, es notable la tensión entre las exigencias de la vida pública y las pulsiones de la literatura. Esa tensión es una de las matrices de la literatura moderna latinoamericana; es un núcleo generador de formas que con insistencia han propuesto resoluciones de la contradicción matriz. [...] esa contradicción intensifica la escritura y produce textos. (Ramos 15. Énfasis mío).

Según Julio Ramos, entonces, el surgimiento de las crónicas en América Latina da cuenta del problemático concepto de autonomización literaria (tributario de lo que él llama “modernización desigual”). Dicho surgimiento se da en un espacio de tensión

\footnotetext{
${ }^{93}$ Es necesario indicar que la hipótesis general del estudio de Julio Ramos completa sin enfrentar abiertamente las conclusiones de Ângel Rama en su trabajo de 1970. La tesis fundamental del libro de Rama - que estudia el Modernismo hispanoamericano en el contexto de la consolidación del liberalismo y del capitalismo en América Latina - es que el Modernismo en general y el de Rubén Darío en particular, representan la "autonomía poética de América Latina", la comprensión de un sistema literario (con un corpus literario coherente, un público efectivo y productores especializados) y la instauración de una tradición poética.
} 
producida por los múltiples roles del escritor y de la escritura en el proceso de organización de los estados nacionales en el fin del siglo XIX. Se trata de una "autoridad literaria" que se encuentra atravesada por las exigencias del proyecto de autonomización, y al mismo tiempo asume como función propia la intervención pública -a través del periodismo y la producción de ensayos- en relación con temas de orden político, social e institucional. En este campo atravesado por propósitos divergentes o contradictorios, tiene lugar una muy activa producción de textos señalada por Ramos. En ese proceso de intensificación productiva, nuestro género tiene un papel protagónico. Su hibridez constitutiva está determinada y en alguna medida se explica por las condiciones de producción en las que se afirma como género, pero está claro que dicha hibridez perdura aun cuando esas condiciones registren cambios a lo largo de la historia del siglo XX.

La obra de Martí es el mejor testimonio de las contradicciones del campo cultural al que perteneció. En ella conviven intereses éticos y políticos con preocupaciones y exigencias estrictamente literarias. Dicha convivencia nos habla del estatuto problemático del escritor latinoamericano en este período y al mismo tiempo, del estatuto problemático -híbrido, inestable, heterogéneo- de la producción literaria, considerado por Ramos como una matriz contradictoria que determinará su futuro desarrollo.

Claramente, los compuestos discursivos (que no han cesado de aparecer en esta parte del mundo, sobre todo desde finales del siglo XIX) son una señal de que la autonomización es más un proyecto ideológico que un movimiento propio del campo literario. O tal vez dicho proceso de autonomización revista la inestabilidad inherente a sus materiales diversos, a su constitución heterogénea. Bien lo ha dicho Mijail Bajtín en su concepto de géneros discursivos: la literatura es un género secundario que se nutre de 
aquellos enunciados que prosperan en el intercambio social. Es decir, un discurso hecho de materiales diversos cuyo origen pragmático-comunicativo anticipa y tal vez reclama por fuerza de necesidad agenciamientos y desbordes propios de su naturaleza móvil, ligada al dinamismo social. Uno de los aportes más productivos de Bajtín a la reflexión sobre la literatura consiste, a mi juicio, en haber planteado en términos lingüísticos la posición secundaria de la literatura respecto de los géneros que él calificó como "primarios", es decir, aquellos que están directamente vinculados a las distintas esferas de la actividad humana:

En efecto, debemos incluir en los géneros discursivos tanto las breves réplicas de un diálogo cotidiano (tomando en cuenta el hecho de que es muy grande la diversidad de los tipos del diálogo cotidiano según el tema, situación, número de participantes, etc.) como un relato (relación) cotidiano, tanto una carta (en sus diferentes formas) como una orden militar, breve y estandarizada; asimismo, allí entrarán un decreto extenso y detallado, el repertorio bastante variado de los oficios burocráticos (formulados generalmente de acuerdo a un estándar), todo un universo de declaraciones públicas (en un sentido amplio: las sociales, las políticas) [...]. Podría parecer que la diversidad de los géneros discursivos en tan grande que no hay ni puede haber un solo enfoque para su estudio, porque desde un mismo ángulo se estudiarían fenómenos tan heterogéneos como las réplicas cotidianas constituidas por una sola palabra y como una novela en muchos tomos, elaborada artísticamente [...]. Se podría creer que la diversidad funcional convierte los rasgos comunes de los géneros discursivos en algo abstracto y vacío de significado. Probablemente con esto se explica el hecho de que el problema general de los géneros discursivos jamás se haya planteado. Se han estudiado, principalmente, los géneros literarios. Pero desde la antigüedad clásica hasta nuestros días estos géneros se han examinado dentro de su especificidad literaria y artística, en relación con sus diferencias dentro de los límites de lo literario, y no como determinados tipos de enunciados que se distinguen de otros tipos pero que tienen una naturaleza verbal (lingüística) común. (Bajtín 1977: 248-249)

He querido citar in extenso la definición de Bajtín por su vínculo con la hipótesis de Julio Ramos en relación con la producción de los cronistas del siglo XIX según la cual "la mezcla y choque de discursos en el tejido de su forma" es uno de los "rasgos 
distintivos" de la literatura en América Latina. Ahora bien, la idea de que la heterogeneidad de la crónica sea "la representación de las contradicciones que confronta la autoridad literaria en su propuesta -siempre frustrada- de purificar y homogeneizar el territorio propio ante las presiones e interpretaciones de otros discursos que limitaban su virtual autonomía" (Ramos: 12) es más difícil de justificar, sobre todo a la luz de las teorías literarias de base sociológica iniciadas por Iuri Tinianov en la década de 1920, y sobre todo por la teoría de Ian Mukařovský que en los años treinta traslada el pensamiento dialéctico al debate sobre el hecho artístico, lo que le permite abandonar el sustancialismo positivista que dominaba la teoría literaria contemporánea y postular el cambio y la heterogeneidad como la condición de la esfera artística. ${ }^{94}$

La crónica hoy se ha desligado de imperativos políticos o programáticos tales como modernización, autonomización literaria, institucionalización; y no obstante perdura su condición heterogénea. Lejos de constituir un hecho limitante para la literatura, su condición nómade la acerca a las discursividades no literarias -entre otras: el discurso periodístico, el ensayo y la crónica histórica- y se configura como una de las claves de su intensa productividad.

Considero necesario indagar más allá de la causalidad sociológica o institucional, de los mandatos del proyecto creador (Bourdieu), y observar el comportamiento de las prácticas literarias que intentan recuperar el proyecto baudelaireano del escritor como paseante, que se deja cautivar y contaminar por lo que pasa en la calle. No es casual que Walter Benjamin, un pensador preocupado por el saber histórico en su dialéctica con lo singular, tome como objeto de análisis y de teorización la experiencia de París (los rostros, las estampas, los cuerpos y las voces parisinas) determinando el discurso del flâneur.

\footnotetext{
${ }^{94}$ La teoría de Ian Mukařovský será comentada más adelante, a propósito del aporte de Susana Rotker a la consideración crítica del género.
} 
A propósito me parece oportuno destacar que en los estudios de Ángel Rama sobre el Modernismo hispanoamericano se observa cierta influencia de Walter Benjamin, especialmente de textos como "El Autor como productor", conferencia de 1934, o del conocido artículo "La obra de arte en la época de su reproductibilidad técnica" de 1936, y también de los estudios benjaminianos sobre Baudelaire a los que me acabo de referir. Ese componente fundamental del marco teórico de Rama, lo llevó a indagar en la posición de Darío dentro del sistema de las relaciones del escritor con las fuerzas productivas del mundo social. Rama se pregunta cómo Rubén Darío se configura como productor en sentido benjaminiano, es decir, lo considera un autor que modificó los medios de producción literarios, los aspectos técnicos específicos de su hacer. En esa transformación estudia los vínculos que establece la obra de Darío con su público y con el campo intelectual, generando una intervención y una renovación de las instancias de legitimación cultural que organizan el nuevo campo.

En una línea de pensamiento cercana a las que acabo de analizar, y a las cuales completa por su atención a la producción contemporánea, Susana Rotker parte de la consideración del arte como una esfera en permanente relación de antinomia dialéctica con los discursos sociales extraartísticos, según la conocida conceptualización del teórico checo Ian Mukařovský. ${ }^{95}$ Según ella, la historia de la literatura lejos de ser inmutable, estaría atravesada por la dinámica propia de los elementos que la constituyen: el objeto literario no es una realidad fija ni estable, sino en permanente cambio, por cuanto su valor artístico depende de la comunidad que lo percibe. Según Rotker, los escritores modernistas han tenido una relación ambigua con su propia producción como cronistas. Para ellos, sus textos periodísticos no tenían el valor artístico que sí le otorgaban a la poesía, y consideraban a aquellos más el fruto de una

\footnotetext{
${ }^{95}$ Ver: "Función, norma y valor estéticos como hechos sociales" (1936) en: Escritos de estética y semiótica del arte, Barcelona, Gustavo Gili, 1977.
} 
profesionalización obligada del escritor que parte de su "obra". Como explica la ensayista:

Tal vez porque, en el fondo, los mismos modernistas no entendían los verdaderos alcances de su profesionalización y se habían contagiado de los principios burgueses, según los cuales arte y mercancía, lo útil y lo sublime, el dinero y la creación, eran polos opuestos (Rotker 2005: 111).

Al mismo tiempo, la autora releva la presencia de otro prejuicio: el de la "no contaminación". Para la estética modernista, como lo ha señalado la crítica de manera homogénea, la pureza de la forma era un imperativo categórico. Si bien es una afirmación difícil de justificar, y que presenta un grado de generalización discutible, es cierto que los modelos parnasianos influyeron en la estética modernista hispanoamericana con su culto a la forma y su concepción de la originalidad ligada a la búsqueda de lo insólito, lo cual llevó a la experimentación con el lenguaje y su consecuente distanciamiento de los temas sociales.

Las definiciones que bordean el fenómeno estético y literario que llamamos "Modernismo" son tan variadas como selectivas, y no me propongo resumirlas aquí. Simplemente señalo un rasgo que motivó, como afirma Rotker, cierta marginalidad de una parte de su producción ${ }^{96}$, cuantitativamente muy importante: los textos periodísticos en prosa. Y en ello hubo acuerdo de la crítica y de los poetas. Susana Rotker llega a una conclusión muy importante para nuestro estudio, y es que la "marginación de las crónicas no responde a un criterio 'científico' o inapelable; es el resultado de una interpretación selectiva, hecha a menudo como una domesticación de la lectura y situada a su vez sobre capas sucesivas de otras lecturas" (2005: 19).

Considero que para entender acabadamente la exposición de Rotker y sus alcances, hace falta un cierto detenimiento en los postulados teóricos de su ensayo.

\footnotetext{
${ }^{96}$ En el mismo sentido Iván Schulman afirma que es en la prosa "tan injustamente arrinconada" de Martí y de Gutiérrez Nájera “donde primero se perfila la estética modernista” (1968: 329).
} 
Como queda dicho, Rotker sostiene su argumentación en el pensamiento dialécticoestructuralista del mencionado teórico checo. El análisis socio-institucional que el autor desarrolló durante su activa participación en el Círculo Lingüístico de Praga-del cual fue, sin dudas, el representante más destacado- permite concebir a la comunidad de lectores como una conciencia colectiva (el término es del autor) que sanciona acerca del valor estético presente o ausente en un determinado artefacto (la obra-cosa ${ }^{97}$ ).

Si la conciencia colectiva en un momento histórico particular determina que un artefacto o conjunto de artefactos sean portadores de función estética, es decir, sean investidos de valor estético, éstos devendrán objetos estéticos en virtud de la energía propia de la función estética otorgada por la comunidad, y como tales pasarán a integrar la esfera estética en ese momento particular de la historia colectiva. De ese modo la constitución de la esfera estética depende de la colectividad y dada su condición histórica, es cambiante, variable. La esfera estética estará configurada, pues, por aquellos objetos estéticos cuyo valor la comunidad ha decidido colectivamente.

La función estética puede competir con otras funciones (práctica, comunicativa, religiosa, etc.) que conviven en el objeto. Ahora bien, cuando la función estética predomina en la jerarquía de funciones desplazando a las otras, entonces ese objeto será considerado artístico. En el interior de la esfera estética se configura, por tanto, la esfera artística, determinada por aquellos objetos en los que la función estética es predominante. En esa configuración interviene, al mismo tiempo, la norma estética, también acuñada por la comunidad, la cual determina y regula el valor estético de los objetos, y por lo tanto es tan cambiante y variable como la función y el valor. La norma es el concepto dialéctico con el que Mukařovský garantiza la ductilidad y la coherencia

\footnotetext{
${ }^{97}$ La denominación "obra-cosa" aparece en el primer artículo del volumen citado, titulado: "El arte como hecho semiológico", término que sustituye por el de "artefacto" en el segundo artículo, "Función, norma y valor estéticos como hechos sociales" que estoy comentando y que toma Rotker como base teórica de su argumentación.
} 
interna de su modelo. La norma estética tiende a la obligatoriedad general, sin la cual no sería una norma, pero también alberga la posibilidad de su violación, lo que garantiza su dinamismo, y la evolución del arte. Por lo tanto la variabilidad de la norma estética es el catalizador del valor y el principio activo de los desplazamientos en el interior de las esferas.

Como podemos advertir, el pensamiento dialéctico de Ian Mukařovský le permite a Susana Rotker dar cuenta de la condición dialéctica que determina la escritura de los poetas y cronistas de nuestra Modernidad y su papel en el campo intelectual: las crónicas constituyen un cuerpo móvil de textos que viajan de la esfera estética a la esfera artística por la variabilidad de su función y los cambios operados colectivamente en las normas estéticas que regulan los desplazamientos internos del sistema literario. No cabe duda de que la crónica es, también en el movimiento modernista, un lugar de encuentro, un género mixto y heterogéneo, cuya naturaleza pone en cuestión la supuesta “especificidad" de la literatura. Está claro que la teoría literaria -al menos desde los trabajos de Iuri Tinianov en la década de 1920, y de un modo más desarrollado en los Escritos de Ian Mukařovský de 1936- considera "dentro" del campo literario los discursos "contaminados" de la práctica social. El desarrollo teórico más acabado en esta línea, a mi juicio, estuvo a cargo de Mijaíl Bajtín en los estudios reunidos bajo el título Estética de la creación verbal (1977), y fue continuado por Iuri Lotman particularmente en sus conceptos de "semiósfera" y "texto cultural" (1998).

Si bien comparto lo que considero la hipótesis central del texto de Susana Rotker, a saber: su consideración de la crónica como discurso literario, apelando para esa inclusión a teóricos de la talla de Ian Mukařovský, Iuri Tinianov y Tzvetan Todorov, señalo mi diferencia con la ensayista venezolana en un aspecto: considero reductivo asociar la crónica exclusivamente con el discurso periodístico. En el caso de 
los textos de Carlos Monsiváis y Néstor Perlongher que serán analizados en esta tesis, es muy evidente la relación entre la crónica y el ensayo filosófico y sociológico que los mencionados autores establecen. En el caso de Elena Poniatowska hay un particular interés por el relato testimonial y su elaboración literaria. Y en el caso singularísimo de Pedro Lemebel, objeto de mi estudio, los vínculos con la historia político-institucional de su país, la poesía, el cancionero popular y la oralidad son decisivos. El ensayo de Rotker, por otra parte, no toma como objeto de análisis la crónica contemporánea, sino sólo la modernista:

[...] esta investigación focaliza sólo los textos de la época del modernismo, puesto que allí surgió su conformación particular como encuentro del periodismo y la literatura. El término crónica se usaba ya desde el comienzo mismo de la literatura hispanoamericana -los cronistas de Indias- pero no contemplaba la inmediatez del periodismo; las reglas del género podrían también aplicarse al cuerpo textual producido por los escritores que frecuentaron los diarios ya en el siglo XX, pero no es el objetivo de este análisis marcar si hubo o no diferencias luego entre la crónica modernista, el nuevo periodismo o la literatura de "no ficción", por ejemplo, sino estudiar el momento en que se constituyó un nuevo sistema de escritura (Rotker 2005: 1718. Énfasis mío).

Para Aníbal González la crónica es un género moderno en términos filosóficos, porque "es en ella donde encontramos delineada con mayor nitidez la problemática filosófica de la temporalidad que es típica de la modernidad y que hace suya el modernismo" (1983: 63). Según González, la modernidad de la crónica proviene de su vínculo con el periodismo, y por lo tanto tiene un papel preponderante en la arqueología del género. En este sentido postula a la chronique parisienne como el antecedente de la crónica modernista, a su vez heredera del artículo de costumbres dieciochesco inglés. Tanto la crónica francesa como el artículo costumbrista inglés, basan su escritura sobre una epistemología clásica, derivada de la tradición del empirismo inglés que emana de John Locke, con metáforas que aluden a la representación de un Mundo Ordenado tales 
como la mente humana como espejo, tabula rasa, camera obscura, en donde la luz que penetra por una pequeña abertura proyecta una imagen del mundo sobre una pantalla. De allí la idea del spectator, observador o "mirón" postulado por el empirismo de Locke. Como afirma González: “El costumbrismo romántico adopta el dispositivo del espectador, con toda la epistemología empirista que implica, y lo pone al servicio de un proyecto de análisis cuasicientífico de la sociedad, cuyo modelo es la anatomía comparada de Cuvier." (66). Intento de síntesis entre la literatura y las ciencias naturales que se manifestó primeramente en las páginas de los diarios. Ahora bien, ese espectador no es neutro, sino "un sujeto con sus propias razones y pasiones [...] analista implacable y rebelde, deseoso de actuar." (González, A. 1983: 67-68). Este rasgo central del género se configura a través de las múltiples formas que puede asumir el distanciamiento crítico respecto de la realidad observada. Entre otras, la ironía, la "pasión crítica" que satura el texto de las crónicas como consecuencia de su aguda observación y análisis minucioso del objeto o suceso observado. Como efecto inmediato de ese rasgo central, configurador del género, se construye una temporalidad sincrónica (o, como la llama mejor Aníbal González, ubicándose en la estela del pensamiento foucaultiano: una arqueología del presente). "Tipos", "escenas" o "cuadros" que registran sucesos o personajes del presente, en vínculo necesario con lo que hemos observado antes: la importancia de la posición del observador. La visión del enunciador en el artículo de costumbres que González sitúa en los orígenes del género crónica, se une a la cuestión de la historicidad de su objeto: los tipos sociales, las costumbres, las modas, los rasgos particulares de los "espíritus nacionales", etc., aparecen estudiados en los artículos en el marco de una temporalidad sincrónica. Es decir, que en el artículo costumbrista la visión de los hechos, objetos, procesos o acontecimientos analizados es "fragmentaria, dividida en compartimientos, de ahí que sean piezas breves carentes de la ilación 
narrativa que es normal en el discurso histórico" (1983: 68). De esa visión fragmentaria propia del artículo de costumbres, Aníbal González hace derivar uno de los elementos distintivos del género: "La crónica se ocupa de eventos, de sucesos que quiebran la rutina del acontecer cotidiano. La crónica subdivide la progresión temporal en una multitud de instantes discretos, en una pululación de eventos que es necesario historiar" (73). El trabajo de Aníbal González será considerado detenidamente en la presente investigación, sobre todo en los dos aspectos señalados: la importancia decisiva de la posición del observador en la constitución del género, y la temporalidad sincrónica como uno de sus rasgos de estructura más destacados de la crónica al enfocar en la discontinuidad de los acontecimientos discretos, particulares y significativos que constituyen la vida en sociedad.

Como queda señalado $-\mathrm{y}$ vuelvo a insistir sobre la idea de Julio Ramos (1989:15) - en efecto, la tensión es una de las matrices de la literatura moderna latinoamericana. Ese rasgo perdura en la producción lemebeliana. La diferencia con la propuesta estética finisecular es que la escritura de Lemebel no pretende resolver esa tensión, como sí lo pretendía el proyecto creador de Martí, porque ha cambiado radicalmente el contexto y sobre todo la posición del escritor: la función social del cronista contemporáneo se diferencia de la del escritor de fin de siglo XIX o principios del XX. El objetivo martiano de proponer y generar "estrategias de legitimación tendientes a consolidar la institucionalidad de la literatura" (Ramos) resulta hoy por completo anacrónico. La "institucionalidad" de la literatura en la actualidad se juega en dos ámbitos: el escolar y el académico, los cuales mantienen con la serie literaria relaciones ambiguas y difíciles de determinar porque cambian constantemente y además varían mucho en relación con autores, géneros y temáticas. Además, esa difícil relación de relativa institucionalidad entre literatura, escuela y academia está atravesada por las 
complejas e inestables relaciones entre literatura y mercado, que afectan y modifican las relaciones internas de la serie.

Lemebel $-\mathrm{y}$ es perfectamente consciente de ello- no comparte el interés por la autonomización literaria: acepta de lleno y desde luego promueve el contacto ("la contaminación", en sus términos) de la escritura con otras materialidades, con otros campos del saber, que no son los saberes ligados convencionalmente a la literatura. En este sentido, Pedro Lemebel opera una ruptura con la crónica modernista.

Otra diferencia importante con la crónica modernista está dada por su condición de "separado", es decir, podemos afirmar que Lemebel "no hace grupo". A su ya señalada condición minoritaria y múltiple a la vez (gay o "loca", "roto", indio, mestizo o "quiltra", "proleta", seropositivo negativizado, todas determinaciones inestables, sujetas al cambio) se suma su carácter de excluido de las comunidades de discurso: no es literato ni periodista ni narrador ni poeta aunque incursiona en todos esos ámbitos discursivos de un modo lateral. En esto podemos compararlo -por contraste- con Enrique Gómez Carrillo o Rubén Darío. Pedro Lemebel no es ni diplomático ni “poeta nacional"; no es periodista ni corresponsal. No es bohemio ni dandy. No habla francés ni inglés y es escasamente reconocido en el exterior. No es un escritor "culto" ni tiene en su haber una carrera literaria temprana, como Gutiérrez Nájera. No forma parte de una nación emergente ni representa a ningún grupo ni corriente intelectual, política o estética, no funda ninguna revista (Gutiérrez Nájera fundó y dirigió Azul, especie de órgano del modernismo en México). No se parece tampoco a Martí, no es héroe nacional ni líder político. El reconocimiento relativo que verifica su obra es, digamos, “exterior" a esos registros: lo valora la crítica literaria académica y también la crítica periodística, o un escritor tan excéntrico al sistema literario chileno como él, Roberto Bolaño. Algunas de sus crónicas registran su relación crispada con el mundo editorial y 
la organización de eventos culturales como presentación de libros (aun los propios) y congresos o conferencias.

En "Las ruinas indias" (134-145) Martí despliega su inteligencia crítica y el escalpelo de su ojo lector. El interés que reviste este texto para nuestro estudio es que recupera y valora un rasgo específico del género crónica que será potenciado, como veremos, en la obra de Pedro Lemebel: el efecto de singularización y de impresión máxima que produce el relato en la percepción del lector:

Y cuando se lee en los viajes de Le Plongeon ${ }^{98}$ los cuentos de los amores de la princesa maya Ara [...]; cuando en la historia del indio Ixtlilxochitl ${ }^{99}$ se ve vivir, elegantes y ricas, las ciudades reales de México a Tenochtitlán y a Texcuco; cuando en la Recordación Florida del capitán Fuentes, o en las crónicas de Juarrós, o en la Historia del conquistador Bernal Díaz del Castillo, o en los viajes del inglés Tomás Gage, andan como si los tuviésemos delante, en sus vestidos blancos y con sus hijos de la mano, recitando versos y levantando edificios, aquellos gentíos de las ciudades de entonces [...] no parece que se lee un libro de hojas amarillas, donde las eses son como efes y se usan con mucha ceremonia las palabras, sino que se ve morir a un quetzal, que lanza el último grito al ver su cola rota. Con la imaginación se ven cosas que no se pueden ver con los ojos. (135136, énfasis mío).

Inmediatamente, en el mismo texto, Martí asume en su propia escritura este procedimiento que acaba de exaltar en diversos cronistas y describe la ciudad de Tenochtitlán al tiempo que narra el día a día de la ciudad azteca como si él mismo hubiera paseado por sus calles, como si hubiera visto con sus propios ojos "las plazas espaciosas y muchas; y los alrededores sembrados de una gran arboleda". El procedimiento, que emplea en muchas de sus crónicas, es eficaz: los lectores vemos, oímos y olemos la ciudad, sus casas, su gente:

\footnotetext{
${ }^{98}$ Auguste Le Plongeon, arqueólogo francés. Estudió las ruinas indias de América Central: Uxmal, Chitchén Itzá, entre otras y escribió crónicas de viaje.

${ }^{99}$ Monarca chichimeca (1406-1409).
} 
Era como una mañana todo el día, y la ciudad parecía siempre como en feria. Las calles eran de agua unas, y de tierra otras; y las plazas espaciosas y muchas; y los alrededores sembrados de una gran arboleda. Por los canales andaban las canoas, tan veloces y diestras como si tuviesen entendimiento; y había tantas a veces que se podía andar sobre ellas como sobre la tierra firme. En unas venían frutas, y en otras flores, y en otras jarros y tazas, y demás cosas de la alfarería. En los mercados hervía la gente, saludándose con amor, yendo de puesto en puesto, celebrando al rey o diciendo mal de él, curioseando y vendiendo. Las casas eran de adobe, que es el ladrillo sin cocer, o de calicanto, si el dueño era rico. [...] En las calles, abajo, la gente iba y venía, en sus túnicas cortas y sin mangas, blancas o de colores, o blancas y bordadas, y unos zapatos flojos que eran como sandalias de botín. Por una esquina salía un grupo de niños disparando con la cerbatana semillas de fruta, o tocando a compás en sus pitos de barro, de camino para la escuela, donde aprendían oficios de mano, baile y canto, con sus lecciones de lanza y flecha, y sus horas para siembra y el cultivo. (Martí 138-139).

Con un inocultable tratamiento romántico del pasado al que idealiza y pinta con tonos paradisíacos ("un pájaro de amarillo de oro, para la pajarera del rey [...] y muchos peces de plata y carmín en peceras de mármol, escondidos en los laberintos de sus jardines”) la prosa de Martí nos instala en las calles de Tenochtitlán. Podemos percibir sus sonidos, sus colores y sus olores. Para ello, el autor borra las circunstancias de la propia enunciación. Este procedimiento, común en la narrativa de ficción de la época, provoca el efecto, ya señalado, de singularizar la ciudad, sus habitantes y sus objetos, las figuras y los acontecimientos evocados, creando una ilusión referencial que hace “olvidar" al lector que Martí jamás estuvo allí. El procedimiento se ajusta conforme avanza la crónica para producir luego (algo que veremos en las crónicas de Lemebel) un suave deslizamiento hacia la ficción. Abandonando -momentáneamente- la intención periodística o historiográfica, el autor ficcionaliza una escena de la vida cotidiana:

En el quicio de su casa cantaba un carpintero, remendando con mucha habilidad una silla en figura de águila, que tenía caída la guarnición de oro y seda de la piel de venado del asiento. Iban otros cargados de pieles pintadas, parándose a cada puerta, por si se les quería comprar la colorada o la azul, que ponían entonces como los 
cuadros de ahora, de adorno en las salas. Venía la viuda de vuelta del mercado con el sirviente detrás, sin manos para sujetar toda la compra de jarros de Cholula y de Guatemala; de un cuchillo de obsidiana verde, fino como una hoja de papel; de un espejo de piedra bruñida, donde se veía la cara con más suavidad que en el cristal. (Martí 139140).

El cuadro, narrado con las estrategias de la ficción realista de la época -narrador omnisciente, cuidadosa y vívida descripción de espacios y personajes, dinamismo de la acción que pasa de figura en figura dando un fresco de la sociedad azteca en un día de actividad- funciona como introducción y contrapunto, por su diferencia de tono, con la elegía por el fin de aquella civilización paradisíaca:

¡De toda aquella grandeza apenas quedan en el museo unos cuantos vasos de oro, unas piedras como yugo, de obsidiana pulida, y uno que otro anillo labrado! Tenochtitlán no existe. No existe Tulán, la ciudad de la gran feria. No existe Texcuco, el pueblo de los palacios. Los indios de ahora, al pasar por delante de las ruinas, bajan la cabeza, mueven los labios como si dijesen algo y mientras las ruinas no les quedan atrás, no se ponen el sombrero. (Martí 140).

A partir de esta escansión, la crónica no se recuperará del tono elegíaco, recordará también amargamente el pasado feliz y la ruina presente de otras regiones de México (las ruinas mayas de Oaxaca y Yucatán, la bella ciudad de Chitchén-Itzá) para concluir con una amarga exclamación irónica: “¿Qué novela tan linda la historia de América!" (145). Señalemos aquí los puntos de coincidencia y de fricción entre las respectivas estéticas e intenciones ideológicas de Martí y de Lemebel. En esta bella crónica de José Martí se hace evidente uno de los elementos centrales de su proyecto literario: su ideario americanista. No es mi propósito analizar el legado de Martí, cosa que superaría el marco de esta breve referencia, sino puntualizar algunos elementos de su producción que permiten tender líneas genealógicas con la crónica actual, y específicamente con la obra de Lemebel. 
En primer lugar señalo como elemento destacado en ambos autores su vínculo intenso y determinante con la poesía presente en todos sus escritos. Nada mejor que recurrir a un poeta de la sensibilidad de Rubén Darío para consignar el carácter de la escritura de José Martí, aun tratándose de textos en prosa. En su celebrado ensayo Los raros, de 1905, Darío se refiere al período neoyorquino de Martí en los siguientes términos:

Su labor aumentaba de instante en instante, como si activase más la savia de su energía aquel inmenso hervor metropolitano. Y visitando al doctor de la Quinta Avenida, al corredor de la Bolsa y al periodista y al alto empleado de La Equitativa, y al cigarrero y al negro marinero, a todos los cubanos neoyorkinos, para no dejar apagar el fuego, para mantener el deseo de guerra, luchando aún con más o menos claras rivalidades, pero, es lo cierto, querido y admirado de todos los suyos, tenía que vivir, tenía que trabajar, entonces eran aquellas cascadas literarias que a estas columnas venían y otras que iban a diarios de Méjico y Venezuela. No hay duda de que ese tiempo fue el más hermoso tiempo de José Martí. (Darío 1905: 236)

En este breve fragmento del ensayo dariano reconocemos una de las marcas de la escritura de Martí: el cronista que se mueve, va y viene, entrevista y sobre todo, escucha, atento, los rumores y las voces de la gran ciudad, de sus habitantes y trabajadores, que pasarían inadvertidos a un ojo o a un oído menos dispuesto a percibir "el inmenso hervor metropolitano", vertido por el maestro en "aquellas cascadas literarias" que fluyen en sus columnas -según la justa imagen dariana- y llegan a diarios de México, Caracas y Buenos Aires. En el mismo sentido elogia Darío sus cartas:

Entonces fue cuando se mostró su personalidad intelectual más bellamente. En aquellas kilométricas epístolas [...] Allí aparecía Martí pensador, Martí filósofo, Martí pintor, Martí músico, Martí poeta siempre. Con una magia incomparable hacía ver unos Estados Unidos vivos y palpitantes, con su sol y sus almas. Aquella "Nación" colosal, la "sábana" de antaño, presentaba en sus columnas, a cada correo de Nueva York, espesas inundaciones de tinta. Los Estados Unidos de Bourget deleitan y divierten; los Estados Unidos de Groussac hacen pensar; los Estados Unidos de Martí son estupendo y encantador 
diorama que casi se diría aumenta el color de la visión real. Mi memoria se pierde en aquella montaña de imágenes, pero bien recuerdo [...] un puente de Brooklin [sic] literario igual al de hierro; una hercúlea descripción de una exposición agrícola, vasta como los establos de Augías; unas primaveras floridas y unos veranos ¡oh, sí! mejores que los naturales; unos indios sioux que hablaban en lengua de Martí como si Manitu mismo les inspirase; unas nevadas que daban frío verdadero, y un Walt Whitman patriarcal, prestigioso, líricamente augusto, antes, mucho antes de que Francia conociera por Sarrazin al bíblico autor de las Hojas de hierba. (Darío: 236-238)

Podríamos continuar citando elogios a Martí periodista, como los de Pedro Henríquez Ureña o Roberto Fernández Retamar, pero dado el propósito acotado de esta referencia (el vínculo genealógico, hecho de cercanía y de distancia, con Lemebel) me limito al elogio de Rubén Darío y al breve análisis de la prosa del propio Martí en vínculo dialógico con la de Lemebel.

Acabamos de observar en Martí su impronta ideológica, el carácter heroico y eminentemente patriótico de su proyecto -frecuentemente destacado en las numerosas semblanzas del poeta cubano- su condición abnegada que lo lleva a renunciar a su vida personal para convertirse en un "apóstol" de la revolución ${ }^{100}$ y de la independencia de Cuba. En el mismo sentido podemos leer muchas de sus crónicas y cartas: su propósito es persuadir al pueblo de la necesidad de la revolución. Como acabamos de leer en la descripción que nos ofrece Darío en Los raros: "visitando [...] a todos los cubanos neoyorkinos, para no dejar apagar el fuego, para mantener el deseo de guerra" (1905: 236). Este es, claramente, un punto de fricción o de diferencia entre Martí y Lemebel. El

\footnotetext{
100 Son innumerables las obras que proclaman a Martí el "apóstol" de la independencia cubana, tanto que este ha llegado a ser un epíteto: Martí, el apóstol. No obstante, me parece necesario nombrar algunas de ellas, aunque a riesgo de caer en la arbitrariedad de la selección. Ver: Ette, Ottmar: José Martí. Apóstol, poeta, revolucionario: una historia de su recepción. México: UNAM. Col. Nuestra América 45, 1995. A propósito, el académico alemán estudia especialmente en dos apartados (2.2: José Martí: "Maestro", "Apóstol", "Mártir", "Héroe"; y 3.4: Martí mito: "hombre mito", santo, semidiós) la investidura mítica que su figura ha generado tanto en su pueblo como en la comunidad académica ligada a los estudios latinoamericanos. También ver los ya clásicos: Fernández Retamar, Roberto. Introducción a José Martí, La Habana, 1978. Griñán Peralta, Leonardo. Martí líder político, La Habana, 1943. O: de Armas, Ramón. La revolución pospuesta: contenido y alcance de la revolución martiana por la independencia, La Habana, 1975. Entre muchas otras semblanzas del poeta que recuperan y subrayan su condición patriótica, abnegada y heroica, cercana a la santidad.
} 
autor chileno no representa un proyecto político, aunque sus textos están claramente determinados por su lectura política de la situación actual de su país, y su mirada es la de un observador crítico que analiza, señala y denuncia la injusticia y la postergación de sus compatriotas. Pero su tono está marcado por el desencanto. No hay en sus relatos el optimismo revolucionario del poeta cubano, ni mucho menos. El objetivo político de sus crónicas es la reconstrucción de la memoria colectiva. Esa es la deuda que los sucesivos gobiernos de la Concertación tienen con el pueblo chileno; el olvido es la acusación que Lemebel lanza contra los intelectuales y militantes cómplices de la ambigüedad que teje consensos a espaldas de la historia y el sufrimiento de los ciudadanos. Pero no hay en la obra de Lemebel un proyecto colectivo que organice o postule movimientos revolucionarios a futuro. Su obra se orienta melancólicamente hacia el pasado, y exige justicia para los caídos, restitución de la memoria para evitar la coronación del neocolonialismo (él lo llama "neoliberalismo capitalista" o “capitalismo" a secas). 
[3] La producción de Pedro Lemebel en el contexto latinoamericano

La profunda y productiva relación entre literatura, historia, periodismo y ficción -por un lado- y entre escritura y oralidad -por otro-, como así también la muy singular relación entre crónica y poesía colocan la obra de Lemebel en vínculo dialógico con autores latinoamericanos contemporáneos como Elena Poniatowska, Carlos Monsiváis y Néstor Perlongher.

En primer lugar, es necesario señalar el lugar excéntrico que ocupa nuestro autor en la escena literaria chilena, tanto por su posición en el campo cultural como por la clara opción discursiva que caracteriza su producción: la crónica. ${ }^{101}$ Como ha sido señalado por la crítica y será retomado en esta tesis, su obra resulta irreductible a categorías de valoración y clasificación tradicionales del discurso literario. Por cierto, igual dificultad presenta en relación con otros campos discursivos, como el periodismo y la crítica cultural de corte académico. Otro tanto podemos decir de su relación de borde, altamente problemática y en ocasiones polémica, con los circuitos de circulación cultural (presentaciones de libros, aun tratándose de los propios, conferencias o

\footnotetext{
${ }^{101}$ Hablo de "opción discursiva" sin ignorar que ha publicado relatos en una antología de cuentos premiados en 1992, Incontables (1986), y una novela, Tengo miedo torero (2002). No obstante insisto en el carácter de cronista de Pedro Lemebel porque considero que los mencionados libros de ficción constituyen otro objeto, ligado de manera débil al sistema de su obra. En primer lugar, es ineludible la diferencia cuantitativa entre sus crónicas y sus dos libros de ficción. Las primeras presentan una continuidad productiva desde 1995 hasta 2012 constituida por siete colecciones. Su único libro de relatos - del cual ha renegado abiertamente- es considerado por él un libro de juventud, nunca quiso reeditarlo, es inhallable y se trata del único texto firmado con su apellido paterno, Mardones. No se ha referido nunca a ninguno de esos textos tempranos en ninguna de sus entrevistas ni ha hecho referencia a ellos voluntariamente. Por su parte, la única novela publicada por el autor hasta la fecha ha sido calificada por él -en una entrevista a la que volveremos en seguida- como un ejercicio y un homenaje tardío a Manuel Puig (es obvia su similitud argumental con El beso de la mujer araña del autor argentino). A propósito de este texto Lemebel afirma: "[...] la novela Tengo miedo torero fue un desafío, un ejercicio de provocación frente al protagonismo mesiánico de los novelistas machos. Y me resultó, ni trascendental ni como proyecto de mundo, apenas una balada guerrillera y romanticona como un eco trasnochado de la obra de Puig." (Costa 7). El autor es muy consciente, y lo hace explícito, de que su proyecto artístico (al que he calificado de poético-político) está constituido por su obra cronística.
} 
entrevistas, participaciones en foros y medios de comunicación masiva) y con el mundo editorial.

En segundo lugar es necesario señalar la dificultad que implica cualquier intento de definición del contexto latinoamericano en atención a la producción del género “crónica". Por un lado, esa dificultad es una consecuencia lógica de los problemas inherentes a su definición, híbrido por naturaleza y vinculado a otros géneros no ficcionales que le son muy afines (como la crónica de viajes, la autobiografía, la crónica periodística, la narrativa de no ficción y el ensayo). Por otro lado, la existencia de gran cantidad de autores que escriben crónica como una opción discursiva más dentro de una obra que se inscribe mayoritariamente en otro género. La mayoría de ellos son cronistas que escriben narrativa (es el caso de Elena Poniatowska). Otros autores son poetas que incursionan productivamente en la crónica (es el caso de Néstor Perlongher); otros son narradores y ensayistas, además de escribir crónica (es el caso de Carlos Monsiváis).

En cuanto a las similitudes y diferencias de Lemebel con estos autores y de estos autores entre sí, digamos que sus respectivos perfiles socio-culturales absolutamente particulares y disímiles, sus estilos marcados por intereses y procedimientos literarios diferenciadores, los usos que los cuatro autores hacen de la lengua (escrita o coloquial, culta o popular) y hasta sus diferencias ideológicas y de género dan lugar a un campo híbrido, atravesado por fuerzas divergentes $\mathrm{y}$, por lo tanto, imposible de someter a generalizaciones abstractas. Por ello, afirmo que el conjunto de cronistas latinoamericanos contemporáneos -tampoco sería posible elaborar una lista completa por las razones apuntadas- es tan heterogéneo como el material discursivo que él produce $^{102}$. No obstante, señaladas las dificultades, es indispensable establecer algunas coordenadas que determinan el contexto de producción en el que se inscribe la obra del

\footnotetext{
${ }^{102}$ En el apartado correspondiente (3.3. Lemebel/Poniatowska: la crónica y la novela de testimonio) será retomada esta cuestión: la compleja y abigarrada diversidad de lo latinoamericano se da también en el universo de la crónica y sus autores.
} 
chileno. La primera coordenada es la temporal. Para contextualizar la obra de Lemebel, mi estudio enfocará la producción de algunos cronistas desde 1980 hasta 2012, tomando como antecedentes ineludibles algunos textos pertenecientes a la llamada "novela de testimonio" de los años sesenta. Esta última referencia es pertinente por cuanto será considerada una instancia genealógica para el género crónica. Como es evidente, la delimitación tiene la cuota de arbitrariedad propia del corte, pero -he aquí su utilidadremite a la publicación de un corpus de textos que considero relativamente establecido para la consideración teórica y crítica del género: la primera fecha remite tanto a la publicación del libro de Elena Poniatowska, Fuerte es el silencio, como a la de los primeros ensayos y crónicas de Néstor Perlongher, reunidos en Prosa plebeya. Ensayos 1980-1992. La segunda fecha que cierra el corte se explica por algunos acontecimientos significativos: a) el último texto publicado hasta ahora por Pedro Lemebel: Háblame de amores (2012); b) la realización de encuentros internacionales de cronistas ("Nuevos cronistas de Indias”, Bogotá, 2008, y su segunda edición: "Nuevos Cronistas de Indias 2", celebrada en México DF en 2012; el "Primer Encuentro Internacional de Literaturas Americanas", celebrado en 2010 también en la ciudad de México; ${ }^{103}$ c) la publicación de importantes antologías del género analizadas en el precedente Estado de la Cuestión, que con sus diferencias y su diverso grado de exhaustividad constituyen, por un lado, una señal de la importancia asumida por él y reconocida dentro de los sistemas literarios

\footnotetext{
${ }^{103}$ En ese encuentro, Fabrizio Mejía Madrid (México, 1968) joven periodista y escritor de fícción reconocido en su país y en Latinoamérica, habló sobre la crónica como el origen de nuestra literatura poniéndola en relación (una relación de naturaleza discursiva) con la poesía y el periodismo, aludiendo para ello a las figuras emblemáticas de Octavio Paz y Gabriel García Márquez. En la segunda edición del Encuentro Internacional "Nuevos Cronistas de Indias", celebrado en el DF en octubre de 2012, Elena Poniatowska se refiere en varias oportunidades a este cronista mexicano, calificándolo como "el más joven de todos" y se refiere a su libro Salida de emergencia: "crónicas hechas a lo largo de 13 años, en las que [...] se preocupa por saber quién era el joven camarógrafo gringo Brad Will, que murió con su cámara en la mano [...] en una batalla en el centro de Oaxaca. [...] También Fabrizio nos entrega a otra luchadora cuyo asesinato a todos nos injurió: Digna Ochoa. Sigue a los migrantes al otro lado del Río Bravo y comparte su heroísmo y sus humillaciones, le perdona la vida al ángel caído de Gloria Trevi”. Lo señalo porque en la conferencia inaugural de ese encuentro la autora mexicana realiza implícitamente un corte en el sistema que vale la pena señalar: Monsiváis y Mejía Madrid son los dos puntos de un arco de gran intensidad en el desarrollo de la crónica en México.
} 
latinoamericanos, y por otro, una puesta al día y un análisis de su circulación y su intervención en el sistema de los discursos culturales.

Como es natural, la coordenada temporal convive con la espacial. Lemebel es un autor latinoamericano -aun teniendo muy en cuenta la mencionada posición excéntrica en el sistema literario chileno- y la publicación de su primer libro de crónicas ( $L a$ esquina es mi corazón, de 1995) coincide con la publicación de un libro decisivo en la producción del escritor mexicano -ya consagrado en ese entonces- Carlos Monsiváis: Los rituales del caos. Por su experiencia itinerante en la gran ciudad, su recorrido como observador y participante (ambivalencia que, con similitudes y diferencias replica Lemebel) y su relación crítica con los acontecimientos que registra, el texto de Monsiváis se vincula con el de Lemebel en una relación compleja que analizaré a continuación.

3.1. Lemebel/Monsiváis: la distancia con el cronista intelectual-letrado

La gran ciudad genera la angustia ante lo múltiple y desordenado, lo caótico. Muchas ciudades latinoamericanas que crecieron vertiginosamente sin planificación, generan la incertidumbre ante la multitud de caminos que parecen no conducir a ninguna parte. Un elemento que configura sin duda una línea de continuidad entre cronistas tan diferentes como Pedro Lemebel y Carlos Monsiváis es su condición urbana. Los dos autores recorren la gran ciudad pero no siempre ni exclusivamente con el paseo despreocupado del flâneur, sino también con la mirada crítica del cronista que pone en relación lo que observa con lo que sabe y espera: es decir, relevamiento del presente en tensión dialéctica con su proyecto intelectual-artístico. En esa tensión ponen 
en juego y producen nuevos saberes, surgidos de las prácticas que observan en su atento y crítico deambular.

"Es en la ciudad y en las culturas urbanas -señala Martín Barbero- donde se encardinan las nuevas identidades, se configuran nuevos modos de representación y participación política, es decir nuevas modalidades de ciudadanía" (41). Estas "grupalidades"104 (término que usa Martín Barbero y que tomo a pesar de su rareza, dado que hay en él un elemento diferencial: no son grupos ni ghettos ni tribus, son algo menos constituido, menos consolidado y más dinámico) hacen coexistir códigos y relatos muy diversos, que no serán homogeneizados. Sus experiencias: otras sensibilidades, otras prácticas, otros saberes, libran su batalla cultural "menor", en términos deleuzeanos. Una instancia de esa batalla cultural es, sin lugar a dudas, la productividad incesante de un discurso: el de la crónica. En otros términos: las crónicas latinoamericanas de los siglos XX y XXI asumen y hacen oír voces que no tenían discurso. Esto explica, en parte, el origen "testimonial” de la crónica contemporánea y justifica la intervención en los discursos y las prácticas sociales y disciplinares que, históricamente, generaron la configuración del otro: o bien fue fotografiado y momificado por la observación etnográfica que lo silenciaba, o bien fue considerado "monolingüe"105 para poder "capturarlo" en la estrategia dominadora de la definición conceptual, o bien fue sistemáticamente excluido para favorecer y conservar los privilegios de las clases dominantes en el campo social. El discurso de la crónica no

\footnotetext{
${ }^{104}$ A propósito de este concepto y su matriz freudiana, ver nota 42 en el Estado de la Cuestión.

${ }^{105}$ El monolingüismo siempre es del otro. En el ensayo que lleva ese título, Jacques Derrida postula dos proposiciones contradictorias: 1 . Nunca se habla más que una sola lengua. 2. Nunca se habla una sola lengua. Esta antinomia irresoluble da cuenta de la imposibilidad de ser "uno mismo" en el lenguaje. Siempre se habla "otra" lengua, porque la lengua propia constituye y des-constituye al sujeto. Considerar al individuo monolingüe es desconocer su irredimible dualidad y su contradicción constitutiva. En el caso del testimonio esa contradicción se sostiene en primer plano, es decir, el testigo -lo sepa o no- no "dirá" nunca su "identidad", pues tal cosa es imposible: “¿Qué es la identidad, ese concepto cuya transparente identidad consigo mismo siempre se presupone dogmáticamente en tantos debates sobre el monoculturalismo o el multiculturalismo, sobre la nacionalidad, la ciudadanía, la pertenencia en general?" (Derrida 27).
} 
pretende fotografiar ni construir y mostrar una imagen de "lo subalterno", es decir, no busca representar lo multicultural, lo otro, lo ajeno, lo heterogéneo, lo que no se deja atrapar en las definiciones establecidas: mi hipótesis es que el discurso de la crónica vocaliza, hace visibles y audibles las diferentes identidades sin pretender definirlas ni mucho menos unificarlas, al contrario, las singulariza: afirmo con Víktor Shklovski que la crónica, como el arte, describe al objeto o sujeto como si se lo viera por primera vez, provocando una impresión máxima en el receptor y generando su visión, no su reconocimiento (1917: 60).

Cabe señalar en este punto que sería incoherente suponer una uniformidad general para las crónicas, cuando estoy postulando una heterogeneidad irredimible para las voces, los territorios y las identidades expresadas por este género. Precisamente, es una de las dificultades de la historiografía literaria al considerar un corpus desde una "visión global" representada en este caso por la categoría de género literario, aun tratándose de un género atravesado por divergencias internas y heterogeneidades irreductibles. Los vínculos entre la producción de los cuatro autores mencionados (Lemebel - Monsivás - Poniatowska - Perlongher) son líneas de tensión, que no articulan una estructura, es decir, un sistema de relaciones que derive de cada uno de ellos analogías o semejanzas, tampoco oposiciones excluyentes. Los cronistas latinoamericanos despliegan sus diferencias en un campo de productividad incesante que no puede ser detenido ni está, de hecho, regulado por leyes homogéneas. Las crónicas dan cuenta de los múltiples desplazamientos de la historia cultural en la que ellas mismas están insertas. Son instrumentos de análisis de lo que ellas mismas integran: son "juez y parte" de una realidad contradictoria y cambiante en la que están comprometidas. Este rasgo paradójico es un elemento común entre la crónica 
modernista y la contemporánea. Me voy a detener en los puntos de fricción más evidentes entre las crónicas de Pedro Lemebel y las de Carlos Monsiváis.

El autor mexicano mantiene en su enunciación la distancia ensayística, letrada, intelectual. Analiza la realidad social y política que está considerando con categorías (siempre muy actualizadas) de las disciplinas que maneja: la sociología y la filosofía, la historia y la etnografía. México es, para Carlos Monsiváis, el producto de una violación múltiple: cuerpo violado por su base cultural violenta (la conquista y colonización españolas) y también por los incesantes movimientos de inmigración interna que lo invaden y lo territorializan hasta el exceso, hasta convertir la ciudad en invivible:

Desde las estadísticas, la gente acecha. Allí, en esa plaza fuerte de la demografía, la gente se sabe a salvo y en expansión continua. Recién abandonamos a la pareja y ya su descendencia colma el estadio. Al amparo de las tempestades demográficas, la gente se ufana de su incontinencia, y, aunque diga lo contrario, se enorgullece de su poderío reproductor. [...] Y todos cuantos vagan, y todos cuantos se inmovilizan, de la demografía sus mil virtudes van refiriendo. El ámbito de las multiplicaciones reta al infinito y despoja de sentido a las profecías. ¿Y qué es el crecimiento sino la negación de los augurios? Siempre, los números, así se les disminuya, hacen palidecer a los vaticinios. ¿Hay una pesadilla más entrañable que la demografía? Y las imágenes iluminan el perpetuo Camino del Exceso (la intimidad masificada), y en las imágenes la gente se acomoda en el espacio físico que es, también, la visión del mundo. Todos juntos aunque nadie lo quiera, en la implosión de recursos y la explosión de familias, en la lujuria y el ascetismo. La diosa de los modernos, la demografía, expulsa y atrae, preserva y anega, es un diluvio y es la sequía que florece. (Monsiváis 1995: 17)

Como la de Martí, la escritura de Carlos Monsiváis no está atravesada por las condiciones de su subjetividad al momento de la enunciación. Predomina la mirada del observador que registra y analiza lo que ve. Este rasgo implica una operación de distanciamiento con el objeto, sujeto o fenómeno observado. Tanto en Amor perdido (1978) como en Los rituales del caos (1995) el autor registra elementos que pertenecen a la cultura popular, recortando su objeto con el utillaje propio de las disciplinas 
sociales que él conoce y maneja: la filosofía, la crítica cultural, la sociología y su profundo conocimiento de la historia de México y de las prácticas sociales propias de la cultura popular a lo largo de todo el siglo XX.

Un elemento constante en su escritura es la ironía, la cual establece y ajusta claramente la distancia entre su propia construcción discursiva letrada y los sujetos y prácticas que observa y analiza, pertenecientes a las capas más bajas de la sociedad mexicana. Aunque lo describa desde muy cerca, el desborde de la multitud (la proliferación, el exceso, lo que él llama "las tempestades demográficas") no lo absorbe ni lo ahoga: el autor instala en su discurso el distanciamiento que impone el encuadre fotográfico. De hecho, en el primer capítulo de Los rituales... y en la primera parábola que lo precede reflexiona sobre las multitudes de la megaciudad en términos fotográficos: "Parábola de las imágenes en vuelo"; "Y las imágenes iluminan el perpetuo Camino del Exceso [...] y en las imágenes la gente se acomoda en el espacio físico que es, también, la visión del mundo" (Página sin número. La edición no numera las páginas de la parábola que acompaña a las fotografías).

A continuación, quince páginas muestran más de veinte fotografías que ilustran lo señalado en el prólogo y en la parábola citada. Esas fotografías irán adquiriendo sentido conforme el lector avance en la lectura del libro, pero desde el comienzo cumplen con una función específica y natural a su condición: enfocan el sentido textual, subrayan la cuestión decisiva para la ciudad de México que el autor quiere mostrar: las multitudes de la "ciudad interminable", "las variedades del caos", el "feroz desorden" (15) de la vida mexicana. En él juegan un papel preponderante los espectáculos multitudinarios, que habrá de analizar en las primeras crónicas del volumen. A diferencia de lo que veremos en Lemebel, a saber: su participación en el relato como sujeto-autor-protagonista, Monsiváis no acorta nunca la distancia entre la enunciación y 
el episodio narrado o el fenómeno observado y analizado desde una perspectiva teórica. Por ejemplo, en "La hora de los amanecidos. Lo que se hace cuando no se ve tele" (114119) el cronista reconoce una urgencia social: los sitios de baile que, si hace falta, se improvisan en las calles. En el primer apartado de la crónica: “I. Los tíbiris: Lo tropical y la tolerancia", el narrador describe "un hoyo tíbiri de la tropicalidad", para permanecer -en todo momento- ajeno a él:

En La Conchita un grupo atrae miradas burlonas que casi de inmediato se apaciguan. Aquí están los travestis o, como se les dice familiarmente, las Vestidas, institución de los tíbiris cuyo rito de aceptación se localiza en los días del Carnaval al filo de la madrugada, cuando todo sucede en los pueblos con el objeto de que al día siguiente nadie se acuerde de nada. (Monsiváis 1995: 115)

En Lemebel, la referencia al grupo de travestis que protagoniza una de sus crónicas ("El último beso de Loba Lamar", que será analizada en el desarrollo de la primera hipótesis) se construye en primera persona. La crónica narra la agonía de Loba Lamar, travesti, bailarina y cantante del vodevil portuario, víctima del SIDA. El texto entronca con la tradición de la picaresca española -aspecto que será analizado luegopero lo que me interesa destacar aquí es que el narrador / narradora es protagonista de la historia: "Nos quedamos con el corazón en la mano, todas emocionadas mirando a la Loba con su trompita chupona tirándonos un beso". (Lemebel 1996: 48). A la distancia que establece técnicamente en el relato, Monsiváis le suma la distancia epistemológica, por cuanto hay en su discurso momentos que pueden ser considerados de ensayo filosófico-cultural. Por ejemplo, en relación con la devoción por la Virgen de Guadalupe, el autor expone sus teorías:

Históricamente, el guadalupanismo, acervo de arraigo y continuidad, es la forma más encarnizada del nacionalismo, ¿pero qué sucede en un mundo postradicional? ¿Cuál es la relación entre nacionalismo y guadalupanismo? Según creo, más que de pasión 
belicosa, se puede hablar de lazos que igualan logros y limitaciones: la miseria, la comprensión del mundo a través de actos rituales, el desamparo, la costumbre, el amor estremecido por los símbolos, el sincretismo como vía de adaptación (primero a la Conquista, luego a la nación que surgía entre batallas, más tarde a la modernización), el fanatismo que es también un testimonio corporal del arraigo en el primer aprendizaje. (Monsiváis 1995: 40).

Clara y explícitamente, cuando el autor se refiere a "la comprensión del mundo a través de actos rituales", no se refiere a su propio modo de comprender el mundo. El sujeto de la enunciación está aquí apartado de la práctica cultural que refiere y describe, posicionándose "por detrás" del acontecimiento, en una actitud propia del cronista letrado y del crítico cultural. Como he señalado, la distancia obliga al escritor a ubicarse en una posición de verdad que determina su opción intelectual, discursiva y necesariamente identitaria. La multiculturalidad en Monsiváis es un elemento ajeno a su posición como sujeto en el discurso, es decir, es válido para "los otros", para "ellos". La mexicanidad multicultural no parece atraversarlo, aunque se considere mexicano y sea un representante muy destacado de la cultura mexicana del siglo XX. Lemebel, en cambio, es en sí mismo una composición multicultural itinerante, en devenir. Sigue siendo un "roto", un sujeto caído del sistema social, lo que le permite oír a los muchachos del bloque, a la pandilla travesti, al homosexual reprimido que hace el papel del "macho" en la cultura urbana de la clase media, al indio olvidado y humillado, a los niños y mujeres del Zanjón de la Aguada.

\subsection{Lemebel/Perlongher: una genealogía neobarroca}

Como ha señalado el autor en su última presentación pública en Buenos Aires, en ocasión del Festival Internacional de Literatura (FILBA) en noviembre de 2008, Néstor Perlongher y Manuel Puig serían sus "tías". Más allá de la cuota de humor del 
comentario, hay relaciones de filiación entre la escritura de Lemebel y la obra de los argentinos que merecen ser observadas con detenimiento.

La relación con el poeta, ensayista y cronista argentino Néstor Perlongher es determinante para pensar la singularidad en el espacio discursivo (crónica) y regional (América Latina) al que de hecho ambos pertenecen, pero al que también ponen en tensión, y por lo tanto modifican y dinamizan. En la obra de Néstor Perlongher se da una muy significativa continuidad entre sus textos poéticos y sus textos ensayísticos, y entre éstos y su producción cronística. El autor argentino justifica esta continuidad en su ensayo "Sobre alambres" (1997: 139-140) que integra el citado volumen de textos en prosa.

En primer lugar, encontramos en la obra de Lemebel dos rasgos importantes de la estética de Perlongher: la noción de sujeto que domina en su escritura, y la condición de continuidad entre ensayo, crónica y poesía, técnicamente habilitada por aquella noción de sujeto. En "Sobre alambres", un ensayo crítico breve sobre su propia obra, ${ }^{106}$ el poeta argentino da cuenta de ella poniendo énfasis en las particularidades del sujeto de la enunciación: “[L]a primera pregunta es: ¿quién escribe? ¿quién habla? $\mathrm{O}$ ¿de parte de quién? [...] Si es que no hay yo, el poeta es yoyó. [...] Es dejarse llevar. La presión de las yemas en prisión maquinal". El poeta es "el que teclea" y su "misión es dejar pasar cortándolos- los flujos de un eco de arroyuelo tenaz" (139). El sujeto de la escritura es un espacio de tránsito que corta los flujos que no son remitidos a ninguna fuente; su condición es pasar: son los "flujos de un eco de arroyuelo". Triple determinación para el texto literario al que se alude con una metáfora líquida y aérea (resulta inevitable pensar en el título de uno de sus libros: Aguas aéreas). En este texto de Perlongher el estatuto ensayístico es indiscernible del poético, y esa transposición está efectuada como una

\footnotetext{
${ }^{106}$ Es el único ensayo de la compilación donde Néstor Perlongher se refiere a su propia poesía. Antes de ser recogido en el libro de referencia, fue publicado en la revista El Porteño $\mathrm{N}^{\circ}$ 74, febrero de 1988.
} 
operación “impersonal”, es decir independiente de una voluntad de autor. Se da en virtud de un atravesamiento no orientado por la razón de un sujeto sino operado más allá de ella, a tal punto que el sujeto resulta implicado en esa operación. Este proceso sería impensable sin un cambio en la concepción tradicional del “autor”. El sujeto -en el contexto de la transposición artística- resulta una entidad de contornos difusos, que determina y a la vez resulta determinada por la materia a la que configura y modela, sin dejar de ser una fuerza, un quantum de pulsión, en términos nietzscheanos. Condición heterogénea e inestable, por cuanto su productividad no cesa.

Esta condición del sujeto poético que domina en la escritura de Perlongher y que influirá de manera decisiva y consciente en la de Lemebel (volveré a esta idea en el desarrollo de las hipótesis), reconoce su deuda filosófica con Gilles Deleuze y Félix Guattari. En el comienzo del ensayo Perlongher los cita: "Si no hay un yo -reza el rizoma de las Mil Mesetas-, si somos todas multiplicidades, verdaderas poblaciones, masas de devenires: nutrias, osos, prostitutas paulistas...” (1997: 139), asumiendo la concepción de sujeto de la enunciación literaria que redistribuye los papeles tradicionalmente entendidos en el acto creativo. Esta poderosa crítica se dirige tanto al concepto de sujeto moderno como a su dispositivo teórico: la oposición binaria jerárquica y excluyente, y determina un cambio radical también en la comprensión del cuerpo. En este contexto lo corpóreo es concebido desde una perspectiva des-organizada que tiende a desactivar la noción de organismo que aísla y tabica los cuerpos. ${ }^{107}$

Por ejemplo en un ensayo clave, muy citado por sus implicancias teóricas y epistemológicas en relación a la cuestión gay, Perlongher afirma:

No pretendo entrar en una discusión teórica sobre el concepto de homosexualidad. Pero lo menos que se puede decir de él es que es muy pobre. Iguala, bajo un denominador común, la infinidad de actos

\footnotetext{
${ }^{107}$ Para el desarrollo de esta idea ver: Deleuze, Gilles y Félix Guattari: Mil mesetas, Valencia, Pre-textos, 1988, especialmente los capítulos 6 y 10.
} 
sexuales a los que un sujeto puede abocarse con otros del mismo "sexo" (aunque no siempre del mismo género). [...] Guattari, el coautor del Antiedipo, habla de un "devenir mujer" que abre a todos los demás devenires. Siguiéndolo, podemos pensar la homo o la heterosexualidad, no como identidades, sino como devenires. Como mutaciones, como cosas que nos pasan. Devenir mujer, devenir loca, devenir travesti.

La alternativa que se nos presenta es hacer soltar todas las sexualidades: el gay, la loca, el chongo, el travesti, el taxiboy, la señora, el tío, etc. (Perlongher 1997: 32-33)

La idea de la identidad en fuga (inspirada, como decíamos, en los textos filosóficos de Deleuze y Guattari que lo deslumbraron) es coherente con la noción de territorialidad itinerante, también presente en los autores franceses y que Perlongher elabora en relación con su estudio sociológico sobre la oferta de homosexualidad en los suburbios de San Pablo ${ }^{108}$. El deambular o la deriva por las calles de la ciudad configura los espacios de circulación, por lo tanto no hay "territorio" acotado o delimitado sino "territorialidades" móviles, a las que Perlongher se refiere como "red de tránsitos" o "red de flujos":

Los puntos de prostitución viril constituyen nudos en una red de flujos. En primer lugar, la microterritorialidad del punto forma parte de otra superficie más amplia y difusa. La dimensión de dicho territorio se verifica en el espacio urbano -tomando la ciudad no sólo desde la perspectiva de la arquitectura que la erige, sino también a partir de las circulaciones que la recorren. [...] Se van delineando los personajes de esta red de tránsitos. Es preciso evitar la tentación de pensarlos en tanto "identidades", para verlos en cambio como puntos de calcificación de las redes de flujos (de las trayectorias y los devenires del margen). (Perlongher 1997: 46-47).

Estas dos nociones: territorialidades e identidades en devenir, en fuga o deriva, siempre heterogéneas y literalmente transitorias influirán de manera decisiva en la estética de Pedro Lemebel, y determinarán en sus textos tanto su concepción de la

\footnotetext{
${ }^{108}$ El ensayo "Avatares de los muchachos de la noche", al que pertenece el fragmento citado, fue escrito mientras el autor terminaba su estudio antropológico y sociológico: $O$ negocio do michê publicado en Brasil en 1986. Está incluido en Prosa Plebeya (Buenos Aires, Colihue, 1997) y se publicó completo bajo el título: El negocio del deseo (Buenos Aires, Paidós, 2002). El ensayo citado puede ser considerado un anticipo o resumen de las hipótesis centrales de ese trabajo académico de campo.
} 
identidad y el territorio urbano como la construcción del lugar de enunciación. Lemebel responde a este desafío en todas sus crónicas, pero de una manera más evidente en su libro Adiós mariquita linda, de 2004. Se inscriben en él las alternativas de un deambular por la ciudad sin meta fija ni propósito definido, efectuando lo que Néstor Perlongher llamó una cartografía deseante, es decir, el deambular del cronista no solamente recorre espacios ya dados o establecidos en el mapa urbano, sino que los configura: el paseo del cartógrafo deseante produce los itinerarios según la fuerza y la dirección de su deseo. Ese recorrido, al producirse en obvia resistencia -0 diferencia- con los itinerarios urbanos previstos por las actividades productivas de la dinámica social: trabajo, estudio, intercambios múltiples, actividad comercial, etc. (lo productivo, útil y bien visto o aceptado), genera otros recorridos y descubre otra ciudad.

En el último apartado del libro, precisamente aquél que le da título al volumen, encontramos cinco crónicas breves y sucesivas que realizan claramente el proyecto "cartográfico" de Néstor Perlongher. "Noche quiltra", "Noche payasa", "Noche coyote", "El gay town de Santiago" y "Ojeras de trasnochado mirar" (Lemebel 2004: 153-169) trazan un recorrido menor por la noche santiaguina, evitando la centralidad resplandeciente de la urbe, abriéndose paso "en los brillos opacos del margen" (Perlongher 1997: 45). Recorridos que van trazando líneas de exterioridad con respecto al cuerpo social normalizado. Perlongher se refiere en el citado ensayo a los puntos y flujos de circulación de la prostitución viril en San Pablo, a la que describe como una práctica social, o "microsocial": "Masas de adolescentes desterritorializados por la miseria, aminorados por la edad, masas de homosexuales pescando en los zanjones de la marginalidad las aguavivas del goce" (45).

Cada narrador-protagonista realiza en las cinco crónicas nombradas distintos recorridos nocturnos por la ciudad. Con la única excepción de "Noche payasa", en la 
que el narrador en primera persona relata una historia a su vez contada por Andrés Pavez, las otras cuatro son protagonizadas por Pedro Lemebel. En este punto me parece indispensable realizar una precisión de orden técnico. La figura del narradorprotagonista, que además de narrar lo que le sucedió en carne propia escribe la historia, haciendo referencia a dicha escritura y, por lo tanto, demostrando una clara conciencia de su enunciación literaria, constituye un procedimiento que astilla y desde luego transforma las figuras del autor-cronista y del narrador-personaje. Esa transformación incide, desde luego, en las relaciones establecidas entre verdad y ficción configurando una estrategia que las desencializa e interviene, como hemos señalado, en las relaciones internas de la serie.

En relación con este aspecto debo señalar una similitud y una diferencia con la escritura de Perlongher. La similitud es que dicha estrategia se produce en abierta polémica con la normativa de los géneros (así como ambos también polemizan con las certidumbres e imperativos culturales acerca del género sexual), y Lemebel publica su primer volumen de crónicas - a tres años de la desaparición del poeta- recorriendo el camino que enlaza la crónica y la poesía. De ese modo la enunciación está a cargo de un sujeto poético sin abandonar la observación y el juicio crítico, propios del cronista, del etnógrafo o del historiador no ortodoxo. La diferencia es que Perlongher no se inscribe “dentro del cuadro", no protagoniza en primera persona los recorridos que narra aunque los ha estudiado desde muy cerca por cuanto sus ensayos son trabajos académicos de campo. De hecho el ensayo citado es parte de su tesis de posgrado: $O$ negocio do michê. Su observación no se aparta en ningún momento del análisis sociológico. Perlongher no es el protagonista en primera persona de esa errancia nómade, y -como Monsiváis- no abandona nunca la enunciación letrada, la elaboración reflexiva desde las ciencias que él domina y con las que elabora su cuidadoso registro crítico: la filosofía y la sociología. 
Lemebel en cambio es el protagonista de su "duro patiperrear" y conserva a lo largo de sus siete libros esa posición y el registro discursivo que se deriva de ella. El texto paradigmático en ese sentido, dentro del breve corpus indicado, es "Noche quiltra $^{109}$, . En él se narra el fin de la noche y comienzo del día de un personaje en primera persona que no se presenta porque está implícito en el texto que los lectores sabemos quién es:

La tiniebla del amanecer sabatino me acompaña de regreso al hogar. Vivo fuera del centro y mi carrete en Bellavista se alargó en copas y fumadas piteras de eufórico trasnoche. [...] La periferia poblacional ilumina de azul marchito el sueño de la plebe; de seguro que a esta hora todos duermen en el habitar de los bloques, todos menos los chicos carreteros que, acomodados en las escaleras, siguen brindando con su caja de vino por la pequeña alegría de su anónimo penar. Un poco temeroso, saludo a la rápida y trato de pasar piola directo al tercer piso. Pero un duende despeinado me ataja diciendo: hola, Pedro, ¿querís un copete? Y la verdad pienso que necesitaba ese último sorbo para ver con cariño la joven cesantía patria tirada a pata suelta en los peldaños orinados del bloque. (Lemebel 2004: 153).

En la prosa de Lemebel hay un desenfado singular. No en el tono ni en una voluntad sobreactuada de "decirlo todo" o de "describirlo todo", sino en la absoluta libertad, sin temor a la opinión ajena bienpensante, sin retaceos moralistas, todo está dicho con naturalidad, precisión narrativa y lenguaje poético:

Ese infaltable compañero de la copa del olvido, cuando todo da lo mismo, cuando la felpa erótica de mi mano trepa el muslo y despliega su desesperado tantear. Siempre es igual, la noche boca abajo y los ojos del péndex turbios de alcohol en la cabalgata eyaculante que me aplasta en el cemento frío de la pobla. Casi siempre

\footnotetext{
${ }^{109}$ La expresión "quiltra" o "quiltro" muy común en el habla chilena, se emplea habitualmente como sinónimo de "mestizo/a" y se aplica a los perros sin raza definida. En el título de esta crónica remite, obviamente, al carácter del perro protagonista. No obstante, esta expresión tiene otras connotaciones un poco más difíciles de precisar. Según Paulina Amenábar, orfebre chilena dedicada a la joyería artística tradicional, "pedir y querer cariño es propio del carácter 'quiltro' de los chilenos". De todos los acercamientos que he podido encontrar a esta hermosa palabra, el de Amenábar es el que más se conecta con la crónica lemebeliana, porque aúna a la condición "mestiza" - tanto del perro como del narrador- una carencia afectiva que domina la atmósfera de este texto desde la primera línea hasta la última. Entre los protagonistas humanos y perruno de la crónica, lo que se produce es, precisamente, un "pedir y querer cariño".
} 
todo es igual en la complicidad tirilluda de mis nupcias pobres. En ese momento el alcohol todo lo empantana, todo lo exagera, y el pozo etílico del sexo malandra estrangula el corazón como un beso ciego. Por eso escribo de mi pueblo con este desenfado, porque conozco y bebo gota a gota la emoción pelleja de su sexo roto. (Lemebel 2004: 154).

En el fragmento citado está la clave de su desenfado: es suya "la emoción pelleja de su sexo roto"; son suyas la complicidad y las "nupcias pobres"; es propio "el pozo etílico del sexo malandra [que] estrangula el corazón como un beso ciego". El nombre propio del autor, Pedro, aparece en muchas de sus crónicas, y no causa sorpresa ni extrañamiento alguno: sabemos que es él su propio personaje, sabemos que la verdad y la ficción están articuladas en sus crónicas. No son opuestos que se excluyen, sino conceptos problemáticos cuya interacción da cuerpo y sentido al tratamiento específico del género "crónica" que realiza Lemebel.

Dije al comienzo de este apartado que la relación de la escritura de Lemebel con la de Néstor Perlongher es genealógica, determinante. Y lo es en varios sentidos de los cuales ya hemos explorado dos: la construcción de un sujeto poético y el devenir crónica-poesía. El aspecto que voy a considerar a continuación es la sorprendente continuidad entre la teorización de Perlongher acerca de las condiciones de una cartografía deseante y la ejecución del proyecto perlongheriano en la escritura de Lemebel. En su crónica-ensayo "Los devenires minoritarios", el poeta argentino afirma: "la tarea del cartógrafo deseante no consiste en captar para fijar, para anquilosar, para congelar aquello que explora, sino que se dispone a intensificar los propios flujos de vida en los que se envuelve, creando territorios a medida que se los recorre" (1997: 65). Por lo tanto la cartografía no consiste en copiar o registrar un fenómeno, sino en reproducir su funcionamiento en tanto práctica, "dentro" de su propio movimiento. El cronista, en este caso Pedro Lemebel, opera una transposición de una práctica y un 
funcionamiento del orden social al registro discursivo. Voy a citar una vez más al argentino para observar luego cómo ese proyecto cristaliza en la escritura del chileno:

Devenir no es transformarse en otro, sino entrar en alianza (aberrante), en contagio, en inmistión con el (lo) diferente. El devenir no va de un punto a otro, sino que entra en el "entre" del medio, es ese "entre". Devenir animal no es volverse animal, sino tener los funcionamientos del animal, "lo que puede un animal" (como en el caso de Hans-devenir-caballo. (Perlongher 1997: 68).

En la crónica que acabamos de comentar, "Noche quiltra", se produce esta alianza aberrante que no se agota en el contacto zoofílico, punto climático de la narración, sino que involucra también al narrador con los muchachos del bloque, al día con la noche, al vagabundeo con el regreso a casa. Eso está cuidadosamente construido en el relato. Leemos en la primera frase: "La tiniebla del amanecer sabatino me acompaña de regreso al hogar”. Así como la tiniebla y el amanecer no son opuestos excluyentes, el brindis en las escaleras del bloque celebra "la pequeña alegría de su anónimo penar". El clímax de la narración coincide en intensidad con el devenir animal. Tan ajustado es el procedimiento que la razón lógica se invierte al aclarar el narrador: "Y en realidad no era humano ese perro". Pero el efecto de esta frase se produce en el contexto de su enunciación:

Y era tan suave el pelaje arisco de su quiltra piel, y era tan velludo ese cuero canino que dormía a mi lado, que no parecía humano ese acezar animal que lamía mis dedos en el estruje de la caricia. $Y$ en realidad no era humano ese perro Cholo que en busca de calor buscaba mi compañía. Era más que humana la orfandad negra de sus llorados ojos. [...] Me sentí San Francisco de Asís lujuriosamente enamorado de su lobo. Y dejé correr su cochambre arestiniento $^{110}$ por mis yemas, por su estómago desnutrido de perro guata de pan, perro trasnochado, perro cunetero, perro sin amo y sin amor. Por eso archivé la moral ecológica en el estante de Greenpeace,

\footnotetext{
${ }^{110}$ Por "arestinado", que padece arestín. Arestín: Salpullido, acompañado de gran prurito, que padecen los niños y aun los adultos. Escoriaciones en las manos y pies que padecen las caballerías. (Fig.) Desazón, molestia.
} 
y le brindé a mi Cholo una paja gloriosa que nunca una caricia humana le había concedido. (154-155, énfasis mío).

La "humana orfandad negra de sus llorados ojos" efectúa en el discurso el devenir animal humano-perruno. Sexo malandra sobre la escalera de la pobla y encuentro zoofílico con un perro quiltra, que pide y quiere cariño tanto como el yonarrador-personaje, tanto como el muchacho del bloque, todo realiza la heterogeneidad más radical de lo humano y lo perruno atravesada por la orfandad, la condición mestiza o quiltra, la soledad (“sin amo y sin amor”) y la pobreza.

Con respecto a la relación de nuestro autor con la estética de Manuel Puig es mucho menos directa pero cabe señalar dos aspectos importantes. El primero, y más evidente, es la polifonía de sus novelas, las cuales están completamente enunciadas por las voces de los protagonistas. Las conciencias autónomas de los personajes interactúan y se modifican en una relación dialógica -como teorizara Bajtín- la cual no se resuelve ni llega al equilibrio en una estructura dramática cerrada, a la manera de la novela decimonónica tradicional. En la novela polifónica el héroe o personaje no ha dicho aún su última palabra: está inconcluso. Las voces y las conciencias autónomas, portadoras de su propia visión del mundo, no están atrapadas por "el lazo mortífero de la conciencia ajena" (la visión ideológica del autor) que las convertiría en "objeto" de la representación. En las novelas de Puig los personajes no son representados ni definidos objetivamente por una posición de sentido superior, jerárquica y por lo mismo totalizadora (la típica posición del narrador omnisciente en la novela monológica). Los personajes están determinados exclusivamente por su propia voz "encarnada" (Bajtín) que la convierte en "posición plena de sentido". Sabemos -porque es evidente y porque Lemebel lo ha dicho- que Tengo miedo torero, su única novela, es un explícito homenaje a El beso de la mujer araña de Manuel Puig. En una entrevista de 2004 
consignada en el Estado de la Cuestión de la presente tesis, la periodista lo interroga acerca de los géneros literarios que aborda, a lo que Lemebel responde:

-Mira: la novela Tengo miedo torero fue un desafío, un ejercicio de provocación frente al protagonismo mesiánico de los novelistas machos. Y me resultó, ni trascendental ni como proyecto de mundo, apenas una balada guerrillera y romanticona como un eco trasnochado de la obra de Puig. Nunca escribí poesía, en Chile era un género colonizado por las próstatas locales. (Costa 7).

Es significativo que su única novela sea un homenaje (o "un eco trasnochado") de una novela de Puig. Entiendo que, además de la ya señalada polifonía que domina en la escritura del novelista argentino y que Lemebel reelaborará y hará propia en sus crónicas, hay un elemento ideológico-literario que toma de él y que se puede definir como una doble deconstrucción frente a la historia de amor entre un homosexual y un militante guerrillero: diluir el melodrama del amor maldito y al mismo tiempo la épica de la lucha revolucionaria. Dos "nudos" muy consolidados dentro de los tópicos literarios universales, altamente cristalizados por la convención y también, ciertamente, banalizados por el discurso político oficial o simplemente por la simplificación popular: buenos contra malos, inocentes contra culpables, derechos contra desviados. Lemebel también asume este desafío, y como Puig, compromete su proyecto artístico en la contestación a los poderes que imponen su orden político y sexual. Ahora bien, esa actitud contestataria en el doble plano señalado, se realiza en su propio campo: política discursiva que despliega múltiples estrategias de disolución del límite en lo textual y lo sexual.

Consigno para finalizar este breve apartado una diferencia entre Lemebel y los dos autores argentinos. Si bien Perlongher y Puig están determinados por la alteridad (discuten con toda la cultura pacata e incluso con la pacatería de su propio ghetto; están determinados como "otros" por su condición genérica y por su transgresión estética, 
entre otros aspectos), no provienen de las capas sociales más bajas, digamos, no han tenido una infancia extremadamente pobre. Ni pobres ni "rotos" ni "indios" ni caídos del régimen social. Pedro Lemebel extrema la alteridad y esa es una marca distintiva de su discurso y de su figura pública. ${ }^{111}$

\subsection{Lemebel/Poniatowska: la crónica y la novela de testimonio}

La obra de nuestro autor también está íntimamente conectada con la de Elena Poniatowska en un aspecto específico que estudiaré en el desarrollo de la segunda hipótesis (Capítulo IV), en la que abordo el vínculo entre escritura y oralidad, tensión que caracteriza la obra de ambos autores por su condición de literatura vocalizada. Asimismo, la obra de Lemebel tiene una relación ineludible con la novela de testimonio que cristalizó como género en la década de 1960. A continuación realizaré un breve recorrido por ese vínculo genealógico de la obra del cronista chileno.

Es posible establecer un punto de inflexión en el dilatado desarrollo de la crónica como género en nuestro continente: entre el final o la declinación del llamado boom de la literatura latinoamericana (cuya producción es básicamente novelística), y el comienzo de una modalidad del relato testimonial asociada a la transcripción (con la necesaria elaboración literaria, desde luego) de conversaciones o entrevistas. Estos relatos, llamados también novela-testimonio, tienen como protagonistas a individuos que representan alguno de los muchos grupos o sectores sociales oprimidos, casi siempre integrantes de una minoría social, étnica o de género, que oponen su resistencia a los gobiernos dictatoriales (o sus representantes locales), los cuales campean en

\footnotetext{
${ }^{111}$ Lemebel se reconoce como un invitado inoportuno. Afirma en una entrevista ya citada: "a mí me aceptan con una risa torcida [...] Me toleran con una náusea educada [...] Uno no deja de ser un polizón en la nave de las letras, pero hay que entrar y salir sin que se sepa por dónde y cuidar que no suenen las alarmas." (Costa 7).
} 
América Latina por esos años. Con el único propósito de avanzar un poco más en la precisión temporal, me atrevería a fechar esa inflexión: las publicaciones, en 1966 y 1969, de Biografía de un cimarrón, del poeta cubano Miguel Barnet y de Hasta no verte Jesús mío, de la escritora mexicana Elena Poniatowska. Como acabo de señalar, en ambos casos las novelas son el resultado -cada uno con sus particulares procedimientos y estilo- de una serie de entrevistas que los autores realizaron con los protagonistas. De allí surgen dos rasgos que conviven sin resolverse: el carácter marcadamente testimonial y la relación dialéctica que plantean, por un lado, entre ficción y realidad, y por otro, entre oralidad y escritura.

En sucesión temporal, pero también en un franco proceso de constitución de una nueva discursividad, la misma Poniatowska publica en 1971 La noche de Tlatelolco, un texto construido con multiplicidad de testimonios orales que dan cuenta, cada uno desde su particular punto de vista, de un episodio trágico de la historia reciente de México. También se observa el propósito de "rescate" de las voces silenciadas en el relato del poeta cubano. Reconstruyendo los momentos previos a la elaboración de su Biografía de un cimarrón, el escritor afirma:

No fui a ver una pieza de museo, no fui a ver a un anciano centenario; fui a buscar eso que no estaba en los libros de Historia con relación al tema negro en Cuba y la esclavitud. Esa magia, esa resonancia que no estaba en los libros de Historia, que no estaba en los documentos, que no se proyectaba en las academias, en las universidades. (http://www.cubaliteraria.com/autor/miguel_barnet/biografia_d e un cimarron.html)

El autor refiere la historia de su libro, y señala que las entrevistas con Esteban Montejo tuvieron su origen en un trabajo suyo en colaboración con Juan Pérez de la Riva, historiador y demógrafo, para la Biblioteca Nacional de Cuba. El resultado de ese trabajo fue el libro El barracón y despertó en Barnet el interés por el tema de la 
esclavitud en Cuba. Comenzó las entrevistas en 1964, y la intención inicial fue complementar aquel libro sobre los barracones de Juan Pérez de la Riva,

[Un libro] que hablara de la vida interna del barracón, de qué ocurría, de cuáles eran las relaciones interétnicas, de cuáles eran las relaciones sexuales, de cuales eran las comidas, de cómo era verdaderamente la vestimenta, cómo se relacionaban los esclavos con la enfermería, cómo vivían los mayorales, los contramayorales, qué era un negro semental y qué significaba dentro de las relaciones sociales internas del barracón. [...] Todo eso me interesaba para hacer un apéndice que complementaría el libro de Juan Pérez de la Riva.

(http://www.cubaliteraria.com/autor/miguel_barnet/biografia_de_un_cimarr on.html)

Me interesa señalar, citando al propio Barnet, cómo su texto fue virando de intención y de naturaleza:

Pero empecé a entrevistar a Esteban y ahí fue donde mi vena de poeta se sintió tocada y me di cuenta, ya en las primeras entrevistas, que Esteban Montejo daba para mucho más, que Esteban Montejo era una vida importante, anónima, de la historia de Cuba y que había que rescatarla. Mi único mérito fue adelantarme, o si no, al menos ver lo que otros no vieron nunca, lo que no habian visto, lo que no habian descubierto en otros hombres llamados "sin historia", gentes increíbles, anónimas, que eran el sedimento de la historia y la cultura cubanas. [...] La idea era hacer mi propio libro, un relato etnográfico. Después lo califiqué de novela-testimonio para ser honesto conmigo mismo, con la metodología que había empleado y con la proyección del contenido.

(http://www.cubaliteraria.com/autor/miguel_barnet/biografia de un_cimarr on.html) Énfasis mío.

Destaco el testimonio de Barnet porque me parece clave para la comprensión de un elemento decisivo en la crónica latinoamericana posterior. El relato indaga en lo que su autor llama "el sedimento de la historia y la cultura cubanas", y al mismo tiempo reconoce que la de Esteban Montejo era una vida importante aunque anónima de la historia de Cuba, y había que rescatarla. Por eso llama a su biografía un "relato etnográfico"; no obstante en las entrevistas con el cimarrón su "vena de poeta" se sintió tocada y comprendió que su texto era "mucho más" que un apéndice de un libro de 
ciencias sociales sobre los barracones. He aquí los elementos heterogéneos que configuran el relato: interés etnográfico, vena de poeta, rescate de determinadas voces y prácticas sociales que la Historia (de Cuba en este caso) no registra.

En 1980 Elena Poniatowska publica: Fuerte es el silencio, libro en el que ya encontramos una diferencia cualitativa respecto de los relatos anteriores. Desde el registro textual que ha sido denominado novela-testimonio, la modulación de la voz que narra ha ido configurando un tipo de relato con características propias. En este último texto de Poniatowska -y que desde luego es acompañado por muchos textos de otros autores, tanto en México como en otros países de la región- se opera un sutil pero decisivo traslado del testimonio a la enunciación narrativa que da cuenta de un corte sincrónico en la historia reciente de un individuo, grupo o comunidad, centrada en un punto de vista que tiene como rasgos distintivos la intención crítica y la vocación de registro de episodios y personajes "caídos" de la escena discursiva institucional, académica y periodística. También en ese texto encontramos una elaboración narrativa de episodios históricos con algún grado de ficcionalización. Ésta alcanza, sobre todo, a situaciones no documentadas y contenidos de conciencia, en ambos casos elaborados a partir de testimonios, entrevistas y otros procedimientos de investigación históricoperiodísticos. Esos procedimientos le dan a la obra un carácter novelístico que podemos asociar a la recientemente inaugurada literatura de no-ficción en el continente norteamericano (recordemos que In cold blood de Truman Capote fue publicada en 1966), la cual contaba ya con el importante antecedente de Operación masacre, el célebre escrito literario-periodístico del argentino Rodolfo Walsh, publicado en $1957 .{ }^{112}$

\footnotetext{
${ }^{112}$ Ver el reciente libro de Marc Weingarten: The Gang That Wouldn't Write Straight (algo así como: "La banda que no podía escribir derecho, o recto") que intenta una genealogía del Nuevo Periodismo. Los títulos que el autor destaca son: In Cold Blood, The Electric Kool-Aid Acid Test, Fear and Loathing in Las Vegas, Slouching Towards Bethlehem, The Armies of the Night. El autor fecha el nacimiento de esta escuela o grupo ("banda") de periodistas en 1965 y considera que su producción se extiende durante los siguientes diez años. Los autores considerados dentro de la escuela son: Tom Wolfe, Norman Mailer,
} 
El campo de producción de este género, como vemos, es tan problemático como el género mismo, y se encuentra también como él atravesado por líneas de fuerza que lo hacen esquivo a cualquier intento de fijación o clasificación definitivas. Dada la creciente producción y circulación masiva de crónicas en el continente latinoamericano durante los últimos años, se han producido encuentros internacionales que reflexionan sobre este fenómeno, y tratan de echar luz sobre el significado social y el futuro del género. Voy a destacar a continuación el papel activo que desempeña Elena Poniatowska ${ }^{113}$ como referente ineludible del género para los autores de la generación de Lemebel (es decir aquellos que tienen hoy entre 50 y 60 años de edad) y también para los más jóvenes.

Durante la Feria Internacional del Libro celebrada en Bogotá en mayo de 2008, cincuenta cronistas provenientes de México, Puerto Rico, Argentina, Chile, Ecuador, Perú, Colombia y Venezuela debatieron sobre el devenir de la crónica como género periodístico y literario y sobre su estado en América Latina. El encuentro fue organizado, en el marco de la Feria, por la fundación Nuevo Periodismo Iberoamericano, en asociación con la revista Soho, bajo el título "Nuevos Cronistas de Indias”. Entre ellos se encontraba el argentino Martín Caparrós quien manifestó al diario El Comercio de Bogotá en su edición del 7 de mayo, que los autores habían concluido el encuentro con más interrogantes de los que se habían planteado al comienzo. Esto nos indica que, por un lado, hay un claro registro de la intensa

\footnotetext{
Truman Capote, Jimmy Breslin, Gay Talese, Hunter S. Thompson, Joan Didion, John Sack y Michael Herr. El trabajo de Marc Weingarten registra el "detrás de escena" de los libros que cita, e incluye jugosas referencias al mundo editorial de la época y a las revistas que hicieron posible la emergencia de este movimiento que el autor considera contra-cultural. (New York, Three Rivers Press, 2010).

Me extiendo en la referencia dada la coincidencia temporal: los autores considerados en esta compilación también escriben y publican la mayor parte de su producción a mediados de la década del 60 .

${ }^{113}$ Digamos, además, que Elena Poniatowska permanece muy activa como autora a pesar de su avanzada edad y ha publicado recientemente un libro singular: Leonora (Seix-Barral, 2011). Si bien puede ser considerado rápidamente como una biografía de la extraordinaria Leonora Carrington, el libro es una nueva inflexión del género híbrido que ella ha contribuido a configurar en América Latina, indefinible e incategorizable: novela no ficcional, biografía, testimonio, crónica e historia.
} 
productividad del género, tanto por parte de la crítica como de los lectores, editores y escritores; y por otro, el hecho da cuenta de las múltiples cuestiones críticas que la condición del género propone, las cuales constituyen un interesante campo de investigación para los estudios académicos en la actualidad.

Cuatro años y medio después, entre el 10 y el 12 de octubre de 2012, se lleva a cabo en la ciudad de México el segundo encuentro: "Nuevos Cronistas de Indias 2" que hemos comentado al comienzo de este capítulo. Al igual que en su primera edición, fue organizado por la Fundación Gabriel García Márquez para el Nuevo Periodismo Iberoamericano (FNPI) y por el Consejo Nacional para la Cultura y las Artes (Conaculta). Elena Poniatowska ofició de anfitriona y abrió el encuentro con una conferencia interesante por algunos conceptos a los que me referiré en seguida y por el sentido homenaje a su compatriota Carlos Monsiváis, desaparecido en 2010, a quien declara el cronista más importante de México.

Elena Poniatowska inicia su conferencia inaugural con una de las cuestiones que la crónica no ha resuelto, y que posiblemente no resolverá: su problemática identidad de género:

La crónica en América Latina responde a una necesidad: manifestar lo oculto, denunciar lo indecible, observar lo que nadie quiere ver, escribir la historia de quienes aparentemente no la tienen, de los que no cuentan con la menor oportunidad de hacerse oír. La crónica refleja más que ningún otro género los problemas sociales, la corrupción de un país, la situación de los olvidados de siempre. Sus hallazgos bien pueden saltar a la novela y por lo tanto resultan muy difíciles de encasillar. ¿No es ficción o es ficción o es las dos cosas? Monsiváis nunca se preocupó por encontrarle solución a este rompecabezas. (Poniatowska 2012: 18)

Continúo la frase de Poniatowska: nosotros tampoco. No se trata - no al menos en esta tesis- de legislar, categorizar o "normalizar" un género que desde su constitución a fines del siglo XIX expresa la heterogeneidad y la polifonía inherente a 
los primeros procesos latinoamericanos en la desintegración de sus lazos coloniales, que coinciden con los primeros intentos de autonomización literaria; en ellos ha jugado un papel protagónico la crónica finisecular. El género en la actualidad acompaña, como hemos señalado, la denuncia de prácticas neo-colonialistas y la defensa de los derechos de las minorías oprimidas. Lemebel se erige como un autor singular en ese campo atravesado por propósitos políticos y estéticos. Su singularidad radica en la intervención eficaz que sus crónicas operan en el relato de la historia de Chile, negada por las políticas oficialistas de la Concertación, que durante veinte años promovieron un forzado y sostenido consenso con los responsables de la dictadura militar pinochetista, con el propio dictador Augusto Pinochet, políticas que permitieron y generaron el olvido de esa historia. 


\section{La obra de Pedro Lemebel como intervención polémica en el universo de los discursos de la historia}

El primer libro de crónicas de Pedro Lemebel, La esquina es mi corazón (1995) plantea desde el principio su propósito de intervención polémica en los discursos establecidos al presentarse como una nueva cartografía de la ciudad ${ }^{114}$. Este propósito está señalado por los paratextos que presentan la obra: el título, La esquina es mi corazón, y el epígrafe general, de Néstor Perlongher: "Errar es un sumergimiento en los olores y los sabores, en las sensaciones de la ciudad. El cuerpo que yerra 'conoce' en/con su desplazamiento.”

Los elementos que los dos paratextos tienen en común aparecen claramente en una primera observación: la identidad postulada por el título aúna un punto nodal del espacio urbano -la esquina- con la más íntima experiencia subjetiva. El epígrafe intensifica ese efecto de sentido al definir cuál será la estrategia elegida para conocer el territorio: la errancia; el desplazamiento del cuerpo, sus recorridos; sumergirse en los olores, sabores y sensaciones de la ciudad. El cuerpo está en primer lugar y proporcionará la vía de conocimiento: con él (corazón y sentidos, sensación y movimiento) el cronista efectuará su cartografía urbana.

Ahora bien, la cartografía lemebeliana no es un fin en sí misma, tiene otro propósito: construir a partir de sus desplazamientos una red de puntos de observación, los cuales funcionan como puntos de emisión de la voz de los sujetos. Ello le permitirá narrar los episodios de la historia reciente desde distintas perspectivas, siempre

\footnotetext{
${ }^{114}$ Esta hipótesis ha sido justificada por varios críticos, cuyos artículos he comentado en el Estado de la Cuestión (Richard 1993; Ostrov 2003; Ruffinelli 2007).
} 
minoritarias. ${ }^{115}$ Por eso he afirmado en la presentación de las hipótesis que Lemebel realiza la cartografía de territorios "no historiados" por el discurso oficial. Las crónicas de nuestro autor configuran un nuevo saber y un lugar diferenciado de enunciación: hacen hablar al cuerpo negado o silenciado, narran desde una experiencia que no tenía discurso. Esta práctica discursiva no se opone a la Historia como disciplina en el marco de la episteme positivista, tal como la hemos definido en el capítulo segundo de esta tesis. La crónica de Lemebel construye un saber-otro al poner en el discurso aspectos de la vida social que no habían sido documentados ni recortados como objeto. A lo largo de este capítulo daremos cuenta de las afirmaciones precedentes.

En “Anacondas en el parque”, primera crónica de La esquina es mi corazón, el espacio -que es espacio narrativo y escénico, ya veremos por qué- es el Parque Forestal de Santiago de Chile durante la noche. Ese espacio se configura con todas las marcas del presente histórico del cual el autor quiere dar testimonio:

A pesar del relámpago modernista que rasga la intimidad de los parques con su halógeno delator, que convierte la clorofila del pasto en oleaje de plush rasurado por el afeite municipal. Metros y metros de un Forestal "verde que te quiero" en orden, simulando un Versailles criollo como escenografía para el ocio democrático. Más bien una vitrina de parque como paisajismo japonés, donde la maleza

\footnotetext{
${ }^{115}$ Esta expresión está empleada en el sentido preciso que la filosofía de Gilles Deleuze y Félix Guattari le otorgan. Es un término dinámico que señala en el objeto o fenómeno minoritario un proceso de resistencia a la estructura o sistema dominante. Una lengua minoritaria, por ejemplo, no es aquella que habla una minoría por cuanto lo minoritario no remite a una determinación cuantitativa. Una lengua minoritaria es aquella que opone su resistencia a las estructuras estandarizadas de la lengua dominante, dentro del propio sistema. Por ejemplo: Deleuze y Guattari sostienen que Franz Kafka emplea el alemán como lengua minoritaria dentro del sistema en uso del alemán oficial (Deleuze y Guattari 1975: 28-30 y ss.). Lo minoritario actúa siempre desde los bordes de un sistema, desde su periferia, y su intensidad puede modificar las condiciones de producción. Por eso es una fuerza subversiva que genera problemas de identidad y de clasificación (un devenir minoritario es siempre una "antigenealogía" porque no determina identidad, la problematiza) dentro de la serie a la que configura y desconfigura al mismo tiempo. Gilles Deleuze ha "re-bautizado" incesantemente este concepto a lo largo de su producción filosófica: punto aleatorio, acontecimiento impersonal, idea genética (1988-1989); devenir minoritario, devenir imperceptible, anomal, línea de fuga o línea de desterritorialización (1972-1975). Este acontecimiento, siempre impersonal, se efectúa en multitud de estados de cosas. La literatura, como han demostrado los autores, no es una excepción: la serie literaria se encuentra atravesada incesantemente por devenires minoritarios (líneas de desterritorialización que modifican los géneros, los modos de enunciación, las categorías literarias) pero sin re-conducir a otras categorías de la estructura, sino modificándolas y poniéndolas en tensión.
} 
se somete a la peluquería bonsái del corte-milico. Donde las cámaras de filmación, que soñara el alcalde, estrujan la saliva de los besos en la química prejuiciosa del control urbano. Cámaras de vigilancia para idealizar un bello parque al óleo, con niños de trenzas rubias al viento de los columpios. Focos y lentes camuflados en la flor del ojal edilicio, para controlar la demencia senil que babea los escaños. (Lemebel 1995: 9).

El "relámpago modernista" de las luces halógenas convierte el pasto en "oleaje de plush rasurado". En esta primera frase encontramos la tensión que dominará el libro: naturaleza y deseo son fuerzas aliadas y en pugna contra una voluntad de poder que siguiendo los verbos de este primer párrafo- rasura, somete, estruja, vigila y controla.

El cronista señala con insistencia la política de simulación que organiza la “escenografía para el ocio democrático". Términos como "afeite", "vitrina” y "cámaras de filmación", entre otros, nos advierten acerca de la intencionalidad falsa del orden democrático, el cual también somete, estruja y camufla. "Cámaras", "focos” y "lentes" crean el universo óptico del cuadro que inviste al relato de una poderosa calidad escénica. El breve fragmento que acabo de transcribir está saturado de alusiones al mirar y al ser mirado. Esta es una de las claves del libro y, por cierto, de toda la obra del autor.

Observemos el primer sintagma de este texto: el relámpago modernista rasga la intimidad del parque con su halógeno delator. Hay una intimidad violada; "rasga" no es un verbo inocente, y mucho menos cuando está asociado a la intimidad: el velo, el himen, las vestiduras se rasgan, descubriendo ámbitos privadísimos cuya ocupación es necesariamente violenta. Aquí conviven el espacio público (se trata, finalmente, de un parque) con la violación de un espacio más que privado, íntimo. Esto provoca un efecto que va a darle cuerpo a la representación narrativa y ficcional de un episodio histórico: la violencia de género señala la continuidad del orden dictatorial en el espacio público, investido de intimidad por ser el lugar de la sexualidad no "oficial", no aceptada ("eran dos hombres, ¿te fijaste?”). Aun en su marginalidad y a pesar de la persecución político- 
policial, la homosexualidad tiene aquí todas las connotaciones del más alto grado de la intimidad humana: "la saliva de los besos", "hacer el amor en la dulzura del parque", "la sábana empapada del césped". La operación es eficaz: el espacio público, devenido escenario de la intimidad violada, condensa la representación de la continuidad de los métodos autoritarios en las estrategias de control urbano durante la transición. El mirar y el ser mirado son las líneas de fuerza que contienen las tensiones de este texto, al tiempo que sostienen su calidad escénica. Veamos de qué modo.

A partir del cuarto párrafo la experiencia sexual se colectiviza (siempre a través de la mirada: "mirar es ser cómplice de un asesinato, estrangulando la víctima en el muñeco vudú que derrama su ponzoña de crótalo entre los dedos”), y ello implica un crescendo de la acción que va a culminar en el corte del silbato policíaco: "Al lampareo púrpura de la sirena que fragmenta nalgas y escrotos, [...] A lumazo limpio arremete la ley en los timbales huecos de las espaldas [...] Entre el apaleo tratan de correr pero caen al suelo engrillados por los pantalones". Finalmente el parpadeo estroboscópico de la sirena se alinea con el halógeno delator nombrado en la primera frase y corta de un solo tajo el clímax del deseo que se había transformado en fuerza colectiva, para culminar en la figura elevada y trágica de un salto suicida:

Alguien en un intento desesperado zigzaguea los autos de la costanera y alcanza el puente perseguido por los disparos. En un salto suicida vuela sobre las barandas y cae al río siendo tragado por las aguas. El cadáver aparece días después ovillado de mugres en la ribera del parque de los Reyes. (Lemebel 1995: 12).

El final trágico disuelve la tensión dramática al tiempo que cancela las líneas de fuerza que la habían construido: el mirar y el ser mirado propios del deseo ${ }^{116}$, sucumben

\footnotetext{
${ }^{116}$ En la sesión del 8 de mayo de 1963, transcripta en el capítulo XVI del Seminario 10 La Angustia (titulado "Los párpados de Buda") Jacques Lacan concluye que la relación con los objetos-causa-de-deseo se fundamenta en la castración, es decir en la aceptación de la propia falta (no lo somos todo, no lo tenemos todo, no lo podemos todo). La relación con los objetos tiende a velar, a disimular esa falta, a
} 
ante el ojo de los focos, lentes, cámaras y sirenas del orden policial. Finalmente "la foto del diario" que muestra al joven fugitivo muerto entre las piedras, "como un pellejo de reptil", detiene la imagen y echa el saldo definitivo de la historia: un suicidado.

Los procedimientos del Barroco también operan y provocan sus efectos en las oposiciones que traban este texto: el relámpago modernista del halógeno delator que campea en el espacio público del control urbano, se opone en violento claroscuro al espacio privado "cuando cae la sombra lejos del radio fichado por los faroles". En esta oposición básica luz/sombra, se articulan otras: las "parejas de la mano que pasan anudando azahares por la senda iluminada de la legalidad" y "el amancebamiento de culebras que se frotan en el pasto". Lemebel toma los términos transitados por el prejuicio pacato del orden establecido para promover la oposición alineando la política del margen (la resistencia) con la naturaleza y el deseo, y la política oficial (a pesar de la posdictadura y los aires democráticos) con la vigilancia, el control, el sometimiento y la persecución que termina con la muerte.

El Parque aparece como la analogía del País en el momento histórico representado: superposición de espacios (público/privado), continuidad de procedimientos de control y exclusión, persecución y muerte para los engrillados, único destino para quienes no se ajustan a la escenografía prevista para el ocio democrático.

Con sus uñas hincadas en la tierra y su zapatilla perdida "en la horcajada del sexo apurado", el deseo homosexual no encuentra su lugar en ningún polo de la dicotomía dictadura-democracia. Lemebel abre un espacio no clasificado, que era un no-lugar-para-el-deseo, un lugar negado, clausurado. Confirmo, pues, lo dicho al comienzo de este capítulo: la operación del cronista es, primero, cartografiar el espacio

intentar recuperar el goce perdido. Se destaca en este momento del pensamiento lacaniano la preeminencia de la mirada en el deseo: el ojo es un espejo que organiza el mundo, al tiempo que se ve a sí mismo en el reflejo, multiplicando el efecto y haciéndolo infinito. Esta dinámica se observa en la crónica de Lemebel que estoy analizando; las recurrentes referencias al mirar y al ser mirado erotizan el lenguaje y son el contrapunto de "las cámaras de vigilancia" y "el halógeno delator" que cortan el flujo del deseo. 
negado, oculto, clausurado, silenciado. Desde allí produce la emisión de la voz -voz audible y reconocible por sus marcas particulares y su posición de sentido- realizando la intervención transformadora en el saber (deficitario) de los discursos que narran la historia reciente. Lo que potencia la intervención en el sistema de esos discursos -lo que le confiere su eficacia- es la construcción de un nuevo espacio para el análisis histórico y social, al tomar como objeto la resistencia del cuerpo y su deseo frente a las políticas de control y los mecanismos oficiales de represión y exclusión.

Las crónicas de Lemebel se instalan en un espacio intersticial, o como diría Aníbal González, habitan el lugar de una tensión ${ }^{117}$ : los análisis políticos o históricos convencionales no hacen lugar a los avatares del deseo, porque no hay disciplina histórica ni sección periodística atribuida a esa inmanejable energía de la vida individual y social. La economía libidinal no está en la agenda de la política global. Los textos de investigación histórica que abundan en los discursos de la posdictadura, enfocan su indagación en la búsqueda de la verdad, particularmente respecto de los responsables de las detenciones ilegales, crímenes y desapariciones durante la dictadura del general Pinochet ${ }^{118}$. Sin superponerse ni mucho menos oponerse a ellos, las crónicas de Lemebel dan cuenta de una historia particular y minoritaria, que no tenía espacio - desde luego- en las voces oficiales de la dictadura, pero que tampoco encuentra su lugar durante la apertura democrática de los 90.

Como hemos observado, Lemebel realiza su análisis a contrapelo de las dicotomías propias de los sesenta y setenta (dictadura o revolución, represión o libertad, ley o transgresión). El autor se propone cartografiar el espacio callejero "donde se

\footnotetext{
117 Ver el citado ensayo de Aníbal González, especialmente las páginas 5-26 del capítulo primero: "Modernismo, Modernidad, Filología: la escritura modernista".

${ }^{118}$ Ver: Esparza, Marcia: "Casi la verdad: silencios y secretos en la posdictadura del general Augusto Pinochet en Chile", Antípoda n ${ }^{\circ} 5$ julio-diciembre de 2007 páginas 121-141. También: Comisión Nacional de Verdad y Reconciliación: Informe de la Comisión Nacional de Verdad y Reconciliación, 1991, Vols. I, II y III, Santiago de Chile, Secretaría de Comunicación y Cultura, Ministerio Secretaría General de Gobierno.
} 
enfrentan las políticas de control y su desobediencia" (2003: 48), configurando un nuevo mapa del descontento que rehúye los límites precisos (por ello es una cartografía itinerante, móvil). El cronista sabe que los tiempos históricos no son bloques homogéneos encadenados positivamente por el consagrado esquema de las causas y sus consecuencias. Quienes protagonizaron la protesta durante la dictadura de Pinochet (pagando el precio del asesinato, la tortura, la persecución, el exilio o la exclusión) se enfrentan ahora (a pesar del gobierno demócrata cristiano de Patricio Aylwin) con "los amarres constitucionales y los aparatos de represión que la dictadura dejó intactos para custodiar probables desenfados sociales" (Lemebel 2003: 55).

Siempre hay una fuga que desmiente las explicaciones demasiado claras, o los mapas de agentes históricos abroquelados en un previsible sistema de posiciones ideológicas globales, ordenadas prolijamente de izquierda a derecha. El apego a esos esquemas afirma una voluntad de simbolizar la historia (una voluntad de verdad ${ }^{119}$ ), otorgándole significados completos (White 1978), aceptables para el pensamiento que quiere capturar la realidad en un sistema conceptual claro y legible. Nuestro autor se desentiende de este recurso a una racionalidad totalizadora y asume el desafío de narrar las cambiantes determinaciones del heterogéneo orden social, siguiendo los impredecibles flujos de territorialización de los espacios urbanos.

III.1. Procedimiento literario-historiográfico: el trabajo con el punto de vista

\footnotetext{
${ }^{119}$ El concepto de "voluntad de verdad" de Friedrich Nietzsche descubre la condición ideológica y el propósito de control inherentes a las verdades establecidas y legalizadas. Dicha condición y dicho propósito son implícitos porque la voluntad de verdad está siempre enmascarada. Como señala Andrés Sánchez Pascual en la introducción a La genealogía de la Moral: "No se trata sólo de examinar críticamente la verdad o falsedad de unas determinadas proposiciones, sino de desenmascarar ilusiones y autoengaños, es decir, de sospechar de aquello que se nos ofrece como verdadero." (Sánchez Pascual 2000: 16). La noción nietzscheana de voluntad de verdad interviene en los debates internos de disciplinas como la filosofía, la epistemología, la historiografía y la sociología. Ver especialmente: Foucault (1969; $1970 ; 1971)$.
} 
En "La esquina es mi corazón (o los New Kids del bloque)", texto que da título al volumen, el cronista se detiene en la observación de los jóvenes desocupados que pueblan los bloques, viviendas precarias con débiles y permeables tabiques de yeso:

Una bolsa cúbica que pulsa su hacinamiento ruidoso donde nadie puede estar solo, porque el habitante en tal desquicio, opta por hundirse en el caldo promiscuo del colectivo, anulándose para no sucumbir, estrechando sus deseos en las piezas minúsculas. (Lemebel 1995: 15).

La crónica está dedicada a "los chicos del bloque", y en la primera oración se presenta el procedimiento literario que configurará el texto: deslizamiento de la tercera a la primera persona del singular. Ese vaivén está sostenido por un tono muy particular. La voz del cronista lejos de la distancia que objetiva y regula el verosímil de la descripción etnográfica convencional (el "corsé cientificista" o la "retórica de representación positivista" en términos de Yanko González), construye su relato en clave afectiva. La dedicatoria inicial se continúa en la segunda oración: "Yo me fumo esos vapores en un suspiro de amor por su exilio rebelde. Un brindis de yodo por su imaginario corroído por la droga [...] expuestos y dispuestos a las acrobacias de su trapecio proletario" (Lemebel 1995: 15).

El tono, consecuente con el "suspiro de amor por su exilio rebelde", es el que opera la revolución de la mirada: el comportamiento marginal, señalado y censurable desde el punto de vista de los "integrados" (el nosotros implícito de toda enunciación) da un giro de ciento ochenta grados para mirar a estos "chicos de la pobla" desde dentro. Entonces la ampolleta quebrada y vuelta a quebrar -la agresión al alumbrado público, a la legalidad iluminada - es vista en su lógica y por lo tanto es comprendida:

Un pasar trashumante de suelas mal pegadas por el neoprén que gotea mortífero las membranas cerebrales, abriendo agujeros negros como ventanas enlutadas o pozos ciegos donde perderse para 
avizorar apenas la ampolleta del poste. Tantas veces quebrada, tantas veces repuesta y vuelta a romper, como una forma de anular su halógeno fichaje. De retornar a la oscuridad protectora de los apagones, transformando el entorno conocido en selvática de escamoteo. (Lemebel 1995: 16).

Aunque rompan las lámparas del alumbrado público y le roben a punta de pistola las zapatillas Adidas “a un loquillo pulento que vino a mover”, la alusión al pegamento mortífero los determina como víctimas que necesitan protección. El punto de vista está alineado con la mirada de los muchachos del bloque, y ello nos acerca a su comprensión del mundo sin explicaciones ni justificaciones sociológicas o psicológicas, sin condena política o moral y sin vindicación demagógica. Nos introduce en su mundo, su lenguaje y su corazón: las condiciones de vida-muerte en el bloque. Sin transición, sin comillas ni guión de diálogo, el punto de vista se desliza en el quinto párrafo hacia la primera persona y le otorga al relato - que ya tenía su mirada- la voz del protagonista. El primer texto de la colección, “Anacondas en el parque”, ya había dado paso a las miradas de los personajes, pero sin abandonar la tercera persona gramatical. Aquí el procedimiento permite que el New Kid, con su propia voz y su lengua marginal, under, caracterice su propia vida ubicada con precisión etnográfica al margen de la ley y del espacio urbano, cuyos agentes han caído detrás del horizonte de la utopía social:

Era broca y se quedó tieso cuando le pusimos la punta y le dijimos "coopera con las zapatillas, loco", y después con los bluyines y la camisa. Y de puro buenos no le pusimos el ñato, porque estaba tiritando. Y aunque era paltrón nos dio lástima y le contamos hasta diez, igual como nos contaban los pacos, igual se la hicimos al loco, porque aquí la ley somos nosotros, es nuestro territorio, aunque las viejas reclaman y mojan la escala para que no nos sentemos. Entonces nos vamos a los bloques de atrás y se queda la esquina sola porque andan los civiles y empiezan las carreras y los lumazos, hasta se meten en los departamentos y nos arrastran hasta la cuneta y después al calabozo. (Lemebel 1995: 16) 
La voz del joven está estilizada ${ }^{120}$ pero no orientada a la representación de un individuo perteneciente a un determinado tipo social, sino que está al servicio de la vocalización del registro escrito. Lemebel transpone a su escritura las voces de la esquina, pero primero ellas han sido oídas y su audición pasa a las páginas de la crónica sin perder su calidad vocal, conservando la urgencia de su enunciación que no se detiene en aclaraciones lexicales (“era broca", "no le pusimos el ñato", "era paltón” son términos propios de la jerga y no serán dilucidados ni por el protagonista ni por el narrador en tercera persona) ni aclara las rápidas alusiones a la vida en el bloque: el cronista las vierte como han sido dichas, sin aclaraciones innecesarias. Por ejemplo: "aunque estemos limpios igual te cargan y la vieja tiene que conseguirse la plata de la multa" (Lemebel 1995: 16).

En el séptimo párrafo la voz del cronista en tercera persona vuelve a enajenar el relato, aunque su enunciación se liga a la del new kid con la mención de la muerte. El joven termina su confidencia (el tono ha sido personal, reflexivo, casi confesional) con una referencia a la continuidad natural entre la vida y la muerte, propia de los bloques:

Y aunque le digo [a la vieja] que se quede tranquila, ya no me cree y me sigue gritando que son las doce, que me levante, cuando para mí las únicas doce son las de la noche, cuando me espera el carrete del viernes o sábado, para morirme un día de estos de puro vivo que estoy. (Lemebel 1995: 16)

\footnotetext{
${ }^{120}$ La estilización, definida por Mijaíl Bajtín como uno de los procedimientos de la enunciación dialógica (1963: 253-270), presenta aquí su carácter bivocal: el texto se orienta hacia su objeto -en este caso, lo que el joven protagonista de la crónica relata- y simultáneamente hacia la "voz ajena" en términos de Bajtín. Es decir, el texto presenta la voz del enunciador con sus marcas de oralidad, sus rasgos de clase, condiciones de vida y visión del mundo. Ahora bien, lo interesante es que no recae sobre su enunciación ni la más leve sombra de "objetividad" o de "intención representativa". Su voz no define ni caracteriza un tipo social, mucho menos un estereotipo. No hay representación abstracta, el procedimiento vocaliza la escritura porque está al servicio de la "posición de sentido" del hablante. Dice Bajtín: "Un estilizador aprovecha la palabra ajena precisamente como tal y con ello le confiere un ligero matiz de objetivación, pero en realidad esta palabra no llega a ser objeto, lo que al estilizador le importa es el conjunto de procedimientos del discurso ajeno, precisamente en tanto que expresión de un peculiar punto de vista" (1963: 264. Énfasis mío).
} 
El cronista entonces vuelve al propósito de registro, elaborando una analogía entre los bloques y el cementerio que muestra la condición literaria de esta crónica:

Muchos cuerpos de estos benjamines poblacionales se van almacenando semana a semana en los nichos del cementerio. Y de la misma forma se repite más allá de la muerte la estantería cementaria del hábitat de la pobreza.

Pareciera que dicho urbanismo de cajoneras fue planificado para acentuar por acumulación humana el desquicio de la vida, de por sí violenta, de los marginados en la repartición del espacio urbano. (Lemebel 1995: 16)

La metáfora es clara y eficaz. Nichos del cementerio / urbanismo de cajoneras: "la estantería cementaria del hábitat de la pobreza". Ahora atendamos a la denuncia que se filtra en el interior de la metáfora: el urbanismo planificado provoca que haya marginados en la repartición. El desquicio de la vida es política urbana y tiene un propósito definido: violencia, muerte y marginación planificadas.

Los dos primeros textos han dado las claves del volumen. Primera clave: el devenir discurso histórico/ discurso literario está articulándose a través de dos estrategias fundamentales que resumiré a continuación.

La primera: el despliegue de un punto de vista particular en el relato de los hechos. Tanto los homosexuales en la noche del parque forestal, como los chicos de los bloques son objetos de persecución -en ocasiones hasta la muerte- por parte del poder oficial, y objetos de la indiferencia social por parte de las clases que caminan por "la senda iluminada de la legalidad”. En ambas crónicas los perseguidos generan sus respectivas y diferenciadas micro-políticas de resistencia. El cronista ha cartografiado el punto de emisión de una voz singular que no tenía discurso. Y esa voz singular se presenta como una posición plena de sentido, no como un rasgo tipológico. Lo dicho se inscribe en la consideración general del problema de la polifonía de voces y consciencias en literatura, estudiado por Bajtín. Al estudiar "la lengua en su plenitud, 
completa y viva" como procedimiento artístico en la novela, el teórico ruso se enfrenta al problema de la diferenciación lingüística y las nítidas "características discursivas" de los personajes:

Cuanto más objetual ${ }^{121}$ aparezca el personaje, tanto más claramente se dibuja su fisonomía discursiva. Ciertamente, en la novela polifónica la importancia de la heterogeneidad lingüística y de las características discursivas se conservan, pero disminuyen y, sobre todo, cambian las funciones artísticas de estos fenómenos. [...] Lo que importa es bajo qué ángulo dialógico se confrontan o se contraponen en la obra. [...] La comunicación dialógica es la auténtica esfera de la vida de la palabra. Toda la vida de una lengua en cualquier área de su uso (cotidiana, oficial, científica, artística, etc.) está compenetrada de relaciones dialógicas. [Estas] Deben ser investidas por la palabra, llegar a ser enunciados, llegar a ser posiciones de diferentes sujetos, expresadas en la palabra, para que entre ellas puedan surgir dichas relaciones. (Bajtín 1963: 254-256. Énfasis en el original)

La voz singular de los chilenos que no habían sido oídos por ningún discurso se imbrica en las crónicas con el espacio connotado por la oposición luz/oscuridad. La metáfora de la luz como delatora y la sombra como estrategia de protección y complicidad se percibe más que como un recurso estilístico, como una regla de producción del significado: el espacio es mucho más que un "escenario" o "marco" en el que se desarrollan los hechos. El espacio permea el tiempo y las conciencias de los personajes: el parque forestal, su humedad y su sombra; la esquina de los bloques, su oscuridad cómplice y su pertenencia (la esquina es "nuestro territorio", no conquistado por las fuerzas del orden) les ofrecen a los protagonistas las condiciones de su ser y estar en la ciudad, intransferibles a otro espacio, pertenecientes a ese lugar. Espacio, tiempo, voz y personajes son categorías literarias, pero aquí juegan un papel decisivo en la construcción del discurso que va a historiar, que está haciendo historia. Como lo sostiene Hayden White, la configuración literaria es una necesidad inherente al relato de

${ }^{121}$ En la traducción del libro de Bajtín que manejamos, el adjetivo "objetual" aparece siempre en un sentido inequívoco: como relativo a la representación objetivada de un personaje, en la que se subrayan sus aspectos caracterológicos. 
los hechos, por cuanto es esa articulación ficcional la que provoca una experiencia de los sucesos narrados, y no meramente una estructura imaginaria, ideal, ajena a los sentidos. La configuración literaria de la crónica es la clave, por lo tanto, de su intervención en el relato de los acontecimientos históricos que ilustran la situación de los grupos silenciados aun durante el gobierno de Patricio Aylwin. Por ello la mención a la risa presidencial no resulta gratuita ni insignificante:

La esquina de los bloques es el epicentro de vidas apenas asoleadas, medio asomándose al mundo para casetear el personal estéreo amarrado con elástico. Un marcapasos en el pecho para no escuchar la bulla, para no deprimirse con la risa del teclado presidencial hablando de los jóvenes y su futuro. (Lemebel 1995: 1415. Énfasis mío.)

La esquina es definida con dos sustantivos poderosos: epicentro (de vidas) y marcapasos (en el pecho). La esquina da la posibilidad de sobrevivir resistiendo la muerte planificada de la urbanización posdictatorial. El pulso resiste, aunque sea ignorado por "la bulla" (el efecto metonímico es inmediato: burla) de la risa presidencial. Procedimientos literarios como la metáfora, la metonimia, la reiteración anafórica (lo veremos en seguida en "La Babilonia de Horcón") potencian en el discurso de la crónica el devenir historia/literatura (o literatura/historia, el devenir no tiene dirección única).

Segunda estrategia: la construcción de un espacio de reflexión para el análisis histórico y social, que tiene en cuenta al deseo como fuerza configuradora de lo humano; por lo tanto, el deseo se erige también como fuerza de resistencia a las estrategias de control -inhumanas, deshumanizantes- de la posdictadura. Este nuevo espacio de análisis genera la apertura de un nuevo registro de acontecimientos en la agenda de los discursos históricos: las políticas del deseo. La continuidad de los métodos autoritarios en las estrategias de control urbano durante la transición se 
manifiesta una vez más en la crónica "La Babilonia de Horcón” (Lemebel 1995: 18-21).

El cronista narra el anonimato y el desnudo indefenso de una mujer transgresora, inocente y sin nombre, la Babilonia, primera desaparecida-exiliada en democracia.

La Caleta el Horcón ${ }^{122}$ es un balneario de la pintoresca costa central del país. La crónica no nos da detalles del lugar, pero en su desarrollo narrativo advertimos que se trata de un lugar conquistado por la clase política chilena, cuyo alto poder adquisitivo le permite comprar casas en Cachagua o alquilar una de "las cabañas aeronáuticas de CauCau”. La reiteración del adjetivo no es un procedimiento meramente estilístico (tal como no lo es el claroscuro de "Anacondas..." o "La esquina..."), sino que es un elemento que describe la apropiación del espacio por parte de aquellos que -todavíadetentan el poder económico, político y militar:

Caminando entre los autos vestida sólo con una copa en la mano, justo al ocaso de la tarde, cuando la comunidad política que se compró casa en Cau-Cau saca a pasear el perro. La familia política que comenta los últimos virajes de las presidenciales, mientras acarrean sacos de machas y limones a los autos japoneses. Las señoras políticas que hacen sonar sus pulseras de plata, mientras hurguetean los cachivaches artesanales que se amohosan al vaho salobre de la caleta. Los caballeros políticos en guayabera y short, comprando el whisky para tomárselo en Cachagua o en las cabañas aeronáuticas de Cau-Cau. Una playa semiprivada donde el perraje se descuelga por andamios y peñascos, y el jet renovado arrastra los pareos franceses por escalinatas de piedra al ritmo de la celulitis. (Lemebel 1995: 19. Énfasis mío)

En este breve fragmento es muy notable la alta condensación de procedimientos ordenados a la historización del suceso. Me voy a detener en ellos. El primero y ya señalado es la reiteración del adjetivo "política" -familia y comunidad- "políticas"-las señoras- "políticos" -los caballeros- efectuando en el discurso narrativo la ocupación, la conquista, la apropiación del territorio. Los autos japoneses, las pulseras de plata, el

\footnotetext{
${ }^{122}$ Horcón se ubica a 44 kilómetros al norte de Viña del Mar y a 163 al noroeste de Santiago.
} 
whisky y las cabañas aeronáuticas de Cau-Cau (barrio "semiprivado" del que será expulsada la causante del escándalo) ajustan el efecto de conquista: son los emblemas del poder económico y del poder militar de la "familia política" de la "comunidad política", de las "señoras políticas" y de los “caballeros políticos". Poder políticoeconómico-militar, comentando "los últimos virajes de las presidenciales" mientras se deslizan en sus autos japoneses.

Otro procedimiento no menos eficaz es la distinción de clases en la Caleta el Horcón. Al final del fragmento citado, se establece la marcada diferencia social en la playa de Cau-Cau: “el perraje se descuelga por andamios y peñascos, y el jet renovado arrastra los pareos franceses por escalinatas de piedra al ritmo de la celulitis". Pero es en el episodio central donde se demuestra la diferencia que genera la exclusión. En primer lugar, la protagonista no tiene nombre, ni filiación de ningún tipo. Tampoco tiene hogar porque vive en la calle y en la playa; se alimenta de mariscos que le arrojan los pescadores: "Tal vez un indefenso desnudo llamado Babilonia, acurrucado en su preñez de anonimato, provocara la alarma". El cronista le arrebata también la distinción de género, aunque las voces de los otros la identifican como mujer, desnuda "aun cuando estaba embarazada". Su desnudo indefenso, su gusto por "empilucharse" (hasta se “encarama pilucha al techo del furgón policial”) provoca la reacción de un personaje central, invisible pero poderoso: el "nosotros" implícito del relato (el mismo que ya había aparecido en "La esquina es mi corazón”). El personaje colectivo aparece sin transición, sin que sea necesaria ninguna referencia, su elisión no provoca ninguna pregunta en los lectores porque sabemos quién es: "Por eso pusimos el cartel y escribimos que la señorita Babilonia, que no sabe su nombre, queda expulsada del balneario. Y nadie dijo nada, nadie se hizo cargo, porque hasta a los hippies con su paciencia oriental, ya los tenía hasta el cintillo”. (Lemebel 1995: 19). 
Este último elemento es digno de atención. La clase política ocupa y determina la distribución de espacios, detenta y ostenta poder. Pero lo que define la expulsión es el "nadie dijo nada, nadie se hizo cargo". El silencio cómplice es el gran tema de este libro. El poder político en complicidad con las estructuras vigentes del aparato militar, en el presente (el presente de esta crónica es 1995) legitimado por la Concertación; más el silencio público en complicidad con las políticas de consenso auto-impuestas por la presidencia y los partidos que integran la coalición gobernante. La frase más significativa de la crónica es la que constituye el tercer párrafo, destacada por los puntos y aparte que la flanquean: "Entonces todo quedó en calma y la Babilonia desapareció en el camino a Viña inaugurando el primer exilio en democracia.” (Lemebel 1995: 19)

Por eso el cronista como la Babilonia, "acurrucado en su preñez de anonimato", provocará las alarmas al señalar la red de complicidades que determina la exclusión y es la causa de la continuidad en lo real de las prácticas más aberrantes de la dictadura militar.

He postulado que en la escritura de Pedro Lemebel se producen múltiples devenires minoritarios. El adjetivo, en este contexto, no pretende calificar a ciertas literaturas o a ciertas obras literarias, tampoco a determinados autores, sino a las condiciones de una escritura que traza -en un movimiento que es político- una línea de heterogeneidad en un sistema mayor, al que pertenece y al que desequilibra a la vez (ver a propósito la nota 116). La escritura de Lemebel traza líneas de heterogeneidad que intervienen en la serie histórica, al atravesar y alterar en ella elementos considerados sustanciales, aquellos que logran definir su estructura, su verosímil, su ley o conjunto de leyes.

A continuación haré un breve análisis de dos textos que fueron dados a conocer a la ciudadanía chilena en junio del año 2000, circularon y fueron leídos en programas 
radiales y televisivos, ocuparon los comentarios de las columnas políticas y editoriales de los diarios santiaguinos, y fueron reproducidos en las escuelas e instituciones educativas del país durante los años subsiguientes, especialmente durante la presidencia de Ricardo Lagos. Me refiero a la "Declaración de la mesa de diálogo sobre Derechos Humanos" y al discurso del presidente Lagos al momento de recibir esa Declaración y comunicársela a la ciudadanía. ${ }^{123}$ Ambos discursos se refieren a la historia reciente y tienen un propósito ideológico a medias confesado: pacificar, a cualquier precio, y mantener la estabilidad -aunque ello comprometa su plena vigencia- de las instituciones democráticas. Esta instancia particular integra la larga cadena de los esfuerzos realizados por los gobiernos de la Concertación para lograr "consensos" y "reconciliación" en el lastimado tejido social chileno, habida cuenta de los vejámenes y violaciones a los derechos humanos que sufrieron los opositores al régimen del general Pinochet. Las más graves de estas violaciones fueron, desde luego, las detenciones ilegales que terminaron en la desaparición y muerte de los ciudadanos a manos del aparato estatal.

La Mesa de Diálogo fue convocada 21 de agosto de 1999 por el presidente Eduardo Frei. En las semanas anteriores el Ministro de Defensa del gobierno de Frei, Edmundo Pérez Yoma, había anunciado públicamente la medida, aun antes de asegurar la participación de quienes pensaba invitar. La Agrupación de Familiares de Detenidos Desaparecidos rehusó sumarse a la iniciativa y también declinaron el llamado algunos abogados de derechos humanos. Paralelamente, el Partido Comunista expresó su enérgica oposición. Quienes se oponían a la Mesa sostenían, entre otras razones, que esta medida buscaba frenar la creciente acción de los tribunales de justicia en casos de derechos humanos y obtener la amnistía para los militares responsables de la

\footnotetext{
${ }^{123}$ Disponibles online por el gobierno de Chile: http://www.ddhh.gov.cl/filesapp/Declaracion_Acuerdo_Final.pdf http://www.ddhh.gov.cl/filesapp/Discurso_Presidente.pdf
} 
desaparición de personas y otras violaciones a los derechos humanos. José Zalaquett expresa claramente en su análisis sobre este período de la historia reciente:

Las Fuerzas Armadas y Carabineros no se hallaban en disposición de aceptar una responsabilidad de sus instituciones por violaciones a los derechos humanos. Más aún, se les hacía difícil aceptar expresamente que las violaciones a los derechos humanos respondieron a una política del gobierno militar. (Zalaquett 2000: 1314)

En efecto, el informe final (llamado "Declaración de la Mesa de Diálogo sobre Derechos Humanos") no condena en ninguno de sus párrafos los crímenes de lesa humanidad cometidos por la dictadura del General Augusto Pinochet.

Tomaré algunos fragmentos de esa Declaración para observar cómo funcionan argumentativamente, en virtud de una estrategia dominante: el retaceo de ciertos significados que, no obstante, poseen la fuerza del implícito; ésta no puede neutralizarse. Como veremos luego, la crónica de Lemebel desenmascara la ambigüedad del documento y denuncia sus zonas de silencio cómplice.

Fragmento de la Declaración de la Mesa de Diálogo:

Chile sufrió, a partir de la década de los '60, una espiral de violencia política que los actores de entonces provocaron o no supieron evitar. Fue particularmente serio que algunos de ellos hayan propiciado la violencia como método de acción política. Este grave conflicto social y político culminó con los hechos del 11 de septiembre de 1973, sobre los cuales los chilenos sostienen, legítimamente, distintas opiniones.

Sin embargo, hay otros hechos sobre los que no cabe otra actitud legítima que el rechazo y la condena, así como la firme decisión de no permitir que se repitan. Nos referimos a las graves violaciones a los derechos humanos en que incurrieron agentes de organizaciones del Estado durante el gobierno militar. Nos referimos, también, a la violencia política cometida por algunos opositores al régimen militar.

En especial, nos preocupa hondamente la tragedia, aún no resuelta, de los detenidos desaparecidos. Es imperativo y urgente contribuir a superar este problema. Ello requiere por parte de todos un 
espíritu de grandeza moral que nos permita concordar medidas efectivas para ese fin. (Documento online:

http://www.ddhh.gov.cl/filesapp/Declaracion_Acuerdo_Final.pdf)

El primer párrafo del fragmento citado expresa, en el nivel del enunciado explícito, que Chile sufrió la violencia política durante la década del '60. Dicho conflicto, afirma el documento, “culminó con los hechos del 11 de septiembre de 1973”. De ello se podría deducir, si no conociéramos los acontecimientos históricos claramente documentados, que "los hechos del 11 de septiembre" no incurrieron en violencia política. No obstante, en el segundo párrafo se afirman las violaciones a los derechos humanos cometidos por el gobierno militar. La contradicción es tan flagrante que para un lector imparcial resulta absolutamente incomprensible. Poniendo en contexto los enunciados, comprendemos que lo que predomina es una voluntad de verdad que -tal es su naturaleza- enmascara lo que esa voluntad quiere, su propósito en este caso: arribar a un consenso "obligatorio" (según el presidente Lagos "necesario") sea o no sea posible desde el punto de vista de la evaluación de los acontecimientos realmente sucedidos. Ajusta ese propósito la deliberada y evidente omisión de la construcción sustantiva “golpe de estado", en cuyo lugar se lee: "los hechos del 11 de septiembre de 1973".

El tercer párrafo, para quienes conocemos los hechos (y es forzoso señalar: para todo el pueblo chileno) resulta ominoso: el documento llama "problema" a la desaparición y muerte de miles de chilenos a manos de las fuerzas armadas, sin juicio previo, con metodologías cruentas y en el marco de la más flagrante ilegalidad. No puede no ser calificado de cínico el llamado a "superar este problema", cuando todos los lectores de ese documento sabemos que los desaparecidos están muertos, y que no hay ninguna posibilidad de "superar" ese "problema". A todas luces el documento escamotea la lúgubre verdad, y su registro ambivalente esconde o pretende ocultar su voluntad de verdad: la "ambigua transición" (en términos de Lemebel) quiere a toda 
costa la reconciliación forzada y la paz obligatoria. Sus armas serán la amnistía y el silencio.

Pedro Lemebel le dedica a este documento y a su contexto histórico, una crónica incluida en Zanjón de la aguada: "La mesa de diálogo (O el mantel blanco de una oscura negociación)" (Lemebel 2003: 283-286). En ella el autor hace resonar las palabras que aparecen silenciadas en el documento y en el discurso presidencial: impunidad, impunidad, impunidad (tres veces), crímenes, cadáver, olvido:

La palabra impunidad aunque no se diga se asoma y juguetea en la boca irónica de los generales. Es más, la palabra impunidad, aunque no ${ }^{124}$ se diga, es la única que resuena en los ecos de este diálogo conciliador. Alguna mano nerviosa derrama una copa y mancha con unas gotas espesas el albo mantel. Otra mano de botamanga con galones alcanza un canapé y mordisquea su sabor a cadáver descompuesto. (Lemebel 2003: 285)

Una vez más la metonimia del texto poético de Lemebel hace historia: es en el evocador contraste de las "gotas espesas" que manchan "el albo mantel" donde se restituye el sentido escamoteado en el documento: sangre. La mano nerviosa, la "mano de botamanga con galones" se lleva a la boca el canapé con "sabor a cadáver descompuesto". La ambigüedad del sustantivo "mesa" es aprovechada poéticamente por Lemebel para reponer el sentido negado en el elíptico documento: "somos capaces de brindar con sangre con nuestros verdugos, en la blanca mesa de la reconciliación". Antes de nombrar en su crónica a los invitados a esta mesa, la llama: "última cena del siglo por los derechos humanos" (Lemebel 2003: 284) imagen que remite a la traición y al vino transubstanciado en sangre. La operación histórico-poética es de una altísima condensación de sentido. La crónica de Lemebel logra remontar la ominosa operación

\footnotetext{
${ }^{124}$ Corrijo la errata de la versión que aparece en el volumen de Seix-Barral, pág. 285 (allí se omite el "no"), y sigo la versión original aparecida en la Revista Punto Final del $1^{\circ}$ de octubre de 1999: "La palabra impunidad se asoma y juguetea en la boca irónica de los generales. Es más, la palabra impunidad, aunque no se diga, es la única que resuena en los ecos de este diálogo conciliador".
} 
de escamoteo y silencio cómplice que realiza el documento. Otro significado potenciado en la crónica y minuciosamente borrado en el documento y en el discurso presidencial, es el reclamo elocuente en la calle:

Y afuera, en la calle, frente al palacio presidencial, las caras de los desaparecidos en los carteles borrosos que los familiares sujetan en el corazón. Y son estas fotos lo único que de ellos quedó, lo único que los hace presentes al margen de este vomitivo cenáculo. Tal vez en la calle, de cara al sol que ilumina sus extintos rostros, es en el único sitio donde pueden estar tan vivos, tan frontales como una proclama ética que devela el punto final buscado en este acuerdo. (Lemebel 2003: 285-286)

El discurso del presidente Lagos también ignora el reclamo de los familiares en las calles, y lo que él llama "la diversidad de Chile" se encuentra, según sus palabras, perfectamente representada en los 24 miembros de la mesa y nada más. El párrafo en el que resuenan los implícitos, donde se manifiesta la voluntad de no-decir las cosas como fueron, es el siguiente:

Pero también este documento se hace cargo de las tareas que están pendientes. Cómo hacer ahora para que todos nosotros, la patria toda, se comprometa con este texto, para que no vuelvan a ocurrir estos hechos nunca más en nuestra historia. Y luego, cómo -a partir de eso- damos cuenta de las tareas pendientes, que en lo esencial tienen que ver con cómo ideamos una forma ecuánime, adecuada, justa, para encontrar a los que todavía no están. (Lagos 2000: Online)

La omisión deliberada del término "cadáveres” resulta evidente, muy notoria. El presidente -democráticamente elegido- en un mensaje a la ciudadanía, señala como "tareas pendientes" idear "una forma ecuánime, adecuada, justa, para encontrar a los que todavía no están”, como si traerlos de regreso fuera posible, como si el efecto durativo dado por el adverbio ("todavía") abrigara alguna esperanza de actualizar la presencia de los que estarán por siempre ausentes. La triple adjetivación: “ecuánime, adecuada, justa" resulta inverosímil en la palabra de un jefe de estado que sabe 
positivamente que se está refiriendo a crímenes aberrantes. Tan aberrantes que los perpetradores (sentados a la Mesa de Diálogo cuyo documento se elogia en este comunicado oficial) han hecho desaparecer, no solamente los cadáveres, sino cualquier vestigio de su paradero. Lemebel también se refiere a este hecho en su crónica:

Enfrente, los carachos impávidos del poder militar, la cara dura de su sarcasmo cuando aseguran no tener ningún dato sobre el destino de los cuerpos desaparecidos, que no se sabe nada, excepto si esta mesa ofrece garantías de absoluta reserva para algún uniformado, que en forma personal quiera entregar información. (Lemebel 2003: 285)

En los discursos históricos analizados por Barthes (1970a: 35-50) uno de los elementos sustanciales al discurso de la historia es lo que él llama "enunciación", al cual define de la siguiente manera:

Se trata del caso en que el enunciador dispone "ausentarse" de su discurso, produciéndose, por consiguiente, una carencia sistemática de todo signo que remita al emisor del mensaje histórico: parece que la historia se cuenta sola. Ese hecho tiene antecedentes considerables, pues corresponde en realidad al discurso histórico llamado "objetivo" (en el cual el historiador nunca interviene). En tal caso, el enunciante anula su persona pasional pero la sustituye por otra persona objetiva; el sujeto subsiste plenamente, pero como sujeto objetivo [...] A nivel del discurso, la objetividad -o carencia de signos del enuncianteaparece así como una forma particular de lo imaginario, el producto de lo que podría llamarse la ilusión referencial, puesto que el historiador sostiene que deja hablar solo al referente. (Barthes 1970a: 41-42)

Este elemento determinante de algunos discursos históricos clásicos (Barthes toma como ejemplos a Herodoto, Maquiavelo, Bossuet y Michelet) implica un punto de vista general, totalizante y abarcador, y una falsa posición "prescindente" respecto de los hechos narrados, la cual es considerada por Hayden White como un "ideal imposible 
de claridad y literalidad" (2003: 49) con el que se comprometió la historiografía durante el siglo $\mathrm{XIX}^{125}$. Este ideal determinó, para White

[...] el fracaso de los historiadores profesionales en nuestro propio tiempo para hacer de los estudios históricos una ciencia. El reciente "retorno a la narrativa" manifiesta el reconocimiento entre los historiadores de que un escrito más "literario" que "científico" es lo que se requiere para un tratamiento específicamente historiológico de los fenómenos históricos. (White 2003: 49)

Más allá de la encendida defensa del modelo tropológico y el "retorno a la narrativa" que White postuló, y habida cuenta de los debates que esta poblemática generó en el seno de la disciplina durante las tres últimas décadas del siglo $\mathrm{XX}$, las posiciones no están unificadas y la polémica continúa. Prueba de ello son las frecuentes referencias del propio White a sus detractores. Por ejemplo:

[...] la principal corriente de historiadores profesionales tiende a desconfiar tanto de la teoría como de la filosofía de la historia; ambas son vistas como fuentes de distorsión "ideológica" en la reconstrucción del pasado. [...] La única "teoría de la historiografía" admitida por los historiadores profesionales son las reglas para escribir historia honradas por el establishment historiográfico en un tiempo y lugar determinados. A cualquiera que trate de conceptualizar una historia de estas reglas, sus variedades y los cambios que han sufrido a lo largo del tiempo en un lenguaje distinto al sancionado por estas mismas reglas, inmediatamente se le tildará de hacer teoría o de practicar la despreciada "filosofía de la historia" (White 2003: 50).

Desde luego, Pedro Lemebel no es un historiador profesional y por lo tanto no integra el establishment del que habla White ni lo combate. No obstante, consciente de su desafío, se propone revocar el silencio cómplice de sus contemporáneos y toma la palabra a través de sus crónicas. La suya y las de otros protagonistas de la historia de

\footnotetext{
${ }^{125}$ White reformula en ese trabajo la hipótesis central de Metahistory: "debido a que el lenguaje ofrece diversas formas de construir un objeto y fijarlo en una imagen o concepto, los historiadores tienen una elección en las modalidades de figuración que pueden usar para tramar las series de acontecimientos manifestando diferentes significados" (2003: 49).
} 
Chile son voces que han sido ignoradas, desoídas, negadas, invisibilizadas. La voz de Lemebel se ubica fuera del pacto de silencio, impunidad y olvido:

Allá ellos, los que aceptaron compartir esta mesa de naipes con cartas marcadas. Acá nosotros, fuera del juego, con el recuerdo de Sola Sierra y junto a las madres, familiares y el temple moral de Viviana Díaz y Mireya García, insobornables en su demanda de justicia sin apellido. Allá ellos, en su larga mesa de reconciliación, compartiendo el pan amargo del olvido y el vino infectado por el brindis de la impunidad. (Lemebel 2003: 286).

Lemebel expresa la exigencia de justicia y la declara insobornable, inconciliable con la demanda de impunidad, enmascarada bajo el pretexto de la reconciliación. Para ello señala los dos campos: “Allá ellos, [...] Acá nosotros”. En su discurso el presidente Lagos propone el consenso obligatorio ("Este acuerdo nos permite mirar al futuro por encima de interpretaciones encontradas de nuestra historia") pero inocultablemente, reconoce una brecha, y otra vez la fuerza del implícito es más fuerte que la omisión de los significados:

También quiero agradecer la valentía y coraje de los abogados de derechos humanos, de aquellos que durante tanto tiempo lucharon por abrir un espacio y, con coraje y valentía también, aceptaron sentarse a dialogar con altura de miras sobre un tema especialmente doloroso para ellos. (Lagos 2000: Online)

La última frase delata el sentido general del documento: el tema de los desaparecidos es doloroso "para ellos", no para "nosotros", ese nosotros implícito que ya hemos señalado en las crónicas de Lemebel, el que expulsa a la Babilonia de la Caleta el Horcón, o el que aparece en la crónica de los muchachos del bloque como la posición de sentido ocupada por "los integrados", los que caminan por la "senda iluminada". En el discurso de Lagos el "nosotros" implícito dibuja la herida que el documento trata de disimular en el tejido social chileno de fines de los noventa. 
En el corazón de la pequeña burguesía chilena de esos años noventa, el cronista denuncia la doble moral que la marca y la complejiza. En el texto "Baba de caracol en terciopelo negro" (Lemebel 1995: 23-24), el cuarto de la colección, el narrador -que en este caso no abandona la tercera persona gramatical- describe las prácticas autoeróticas, más o menos clandestinas, de los clientes habituales del cine Nagasaki, caracterizado como "un territorio pendular" porque en él son atravesadas las rígidas divisiones entre clases que tabican la vida social de puertas para afuera. Pero la metáfora más eficaz -en lo que atañe a la denuncia de la doble moral-es, a mi juicio, la "radiografía obscena del álbum familiar". En un tono reflexivo y sin pretensiones apodícticas, el cronista afirma:

Quizás a toda luz los deseos se compriman, y en este terciopelo enguantado, aflore el revés de todo rostro puritano que se cruza con otro en el vaivén del paseo público. [...] Quizás la función en las butacas sea el espejo de la superproducción empañado por el urgimiento y la paranoia. Lo que no se dice y nadie sabe, porque al final de cuentas el sexo en estas sociedades pequeño burguesas sólo se ejercita tras la persiana de la convención. [...] Ninguna esposa reconocería a su negrito en esas acrobacias, por cierto otro. Una sociedad secreta de desdoblaje. (Lemebel 1995: 24)

En efecto, el álbum familiar se desdobla; la crónica muestra el negativo de la imagen esperable del oficinista, empleado público o bancario ("lo que no se dice y nadie sabe"); narra lo negado, la cara oculta del padre de familia ("Nadie sabe de los suspiros nocturnos del macho, que en la mañana vocifera porque no encuentra la corbata"). La historia privada revela un estado de cosas que la Historia oficial (la Historia de los historiadores, ha dicho Michel Foucault) no puede revelar por imperativos estrictamente epistemológicos: los discursos de la historiografía no pueden revelar los pliegues de la doble moral, porque no están diseñados para ello. Faltan el tono personal propio del punto de vista particular o íntimo, siempre minoritario; el registro de los detalles, 
especialmente de la vida privada de quienes han caído del régimen social medio o superior; y falta sobre todo el lenguaje literario que dé cuenta de esos pliegues.

Por ejemplo, en el primer texto analizado de esta colección, “Anacondas en el parque", términos como: "convierte la clorofila del pasto en oleaje de plush rasurado por el afeite municipal", o: "culebras que se frotan en el pasto", o bien: "parejas de la mano que pasan anudando azahares por la senda iluminada de la legalidad" permiten al lector (que es también espectador por la calidad escénica del relato) registrar lo narrado en una dimensión que el lenguaje opaco y oficial de la convención historiográfica no puede dar ni sugerir. Tampoco las demás disciplinas se han hecho cargo de las políticas del deseo hasta la aparición del psicoanálisis. Conviene recordar que sólo el discurso literario -en el campo de las formaciones discursivas establecidas- había abordado la temática del deseo antes del siglo XX, y en términos más generales, la preocupación por el cuerpo y sus demandas. Ni la medicina, ni la filosofía (hasta la figura polémica y las argumentaciones tardíamente aceptadas de Friedrich Nietzsche acerca de la pulsión), ni mucho menos la Historia durante la época clásica o los discursos de las religiones dominantes habían asumido como propio este "oscuro objeto" llamado deseo.

En su célebre Arqueología del saber, Michel Foucault establece con claridad la distinción entre disciplinas y saberes. Estos últimos se configuran como positividades surgidas a partir de una práctica discursiva que forma objetos, enunciados, conceptos: "una práctica discursiva puede formar grupos de objetos, conjuntos de enunciaciones, juegos de conceptos, series de elecciones teóricas" (1969: 304-305). Los saberes son aquello a partir de lo cual se construyen proposiciones, se desarrollan descripciones, se efectúan verificaciones, se despliegan teorías, ponen en relación objetos y sujetos, diseñan estrategias de discurso y de acción. La práctica discursiva que configura un saber también asume, por cierto, una estética y una posición ideológica respecto de 
cuestiones vigentes y en debate. Por lo tanto, los saberes no siempre están destinados (o no necesariamente) a la constitución de una ciencia. En este caso, las crónicas como prácticas discursivas en sentido foucaultiano, se configuran como un saber, poniendo en relación objetos y enunciados, sujetos y proposiciones que dan cuenta de un particular estado de cosas desde una perspectiva - una mirada- que no había participado del juego, es decir, cuyo punto de vista era, hasta el momento, silenciado o por lo menos silencioso. Las crónicas de nuestro autor configuran un nuevo saber y un lugar diferenciado de enunciación: hacen hablar al cuerpo, narran desde una experiencia que no tenía discurso.

En el texto "Censo y conquista (¿y esa peluca rosada bajo la cama?)" se hace explícita la intención de registrar las "micropolíticas de sobreviviencia que trabajan con el subtexto de sus vidas, escamoteando los mecanismos del control ciudadano" (Lemebel 1995: 58). La primera operación de este texto, como lo indica su título, es homologar el primer censo de la conquista $^{126}$ con el censo contemporáneo que se registra (con toda seguridad el autor hace referencia al censo poblacional llevado a cabo en Chile en 1992, en el que se contaron 13.348.401 habitantes). Ahora bien, el eje de la comparación está claramente establecido: el acoso a la intimidad y la intrusión, con el único propósito -según el autor- de ajustar el control y detectar "las imbricaciones clandestinas que van alterando el proyecto determinante de la democracia”.

El gobernador colonial Agustín de Jáuregui, quien ordenó el primer empadronamiento general de población en 1778, se caracterizó por poner en práctica una política enérgica en materia de seguridad ciudadana, dictando medidas severas contra los ladrones, vagos o mendigos y aquellos que violaran el toque de queda;

\footnotetext{
${ }^{126}$ Cabe aclarar que no fue realizado por los jesuitas, como afirma la crónica. La Compañía de Jesús había llegado a establecerse en Chile en 1593, por orden del Rey Felipe II de España, y fue expulsada en 1767 por decisión del rey Carlos III, diez años antes de la realización del primer empadronamiento general de población, ordenado por el gobernador Agustín de Jáuregui entre 1777 y 1778, el cual dará paso a los primeros censos oficiales en ese territorio.
} 
también contra la embriaguez, el crimen y el ocio. Aunque Lemebel es inexacto al atribuirles el procedimiento de control a los jesuitas (error voluntario o desliz, no lo sabemos), está claro que el propósito de controlar las prácticas ciudadanas domina los dos censos, y articula la evocación histórica que promueve la analogía colonizacióncontrol democrático (en la crónica se habla de "el recolonizaje por la ficha"). La crónica que nos ocupa no tiene como propósito ni registrar ni narrar la ejecución o los resultados del censo; el autor ni siquiera se preocupa por darnos la fecha, ni los habitantes contados, ni las viviendas registradas. Como lo afirma el narrador, nos muestra el "subtexto", vale decir, por un lado el propósito no declarado ("Supuestamente para ajustar los índices de carencias con el desarrollo de la economía [...] el súper censo como oso hormiguero mete su trompa en los pliegues mohosos de la pobreza"), y por otro, la desobediencia civil que despliega su estrategia sutilmente, engañando a la "gran visitación con el atuendo de asistente social" con el fin de eludir el mecanismo de control y así poder continuar con sus medios de vida marginales (el travestismo, la droga, la prostitución) que aparecen en el relato con la naturalidad propia de la vida cotidiana y constituyen "el negativo del censo que no tiene casillero".

Como afirma Hayden White, las crónicas (también los anales) no son "historias imperfectas", como convencionalmente se las considera, sino más bien "productos particulares de posibles concepciones de la realidad histórica, concepciones que constituyen alternativas, más que anticipaciones fallidas del discurso histórico consumado que supuestamente encarna la historia moderna". (White 1978: 21-22).

La falta de precisión histórica que he señalado particularmente en este texto, no es inocente ni casual. Esta ausencia de datos precisos y de reconstrucción "acabada" del contexto histórico tanto colonial como contemporáneo en el que se produjeron ambos acontecimientos, no nos permite remitir el significado del texto al propósito de darle 
"sentido histórico" al censo de 1992 ni al de 1778. Es decir, no existe por parte del enunciador la menor voluntad de narrativizar los hechos con el fin de incorporarlos y hacerlos significativos dentro de una secuencia ordenada y teleológica. Incluso puede resultar frustrante para la expectativa del lector actual que se acerca a la crónica con un deseo de información precisa y específica. No hay introducción, simplemente comienza. No hay conclusión ni cierre, simplemente el texto termina. No obstante, hay relato; y desde luego, relato histórico. Tampoco encontramos continuidad, esa estructura que identifica a los elementos del relato como parte de un todo, pero ello no significa que no haya discurso histórico. El texto de Lemebel opera según otro principio, otra regla de construcción del significado. Se propone leer en los pliegues del acontecimiento, y construir un saber del contenido invisibilizado: aquello que el censo no registra, ni la asistente social vuelca en su ficha por cuanto no hay encuesta oficial que pueda medir el azul de las ojeras, o ubicar en algún casillero "la otra parte del presupuesto familiar", cuya procedencia el texto sugiere a través de algunas palabras clave: la peluca rosada y los tacos altos del hijo mayor, que manda regalos desde Iquique; la hija de dieciocho años que se esconde detrás de la cortina para que la censista "no le vea el patinaje violáceo de las ojeras", o "la movida del hijo menor que le va tan bien trabajando con un tío desconocido que le compra zapatillas Adidas y lo viene a dejar en auto”.

Las preguntas del censo contemporáneo, tanto como aquellas de la época colonial, no comparten con sus destinatarios el mismo interés por el sistema social, ni lo comprenden ni lo experimentan de la misma manera. Ese interés determina y encauza la concepción y percepción de las tensiones y los conflictos, las carencias y necesidades sociales con sus respectivos anhelos de resolución. El tema de esta crónica es el doble fondo del sistema legal en el que se sostiene el sistema social. Al enfrentarse (durante los dos censos evocados) dos comprensiones completamente distintas de ese sistema, 
tiene lugar el conflicto. Todo texto historiográfico está sostenido por una representación de la realidad que opera tanto en lo que narra como en lo que omite. Las tensiones puestas en juego se resuelven aquí -en este texto particular- a través del escamoteo: tanto los pobladores del siglo XVIII como los del siglo XX eluden la "avalancha de acoso" a su intimidad, y contestan las preguntas en otro registro:

Los indígenas contestaban sin la matemática de la pregunta [...] contestaban ocho u ochocientos por decir algo, por la posición de los labios al recircularse en ocho. Decían mil por el campanilleo de la lengua aleteando como un insecto extraño en el paladar. Elegían el tres por el silbido del aire al cruzar sus dientes rotos. Murmuraban seis por el susurro de la ese en la lluvia benefactora sobre sus techos de paja. [...] Desviando elípticamente el ítem paralelo de la encuesta, fugándose de la interpelación con una aparente idiotez que desbarataba los cálculos góticos de los misioneros. (Lemebel 1995: 59)

Otro tanto ocurre con los encuestados contemporáneos:

La otra parte del presupuesto familiar [...] se enmascara de azulada inocencia para el ojo censor. [...] De esta manera, las minorías hacen viable su tráfica existencia, burlando la enumeración piadosa de las faltas. (Lemebel 1995: 60).

El aspecto más interesante de esta breve crónica es aquello que la hace, al mismo tiempo, cuestionable o dudosa en cuanto a su autenticidad, y susceptible de ser considerada relato histórico. La crónica sostiene su coherencia formal en la construcción de un punto de vista que desdobla lo que podría concebirse -según la representación de la realidad dominante en nuestro orden cultural- como monolíticamente unívoco: un censo poblacional. ¿Qué más “objetivo” que un censo?, ¿qué podría ser menos culpable de ambigüedad que una cuadrícula de casilleros vacíos donde se colocan -o no- marcas impersonales y anónimas? Muy bien: es precisamente ese el acontecimiento elegido por el autor para dar cuenta de lo que significa la construcción de una historia. También allí, 
en el espacio aparentemente sin fisuras de un registro impersonal donde no parece haber lugar para la ambigüedad o para la tensión entre juicios críticos divergentes, se despliegan distintas perspectivas de la realidad histórica. Una vez más recurro a los lúcidos desarrollos teóricos de Hayden White:

Para poder ser considerado histórico, un hecho debe ser susceptible de, al menos, dos narraciones que registren su existencia. Si no pueden imaginarse al menos dos versiones del mismo grupo de hechos, no hay razón para que el historiador reclame para sí la autoridad de ofrecer el verdadero relato de lo que sucedió realmente. (White 1978: 34).

La argumentación de White forma parte de su reflexión sobre la coherencia formal que la narrativa histórica le impone a los acontecimientos representados. Y, como acabamos de leer, la existencia misma de los discursos históricos se debe a la posibilidad de concebir, al menos, dos versiones de los hechos. Esa ambigüedad justifica y contiene el deseo del historiador o del cronista.

Los textos del autor chileno son un claro ejemplo de este deseo, que busca con una legítima conciencia histórica indagar en los pliegues de los documentos oficiales a fin de descubrir otra cara de la "herencia prehispánica": la que "aflora en los bordes excedentes como estrategias de contención frente al recolonizaje por la ficha".

III.2. Lemebel y la ambigüedad constitutiva de la práctica histórica

La construcción del discurso de la crónica desde un punto de vista particular que permanecía invisibilizado, excluido o silenciado, (la homosexualidad perseguida en el espacio público-privado; la mirada y la voz de los muchachos del bloque; la doble moral del jefe de familia clase media; el trabajo informal-ilegal que no puede registrar el casillero del censo) lejos de ser un desvío para el ejercicio de la práctica histórica, es 
uno de sus elementos constitutivos. Los rasgos de las crónicas que ya hemos relevado, a saber: carencia de introducción y cierre; carencia de "tema central"; construcción de puntos de vista particulares y sobre todo invisibilizados; asunción de una política del deseo en el discurso, y en consecuencia, de una política del cuerpo, contribuyen todos a potenciar la apelación a la percepción como uno de los propósitos de estos textos, y en consecuencia a poner en tela de juicio una representación de la realidad histórica que sólo podemos imaginar, y no experimentar.

Las características apuntadas rehúyen (y desconstruyen) la ficción de "un" mundo social narrativizado. Sostener y articular esa ficción exige la estructura canónica: introducción, desarrollo y conclusión; también exige la opción por "temas centrales" y la continuidad como recurso indispensable de la lógica formal que funda y sostiene un punto de vista unitario, condición necesaria para la representación de un relato "bien" hecho, "bien" formado. Pero esa representación de los acontecimientos sólo puede ser imaginaria. Lemebel busca y consigue una representación del mundo que elude la vía del racionalismo histórico, apelando a la percepción, generando imágenes de vida que se despliegan en un discurso atravesado por la experiencia de los agentes de sus historias minoritarias, por los deseos de sus protagonistas, por su particular comprensión del mundo. Las crónicas de Pedro Lemebel postulan al tiempo que construyen (exigen y configuran) un sujeto de percepción. Quien lee/escribe estas crónicas participa de la mirada que tensa el espacio intersticial inaugurado en "Anacondas en el parque"; mira desde dentro la exposición y la cercanía de la muerte en la oscuridad de la esquina que protege y escamotea a los muchachos del bloque; cartografía la red de silencios y complicidades que expulsa del territorio ocupado (metáfora del Chile democrático) a la primera exiliada en democracia, la Babilonia de Horcón; denuncia la falsa reconciliación en la Mesa de Diálogo cuyo verdadero objetivo es la amnistía y el olvido, 
y para ello pone en el discurso la voz y la mirada de los desaparecidos: "brindar con sangre con nuestros verdugos" es lo inaceptable; observa el pliegue de la doble moral del macho-jefe de familia clase media en el interior del cine Nagasaki; advierte la distancia entre el sistema social real y el sistema legal oficial, ilegible para el censo colonial, invisibilizada en el censo contemporáneo. Las hipótesis de Hayden White que integran el marco teórico de esta investigación se incriben en la posición epistemológica inaugurada por la "escuela de la sospecha"127. Vuelvo a algunos de los términos ya citados de Friedrich Nietzsche:

[...] señores filósofos, guardémonos mejor, por tanto, de la peligrosa y vieja patraña conceptual que ha creado un "sujeto puro del conocimiento, sujeto ajeno a la voluntad, al dolor, al tiempo", guardémonos de los tentáculos de conceptos contradictorios, tales como "razón pura", "espiritualidad absoluta", "conocimiento en sí": aquí se nos pide siempre pensar un ojo que de ninguna manera puede ser pensado, un ojo carente en absoluto de toda orientación, en el cual debieran estar entorpecidas $y$ ausentes las fuerzas activas $\mathrm{e}$ interpretativas, que son, sin embargo, las que hacen que ver sea veralgo, aquí se nos pide siempre, por tanto, un contrasentido y un noconcepto de ojo. (Nietzsche 1887: 154. Comillas en el original).

No habrá, pues, fuerza activa ni interpretativa sin un ojo direccionado, posicionado. Un sujeto de conocimiento ajeno a la voluntad, al dolor, al tiempo (ajeno a las políticas del cuerpo) no será nunca el sujeto de un saber (no al menos del saber que reclama la poderosa exhortación del filósofo alemán a sus colegas). El saber es necesariamente el resultado de un sujeto "en perspectiva", de un "ojo direccionado":

Existe únicamente un ver perspectivista, únicamente un "conocer" perspectivista; y cuanto mayor sea el número de afectos a los que permitamos decir su palabra sobre una cosa, cuanto mayor sea el número de ojos, de ojos distintos que sepamos emplear para ver una misma cosa, tanto más completo será nuestro 'concepto' de ella, tanto

\footnotetext{
${ }^{127}$ Término general dado por Paul Ricoeur a los pensadores de fines del siglo XIX y principios del XX que protagonizaron la crisis del paradigma filosófico y epistemológico de la Modernidad. Estos pensadores son: Friedrich Nietzsche, Karl Marx y Sigmund Freud (Ricoeur 1965: 29-35).
} 
más completa será nuestra “objetividad”. (Nietzsche 1887: 154-155. Énfasis y comillas en el original).

La concepción perspectivista de todo sujeto de conocimiento, de cuño nietzscheano, justifica filosófica y cognoscitivamente el punto de vista adoptado en las crónicas del autor chileno. La historia particular, contada por un único "sujeto puro de conocimiento", será siempre una abstracción. Historiar el suceso exige la multiplicidad del punto de vista, lo cual permite la expresión de una vivencia fragmentaria, postulada como "menor" porque elude la pretensión de verdad absoluta y el afán totalizador.

En "Coleópteros en el parabrisas" (1995: 71-73) el trabajo con el punto de vista genera la percepción fragmentaria, imposible de "totalizar" en el interior de $1 a^{128}$ micro. El procedimiento es minucioso y eficaz. El texto presenta una multiplicidad de sensaciones y percepciones de un sujeto no anclado en ninguno de los individuos afectados. Dicho de otro modo: ningún individuo es el soporte del relato ni el sujeto de la enunciación. El texto nos introduce a los lectores en la micro, por lo tanto somos los lectores los sujetos de la visión, la audición, la suma de sensaciones físicas por las que atraviesan los pasajeros. Estas percepciones se producen simultáneamente, pero dada la condición sucesiva de la articulación lingüística, el enunciado las presenta en cadena incesante. Lo singular de esta crónica es que no hay ningún sustantivo colectivo que pueda generalizar la experiencia. Cada personaje es uno: el chofer; "la gorda que atascada en el pasillo..."; "un macho que la puntea fugaz..."; "una mujer sentada..."; "la seda de una mano que despabila la billetera..."; "un escolar que de verlo se le fuga el alma..."; "un paco sentado que se hace el civil..."; "la señora de los tres niños...”; "el caballero pituco que disgustado se arregla el sombrero", entre otros. Ningún sujeto es comprendido por un concepto o sustantivo colectivo; cada individuo es único y por lo

\footnotetext{
128 Respeto aquí y en las siguientes apariciones el artículo femenino aplicado al sustantivo "micro", común en el habla chilena.
} 
tanto, no hay punto de apoyo para colectivizar la experiencia ni para generalizarla; el resultado es que no hay espacio para la abstracción: la crónica es la presentación de una multiplicidad sensorial. Un procedimiento poético que intensifica ese sujeto en deriva es la hipálage:

Nunca se sabe lo que se paga; si la entrada a una discoteca ambulante o un safari a los pantanos del Zanjón de la Aguada. Solamente acomodarse en los asientos destripados por alguna gillette perversa y escuchar la música impuesta por el chofer, que se traviste en disjockey ${ }^{129}$, piloto de fórmula uno, o cobrador implacable de los que se suben por atrás sin pagar. Entonces chanta la máquina pidiendo que echen a correr la moneda, pero la moneda que venía pasando de mano en mano se perdió en algún bolsillo oportunista. (Lemebel 1995: 71)

“Alguna gillette perversa” y "algún bolsillo oportunista” operan la transmutación de la cualidad (perversa, oportunista) del sujeto al objeto. Como queda señalado, el uso de la hipálage ajusta el procedimiento: no hay sujeto individual o personal identificado en el que la crónica se detenga o que cubra una función particular dentro de la lógica de las acciones. Lo que sostiene este relato es la multiplicidad de percepciones en el azar de los encuentros:

Más bien una loca que haciéndose la lesa, la que mira la numeración de las calles, se agacha cuando un macho pasa a su espalda. Un macho que la puntea fugaz y ella se queda muy quieta gozando la dureza. [...] La micro es una lata de sopa que revuelve los intestinos. Un pastiche de eructos, flatos y peos que colorean el duro tránsito que se desbarranca a la periferia. Mientras bajan y suben pasajeros que en la desesperación por agarrar un asiento, no sienten la seda de una mano que despabila la billetera (Lemebel 1995: 71-72)

En "el brillo de la fiesta micrera" se dan cita el sexo casual (la loca y el péndex) la gorda, el paco, la madre o el caballero pituco, todos reunidos en una alegre relatividad. El desvencijado vehículo avanza al ritmo maraco de la canción "Todo,

\footnotetext{
${ }^{129}$ No he encontrado en ningún diccionario de uso o de americanismos esta grafía. Sí en cambio otros desvíos del original inglés disc-jockey tales como: DJ, pinchadiscos, deejay, diyéi o disyóquey, según el Diccionario Panhispánico de Dudas de la Real Academia Española. Online: http://lema.rae.es/dpd/
} 
todo", de Daniela Romo. El título remite a la pluralidad heterogénea del interior de la micro y anticipa el "carnaval ceniciento" en la confusión del choque:

Todo es charco en la violencia del impacto. Todo es chispazo y ardor de huesos astillados. Todo es gritadera de auxilio; que saquen a los niños por la puerta de escape que se incendia. Todo es alarido y combustión cuando estalla la bencina y la puerta trancada no cede y entre los fierros retorcidos se asoma una mano despidiéndose. Como si en un momento el "Todo, todo" se hubiera hecho real en un todo de tragedia que reventó a la gorda como un zepelín sangriento. Una cachetada metálica que al caballero le voló el sombrero con la masa encefálica. Un todo de dolor que comprimió para siempre a la loca y al péndex en un abrazo de tripas al aire, justo cuando al chico le venía el chorro de perlas. (Lemebel 1995: 73)

Ahora bien, en dos momentos estratégicos de la crónica -por cuanto son momentos que determinan una escansión en la cadena de percepciones que acabo de describir- hay un cambio de tono y una referencia a la vida de los trabajadores que viven en la periferia y trabajan en la ciudad. Ambos fragmentos comienzan con el adverbio "así', adquieren un tono melancólico y remiten a la dura cotidianidad de la clase obrera, "el regreso a casa de los cuerpos":

Primer fragmento, en el medio de la crónica:

Así pasan y pasan las calles en una filmografía que recorta la ciudad cuadro a cuadro, reproduciendo en su reverso de cristal empañado el rostro laboral repetido en un bostezo de agotamiento. El regreso a casa de los cuerpos, que colgando de los fierros, dormitan acunados por el vaivén gelatinoso de la rutina vehicular. (Lemebel 1995: 72)

Segundo fragmento, al final de la crónica:

Así, las micros se exilian en su desguañangada senectud. Buses aerodinámicos borran su carnaval ceniciento, trazan nuevas rutas sin riesgo y numeraciones codificadas que reemplazan la poética de los antiguos recorridos (Lemebel 1995: 74). 
Las crónicas de Pedro Lemebel promueven una experiencia de la historia a partir de la experiencia del cuerpo. En palabras de Michel de Certeau: hacen "hablar al cuerpo que calla". Las crónicas constituyen una señal de la caída de los postulados racionalistas del historicismo moderno -tributarios de la episteme positivista- en el marco de la crisis general de la Modernidad. Prueba de ello es la valoración de la sensualidad y del orden material-corporal que en ellas se manifiesta. En el corpus textual objeto de esta tesis, los cuerpos se proponen como superficie de inscripción y registro de los acontecimientos.

Lo antedicho vuelve a observarse en dos crónicas que analizaré para cerrar la referencia al primer libro de Lemebel en relación con mi primera hipótesis. Se trata de "Encajes de acero para una almohada penitencial" (1995: 35-38), y el texto que cierra la colección: "Las amapolas también tienen espinas" (1995: 83-88). El primero ${ }^{130}$ aborda una práctica que muestra -una vez más- la trama de desprotección y abandono que teje la ausencia del Estado para los que viven "a la sombra”. Esta última expresión, leída después de las crónicas que ya hemos analizado, evoca paragramáticamente otros colectivos que desarrollan sus vidas según su propia ley al amparo de las sombras ${ }^{131}$. En ese sentido también se lee la primera afirmación de este texto: "Un espiral erizado retuerce la moral cuando el tema de las violaciones en cárceles masculinas destella al impacto de la noticia” (Lemebel 1995: 35). La denuncia de la doble moral se ajusta con la referencia a la Edad Media:

Pareciera que la subjetividad colectiva se crispara como en el medioevo por la profanación de estos santos lugares; último reducto del intestino para salvaguardar las reliquias de la hombría. Una caverna tibia que protege celosamente en la felpa mojada de su estuche, el secreto de los templarios. (Lemebel 1995: 35)

\footnotetext{
${ }^{130}$ Si bien el artículo de Jean Franco que he comentado en el Capítulo I: "Encajes de acero. La libertad bajo vigilancia" (2004: 11-23) toma su título de esta crónica, el contenido no se refiere en ningún momento a ella.

${ }^{131}$ Ver antes los análisis de: "Anacondas en el parque"; "Los New Kids del bloque"; "Baba de caracol en terciopelo negro"; "Escualos en la bruma", todos de esta misma colección.
} 
El efecto de rechazo colectivo deja al descubierto la hipocresía social que se escandaliza, según la crónica, ante "la profanación de estos santos lugares" -alusión paródica al ano masculino- pero no se escandaliza ante la desprotección de los encarcelados, especialmente los novatos, que padecen las violaciones en el presidio como si eso fuera parte del sistema legal que los condena: "Así es la ley de los que viven a la sombra con el cielo repartido por los barrotes [...] Algunos, con el alcatraz ${ }^{132}$ mudo de espanto, tendrán que pagar el noviciado cruzando un callejón oscuro boca abajo y goteando lágrimas de suero por la entrepierna" (Lemebel 1995: 36).

En "El resplandor emplumado del circo travesti” (1995: 67-70) Lemebel cartografía un proceso de resistencia a la apropiación del circo Timoteo (una "fantasía morocha que recorre los barrios", 1995: 68) por parte de una clase social más encumbrada. El texto narra el éxito del circo travesti en los tierrales:

Así corre la fiesta entre los mambos de la Vanessa agitando las perlas de su bikini en la cara de algún obrero, las cabritas que venden las propias luminarias y los rugidos de un puma coliza, que tiene el circo para animar la matiné de los domingos. Un día en la semana que el travestismo se saca el rouge de los labios, para convertirse en hada madrina de la infancia deshilachada por la desnutrición. (Lemebel 1995: 68)

La crónica testimonia la alianza entre el circo travesti y la pobreza de los márgenes de Santiago. A consecuencia de su fama: "Otra clase social redobla el perímetro de la pista, tratando de apropiarse de una latencia suburbana que no les pertenece. Estacionan sus autos Lada en el barro y sujetan sus carreras y abrigos con el terror de ser asaltados en estas latitudes" (Lemebel 1995: 68). Sigue creciendo la fama del circo y un día llegó el contrato para hacer una temporada en el gran teatro Caupolicán de Santiago. Allí comenzó la declinación: “algo no funcionaba en ese lugar

\footnotetext{
${ }^{132}$ Alusión paródica a la famosa cárcel y al pájaro o ave marina para referirse metonímicamente a los genitales masculinos. Como éste, hay en la crónica muchos otros procedimientos propios de la sobredeterminación barroca (alusión doble, metáfora y metonimia simultáneas).
} 
grandilocuente. El público estaba tan lejos" (1995: 69). Finalmente, cayeron en la cuenta de que era el "contacto directo con la familiaridad hacinada bajo la carpa" lo que mantenía la "corriente de aire vital" del circo travesti, "donde las pasiones y pequeños deseos del colectivo compiten con el relámpago de la televisión y le gana” (70). El circo Timoteo regresa entonces a su público moreno,

[...] sigue circulando en casi todas las poblaciones de la periferia, como una corriente vital que se ríe libremente de la moral castiza. Un escenario de travestismo que se parece a cualquier otro, pero sin embargo, por estar confrontado a la penumbra del excedente social, se transforma en radiografía que vislumbra el trasluz de una risa triste. Mueca quebrada por el áspero roce que decora sus bordes. (Lemebel 1995: 70)

Este texto también historiza lo marginal, como hemos visto en otras crónicas, al reconocer y describir los pequeños pero eficaces mecanismos de resistencia colectiva frente a las políticas de apropiación y negación de la identidad mestiza. El circo afirma esa identidad: "esta fantasía morocha [...] frente al ojo turbio del océano” (Lemebel 1995: 67), la recorre, por cuanto es un circo itinerante, y en ella se sostiene, por cuanto su aire vital depende de la alianza entre travestismo y excedente social: "Así transforman la desventaja transexual en metales de aplausos, que los hacen volver una y otra vez al escenario para mariconear otro poco." (Lemebel 1995: 80).

La crónica que cierra la colección envía circularmente al epígrafe del libro por su intertextualidad con la obra de Néstor Perlongher. En octubre de 1988, el poeta argentino publica su ensayo: "Matan a una marica" (1997: 35-40) ${ }^{133}$. La crónica está emparentada con ese ensayo por una condición que determina a ambos textos: su elaboración literaria de altísima densidad, cuyos procedimientos evocan el estilo, los modos de representación (o más bien del retaceo de la representación) y la sintaxis del

\footnotetext{
${ }^{133}$ Publicado originalmente en la Revista Fin de Siglo, $\mathrm{N}^{\circ} 16$, octubre de 1988. Luego fue publicado en Comunicaçoes do ISER, año 9, № 35, Río de Janeiro, 1990. Recogido en: Prosa plebeya, Buenos Aires, Colihue, 1997. Todas las citas están tomadas de esta edición.
} 
escritor cubano José Lezama Lima. Desde luego, la intertextualidad aparece en primer plano dada por el tema: el asesinato de un homosexual en el marco de una violencia homofóbica socialmente aceptada y protegida por el aparato policial.

En la crónica de Lemebel, el asesinato se narra en tercera persona. El encuentro asume, primero, el punto de vista de la loca que será asesinada, quien sabe que se arriesga: "presiente que el después deviene fatal, sobre todo esta noche cargada al reviente" (1995: 83). En el segundo momento, el punto de vista se traslada de la loca al personaje que es nombrado como "el chico" o "el pequeño hombrecito". No obstante esta aparente minimización, el relato del crimen salvaje y la fuga cobarde lo presenta como sujeto de una furia demencial y lo homologa a la figura literaria del asesino serial o destripador.

El crimen es relatado en un vértigo poético indetenible que adscribe el texto de la crónica a la densa materialidad de imágenes en tensión descripta por Severo Sarduy en su ensayo sobre Barroco y Neobarroco. En los ejemplos que cito a continuación se verá la similitud de procedimientos orientados a materializar el lenguaje, contorsionarlo, complejizarlo hasta exasperar la sintaxis y lograr el efecto de "salirse de sí" señalado por Sarduy como finalidad del trabajo poético sobre la lengua:

Guiñapo de loca que resiste amanerado llevando al extremo la templanza del macho. Conteniendo el vómito de copihues lo coquetea, lasciva al ruedo lo desafía. La noche del erial es entonces raso de lid, pañoleta de un coliseo que en vuelo flamenco la escarlata. Espumas rojas de maricón que lo andaluzan flameando en el tajo. Torero topacio es el chico poblador que lo parte, lo azucena en la pana hirviendo, trozada Macarena. Atavío de hemorragia la maja cola menstrua el ruedo, herida de muerte muge gorgojos y carmines pidiendo tregua, suplicando un impás, un intermedio para retomar borracha la punzada que la danza. Pero el nene nuevamente erecto, sigue desguazando la charcha gardenia de la carne. Un velo turbio lo encabrita por linchar al maricón hasta el infinito. (Lemebel 1995: 8687) 
Impresionante condensación metonímica: "tajo" en el contexto de la frase, es el río evocado con insistencia en la poesía del barroco áureo y es el tajo repetido hasta el paroxismo en la escena de violencia irrepresentable de esta crónica. Los sustantivos "ruedo", "lid y "coliseo" y más adelante la expresión "herida de muerte muge gorgojos y carmines" nos instala en el universo de la lucha en la arena: la marica es toro y gladiador. Lo que acabo de transcribir es un fragmento muy breve de una cadena significante $^{134}$ que se extiende y se estría a lo largo de cinco páginas de escritura. A continuación transcribiré un fragmento del citado ensayo de Néstor Perlongher, "Matan a una marica”, en el que se observa, además de la coincidencia temática con la crónica de Lemebel, el tratamiento de las imágenes orientado a causar el efecto del objeto que se sustrae a la representación:

Lo primero que se ven son cuerpos: cuerpos charolados por el revoleo de una mirada que los unta; cuerpos como películas de tul donde se inscribe la corrida temblorosa de un guiño; la hiedra viboresca de cuerpos enredados (drapeado en erección) al poste de una esquina; cuerpos fijos los unos, en su dureza marmoleante donde se tensa, prámbulo de jaba, jadeo en jade, la cuerda certera de una flecha; cuerpos erráticos los otros, festoneando el charol aceitoso con rieles en almíbar, caricias arañescas que se yerguen al borde de la vereda pisoteada.

Cuerpos que del acecho del deseo pasan, despues, al rigor mortis. En enjambre de sábanas deshechas las ruinas truculentas de la fiesta, de lo festivo en devenir funesto: cogotes donde las huellas de los dedos se han demasiado fuertemente impreso, torsos descoyuntados a bastonazos, lamparones azules en la cuenca del ojo, labios partidos a que una toalla hace de glotis, agujeros de balas, barrosas marcas de botas en las nalgas. (Perlongher 1997: 35)

\footnotetext{
${ }^{134}$ Uso deliberadamente esta expresión lacaniana. El objeto de la representación, en este caso el crimen aberrante motivado por una violencia de género tan feroz como aceptada por el sistema policial y por la indiferencia social, es retaceado en la escritura. El objeto se resiste a ser representado, y por ello la cadena significante, aquejada de una negatividad radical, es incesante: falta el objeto, pero la falta no es absoluta porque los significantes hacen circular el deseo. Para el psicoanalista francés, la articulación de un significante con otro significante en la cadena significante es la presencia misma del deseo. (Ver: Lacan, Jacques: "La cosa freudiana o sentido del retorno a Freud en psicoanálisis", Escritos I). Esta idea se complementa con otra, desarrollada en el Seminario 3, Las Psicosis, según la cual la relación entre significado y significante es "siempre fluida y a punto de deshacerse". Por ello el movimiento de la cadena se renueva constantemente y avanza en una dinámica que tiende al infinito. Severo Sarduy reflexiona sobre estos conceptos de cuño lacaniano en sus ensayos sobre el Barroco, ya citados en esta tesis. A propósito del deseo y su dinámica metonímica, ver nota 116.
} 
Como en la crónica de Lemebel, en el ensayo de Perlongher la violencia contra el homosexual es feroz, sangrienta y su responsabilidad se le atribuye a la policía ("torsos descoyuntados a bastonazos", "marcas de botas en las nalgas") con la anuencia indiferente del colectivo social que acepta y acompaña la homofobia.

Transcribo a continuación un fragmento de la célebre y extensa novela Paradiso de José Lezama Lima, en el que se puede observar la erotización del lenguaje; la escena ambigua -que enlaza metonímicamente la energía eléctrica y el deseo sexual, la escalera, la lámpara y las acrobacias de Tránquilo ante los “escarceos chinescos” de Luba Viole con las alternativas de una escena erótica- está cargada de imágenes cuyo propósito no es "representar" la escena, sino sugerirla perceptivamente a través del impacto sobre los sentidos, el "goteo" de las formas rítmicas y los grupos consonánticos lúbricamente proferidos por la voz textual que liga, "pringa", unta las palabras y sostiene la función erótica del lenguaje:

Tránquilo desesperaba de las labores minúsculas que se le encomendaban. $\mathrm{Su}$ robustez de veinte años, era empleada en los subterfugios más sutiles del trabajo doméstico. Luba Viole, la hermana solterona del capitán Frunce Viole, por innumerables vericuetos y chinescos escarceos, lo quería prender a los pequeños trabajos que ella hacía para llenar con un minúsculo laboreo el apetito suelto de un ocio de cuarenta años, sin junio, sin diálogos, sin cansancio para el sueño más venturoso.

A las diez de la mañana, la despertada y sudorosa intuición de Luba comprobaba la ausencia de los otros familiares. Tránquilo y ella se quedaban solos, y era entonces cuando ella procuraba una coincidencia en sus labores domésticas. Tránquilo comenzaba los enjuagues y destornillos de cada una de las piezas de la lámpara de centro de sala; Luba a una terrible distancia de un metro, sobre una banquetilla que alzaba sus jamonamientos y sudores, con algodonosos papeles de periódicos mojados en alcohol, comenzaba un movimiento rotatorio en torno del espejo ochocentista, encuadrado en un marco con relieve de ornamentación vegetativa tropical, trifolias, pétalos de agua, avisados antílopes, rocas de descanso para la descompuesta corriente. Luba, como una napolitana vendedora de flores, abría los brazos en arco, como al desgaire, mientras fingía que pensaba en 
cosas inencontrables, enrojeciendo a Tránquilo hasta la sangre cargada de apoplejía. Desarmaba la lámpara pieza tras pieza, y lo recorría acentuado temblor al recibir, mientras sus manos pasaban la badana húmeda por una de las piñas de cristal, los dedos del extremo del arco eléctrico que Luba como bobeando pespunteaba. Un inusitado gruñido le cargaba más la apoplejía. La badana enjuagaba después un cupidillo, que se escurría voluptuoso entre la humedad pulimentada, cuando recibió de nuevo la brevedad o centellita del manual arco voltaico. Crujió la escalera que enarbolaba el vigor ecuestre de Tránquilo. Lépero, que se afirmaba en una disimulada y espesa sabiduría para tan arremolinado trance, trabajaba más lentamente con la badana la agujeta que en la cabeza del cupido levantaba como una guinda, y así iba trepando, escurriéndose, para alcanzar las más altas piezas de la lámpara y ponerse fuera del alcance de aquel renovado arco que buscaba su energía.

Luba esgrimía el papel alcoholizado con redomado furor, llegando los corpúsculos del espíritu del alcohol a pegar en la vibración de las aletas de la nariz con suave mordisqueo. (Lezama Lima 1993: 26-27) ${ }^{135}$

La escena se sustrae a ser representada en un sentido estricto. Más bien la intuimos, la percibimos a grandes pinceladas, la olemos, la palpamos. Y sobre todo nos llega la altísima erotización del enunciado, que no puede nombrar ni representar el objeto del deseo, pero lo hace circular incesantemente por la superficie textual. A propósito de la erotización del lenguaje y de las metáforas neobarrocas de Lezama Lima, dice Sarduy:

Es el lenguaje en sí, con su lentitud, con su enrevesamiento, con su proliferación de adjetivos, de paréntesis que contienen otros paréntesis, de subordinadas que a su vez se bifurcan, con la hipérbole de sus figuras y su avance por acumulación de estructuras fijas, lo que, en Paradiso, soporta la función erótica, placer que se constituye en su propia oralidad. (Sarduy 1987: 297)

Otro elemento muy presente en las crónicas de Lemebel que también observamos en la novela de Lezama Lima es el efecto paródico. Es muy claro, dentro del fragmento citado, en este pasaje de reminiscencias cervantinas: “Crujió la escalera

\footnotetext{
${ }^{135}$ La cita está tomada de la edición crítica de Cintio Vitier, Buenos Aires, Fondo de Cultura Económica, Col. Archivos, 1993. Por razones de espacio y dado el propósito de esta cita, no consigno las numerosas notas al pie, de variada naturaleza, que la edición ofrece al lector.
} 
que enarbolaba el vigor ecuestre de Tránquilo. Lépero, que se afirmaba en una disimulada y espesa sabiduría para tan arremolinado trance, trabajaba más lentamente con la badana la agujeta que en la cabeza del cupido levantaba como una guinda". Desde luego no se observa en el texto de Lezama Lima el tema de la violencia homofóbica, presente en los de Lemebel y Perlongher. Traje a colación la novela del célebre autor cubano porque -tal como lo señala unánimemente la crítica- es el fundador y máximo representante de los procedimientos poéticos que he descripto aquí y que resultan ineludibles en un análisis crítico de estas características.

III. 3. Lemebel y su inscripción política en las estéticas neobarrocas

En Loco afán. Crónicas de Sidario (1996) Lemebel se propone narrar los padecimientos y la muerte por SIDA en el Chile de la posdictadura. Elige para ello procedimientos propios del Barroco áureo, e incluso repone una de las tradiciones literarias del barroco español: la picaresca. En dicha opción se lee, por un lado, el relato de las historias particulares de discriminación homofóbica, persecución y desprecio por las diferencias de género más la experiencia dramática de la muerte; por otro, la crítica del autor a las políticas neocoloniales que aparecen aquí representadas por la epidemia dramática que re-coloniza a través del contagio. Desde el epígrafe el autor insiste en una hipótesis que reinterpreta la trama de la historia latinoamericana:

La plaga nos llegó como una nueva forma de colonización por el contagio.

Reemplazó nuestras plumas por jeringas, y el sol por la gota congelada de la luna en el sidario.

(Loco afán, 1996: 7) 
No hace falta destacar la calidad poética del epígrafe, que además de condensar en cuatro líneas la hipótesis del libro, tiene la potencia de historiar el proceso al dar una imagen condensada y eficaz que lo narra. Por ello me voy a detener en sus procedimientos poéticos acumulados en los dos últimos versos ${ }^{136}$. "Reemplazó nuestras plumas por jeringas": "plumas" alude metonímicamente a los pueblos originarios que habitaron estas tierras antes de la conquista y a los travestis. Esa condensación está subrayada por la mención del sol y la luna, astros venerados como dioses por las culturas mesoamericanas. Y en el interior de esa mención se cuela la epidemia (presente desde la mención de los términos "plaga" y "jeringas"): "la gota congelada de la luna en el sidario" (aprovechando el efecto de la paronomasia implícita: sidario/ sudario, se potencia el primer significado del epígrafe: conquista/ muerte). Esta idea (colonización, recolonizaje o recolonización, el autor emplea los tres términos) se reitera y se despliega a lo largo del volumen, y es uno de los núcleos de sentido del libro. Antes de analizar algunas crónicas que así lo demuestran, me voy a detener en las ideas de José Lezama Lima a propósito del Barroco en su ensayo: "La expresión americana" (1969) por la sorprendente cercanía de significados que se observa entre la interpretación lezamiana del barroco americano como "contraconquista", y la operación de re-lectura de la colonización que realiza Lemebel a partir de la epidemia del SIDA optando, precisamente, por estrategias poéticas características del Barroco áureo y del Neobarroco americano.

El historicismo hegeliano expuesto en Lecciones sobre la filosofía de la historia universal (1822-1831) ${ }^{137}$ concebía la historia como la exposición del espíritu (la razón o el logos) en un proceso que conduce al autodesarrollo y al autoconocimiento. Lezama

\footnotetext{
${ }^{136} \mathrm{Si}$ bien por la forma en la que se presenta el epígrafe puede ser considerado prosa, hablo aquí de "versos" por su poderosa musicalidad que convierte la última línea en dos equilibrados octosílabos: "por la gota congelada / de la luna en el sidario".

${ }^{137}$ La primera edición española, de José Gaos, data de 1928.
} 
pretende oponer a esta concepción hegeliana -que ha dominado el pensamiento historiográfico del siglo XIX y también del siglo XX por lo menos hasta los años cuarenta- una visión histórica orientada no por la razón sino por el "logos poético". En otros términos: Lezama Lima promueve la imagen (en rigor: el contrapunto de imágenes) al estatuto de método histórico, con el fin de superar el causalismo historicista. Dicho contrapunto postula el poder de la imagen que permite -mediante analogías y metáforas- abarcar las múltiples formas de lo real, sin las restricciones del $a$ priori histórico que, en la concepción hegeliana, regula tanto la producción como la comprensión de los hechos. A propósito Ildemar Chiampi señala en el Prólogo a $L a$ expresión americana:

Ahora bien, si la historia es un tejido entregado por la imagen, debe asumirse que es una ficción del sujeto, y no una exposición objetiva del hecho americano. Con esta idea Lezama no pretende descalificar la veracidad de la imagen, sino traer el historicismo al plano del lenguaje. Apoyándose en Toynbee, uno de los eminentes filósofos que revisó el enfoque de la historia con la plataforma del empirismo inglés, y en Curtius, Lezama invocará que todo discurso histórico es, por su propia imposibilidad de reconstruir la verdad de los hechos, una ficción, una exposición poética, un producto necesario de la imaginación del historiador. (Chiampi: 17)

Sobre la base de estas hipótesis, Lezama Lima sitúa el comienzo de la historia americana en el siglo XVII, a diferencia de la historiografía convencionalmente aceptada que la hace comenzar con la independencia de España y Portugal, en el Romanticismo. Ahora bien, lo que nos interesa de estas hipótesis es el sentido revolucionario que Lezama le atribuye al barroco americano por su política de apropiación de técnicas y procedimientos del barroco europeo (español), la cual genera un poder de contra-conquista tendiente a configurar un nuevo orden cultural con las “armas estéticas", digamos así, del propio conquistador. Para ello apela a la noción clásica del plutonismo ("el fuego originario que rompe los fragmentos y los unifica") la 
cual le ofrece una imagen, precisamente, del proceso de ruptura y unificación que define el arte de los mestizos barrocos y determina así el auténtico comienzo de la historia en nuestro continente. En "La curiosidad barroca" (Lezama Lima 1969: 79-106), artículo que integra la colección, Lezama evoca dos figuras legendarias: el indio (o mestizo) Kondori, del que tenía una imprecisa noticia por vía indirecta (así lo señala Chiampi en el exhaustivo aparato crítico de la edición que manejamos) y el Aleijadinho, un negro de Ouro Prêto. El autor se refiere a ellos en los siguientes términos:

La gran hazaña del barroco americano, en verdad que aún ni siquiera igualada en nuestros días, es la del quechua Kondori, llamado el indio Kondori. En la voluntariosa masa pétrea de las edificaciones de la Compañía, en el flujo numeroso de las súmulas barrocas, en la gran tradición que venía a rematar el Barroco, el indio Kondori logra insertar los símbolos incaicos de sol y luna, de abstractas elaboraciones, de sirenas incaicas, de grandes ángeles cuyos rostros de indios reflejan la desolación de la explotación minera. Sus portales de piedra compiten en la proliferación y en la calidad con los mejores del Barroco europeo. [...] Sus soportes de columnas ostentan en una poderosa abstracción soles incaicos, cuya opulenta energía se vuelca sobre una sirena con quejumbroso rostro mitayo ${ }^{138}$, al propio tiempo que tañe una guitarra de su raza. El indio Kondori fue el primero que en los dominios de la forma, se ganó la igualdad con el tratamiento de un estilo por los europeos [...] igualaba la hoja americana con la trifolia griega, la semiluna incaica con los acantos de los capiteles corintios, el son de los charangos con los instrumentos dóricos y las renacentistas violas de gambas. (Lezama Lima 1969: 103-104)

Así como el indio Kondori "representa la rebelión incaica [...] en que todos los elementos de su raza y de su cultura tienen que ser admitidos", del mismo modo el Aleijadinho simboliza la rebelión artística del negro. Según Lezama

[...] su triunfo es incontestable, pues puede oponerse a los modales estilísticos de su época, imponiéndoles los suyos [...] su obra va inundando la ciudad de Ouro Prêto y las otras ciudades vecinas, pues hay en él las mejores esencias feudales del fundador, del que hace una ciudad y la prolonga y le traza sus murallas. (Lezama Lima 1969: 104)

\footnotetext{
${ }^{138}$ Indio que trabajaba en la mita (en quechua, trabajo forzado que, por turnos, los indios hacían en las minas).
} 
De la importancia y singularidad de estas figuras legendarias ("personajes oscuros, olvidados o marginales que ninguna historia oficial se atrevería a incluir" señala Chiampi en el Prólogo) Lezama deriva la fuerza revolucionaria del barroco americano que opera una verdadera contra-conquista y se opone así a la historiografía oficial que señala el comienzo de ese proceso en las revoluciones del siglo XIX. De todos estos desarrollos y referencias históricas Lezama concluye: "El Barroco como estilo ha logrado ya en la América del siglo XVIII el pacto de familia del indio Kondori, y el triunfo prodigioso del Aleijadinho, que prepara ya la rebelión del próximo siglo, es la prueba de que se está maduro ya para una ruptura.” (Lezama Lima 1969: 104).

En las crónicas de Lemebel se observa un elemento muy importante en común con la orientación argumentativa de Lezama Lima: la decisión y la capacidad revolucionaria de los artistas mestizos, quienes haciendo un uso político de los procedimientos barrocos, oponen su resistencia a los mecanismos neocoloniales de dominación. Ahora bien, Pedro Lemebel amplía y radicaliza el concepto de mestizaje que domina en la argumentación lezamiana. Aquí los "mestizos" no son los refinados artistas que, según el panegírico de Lezama -visión posiblemente idealizada por la distancia y la necesidad argumentativa de su ensayo- igualaban en proliferación y calidad barrocas a los mejores artistas europeos. Lemebel narra la gesta contra-colonial de artistas callejeros, perseguidos durante la dictadura y discriminados y expulsados durante la democracia. Él mismo es uno de ellos. Estas políticas contra-coloniales están presentes en el desarrollo de todo el libro, pero se reflexiona sobre ellas explícitamente en tres crónicas: "La noche de los visones (o la última fiesta de la Unidad Popular)" (Lemebel 1996: 11-23), la primera de la colección, "La muerte de Madonna" (1996: 3340) y "Nalgaslycra, Sodoma Disco" (1996: 51-53). 
"La noche de los visones" (sobre la que volveré a propósito de mi segunda hipótesis) denuncia "el modelo importado del estatus gay, tan de moda, tan penetrativo en su tranza con el poder de la nova masculinidad homosexual”, al evocar con nostalgia la foto de aquella noche en lo de la Palma, la loca "rota", pobre y feliz con su "plumaje raído", emblema de las locas "aún torcidas, aún folclóricas en sus ademanes ilegales." La foto parece "un friso arcaico donde la intromisión del patrón gay todavía no había puesto su marca." A través de la mirada nostálgica que recorre una vieja fotografía, la crónica rechaza el modelo de "hombre homosexual" o "mister gay" (moda importada desde otras latitudes) y valoriza esos otros delirios de aquel lejano fin de año de 1972 que "enriquecían barrocamente el discurso de las homosexualidades latinoamericanas" (Lemebel 1996: 22). La evocación de aquella noche y aquella "pandilla travesti" condensa varios contrapuntos: a) el patrón gay masculinizante y foráneo contra las locas folclóricas de los años setenta, cuyo paradigma en la crónica es "la Chumilou" ("Toda capullo, toda botón de rosa enguantada en el ramaje del visón”); b) las regias, "las locas más viajadas que copiaron el modelito en New York y lo transportaron a este fin de mundo" contra las locas pobres, locales, descriptas como "algo que brilla en un mundo sumergido. Todavía es subversivo el cristal obsceno de sus carcajadas, desordenando el supuesto de los géneros"; c) "la imagen rubia", “el imberbe mármol”, "la aséptica envoltura de esa piel blanca, tan higiénica" contra "el cuero opaco de la geografía local" representado por la Palma (y, en otras crónicas, por Madonna y por Loba Lamar). Finalmente, englobando todos los contrapuntos, la oposición conquistador / conquistado, núcleo temático de la crónica y de todo del libro:

La foto es borrosa, quizás porque el tul estropeado del SIDA entela la doble desaparición de casi todas las locas. Esa sombra es una delicada venda de celofán que enlaza la cintura de la Pilola Alessandri, apoyando su cadera maricola en el costado derecho de la mesa. Ella se compró la epidemia en Nueva York, fue la primera que 
la trajo en exclusiva, la más auténtica, la recién estrenada moda gay para morir. La última moda fúnebre que la adelgazó como ninguna dieta lo había conseguido. (Lemebel 1996: 16. Énfasis mío)

El significante destacado en este breve fragmento es "doble desaparición". La desaparición evidente, el primer significado del término es la muerte ("Del grupo que aparece en la foto, casi no quedan sobrevivientes", Lemebel 1996: 21) y la segunda desaparición: la identidad alegre y subversiva de las locas pobres, de su valiente desenfado "jugándoselas todas en la esquina del maraqueo sodomita, peleando a navajazos su territorio prostibular" (18). Las viscosas aguas de la plaga sumergió ese maraqueo lentamente. Una a una, la Palma, la Chumilou, la Pilola Alessandri y las demás locas del territorio nativo, recibieron el contagio "como recolonización a través de los fluidos corporales" (22). Doble desaparición: muerte real y muerte simbólica; "pasaje de ida en la siniestra barca" y borramiento de la identidad chilena, golosa y glamorosa como la Chumilou. Desde luego, el sustantivo "desaparición” también nombra la práctica siniestra de la reciente dictadura, que sobrevuela el texto de la crónica desde el comienzo: "Santiago se bamboleaba con los temblores de tierra y los vaivenes políticos que fracturaban la estabilidad de la joven Unidad Popular" (Lemebel 1996: 11), hasta el final: "en este mapa ultracontrolado del modernismo, las fisuras se detectan y se parchan con el mismo cemento, con la misma mezcla de cadáveres y sueños que yacen bajo los andamios de la pirámide neoliberal” (23). El procedimiento es la condensación extrema de la palabra "desaparición": SIDA, borramiento de la identidad del travestismo chileno, femenino, glamoroso, pobre y desenfadado; desaparición forzada de ciudadanos durante la dictadura de Pinochet, evocada en el texto por la caravana que colma las calles festejando el triunfo del NO.

Este texto pone el acento en la pérdida. Frente a ella, altamente condensada, se oponen -no obstante- tenaces estrategias de resistencia: “Quizás, las pequeñas historias 
y las grandes epopeyas nunca son paralelas, los destinos minoritarios siguen escaldados por las políticas de un mercado siempre al acecho de cualquier escape." (Lemebel 1996: 23). En la misma línea discurre la crónica "Nalgaslycra, Sodoma Disco" (Lemebel 1996: 51-53). Se leen aquí dos líneas de rechazo a la nueva colonización por el contagio: "el folclor mariposón que decora la cultura homo, delirios de faraonas que aletean en los espejos de la disco" constituye la fuerza contracultural ante el "modelo Travolta sólo para hombres". Como ya había sido señalado en la crónica anterior, la moda gay importada es "camuflaje viril que va uniformando [...] la diversidad de las homosexualidades locales" (53). Por eso las estrategias de resistencia de la cultura local, configuran "una distancia politizable":

Quizás, aunque la disco gay existe en Chile desde los setenta, y solamente en los ochenta se institucionaliza como escenario de la causa gay que reproduce el modelo Travolta sólo para hombres. Así, los templos homo-dance reúnen el ghetto con más éxito que la militancia política, imponiendo estilos de vida y una filosofía del camuflaje viril que va uniformando, a través de la moda, la diversidad de las homosexualidades locales. Si no fuera que aún sobrevive un folclor mariposón que decora la cultura homo [...] Si no fuera por eso, por esa brasa de la fiesta cola que el mercado gay consume con su negocio de músculos transpirados. Acaso sólo esa chispa, ese humor, ese argot, sean una distancia politizable. (Lemebel 1996: 53).

La resistencia contra-colonial ${ }^{139}$ se sostiene en la diversidad de las homosexualidades locales, el humor, la chispa de la "fiesta cola", su argot, su diferencia inasimilable a la moda Travolta. Esa diferencia, consumida por "el negocio de músculos transpirados", puede ser una estrategia de liberación, o al menos, una forma original y eficaz de militancia política, más exitosa que la convencional.

La segunda línea se filtra sutilmente en el discurso de la crónica. Hace a la cartografía de Santiago y su irreductible condición mestiza: la disco gay se encuentra

\footnotetext{
${ }^{139}$ Vale observar aquí la asombrosa coincidencia entre el núcleo de sentido de esta crónica y las hipótesis de Lezama Lima acerca de la diferencia mestiza como fuerza revolucionaria de contra-conquista, singularidad del barroco americano.
} 
"al borde de la Alameda, casi topándose con la iglesia colonial de San Francisco", y funciona "en un subterráneo que ocupaba un cine de Santiago, donde quedaron los frisos etruscos en dorado y negro, las columnas helénicas" (Lemebel: 1996: 51). La disco avanza sobre la cartografía colonial y moderna de la ciudad, lo cual señala también desde la dimensión del espacio las políticas de resistencia de "la maricada [que] desciende la amplia escalera de medio lado, como diosas de un Olimpo Mapuche" (51). Esta última referencia es el pie del arco que nos llevará, al final de la crónica, a la afirmación de la diferencia como "distancia politizable". La maricada resiste a las estrategias de colonización con su diferencia de color (“cuero opaco") y su afirmación étnica minoritaria en clave mitológica (“Olimpo Mapuche”).

"El último beso de Loba Lamar", cuarto texto de la colección que cierra la primera parte del libro (titulada: "Demasiado herida"), está saturado de la tensión entre tragicidad y humor. Una de las estrategias utilizadas es el humor, y por tratarse de un objeto de representación asociado con lo sagrado y lo trascendente, su tratamiento humorístico provoca un efecto de "alegre relatividad" propia de la carnavalización ${ }^{140}$.

Esa tensión nunca decae conservando el difícil equilibrio entre sus componentes, por lo tanto, la representación de los personajes no roza en ningún momento ni la ridiculización simple ni el melodrama. Es un verdadero mecanismo de relojería donde cada pieza se ajusta y cumple su cometido con precisión. Narrado en primera persona del plural (un "nosotras" explícito: las travestis, llamadas "locas" en el texto de la crónica, que comparten la pieza con Lobita), el relato desgrana minuciosamente cada

\footnotetext{
140 "Explicaremos previamente la naturaleza compleja del humor carnavalesco. Es, ante todo, un humor festivo. No es en consecuencia una reacción individual ante uno u otro hecho singular aislado. La risa carnavalesca es ante todo patrimonio del pueblo (este carácter popular, como dijimos, es inherente a la naturaleza misma del carnaval); todos ríen, la risa es general; en segundo lugar, es universal, contiene todas las cosas y la gente (incluso las que participan en el carnaval), el mundo entero parece cómico y es percibido y considerado en un aspecto jocoso, en su alegre relativismo; por último esta risa es ambivalente: alegre y llena de alborozo, pero al mismo tiempo burlona y sarcástica, niega y afirma, amortaja y resucita a la vez". (en: Bajtín, Mijaíl. La cultura popular en la Edad Media y el Renacimiento. El contexto de François Rabelais, Madrid, Alianza, 1987).
} 
momento de la lenta y larga agonía de Loba Lamar, bailarina y cantante del vodevil portuario, víctima del SIDA. El personaje se caracteriza por su piel oscura ("un rescoldo pisoteado del África travesti”), su delgadez, su pobreza y su buen humor. Marginal entre los marginales: homosexual, travesti, prostituta, pobre, enferma y desahuciada, la crónica convierte su destino - marcado con todas las determinaciones del fracaso y la exclusión- en un personaje picaresco.

El texto de Lemebel se inscribe en la tradición de la picaresca española del siglo XVI. El relato en primera persona repone la doble perspectiva de aquella tradición: el narrador es personaje y emisor de la historia, configurando una falsa autobiografía que parodia la estrategia ascética de las confesiones de pecadores escarmentados. Aquí hay escarmiento sin pecado, castigo sin confesión, crítica mordaz a la hipocresía de la sociedad burguesa que enarbolando las banderas de una falsa moral, estigmatiza al diferente, lo excluye y lo condena. Asistimos a la creación lemebeliana de una especie menor de la epopeya del hambre. Loba vive en un mundo miserable, en el que sobrevive gracias a su ingenio. La primera frase de la crónica lo explicita: "Ingenio de cola y astucia callejera tuvo ella para lucir ese nombre" (Lemebel 1996: 41). El ingenio y la astucia son las características más destacadas del pícaro, y tal como ocurre en el Lazarillo o el Buscón, para Loba Lamar no hay esperanza de ascenso social. Ella y el colectivo narrador ("nosotras") pasan hambre y sobreviven gracias a su ingenio en un mundo hostil y cruel, siempre en soledad. Si bien aquí no se trata de soledad individual, ellas (las locas, las travestis) están solas: no hay ningún otro personaje que acerque algún alivio o resuelva alguna de las situaciones penosas por las que atraviesa la protagonista. Loba reúne todos los rasgos del pícaro: es dicharachera, vagabunda, ama la libertad, por ello su medio de vida es marginal, y aunque acaba víctima de la epidemia (la peste, la plaga, la sombra, el misterio, la llamará Lemebel 
alternativamente) nunca se da por vencida ni abandona la esperanza. Tanto, que convierte el contagio en embarazo, la semilla de muerte en promesa de vida: “tratábamos de complacerla en sus antojos de Loba parturienta [...] le dio por preparar el ajuar del príncipe que iba a dar a luz" (44). Esta transformación de la muerte en vida recuerda uno de los emblemas de las celebraciones carnavalescas callejeras en la Edad Media: la Muerte embarazada. ${ }^{141}$ En un último y largo párrafo la crónica lleva a su máxima posibilidad la tensión entre tragicidad y humor de la que hablé al comienzo de este apartado. Loba Lamar muere en un grito sofocado, y esa situación, lejos de configurar un punto de partida para el melodrama o la elegía, se convierte en material satírico ubicando este texto en la mejor tradición de los géneros cómico-serios:

Su boca sin fondo, su boca paralizada en la "a" gigante de esa ópera silenciosa. Su bella boca descerrajada como un túnel, como una alcantarilla que se había llevado a la Lobita en las aguas cochinas de ese remolino siniestro. [...] No puede irse así la pobrecita, dijeron las locas ya más tranquilas. No puede quedar con ese hocico de rana hambrienta, ella tan divina, tan preocupada del gesto y de la pose. [...] Traigan un pañuelo para cerrarle la boca antes que se agarrote. Un pañuelo bien grande que alcance para subirle el mentón y amarrarlo en la cabeza. Amarillo no tonta porque es desprecio. A lunares tampoco porque parece mosca pop... (Lemebel 1996: 45-46).

Reponiendo tópicos del sainete y la comedia de enredos, las protagonistas se afanan por cuidar el aspecto del cadáver y después de cerrarle trabajosamente la boca que había quedado abierta como "hocico de rana hambrienta", al retirar la amarra de la cara para maquillarla,

\footnotetext{
${ }^{141}$ Bajtín explica el carácter relativo y ambivalente de los ritos carnavalescos que durante milenios se han ido transponiendo a la literatura: "Coronación-destronamiento es un rito doble y ambivalente que expresa lo inevitable y lo constructivo del cambio-renovación, la alegre relatividad de todo estado y orden, de todo poder y de toda situación jerárquica. [...] Así son todos los símoblos carnavalescos: siempre incluyen la perspectiva de la negación (muerte) o su contrario. El nacimiento está preñado de muerte, la muerte, de un nuevo nacimiento. [...] Es necesario subrayar una vez más la naturaleza ambivalente de las imágenes carnavalescas. Todas las imágenes del carnaval son dobles, reúnen en sí ambos polos del cambio y de la crisis: nacimiento y muerte (imagen de la muerte embarazada)". Bajtín, Mijaíl (1963: 175-177).
} 
[...] los labios apretados de la Loba comenzaron a dibujar la macabra risa post mortis. Ay no, gritó una de las locas, mi amiga no puede quedar así, con esa mueca de vampiro. Hay que hacer algo. [...] Pero al calor de los trapos, el nervio maxilar se encrespó como un resorte y los labios de la Loba se entreabrieron en una carcajada siniestra. (47).

La Tora, una loca maciza que había sido luchador, toma la iniciativa y, enfundada en su traje de lucha libre "se encaramó sobre el cadáver agarrándolo a charchazos. Paf, paf, sonaban los bofetones”. Finalmente, con el pulgar y el índice de su manaza eficaz,

[...] le apretó fuerte los cachetes a la Loba hasta ponerle la boquita como un rosón silbando [...] y todas pudimos ver el maravilloso resultado de esa artesanía necrófila. Nos quedamos con el corazón en la mano, todas emocionadas mirando a la Loba con su trompita chupona tirándonos un beso. (47-48).

En la picaresca española (que recupera procedimientos de los géneros cómicoserios de la antigüedad), el humor y la ironía se asocian con la crisis de los ideales ascéticos y la caída de los géneros discursivos moralizantes. Al mismo tiempo se despliega la crítica social señalando la hipocresía y la debilidad intrínseca de los valores burgueses. El texto lemebeliano se incribe, como se ha dicho, en esa tradición haciendo propia la tensión de la crisis de valores y el propósito satírico. Además, el sesgo de crítica social se potencia por la oposición subrayada entre la sociedad burguesa que entabla relaciones utilitarias con las locas, en oposición a la fuerza del personaje colectivo, dada por los lazos de solidaridad entre sus integrantes. Este elemento envía al primer texto de la colección, "La noche de los visones (o la última fiesta de la Unidad Popular)" en el que el grupo de locas también constituye un personaje colectivo -más allá de la diferencia entre locas pobres y "regias"- que celebran la última cena (la alusión al cuadro de Leonardo es explícita) de la Unidad Popular. La carnavalización de la muerte también está presente en esa primera crónica que abre el libro, cuando el 
pobre cortejo de la loca rota, la Chumilou, se cruza con las marchas que festejaban el triunfo del NO en la Alameda:

Y por un momento se confundió duelo con alegría, tristeza y carnaval. Como si la muerte hiciera un alto en su camino y se bajara de la carroza a bailar un último pie de cueca. [...] cientos de jóvenes descamisados que se encaramaron a la carroza, brincando sobre el techo, colgándose de las ventanas, sacando pintura spray y rayando todo el vehículo con grafitis que decían: Adiós tirano. [...] la carroza quedó convertida en carro alegórico, en una murga revoltosa que acompañó el sepelio por varias cuadras. Después retomó su marcha enlutada, su trote paquidermo por las desiertas calles hacia el cementerio. (Lemebel 1996: 21).

La "fiesta de cadáveres", que hace presente y operante la estética del Barroco áureo, es recurrente en este volumen de crónicas, y al mismo tiempo es señal inocultable de intertextualidad perlongheriana:

La luz pálida del alba entraba por las ventanas evaporando los pétalos de la orgía. Por todos lados fragmentos de cuerpos repartidos en el despelote sodomita. Un abrazo acinturando un estómago [...] Un torso moreno con el garabato de la loca derramada en su pecho. [...] Así, restos de cuerpos o cadáveres pegados al lienzo crespo de las sábanas. Cadáveres de boca pintada enroscados a sus verdugos. Aún acezantes, aún estirando la mano para agarrar el caño desinflado en la eyaculada guerra. Aún vivos, incompletos, desmigados más allá de la ventana, flotando en la bruma tísica de la ciudad que aclaraba en los humos pardos de la protesta.

Sin duda eran cadáveres de fiesta, parcelas de piel estrujadas en el arrebato del clímax. (Lemebel 1996: 29-30. Énfasis mío).

Tres veces, en el breve fragmento citado, se nombra a los "cadáveres" que, como queda claro en la continuidad de la lectura, no están muertos. "La luz pálida del alba" ilumina los "fragmentos de cuerpos repartidos", los “cadáveres pegados al lienzo crespo de las sábanas" que pronto habrán de despertar. La muerte es evocada en la escena de "bruma tísica" y "lienzo crespo", en delicado vaivén con imágenes vitales: “cadáveres de boca pintada", "aún acezantes", “aún vivos", e inmediatamente se agrega: 
“incompletos, desmigados", "flotando". Cadáveres de fiesta es sin duda la imagen que mejor sintetiza y opera el devenir vida-muerte. No hay una representación de la muerte en Loco afán, ni una alusión, a modo de homenaje, de los maestros del Siglo de Oro español. Lo que se produce es un acontecimiento original: el relato de la muerte por SIDA en el Chile de la posdictadura, narrado por las voces de sus protagonistas, seres caídos de la escena institucional, historiográfica y periodística.

Acabamos de recorrer un texto en el que circula el término "cadáveres". El más conocido poema de Néstor Perlongher lleva precisamente ese título ${ }^{142}$ y es objeto de análisis en varias entrevistas. En una de ellas el poeta argentino afirma:

Cadáveres es un poema que escribí en el '82, cuando estaban apareciendo los cadáveres. No se hablaba de otra cosa entonces. Era lo que estaba en la calle [...] Había que trabar la batalla en el mismo plano. Había que mostrar que el barroco, el neobarroco [...] tenía la fuerza suficiente como para meterse en otras zonas, como para invadir otros territorios también. (Perlongher 2004: 283).

Dos años más tarde, en otra entrevista, agrega:

Cadáveres podría incluirse en un grupo de textos que dijeran algo sobre la guerra sucia, pero no creo que estuviera muy cómodo entre esos textos. Yo no voy a asumir esa postura de poeta social. Hay siempre que irse para el otro lado, tender líneas de fuga. [...] Podría decirse que esa cuestión se resuelve entre el deseo y la historia, entre el deseo y lo social. (312. Énfasis mío).

Creo que Perlongher toca aquí un punto sensible y muy productivo para esta investigación: hay un "entre", tal como lo señala el poeta, que liga y desequilibra el deseo y la historia, el deseo y lo social. Y allí se juega una nueva conexión, una alianza posible entre la escritura y el acontecer histórico, aquella que recupera (o se deja atravesar) por las afecciones de los cuerpos. No es casualidad que el "tema" del poema

\footnotetext{
${ }^{142}$ Fue publicado en Revista de Poesía $\mathrm{n}^{\mathrm{o}}$ 1, abril de 1984. Luego incluido en Alambres, Buenos Aires, Ed. Último Reino, 1987. Recogido en Poemas completos, Buenos Aires, Seix Barral, 1997, pp. 109 y ss, y también en Prosa plebeya, Buenos Aires, Colihue, 1997, pp. 227 y ss.
} 
sean los cadáveres: la escritura de aquello que ha sido silenciado, la historia de un país, los cuerpos, constituyen un bloque de devenir, y el poema de Perlongher, su cifra, por cuanto no hay representación posible de la muerte. En el marco de la crítica ontológica a los postulados de la metafísica occidental clásica y moderna, podemos concebir la poesía, y también la crónica, como "palabra que interviene sobre lo real, antes que comunicarlo" (Perlongher 2004: 307). Considero que esta opción del escritor chileno es estética y también política, por cuanto la condición neobarroca de su obra opera como dispositivo para vehiculizar aquello que he postulado en las páginas precedentes, es decir, la experiencia de la historia a partir de la transposición del cuerpo - de su condición material- a la escritura (lo que en términos de Antonin Artaud podemos llamar una "comprensión energética del texto""143).

En efecto, las crónicas de Pedro Lemebel se ubican en una doble posición de borde: a) entre la literatura y la historia; b) entre la escritura y el campo vibratorio de los cuerpos (relación dialéctica que me propongo analizar en esta segunda parte de la primera hipótesis, en relación con la estética neobarroca en la que considero que nuestro autor se inscribe por las características de su escritura y por el propósito estéticopolítico de diluir las categorías absolutas, desactivar las dicotomías inferiorizantes y erotizar el lenguaje. Todos estos procedimientos serán justificados en los desarrollos que siguen). Tal como ocurre en cualquier borde o límite problemático, la oposición no se resuelve en el equilibrio de la síntesis, sino que ejerce su operatividad construyendo una discursividad móvil y heterogénea, difícil de clasificar, y "desobediente" tanto al mandato cultural de la historiografía clásica: ser el relato objetivo de un suceso real,

\footnotetext{
${ }^{143}$ Este problema teórico está desarrollado en el trabajo de Julia Kristeva sobre la poética de Antonin Artaud, artículo ya mencionado en esta tesis: "El sujeto en proceso" (Kristeva 1977), comunicación leída por primera vez en el "Coloquio Artaud" celebrado entre el 29 de junio y el 9 de julio de 1972 en el Centro Cultural Internacional de Cerisly-la-Salle, París. Fue publicada en el volumen que colecta las ponencias de ese encuentro (Gauthier 1973: 35-94) y recogida en la compilación de artículos de la autora titulada Polylogue (1977). De esta última no hay versión castellana.
} 
como al imperativo epistemológico que supone a la escritura completamente separada del universo físico, reponiendo la dicotomía cartesiana res cogitans - res extensa. ${ }^{144}$

La problemática que acabo de esbozar no es nueva. De hecho, la intersección activa entre escritura y materialidad se remonta, por lo menos, hasta la filosofía estoica $^{145}$. Pero considero que la reflexión crítica que ha tenido lugar a propósito del Barroco y su intensa productividad en la literatura hispanoamericana del siglo veinte es un marco necesario y adecuado para acotar y al mismo tiempo hacer productivo el análisis de la obra de Pedro Lemebel. Me refiero particularmente $-\mathrm{y}$ lo tomo como punto de partida- a la ineludible obra teórica y ensayística de Severo Sarduy ${ }^{146}$. A partir de sus reflexiones, que considero fundamentales para el problema de la dialéctica de identificación y diferencia entre el Barroco áureo y el campo complejo y heterogéneo de escrituras que él llamó Neobarroco, el poeta y ensayista argentino Néstor Perlongher apoyándose en textos críticos de José Lezama Lima y Roberto González Echevarría, y también en nociones teóricas y filosóficas de Gilles Deleuze- intenta una definición de estas poéticas:

Es en el plano de la forma que el barroco, y ahora el neobarroco, atacan. Pero esas formas en torbellino, plenas de volutas voluptuosas que rellenan el topacio de un vacío, levemente oriental, convocan y manifiestan, en su oscuridad turbulenta de velado enigma, fuerzas no menos oscuras. [...] Poética de la desterritorialización fabulosa, el barroco siempre choca y corre un límite preconcebido y sujetante. [...] Libera el florilegio líquido (siempre fluyente) de los versos de la sujeción al imperio romántico de un yo lírico. Se tiende a la inmanencia y, curiosamente, esa inmanencia es divina; alcanza, forma e integra (constituye) su propia divinidad o plano de trascendencia. [...] El lenguaje, podría decirse, abandona o relega su función de comunicación, para desplegarse como pura superficie,

\footnotetext{
${ }^{144}$ Si bien la postulación cartesiana es muy conocida, aparece claramente expuesta y argumentada en las Meditaciones metafísicas, su obra de 1641. Ver: Descartes, René: Discurso del método y Meditaciones metafísicas. Traducción y notas de Manuel García Morente. Bs.As., Espasa-Calpe, 1950. Especialmente: Meditación tercera y Meditación cuarta, páginas 104-125.

${ }^{145}$ Ver a propósito: Deleuze, Gilles (1969): Lógica del sentido, en especial $5^{\mathrm{a}}$. y $6^{\mathrm{a}}$. series.

146 Sarduy, Severo: Ensayos generales sobre el Barroco, Buenos Aires, FCE, 1987. Reúne cuatro ensayos, los tres primeros publicados anteriormente por el autor: Escrito sobre un cuerpo, Buenos Aires, Sudamericana, 1969. Barroco, Buenos Aires, Sudamericana, 1974. La simulación, Caracas, Monte Ávila, 1982, y Nueva inestabilidad, Buenos Aires, FCE, 1987.
} 
espesa e irisada, que "brilla en sí" [...] un "teatro de las materias" (Deleuze) [...] Materia pulsional, corporal, a la que el barroco alude y convoca en su corporalidad de cuerpo lleno, saturado y doblegado de inscripciones heterogéneas. ${ }^{147}$ (Perlongher 1997: 95-96).

Resulta difícil incluir en un texto de crítica académica la deriva del texto crítico de Perlongher que hace uso de las filigranas, los pliegues discursivos y la dinámica metonímica del lenguaje neobarroco, el cual se estría sobre la superficie -insuficiente, siempre en defecto- del lenguaje comunicativo. No obstante considero que pueden leerse en esta cita los matices distintivos del neobarroco: una fuerza ("ataca") caracterizada por su dinamismo turbulento que tiende a la aniquilación o corrimiento de las posiciones firmes del sujeto, "siempre fluyente"; lenguaje saturado de materialidad y de inscripciones heterogéneas.

Tanto Sarduy, en los ensayos citados, como Perlongher en su prólogo a Caribe transplatino. Poesía neobarroca cubana y rioplatense (1991) del que acabo de transcribir un fragmento, señalan la posición excéntrica del barroco europeo y también hispanoamericano, refiriéndose deleuzianamente al neobarroco como una “desterritorialización fabulosa". Me detengo en este rasgo porque advierto en las crónicas del escritor chileno una potencia de ataque a la neutralidad positivista del discurso de la historia, a favor de una experiencia del cuerpo (y en el caso de Loco afán. Crónicas de Sidario, una experiencia del cuerpo enfermo), desalojando del discurso de la historia oficial el imperativo de objetividad, según la propuesta de la epistemología clásica: dar un sentido pleno y unívoco de los hechos, organizado y concluido.

Cuando intentamos (legítimamente) una definición de un fenómeno artístico o al menos, un acercamiento crítico que pueda elaborar alguna categorización o sistema, nos

\footnotetext{
${ }^{147}$ Prólogo a Caribe transplatino. Poesía neobarroca cubana y rioplatense, San Pablo,Illuminiras, 1991. Fue publicado como "Neobarroco transplatino", en la Revista La Caja, n 1, septiembre-octubre de 1992. Integra la compilación de ensayos de Néstor Perlongher Prosa plebeya, Buenos Aires, Colihue, 1997. Pp. 93-102.
} 
encontramos siempre ante un elemento paradójico el cual se resiste, por naturaleza, a todo intento de definición, por ser incorporal y dialéctico, fuente de singularidades irreductibles a cualquier identificación. Creo que es legítimo asociar esta idea con la noción problemática que la crítica ha tratado de domesticar sin éxito, a mi juicio: el Neobarroco. En este sentido me parece orientadora la perspectiva general planteada por Susana Cella (148-171) acerca de lo que denomina la "controversia" (149) con respecto al término y a sus características, aunque discrepo con algunas de sus afirmaciones. Por ejemplo: me parece difícil de justificar la existencia de una "base de operaciones" llamada Lezama Lima, y en términos más generales, la afirmación de que

[...] el trabajo de los neobarrocos produce una forma de apropiación que recorta convenientemente un corpus vasto. Si esto se pensara como la operación típica de los movimientos de ruptura, en este caso es preciso ver cuál ha sido la de los poetas neobarrocos, habida cuenta de su variada producción, y también, qué alcances tiene esa poética y hasta dónde el conjunto de la obra de cada uno de ellos la sostiene. $(151)$

¿Es recortar un corpus la “operación típica de los movimientos de ruptura”? Esta pregunta incluye otra: ¿es el llamado Neobarroco un movimiento de ruptura? Me parece muy arriesgado afirmar que haya una operación típica y que ésta sea recortar un corpus. Creo más bien que los poetas leen y, empleando una metáfora de Néstor Perlongher, realizan al mismo tiempo

[...] la tarea del cartógrafo deseante [que] no consiste en captar para fijar, para anquilosar, para congelar aquello que explora, sino que se dispone a intensificar los propios flujos de vida en los que se envuelve, creando territorios a medida que se los recorre. El mapa resultante, lejos de restringirse a las dimensiones físicas, geográficas, espaciales [...] ha de ser un mapa de los efectos de superficie. (Perlongher 1997: 65). El énfasis es mío. 
La clave de esta metáfora es la naturaleza de lo que Cella llama "operación", y que Perlongher señala como "deriva" en virtud del cual "se captan los flujos de vida que animan el territorio". Tampoco comparto la elección del término "ruptura" para abordar este problema. Siguiendo con la metáfora del cartógrafo deseante, “intensificar los propios flujos de vida en los que se envuelve" me parece mucho más cercano al trabajo de Perlongher o de Lezama, por ejemplo, con las metáforas de Góngora, que calificarlo de gesto de ruptura. La especificidad de la tarea del crítico no consiste únicamente en "definir". Resulta sorprendente que de esta actitud ni siquiera se encuentre a salvo la imagen poética, justamente aquello que se produce en la tensión contraria al gesto racionalista que alienta cualquier definición: "la concepción de Lezama de la imagen, que bien podría definirse con las propias palabras de Milán como instancia de fijeza" (Cella 154). ¿Puede hablarse de "la concepción (¿hay trabajo especulativo previo, hay arte conceptual?) de la imagen (¿qué es "la imagen” en Lezama?) que bien podría “definirse” (¿puede de-finirse: establecer sus límites?) como "instancia de fijeza”? La “violenta pulsión de unificación" que Sarduy (1987: 24) atribuye a la ciencia de Parménides a Einstein, parece llegar, a veces, a los "territorios” de la crítica. ¿Cuál es, me pregunto, la relevancia crítica de hallar una categoría unificadora, que con seguridad, no unificará nunca poéticas lo suficientemente divergentes como para sustraerse, por fuerza (por la fuerza de su deseo: por su política del margen) a una definición?

Asumida la dificultad de definir (y en algunos casos la inoperancia crítica de su ejercicio), trato de ejercer el gesto productivo de señalar rasgos, procedimientos, señales que permitan una reflexión crítica y teórica acerca de aquellas escrituras que se presentan marcadas por una poética anterior, reconocible y actuante en el movimiento de su produción. Lo que cuestiono, y vuelvo a citar la frase de Sarduy, es la pulsión de 
unificación que es estéril ante una categoría inarticulable, al menos en el estatuto descriptivo que sostiene cualquier categorización. Admito, por lo tanto, el empleo del adjetivo "neobarroco/a", es decir, lo considero una atribución ${ }^{148}$ posible, atendiendo a su conexión directa o indirecta con lo que Sarduy llama el primer Barroco, pero sin perder de vista que esta materia discursiva, este cuerpo vivo de textualidades recorridas por intensidades "en las que se envuelven", al decir de Perlongher, rechaza por su natural nomadismo cualquier género de domesticación crítica. En la evocación -explícita o muda- de sus maestros, Lemebel se inscribe a conciencia en la estética neobarroca. Se reconoce especialmente la huella de José Lezama Lima en la sintaxis recargada de pliegues y en la adjetivación plástica y musical. Se evocan los textos de Néstor Perlongher en el desenfado y en la materialidad viscosa del discurso: en la profusión de goteos, sudores, vahos, sueros, fluidos y vapores que se deslizan en este territorio discursivo móvil de fronteras cruzadas.

Por todas las razones expuestas, postulo que Pedro Lemebel ha llevado el neobarroco al terreno de la crónica, en la que historia y poesía se cruzan, no al modo surrealista, en el que la poesía es presentada como "visión" o clave secreta, ${ }^{149}$ sino en virtud de un encuentro que produce una "falla" (en sentido lógico y geológico) en la homogeneidad positivista de los discursos de la historia, y pone en primer plano el fragmento y la experiencia del cuerpo.

Como ha sido señalado en el estado de la cuestión, uno de los primeros artículos de crítica académica que se refieren a la obra del chileno, ya lo inscribe en el campo de

\footnotetext{
${ }^{148}$ Lacan reparó en el hecho -sin duda, un hecho de lenguaje- de que Freud sólo emplea el atributo fálico, sin definir en ningún momento de su obra aquello que, en la estela del pensamiento lacaniano, Deleuze consideró como uno de los Acontecimientos por excelencia: el falo. En esta línea de pensamiento que trata de horadar, o por lo menos de desestabilizar y poner en duda la normatividad del platonismo, considero productivo pensar lo neobarroco como atributo que se efectúa en algunas escrituras, sin definirlas ni capturarlas, sin "identificarlas" ni "fijarles" condición alguna. Lo neobarroco como marca, como huella (a veces invertida o des-bordada) de una ausencia, o de una presencia borrada.

${ }^{149}$ En la literatura argentina, es ineludible la referencia a Enrique Molina y su única novela: Una sombra donde sueña Camila O'Gorman, Buenos Aires, Losada, 1973.
} 
las estéticas neobarrocas. Me refiero a la ya mencionada comunicación: "Un guante de áspero terciopelo. La escritura de Pedro Lemebel”, de Soledad Bianchi, ${ }^{150}$ en el que la autora integra los textos de Pedro Lemebel en la "red" del Neobarroco; del mismo modo Carlos Monsiváis (tanto en el mencionado prólogo a la reedición de La esquina es mi corazón como en su artículo de 2007) vincula al autor con el universo neobarroco, aun en su irreductible diferencia, y reconoce en su escritura las "atmósferas lezamianas" y los fluidos, vapores y viscosidades del poeta Néstor Perlongher.

Las materias gomosas, los humores y texturas de las poéticas neobarrocas, su sonoridad estriada, convergen y dan cuerpo a un relato cuya fuerza está en su dinamismo nómade: entre el deseo y la historia, entre el registro y la experiencia, entre la escritura y los cuerpos. Precisamente de esto trata la crónica "El proyecto nombres. (Un mapa sentimental)", incluido en el volumen que estoy analizando: Loco afán. Crónicas de Sidario. En su ya citado ensayo "Caribe transplatino", Perlongher afirma:

El barroco teje, más que un texto significante, un entretejido de alusiones y contracciones rizomáticas, que transforman la lengua en textura, sábana bordada que reposa en la materialidad de su peso. [...] Materia pulsional, corporal, a la que el barroco alude y convoca en su corporalidad de cuerpo lleno, saturado y doblegado de inscripciones heterogéneas. [...] La carnavalización barroca no es meramente una acumulación de ornamentos [...] En esas contorsiones, las palabras se materializan, se tornan objetos, símbolos pesados y no apenas prolegómenos sosegados de una ceremonia de comunicación. (Perlongher 1997: 95-96).

Lector de Perlongher y agente de la "desterritorialización fabulosa" que el poeta argentino postulara en sus ensayos como marca del barroco latinoamericano, Lemebel escribe en esta crónica el Quilt (paño o tejido) que los familiares, parejas o amigos tejen con las prendas del "deudo sidado". Pero, extremando el procedimiento, lo llama "la arpillera del epitafio [confeccionada] con las prendas del recuerdo, con las babas hiladas

${ }^{150}$ Ver: Estado de la cuestión. 
de la supuración" (1996: 91). Los Quilts se multiplican conforme avanza la epidemia y forman "un gran mapa de sudarios" en el que se incriben los nombres de los fallecidos, o pequeños recados, mensajes, "susurros en pasamanería, post datas en cursiva [que] alargan el eco del llamado" (92). Toda la crónica es un nombrar y re-ferir (reparo en la etimología latina de este término: volver a llevar) la sábana, la arpillera, el Quilt, el tejido, el paño, los sudarios, la ropa, la trama, el tapiz monumental, en una cadena de nominaciones que parece no tener fin. En efecto, las cinco páginas de esta crónica están llenas, o más bien digamos, son una pura acumulación de nombres dados al Quilt: además de los transcriptos en el párrafo anterior, encontramos: "banderas de naufragio"; "restos indumentarios"; "vestuario post mortis de telas y ropas con poco uso"; "una colección de pilchas marchitas"; "estandartes luctuosos"; "banderas de pérdida"; "pañuelos derrotados"; "paños desvaídos"; "despojos"; "necrópolis de pieles”, entre otras expresiones que cifran el lenguaje barroco, su poder de afección. Al decir de Perlongher, el Quilt es convocado “en su corporalidad de cuerpo 1leno, saturado y doblegado de inscripciones heterogéneas". La palabra se estría y se contorsiona, desobediente al mandato cultural que la somete a ser nada más que un vector de referencialidad (una señal de otra cosa); la palabra barroca es cuerpo opaco, materialidad espesa "entretejido de alusiones y contracciones rizomáticas, que transforman la lengua en textura, sábana bordada que reposa en la materialidad de su peso". Ahora bien, por qué he dicho que Lemebel extrema el procedimiento. Porque es la sábana mortuoria, el sudario el que se escribe en esta crónica. Es la tela que se ubica en el lugar exacto en que el deseo y la muerte se imbrican; allí se escribe el saludo imposible, el mensaje inescribible.

Los artistas del Manierismo y del primer Barroco representan obsesivamente a la muerte. Los del Neobarroco saben que la muerte no puede ser representada, no puede 
ser nombrada, porque es el acontecimiento insimbolizable. Esta es una de las diferencias cualitativas entre ambos movimientos. El segundo Barroco, como lo llamó Severo Sarduy, es heredero de los profundos cambios ideológicos y filosóficos de la segunda mitad del siglo XX, y en su haber epistemológico se encuentra el desvanecimiento de la distancia trágica que domina la sensibilidad del Barroco europeo. El Neobarroco cifra la muerte, la transpone en los objetos de lenguaje: "las babas hiladas de la supuración". Hablo de cifra, y no de representación, símbolo o clave, porque la cifra no oculta ni disfraza, tampoco señala nada más allá de sí misma: su ley es informulable, su sentido no está velado sino perdido; la cifra remite, insistentemente, a sí misma. Nueva forma del descentramiento barroco: una falta de centro no por referencia tangencial o tortuosa (la elipsis, el hipérbaton, la metonimia, la sinécdoque) sino por ausencia de centro, en una experiencia de la lengua que se abisma sin dejar de ser superficial: un "puro afuera". El vector de la referencialidad dibuja una voluta. El descentramiento que leemos en figuras retóricas como el encabalgamiento, o las ya nombradas hipérbaton y elipsis, de evidente profusión en las poéticas barrocas del siglo XVII, dan cuenta, como lo han señalado incesantemente la crítica y la historiografía, de un universo que se deformaba, de un conjunto de certezas que se desmoronaban ${ }^{151}$. El gran tópico del Barroco español del Siglo de Oro, la fugacidad de la vida (“cuán frágil es, cuán mísera, cuán vana” es el final de un famoso soneto de Quevedo), es la metáfora de una escena ominosa: la vida humana se desliza, muda, hacia la muerte, y si bien hay en ella una recuperación del ubi sunt medieval, se da a través de la caída de la esperanza religiosa en un más allá trascendente. La metáfora barroca subraya la nada de la vida; tal vez se trate del primer absurdo literario, antecedente ilustre del que tendrá lugar a mediados del siglo XX. Hemos citado el último verso de un soneto de Quevedo. Más extremo en esta

${ }^{151}$ Ver: Sarduy (1987: 35-50), Capítulo V: "Nueva inestabilidad". 
línea de desustancialización del mundo y sus certezas, resultan los tercetos finales del famosísimo soneto de Luis de Góngora:
goza cuello, cabello, labio y frente
antes que lo que fue en tu edad dorada
oro, lilio, clavel, cristal luciente, no sólo en plata o vïola troncada se vuelva, mas tú y ello juntamente en tierra, en humo, en polvo, en sombra, en nada. ${ }^{152}$

Lo que para estos poetas es "sombra" y "nada", fragilidad y vanidad, es retomado en algunos modos de representación del Neobarroco asumiendo figuras y procedimientos de una desustancialización aún más extrema. Pero la operación que tiene lugar en estos textos implica una torsión respecto de la nada ominosa y desestabilizadora del primer Barroco. La cifra neobarroca se presenta ilegible por exceso de opacidad ${ }^{153}$, oponiendo resistencia al modelo representativo-interpretativo dominante en las estrategias de la lectura moderna. Así como los cadáveres de Néstor Perlongher no son "recuerdo de la muerte", ${ }^{154}$ sino pura yacencia, puro estar, del mismo modo el Quilt, el paño, tejido o sudario de Pedro Lemebel, tramado con las innumerables prendas heterogéneas (camisa a rayas, short de lycra, ropa de noche, buzo deportivo, bata de seda china, cuello almidonado) "se convierten en el look agónico, en el look de un postrero desfile, donde se traviste la falta con los fragmentos que encintaron la vida" (1996: 93. Énfasis mío). El autor chileno lo hace explícito: travestir la falta significa nombrarla una y otra vez, en proliferación indefinida. Potencia de la nominación neobarroca: la metonimia infinita expresa (y sabe) que la falta no puede cubrirse con ninguna representación, con ningún símbolo o disfraz. Nombrar la muerte es transferir siempre, en una cadena que es desfiladero, esa inexistencia (el cuerpo

\footnotetext{
${ }^{152}$ Góngora, Luis de. Obras poéticas I. Madrid, Clásicos Castellanos, 1974.

${ }^{153}$ Ver: Sarduy (1987: 68 y siguientes) a propósito de la obra de Andy Warhol y el hiperrealismo.

${ }^{154}$ Final del soneto 11 de Francisco Quevedo: Obras compeltas, Madrid, Aguilar, 1943.
} 
ausente del "deudo sidado"), provocando un vacío en el que se derrama indefinidamente el lenguaje. ${ }^{155}$ El Quilt no representa ni significa: el lenguaje lo redobla. El texto parece saberlo, y lo llama, también: "susurros en pasamanería [que] alargan el eco del llamado".

Lo neobarroco también se observa en la crónica que evoca un cuerpo mutilado en devenir. Era un adolescente nacido en Punta Arenas, hijo de inmigrantes alemanes. Narra la crónica que amaba los pájaros, y que un día quiso atrapar uno que estaba posado en un alambre, pero "Ernst nunca supo que ese alambre era un cable de alta tensión” (Lemebel 1996: 152). El accidente le carbonizó las manos, y la gangrena posterior le fue cercenando primero los antebrazos, después los codos. Entonces su madre vendió todo lo que tenía y se lo llevó a Alemania. "Ernst fue sometido a una operación que detuvo la pesadilla y borró las cicatrices de sus hombros, dejándolos tan lisos como un mármol griego" (152). En Alemania estudió pintura, dibujo, arte clásico, reemplazando las manos perdidas por sus pies. Y una "cosmética travesti [...] hizo crecer las alas calcinadas de su pequeño corazón homosexual. [...] Entonces nació Lorenza Böttner [quien] hizo de su propia corporalidad una escultura en movimiento [...] Una cariátide suelta” (152). Desde su formación plástica se desplaza por otros géneros de las artes visuales: fotografía, cine, instalación. Y en este último género se propone como obra: su cuerpo, que exhibe minusválido, se configura "como una bella intervención en Nueva York, Barcelona o California” (153), se convierte en escultura viviente y participa en eventos de arte corporal. Este procedimiento es lo destacado de la crónica: Lorenza produce a partir de su mutilación un cuerpo escultórico que evoca

\footnotetext{
155 "el sujeto que habla no es tanto el responsable del discurso (aquel que lo detenta, que afirma y juzga mediante él, representándose a veces bajo una forma gramatical dispuesta a estos efectos), como la inexistencia en cuyo vacío se prolonga sin descanso el derramamiento indefinido del lenguaje" (Foucault, Michel: El pensamiento del afuera, Valencia, Pre-textos, pág. 11).
} 
las célebres Venus de Milo y Victoria de Samotracia. Su performance "amortigua el hachazo de los hombros" y traviste la "evidencia mutilada" en "cirugía helénica" (153).

La heterogeneidad es el principio ontológico del devenir. En este caso se efectúa por un travestimiento múltiple: del sur chileno al centro de Europa; de Ernst a Lorenza; de evidencia mutilada a paradigma de belleza: escultura griega victoriosa y alada. Lorenza posó para el famoso fotógrafo Robert Mapplethorpe como la célebre Niké, Victoria alada de Samotracia, escultura del período helenístico exhibida en el Museo del Louvre, cuyas alas desplegadas parecen compensar su falta de brazos y su perdida cabeza. La fotografía aparece, según consigna el cronista, en catálogos y revistas gays. No obstante su desempeño artístico que le valió un notable reconocimiento en Europa y Estados Unidos, persiste lo particular de su destino minoritario: "invitada de contrabando al bacanal postmoderno", su aire de ángel caído no la abandona. El cronista logra dar ese tono a su retrato:

A veces, se instala en la calle y tiza con sus pies delicados dibujos, que luego los zapatos de los transeúntes se encargan de borrar. Mientras a su lado, la madre suple la carencia del hijo estirando la mano que recoge las propinas (153).

Vale la pena detenerse en este fragmento por su poder de síntesis y su calidad narrativa. Instalada en la calle, Lorenza "tiza" (reiterado y eficaz procedimiento en Lemebel: hacer verbo de un nombre o adjetivo; en este caso el efecto es evidente, le transfiere a la acción el esfumado de la tiza sobre el pavimento) con sus pies delicados dibujos, simple y efectivo procedimiento poético, el adjetivo vale para los dos sustantivos que lo enmarcan y da la clave narrativa del fragmento: fragilidad, delicadeza sobre lo áspero y mundano (la calle); a esa aspereza pertenecen los zapatos que borran al pasar, indiferentes, el delicado dibujo. Cierra el cuadro la madre-suplicante y dos construcciones sustantivas en contrapunto especular: carencia del hijo, mano que recoge 
las propinas. Es importante advertir cómo se juega la síntesis conectiva en esta crónica. La muerte, que transita por la vida de la/el protagonista y la determina desde el accidente en Punta Arenas hasta la enfermedad terminal, es el acontecimiento que traba los retazos de su historia (el devenir nunca es lineal ni homogéneo). Por su mutilación deviene cuerpo escultórico simulado, es decir, un doble del paradigma de la belleza clásica igualmente mutilada, cuya ruina -los brazos y la cabeza de la Niké nunca fueron encontrados por los arqueólogos- lejos de disminuir su magnificencia la realza. Ese desplazamiento se calca sobre Lorenza en quien se opera una transformación análoga representada en la fotografía de Mapplethorpe por las alas (que tanto en ella como en la escultura evocada representan la victoria) y en la vida de Lorenza por su relevancia artística y el hecho de haber sido "elegida símbolo de las Olimpíadas Mundiales de Minusválidos, realizadas en Barcelona". ${ }^{156}$ No obstante la representada victoria (como su doble de Samotracia, alada y manca), el SIDA “calcinó en el aire su aleteo imaginario" (154). En nota a pie de página el cronista consigna su muerte en 1993. Extranjera en su tierra natal, traviste su masculino nombre alemán por uno femenino y latino $^{157}$, sin dejar de ser jamás la múltiple determinación del margen: homosexual y travesti, artista callejera y performer, discapacitada motriz y, finalmente, seropositiva y muerta por SIDA antes de cumplir cuarenta años. Desdoblamiento, mutilación y sobredeterminación minoritaria producen un personaje marginal (border, under, gay, performer proliferación de nombres extranjeros que circulan en el texto y parecen redoblar la extranjería, la condición de este personaje singular), una figura que por defecto o por exceso está en discordia, puro desborde, pura anomalía. Cuerpo mutilado en devenir, cuya falta no puede ser recubierta. De hecho las alas son nombradas en el

\footnotetext{
${ }^{156}$ El autor se refiere a los Juegos Paraolímpicos de 1992, que convocaron a 3.020 atletas de 82 países.

${ }^{157}$ El nombre "Lorenzo" es una variante de "Laurentino". Este nombre es un gentilicio de la ciudad italiana del Lacio llamada Laurentum. Según la versión de Virgilio en La Eneida fue llamada así por un célebre laurel consagrado a Apolo. El laurel era -y sigue siendo- símbolo de triunfo y honores.
} 
texto en vínculo inmediato con la falta: “ortopedia alada”. El final de la crónica nos muestra a Lorenza a punto de subir las escaleras del avión, yéndose de Santiago por segunda vez, ahora para no volver. Esta escena es aprovechada por el autor para señalar, una vez más, la mutilación: “su memoria quiso levantar un guante para despedirse. Pero sólo le temblaba un hombro, cuando desplegando su ortopedia alada, desapareció en el cielo sin mirar atrás" (154). El texto termina con la mención del vuelo y de las alas que remiten metonímicamente a la muerte ("atiende al vuelo sin mirar las alas", dice el famoso soneto de Quevedo, en clara referencia a la omnipresente preocupación barroca por la muerte).

En el transcurso del siglo que media entre la muerte de Felipe II en 1599 y la de su bisnieto Carlos II, el último de los Habsburgos, en 1700, la oración fúnebre alcanza en España un extraordinario desarrollo. Prueba de ello es la multiplicación de impresiones y folletos sueltos que conservan la memoria de discursos, sermones funerales y oraciones panegíricas. ${ }^{158} \mathrm{Me}$ interesa detenerme en una progresión notable, señalada tanto por los estudiosos del género como por un grupo de sonetos de Góngora dedicados a los funerales de personajes importantes. Me refiero a la creciente orquestación o, digamos a falta de término más preciso, "teatralización" de las honras fúnebres, en cuyo despliegue se integran expresiones literarias bajo la forma de carteles, emblemas o epigramas, formando parte de una arquitectura efímera constituida por catafalcos o monumentos, algunos de gran pompa. Hacia fines del siglo XVI ya no es posible establecer una separación neta entre las oraciones fúnebres propiamente dichas y el aparato (lo que Góngora llama "máquina funeral”) que acompañaba las solemnes exequias. Por ejemplo, las honras fúnebres organizadas en numerosas ciudades de España por la muerte de la Reina Margarita de Austria (durante los años 1611 y 1612),

\footnotetext{
${ }^{158}$ Francis Cerdán, en su artículo: "La oración fúnebre del Siglo de Oro. Entre sermón evangélico y panegírico poético sobre fondo de teatro" (en: Criticón, Toulouse, $\mathrm{N}^{\circ}$ 50, 1985: 79-103) consigna un gran número de ellas, tomadas de entre las quinientas piezas que pudo reunir y estudiar.
} 
marcan un progreso en la compenetración barroca de la función religiosa y el acto público festivo con gran despliegue estético: plástico, poético y teatral. Al respecto, Francis Cerdán afirma:

Para la construcción de esos monumentos, capelardentes, catafalcos, piras, pirámides, etc. colaboraban arquitectos, escultores, pintores y poetas en la edificación de la obra de cartón-piedra. Como testimonio de la importancia de este aspecto funerario de la cultura española, particularmente en la época barroca, nos quedan numerosos opúsculos y libros de descripción, como se puede ver en la abundante bibliografía que existe ya sobre este tema. (Cerdán 1985: 91-92).

Leamos el soneto de Luis de Góngora escrito para la ocasión:

\title{
Del túmulo que hizo Córdoba en las honras de la señora reina doña Margarita
}

\author{
Máquina funeral, que desta vida \\ nos decís la mudanza, estando queda; \\ pira, no de aromática arboleda, \\ si a más gloriosa Fénix construida; \\ bajel en cuya gabia esclarecida \\ estrellas, hijas de otra mejor Leda, \\ serenan la Fortuna, de su rueda \\ la volubilidad reconocida, \\ farol luciente sois que solicita \\ la razón, entre escollos naufragante, \\ al puerto; y a pesar de lo luciente, \\ obscura concha de una Margarita \\ que, rubí en caridad, en fe diamante, \\ renace a nuevo Sol en nuevo Oriente.
}

Tanto en el título como en las cuatro estrofas del soneto el objeto evocado es claramente la "máquina funeraria": "túmulo" "pira", "bajel”, "farol luciente", "obscura concha", todas nominaciones del catafalco mortuorio que contiene y lleva a mejor puerto a Margarita. El único verso que obedecería al panegírico -propio de la oración fúnebre clásica y medieval- es el segundo del último terceto. Con esa única excepción, 
el poema le canta a la máquina funeraria y ensalza su feliz propósito: bajel cuya "esclarecida gavia" -vela central del buque- lleva a la ilustre señora al "nuevo Oriente" bajo estrellas auspiciosas; "farol luciente" que evitará el naufragio. Además, la arquitectura tumular expone su principio constructivo: el cuerpo del difunto no está allí, el túmulo es la representación de una ausencia doble: metafísica-metafórica (la persona ausente) y física-literal (el cadáver): el túmulo señala doblemente lo que no está.

Lo que resulta de este breve análisis en el que me he detenido es la progresiva importancia que adquiere a lo largo del siglo XVII la llamada "arquitectura efímera", esto es: una armazón de madera vestida con pesados paños -generalmente morados o muy oscuros- que se erige para la celebración de las honras de un difunto. Luis Gusmán ${ }^{159}$ postula una interesante relación entre el catafalco mortuorio y la concepción de la muerte en el Barroco:

La armazón de madera y los paños mortuorios son una figura privilegiada del barroco. Aluden al movimiento, dado que en ese período histórico los signos de la muerte se multiplican y hasta podría decirse que la muerte se ha puesto en movimiento. [...] Podemos pensar que ese movimiento, que en el barroco abarca también la muerte, ese flamear de las vestiduras del que habla Lacan, contrasta en cierto modo con la piedra quieta que figura la representación de un dolor petrificado, presente en el mito de Dafne y de alguna manera en la mayor parte de la arquitectura barroca. [...] En Góngora, la figura de la máquina reaparece como máquina alada -esto eso, animada de movimientos y capaz de volar. (Gusmán 41-42).

Sin discutir la atractiva hipótesis de Gusmán, lo que observo en el soneto de Góngora es el desplazamiento del foco: ya no es la muerte (ni la Muerte en general ni esta muerte particular de la "señora reina") sino su máquina, su teatralización fabulosa, verdadera operación barroca que materializa el acontecimiento inmaterial por excelencia, que da cuerpo y textura (madera, paño, cartón-piedra) al Desvanecimiento

\footnotetext{
${ }^{159}$ El ensayo de Luis Gusmán: Epitafios. El derecho a la muerte escrita, Buenos Aires, Norma, 2005, estudia con singular erudición las relaciones entre la escritura, la inscripción fúnebre y su traducción en la piedra o en el cuerpo.
} 
Final que perturba la sensibilidad de los poetas y artistas del Manierismo y del Barroco. El catafalco es ya un monumento-metonimia por cuanto desplaza el acontecimiento que "representa", lo eclipsa, y por lo tanto lo desactiva (la muerte y sus despojos están fuera de escena), pero el soneto de Góngora es una duplicación de la primera metonimia, que potencia el procedimiento al convertir la materia verbal en pantalla que opaca y niega la muerte; segundo desplazamiento de la serie, más eficaz porque duplica la materia significante: sobredeterminación barroca, lenguaje verbal (oscurecido y denso, saturado de culteranismos arcaizantes, cuerpo opaco por complicación sintáctica y solecismo) sobre el lenguaje plástico, arquitectónico, escultórico y pictórico. La muerte queda fuera de lugar, fuera de $s u$ escena, más que desplazada ausente pero no por negación simple o exclusión directa, sino por la suma y la potenciación de procedimientos estéticos. Digamos con Perlongher: una desterritorialización fabulosa. En el mencionado grupo de sonetos de don Luis de Góngora es recurrente la figura del ave Fénix asociada a la representación de la muerte; asimismo las alas y las plumas -como lo señala Luis Gusmán- están presentes en casi todos sus sonetos funerarios. El más ilustrativo en este sentido -aunque no el único- es el titulado: "En el sepulcro de la Duquesa de Lerma", del cual transcribo a continuación el primer cuarteto y el segundo terceto:

\footnotetext{
¡Ayer deidad humana, hoy poca tierra: Aras ayer, hoy túmulo, oh mortales! Plumas, aunque de águilas reales, Plumas son; quien lo ignora, mucho yerra.

La Fénix que ayer Lerma fue su Arabia Es hoy entre cenizas un gusano, $Y$ dé consciencia a la persona sabia.
}

La creciente importancia de la máquina funeraria, los paños que visten la estructura y le otorgan movimiento, las plumas, los bajeles o buques y los pájaros 
(vuelo o viaje), todo da el efecto de fuga, velocidad o movimiento. En las crónicas de Pedro Lemebel, la insistencia en la materia le otorga al soporte (la lengua, el cuerpo, la tela) una densidad y un espesor que no permiten asimilarlo a la imagen: desplazamiento múltiple y pérdida del foco en Góngora, duplicación de la falta en Lorenza, proliferación indefinida en el Quilt. El oscurecimiento (pictórico y poético) tan mentando por todos los historiadores del arte y la literatura del Barroco, es otra eficaz fuerza metonímica: oscurecer es siempre desplazar, lo oscuro es una forma tan poderosa como lateral, indirecta, "barroca", de provocar la ausencia: configurar la presencia borrada. Qué otra cosa son la mutilación de Lorenza, la ausencia de los deudos sidados en la confección del Quilt. Las dos crónicas son muy breves: cinco páginas la primera, cuatro la segunda. Una brevedad consecuente con la altísima concentración y densidad narrativas que el procedimiento básico en ambas necesita. La sobredeterminación barroca, la configuración - por vía metonímica- de una presencia borrada, único objeto de la crónica: narrar la ausencia, la desaparición, el desvanecimiento.

El oscurecimiento del significado es, en rigor, el rechazo de las leyes de la composición clásica: perspectiva, codificación jerárquica del espacio, tratamiento "natural" de la luz. En términos de Sarduy: "La impugnación de lo visual como categoría privilegiada de conocimiento [...] implica la crítica de un orden idealizado: el que instaura la imagen como análogo puro, el de la duplicación especular como aprehensión del mundo” (1987: 119). En esta impugnación de lo visual como categoría privilegiada de conocimiento y por lo tanto, como garantía de la aprehensión del mundo, se leen tanto las Soledades y los sonetos gongorinos como la inquietante duplicación mutilada de Lorenza Böttner o la proliferación de prendas-nombres en la confección del Quilt. Así como durante la vida Lorenza Böttner fue desdoblamiento y disfraz (la simulación de la escultura menguada disfraza la carencia y -segunda 
operación- las alas duplican la falta), su muerte está narrada en la crónica como un desvanecimiento: "no quiso volver nunca más [...] desapareció en el cielo sin mirar atrás" (154). Lemebel utiliza, una vez más, el procedimiento literario como necesidad intrínseca al relato de su historia. La imagen poética del desvanecimiento final es necesaria para narrar la vida de un ser cuya frágil marginalidad rechaza la determinación inherente al discurso positivo de la descripción histórica y etnográfica convencional. En el caso de "El proyecto nombres" el paño tejido es lo que queda, la huella -proliferante- de una presencia borrada.

\section{4. Lemebel y la historia reciente de Chile}

Cuando el presidente Patricio Aylwin declara en agosto de 1991: "la transición ya está hecha" 160 , despertando polémicas desde luego, parece sin embargo interpretar la percepción del ciudadano común que no vislumbraba amenazas al orden constitucional -no las hubo- y parecía satisfecho por haber alcanzado la "normalidad", después de los largos años de la dictadura pinochetista ${ }^{161}$. Al respecto en su estudio sobre los medios de comunicación en Chile durante la transición, Eugenio Tironi señala:

En cierto modo, los chilenos se conmueven cada vez menos por los "grandes conflictos" característicos de la etapa de la transición a la democracia. Su interés parece volcarse, en cambio, a temas más

\footnotetext{
${ }^{160}$ Extraído de: Aylwin, Patricio: El reencuentro de los demócratas. Del golpe al triunfo del NO. Grupo Zeta Editor, 1998, p. 259 (nota original aparecida en: El Mercurio el 8 de agosto de 1991). La polémica frase completa es: "Realmente, a mi juicio, la transición ya está hecha. En Chile vivimos en democracia". En septiembre de 2005, luego de que se votaran en el Congreso las llamadas "reformas duras", Ricardo Lagos afirmaba al sustituir en la Constitución la firma de Pinochet por la de él: "[Este acto] Marca el término definitivo de la transición. Comenzaron los gobiernos democráticos. Ahora podemos decir que la transición en Chile ha concluido. Ahora tenemos un cuerpo constitucional que está acorde con la tradición histórica de Chile". Ambas frases, con catorce años de diferencia, dan la pauta de la posición que los sucesivos gobiernos de la Concertación manifestaron frente al proceso de recuperación de las instituciones en la etapa posdictatorial.

161 Para un análisis más detenido de esta cuestión, ver el artículo completo: Tironi, Eugenio, "Las políticas de comunicación en la transición y la transición en los medios de comunicación. Cuatro reflexiones", en: Garretón, Manuel y otros (1993): Cultura, autoritarismo y redemocratización en Chile, Santiago de Chile, Fondo de Cultura Económica, pp. 235-247.
} 
sectoriales, en función de los cuales evalúan el desempeño del gobierno, y también de la oposición. Se observa un relativo desvanecimiento de los "macro-conflictos" -que eran precisamente los que llevaban a una extrema politización- y el espacio que ocupaban en la atención pública se ha ido llenando de una multiplicidad de temas-problema y de "micro-conflictos". El fin de la confrontación sobre proyectos nacionales globales ha permitido que se expresen una serie de temas y problemas sectoriales, generacionales, culturales, que afectan al común de los ciudadanos. (Tironi 241)

Considero por lo menos ingenua y muy discutible la distinción entre macroconflictos y micro-conflictos a los que se refiere el ensayista, sobre todo si tenemos en cuenta que es allí, en los mal llamados "micro" conflictos, donde se juega la recuperación democrática real para la vida cotidiana de los chilenos $\mathrm{y}$, por lo tanto, la posibilidad de erradicar las estrategias de control urbano y de exclusión que dominaron el orden social durante la dictadura y permanecen vigentes durante la transición. De eso hablan las crónicas de Pedro Lemebel. Al respecto el sociólogo chileno Felipe Portales analiza un hecho político elocuente. Señala que

Aylwin y el liderazgo de la Concertación comenzaron a ver a la Constitución de 1980, en sus preceptos permanentes, como democrática, sólo que imperfecta. Esto es, transformaron su concepto mismo de democracia, al valorar como tal la propia Constitución impuesta en 1980 con todos sus "enclaves autoritarios" vigentes e intocados (Portales 2005: online).

Portales explica en su artículo por qué los gobiernos de Aylwin, Frei y Lagos (es decir desde 1990 hasta 2004) no han tenido dentro de sus prioridades ni le han dado ninguna urgencia a las reformas constitucionales democratizadoras. Tanto en sus programas presidenciales, en las campañas del mismo carácter; en las parlamentarias y municipales, en sus alocuciones y mensajes presidenciales, y, sobre todo, en el tratamiento legislativo de las reformas propuestas, ninguno de los tres gobiernos ha ubicado el tema como prioritario. 
Parto de estas observaciones para plantear un elemento central en la intervención que Lemebel realiza en el campo social y cultural de su país. El autor publica su producción cronística durante los mencionados gobiernos de la Concertación; ese no es un dato casual, y a continuación voy a explicar por qué.

Durante los años de la dictadura del general Augusto Pinochet, el objetivo de la lucha de "los vencidos" (tanto de los que se fueron al exilio como de los que se quedaron) no podía ser otro que el de recuperar las instituciones democráticas de la nación. Conseguido ese objetivo nacional (que Tironi califica como "global") los sucesivos gobiernos de la Concertación dieron lugar a la expresión de los reclamos y las reivindicaciones sectoriales. Es decir, garantizados los derechos civiles de toda la comunidad, comienzan a hacerse oír las demandas particulares. Sólo para indicar las más destacadas y representativas, podemos mencionar los derechos de las comunidades indígenas o pueblos originarios, los derechos de las mujeres y de las minorías sexuales y la exigencia de inclusión social para las capas más bajas de la sociedad. Desde luego, cada uno de estos "núcleos" de reclamos abarca una miríada de reivindicaciones como entre otras- el acceso a la educación, al trabajo en condiciones dignas y al bienestar, o el reconocimiento territorial, político y social de los marginados.

Ahora bien, lo que quiero subrayar es que todos estos reclamos son percibidos por el conjunto de la sociedad como las demandas "del otro", desde una posición que se percibe a sí misma como homogénea, como "la normalidad"; y esa normalidad es, desde luego, blanca, "no marcada", común, esto es: “chilena”. El agente de aquellos reclamos particulares o sectoriales sería, por lo tanto, desde esta percepción de la identidad chilena, un individuo que pertenece a tal $o$ cual extracción social, a tal $o$ cual grupo etáreo, a tal $o$ cual identidad cultural, étnica o de género (pertenece o se reconoce en uno de ellos, y levanta como bandera esa pertenencia). Pero una gran cuestión del pueblo 
chileno, a saber, su identidad mestiza, no se plantea. No está en la agenda de la Concertación ni en el discurso de los ciudadanos que reclaman. Digamos más: su reconocimiento no se configura en los discursos como un "derecho" a conquistar. Más bien todo lo contrario. El derecho a la identidad se plantea (de manera implícita, y por lo tanto pre-reflexiva) como una cuestión sectorial, de una "parcialidad" equis, llámese indígena, pobre, proletario, sujeto femenino o gay. Y por lo tanto, de una manera también implícita, esos reclamos dibujan la fisonomía de la pluralidad aparentemente recuperada como una suma de parcialidades perfectamente definidas, "discretas", separadas en su autoconsciencia identitaria. Lemebel viene a discutir con esa autoconsciencia blanca o no-blanca, heterosexual u homosexual, y proclama el derecho a ser chileno, mestizo, "quiltra"; también "loca" o "coliza". Pone en la escena discursiva y pública el mestizaje como identidad, no como "problema a resolver". Lemebel propone dejar de pensar la identidad chilena en el marco de la oposición blanco / indígena (o blanco / no-blanco) y obliga a pensarla en una perspectiva latinoamericana, en la que conviven sin resolverse los muchos términos de la pluralidad cultural. En su artículo "El mundo indígena en el Chile de hoy", Sonia Montecino explica al respecto:

Nombrar en Chile indio, es equivalente a decir atraso, pobreza, flojera, borrachera; también, rostro oscuro, piernas cortas, cabello tieso. Así, la alegoría indígena es cuerpo social, cultural y biológico que expresa lo "otro" de un "uno" que se piensa como blanco. Desde esos paradigmas de lo blanco y lo no blanco la cultura mestiza chilena construye una identidad en donde lo "mismo" -la blanquidad - no se cuestiona, pues ni siquiera se piensa como diferencia frente a los "otros" blancos, los del primer mundo, los del desarrollo, los de la cultura de la palabra. (Montecino 114).

Es precisamente esa la intervención crítica que incorpora Pedro Lemebel cuando atenta contra la autoconsciencia blanca que no se cuestiona, que se reconoce una y la misma. La identidad chilena mestiza se oculta bajo la máscara de lo homogéneo, se 
niega. Y en la señalización del otro (pobre, marica, roto, loca, gay, travesti, indio), se disimula más aún. Por lo tanto, aunque parezca contradictorio, los reclamos sectoriales ajustaron la sensación de homogeneidad, al subrayar las diferencias como identidades fijas y absolutas, comprendidas en el marco del pensamiento binario. Recordemos que la oposición binaria siempre es excluyente y jerárquica: uno de los polos de la dicotomía está devaluado, negado o excluido. Desactivar esa exclusión no se logra optando por uno de los términos, cualquiera sea, sino deconstruyendo la dicotomía. Por ello Lemebel afirma radicalmente la heterogeneidad ontológica: opta por los devenires minoritarios.

Otro tanto ocurre en el campo de la identidad sexual y en el campo ideológico. En este último sentido Nelly Richard describe el mapa cultural de Santiago en los años de la transición, proceso del que fue protagonista, subrayando la dicotomía de la que hablé en el párrafo anterior. En su artículo: "En torno a las diferencias" (1991: 39-46) señala que durante la fase post-golpe las energías contestatarias que circulaban en el sector disidente se fueron expresando y ubicando en el "mapa de la contra-oficialidad". Ahora bien, "no todos defendían una misma política de los espacios frente a la clausura institucional ni concertaban iguales estrategias de lenguajes en respuesta a la censura ideológica" (39). La ensayista describe un panorama no uniforme ni homogéneo, sino más bien diferenciado en el que conviven modos muy diversos de la resistencia. Según ella, los conflictos internos de la contra-oficialidad fueron silenciados. "La plástica, el teatro, la poesía, el video, la literatura, narraban vivencialmente un cotidiano en lucha, y sellaban el pacto comunicativo de la denuncia en clave emotivo-referencial" (40). La autora señala la presencia de una "cultura militante" durante los años de la dictadura que va convirtiendo en "rito ideológico" cada una de sus prácticas. Richard es fuerte y no ahorra determinaciones peyorativas. Habla de una "épica de la Resistencia" como "el 
fundamentalismo mesiánico y redentor de las utopías; la re-mitificación de lo nacionalpopular [...] la re-trascendentalización de la Historia como monumento a los caídos y gesta redentora" (41).

Tal vez para no fragilizar más la trama solidaria del arte contestatario, los conflictos que generaba esta "verticalidad doctrinaria del sentido" fueron desatendidos o negados. La hostilidad del contexto durante aquellos años llevaba a proteger los agrupamientos que resistían y fue gestando una atmósfera dogmática que silenciaba las diferencias internas. Tanto Nelly Richard en el artículo citado como Grinor Rojo (1991: 57-70) reivindican el gesto de la neovanguardia que propuso la ruptura con el dogma militante y prefirió "el vocabulario micro-biográfico a la epopeya historicista" (Richard 1991: 42) a fin de interferir críticamente en las estrategias de una épica revolucionaria que caía en los mismos -o parecidos- mecanismos hegemónicos del oficialismo. Esto es muy importante para observar cómo opera Lemebel en esta trama de propuestas hegemónicas en contradicción, por cuanto su obra (tanto sus performancias como sus crónicas) y su participación pública (por su declarada diferencia de género y su desenfado, reactivo a cualquier verticalidad o dogmatismo) rechaza el fundamentalismo contra-hegemónico del discurso épico revolucionario tanto como los mecanismos violentos de la represión de Estado.

Todo el libro Loco afán. Crónicas de Sidario insiste en la falta de memoria y “el maquillaje" ambiguo del presente democrático que huele a dictadura. En su famoso "Manifiesto. (Hablo por mi diferencia)" (Lemebel 1996: 83-90) el autor expresa en un acto político de la izquierda chilena, fechado en septiembre de 1986, su condición triplemente minoritaria (poeta, pobre y "maricón") y subraya su hombría sin que haya en ello la menor contradicción: "Mi hombría me la enseñó la noche [...] Mi hombría la aprendí participando / En la dura de esos años [...] Mi hombría fue la mordaza [...] 
Comer rabia para no matar a todo el mundo" (1996: 87-88). Lo que pone en evidencia esta proclama es la sospecha de que ni la democracia ni el socialismo ni la izquierda traerán la libertad o la condena a la discriminación de género:

\author{
Y viene la democracia \\ $\mathrm{Y}$ detrasito el socialismo \\ ¿Y entonces \\ ¿Qué harán con nosotros compañeros? \\ ¿Nos amarrarán de las trenzas en fardos \\ con destino a un sidario cubano ${ }^{162}$ ? \\ Nos meterán en algún tren de ninguna parte \\ Como en el barco del general Ibáñez \\ Donde aprendimos a nadar \\ Pero ninguno llegó a la costa \\ Por eso Valparaíso apagó sus luces rojas (Lemebel 1996: 84)
}

El Manifiesto identifica términos aparentemente opuestos como "dictadura" y "democracia" y vincula a muy distintos colectivos políticos en la misma actitud de discriminación y violencia de género: la izquierda, el socialismo y el general Ibáñez. La última referencia alude al General Carlos Ibáñez del Campo, quien fuera dos veces presidente de Chile (1927-1931 y 1952-1958). La persecución a minorías sexuales se realizó durante su primer gobierno, amparándose en los artículos 365 y 373 del Código Penal y, durante su segundo periodo, en base a la Ley 11.625 de Estados Antisociales. La tradición sostiene que la persecución se habría manifestado en razias, organizadas desde la Presidencia y llevadas a cabo por Carabineros, contra grupos de homosexuales en Santiago, siendo capturados y trasladados a Valparaíso e Iquique, donde habrían sido embarcados y luego arrojados al mar atados a pesos, práctica conocida como "fondeo". El gobierno de Ibáñez instauró en el puerto de Pisagua un campo de concentración donde mantenían a homosexuales, gitanos, indigentes e inmigrantes, finalmente

\footnotetext{
${ }^{162}$ Alusión a la tenebrosa estrategia del "gobierno revolucionario" cubano que persigue, apresa y aísla a los homosexuales en instituciones de salud pública conocidas popularmente como "sidarios". Esta crítica se explicita en las crónicas habaneras del volumen: Adiós mariquita linda, que será analizado en el desarrollo de esta tesis.
} 
asesinados por grupos paramilitares. Si bien no existen pruebas de que efectivamente se hubiesen realizado dichos fusilamientos, Ibáñez del Campo era profundamente homofóbico -según algunos testimonios, debido a que su hijo Carlos era homosexual-y ejecutó numerosas redadas y detenciones contra homosexuales. Más allá de las dudas y la falta de documentación sobre la persecución y los asesinatos del General Ibáñez, “el barco del General" forma parte de la tradición popular chilena y -como es propio de la cultural oral- "todo el mundo sabe" qué significa esa alusión. Lo poderoso de la crítica de Lemebel es la inclusión en el texto de su Manifiesto de todo el arco político de la historia de Chile, irónicamente "unido" ante la discriminación homofóbica. La ironía se afila cuando se refiere directamente a la izquierda -que predominaba en el auditorio al cual se dirige el Manifiesto- y sus "banderas de la patria libre":

¿No habrá un maricón en alguna esquina desequilibrando el futuro de su hombre nuevo? ¿Van a dejarnos bordar de pájaros las banderas de la patria libre? (Lemebel 1996: 84-85).

A usted le doy este mensaje

Y no es por mí

Yo estoy viejo

Y su utopía es para las generaciones futuras

Hay tantos niños que van a nacer

Con una alita rota

Y yo quiero que vuelen compañero

Que su revolución

Les dé un pedazo de cielo rojo

Para que puedan volar. (Lemebel 1996: 89-90)

Los dos fragmentos que acabo de transcribir dejan en claro que el interlocutor es el militante revolucionario, y lo que el texto reclama y les exige a los presentes en el acto es abandonar la hipocresía, la ambigüedad y la discriminación de género que, de persistir, comprometerá el futuro de la proclamada "patria liberada". 
En la crónica "Gonzalo (o el rubor maquillado de la memoria)" (Lemebel 1996: 123-125), el estilista de Lucía Pinochet es una figura a un tiempo micro y macro política. Gonzalo maquilla a la esposa del dictador, pero "su elefántica silueta" es presentada en la crónica "maquillando la cara de la dictadura, tapando esa grieta, ese pliegue, esa mugre en la comisura del tirano, cuando ironizaba por televisión sobre el número exacto de desaparecidos" (123). La crónica de Lemebel pivotea siempre entre la historia menor o particular y la historia colectiva, trazando la diagonal que las atraviesa y las hace recíprocamente significativas. Gonzalo maquilla "eligiendo el tono manzana juppy para acentuar la prosperidad del régimen, irradiando de fresas estivales el crudo invierno dictatorial, que en la periferia arrumbaba cadáveres sin maquillaje." (Lemebel 1996: 124). Y tal como ocurrió con el alto mando militar, el estilista se benefició con el olvido consensuado de la posdictadura:

Nadie supo cómo Gonzalo, aprovechando la amnesia local y los festejos por el triunfo de la Concertación, se cambió de fila o se agarró a la cola de la bienvenida democracia. En el tumulto de muchos que vieron aguarse los privilegios del aura castrense, pasó colado agregándose rosa al arco iris de Aylwin ${ }^{163}$. (Lemebel 1996: 124)

La referencia irónica al "arco iris de Aylwin" da la clave de este libro: desencanto y pérdida de la ilusión ante "la amnesia local", la reconciliación forzada y la ambigüedad de los gobiernos de la Concertación que pactaron con los responsables de los crímenes de la dictadura un falso perdón hecho de olvido y de silencio.

El breve texto "Los cinco minutos te hacen florecer", en De perlas y cicatrices, es una postal de la mañana del doce (el día posterior al golpe de 1973). En él la imagen narra la historia con una eficacia mayor que la del discurso histórico convencional, por

\footnotetext{
${ }^{163}$ Como hemos señalado antes, el arcoiris fue el emblema de la Concertación, es decir, de la coalición de partidos que llevó al triunfo del NO en el prebiscito de 1988 y al consecuente llamado a elecciones que terminó con el régimen del general Pinochet, aunque no eliminó el poderoso aparato cívico-militar que convalidó políticas de consenso forzado y de amnistía encubierta, insistentemente denunciadas en las crónicas de Lemebel.
} 
cuanto los encargados de historiar el suceso son los cuerpos -sobre todo los tres cuerpos sin vida que yacen en el basural-, los niños que juegan en "esa pequeña cordillera de mugres" y los desechos acumulados que configuran el paisaje urbano marginal. También es determinante la pluralidad de los puntos de vista. En principio, el punto desde el cual se narra es la visión de un niño:

En esa pequeña cordillera de mugres, los niños de los bloques jugábamos al ski en los cerros de basura, nos deslizábamos en una palangana por las laderas peligrosas de fonolas humeantes. Allí en los acantilados de escoria urbana, buscábamos pequeños tesoros, peinetas de esmeraldas sin dientes, papeles dorados de Ambrosoli, el pedazo de Revista Ritmo bajo un espinazo de quiltro, una botella de magnesia azul churreteada de caca viva, un pedazo de disco 45, semienterrado, espejeando la muda música del basural que hervía de moscas, gusanos y guarenes esa mañana de septiembre en 1973. (Lemebel 1998: 86).

Luego el punto de vista se desplaza hacia los bloques: "Desde el tercer piso de los bloques, se podían ver los tres cadáveres en el rastrojo de los desperdicios, se veían todavía encarrujados por el último estertor, aún tibios en la carne azulosa, perlada de garúa con la gasa húmeda del amanecer.” (Lemebel 1998: 87)

Me detengo en la imagen que acabo de transcribir por la sobredeterminación sensorial que la hace insustituible para historiar el suceso: es una imagen visual y táctil (hay en ella textura, humedad y temperatura), auditiva (“estertor"), y de nuevo visualtáctil-visual. La imagen narra porque permanece viva en el presente del acontecimiento historiado. El texto histórico de Lemebel atraviesa la separación entre el tiempo de lo narrado y el tiempo del relato, imperativo epistemológico de la historiografía. Y lo consigue a través del lenguaje poético cuya saturación barroca le permite vehiculizar una experiencia física, ideológica y emocional, que hace historia. Por ello he subrayado la reticencia de las crónicas a dejarse capturar por el orden imaginario de un discurso 
histórico que postula una estructura inmanente a los hechos, la cual los dotaría de un "significado" o "sentido histórico". En este sentido Michel Foucault ha afirmado:

La historia será efectiva en la medida en que introduzca lo discontinuo en nuestro ser [...] Hay toda una tradición de la historia (teológica o racionalista) que tiende a disolver el suceso singular en una continuidad ideal al movimiento teleológico o encadenamiento natural. La historia "efectiva" hace resurgir el suceso en lo que puede tener de único, de cortante. (1971: 20)

Habida cuenta del campo teórico y metodológico que he presentado, marco de mi reflexión sobre la naturaleza de la narración histórica, y después del análisis de las crónicas realizado en el presente capítulo, queda claro que las crónicas de Pedro Lemebel rechazan en su discurso la continuidad ideal de una historia teleológica y providencial, y se configuran como textos capaces de vehiculizar y provocar una experiencia de la historia. La crónica provoca una relación dialéctica entre el discurso histórico y la economía de los cuerpos, en la medida en que recupera e integra los materiales (“particularidades", en términos de de Certeau) que la historiografía moderna descarta: "palabras, posiciones, experiencias [...] materiales devaluados por las economías utilitarias de la racionalización” (Ramos 1989: 10).

En este caso particular (me refiero a la crónica que acabo de analizar: "Los cinco minutos te hacen florecer", imagen-narración-testimonio de la mañana del doce) esos materiales devaluados por la historiografía moderna ("los acantilados de escoria urbana" y sus "pequeños tesoros, peinetas de esmeraldas sin dientes, papeles dorados de Ambrosoli, el pedazo de Revista Ritmo bajo un espinazo de quiltro") son recuperados por la escritura de Pedro Lemebel con el fin de generar la visión del acontecimiento inolvidable: "La imagen vuelve a repetirse a través del tiempo, me acompaña desde entonces como 'perro que no me deja ni se calla'. A la larga se me ha hecho familiar recordar el tacto visual de la felpa helada de su mortaja basurera." (Lemebel 1998: 87. 
Énfasis mío). El basural "que hervía de moscas, gusanos y guarenes esa mañana de septiembre en 1973" es el lugar elegido por Lemebel para que un niño emita su voz desde su mirada inocente y narre la muerte incomprensible, o lo incomprensible de la muerte:

Para mí, algo de esa sospecha no correspondía, no encajaba el adjetivo delictual en esos cuerpos de 45 a 60 años, de caballeros sencillos en su ropa triste, ultrajada por las bayonetas. Tal vez, abuelos, tíos, padres, mecánicos, electricistas, panaderos, jardineros, obreros sindicales, detenidos en la fábrica, y rematados allí en el basural frente a mi casa, lejos de sus familiares esperándolos con el credo en la boca, toda esa eterna noche en vigilia de siglos, para no verlos nunca más. (Lemebel 1998: 87)

La descripción de los cuerpos es un alegato en favor de su inocencia. Con una simple enumeración nominal ("abuelos, tíos, padres, mecánicos, electricistas, panaderos, jardineros, obreros sindicales") articulada en la voz y la mirada de un niño, Lemebel traza la línea de heterogeneidad que desequilibra el discurso oficial de la Concertación, aquel que fuerza los consensos y legaliza la amnistía, el falso perdón, el olvido y el silencio. Lemebel narra la muerte aunque sabemos que se trata de un acontecimiento que no se deja narrar, por cuanto no es simbolizable. El autor chileno elige transitar el camino de las estrategias barrocas para configurar un texto de altísima densidad, cuerpo opaco que se erige (como la máquina funeraria del siglo XVII) en el lugar de la presencia expulsada de la escena por superposición metonímica. Tal vez no sea la única posibilidad - nunca hay una sola- pero claramente es la necesidad inherente a la obra, la de dar cuerpo a lo que ya no está al tiempo que configura su presencia desvanecida.

"Las campanadas del once", en: De Perlas y Cicatrices se inicia con una imagen que prefigura la contradicción en la vivencia de esa fecha histórica crucial, preñada de ambigüedad: "Pa más recachas siempre hay un lindo día el once de septiembre, una 
mañana nacarada en el aire primaveral que contradice la nube tenebrosa de su recuerdo" (Lemebel 1998: 28). Mañana nacarada y nube tenebrosa condensan la contradicción del once que, a pesar de la vigencia de las instituciones democráticas, amanece militarizado hasta la crispación:

Casi todo es igual al primer once, como si de antemano se escenografiara el teatro crispado de una nueva puesta en escena. Entonces, ¿para qué tanto blindaje estacionado en las calles? ¿para qué tanto despliegue de pacos a caballo por todos lados? ¿para qué tanta exhibición de cucas aullantes, guanacos, zorrillos y arsenales de bombas lacrimógenas si no se van a usar? Si las legiones de policías, con sus escudos, se van a quedar todo el día sudándoles las verijas expectantes, esperando con ansias que aparezca una banderita roja para movilizar la repre. (Lemebel 1998: 28)

La militarización del "festivo democrático" funciona como analogía de la ambivalencia política de la transición. La crónica está atravesada por los contrastes de esa experiencia: "las violentas campanadas del once" que acompañan "los tunazos de los cañones" dan el marco de este "extraño festivo" que la democracia ha canonizado "[n]adie sabe a santo de qué". En una crónica anterior del mismo libro, el autor hace referencia a la "negociada transición" (18); aquí se refiere a "las contradicciones ideológicas [que] toman palco de acuerdo al remember trágico o festivo" (29). Pero lo que domina es aquello que Lemebel quiere poner en primer plano, y como es propio de su estética, escribe en un registro sensorial, que provoca la experiencia física de la ambivalente jornada:

En la mañana de un once, aunque brille un dorado sol, hay quienes aún despiertan tiritando, hay quienes no se levantan, y se quedan enredados en las sábanas de la vigilia, dormitando, tratando de alargar la noche anterior para borrar o saltarse los números paralelos de esta efeméride. Son muchos los que no quieren saber el día que están viviendo, y no despiertan, y duermen, y tratan de flotar en las aguas gelatinosas del presente once. Tratan de huir, de evitar la evocación de esa fecha nadando en cámara lenta, nadando contra la corriente en el río numeral del calendario, que inevitablemente los 
estrella contra los unos apareados de esas columnas. En la mañana de un once hay quienes no dan la cara, y andan todo el día mostrando sólo un perfil, y la otra faz la ocultan en la sombra. (Lemebel 1998: 29)

"Tiritando"; "quedan enredados en las sábanas de la vigilia, dormitando"; "no despiertan, y duermen, y tratan de flotar en las aguas gelatinosas del presente once. Tratan de huir"; "nadando contra la corriente en el río numeral del calendario": imágenes que provocan "una comprensión energética del texto", "tienden un lazo a los órganos", "penetran en la sensibilidad" (son términos de Antonin Artaud en El teatro y su doble), es decir, son capaces de generar la experiencia de aquellos ("son muchos") que no pueden negociar con sus recuerdos. Es la manera que elige Lemebel de contrarrestar el efecto "negociado" del festivo democrático. La crónica recuerda y pone en la escena textual la experiencia de los que no quieren despertar, de los que no quieren saber qué día es, y hace oír -como contrapunto dialógico- las voces de los que aún glorifican la masacre y recuerdan con nostalgia los bombardeos del "día más brutal de las últimas décadas", de aquellos que santifican y añoran la gesta pinochetista: "La segunda independencia, Pichy. Seguro que fue inolvidable pos oye. Me acuerdo clarito porque Felipe Ignacio estaba chico, y se escondió en la pieza de la empleada cuando bombardearon Tomás Moro. ¿No te digo?” (1998: 30).

En la crónica: "El encuentro con Lucía Sombra (o 'nunca creí que fueran de carne y hueso')", publicado en De perlas y cicatrices (Lemebel 1998: 24-25), el narrador -claramente identificado en el texto de la crónica como Pedro Lemebel- visita una exposición de arte a la que ha sido invitado. La crónica narra un episodio de violencia política en plena democracia, a raíz de la inesperada visita de Lucía Pinochet:

[...] la hija del tirano, la Lucía Chica, tan quebrada en su alcurnia de sables y guardaespaldas C.N.I., evaluando los óleos [...] como si todavía ostentara el cargo de autoridad cultural que le regaló su papi. 
Y lo peor, veo que la gente la saluda, rodeándola, mostrándole los dientes, como si aún ejerciera el sombrío poder de su pasada gestión. (Lemebel 1998: 25, énfasis mío)

A continuación, nuestro protagonista y autor se indigna e invita a los artistas presentes a retirarse juntos, para no "seguir respirando el aire macabro de esa presencia". El resultado es que lo hacen callar, lo tratan de "roto" y "pegado" y finalmente el pintor responsable de la exposición se hace presente:

[...] enterado de la escandalera, se acercó con los matones y me dijo: si no te gusta te vas. Claro que no me gusta le contesté, porque si quieres hacer negocios con el fascismo, no me invites de espectador. Casi no alcancé a terminar la frase, porque los dos gorilas de gafas negras me alzaron con sus manazas, sacándome en punta de pies a la calle, donde me dieron una golpiza que me dejó inconsciente tirado en la vereda. (Lemebel 1998: 25)

El final amargo de la crónica describe esa galería como el lugar "donde pintura, mercado y fascismo se dieron la mano, manchándose los dedos, en el día cómplice de aquella inauguración". En este cierre queda resonando el adjetivo "cómplice" que es el significante destacado de la crónica. Por eso el cronista ha dicho " $Y$ lo peor, veo que la gente la saluda, rodeándola, mostrándole los dientes...". Lo peor del episodio es, sin duda, la complicidad entre el pasado y el presente, y la naturalidad con la que la hija del tirano, ex-funcionaria del área de cultura en los años oscuros, se pasea entre sonrisas y saludos como si no hubiera participado de la dictadura sangrienta llevada adelante por su padre.

La evocación melancólica en "Camilo Escalona" (o sólo sé que al final olvidaste el percal)" (Lemebel 1998: 39-41) es una crítica al líder revolucionario que

\footnotetext{
${ }^{164}$ Camilo Escalona (Santiago, 15 de junio de 1955) es actualmente -desde el 20 de marzo de 2012presidente del Senado. Es Senador por la Región de Los Lagos, fue Diputado por la Región del Biobío entre 2002 y 2006, y por la Región Metropolitana entre 1990 y 1998, cargo que ocupaba durante la publicación de esta crónica. Fue, además, Presidente del Partido Socialista de Chile entre los años 1994 y 1998, 2001-2003 y 2006-2010. (Su dimisión le fue solicitada en diciembre de 2009 por conflictos
} 
salido de "la pobla" llega al parlamento para olvidar su origen proletario. El relato en primera persona se remonta al año sesenta,

[...] cuando las familias atorrantes llegaron a ese barrio nuevecito, recién pintado, con plaza, escuela y mercado [...] y todo el traperío chillón de los pobres que trasladaban del Cerro Blanco o Cerrillos para habitar las casas y bloques, que los panaderos y molineros habían logrado levantar en la Gran Avenida a puro ahorro y esfuerzo. (Lemebel 1998: 39)

La crónica no cae en la dicotomía izquierda-derecha o centro-periferia. Camilo es recordado con intensa ternura ("no puedo dejar de ver el acuario de sus ojos, lo único verde que chispeaba en el descolorido paisaje de la zona sur, en esos bloques de tres pisos [...] esas cajas de cemento para almacenar familias de mapuches panaderos que eran nuestros vecinos"). Camilo integra ese paisaje y esa población, aunque se destacan sus ojos verdes del gris descolorido de la zona así como su agilidad para alcanzar "los damascos maduros, tan arriba esos soles niños que mordía tu boca jugosa" (40). "Fuiste el único", "fuiste el único"; la frase se repite para introducir el momento climático del texto, en el que Lemebel astilla el discurso épico revolucionario al declarar -sin asumir su tono ningún matiz de denuncia ni de reivindicación política o ideológica- que Camilo se olvidó de ellos, se fue del barrio y se convirtió en un parlamentario de terno azul porque

[...] tal vez, nunca fuiste de los nuestros, ni siquiera con el puño en alto atragantándote con esas frases rojas que les discurseabas a los estudiantes para que te eligieran presidente de la FESES, en el Liceo Barros Borgoño donde también yo estudiaba. Nunca te creí del todo Camilo, y tú nunca me viste. ¿Cómo me ibas a ver desde las alturas del Marxismo Leninista? ¿Cómo ibas a mirar al mariquilla de la pobla, un colijunto temeroso que no se atrevía a realizar las hazañas de los niños machos. Un niño raro que te veía boquiabierto chuteando la

internos del partido). Acaba de publicar una biografía novelada en primera persona: De Allende a Bachelet, en la que realiza un análisis de la realidad política chilena desde los años sesenta hasta la actualidad. Cabe aclarar que el Partido Socialista integra la Concertación por la Democracia, coalición que gobernó Chile desde 1990 hasta 2010. 
pelota en la polvareda de la plaza, que se moría por tocar el pelaje dorado de tus muslos enrojecidos por el día de playa? (Lemebel 1998:

40).

Lemebel no recorre los caminos convencionales del odio clasista o la confrontación ideológica binaria (la cual repone, quiéralo o no, la gastada oposición entre buenos y malos, o inocentes y culpables). Camilo fue un chico de la pobla, hijo de un sindicalista panadero que construyó junto a otros sindicalistas los edificios de la populosa comuna de San Miguel, en el Gran Santiago. Tal como lo evoca la crónica, jugaba y correteaba como todos por los potreros del barrio. Resuena aquel "fuiste el único, fuiste el único", cuando el texto repite anafóricamente "ninguno creció como tú", "ninguno recorrió el mundo", "ninguno fue a la universidad, ni menos llegó a presidente del partido socialista" (40). El final de la crónica destila su crítica a la clase política cuando señala la distancia -que parece insalvable- entre los dirigentes (aun tratándose de un "héroe" del socialismo perseguido por la dictadura) y la comunidad que permanece en la pobreza, el abandono y la depresión:

Alguno murió en dictadura, otros en peleas de borrachos, y el resto se pudrió de cesantía, alcohol, drogas o delincuencia en alguna celda de la cárcel. [...] Como ves, en la población está todo casi igual, a no ser por todos los que faltan, los que se fueron esperando el día triunfal de tu regreso. Todos tenían algo que pedirle al parlamentario orgullo de la población. (Lemebel 1998: 41. Énfasis mío).

La crítica es mucho más aguda por tratarse de un político popular, un socialista de la Concertación que vivió en el exilio, regresó en 1982 con pasaporte falso para luchar contra el régimen, y permaneció en la clandestinidad hasta 1988, año en que se levantó la prohibición de regresar a Chile que pesaba en su contra. Los unos y los otros forman parte del campo popular: la homogeneidad es falsa, la realidad contradictoria y compleja. Esa es la historia que escribe Lemebel, porque no hay una Historia. 
También el exilio es una experiencia "canonizada" por el discurso mitificador de la izquierda revolucionaria (lo que Richard ha llamado "épica de la Resistencia” o “fundamentalismo mesiánico y redentor de las utopías”). En "El exilio fru-fru (o había una fonda en Montparnasse)" (1998: 42-44) Lemebel una vez más desbroza el heterogéneo entramado de la Resistencia y muestra que no todo era heroísmo lo que se opuso al régimen de Pinochet. La "sofisticación apátrida" de los que volvieron, es vista y descrita sin la menor concesión a lo políticamente correcto. Sin reparos, califica a algunos de los que regresaron del exilio como "esta clase del snobismo-return" que rechaza su sencilla procedencia para "adoptar los ritos de la neoburguesía cultural que engalana la política" (43).

En la aparente o forzada homogeneidad del campo popular, Lemebel hace saltar las diferencias: están los que "frivolizan en espumas de champán la película huacha del exilio chileno" frente al "desarraigo involuntario de tantos otros que la lejanía enfermó de regreso [...] Tantos más, famosos o no, doblemente exiliados por el suicidio, la enfermedad mortal o la depresión sin fondo de preguntar a diario: ¿te llegó carta? Lo supe. Ya me lo contaron" (44). No hay homogeneidad tampoco en la voz del cronista: reconocimiento doliente para los "anónimos patipelados que los tiraron donde cayeran: México, Argentina, Cuba o la lejana Escandinavia, donde eran cucarachas de carbón en el cielo albino de los vikingos" (42). Ironía implacable para los

[...] que tenían amigos y familiares en la Europa taquilla [...] y se hacían los franchutes hablando esa gárgara de idioma, mientras se abanicaban con un diario chileno en un boulevard, lamentando los días negros que pasábamos los compatriotas en Chile con la mierda milica hasta el cuello y las balas limpiándonos el poto. (Lemebel 1998: 42). 
Lemebel también consigna la voz del hijo del exilio, “jóvenes nacidos en las sábanas europeas" en los que se activó "un cierto rechazo al descubrir en el retorno a su sencilla procedencia":

Una vuelta siniestra al pobre aeropuerto de Pudahuel, que por más que lo modernicen, sigue siendo un ridículo mall plantado en los tierrales de la periferia. "Casi una cabina telefónica, una estación de juguete comparado con Oslo, Zurich o Fiumicino. Casi me dan ganas de devolverme cuando veo al Chile verdadero, tan feo y pobre. Ni parecido a la tierra añorada por mis viejos allá en Copenhague. Qué le encontrarán a esta porquería para querer venirse, digo yo". (Lemebel 1998: 43)

El cronista cuestiona a la actual "izquierda dorada" que se pavonea "en los eventos de la cursilería democrática". En todos los casos, lo puesto en tela de juicio es el olvido, lo que no se quiere recordar, la falsa democratización del sistema de gobierno que pacta con la garra autoritaria del pinochetismo que ha quedado en pie. ${ }^{165}$

Los textos de Lemebel se presentan como una historia particular y minoritaria, narrada desde los márgenes del espacio urbano y del tejido social. Los sujetos de estos relatos se encuentran siempre al borde de la legalidad, en los márgenes de Santiago, o bien son seres caídos del régimen social y por ello, forzados a practicar lo que el autor ha llamado "políticas del descontento". Los protagonistas marginales de estas crónicas no encuentran su lugar en el presente durante la sucesión de gobiernos democráticos que se inicia con el presidente demócrata-cristiano Patricio Aylwin, quien gobierna entre 1990 y 1994, continúa con la presidencia de Eduardo Frei quien gobierna hasta el año 2000; luego lo sucede Ricardo Lagos hasta 2006, y Michelle Bachelet quien gobierna

\footnotetext{
${ }^{165}$ La Constitución de 1980, promulgada durante la dictadura y firmada por el propio Gral. Pinochet, es la base de la Constitución actual, que garantiza la continuidad del cuestionado sistema binominal, según el cual cada región electoral cuenta con dos representantes en el parlamento, equiparando así antidemocráticamente- la mayoría con la minoría, o la primera minoría con la segunda. A esto se le suman todas las leyes básicas, que rigen hoy el sistema económico, social y cultural de Chile, que fueron impuestas por la dictadura. "Es el caso de las leyes que limitan el rol del Estado en la economía, que rigidizan el sistema de propiedad, conculcan los derechos laborales y sindicales de los trabajadores, atomizan a los sectores medios y populares, establecen sistemas mercantiles de salud, educación y previsión" (Portales 2005: online).
} 
hasta el 11 de marzo de 2010, fecha en que traspasa el mando al primer presidente conservador de la posdictadura, el empresario Sebastián Piñera.

La decisión, entonces, de narrar desde los márgenes del cuerpo social, dando voz y lugar a los protagonistas de una historia menor, implica una opción que presenta un triple carácter: ideológico, epistemológico y estético. Narrar desde un punto de vista marginal y minoritario exige hacerlo desde la experiencia del sujeto que vive o ha vivido esas historias particulares. Ello no significa que la crónica tenga que ser necesariamente testimonial; el sujeto siempre será de naturaleza ficcional, aunque el autor hable en primera persona. Aun en la llamada novela-testimonio de importante desarrollo durante los años sesenta, los sujetos del relato son construcciones discursivas (lo cual, por otra parte, es inevitable), aunque se llame Jesusa Palancares y ése sea el nombre de una mujer real a quien Elena Poniatowska entrevistó y grabó; o se trate de jóvenes que presenciaron y sufrieron en carne propia la Noche de Tlatelolco; o sea un anciano negro que narra y describe con detalle y precisión histórica las desventuras de su pasado de cimarrón. De lo que se trata es de remontar la generalidad y abstracción totalizante del discurso histórico para llevar -casi una utopía- los cuerpos al papel. Ése es el desafío que asumen y realizan las crónicas de Lemebel.

En su breve crónica "Hacer como que nada, soñar como que nunca (Acerca del video La venda, de Gloria Camiroaga)" en Zanjón de la Aguada (2003: 148-151) Lemebel reflexiona sobre una imposibilidad: la de "dar cuenta de la ciénaga oscura donde fueron sumergidas aquellos días" las mujeres cuyos rostros aparecen en la pantalla del video testimonio. El autor no narra lo narrado por las protagonistas, no nos cuenta a nosotros, lectores del siglo veintiuno, lo ocurrido tres décadas atrás, porque sabe que tampoco lo harán ellas, las mujeres torturadas cuya experiencia es intransferible. El texto sabe de esa imposible -aunque legítima y necesaria- 
transposición de la experiencia al habla. La historia seguirá "traspapelada", sin ninguna posibilidad de saltar el límite del papel, el límite de la palabra. Con la cadencia propia del ritmo poético, el texto insiste: "Habría que decir mil veces esto ocurrió, esto pasó [...] cerca de aquí mismo [...] cerca de la iglesia $[\ldots]$ en esa misma casa tan igual a otras casas. Esto ocurrió bajo este cielo" (Lemebel 2003: 149). Pero el cronista sabe que no alcanzarán mil veces, que el "deletreo ficticio" de la evocación sólo podrá dibujar testimonios desmembrados.

En la prosa del chileno se producen nudos de cristalización (esta crónica pertenece a la cuarta parte del libro titulada: "Cristal tu corazón”. Retratos) en los que la materialidad se adensa como queriendo colmar el vacío del relato, el lugar de aquella intransferible experiencia que evoca una y otra vez. Esos puntos están bien distribuidos en la breve extensión de este relato: "el roce del guante militar que timbró sus carnes con los hematomas dactilares del sello patrio"; "el triste emblema amoratado de sus llagas"; "lo gritan empañados estos ojos femeninos en el video". "La materia fonética y gráfica en expansión accidentada -dice Sarduy constituiría la firma del segundo [Barroco]. Una expansión irregular cuyo principio se ha perdido y cuya ley es informulable" (1987: 41). No se "habla" de nada en estos textos, hay sólo “acontecimientos perceptibles a través de los laberintos y los entrelazamientos fibrosos de la materia”, en palabras de Antonin Artaud. ${ }^{166}$ Y articulando la tensión que traba los fragmentos (ojos, bocas, hematomas): la suspensión. Ella parece no pertenecer a ningún campo: es lo puesto entre paréntesis. La suspensión no media ni vincula, es un punto de máxima tensión, de máxima saturación del suceder, un pasaje de máxima intensidad y de densa materialidad conectando con tensión y torsión la fuga y los retazos.

\footnotetext{
${ }^{166}$ En El teatro y su doble (1938) Antonin Artaud postula la necesidad de un cambio de posición para la palabra en el teatro. Tomando como modelo el teatro balinés, rechaza los usos occidentales y propone una "poesía de los sentidos que otorgue extensión a la voz" a fin de poder configurar en el lenguaje "los entrelazamientos fibrosos de la materia".
} 
“Dispositivo de proliferación que pliega y despliega la superficie de la lengua, y la transforma en materia" (Perlongher 1997: 94). Claramente lo que pesa en este texto es la ausencia. Es lo que no se ha podido contar en el video, es lo que el propio cronista no nos podrá comunicar a los lectores, es lo que "medio país" prefiere no saber, no recordar. Es el grito pero de ojos femeninos empañados. "Fue cierto, y a quién le interesa si medio país aún no cree" (Lemebel 2003: 150). Sin embargo, la suspensión, que adensa la materialidad trabada de este texto lo convierte en el más potente de la colección.

III.5. Hacia una nueva alianza entre la escritura y la historia

Como he dicho en la Introducción y a propósito de los textos analizados en este capítulo, Lemebel escribe historias que pertenecen al pasado reciente de su país, más precisamente al período signado por los gobiernos de la Concertación para la Democracia, comprendido entre 1990 y 2010. Por las razones que he desarrollado y a través de los procedimientos relevados, puedo afirmar que las crónicas de Pedro Lemebel constituyen una nueva alianza entre la escritura y la historia.

Su novedad va mucho más allá de su estilo singular o de la vigencia de sus opciones ideológicas, aspectos siempre señalados en la crítica periodística acerca de su obra. Su producción es decisiva porque interviene en la serie literaria y en la serie histórica, generando un nuevo estado de cosas en ambos campos. Los hechos narrados son episodios ocurridos y, en la mayoría de los casos, minuciosamente documentados. Pero ese recurso a lo real no determina su novedad. Lemebel despliega en sus crónicas un conjunto de procedimientos que ya han sido cartografiados en las páginas precedentes y que me parece oportuno recapitular aquí: 
$1^{\circ}$ ) Construcción de un punto de vista particular y minoritario, el cual permite narrar los hechos desde una perspectiva que el discurso de la Historia escrita hasta el momento había excluido o silenciado, o simplemente ignorado. Me refiero a las convenciones o protocolos del discurso historiográfico de la Modernidad a los que Latinoamérica no es ajena.

$2^{\circ}$ ) Inclusión de las políticas del cuerpo y del deseo en la agenda de la historiografía. Esta operación conlleva la necesidad de incluir en el relato histórico un registro de la experiencia de los protagonistas, registro cuya condición de posibilidad está dada, en primer término, por la apelación a la percepción que impera en las crónicas del escritor chileno, y en segundo lugar por el reconocimiento de un espacio para la energía vital-pulsional entre los agentes históricos. Es decir: el deseo es también una fuerza social, que determina prácticas y comportamientos no registrados en los discursos históricos convencionales, y por ello es creadora de nuevos saberes. Esto implica la decisión de intervenir en las políticas y prácticas de la enunciación historiográfica diseñadas para lograr la estructura ideal-imaginaria del discurso histórico moderno. Esa decisión exige construir nuevas políticas y prácticas de enunciación. Los procedimientos discursivos que hacen efectivas esas políticas y prácticas son, pues, de carácter literario y de carácter histórico, generando nuevas formas en ambos campos. Esas formas, además de generar cambios y redistribuciones en el sistema historiográfico y en el sistema literario, al hacerse cargo de una demanda colectiva de enunciación (“función", en términos de Tinianov), opera según otro principio, otra regla de construcción del significado histórico. Al leer en los pliegues del acontecimiento, construye un saber nuevo (Foucault 1969) a partir de la indagación y el despliegue del contenido invisibilizado. 
$3^{\circ}$ ) Nomadización del sujeto enunciador a través de la construcción de un espacio y tiempo no fijados, en tensión, en devenir. Esa tensión de un suceder que se presenta incompleto y fragmentario, no opera "en menos" según el prejuicio de la epistemología clásica que valora la presentación de la realidad según una imagen (ideal) de completud e integridad. El acontecer que presentan las crónicas de Lemebel tienen la calidad del fragmento y proponen como su específico saber un recorte de la realidad dado por esa visión parcial desde un sujeto en movimiento. El fragmentarismo se potencia al rehuir la selección de "temas centrales" optando por lo ocasional, que puede ser de apariencia nimia o irrelevante, como la mentira nunca registrada en el casillero del censista, o las prácticas autoeróticas en el cine Nagasaki que revelan la doble moral del jefe de familia clase media. En ambos casos el cronista releva un comportamiento social que la Historia oficial ha relegado o desconocido, y al mismo tiempo señala o denuncia la invisibilización de prácticas sociales ocultas en un cono de sombra para los discursos históricos.

$4^{\circ}$ ) Las crónicas de Pedro Lemebel se distancian del procedimiento muy frecuente en los discursos sociales de la posdictadura (presente o dominante, según los casos, en textos periodísticos y políticos sobre todo, pero también en las canciones de protesta de los setenta y ochenta y, en general, en el discurso de los intelectuales y artistas comprometidos con la recuperación democrática): la oposición binaria y dicotómica, es decir excluyente, del tipo: dictadura/ revolución, represión/ libertad, ley/ transgresión, dictadura/ democracia, izquierda justa y revolucionaria/ derecha inmoral y represora, entre otras posibilidades. Nuestro autor prefiere indagar en los pliegues de las prácticas sociales desatendidas por los discursos históricos y también por las voces de agentes culturales -escritores, compositores, cantantes- y desconstruir la oposición binaria, por cuanto no ha logrado nunca dar cuenta eficazmente de ningún 
acontecimiento o proceso de la realidad social. La representación de la realidad que se ciñe a esquemas dicotómicos sólo puede producir una reificación ideal-imaginaria del proceso o acontecimiento evocado. El autor chileno se propone cartografiar (no representar ni capturar) las líneas de fuerza que operan en el cambiante universo del proceso social (o bien de algunos fragmentos de ese proceso), determinando flujos de territorialización difíciles de predecir por esquemas previos rígidos y altamente convencionales.

$5^{\circ}$ ) Las crónicas abordan siempre una temática o cuestión que habilita, por lo menos, dos miradas. Sostienen su coherencia formal en la construcción de un punto de vista no hegemónico que desdobla lo que podría concebirse como unívoco, y de ese modo desnaturalizan - ponen en evidencia- la condición imaginaria e idealizante de una estructura del significado íntegra, sin fisuras. El tratamiento de la historia narrada en estas crónicas devela casi siempre un desajuste entre el sistema social y el sistema legal en el que se sostiene. Al ser confrontadas dos comprensiones completamente distintas de ese sistema, tiene lugar el conflicto. Las tensiones puestas en juego -se resuelvan o no a nivel de los acontecimientos- abren un espacio para la ambigüedad o el conflicto entre juicios críticos divergentes. Como señala Hayden White: "Para poder ser considerado histórico, un hecho debe ser susceptible de, al menos, dos narraciones que registren su existencia” (1978: 34).

La operación historiográfica implica introducir en lo narrado un principio de inteligibilidad. Ahora bien, para introducir ese principio es indispensable una operación previa, a saber: el corte. "El corte es el postulado de la interpretación" (de Certeau 18), y al mismo tiempo su dispositivo dominante. Las divisiones que producen los cortes organizan la representación que debe ser interpretada. Por lo dicho, en la cultura occidental moderna la inteligibilidad se establece necesariamente en relación al "otro" 
(de Certeau), sea el salvaje, el pueblo, el loco, el niño (el origen, la tradición oral, el cuerpo social como cuerpo mudo y por lo tanto "inconsciente"). A través de las disciplinas que van a configurarse en los siglos XVII y XVIII, se elabora un "saber decir" que interpreta todo lo que el "otro" calla. La medicina moderna nace a partir del momento en que el cuerpo se convierte en un cuadro legible (Foucault 1963), y por lo tanto, en algo que puede escribirse. Así la medicina y la historiografía modernas se construyen como "heterologías" (discursos sobre el "otro"), por cuanto el discurso provoca la separación y protege la distancia que lo separa de su objeto.

En las crónicas de Lemebel se opera un trazado que desanda el camino de la separación, acorta la distancia y se propone atravesar el corte. Esta operación múltiple y altamente transgresora, lejos de expulsarlo del espacio discursivo en el Chile de la posdictadura, lo integra como catalizador de la alteridad silenciada o silenciosa. Forma que ha encontrado su función (Tinianov 1927) e interviene en el sistema historiográfico incluyendo en él una estética y un conjunto de formas literarias como necesidad intrínseca al relato de la historia. A través de sus operaciones discursivas y de sus performances, Lemebel deconstruye los pilares del discurso historiográfico de la Modernidad, esto es:

la escritura en oposición dicotómica con la oralidad (entendida ésta como comunicación propia de la sociedad salvaje o primitiva). Lemebel opera el devenir oralidad-escritura: las voces de la calle y los registros populares (la canción chilena y latinoamericana, el refranero, la balada romántica, el bolero, el tango, el corrido mejicano) territorializan su discurso transformándolo en material sonoro.

la temporalidad propia de la episteme positivista, que organiza y permite la representación de una historia hegemónica y lineal. Lemebel opta por la categoría que 
teorizara Mijaíl Bajtín: el tiempo-espacio ${ }^{167}$. Sus crónicas son, más que secuencias ordenadas, cuerpos llenos, densa materialidad del enunciado que acorta la distancia narrativa interpuesta por la tercera persona y el pretérito perfecto. La materialidad de la cifra neobarroca, el presente de la enunciación y el sujeto nómade (Blanchot 1973; Kristeva 1974) construyen la condición material-espacial de estas crónicas.

la identidad. Lemebel toma como objeto privilegiado la alteridad, (la diferencia, "el otro lado" del corte historiográfico). La elección del objeto de las crónicas está siempre orientada hacia el acontecimiento histórico singular y minoritario, eludiendo las dicotomías -cristalizadas en "posiciones globales" y siempre jerárquicas- del tipo: izquierda/derecha; femenino/masculino; centro/periferia, historia/ficción, integrándolas en un compuesto heterogéneo, abierto a múltiples afecciones, en los términos de Baruch Spinoza.

la conciencia. Lemebel opone al privilegio de la conciencia ordenadora, que toma distancia y proyecta su principio de legibilidad sobre el objeto tratado, la comprensión de los protagonistas del margen según un principio de significación y de legibilidad propio, interno, no "venido de afuera" (la criminalidad "inconsciente" de los muchachos del bloque; la lógica de la familia censada irreductible a la lógica del censo oficial; la vida y la muerte de Loba Lamar compendidas sin el marco estigmatizador y objetivante de la categoría de análisis exterior y superpuesta: "una travesti”).

\footnotetext{
${ }^{167}$ Según el célebre teórico ruso "El cronotopo es el lugar en que los nudos de la narración se atan y se desatan. Puede decirse sin ambages que a ellos pertenece el sentido que da forma a la narración. [...] El tiempo se vuelve efectivamente palpable y visible; el cronotopo hace que los eventos narrativos se concreticen, los encarna, hace que la sangre corra por sus venas. Un evento puede ser comunicado, se convierte en información, permite que uno pueda proporcionar datos precisos respecto al lugar y tiempo de su acontecer. Pero el evento no se convierte en una figura. Es precisamente el cronotopo el que proporciona el ámbito esencial para la manifestación, la representabilidad de los eventos. (Bajtín 1938a: 250. Énfasis mío).
} 


\section{La crónica de Pedro Lemebel: Cuerpo y voz de identidades minoritarias}

La primera y más evidente señal de heterogeneidad en los textos de Pedro Lemebel es la complejidad de su universo intertextual: Néstor Perlongher; Manuel Puig; José Lezama Lima; José Joaquín Blanco; los géneros cómico-serios de la antigüedad y su transposición barroca; el cancionero popular, desde el "terciopelo ajado del bolero" hasta la balada pop española, aun aquella complaciente con el régimen franquista en la “afectada vocalización” de Raphael; los chilenos Violeta Parra y Víctor Jara, entre otros. $^{168}$

Esta composición de líneas intertextuales se produce en virtud de una operación de cruce de registros muy significativa, por cuanto es el vehículo de la recuperación de las voces que no tenían discurso, el proyecto poético-político de Pedro Lemebel. En efecto, los procedimientos discursivos que serán analizados en este capítulo visibilizan una diferencia en el tejido social: la crónica la hace audible (la convierte en voz) y la

\footnotetext{
${ }^{168}$ Considero oportuno realizar aquí un relevamiento de esa heterogeneidad, que recorre no solo el cancionero popular sino también películas y figuras conocidas de la radio, el cine y la TV. La canción popular latinoamericana está presente en todos géneros: Chabuca Granda y "el ritmo de sus caderas"; Daniel Viglieti y su famosa "A desalambrar"; a veces la canción domina el ritmo de la crónica como la pegadiza "Todo, todo" de Daniela Romo; el rock latinoamericano: Ney Matogrosso, Charly García, Fito Páez. La balada pop y el bolero sin distinción de nacionalidades: Maria Bethânia, Caetano Velloso, João Gilberto; Joan Manuel Serrat, Raphael, Nino Bravo; Mercedes Sosa, Dean Reed, Paul Anka, Chuby Checker, Neil Sedaka; Lucho Gatica, Lorenzo Valderrama, Palmenia Pizarro; Julio Iglesias, Miguel Bosé; Hervé Vilard; Lucho Barrios, el olvidado Joselito; María Félix, Sara Montiel, Lola Flores y Carmen Miranda; Celia Cruz y Chavela Vargas; Estela Raval y Los Cinco Latinos; Sandra Mihanovich y Celeste Carvallo; Moris; las bandas Virus y Los abuelos de la nada; Quilapayún, Los prisioneros, Illapu, Los Blops y Los Jaivas; Sergio Inostroza, Víctor Jara, Violeta Parra, Silvio Rodríguez y Pablo Milanés; Patricio Manns; Fernando Ubiergo; el Buena Vista Social Club al ritmo maraqueado del "Óigame compai”. El rock y sus géneros vecinos están presentes a través de John Lennon, Freddy Mercury, Bob Dylan, Joan Baez, David Bowie; Mick Jagger; Luca Prodan; Manu Chao; la cultura del video clip representada por Grace Jones, Michael Jackson, Gloria Gaynor. La mención de Errol's (empresa que, antes de la llegada de la transnacional Blockbuster, dominaba el mercado de videos en Chile) trae al texto de la crónica multitud de clásicos del cine: Franco Nero evocado en el film Querelle, de Fassbinder; La naranja mecánica; "el beso en Tokio de Bruce Lee"; Sylvester Stalone y su personaje Rambo; Schwarzenegger y Terminator; Pelotón; Mississippi en llamas. La "Carta a Liz Taylor" evoca, además de la diva de ojos "calipso", a Montgomery Cliff, Liza Minelli, Barbra Streisand. Y presente en muchas de sus crónicas como una figura de múltiples significaciones, Marylin Monroe.
} 
señala como discurso de un saber. ${ }^{169}$ Para efectuar esa operación, la crónica actúa como dispositivo de intervención en el sistema de identidades fijas que expulsa al "otro" fuera del marco de la representación social (imaginarios simbólicos no cuestionados por el paradigma dominante en los discursos historiográficos de la Modernidad).

Como se verá en los textos que analizaré en este capítulo, Lemebel deconstruye la "fábula exótica" (de Certeau) del amplio cuadro del universo marginal y la transforma en discurso efectivo, un discurso que cuenta una historia y comunica experiencias vividas por un colectivo "marginal" (en este caso: una minoría sexual estigmatizada y perseguida) sin caer en el estereotipo "gay" que, como todo estereotipo, constituye una abstracción, una categoría imaginaria. Y del mismo modo narra la experiencia de seres individuales, únicos, singulares, que si bien pertenecen imaginariamente a ciertos colectivos sociales (o "grupalidades" según el concepto empleado por Jesús Martín Barbero ${ }^{170}$ ) resultan singularizados en la crónica de nuestro autor. El discurso lemebeliano conjura la abstracción, inviste a sus personajes de una identidad que es particular y perceptible, porque accedemos a su conocimiento a través de los procedimientos de singularización y condensación que analizaremos en seguida. Con esas estrategias evita convertir la hermenéutica en un mero dispositivo de

\footnotetext{
${ }^{169}$ Todo el desarrollo de esta tesis asume -en algunos capítulos de manera explícita, en otros de manera implícita- los postulados de Michel Foucault en La arqueología del saber, texto canónico en el campo de la crítica del paradigma historiográfico de la Modernidad. En la Introducción a ese célebre tratado, Foucault reflexiona sobre el papel de la discontinuidad en los discursos históricos: "Para la historia en su forma clásica, lo discontinuo era a la vez lo dado y lo impensable: lo que se ofrecía bajo la especie de los acontecimientos dispersos (decisiones, accidentes, iniciativas, descubrimientos), y lo que debía ser, por el análisis, rodeado, reducido, borrado, para que apareciera la continuidad de los acontecimientos. La discontinuidad era ese estigma del desparramamiento temporal que el historiador tenía la misión de suprimir de la historia, y que ahora ha llegado a ser uno de los elementos fundamentales del análisis histórico." (1969: 13). Lo que Foucault llama "acontecimientos dispersos" (y resume en el interior del paréntesis con cuatro sustantivos a los que les podríamos sumar muchos otros) representan la diferencia, lo discontinuo, lo accidental, lo menor, que debe ser borrado según el imperativo epistémico de la Razón moderna que rige la construcción de la historia en su forma clásica. Las crónicas de Pedro Lemebel provocan, conllevan y son en sí mismas la insistencia de lo discontinuo que terminará por alterar el escenario discursivo en el que se producen, dominado por el statu quo inercial de los gobiernos de la Concertación (el "reconciliado sopor" cuyos requisitos son la impunidad, el olvido y el silencio).

${ }^{170}$ Respecto de la deuda epistemológica de este término con la obra de Sigmund Freud, ver nota 42 en el Estado de la Cuestión.
} 
traducción cuyo propósito sería capturar la diferencia para aplanarla y reintroducirla en el sistema. Lemebel logra mantener la diferencia sin separación y sin disolución. Por ello hace oir; transforma lo que se mantenía silenciado o silencioso en un saber que pueda oirse en la academia, en los medios de comunicación masivos -sobre todo radio y prensa gráfica-, en el libro y su sistema de distribución, en los escenarios callejeros de sus performances, en los paneles y mesas de debate, en las entrevistas, en los videos, es decir, en diferentes espacios y soportes de la comunicación social, y a través de ellos, al tiempo que modifica la serie literaria en su interacción dialéctica con las series vecinas, ${ }^{171}$ apela a la memoria a través de los sentidos: es la calidad sensorial de su escritura el vehículo de sus historias, lo que Pedro Lemebel quiere rescatar del olvido. Esas historias son narradas a partir de su propia voz reactiva a la identificación (no quiere integrar ningún colectivo contenido dentro de la vasta serie de "subalternidades" reconocidas); o bien a través de las voces de seres singulares, que, como él, no pueden ser enmarcados en una categoría social ni política ni sexual determinada.

En otros términos, aquello que se mantenía silenciado no se configura en sus textos como un núcleo esencial, entendido como identidad homogénea. Las minorías que nuestro autor se propone recuperar para el relato de la historia, no son abstracciones ni formas vacías, es decir, estereotipos, seres esquematizados y por lo tanto, imaginarios. Los personajes de las crónicas lemebelianas viven e interactúan como consciencias independientes y despliegan sus acciones y pasiones en el espacio-tiempo al que pertenecen y que comparten con los lectores de esas crónicas ${ }^{172}$.

\footnotetext{
${ }^{171}$ Como he señalado en otros momentos de la tesis, la noción de "series vecinas" de Iuri Tinianov (1927) es determinante para comprender la dialéctica interna al sistema literario. La correlación de la literatura con las series histórica, lingüística, social es ineludible para pensar su propia naturaleza dado que la literatura es un sistema en permanente tensión, o, como lo definiera Ian Mukařovský (1936), parte de la esfera artística, que se configura en antinomia dialéctica con la esfera extra-artística, y aun con la extraestética.

${ }^{172}$ Como es obvio, los lectores pueden habitar cualquier espacio-tiempo, pero sabemos que las crónicas de Pedro Lemebel han tenido una circulación inmediata en medios masivos de comunicación y es a estos lectores "inmediatos" a los que me refiero aquí.
} 
El problema de las identidades latinoamericanas, su heterogeneidad y su relación con los fenómenos de mundialización de la cultura, ha sido objeto de la reflexión de reconocidos especialistas, cuyos desarrollos voy a analizar a continuación dado que la obra de Lemebel está vinculada a este debate.

Según Jesús Martín Barbero, la cuestión de las identidades culturales "salta hoy al primer plano de las agendas tanto sociales como académicas" (2001: 40). La cuestión es crucial: o bien las identidades culturales asumen un papel activo en la constitución de los modelos y procesos de desarrollo de los pueblos, o bien tenderán a "atrincherarse" en particularismos a ultranza y fundamentalismos étnicos que los colocarían en una posición de antimodernidad. Esta observación forma parte de una reflexión general acerca de los procesos de globalización económica y mundialización cultural. Según Martín Barbero, la globalización es un objeto nuevo, que implica pensar la rearticulación de las relaciones entre países. En ese sentido, la globalización no integra la serie: imperialismo, colonización, invasión, dependencia, etc., porque

[...] lo que la globalización nombra ya no son movimientos de invasión sino transformaciones que se producen desde y en lo nacional y aun en lo local. Es desde dentro de cada país que no solo la economía sino la cultura se mundializa. Lo que ahora está en juego no es una mayor difusión de productos sino la rearticulación de las relaciones entre países mediante una des-centralización que concentra el poder económico y una des-localización que hibrida las culturas. (Martín Barbero 2001: 36)

Para comprender este cambio de paradigma, es necesario someter a una profunda reformulación las nociones de imperialismo y dependencia, por cuanto ha cambiado sustancialmente la idea de nación (también las de territorio, Estado y tradición, entre otras). La globalización no implica meramente un cambio cuantitativo ni cualitativo de las condiciones de extensión o de las políticas de expansión de un territorio o Estado, tampoco es una nueva instancia de los ejes centro / periferia, norte / 
sur, entre otras posibilidades; eso sería leer el nuevo proceso inscripto en la vieja lógica de la colonización. Tampoco se trata de negar los imperialismos actuales, que por cierto siguen existiendo y se reinventan y metamorfosean con habilidad sorprendente. La globalización es un fenómeno que se produce desde dentro de las comunidades locales, y una de sus estrategias es la virtualización del espacio vía interconexión satelital o informática. A propósito Martín Barbero cita a Milton Santos, quien reflexiona sobre las transformaciones que ha sufrido en este proceso la noción de espacio (y yo especificaría: la experiencia del espacio ${ }^{173}$ ). La falta de categorías analíticas para asumir esta transformación en las disciplinas sociales hace que nuestro mundo altamente interconectado (a través de los satélites, la informática y la televisión) caiga en la ilusión de homogeneidad. El espacio virtual indiferenciado diluye las contradicciones y ambigüedades de la cultura, de modo que se convierte en el gran vehículo del mercado. "Pues más que unir, una globalización enferma busca unificar" (2001: 36, énfasis del autor). Por ello el capitalismo y su lógica consumista promueven la producción de signos y de imágenes, aspecto que se vuelve tan importante como la inversión en nueva maquinaria. Los cambios se producen en el registro de la vida cotidiana: en el trabajo, los vínculos interpersonales, las comidas, el ocio, y en general, los modos de sociabilidad. A esto llama el autor "fenómenos de mundialización de imaginarios ligados a músicas, a imágenes y personajes que representan estilos y valores desterritorializados y a los que corresponden también nuevas figuras de la memoria" (Martín Barbero 2001: 38). Por ello la cultura es el gran vehículo del mercado en las

\footnotetext{
${ }^{173}$ Los fenómenos de globalización han generado innumerables modificaciones en la experiencia del espacio urbano (más allá de la noción o concepto que se tenga de él) porque han determinado cambios profundos en el desarrollo concreto de la vida cotidiana de los habitantes de la ciudad. Por ejemplo la masividad de los medios de comunicación y en particular la omnipresencia de la televisión en las capas altas, medias y bajas de la sociedad produce modificaciones sustanciales sobre los ejes que organizan la percepción, vivencia y apreciación del tiempo y del espacio. La globalización exige superar las versiones locales del tiempo, o sea, instalar la simultaneidad en tiempos y espacios (deberíamos decir: tiempoespacios) culturales distintos, en horas diferentes del día y de la noche. La comunicación global crea una nueva percepción, independiente de los meridianos, de la rotación de la Tierra, de la sucesión del día y la noche.
} 
estrategias de mundialización. Este proceso conlleva una paradoja: el capital es sensible a las "diferencias del lugar"; esto hace que las culturas locales acentúen o, podríamos decir, sobreactúen sus diferencias para hacerse visibles y atractivas. "La identidad local es así conducida a convertirse en una representación de la diferencia que la haga comercializable, esto es, sometida al torbellino de los collages e hibridaciones que impone el mercado" (Martín Barbero 2001: 37).

Por lo tanto la cultura es un espacio estratégico. Desde la diversidad cultural (historias, territorios, geografías, experiencias, memorias) no sólo se resiste, también se negocia e interactúa con la globalización. Según el autor, es necesaria una nueva conciencia de identidad cultural "no estática ni dogmática, que asuma su continua transformación y su historicidad como parte de la construcción de una modernidad sustantiva". La experiencia social de las identidades culturales (plurales) garantiza el saludable desborde de los "marcos maniqueos de una antropología de lo tradicionalautóctono y una sociología de lo moderno-universal. La identidad no puede entonces seguir siendo pensada como expresión de una sola cultura homogénea perfectamente distinguible y coherente" (Martín Barbero 2001: 40-41).

Pedro Lemebel interviene con su obra en este debate decisivo para el presente y el futuro de la identidad cultural en América Latina. Los marcos maniqueos a los que se refiere Martín Barbero en la cita precedente promueven la "autoconsciencia blanca" de la que he hablado en el desarrollo de la primera hipótesis. (Recordemos que nuestro autor rechaza el pensamiento de la identidad chilena en el marco de la oposición blanco/ indígena (o blanco/ no-blanco), para pensarla en una perspectiva en la que conviven sin resolverse los muchos términos de la pluralidad cultural ${ }^{174}$.) La identidad, pensada como

\footnotetext{
${ }^{174}$ Recordemos la reflexión de Sonia Montecino, ya citada: "Nombrar en Chile indio, es equivalente a decir atraso, pobreza, flojera, borrachera; también, rostro oscuro, piernas cortas, cabello tieso. Así, la alegoría indígena es cuerpo social, cultural y biológico que expresa lo "otro" de un "uno" que se piensa como blanco." (114).
} 
"una sola cultura homogénea perfectamente distinguible y coherente" es tan falsa e imaginaria como la estructura inmanente al relato de "la" historia, postulado implícito del historicismo hegeliano, al que tanto Lemebel desde su obra como Lezama Lima desde su reflexión ensayística y Hayden White desde su elaboración teórica cuestionan y a mi juicio desmienten. La identidad cultural es siempre compleja, heterogénea, dinámica, y por razones históricas en América Latina, mestiza. En el mismo sentido García Canclini propone:

La reflexión actual sobre la identidad necesita situarse en relación con varios soportes culturales, no sólo en el folclor, la literatura y la discursividad política, como ocurrió en los nacionalismos del siglo XIX y principios del XX. Debe tomar en cuenta la diversidad de repertorios artísticos y medios comunicacionales que contribuyen a reelaborar las identidades. Por lo mismo, su estudio no puede ser tarea de una sola disciplina (la historia literaria, la antropología o la sociología política), sino de un trabajo transdisciplinario, en el que intervendrán los especialistas en comunicación, los semiólogos, los urbanistas, y donde sería útil que participaran otros expertos, como los economistas y los biólogos, por ejemplo, que se ocupan de escenarios decisivos para la recomposición presente de las identidades. [...] La identidad, dinamizada por este proceso, no será sólo una narración ritualizada, la repetición monótona pretendida por los fundamentalismos. Al ser un relato que reconstruimos incesantemente, que reconstruimos con los otros, la identidad es también una co-producción. (García Canclini 1995: 14)

Esta concepción dinámica de las identidades culturales (necesariamente enunciadas en plural) está muy ligada a la concepción lemebeliana de la producción literaria. El saberse otro y construir su lugar móvil de enunciación a partir de la alteridad o de una alteridad cambiante (itinerante) lo hace reactivo a las estrategias del mercado, y de aquello que Nelly Richard llamó: "el supermercado de la subalternidad". Su experiencia de la historia reciente no se deja capturar en el marco de los "nuevos imaginarios mundiales" o más precisamente, en términos de Jesús Martín Barbero, los “fenómenos de mundialización de imaginarios" (2001: 38), dado que su nomadismo 
irredento lo aleja de toda construcción de ghetto que proponga lo subalterno como una nueva forma de conquistar territorialidad. Su política es siempre extra-territorial, por cuanto se obstina en permanecer en el margen, y si ese margen se transforma en una avanzada de lo "políticamente correcto", será Lemebel quien señale esa ubicación como un límite que deberá ser cruzado. El autor sostiene en una entrevista:

Mi inquietud cultural es hacer el contrabando de contenidos culturales a la periferia y llevar a ésta a la catedral cultural. Las crónicas de Loco Afán, que acaba de sacar una editorial tan prestigiosa como Anagrama, antes pasaron por revistas y diarios al alcance de todos, como The Clinic. Y en radio Tierra mi proyecto es llegar a hogares donde los libros son inalcanzables. He visto, de todos modos, que mis publicaciones tienen llegada en el pueblo. Hablo de sus cosas elaboradamente, con un poco de aparatosa literatura, pero porque creo que la supuesta identidad chilena es más compleja que la imagen simplona y atontada que nos da el rating televisivo. (PP) ${ }^{175}$

En otra entrevista ya citada, Lemebel reconoce y reivindica como una necesidad vital para su escritura la condición marginal:

Con respecto a Chile, la catedral literaria se yergue sobre las plumas de closet; a mí me aceptan con una risa torcida, debe ser porque la crónica marucha no compite con los géneros sacralizados por el canon literario. Me toleran con una náusea educada [...] También no se puede desconocer que hay una calentura mercantil por estos temas, donde cierta morbosidad de lo políticamente correcto mete su espéculo curioso. Uno no deja de ser un polizón en la nave de las letras, pero hay que entrar y salir sin que se sepa por dónde y cuidar que no suenen las alarmas. (Costa 2004: 6)

Numerosas crónicas de Lemebel (muchas de las cuales he analizado en el desarrollo del capítulo anterior) hacen referencia directa al clima de consenso forzado típico de la Concertación, en el que el pueblo chileno parece no querer despertar del letargo al que se vio sometido durante los años de la dictadura militar. También en ese campo nuestro autor es y se presenta como “otro". Así como no participa del "cóctel de

\footnotetext{
${ }^{175}$ Fuente: Archivo Lemebel. Proyecto Patrimonio (http://www.letras.s5.com/archivolemebel.htm)
} 
la concertación", no comulga con la ideología cómplice que fuerza los consensos y promueve el olvido y el perdón obligatorios, sin saldar cuentas; tampoco olvida su propia condición heterogénea, marcada por la diferencia en todos los campos (político, étnico, social y sexual) y la identidad mestiza del pueblo chileno. Precisamente, sus textos se proponen como un ejercicio de la memoria, como una intervención -muy eficaz- en la "puesta en escena" de la (falsa) homogeneidad cultural. ${ }^{176}$

Como hemos dicho, ese "otro" no es una identidad estable y por ello no se deja "representar"177. La conciencia de ello es el rasgo que lo distingue, por lo tanto su discurso no se presenta como una verdad, sino como un saber. Consecuentemente, evita la barra de separación ellos/ nosotros, por cuanto esa separación convertiría al "nosotros" en una posición fija, "encabalgada" en las dicotomías jerárquicas propias de la Modernidad (verdadero/ falso; existente/ inexistente; real/ ficticio; mito/ logos, entre otras) configuradas como polaridades de términos absolutos. Lemebel elude todo posicionamiento dicotómico y por fuerza descalificador de su opuesto. La dicotomía jerárquica no acepta otro funcionamiento: uno de los polos se convierte en el lugar de la verdad, puesto que en él se produce "el discurso que comprende a un mundo" (de Certeau 1978: 220). La escritura de Pedro Lemebel deconstruye ese dispositivo al

\footnotetext{
${ }^{176}$ En este sentido es importante recordar el contenido ideológico de sus performances: "La conquista de América", instalación y performance, baile nacional descalzo en mapa y vidrios, recuerda la obliteración cultural que implicó la conquista (Comisión Chilena de Derechos Humanos, Santiago, 1989); "Suda América", instalación y performance en la Obra Gruesa del Hospital del Trabajador, Proyecto de salud pública del gobierno de Salvador Allende, (Santiago, 1989); "Cuerpos contingentes", performance y exposición colectiva, (Galeria de Arte CESOC, Santiago, 1990); "La mirada oculta", exposición colectiva, fotografía, (Museo de Arte Contemporáneo, Universidad de Chile, Santiago, 1994); "N.N.", instalación y video, (Universidad de Talca, 1995). Como indican sus títulos la obra performática del colectivo de arte que integró con Francisco Casas pone en escena, recuerda y reivindica la diversidad cultural amenazada.

${ }^{177}$ Empleo aquí el concepto de "representación" en un sentido específico: el que le otorga la metafísica occidental de raíz platónica, según el cual la representación implica la generalización y por lo tanto la abstracción, puesto que remite a un conjunto de "notas esenciales" que corresponderían a un universal sin cuerpo ni materia. Por ello sostengo que la representación es impotente para dar cuenta de la heterogeneidad y el devenir. La crítica a la representación y sus consecuencias en el pensamiento occidental -de cuño nietzscheano- se encuentra desarrollada en la obra de numerosos pensadores contemporáneos que integran el marco teórico de la presente investigación (Michel Foucault, Maurice Blanchot, Gilles Deleuze y Julia Kristeva, entre otros).
} 
presentarse a sí mismo y al orden cultural al que pertenece como una heterogeneidad en devenir. Para dar cuenta de esas identidades heterogéneas, sus crónicas se configuran también como una entidad compuesta, atravesada por otros discursos ("oralidades" propias de diferentes sectores, como la del joven ex-convicto de "Solos en la madrugada" que analizaré a continuación, con su jerga particular y su extraño tono íntimo, endurecido por la exclusión, dulce y emotivo a la vez), ligada a otros géneros (sobre todo la poesía), vinculada a otros registros no literarios como la entrevista, la carta, el manifiesto, la canción y aun a registros no verbales como la fotografía y el dibujo. A continuación realizaré un recorrido por sus textos cartografiando las tres tensiones que articulan su escritura, a saber: historia/ ficción; crónica/ poesía y escritura/ oralidad.

\section{La tensión historia/ficción}

Yo escuchaba las historias que me contaba mi padre de hazañas de capitanes y gobernadores y pensaba en el gesto oculto, en la osadía colectiva de quienes quedaban detrás de los muros invisibles de la historia.

Miguel Barnet, Cimarrón

Como ya he señalado en los capítulos precedentes, Lemebel construye estratégicamente el lugar desde donde se enuncia. Cuando las crónicas están narradas en tercera persona, se trata de un sujeto que asume, por momentos, un registro que parece alcanzar la "objetividad", imperativo epistemológico del saber oficial. Pero esa tercera persona revela rápidamente su condición de máscara. Se habla desde un lugar particularizado, personal o íntimo. ${ }^{178}$ Esas dos modulaciones conviven, la voz que

\footnotetext{
${ }^{178}$ Las reflexiones de este apartado se sostienen, como es evidente, en la consideración del discurso histórico en el marco del análisis de la enunciación. Cuando señalo que el enunciador, en esta crónica en particular y en otras, oscila entre dos modulaciones de la voz narrativa: la "objetividad" -o su máscara- y el tono íntimo y personal, hago explícita referencia a la relación que el texto establece entre el plano del
} 
enuncia se desplaza de una a otra en suave deslizamiento sin bordes. Con este

procedimiento, el texto abre un campo de heterogeneidad, operándose un devenir entre una historia de ficción y el registro de los sucesos reales ${ }^{179}$.

Observemos cómo se configura el procedimiento en "La noche de los visones" (Lemebel 1996: 11-23), subtitulada: "la última fiesta de la Unidad Popular" en Loco afán. Un hecho de ficción (la cena de fin de año de un grupo de travestis) se convierte en el núcleo de una crónica, por cuanto nos ofrece un cuidadoso relevamiento de datos históricos, sociales, políticos y aun geográficos del contexto de esa noche. De este modo instaura en el texto una travesía: crónica en el corazón de la ficción, ficción como principio activo de la crónica.

El episodio de naturaleza ficcional es el encuentro de la "pandilla travesti" en ese lejano diciembre de 1972. En la cena festiva se confundían matices sociales, y la historia mínima y privada puede ser leída como una alegoría de la fiesta nacional que el relato evoca, por cierto idealizada, con la figura de los obreros sonrientes "a toda hilera de dientes frescos, a todo viento libre que respiraban felices cuando hacían cola frente a

enunciado (la historia narrada, sus protagonistas y sus acciones) y el plano de la enunciación (las condiciones del hablante que determinan y "marcan" la producción, su presencia en el relato). Esta perspectiva permite comprender que todo lo escrito es discurso, y por lo tanto, es significado. Como sostiene Roland Barthes: "A partir del momento en que interviene el lenguaje (¿y cómo podría no intervenir?), el hecho sólo puede ser definido en forma tautológica: lo anotado proviene de lo notable, pero lo notable es -desde Herodoto, en quien la palabra ha perdido ya su acepción mítica- sólo aquello que es digno de recordar, es decir digno de ser anotado. Se llega así a esa paradoja que regula toda la pertinencia del discurso histórico (con relación a otros tipos de discurso): el hecho nunca tiene sino una existencia lingüística (como término de un discurso) y sin embargo todo ocurre como si esa existencia fuera sólo la 'copia' pura y simple de otra existencia situada en un campo extra-estructural, lo 'real'. Ese discurso es sin duda el único en que el referente es considerado exterior al discurso; sin embargo, nunca es posible encontrarlo fuera de ese discurso". (Barthes 1970a: 48)

${ }^{179}$ Es importante puntualizar que "el registro de los sucesos reales" es siempre una ilusión, el reflejo de una decisión del enunciador, en razón de la cual decide evitar todo signo que remita a su presencia o a sus operaciones de recorte y selección: "Se trata del caso en que el enunciador dispone 'ausentarse' de su discurso, produciéndose, por consiguiente, una carencia sistemática de todo signo que remita al emisor del mensaje histórico: parece que la historia se cuenta sola. [...] A nivel del discurso, la objetividad -o carencia de signos del enunciante- aparece así como una forma particular de lo imaginario, el producto de lo que podría llamarse la ilusión referencial, puesto que el historiador sostiene que deja hablar solo al referente" (Barthes 1970a: 41-42) 
la UNCTAD ${ }^{180}$ para almorzar.” (Lemebel 1996: 11). A esa fiesta nacional que iguala y celebra, todos están invitados, igual que a la cena de fin de año en casa de la Palma. El relato se construye sobre la base de esta analogía: fiesta de fin de año en casa de la loca pobre, y fiesta nacional igualitaria y obrera, evocada nostálgicamente en el recuerdo de “ese primer amanecer del año 73" (13). En la trama de la historia ficcional, se filtra, vigoroso, el discurso histórico que ciñe y perfila el carácter fuertemente ideológico de la enunciación:

[...] la foto de la fiesta donde la Palma, es quizás el único vestigio de aquella época de utopías sociales, donde las locas entrevieron aleteos de su futura emancipación. Entretejidas en las muchedumbres, participaron de aquella euforia. Tanto a la derecha como a la izquierda de Allende, tocaron cacerolas y protagonizaron desde su anonimato público, tímidos destellos, balbuceantes discursos que irían conformando su historia minoritaria en pos de la legalización. (Lemebel 1996: 21).

Esta crónica se enlaza con la visión carnavalesca del mundo que ya hemos señalado en el Capítulo III, durante el desarrollo de la primera hipótesis. Aquí la “última cena", en alusión directa al cuadro de Leonardo, potencia la carnavalización de la muerte que permea todo el texto de la crónica y tiene como efecto relativizar la carga dramática del SIDA, lo cual permite narrar los hechos en clave humorística. Como señala Bajtín a propósito de esta transposición de la alegre relatividad carnavalesca a la literatura, el procedimiento es el punto de partida para crear un nuevo género literario:

Este nuevo género literario casi infinito, estaba consagrado por la tradición y tolerado en cierta medida por la Iglesia. [...] Sus autores debían poseer seguramente un cierto grado de instrucción, en algunos casos muy elevado. Eran los ecos de la risa de los carnavales públicos que repercutían en los muros de los monasterios, universidades y colegios. (Bajtín 1938 b. Énfasis mío)

\footnotetext{
${ }^{180}$ La III Conferencia de las Naciones Unidas sobre Comercio y Desarrollo (UNCTaD por sus siglas en inglés: United Nations Conference on Trade and Development) inauguró su edificio en Santiago de Chile durante la presidencia de Salvador Allende. Ver al respecto nota 6.
} 
A propósito de la heterogeneidad textual en las crónicas de Lemebel, vemos la configuración de un nuevo género literario que entronca en los modos populares de la antigua tradición de los géneros cómico-serios, estudiados por Bajtín como el contexto de François Rabelais. Bajtín inscribe en esta tradición, además, a autores como: Erasmo de Roterdam (su Elogio de la locura es considerado por el teórico ruso como uno de los textos emblemáticos de la visión carnavalesca del mundo), Cervantes, Lope de Vega y Quevedo. Y en la cita que acabo de transcribir, subraya la presencia de la risa carnavalesca en ámbitos institucionales "serios". Del mismo modo, la risa carnavalesca es traída por Lemebel al espacio de la seriedad institucional de los discursos de la historia, para configurar un mundo en el que las jerarquías se invierten y los valores sociales considerados menores o caídos del régimen social reconocido, adquieren visibilidad.

El procedimiento se suma a los ya analizados en el desarrollo de esta investigación, y su convergencia tiene como resultado -además de la escritura híbrida que estoy cartografiando- señalar la existencia de identidades "otras" y por lo tanto configurar un nuevo mapa social: las travestis también protagonizan la historia de Chile, y el drama del SIDA se juega en el entramado social, dentro del mapa urbano. El eje del pensamiento social se traslada del punto medio consagrado por los discursos hegemónicos de la historiografía (la clase media, la burguesía, los trabajadores formales, la familia, es decir, los grupos sociales o los estamentos reconocidos por los imaginarios simbólicos del pensamiento moderno) a una identidad social "marcada", no reconocida más que por su marginalidad.

Es importante puntualizar que a esta marginalización contribuyen, en parte, los mismos activistas que claman por el reconocimiento de una identidad minoritaria, con el fin consciente o inconsciente de reclasificar los márgenes y convertirlos en una etiqueta 
más, o en una identidad cristalizada y homogénea. ${ }^{181}$ Las crónicas de Pedro Lemebel operan en este sentido (lo que Richard llama "microdiferenciación" al distinguirla de la militancia social reivindicativa que postula la "diferencia" como consigna pedagógica y esencializante) por cuanto genera una intervención transformadora en la trama de discursos, prácticas y sujetos que configuran el complejo, heterogéneo y móvil campo de las fuerzas sociales y sus regímenes de identificación.

Lemebel interviene de un modo que cabe analizar aquí en el amplio y diversificado campo problemático de los estudios culturales, revisados intensamente por destacados teóricos y críticos de la literatura quienes, desde mediados de los años sesenta y hasta la actualidad, debaten acerca del papel de dichos estudios (también llamados estudios de "cultura y poder" o "crítica cultural") en el campo inestable articulado por las tensiones "entre lo simbólico y lo institucional, lo histórico y lo formal, lo antropológico y lo literario, lo ideológico y lo estético, lo académicouniversitario y lo cotidiano”. (Richard 2005: 186). Uno de los aspectos más productivos del proyecto de los estudios culturales, como afirma Nelly Richard:

[...] fue su voluntad de democratizar el conocimiento y de pluralizar las fronteras de la autoridad académica, dándoles entrada a saberes que la jerarquía universitaria suele discriminar por impuros en cuanto se rozan, conflictivamente, con el fuera-de-corpus de ciertos bordes llamados "cultura popular", "movimientos sociales", "crítica feminista", "grupos subalternos", etc. Los estudios culturales han favorecido el libre ingreso universitario de saberes que cruzan las construcciones de objetos con las formaciones de sujetos: el "adentro"

\footnotetext{
181 Como lo señala en muchos de sus trabajos críticos Nelly Richard: "El discurso de las identidades minoritarias y de sus políticas de representación ha terminado por someter cuerpos y textualidades a la consigna pedagógica de una 'diferencia' [de la] que casi siempre debe hablarse en tono reivindicativo y militante. Esta consigna ha dejado fuera de análisis las difusas simbolizaciones estéticas de ciertos trances de la identidad cuyos juegos interpretativos están hechos para burlar esta demanda políticamente ortodoxa de los estudios culturales - una demanda que reclasifica márgenes y marginalidades para su etiquetaje metropolitano en el gran supermercado de las subalternidades" (Richard 2005: 190). En el mismo sentido: "El manejo necesariamente localizado de las operaciones que demanda el conocimiento-en-situación de los estudios culturales, tal como Hall los concibe, supondría la microdiferenciación de las especificidades de contextos de lo latinoamericano a través del detalle práctico de cómo se trama la relación -material y contingente- entre discursos, sujetos, prácticas e instituciones, en cada sitio de intervención". (Richard 2005: 188).
} 
de la máquina de enseñanza con "afueras" múltiples que des-bordan el texto académico (sus archivos y bibliotecas) con los flujos conectivos de un pensar que no se basta a sí mismo y que desea poner en acción ciertas energías de transformación social. (Richard 2005:189).

En este campo cruzado de tensiones y posicionamientos epistemológicos, la crítica cultural postula la necesidad de una apertura del saber académico hacia otros registros (múltiples “afueras"), los cuales permean en el ámbito de la cultura -término también sometido a debate- configurando nuevas construcciones de objetos y nuevas formaciones de sujetos. El saber está vinculado a redes heterogéneas de producción social -no sólo producción de objetos sino también de prácticas- que le son inherentes. De esta interacción productiva da cuenta la literatura desde siempre. A propósito de las crónicas de Lemebel y la renovación formal que conllevan, cabe la pregunta: ¿no implica un profundo prejuicio de exclusividad y distinción de lo literario, sostener que la crónica y sus nuevas formas de subjetivación "traen" al sistema literario nuevos objetos y sujetos? ¿No ha sido siempre el sistema literario permeable y aun proclive a estos agenciamientos heterogéneos? Este debate se encuentra en la estela de la reflexión foucaultiana de la arqueología del saber, de allí que partiéramos de sus premisas singulares ${ }^{182}$ planteándolas de forma sucinta en la Introducción de esta tesis doctoral. La práctica cultural de Pedro Lemebel se constituye como objeto de altísimo interés de la crítica cultural, por su condición de dispositivo heterogéneo (una escritura en devenir: histórico-literaria-periodística-poética-política) que obliga a examinar las categorías tradicionales y los límites de las problemáticas académicas. La producción de Lemebel

\footnotetext{
${ }^{182}$ Foucault distingue el apriori histórico del apriori formal. El primero es "una figura puramente empírica [...] que permite captar los discursos en la ley de su devenir efectivo" (1969: 217). El apriori formal es definido como "una gran figura inmóvil y vacía", (imagen análoga a la que Deleuze define como "forma pura y vacía del tiempo" y denomina Tiempo-Cronos en su libro Lógica del Sentido, publicado en 1969, el mismo año que La Arqueología del Saber). El dominio de los enunciados articulados según el apriori histórico no es una superficie lisa y homogénea, trascendental e imaginaria, sino un espacio complejo, en el que se diferencian y despliegan regiones heterogéneas dando lugar al "espesor de las prácticas discursivas, sistemas que instauran los enunciados como acontecimientos" y también como "cosas". (Foucault 1969: 217-219)
} 
-precisamente por su registro heterogéneo y su condición nómade, siempre inestableda batalla también en el plano de la forma, y sus estrategias de lenguaje se juegan en un doble movimiento de territorialización: "desde" los discursos sociales territorializa el registro académico, generando una apertura, un borde problemático, una frontera permeable ("filtro" en términos de Iuri Lotman, si concebimos el universo simbólico académico-universitario como una semiósfera ${ }^{183}$ ); “desde” su estética y el valor poético de su discurso territorializa el género crónica y lo integra a la esfera estética dando lugar a la consecuente transformación del sistema literario vigente (la norma estética, como la entiende Mukařovský, en el sistema literario o esfera artística es más violada que mantenida, clave de la inestabilidad dialéctica de la serie).

El caso Lemebel realza el juego de las tensiones que estoy describiendo en el desarrollo de este capítulo (historia-ficción, crónica-poesía, escritura-oralidad) y plantea la necesidad de revisar los mecanismos intra-académicos que tienden a modelar representaciones reductivas de la literatura o -lo que es equivalente- una establecida "normatividad" de lo literario cuyo riesgo esencializante la crítica literaria intenta abolir desde 1927, año en que Tinianov responde a las críticas provenientes de la ortodoxia stalinista y escribe con lucidez admirable su ya comentado artículo: "Sobre la evolución literaria”. En la línea abierta por el eminente teórico ruso, trabajarán Mukařovský,

183 Según Lotman (1984) la condición dinámica de la semiósfera está garantizada por la pluralidad de códigos que en ella transitan. A diferencia de su maestro Jakobson, Iuri Lotman concibe que la decodificación se produce aun en el caso de que los agentes de la semiósfera no compartan natural o espontáneamente sus códigos. Por ello es clave en este desarrollo teórico el concepto de "filtro" (en rigor: los traductores-filtro que se encuentran en la frontera de la semiósfera) que acabo de usar en el cuerpo de mi argumentación: es en la frontera o límite de la semiósfera donde se alcanza la mayor actividad semiótica por el intercambio de códigos. A Lotman le interesan las discontinuidades, las interrucpiones y disrupciones en la transmisión cultural. De hecho, esta postulación complejiza el modelo comunicativo del formalismo ruso y lo hace apto para la consideración del dinamismo y la diversidad interna del campo cultural. En este marco teórico, los diversos tipos de cultura son considerados como lenguajes distintos y particulares. Por ello, los textos son creadores de sentido producto de la dialéctica interna, de los constantes diálogos intratextuales entre semiósferas. El autor da como ejemplo las catedrales en las que la fusión del estilo árabe, románico y gótico producen un nuevo sentido, una nueva lectura sobre ese campo semiótico. Por ello la hibridez cobra un sentido productivo en términos semióticos. Para Lotman comprender la vida significa estudiar su "oscura lengua", la actividad cultural cotidiana consiste en traducir una parcela de la realidad en alguna de las lenguas de las culturas, ver en el mundo un texto que requiere ser interpretado, que requiere ser traducido. 
Bajtín y Lotman. Por ello he recurrido reiteradamente a sus lúcidos desarrollos durante el trámite de esta tesis. Los cuatro autores dan cuenta desde sus diversas perspectivas y con dispositivos conceptuales diferentes pero compatibles, de la intensa heterogeneidad que da vida al sistema literario.

En virtud de una multitud de procedimientos que analizaré a continuación, Lemebel opera una transformación -lo que he llamado, empleando los términos de Michel de Certeau, una "hermenéutica del otro"- cuyo efecto no es sólo transformar las series literaria e histórica, sino dar cuenta de esas identidades en sus textos sin esencializarlas. Conservando sus diferencias particulares, las hace audibles, portadoras de un saber específico e integrado, parte activa y diferenciada dentro del mapa social (como fuera señalado en el estado de la cuestión, esta problemática es abordada también por: Richard 1998 y 2005; Ostrov 2003 y Ruffinnelli 2007). "Des-exotiza" la alteridad sin traducirla ni aplanarla; no la reintroduce en el sistema como un otro des-calificado, es decir fijado como identidad subalterna, en un allá siempre exterior (travesti, gay, pobre, delincuente, indígena, outsider, las nominaciones del "afuera") sino que la integra a través de sus propias voces, en la materialidad de su espacio-tiempo singularizado en la escritura, lo que le permite dar cuenta de ella en su particularidad irreductible a los estereotipos abstractos que la estigmatizan y excluyen.

La barra que separa el nosotros-aquí del ellos-allá se mantiene pero con una función distinta, por cuanto en el "otro" se reconoce una identidad singular y una posición de saber. Veamos un ejemplo. En "Los ojos achinados de la ternura mongólica" (Lemebel 2003: 40-43) incluido en Zanjón de la aguada, se narra un encuentro imprevisto entre nuestro autor y una niña con síndrome de Dawn. La crónica comienza con una crítica al privilegio de la razón y sus sistemas de control que dominan 
la organización social, estableciendo las categorías de "lo sano y lo enfermo" como procedimiento de exclusión:

En este sentido, el llamado síndrome de Dawn agrupa, excluyendo, a una parte de los ciudadanos que viven esta característica. Les pone etiqueta de tontos sin retorno, suavizando la agresividad de la palabra mongólico con la ficha clínica de "síndrome de Dawn", como si se bautizara a la comunidad entera con el apellido del científico que aisló y catalogó la enfermedad en el extremo intratable de la locura. (Lemebel 2003: 41)

Narra el cronista que el mencionado encuentro tuvo lugar en la presentación de su libro Loco afán. La niña, de alrededor de 12 años, estaba acompañada por su madre, quien le explicó que la pequeña escuchaba todos los días al autor en su programa de radio. La madre la llevó a la presentación para que lo conociera y lo saludara. Ella, sin embargo, parecía ausente y distraída hasta que reconoció la voz de Pedro, entonces "su mirada divagante me sintonizó. Me sentí invadido por la presencia de la niña, que transformó todas las líneas horizontales de su cara en una emotiva sonrisa. Y me abrazó tan bruscamente, estrujándome" (41-42). El núcleo de sentido de este texto es la lección que ese encuentro significó para el autor. Lemebel reflexiona acerca del concepto de lo "minoritario", lo revisa y reformula, cuestionando ya no solo los mecanismos de exclusión y control social mencionados al comienzo de la crónica, sino sus propios estándares de separación:

Allí, esa niña me enseñó una lección o reafirmó ciertos discursos que yo había leído sobre lo minoritario. Ella era la minoría entre todos mis lectores homosexuales, mujeres, proletarios con rasgos indígenas y militantes de izquierda que me estiraban el libro para autografiarlo. Ella, allí, era un desvío de la emoción, proponiendo otras formas quizás más oblicuas de comunicarse. (Lemebel 2003: 42)

En el mismo sentido Lemebel cuestiona una nueva tendencia que enmascara la segregación: contratarlos de mozos "para situarlos en el lugar domesticado de la 
servidumbre. Por cierto, al parecer ésta sería la solución más lógica y mercantil para integrar con piedad al mongolismo a una civilidad que no lo soporta" (2003: 43). Como hemos visto en otros textos, Lemebel no hace concesiones: rechaza una integración forzosa disfrazada de piedad y exige comprender al otro en su propia diferencia; en este caso: como un desvío positivo de la emoción, como un ser que propone otro modo de expresión del sentimiento. Ante la efusión de besos con la que ellos colman a sus seres queridos, el autor reflexiona: "Como si en esta fiesta de caricias, develaran el cortinaje de cinismo que educa nuestros afectos". He ahí la posición plena de sentido, como diferencia positiva, que caracteriza a la niña: su afectividad sin vergüenza, su lección de amor que pone en cuestión la comprensión que el propio autor tenía de "lo minoritario". La crónica señala el riesgo de estabilizar o cristalizar dicha noción en una parcialidad social atribuyéndole una "condición minoritaria fija" lo cual es abiertamente una contradicción. Como hemos señalado en el desarrollo del capítulo precedente, lo minoritario $^{184}$ es siempre móvil e inestable, por cuanto no participa de ninguna sustancia o estructura sino que es una fuerza desestabilizadora de aquello que se propone como dominante, sea una posición ideológica, un sector de la sociedad, una lengua o una rama del saber.

En igual sentido, Lemebel deconstruye la oposición binaria sujeto social/ sujeto marginado en el relato: "Solos en la madrugada" (o "el pequeño delincuente que soñaba ser feliz"), incluido en De perlas y cicatrices (Lemebel 1998: 147-149). En una noche de invierno el narrador se encuentra solo caminando por las calles de Santiago, "una ciudad donde todos somos extraños, a esa hora, cuando cae el telón enlutado de la

\footnotetext{
${ }^{184}$ Como hemos aclarado antes, esta expresión está empleada en el sentido preciso que la filosofía de Gilles Deleuze y Félix Guattari le otorgan. Es un término dinámico que señala en el objeto o fenómeno minoritario un proceso de resistencia a la estructura o sistema dominante. Una lengua minoritaria, por ejemplo, no es aquella que habla una minoría por cuanto lo minoritario no remite a una determinación cuantitativa. Una lengua minoritaria es aquella que opone su resistencia a las estructuras estandarizadas de la lengua dominante, dentro del propio sistema. Ver nota 115.
} 
medianoche $[\ldots]$ esta urbe se ha vuelto tan peluda, tan peligrosa, que hasta la respiración de las calles tiene ecos de asalto y filos de navaja" (Lemebel 1998: 147). En medio de esa sensación de acecho, el protagonista escucha pasos y alguien le pide un cigarrillo.

En ese momento climático de la narración se produce el encuentro:

[...] al decirle que fumo Life, para que supiera mi estado económico, igual me dice que bueno aspirando mi tabaco ordinario, igual me busca conversa $\mathrm{y}$ de pronto se interrumpe. De pronto se queda en silencio escuchándome y mirando fijo. Y yo, tartamudo, lo cuenteo hablándole sin pausa para distraerlo, pensando que viene el atraco, el golpe, el puntazo en la ingle, la sangre. Y como en hemorragia de palabras, no dejo de hablar mirando de perfil por dónde arranco. Pero el chico, que es apenas un jovenzuelo de ojos mosquitos, me detiene, me chanta con un: yo te conozco, yo sé que te conozco. Tú hablai en la radio. ¿No es cierto? Bueno sí, le digo respirando hondo ya más calmado. ¿Teníai miedo?, me pregunta. Un poco, me atreví a contestar. A esta hora es muy tarde y uno no sabe. No te equivocaste, dijo soltando la risa púber que iluminó de perlas el pánico de ese momento. Yo te iba a colgar, loco, agregó sonriendo. Mostrándome una hoja de acero que me congeló el alma colipata. Te iba a hacer de cogote, pero cuando te oí hablar me acordé de la radio, caché que era la misma voz que oíamos en Canadá. Pero la Radio Tierra es onda corta y no se escucha tan lejos. ¿Estuviste afuera? No, ni cagando, yo te digo en cana, en la cárcel, en la peni, tres años y salí hace poco. Me acuerdo que a las ocho, cuando dan tu programa, adentro jugábamos a las cartas, porque no hay na' que hacer. ¿Cachái? La única entretención a esa hora era quedarnos callados pa' escuchar tus historias (Lemebel 1998: 147-148).

Ha sido necesario extender la cita para respetar la dinámica de la narración y sus efectos. El espacio y el tiempo están eficazmente connotados para darle su lugar al acontecimiento. En las condiciones creadas por esa condensación única, absolutamente particular (la medianoche de un fin de semana de invierno en Santiago, una ciudad peligrosa, en la que "cada calle, cada rincón, cada esquina, cada sombra, nos parece un animal enroscado acechando") constituida por oscuridad, silencio, peligro, miedo y soledad, la voz es el registro en el que se produce el acontecimiento. La voz del narrador, inmediatamente reconocida por el joven que escuchaba el programa de Radio Tierra "en Canadá” (“en cana, en la cárcel, en la peni”), produce un cambio inmediato 
en la sensación de terror que invadía en ese momento al narrador protagonista ("Bueno sí, le digo respirando hondo ya más calmado"), y un cambio en el registro narrativo, por cuanto el discurso literario da paso al diálogo espontáneo con marcas de oralidad informal (“Tú hablái”, “¿Teníai miedo?”, “ni cagando”, “¿Cachái?”). Ahora bien, lo decisivo es el reconocimiento: "yo te conozco, yo sé que te conozco. Tú hablai en la radio." La voz produce la transformación, el cambio en la disposición del personaje ("Yo te iba a colgar, loco, agregó sonriendo [...] Te iba a hacer de cogote, pero cuando te oí hablar me acordé de la radio") y modifica el destino de agresión y muerte probable que le habría cabido al caminante si éste no hubiera sido Lemebel.

El punto de inflexión del relato (lo que he llamado "acontecimiento") se cristaliza en una imagen: "dijo soltando la risa púber que iluminó de perlas el pánico de ese momento". Todas las palabras de esta breve y condensadísima imagen tienen una función: "dijo soltando" - oralidad y distensión-; "la risa púber" -sonido fresco y juvenil de la voz más la risa que disuelve por completo la tensión acumulada-; “iluminó de perlas el pánico" - un haz de luz con el brillo de los dientes jóvenes disuelve la penumbra, ligada por los procedimientos literarios que describí antes a las acechanzas de la noche santiaguina condensadas en el breve y sonoro sustantivo "pánico", en el que resuenan por aliteración "perlas” y “púber”.

Me detuve en la descripción minuciosa del procedimiento por cuanto la suma de estrategias literarias produce el efecto buscado: comunicar la experiencia de ese encuentro; para ello el discurso tiene que hacerse sensitivo, ser vehículo de sensación. El joven ex-convicto aparece aquí con rasgos singulares y por ello no puede ser percibido como un "tipo", no es portador de una categoría social. Ese chico de "risa púber", “apenas un jovenzuelo de ojos mosquitos"-aunque dispuesto a "hacer de cogote" a su víctima- es sujeto de más de una contradicción: inocente y culpable, 
víctima y victimario, libre de toda sujeción y condenado a la marginación. El texto de Lemebel lo singulariza y hace oír su voz, vehículo de un saber. Por un lado, nos acerca su conocimiento directo de la vida carcelaria refiriendo la rutina de ocio y violencia que la signa:

[...] adentro jugábamos a las cartas, porque no hay na' que hacer [...] La única vez que no pudimos escuchar, fue cuando un loco agarró a patás la radio porque estaba hablando el ministro de justicia, y pasamos como un mes con la radio mala, hasta que la mandamos a arreglar al taller de electricidad. A veces alguien estaba preparando comida y hacía sonar las ollas y lo hacíamos callar para oír bien, porque tu radio se escucha pa' la goma. Otras veces se escuchaba clarita, pero los otros presos andaban amargados pateando la perra porque les habían negado el indulto, porque no tenían visitas, porque el abogado les pedía más plata, o porque los gendarmes güeviaban tanto. Ahí, antes que estallara la mocha, ${ }^{185}$ yo agarraba la radio cassette y la ponía bien bajito debajo de las frazadas pa' escucharla. (Lemebel 1998: 148).

El fragmento marca la oposición entre la violencia carcelaria y el refugio de la escucha en la intimidad de la cama ("la ponía bien bajito debajo de las frazadas pa' escucharla"); el personaje está humanizado, escapa por completo a la abstracción imaginaria y homogeneizadora de los estereotipos. Además, tengamos en cuenta que otro saber que vehiculiza el personaje es la realidad del ex-convicto:

Y qué otra cosa voy a hacer, me dijo triste. ¿Cómo voy a trabajar con mis papeles sucios? En todas partes piden antecedentes, y si me encuentran los pacos les tengo que mostrar los brazos. Mira. Y se levantó la manga de la camisa y pude ver la escalera cicatrizada de tajos que subían desde sus muñecas. Uno se los hace para que no te lleven preso y te manden a la enfermería. Pero cuando los pacos te ven las marcas, te mandan al tiro pa' dentro. No hay caso, no puedo salir de esto. Es mi condena. (Lemebel 1998: 148).

Queda resonando al final de este fragmento la palabra "condena". El jovencito está libre ("salí hace poco") pero pesa sobre él la condena de la marginación sin salida.

\footnotetext{
${ }^{185}$ Se refiere a la violencia intracarcelaria; "la mocha" alude al remate grueso y romo de la culata de un arma de fuego.
} 
Los "papeles sucios" le cierran el ingreso a muchos puestos de trabajo, las marcas de los tajos autoinfligidos para evitar ir preso lo conduce a la prisión ("te mandan al tiro pa' dentro") lo cual dibuja un círculo infernal e ineluctable. ${ }^{186}$

La crónica nos pone al tanto de un saber y nos hace participar de una experiencia. La fuerza del texto, su potencia, está dada por procedimientos literarios que permiten historiar el suceso, encarnado por un personaje real (Pedro Lemebel, narrador en primera persona de esta crónica, creador y conductor del programa que el jovencito escuchaba a las ocho de la noche por Radio Tierra en la prisión) y un personaje cuya condición ficcional o real no se plantea como problema en la lectura. Participa de la condición "real" del escritor que lo incluye en un relato autobiográfico; es sujeto de las contradicciones que han sido señaladas y por lo tanto, es portador de una posición plena de sentido, de una visión particular de su mundo; dichas condiciones constituyen su verosimilitud y lo salvan de la objetivación totalizante, ideal e imaginaria propia del estereotipo.

Del mismo modo la prosa lemebeliana des-exotiza otro colectivo salvándolo del riesgo de la "subalternidad" que homogeneiza y aplana diferencias. Se trata de un grupo muy cercano al autor, precisamente los portadores del mal del siglo: el HIV. Para detenerme en él vuelvo al libro anterior, publicado en 1996. Uno de los núcleos de sentido que hilvana Loco afán. Crónicas de Sidario es la crítica -aguda y cuidadosamente documentada- de la hipocresía del mercado que fagocita el drama del SIDA y lo gana para su beneficio. En el texto "Y ahora las luces" (Lemebel 1996: 6768) el discurso de la crónica brilla con luz propia, desalojando la ficción, y sostiene con dureza la acusación contra "la garra comercial del mercado AIDS":

\footnotetext{
${ }^{186}$ Ver el análisis de esta misma crónica en: "Las travesías del imaginario: la poética del des-borde en la obra de Pedro Lemebel", artículo de María A. Semilla Durán, incluido en el libro que ella misma compila (Semilla Durán 2012: 101-103).
} 
La propaganda de prevención dirigida a los homosexuales, pareciera estar resuelta en el abanico publicitario que multiplica la enfermedad a través de sus diferentes versiones. Así el SIDA se espejea entre los productos del mercado, travestido como un fetiche más en el tráfico gitano de la plaga. (Lemebel 1996: 67).

El SIDA vende, y la crónica denuncia y analiza, entre otros casos, "el negocio SIDARTE de Benetton", y "la superproducción hollywoodense que multicopia la postal gay de Filadelfia, enmarcada de amapolas venenosas" (Lemebel 1996: 68). La cercanía con la crónica periodística también se evidencia cuando expone, con notable rigor crítico, el intento de configurar un espacio gay en el mundo rockero inaugurado en América Latina por Ney Matogrosso; intento asfixiado por las estrategias del mercado que lo convirtieron en máscara y en receta de éxito: la escenificación de un imaginario y "una erótica bisexual para todo consumidor" (Lemebel 1996: 99). O bien el lugar ambivalente del personaje de Sergio, protagonista de la segunda crónica de Loco afán, en la que se narra una conmovedora historia de amor platónico entre la Regine y Sergio, un conscripto torturador-torturado por la culpa. La historia transcurre durante una noche de protesta popular en plena dictadura, vista desde la ventana del cuarto piso donde "el palacio de la Regine" se ilumina con el neón de "Aluminios El Mono", en los arrabales de Santiago. El relato filtra el discurso de la historia atravesado por la conciencia desgarrada de Sergio en "la noche protesta", oyendo en el silencio "los gritos de mujeres agarradas a los hombres que él arrastraba a culatazos hasta los camiones", o "el gemido del nylon al rasgarse las camisas de dormir de esas mujeres, que él separaba de sus familiares" (29); la voz de Lemebel lo hace escapar del posicionamiento polarizado y homogéneo: no está en el "lugar" que la historia de los significados completos ${ }^{187}$ le

\footnotetext{
${ }^{187}$ Con esta expresión me refiero a la Historia Monumental, o la de los "significados completos", según Michel Foucault, estructura imaginaria y abstracta regida por los postulados de la racionalidad moderna. Toda mi investigación se inscribe en la reflexión genealógica, de origen nietzscheano, que revisa los presupuestos de la historiografía clásica e introduce la valoración tanto de la pluralidad de los puntos de vista particulares, como de la sensualidad de los sujetos considerada como vía de conocimiento. En el
} 
otorgaría a un militar al servicio de la dictadura de Pinochet. Lo mismo sucede en el texto que relata la muerte de Willy, el integrante de Quilapayun, (calificada como “muerte de tango, de página amarilla, de riña callejera"), en el que se diluye el mito del artista-héroe popular, "recién retornado al Chile democrático" (Lemebel 1996: 105):

Porque la verdad, éste era un Chile desconocido para el Willy tantos años lejos, cantando las mismas canciones, la misma "Plegaria del labrador" para gringos solidarios. La misma cantata del "Pueblo unido jamás será vencido", que tanto emocionaba a los italianos chupando pastas con tuco. El mismo "Potito embarrado" del niño Luchín para la elegancia francesa. Las mismas huijas dolorosas de la Violeta Parra, reestrenadas mil veces para la piedad europea. El mismo avión, los mismos estadios y peñas de exiliados entonando la cueca del regreso, comiendo la empanada sintética y la humita de choclo congelado. (Lemebel 1996: 106).

Hay una evidente operación de desmitificación del héroe, presentado aquí como un exiliado de regreso que desconoce los lugares y los códigos del pueblo que dejó al partir como refugiado político, y vuelve para morir de un modo absurdo, "a manos de la noche cafiola y travesti” (Lemebel 1996: 105).

En el texto "Los diamantes son eternos. (Frívolas, cadavéricas y ambulantes)” de Loco afán (1996: 69-74), Lemebel realiza una estrategia de reversión de un género discursivo testimonial: la entrevista. Se propone transcribir las respuestas de un homosexual portador de HIV "sin la mascarada cristiana de la entrevista televisiva [...] jugando con el aura star de la epidemia" (69-70). El género discursivo aparece parodiado, lo cual provoca dos efectos: por un lado, se "frivoliza el drama" a través de

contexto de la obra lemebeliana, la caída de esos postulados está dada por la deconstrucción de las figuras emblemáticas que estoy analizando en este apartado: el conscripto Sergio no resulta aquí -en la crónica de Lemebel- un "agente" del proyecto despótico del dictador, sino un hombre sensible, torturado y solo, sin dejar de ser por ello un "torturador" del régimen. Su ambigüedad lo gana para la historia particular y minoritaria, que solo puede ser leída "por fuera" de las formaciones discursivas (Foucault) que constituyen la historia en su forma clásica. Recordemos las palabras del autor, ya citadas: "lo discontinuo era a la vez lo dado y lo impensable: lo que se ofrecía bajo la especie de los acontecimientos dispersos (decisiones, accidentes, iniciativas, descubrimientos), y lo que debía ser, por el análisis, rodeado, reducido, borrado, para que apareciera la continuidad de los acontecimientos. La discontinuidad era ese estigma del desparramamiento temporal que el historiador tenía la misión de suprimir de la historia, y que ahora ha llegado a ser uno de los elementos fundamentales del análisis histórico.” (1969: 13). 
respuestas cargadas de ironía y humor; y por otro, el entrevistado se sustrae con sus respuestas a la segregación y a la falsa piedad. Cuando el entrevistador le pregunta si el SIDA es un privilegio, "la loca positiva" responde: "-Completamente, me hace especial, seductoramente especial. Además tengo todas las garantías [...] como portador, tengo médico, sicólogo, dentista, gratis. Estudio gratis.” (Lemebel 1996: 71)

En las historias de Lemebel no hay héroes ni figuras idealizadas. La historia se narra a escala humana, sin ninguna operación que promueva la trascendentalización de los seres que protagonizan las crónicas; no se pretende sustituir una mitificación por otra, sino echar luz sobre los intersticios de la historia. Al respecto, el autor nos presenta aquí el drama social en una dimensión individual, por cuanto su propósito es, una vez más, historiar lo particular. El soporte es una estrategia paródica que opera la dilución de la falsa piedad o la conmiseración social que dominan el discurso habitual en estos casos. Aquí los actores juegan con el "aura star de la epidemia" dándole aires de vampiresa a la infectada y sobre todo, conjuran la muerte con la risa, procedimiento dominante en Loco afán, ligado a los artificios literarios del Siglo de Oro español que ya hemos analizado en el desarrollo del Capítulo III. La ironía se filtra eficazmente en el discurso del seropositivo. Su eficacia radica en que logra invertir la carga de la prueba: al habitual "interrogatorio indigno que siempre coloca en el banquillo de los acusados al homosexual portador", el texto opone una dinámica de preguntas y respuestas que pone en evidencia un estado vacante, un drama social cuya responsabilidad la opinión pública suele atribuirle a las víctimas. El propósito es desactivar el "estigma sidático" señalando la falta de políticas institucionales que den respuestas al drama del portador, y al mismo tiempo señalar la mascarada piadosa en el tratamiento mediático (reparemos en el juego de palabras: el estigma sidático) de la epidemia, desautorizándola con las armas de la ironía, la risa y la frivolidad. La crónica logra restituir la dignidad al personaje quien 
sostiene la alegría y el humor en el lugar habitualmente ocupado por la victimización y la vergüenza:

-¿Por qué portador?

-Tiene que ver con puerta.

-¿Cómo es eso?

-La mía es una reja, pero no de cárcel ni de encierro. Es una reja de jardín llena de florcitas y pájaros.

-¿Barroca?

cardenales.

-No sé lo que es eso, pero puede ser, una verja llena de

- ¿Y a dónde conduce?

-Al jardín del amor.

(Lemebel 1996: 70)

Como vemos en este texto, y tal como lo he señalado en la Introducción, uno de los rasgos que caracteriza a las crónicas de Lemebel y que permite tender líneas genealógicas tanto con las crónicas de Indias como con la crónica modernista, es la clara conciencia autoral de ser una mirada, un pensamiento vehiculizado por la escritura, como consecuencia directa de la posición del observador. Afirmo, como he señalado en la Introducción, que todos los discursos de la historia lo son, pero el sujeto de la crónica lo sabe, porque si bien el discurso historiográfico (como otros que se vinculan estrechamente con el acontecer histórico: periodismo narrativo o novela no ficcional, por ejemplo) es el resultado de una posición particular del observador, desde la cual se ajusta la regla fundamental de su verosímil: ser un punto de emisión de la voz que registra y da testimonio fidedigno de los hechos narrados, en Lemebel el discurso narrativo -lejos de disimular u omitir las particularidades de la enunciación y de su emisor para presentarse como voz que registra- capitaliza un punto de observación y una identidad (india o mestiza, loca o coliza, gay o marica, travesti, pobre o infectado, chileno o cubano emigrado, entre muchas otras) para producir un discurso que conoce y 
narra cada historia en su propia particularidad incategorizable; ${ }^{188}$ un discurso cuyo propósito es expresar el lugar, el tiempo y la voz (o las voces) como condensación de sentido, lo cual le permite al lector acceder a una experiencia de los sucesos narrados y no a un conocimiento abstracto del acontecer histórico ${ }^{189}$. A continuación voy a desarrollar más detenidamente este aspecto dando cuenta de él en algunas crónicas en las que se manifiesta de modo paradigmático.

En "Su ronca risa loca. (El dulce engaño del travestismo prostibular)" (Lemebel 1996: 77-79) se registra y se narra el callejeo nocturno de una travesti. La crónica enfoca en el juego de mascarada y autoengaño que se produce noche a noche a la vera de la rotonda o "al rojo vivo de los semáforos que sangran la esquina donde se taconea el laburo filudo del alma ramera" (77). El transeúnte "siempre sospecha que esa bomba plateada nunca es tan mujer", pero "igual engancha su deseo en las alas nylon de esas mariposas patipeladas" y se presta al juego.

Lo que quiero señalar en este texto es la poderosa condensación producida en y por los planos de la historia: el espacio, el tiempo, la particularidad de esta travesti y la singularidad delineada con perfiles precisos del cliente. El espacio narrativo, connotado al comienzo de la crónica como “el zaguán del prostíbulo urbano” (Lemebel 1996: 77)

\footnotetext{
${ }^{188}$ Reenvío en este punto a la primera parte del presente capítulo, en la que analizo las relaciones entre las crónicas de Lemebel y el problema de las identidades latinoamericanas en el presente globalizado. Nuestro autor narra la experiencia de seres individuales, únicos, singulares, inviste a sus personajes de una identidad que es particular y perceptible, conjurando la abstracción propia del estereotipo o de los colectivos sociales.

${ }^{189} \mathrm{Al}$ principio de su artículo "Formas del tiempo y del cronotopo en la novela" Bajtín define el concepto que permite comprender la condensación que he señalado en las crónicas de Lemebel: "Llamaremos cronotopo (literalmente, tiempo-espacio) a la conexión intrínseca de las relaciones temporales y espaciales que se expresa artísticamente en la novela. Este término es empleado en matemáticas y fue introducido como parte de la Teoría de la Relatividad de Einstein. [...] Lo que nos importa es el hecho de que expresa la inseparabilidad del tiempo y del espacio (el tiempo como cuarta dimensión del espacio). (Bajtín 1938a: 84-85). Más adelante, explica que el cronotopo constituye la columna vertebral de cualquier narración: "El cronotopo es el lugar en que los nudos de la narración se atan y se desatan. Puede decirse sin ambages que a ellos pertenece el sentido que da forma a la narración. [...] El tiempo se vuelve efectivamente palpable y visible; el cronotopo hace que los eventos narrativos se concreticen, los encarna, hace que la sangre corra por sus venas. Un evento puede ser comunicado, se convierte en información, permite que uno pueda proporcionar datos precisos respecto al lugar y tiempo de su acontecer. Pero el evento no se convierte en una figura. Es precisamente el cronotopo el que proporciona el ámbito esencial para la manifestación, la representabilidad de los eventos". (Bajtín 1938a: 250)
} 
se va cargando de rasgos particulares: primero es la medianoche, el rojo vivo de los semáforos, la lluvia, el frío; luego las travestis calientan la espera con un cigarro barato; en ese espacio-tiempo se producen los guiños, la mirada del cliente "boquiabierto", el juego cómplice de mentira velada y autoengaño (términos como "mascarada", "sospecha", "montaje" "sobreactúa" connotan esa situación) hasta que finalmente, "de un salto se acomoda en la felpa del asiento" y después de algunos regateos "sellan el trato abaratando el costo al trasladar el motel al asiento reclinable del Toyota" (78). Vemos, percibimos la situación que se singulariza progresivamente; el evento se hace carne y voz en la materia narrativa. Como dice Bajtín: "el cronotopo hace que los eventos narrativos se concreticen, los encarna, hace que la sangre corra por sus venas". (1938a: 250). Ya es madrugada cuando el travesti regresa a su "vereda tropical" y cuenta los "escasos billetes sustraídos al presupuesto de la familia chilena". Sabe que no le alcanzarán "para pagar el arriendo, menos para comprarse esos zapatos de Cenicienta que vio en el centro. Tampoco para mantener a su mamá y los hermanos chicos" (Lemebel 1996: 78). Sabe también que su "aleteo trashumante" es peligroso, que acaso "esta misma madrugada de viernes, cuando hay tanta clientela, cuando los niños del barrio alto se entretienen tirándoles botellas desde los autos en marcha" puede terminar con su pellejo en un charco. Finalmente la ciudad emerge "entre los algodones rosados del alba", y ella queda “tan sola, tan entumida, tan gorriona preñada de sueños, expuesta a la moral del día" (79). El dulce engaño de su travestismo seguirá desviando cada noche el rutinario destino del marido camino al hogar: el "oficinista estresado en el autito a crédito, que no quiere llegar a su casa [...] que odia volver temprano y tener que escuchar la secuencia de quejas, gastos y pesares que le tiene su mujer en bandeja doméstica" (78). 
El texto es escritura porque construye su lugar de enunciación y condensa todos los planos del relato a fin de hacer visible, audible, palpable la experiencia -en este caso- del travestismo callejero. Este procedimiento es el vehículo y la condición de posibilidad de la singularización. Nos acercamos a la experiencia subjetiva del travesti en su "aleteo trashumante", y esa experiencia lo des-exotiza (por cuanto el exotismo es una producción imaginaria) y lo hace único; de ese modo los lectores accedemos a su visión (y no a su reconocimiento). Como postulara Viktor Shklovski, el discurso poético nos presenta a los personajes (el "glamour a la deriva", los guiños, los regateos y los acuerdos en la noche travesti) como si los viéramos por primera vez. ${ }^{190}$

Las crónicas de Lemebel promueven, como hemos observado, lo discontinuo y lo minoritario, optando por el caso singular con el propósito de historiar el suceso. Su mirada asume desde un punto de vista particular la dimensión social y política del acontecimiento. En su escritura se imbrican consideraciones de orden político y social, relevamiento de datos muy precisos del contexto histórico y cultural de los personajes y procedimientos literarios propios del discurso ficcional, como la condensación del espacio-tiempo y la singularización de los caracteres y sus condiciones de existencia, convirtiendo la crónica en historia y transformando la historia en discurso literario. La simultaneidad de estos procesos justifica el empleo de la categoría filosófica de devenir ${ }^{191}$ en la presente investigación.

\footnotetext{
${ }^{190}$ La singularización es el procedimiento que caracteriza, para Víktor Shklovski, la especificidad de la obra de arte. Este consiste en provocar la visión del objeto, y no su reconocimiento. El efecto causado por la imagen poética es el de generar "una impresión máxima" en el receptor, aumentando su fuerza y duración. Ver a propósito: "El arte como artificio" (1917) en: Todorov 1987: 55-70.

${ }^{191}$ Deudora del pensamiento de Baruch Spinoza, la noción de devenir se opone radicalmente a la concepción sustancialista de la metafísica occidental clásica y moderna. Este concepto fue elaborado por Nietzsche en el siglo XIX y reelaborado por Gilles Deleuze, Félix Guattari, Michel Foucault, Julia Kristeva y Jacques Derrida en el siglo XX. Lo que estos autores denominan devenir es un proceso en y por el cual se desconfigura (o deconstruye) la identidad normalizada y reconocida como esencia por los discursos técnicos y disciplinares. Deleuze repara en el hecho de que todo el libro V de la Ética de Spinoza funda la noción de "auto-afección" -que será desarrollada mucho más tarde por la filosofía alemana- la cual consiste en las determinaciones intrínsecas de las esencias: "una esencia afecta mi esencia, pero como todas son interiores las unas a las otras, una esencia que me afecta es una manera bajo la cual mi esencia se afecta a sí misma" (2004: 163). Los poderes de afección determinan la esencia,
} 
Gilles Deleuze y Félix Guattari reelaboran las nociones spinozianas de poder de afección y conatus. En su ontología conservan el sesgo radicalmente inmanente de la Ética de Spinoza y proponen el concepto de territorialización como principio activo de la producción, regida por el deseo: "La producción como proceso desborda todas las categorías ideales y forma un ciclo que remite al deseo en tanto que principio inmanente" (Deleuze-Guattari 1972: 14). Destaco: "la producción como proceso", no como finalidad. El proceso está marcado por puntos intensivos que se cruzan con otros y producen nuevas líneas que hacen ramificar la red: a ese proceso indetenible llamamos "devenir". Su régimen intensivo lo distingue de toda forma de desarrollo evolutivo, ascendente o descendente, positivo o negativo, exterior o interior, dado que esas formas de evolución o desarrollo reponen siempre la noción de identidad, por exceso o por defecto. Desde esta perspectiva nada es definitivamente: lo existente está ligado a los procesos de composición y descomposición que lo atraviesan. ${ }^{192}$ Las crónicas de Pedro Lemebel producen devenires, a los que también podemos llamar "agenciamientos heterogéneos" o modos de composición. Si bien he postulado tres modos de composición visibles en su escritura, a saber: historia/ ficción; crónica/ poesía y escritura/ oralidad, estos agenciamientos no pueden ser clasificados sin traicionar en alguna medida su naturaleza. Lo que quiero decir es que en la lectura crítica es forzoso “detener" la productividad incesante del discurso para ordenar, observar y clasificar sus

porque "la afección es el estado de un cuerpo en tanto que sufre la acción de otro cuerpo -teniendo en cuenta que por razones de su física, Spinoza no cree en una acción a distancia, la acción implica siempre un contacto-." (173-174)

${ }^{192}$ Dice Baruch Spinoza en una de sus cartas a Blyenbergh: "soy tan perfecto como puedo serlo en función de las afecciones que tengo". En esta fórmula captamos el sentido del término afección (también el de su correlativo conatus, traducido habitualmente por apetito o deseo): todo apetito es una virtud porque es potencia de afección que estimula nuestra capacidad de componernos. (Epistolario Baruch de Spinoza, Bs. As., Raíces, 1988, p. 68, citado por Deleuze, 2004: 76). 
procedimientos, pero sabemos que dicho proceder es una imposición de nuestros modos de lectura, ajenos a la naturaleza dinámica e incategorizable de los textos tratados ${ }^{193}$.

\section{La tensión crónica/poesía}

Amo las sonoridades dificiles, el verso escultórico, vibrante como la porcelana, volador como un ave, ardiente y arrollador como una lengua de lava.

José Martí, "Mis versos"

Así como el devenir historia/ ficción permite que el enunciado transmita la experiencia de las historias particulares $\mathrm{y}$, con ellas, la recuperación de voces diversas que expresan una memoria silenciada, la tensión crónica/ poesía resulta eficaz para transformar la escritura en materialidad sonora y vibrante. ${ }^{194}$ En este punto del análisis tenemos que retomar nuestra reflexión acerca de la prosa modernista que realizáramos en el Capítulo II. Aníbal González entiende que la crónica modernista hispanoamericana surge al calor de una relación problemática (hecha de admiración y de rechazo) con la filología:

[...] la filología es la institución en torno a la cual el modernismo construye su literatura; es el lugar de donde se derivan el vocabulario, los procedimientos y la "ideología" crítica del modernismo. [...] La filología es el modelo para la escritura modernista y, como modelo al fin, su relación con el modernismo está marcada por una dialéctica de adoración y rechazo - de amor y de odio, si se quiere- a tenor con la distancia entre ambas entidades dentro del espacio textual en que se desenvuelven. (A. González 1983: 12)

\footnotetext{
${ }^{193}$ En este mismo sentido Nicolás Rosa consideró "intratables" los textos de Néstor Perlongher: "La convención retórica 'tratado' debe ser leída paródicamente, en tanto toda la materia de este texto es absolutamente in-tratable en los límites ideológicos de nuestro logos crítico" (Rosa 1997: 21).

${ }^{194}$ Recuerdo aquí lo señalado en el Capítulo II acerca del valor de la obra como "alianza de los contrarios" (Blanchot 1955: 213): "La obra no es la unidad mitigada de un reposo. Es la intimidad y la violencia de movimientos contrarios que nunca se concilian ni se apaciguan mientras la obra es obra. Esta intimidad donde se afronta la contradicción de antagonismos que son inconciliables pero que, sin embargo, sólo tienen plenitud en la oposición que los opone, esta intimidad desgarrada es la obra [...] en la violencia que la hace una, realiza como el acontecimiento único de una discordia esencial en el corazón de la cual sólo lo que está en lucha puede aprehenderse y calificarse.” (213-214. Énfasis mío).
} 
Esta relación decisiva para la constitución de la prosa modernista trae a la escritura de la crónica un rasgo medular: el lenguaje es objeto de su propia re-flexión, se mira y se estudia a sí mismo, se erige en objeto de atención, descripción y análisis; descubre y explora su propia historia, sus rasgos distintivos, en fin, su especificidad. La filología ${ }^{195}$ sienta las bases, en rigor, para una caracterización del lenguaje en lo que tiene de particular, de específico. Esta actitud de "descubrimiento" del lenguaje como objeto de un saber tiene consecuencias en nuestra modernidad latinoamericana, por cuanto los escritores adquieren una clara consciencia de la opacidad de un sistema que ya no es puro instrumento o vehículo de comunicación, que "se resiste a ingresar en la transparencia ideal que supuestamente tuvo durante la época clásica, y en el espacio de este fracaso es donde se alojará la literatura" (A. González 1983: 16, énfasis mío). La filología y la investigación lingüística dejan al descubierto la ambigüedad inherente a todo enunciado, imposible de "someter" a sus estándares disciplinares; de allí que se produzca una tensión entre filología y literatura que no será resuelta. En el interior de esta tensión se producen puntos de encuentro y de fricción. El laboratorio filológico y el taller literario, nos ilustra Aníbal González, son espacios de investigación y de creación: "producen objetos hechos de palabas; poemas que se imprimen en libros, y conceptos con una supuesta concreción en el mundo real" (27). La diferencia es su función: los objetos que se fabrican en el taller literario carecen de finalidad, son "arte por el arte", en cambio en el laboratorio filológico se producen herramientas que serán útiles para futuros análisis, los cuales revelarán -en última instancia- la verdad, el propósito y la justificación última del saber.

\footnotetext{
${ }^{195}$ Es necesario aclarar que cuando se habla de filología en este contexto, los teóricos se refieren siempre a la "nueva filología", posterior a la crisis epistemológica de fines del siglo XIX y comienzos del XX, la cual incluye, por ejemplo, la gramática comparada dado su interés en remontarse al pasado original. Dice Aníbal González: "Si la metáfora que mejor define el saber clásico es la del tablero, o la escena, donde la información se despliega sincrónicamente ante la mirada de un espectador privilegiado, el saber de la modernidad preferirá las metáforas genéticas: fuente, origen, raíz." (1983: 14). De ahí la importancia que adquiere la indagación arqueológica en todos los campos del saber.
} 
Lo que quiero subrayar con esta referencia a los orígenes de la prosa modernista y su vínculo problemático con la filología, es la opción de estos autores (marca evidente sobre todo en la producción de Martí, Darío y Gutiérrez Nájera) por el trabajo con la materialidad del verbo. La escritura modernista presenta un espesor y una densidad que inviste de función poética a toda su producción, más allá de la división tradicional -y ya envejecida en ese entonces- de los géneros literarios. La relación entre crónica y poesía es muy estrecha en la prosa modernista, como hemos subrayado en el Capítulo II a propósito de Martí. Es tal vez en las páginas de su Diario, el más “contingente” de los escritos de un autor, donde la calidad poética salta a la percepción del lector:

\section{4 de marzo}

Y abrí los ojos en la lancha, al canto del mar. El mar cantaba. Del Cabo salimos, con nubarrón y viento fuerte, a las diez de la noche; y ahora, a la madrugada, el mar está cantando. [...] La larga música, extensa y afinada, es como el son unido de una tumultuosa orquesta de campanas de platino. Vibra igual y seguro el eco resonante. Como en ropa de música se siente envuelto el cuerpo. Cantó el mar una hora, más de una hora. La lancha piafa y se hunde, rumbo a Monte-Cristi.

6 de marzo

Oigo un ruido, en la calle llena de sol del domingo, un ruido de ola, y me parece saber lo que es. Es el fustán almidonado de una negra que pasa triunfante, quemando la manta por los hombros. La haitiana tiene piernas de ciervo. El talle natural y flexible de la dominicana da ritmo y poder a la fealdad más infeliz. La forma de la mujer es conyugal y cadenciosa.

1 de abril

A paso de ansia, clavándonos de espinas, cruzábamos a la medianoche oscura, la marisma y la arena. A codazos rompemos la malla del cambrón. El arenal, calvo a trechos, y el gallo se le encara, erizado el cuello, y le pide pelea. De la casa traen café, con anís y nuez moscada.

(Martí 1968: 299-300) ${ }^{196}$

\footnotetext{
${ }^{196}$ Ver Obras Completas, t. 19, pp. 183- 212.
} 
La condensación sensorial es lo distintivo de este breve fragmento de una crónica de viaje. La fuerza visual, auditiva, olfativa y táctil de estas breves prosas, su densa materialidad, las convierte en textos resistentes a la clasificación tradicional: su propósito de registro queda en segundo plano, aunque no desaparece; su musicalidad las acerca a la lírica (de hecho se leen como versos libres: La larga música, / extensa y afinada, / es como el son unido / de una tumultuosa orquesta / de campanas de platino. Vibra igual y seguro el eco resonante).

De un modo que reconoce su "precursor" o antecedente genealógico en la prosa martiana, la condición poética de las crónicas lemebelianas provoca un régimen de lectura que apela a los sentidos a fin de instaurar la visión y la audición de los hechos narrados de un modo intransferible a otro registro. Para ello el discurso de Lemebel asume procedimientos poéticos que serán elucidados a continuación. En primer lugar me voy a detener en el tratamiento del sujeto de la enunciación.

El decimotercer texto de La esquina es mi corazón, "La música y las luces nunca se apagaron" (Lemebel 1995: 61-62) está constituido por un único largo párrafo. Este rasgo, que se destaca visualmente aún antes de comenzar la lectura, acompaña otro rasgo no menos relevante de su construcción: no hay sujeto enunciador a la vista.

La primera forma verbal conjugada es "pica" (de: picar), pero el texto omite o retacea el sujeto de esa acción. Además, ese verbo tiene nada menos que 46 acepciones según el Diccionario de la Real Academia Española. La gran mayoría son de uso habitual, al menos en el habla de los países del cono sur. Transcribo en nota al pie algunas de esas acepciones, porque me interesa señalar que en este texto, curiosamente, cualquiera de ellas podría perfectamente armonizar con el contenido de la frase en cuestión, sea en sentido literal o figurado, lo cual potencia el carácter difuso o 
ambivalente de la acción y en consecuencia de su agente: "Como cualquier sábado que pica $^{197}$ la calle por darse un reviente, un pequeño placer de baile, música y alcohol”.

La frase citada inicia la crónica; dada la señalada polisemia del verbo, el sujeto de "pica" puede ser el sujeto de la enunciación - un yo tácito que narra los hechos-, también puede ser el sábado, y, también, la que "pica" puede ser la calle. En las oraciones que siguen la omisión del sujeto se consolida como procedimiento:

Por si aparece un corazón fugitivo reflejado en los espejos de la disco gay. Cuando todavía es temprano para una noche porteña, pero el loquerío está que arde en la Divine [...] En la fantasía coliza de soñarse jet set en Marbella o Cannes, bailando la misma música, salpicadas por las mismas luces, juntando las monedas para otra piscola y no deprimirse viendo el sucio puerto y sus latas mohosas. (Lemebel 1995: 61).

¿Por qué he descartado desde el vamos la posibilidad de que el relato esté narrado en tercera persona omnisciente? Porque el texto no habilita esa lectura. Desde la primera oración advertimos que el enunciador es un punto de vista individual, móvil y partícipe de los hechos. El retaceo de un "yo" en la enunciación se hace evidente porque el relato se inicia con una voz que parece estar a cargo de un sujeto individual ("por darse un reviente, un pequeño placer [...] Por si aparece un corazón fugitivo reflejado en los espejos de la disco"). Inmediatamente el punto de vista del relato pasa de la calle a estar dentro de la disco, es decir que el sujeto textual parece acompañar a un sujeto itinerante que -suponemos- será protagonista. El texto además es rico en

\footnotetext{
${ }^{197}$ Consigno algunas acepciones del verbo "picar" según el DRAE: PICAR: 1. tr. Pinchar una superficie con instrumento punzante. Ú. t. c. prnl. 3. Morder o herir con el pico o la boca ciertos animales. 4. Cortar o dividir en trozos muy menudos. 5. Tomar las aves la comida con el pico. 6. Morder el pez el cebo puesto en el anzuelo para pescarlo; y por ext., acudir a un engaño o caer en él. 7. Enardecer el paladar ciertas cosas excitantes; como la pimienta, la guindilla, etc. Ú. t. c. intr. 9. Avivar con la espuela a la cabalgadura, espolear. 11. Llamar a la puerta. 15. Corroer, horadar un metal por efecto de la oxidación. Ú. m. c. prnl. 16. Golpear con pico, piqueta u otro instrumento adecuado, la superficie de las piedras para labrarlas, o la de las paredes para revocarlas. 18. fig. Mover, excitar o estimular. Ú. t. c. intr. 29. intr. Experimentar cierto ardor, escozor o desazón alguna parte del cuerpo. 31. Tomar una ligera porción de un manjar o cosa comestible. 36 . Volar las aves veloz y verticalmente hacia tierra. 42. Estar en celo los animales por haber conocido hembra. 44. fig. Ofenderse, enfadarse o enojarse, a causa de alguna palabra o acción ofensiva o indecorosa.
} 
procedimientos que provocan en el lector la experiencia física del ruido, la música a todo volumen, las luces, el humo, el olor y la asfixia provocados por el incendio.

En resumen: el relato del acontecimiento, que crece en intensidad y en velocidad narrativas, está dado por una conciencia que acompaña al personaje, aunque no sepamos exactamente quién es. Se trata de una voz que narra instalada en la conciencia del protagonista, un caso del procedimiento que describe Tzvetan Todorov en su conocido artículo "Las categorías del relato literario", llamándolo "visión con” 198 el personaje (Todorov 1970c: 178). Sin embargo cuando se refiere a Grace Jones, cuya voz suena a todo volumen en la disco, el narrador deja caer un "nos" que confirma la primera impresión de lectura: "Esa africana de lengua ardiente que nos lleva por 'la vida en rosa' de la costa francesa, en un auto sport tapizado de armiño" (61, énfasis mío). La primera persona no vuelve a ser indicada en el discurso, no al menos a través de los deícticos que serían propios del caso, como "yo", o sus formas verbales correspondientes. Promediando el texto -que es muy breve- la voz narrativa opta por las formas pronominales "nadie", "alguien", "alguna” o "todos” otorgándole una calidad impersonal y "objetivista” a lo narrado:

Por eso nadie se da cuenta del olor a humo que sube la escalera, que hace toser a una loca con asma, que dice que tiene asma de losca. "Que se quema el arroz", grita alguna. Y las ensaladas también, niña, pero la música y las luces nadie las apague; ni siquiera la bomba incendiaria que un fascista arrojó recién en la entrada. (Lemebel 1995: 62. Énfasis mío)

\footnotetext{
${ }^{198}$ Los aspectos del relato, para Tzvetan Todorov, son fundamentales por configurar la visión que el lector tiene de los hechos narrados. Esa visión depende enteramente del grado de conocimiento que el narrador demuestra respecto de la conciencia de los personajes. El narrador "por detrás" (tradicionalmente llamado omnisciente) conoce la interioridad - pensamientos y sentimientos- de todos los personajes; el narrador cuya visión acompaña la mirada del protagonista ("visión con") conoce los pensamientos y los sentimientos de ese personaje, está instalado en su subjetividad, podríamos decir que ve con sus ojos; el narrador observador o testigo, sabe menos que cada uno de los personajes, por cuanto no conoce la interioridad de ninguno de ellos, sólo sabe lo que se ve y se oye. En la crónica que estoy analizando, observamos que la posición del narrador es compatible con la "visión con".
} 
El procedimiento está minuciosamente construido: ninguno de los sujetos gramaticales que aparecen en el texto corresponden al enunciador. El sujeto del relato es -si se me permite la invención- un "yo flotante", que en ningún momento dice "yo" ni ninguna otra forma pronominal ni verbal en primera persona (excepción hecha del "nos" ya mencionado), lo cual produce el efecto cinematográfico de la cámara subjetiva: el sujeto de la enunciación, que está allí dentro de la discoteca ardiente, es un ojo (también oído, boca, piel, en suma: percepción), un punto de observación y percepción que narra:

Como si la música y las luces acompañaran la escena dantesca que arde a puerta cerrada. Con demasiado calor para seguir bailando, demasiado terror para rescatar la chaqueta Levis en el guardarropía. Atrapados en el choclón de locas gritando, empujando, pisando a la asfixiada que prefiere morir de espanto. Buscando la puerta de escape que está cerrada y la llave nadie sabe. Entonces a los baños, dice alguien que lo vio en una película. Atravesando la pista encendida entre las brasas de locas que danzan con la Grace y la música que sigue girando. Pisar las vigas y espejos al rojo vivo que multiplican la Roma disco, de Nerón Jones, atizando la fogata desde los parlantes. Sin mirar atrás las parejas gays calcinadas en los carbones de Pompeya. (Lemebel 1995: 62).

La música, las luces, los espejos, el humo y el calor abrasador determinan la intensidad auditiva, visual, olfativa y táctil del relato, y al mismo tiempo dan la condición itinerante y la posición frágil del enunciador. La voz no representa los hechos, es parte de ellos y del colapso inminente. En razón de este procedimiento los lectores participamos, estamos allí en medio de la hoguera; percibimos el humo, los carbones, el calor, el pisoteo, la asfixia. El efecto cinematográfico se intensifica por la asociación libre de la voz interior: Roma, Nerón, Pompeya, como cuadros que se agolpan en el fluir de una conciencia aterrada. Las acciones que proliferan dándole un ritmo vertiginoso a la última parte, están sin conjugar: atravesando, pisar, sin mirar atrás, encontrar los baños, abrir todas las llaves, quemándose las manos, decidirse a dar 
el salto, atreverse ahora que la cola está ardiendo, empujada por la hoguera, volando sobre el muelle de Valparaíso.

El salto mortal huyendo del fuego nos recuerda el primer texto de este libro, en el que también se registra un episodio de violencia de género. Tras la persecución policial, el salto suicida que termina con el joven fugitivo muerto entre las piedras barrosas del río. Tras el incendio intencional de la disco gay, el salto mortal de la loca ardiendo que trata de salvar el pellejo volando sobre el muelle de Valparaíso. En este texto Lemebel construye lo que Julia Kristeva ha denominado "sujeto cerológico". Si bien este concepto se inscribe en su análisis del significado poético que desarrolla en el artículo "Poesía y negatividad" (1969: 55-93), en el que aborda textos de Charles Beaudelaire y de Stéphane Mallarmé, considero absolutamente pertinente su traslado a otros géneros. De hecho, en su artículo "El engendramiento de la fórmula", incluido en el mismo volumen (95-216), la autora realiza dicho traslado cuando considera a la narración y al teatro como casos de la dialéctica fenotexto / genotexto.

Las leyes del habla, es decir, las reglas del lenguaje comunicativo (lo que Kristeva llama "el pensamiento del signo y del sujeto") se diferencian de la práctica significante llamada "lenguaje poético", porque en aquellas la negación excluye a lo negado, lo expulsa, es decir, le aplica un índice de inexistencia que lo borra, lo anula. En el lenguaje poético, en cambio, la negación instala la ambivalencia del significado poético, por cuanto la negación es la afirmación de una no-existencia: "la reunión nosintética" de lo existente y de lo no-existente, de lo verdadero y de lo no-verdadero, de lo posible y de lo imposible. Para Kristeva, la especificidad de la práctica poética es un movimiento pendular que va de lo semiótico (instancia pulsional que engendra toda construcción simbólica, todo lenguaje, llamada "genotexto") a lo simbólico (la fórmula o "fenotexto", es decir, lo que podemos leer, lo observable de la interacción incesante 
entre el orden simbólico y el orden pulsional-semiótico). Lo semiótico, por su naturaleza pulsional, es anterior a la constitución del sujeto, por ello es pre-verbal y por consiguiente inobservable. Lo que tenemos a la vista los lectores es su resto: la recaída desajustada de la fórmula, marcada por los embates de lo semiótico (en esta perspectiva teórica, no leemos más que huellas). Lo visible textual es el resultado de un desfase: el texto muestra su imposibilidad de dar paso $^{199}$ a la fuerza que lo engendra, por cuanto esta fuerza no es simbolizable.

La construcción del sujeto en este texto particular de Lemebel, "lo destituye" afirmo con Blanchot, "del papel de sujeto que parece aceptar". Un sujeto ausente pero activo, por cuanto permanece desocupado para diseminarse en una serie infinita de lugares y de percepciones (música, luces, fuego, humo, olores). Me detengo en la consideración de la impersonalidad del sujeto así construido, por cuanto -desde la perspectiva teórica asumida- es la condición de posibilidad del discurso poético en el enunciado, el rasgo técnico que habilita una apertura indicada en el discurso -el lugar de la emisión de la voz- pero que no designando a nadie, da la posibilidad de una repetición infinita, no visible pero activa: cualquier lector de esta crónica puede ser el sujeto de la enunciación. El procedimiento discursivo es literario y es histórico: construye un punto de observación que nomadiza el espacio y la temporalidad del relato, y al mismo tiempo refiere un episodio sucedido, del cual ofrece datos precisos y verificables. Hay un suceder: el incendio infestado de música, luces y locas huyendo y

\footnotetext{
${ }^{199}$ Una muy similar concepción del sujeto textual puede verse en la obra de Maurice Blanchot, de intraducible título: Le pas au-delà, París, Gallimard, 1973. (Versión castellana: El paso (no) más allá, Barcelona, Paidós, 1984). "il [él, lo, ello, a veces no se traduce] la apertura prohibida: eso es lo que indicaba ese nombre, apenas una palabra que lo designaba de una forma tan eminente no designando a nadie y, además, con una indicación indirecta pero que parecía referirse cada vez más indirectamente a ese punto preciso, determinado-indeterminado, un vacío de universo" (49). "Lo más difícil: no identificar ni fijar el $i l$ como si fuese lo mismo y estuviese siempre en el mismo lugar donde se ha decidido asirlo. El hecho de que $i l$, en la frase más sencilla, esté un poco retirado de la frase y más bien en cada momento vacío que la articulación reserva para su juego, lo destituye del papel de sujeto que parece aceptar. $I l$ se desdobla así redoblándose indefinidamente: [...] es como la coartada de otro $i l$, el cual no jugaría ningún papel, no desempeñaría ninguna función, salvo la de permanecer desocupado repitiéndose invisiblemente en una serie infinita que el análisis trata de recuperar (50).
} 
aplastándose en la disco "que arde a puerta cerrada". El suceder tiene la dinámica indetenible que genera su construcción sintáctica: no hay puntos y aparte, no hay marcas gramaticales del enunciador ni deícticos que permitan establecer el lugar, el tiempo, los actores. El vértigo textual efectúa la vivencia fragmentaria de la conciencia que narra: el sujeto de esta historia. "La música y las luces nunca se apagaron" es el título y la frase final: la circularidad textual acompaña el devenir del acontecimiento que no cesa.

Esta crónica narra un episodio fechado entre paréntesis al final del texto: “Discoteque Divine, Valparaíso, 4 de septiembre, 1993”. Se trata del incendio de una discoteca gay, que dejó un saldo de dieciséis muertos y más de veinte heridos. El 23 de marzo de 1994 el magistrado interviniente cerró el caso sin culpables ni procesados y sin llegar a una conclusión sobre las causas del siniestro. Durante los años siguientes el Movimiento de Integración y Liberación Homosexual (Movilh) llevó adelante una intensa investigación que tenía como principal objetivo la reapertura del caso. El 29 de agosto de 2002 el Movilh dio a conocer a la opinión pública el denominado "Informe

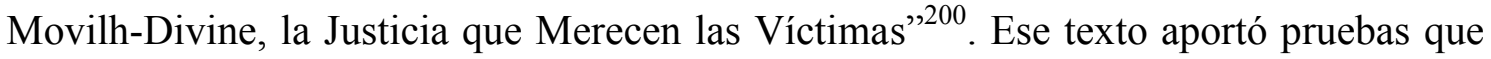
finalmente derivaron en la reapertura del caso casi una década después de la tragedia, y pusieron en evidencia muchas irregularidades, a saber: que los tribunales no habían agotado todas las diligencias para aclarar las causas y responsabilidades del siniestro; que durante las investigaciones hubo presiones y aun apremios ilegales por parte de policías y autoridades judiciales; la inexistencia de un documento que diera cuenta sobre el número e identidad de los lesionados y víctimas fatales; y la carencia de sanciones contra los responsables del incendio, aun en el caso de que éste hubiera sido causado por un desperfecto eléctrico.

\footnotetext{
${ }^{200}$ Fuente: www.movilh.cl/documentacion/informedivine.l.doc
} 
Un segundo informe publicado en el año 2004 no descarta la hipótesis del atentado y señala la posible participación de un sospechoso al cual identifica. Finalmente, en diciembre de 2009, la jueza Patricia Montenegro determina (dando la razón a peritajes oficiales que datan de 1993) que el origen del incendio se debió al mal estado de las instalaciones eléctricas, y que la hipótesis del atentado fue una estrategia del dueño de la discoteca y responsable del siniestro. En abril de 2010 el Movilh publicó su informe definitivo, elaborando una cuidadosa cronología del caso. El texto de Lemebel abona la hipótesis del atentado (vigente aunque no demostrada al momento de la publicación del libro). No sabemos si hubo por parte del autor alguna motivación para inclinarse por dicha hipótesis (finalmente descartada por los investigadores). Sí sabemos que el autor no hace explícito ningún propósito. Toma conocimiento del hecho y lo construye. Este texto -con las características que he relevado en las páginas precedentes- declara una vez más el carácter histórico y literario de su escritura: narrativizar, recurrir al habla figurativa, en la cual se emplean todas las condensaciones y desplazamientos del discurso literario.

Recordemos lo sostenido por Hayden White: los acontecimientos ocurren, y son atestiguados por los registros documentales y los monumentos o sus rastros; "los hechos son construidos conceptualmente en el pensamiento $y / 0$ figurativamente en la imaginación” (2003: 53), ése es su espacio y su condición de posibilidad. En la crónica que acabamos de leer el espacio, el tiempo y el sujeto participan de la misma tensión. Un acontecer se presenta en su calidad fragmentaria, con la incompletud del movimiento. ${ }^{201}$ El incendio en la disco está sucediendo. Sólo el paréntesis final lo

\footnotetext{
${ }^{201}$ El dinamismo que estoy cartografiando en este análisis crítico está directamente asociado a los procedimientos de construcción del sujeto a los que me he referido en los párrafos precedentes. Esa apertura impersonal, que abre el enunciado a la multiplicidad de puntos de emisión de la voz, hace participar al sujeto lector en la producción textual y genera el efecto vertiginoso. Estos efectos de sentido han sido teorizados por Maurice Blanchot y por Julia Kriseva en los ensayos citados. Lo que Blanchot denomina "intermitencia" es "el espacio violentamente desplegado por el enfrentamiento mutuo del poder
} 
detiene, como marca inevitable de lo que se quiere historiar: lo acontecido en un tiempo, en un lugar. Pero su construcción es tan dinámica como los hechos, dando lugar a una paradoja: decir lo indecible, narrar lo inenarrable. La crónica se juega en el límite de esa tensión, en la cual el sujeto se adelgaza hasta ser un punto de emisión de la voz, un lugar móvil de enunciación, estrategia necesaria para poder cartografiar el espacio y ajustar la escritura a la dinámica de un tiempo indetenible.

La crónica roza los límites de la enunciación: narra el colapso del lugar; el tiempo se subsume en un instante y ya no puede oficiar de eje ordenador; el sujeto barre con las convenciones de la enunciación historiográfica y se sustrae a los mecanismos de la mímesis clásica. La frase final, que es también el título, condensa el efecto de estos procedimientos ("la música y las luces nunca se apagaron") poniendo énfasis en la cualidad diferencial de esta historia: más que "representar", actualiza el acontecimiento. Esto último es propio del género poético. Cuando postulo que en la obra de Pedro Lemebel se produce una composición discursiva, es decir, un agenciamiento entre naturalezas discursivas heterogéneas, me propongo demostrar la naturaleza poética de su relato histórico. Una "alianza" original, profundamente renovadora de las series en las que interviene, un dispositivo eficaz para narrar la historia que no ha sido contada y que el autor se propone conservar, recuperándola para la memoria colectiva.

El análisis textual de "El informe Rettig (o 'recado de amor al oído insobornable de la memoria’) (Lemebel 1998: 102-103) me permitirá avanzar en la demostración de esta hipótesis. La creación de la Comisión Nacional de Verdad y Reconciliación, el 25 de abril de 1990, fue una de las primeras resoluciones tomadas por el Presidente Patricio Aylwin en el ámbito de derechos humanos. Esta comisión de ocho miembros,

de decir y del poder de oír" (1955: 31). Ese enfrentamiento le otorga al texto un dinamismo que el lector percibe y produce como si se tratara de su propia experiencia vital: "Donde creemos tener palabras, nos atraviesa 'un virtual reguero de fuego', una prontitud, una exaltación centelleante [...] Entonces todo se hace suspenso, disposición fragmentaria con alternancia y enfrentamiento.” (38-39) 
encabezada por el abogado Raúl Rettig, fue creada por decreto del Ministro de Justicia para "clarificar toda la verdad acerca de las más graves violaciones a los derechos humanos"202. La creación de la Comisión provocó de inmediato el rechazo de las Fuerzas Armadas y de quienes las apoyaban. Las tensiones se hicieron evidentes cuando durante el primer mes de trabajo de la Comisión, el Mayor del Ejército Gral. Jorge Ballerino, bajo expresas órdenes de su Comandante en Jefe, Augusto Pinochet, visitó a Rettig para manifestarle la preocupación del Ejército de que el trabajo de la Comisión fuera utilizado por sectores políticos deseosos de desprestigiar a las Fuerzas Armadas y al Ejército en particular. El Ejército además advirtió, a través de Ballerino, que la Comisión podría eventualmente sobrepasar su misión legal al asumir un trabajo que pertenecía al ámbito de la justicia. Si bien el nuevo gobierno percibió estas advertencias del Ejército como un cuestionamiento indirecto a su autoridad, por lo cual el presidente Aylwin citó al Comandante en jefe a una audiencia en La Moneda para que respondiera por su inaceptable intromisión en la esfera política, el episodio muestra a las claras, por una parte, el nivel de conflictividad de los primeros años del gobierno democrático, y por otro, la enorme resistencia que las Fuerzas Armadas, respaldadas por el propio Pinochet, opusieron a la investigación de las violaciones a los derechos humanos cometidas durante el período 1973-1990. La situación deja en evidencia, además, el poder que los altos mandos militares conservaban en 1990 y conservarían hasta el gobierno del presidente Lagos inclusive.

Estas tensiones, ya referidas durante el desarrollo del capítulo precedente a propósito del texto "La mesa de diálogo. (O el mantel blanco de una oscura negociación)", incluida en Zanjón de la Aguada (Lemebel 2003: 283-286), vuelve a ocuparnos ahora porque Lemebel elige otra estrategia discursiva para desenmascarar el

\footnotetext{
${ }^{202}$ El texto completo del informe está disponible online: http://www.derechoshumanos.net/lesahumanidad/informes/Informe-Rettig
} 
verdadero propósito de esta Comisión, es decir, consolidar la impunidad, el olvido y el silencio. La decisión de nuestro autor en este caso es dar a conocer un texto cuyo título alude claramente a aquel vehículo de impunidad ("El informe Rettig") y, con procedimientos estrictamente poéticos, producir la contracara de aquél, esto es: un vehículo de la verdad, denunciando lo que el informe calla, refiriendo los hechos tal como sucedieron, atribuyendo las responsabilidades de los criminales y señalando los ocultos propósitos de "la ambigua transición”. El texto está organizado en párrafos que funcionan como estrofas. En la primera edición de De perlas y cicatrices, publicada por LOM en noviembre de 1998, el texto ocupa el centro exacto del libro, y se despliega en dos páginas que fluyen en suaves deslizamientos de ritmo poético sostenido, similar al de un oleaje. Esto es muy evidente desde la primera lectura, y se presenta como el rasgo dominante de la enunciación, marcada también por el tono melancólico y doliente propio de la elegía. Para percibir las dos dominantes del texto que acabo de señalar es indispensable citar un fragmento. Transcribo a continuación los dos primeros párrafosestrofas, el tercero que funciona como un breve punto de escansión, y el antepenúltimo:

Y fueron tantas patadas, tanto amor descerrajado por la violencia de los allanamientos. Tantas veces nos preguntaron por ellos, una y otra vez, como si nos devolvieran la pregunta, como haciéndose los lesos, como haciendo risa, como si no supieran el sitio exacto donde los hicieron desaparecer. Donde juraron por el honor sucio de la patria que nunca revelarían el secreto. Nunca dirían en qué lugar de la pampa, en qué pliegue de la cordillera, en qué oleaje verde extraviaron sus pálidos huesos.

Por eso, a la larga, después de tanto traquetear la pena por los tribunales militares, ministerios de justicia, oficinas y ventanillas de juzgados, donde nos decían: otra vez estas viejas con su cuento de los detenidos desaparecidos, donde nos hacían esperar horas tramitando la misma respuesta, el mismo: señora, olvídese, señora, abúrrase, que no hay ninguna novedad. Deben estar fuera del país, se arrancaron con otros terroristas. Pregunte en investigaciones, en los consulados, en las embajadas, porque aqui es inútil.

Que pase el siguiente.

$Y$ aun así, a pesar del viento frío que entra sin permiso por la puerta de par en par abierta, nos gusta dormirnos acunados por la tibieza terciopela de su recuerdo. Nos gusta saber que cada noche los exhumaremos de ese pantano sin dirección, ni 
número, ni sur, ni nombre. No podría ser de otra manera, no podríamos vivir sin tocar en cada sueño la seda escarchada de sus cejas. No podríamos nunca mirar de frente si dejamos evaporar el perfume sangrado de su aliento. ${ }^{203}$ (Lemebel 1998: 102-103)

El texto asume en primera persona la voz de una madre, una de aquellas que protagonizaron la búsqueda de los detenidos desaparecidos y que Lemebel evoca reiteradamente a lo largo de sus crónicas. En la voz de ese sujeto atravesado por el dolor (el cual protagonizó, como sujeto colectivo, el reclamo por la aparición de sus muertos) el autor sostiene la intensidad de su discurso poético, marcado por el pulso de la reiteración que evoca la infinita pregunta sin respuesta ("Nunca dirían en qué lugar de la pampa, en qué pliegue de la cordillera, en qué oleaje verde extraviaron sus pálidos huesos"). El cuarto párrafo está marcado por la reiteración anafórica: "No podíamos":

No podíamos dejarlos descalzos, con ese frío, a toda intemperie bajo la lluvia tiritando. No podíamos dejarlos solos, tan muertos en esa tierra de nadie, en ese piedral baldio, destrozados bajo la tierra de esa ninguna parte. No podíamos dejarlos detenidos, amarrados, bajo el planchón de ese cielo metálico. En ese silencio, en esa hora, en ese minuto infinito con las balas quemando [...] No podíamos dejar esos ojos queridos tan huérfanos. [...] No pudimos dejarlos allí tan muertos, tan borrados, tan quemados como una foto que se evapora al sol.

El que acabo de transcribir es un texto poético. Así lo determina su ritmo, el tratamiento de las imágenes: "tan muertos en esa tierra de nadie", "destrozados bajo la tierra de esa ninguna parte", "en ese silencio, en esa hora, en ese minuto infinito con las balas quemando". No hay prosa historiográfica que pueda transmitir la experiencia del infinito dolor de la búsqueda de los cuerpos que han sido cobardemente mutilados y perdidos; que pueda dar cuenta del dolor intransferible de las madres que preguntan inútilmente por ellos en la oficina de quienes se los arrebataron.

\footnotetext{
${ }^{203}$ Transcribo este fragmento en un formato diferente al de las citas textuales por cuanto el texto poético de Lemebel exige ser leído sin esa determinación externa. He respetado aquí la forma dada al texto por el autor, en atención a lo que sostengo en esta hipótesis: se trata de un texto poético que establece relaciones potentes con la sonoridad (es escritura vocalizada) y también con el espacio de la página. Como todo texto poético es una materialidad que impone su propio régimen de lectura.
} 
Lemebel elige la poesía frente al discurso del informe cuyos autores subtitularon -con una cuota importante de cinismo- "toda la verdad". Lemebel hace resonar el vacío de esa expresión, señala y denuncia la contradicción entre los declarados propósitos del informe y su velada concesión al alto mando militar que conserva intacto su poder y no está dispuesto a reconocer su responsabilidad en los hechos.

"El informe Rettig", que acabo de analizar, es el último texto de la sección "Sufro al pensar"204 (Lemebel 1998: 81-104), título que reúne ocho crónicas, algunas de las cuales abordaré a continuación. ${ }^{205}$ Me voy a detener en ellas porque su propósito es evocar la memoria de un conjunto preciso de personas detenidas durante la dictadura militar que se caracterizan, todas, por su inocencia e indefensión extremas a la hora de ser secuestradas, torturadas, desaparecidas o asesinadas. Las analizaré en este capítulo por las mismas razones por las que he incluido "El informe Rettig": por la condición poética del discurso que singulariza el acontecimiento histórico, lo hace único y logra vehiculizar su experiencia. Los lectores no olvidaremos el rostro quemado de Carmen Gloria Quintana, la falsa confesión televisada de Karin Eitel, quien “como una muñeca sin voluntad", "confusamente ebria por los barbitúricos", después de largas sesiones de tortura, fue obligada a renegar de su pasado en el Frente Patriótico Manuel Rodríguez. El inconcebible secuestro y posterior apropiación de una beba de ocho meses, Claudia Victoria Poblete Hlaczik, demasiado pequeña “como para cargar en su frágil cuerpo la banda fúnebre que encinta el álbum familiar de América Latina” (83).

El texto "Corpus Christi (o 'la noche de los alacranes')" (Lemebel 1998: 93-94) denuncia en clave poética la ominosa crueldad de la masacre llevada a cabo por las

\footnotetext{
204 "Sufro al pensar" es la primera línea del bolero "Mis noches sin ti”, música de Demetrio Ortiz y letra de María Teresa Márquez. Una versión muy conocida, posiblemente la que Lemebel escuchó en su infancia y adolescencia es la que grabó el cantante paraguayo Luis Alberto del Paraná junto al trío "Los Panchos". La versión de Nino Bravo -menos abolerada- popularizó la canción en los años setenta.

${ }^{205}$ A este grupo pertenece también "Los cinco minutos te hacen florecer" (Lemebel 1998: 86-87), analizado en el capítulo precedente.
} 
fuerzas de seguridad de Pinochet, llamada por la C.N.I. "Operación Albania", esa "noche de lobos y cuchillos", en términos de Lemebel, que consigue narrar lo inenarrable, que desafía la imposibilidad de relatar el horror. En las primeras líneas el cronista refiere brevemente "los repugnantes hechos" y de inmediato denuncia "su doble standard noticioso". El múltiple asesinato fue registrado por el periodismo cómplice (El Mercurio y Canal Trece); según esos medios oficialistas los muertos eran el saldo del "enfrentamiento" de la "subversión armada y los aparatos de seguridad que protegían al país del extremismo". El otro punto de vista ("el relato clandestino") está dado por la imagen:

[...] el chorreo achocolatado de la masacre, la parapléjica contorsión de los doce cuerpos, sorprendidos a mansalva, quemados de improviso por el crepitar de las ráfagas ardiendo la piel, en la toma por asalto del batallón que entró en las casas como una llamarada tumbando la puerta, quebrando las ventanas, en tropel de perros rabiosos, en jauría de hienas babeantes, en manada de coyotes ciegos por la orden de matar, descuartizar a balazos cualquier sombra, cualquier figura de hombre, niño o mujer herida, buscando a tientas la puerta trasera. Alli, cegada por el alfilerazo de pólvora en la sien, la niña aprendiz de guerrillera, parecía danzar clavada una y otra vez por el ardor caliente de la metraca. Más allá, el joven idealista no alcanzó a beber de la taza en su mano, y cayó sobre la mesa hemorragiado de sangre y café que almidonaron su camisa blanca. Aún más blanca, en el ramalazo de crisantemos lacres que brotaron de su pecho. (Lemebel 1998: 93)

Me voy a detener en el fragmento que acabo de transcribir por su saturación sensorial que lo hace irreductible a otro discurso, porque lo que este texto describe no es del orden del relato ni de la representación; es de naturaleza poética, se dirige a los sentidos, "tiende un lazo a los órganos", "penetra en la sensibilidad"206. Las imágenes enmarcan el primer párrafo en clave cromática. El color de la sangre en relación metonímica con la mesa familiar (sangre-chocolate, sangre-café) sugiere la irrupción violenta de la patrulla asesina en la intimidad de la escena doméstica, subrayando el

\footnotetext{
${ }^{206}$ Si bien estos términos de Antonin Artaud se refieren al teatro de la crueldad, considero pertinente su relación con estos textos de Pedro Lemebel en los que el discurso narrativo resulta insuficiente para transmitir la experiencia histórica representada, y por ello, apelan a lo que el poeta francés concibió como “comprensión energética del texto" (1938: 99-111).
} 
atropello a la inocencia y la indefensión de las víctimas. En el resto del fragmento citado, que es la presentación del acontecimiento, predominan las imágenes auditivas y sobre todo, táctiles (quemados de improviso por el crepitar de las ráfagas ardiendo la piel, en la toma por asalto del batallón que entró en las casas como una llamarada tumbando la puerta, quebrando las ventanas, en tropel de perros rabiosos, en jauría de hienas babeantes, en manada de coyotes ciegos por la orden de matar, descuartizar a balazos cualquier sombra). Estos efectos se encuentran potenciados por la animalización del grupo comando, también muy saturada. La crónica de Lemebel se presenta a sí misma como la otra cara del periodismo cómplice, y lo hace con procedimientos propios del registro poético. Ese es el vehículo elegido para dar cuenta de los hechos desde la perspectiva de las víctimas.

Sabemos que el discurso historiográfico, por su naturaleza y su posición epistémica, no puede dar cuenta del dolor, de la transgresión del límite en el atropello a la inocencia, de aquellos hechos que van, incluso, más allá de la violencia, la represión o el atentado a la civilidad. El registro poético es el enunciado artístico que afronta ese límite y lo pone en tensión. Por esa razón en la prosa de Lemebel el registro poético es acto de enunciación política. De ahí que sea, como hemos dicho, el vehículo de una identidad silenciada: las víctimas hablan a través de su discurso poético-político. En todos los textos de esta sección se subraya, como una presencia opresiva, el olvido: esa suma de indiferencia, perdón judicial y "reconciliado sopor" (Lemebel 1998: 92) que caracteriza los tiempos de la Concertación. Lemebel saca a estas víctimas del olvido al que han sido condenadas y hace presente su historia, demorándose en las imágenes, vehículo de la presencia física - de sus cuerpos y sus voces- en el espacio textual. ${ }^{207}$

\footnotetext{
${ }^{207}$ Insisto en señalar la condición específica del enunciado poético: constituirse como un espacio (según lo que Kristeva denominó kora semiótica, tomando el término con el que Platón se refiere a la "materia preexistente" a partir de la cual fuera creado el mundo de los objetos sensibles) en el que se juega la dimensión pulsional, energética del discurso (la "poesía de los sentidos", en la lúcida denominación de
} 
Carmen Gloria Quintana y Rodrigo Rojas de Negri fueron rociados con bencina

y quemados como escarmiento por participar de una protesta, en los años ochenta. La

breve crónica “Carmen Gloria Quintana (o "una página quemada en la feria del libro”),

(Lemebel 1998: 88-89) narra paso a paso el macabro asesinato, y repone el presente

vivo de la historia haciendo un uso muy particular -que pasa inadvertido pero logra el

efecto buscado- de los gerundios:

Y estaban Rodrigo Rojas de Negri y ella con el bidón de bencina, en esa esquina del terror cuando llegó la patrulla. Cuando los tiraron al suelo violentamente, riéndose, mojándolos con el inflamable, amenazando con prenderles fuego. Y al rociarlos todavía no creían. Y al prender el fósforo aún dudaban que la crueldad fascista los convertiría en mecheros bonzo para el escarmiento opositor. Y luego el chispazo. Y ahí mismo la ropa ardiendo, la piel ardiendo, desollada como brasa. Y todo el horror del mundo crepitando en sus cuerpos jóvenes, en sus hermosos cuerpos carbonizados, iluminados como antorchas en el apagón de la noche de protesta. Sus cuerpos, marionetas en llamas brincando al compás de las carcajadas. Sus cuerpos al rojo vivo, metaforizados al límite como estrellas de una izquierda flagrante. Y más allá del dolor, más allá del infierno, la inconsciencia. Más allá de esa danza macabra un vacío de tumba, una zanja donde fueron abandonados creyéndolos muertos. [...] Y vino el amanecer, sólo para Carmen Gloria, porque Rodrigo, el bello Rodrigo, quizás más débil, tal vez más niño, no pudo saltar la hoguera y siguió ardiendo más abajo de la tierra.

Después vinieron sus funerales envuelto en la mortaja cardenal de las banderas, y luego el juicio y los culpables. Y más pronto el perdón judicial y el olvido que dejó libres esas risas pirómanas, quizás confundidas hoy con el bullicio de la Feria del Libro [...] esa página de la historia no tiene precio para el mercado librero (Lemebel 1998: 8889).

Riéndose, mojándolos, amenazando; ardiendo, ardiendo, crepitando; brincando,

ardiendo. El efecto durativo de los gerundios, perfectamente distribuidos en el texto,

\footnotetext{
Artaud). Bisagra entre lo psíquico y lo somático, la dimensión semiótica es de naturaleza pre-verbal, por ello es un espacio atravesado por las pulsiones no gobernadas por el universo simbólico (la ley, en términos lacanianos). Esto explica su potencia transgresora: el enunciado artístico resulta así un texto dinamizado, una fórmula (fenotexto) de naturaleza simbólica pero desajustada, marcada por los embates de lo semiótico (genotexto) que insiste en ella. Esta singular concepción del enunciado poético resulta particularmente productiva para pensar las relaciones - poco exploradas por la teoría- entre el lenguaje y el cuerpo. (Ver: "Poesía y negatividad" (1968) y especialmente: "El engendramiento de la fórmula" (1969) en: Semiótica 2, Madrid, Fundamentos, 1981.
} 
sumado y potenciado por el carácter sensorial de cada uno y la repetición del más eficaz: "ardiendo", hacen de este texto un testimonio en presente de una página olvidada ("una página quemada" indica el subtítulo) de la historia de Chile. El final de la crónica vuelve al presente del comienzo: la Feria del Libro bajo el signo del consumo. En las primeras líneas el cronista confronta "su cara tatuada a fuego, con las 'boquitas de caramelo y los cutis de seda' de las niñas top que chispean las tapas de best sellers y revistas. Carmen Gloria Quintana, la cara en llamas de la dictadura” (88). En ese contexto, Lemebel declara que "son muy pocos los que recuerdan", "Son contados los que descubren su cara", "Son escasos los que pueden leer en esa faz agredida una página de la novela de Chile". Por eso afirma: "Quizás, decir algo de ella pasa inevitablemente por narrar su historia" (88). Cumplido el relato de violencia armada y fuego criminal contra dos jóvenes sin armas, "Carmen Gloria ha sido tragada por la multitud"; el cronista asume la primera persona y le imprime a su discurso un tono íntimo para subrayar el olvido, el signo del presente que une a la protagonista de este texto y a su autor en un espacio común de soledad y nostalgia: "sigo viendo su cara como quien ve una estrella que se ha extinguido, y sólo el recuerdo la hace titilar en mi corazón homosexual que se me escapa del pecho, y lo dejo ir, como una luciérnaga enamorada tras el brillo de sus pasos" (89). Es muy significativo el uso que hace Lemebel del verbo "leer". Observemos su funcionamiento en la frase: "Son escasos los que pueden leer en esa faz agredida una página de la novela de Chile.” (88). Cada término tiene en esa frase un peso propio; leer en un rostro la novela de un país puede interpretarse como una bella metáfora, pero está claro aquí que en la metáfora subyace un sentido poderoso, ligado a la concepción lemebeliana de la escritura y de la lectura. Los rostros hablan, dicen, cuentan su historia, y quienes así lo decidan podrán leer en ellos un fragmento de la historia, porque la historia se lee en un registro que no es 
monumental ni documental, sino físico y personal. Muchos rastros y rostros cuentan la historia de Chile: el esqueleto de la UNCTaD, los rostros de Karin Eitel y de Carmen Gloria Quintana -que acabamos de recorrer-, el rostro cadavérico de Loba Lamar, el cuerpo retaceado de la loca asesinada en "Las amapolas también tienen espinas", la voz y la risa púber del joven ex-convicto perdido en el círculo sin salida de sus "papeles sucios" - la falta de oportunidades laborales-, la figura ambigua de la loca del carrito, los cadáveres que un niño reconoce sin entender en la mañana del doce. La historia tiene un registro físico y Lemebel ha sabido escribirlo, en virtud de una prosa que es vehículo de sensación. ${ }^{208}$ Deleuze y Guattari hablan en su último libro de "liberar la vida" (1991: 173), tal sería la finalidad del arte. Pero esa frase no está dicha en un sentido político "libertario", sino en un sentido estrictamente ontológico. El artista es un vidente porque ha visto algo, "el rincón de naturaleza que percibe, o los barrios de la ciudad" (172) y sus personajes acceden a una visión que el escritor compone a través de ellos, haciendo estallar las percepciones vividas en la superficie material de la obra, en este caso, en el lenguaje de la crónica.

\section{3. $\quad$ La tensión escritura / oralidad}

Y cómo te lo digo y con qué humedad de letras te lo cuento, chiquito llocalla [...] si nunca fuiste testigo de esa música y sus olas crespas chasconenando el concierto de la bella mar. Cómo te lo digo, niño boliviano, cómo alargo la palabra m-a-r, y que ahorita zumbe en tus oídos como mil abejas moluscas, como millones de susurros que salpican tu carita aymara con su aliento materno-mar-tierno-marimaternal.

Pedro Lemebel "Canción para un niño boliviano que nunca vio la mar"

\footnotetext{
${ }^{208}$ Al respecto cito un pasaje luminoso de ¿Qué es la filosofía?, el último libro que escribieron juntos Gilles Deleuze y Félix Guattari: "Bien es verdad que toda obra de arte es un monumento, pero el monumento no es en este caso lo que conmemora un pasado, sino un bloque de sensaciones presentes que sólo a ellas mismas deben su propia conservación, y otorgan al acontecimiento el compuesto que lo conmemora. El acto del monumento no es la memoria, sino la fabulación. No se escribe con recuerdos de la infancia, sino por bloques de infancia que son devenires-niño del presente.” (1991: 169, Énfasis mío)
} 
La tensión entre escritura y oralidad que observo en la obra de Pedro Lemebel tiene un antecedente ineludible: la obra de Elena Poniatowska. La novela Hasta no verte Jesús mío, publicada en 1969, presenta una interesante estrategia de ficcionalización del discurso oral. Hay una evidente voluntad estética de "naturalizar" el discurso literario otorgándole la voz narrativa al personaje, Jesusa Palancares, quien tiene a su cargo el relato de los hechos de manera absoluta. Esa voz está diseñada según un modelo de discurso oral altamente verosímil ${ }^{209}$, coherente con las marcas de clase social, etnia, edad, sexo, y, en general, con los condicionamientos histórico-culturales que construyen el personaje. Este recurso verosimilizante se encuentra reforzado por el relato de episodios vinculados con sucesos y nombres propios muy conocidos de la historia de México. Para cualquier lector latinoamericano este discurso presenta rasgos reconocibles y rápidamente identificables con el habla mexicana correspondiente a determinado sector de esa sociedad en determinado período histórico, delatando posicionamientos políticos y culturales inherentes a él. Lo dicho genera una consecuencia tan inmediata como imperceptible, o, al menos, cuidadosamente disimulada en el tejido narrativo: la homologación del discurso literario con ese discurso "que está en relación de similitud, de identificación de reflejo con otro" (Kristeva 1967: 7) -el discurso oral comunicativo de ese lugar y ese momentoinvisibilizando el artificio. Este texto es un narrar, es un habla. Para construirlo como "novela" y considerarlo "literario" según la categorización discursiva convencional,

\footnotetext{
${ }^{209}$ Empleo este término en el sentido preciso que le da Julia Kristeva en su artículo: "Una productividad denominada texto" (1967: 7-54). En ese artículo la autora sostiene que la verosimilitud se desentiende de la relación lenguaje-objeto, por lo tanto, la ley constructiva del texto no está regida por las condiciones de la realidad, sino por las de otro discurso que circula como verdadero: "El espejo al que lo verosímil lleva el discurso literario es el discurso llamado natural. Ese 'principio natural' que no consiste en otra cosa para una época que en el sentido común, lo socialmente aceptado, la ley, la norma, define la historicidad de lo verosímil" (12). Por ello la verosimilitud es para la autora "un efecto interdiscursivo [...] el efecto verosímil es una cuestión de relación de discurso.” (12-13)
} 
hace falta recurrir a elementos por completo extratextuales, constitutivos de la materialidad que lo vincula con el universo de las cosas, como su calidad de libro impreso y los datos de edición. Por ello sostengo que la invisibilización del artificio es aquí extrema y singularmente eficaz. El efecto es nada menos que la desaparición de la novela, pero no por la voluntad autoral de ofrecer un testimonio. Este texto no es una entrevista ni su simulacro. Es cierto que hay referencias, muy esporádicas, a una segunda persona no nombrada, a quien el lector podría decodificar como un interlocutor mudo (por ejemplo: “Tenía razón, porque mire, en la revolución hubo un regimiento que tuvo muchas bajas antes de encontrase con el enemigo...", Poniatowska 1969: 92, énfasis mío) pero esas apelaciones no prueban ni garantizan el carácter testimonial. También rechazo la hipótesis -sostenible- de que se trate de una confesión o de una autobiografía relatada por una mujer presa y "transcripta" por Elena Poniatowska; en primer lugar porque, aunque nos propusiéramos la construcción imaginaria de ese "autor", su paternidad se encontraría cuestionada de antemano por esa instancia mediadora (Jesusa es absolutamente analfabeta, según se nos cuenta en el relato); y, como sabemos, tratándose de una biografía, esa instancia (la escritura de Poniatowska) más que limitarse a la mediación se investiría de aquella paternidad que -quiérase o noel lector trata de establecer en todo texto. La relación de identidad empírica entre sujeto del enunciado y sujeto de la enunciación, elemento estructurante en cualquier escritura del yo, como es obvio, no se verifica en este texto. Pero sobre todo rechazo la hipótesis autobiográfica, confesional o testimonial por los rasgos particulares que presenta esta enunciación. Me refiero a su oralidad "sin fisuras", al modo de organizar -y creo que el verbo es excesivo, se trata más bien de yuxtaponer- los fragmentos de relato, y en términos más generales, a la constitución de una voz que enajena el discurso narrativo y 
le otorga una calidad que no nos permite hablar de un texto ajustado a la dudosa y ya muy cuestionada normatividad del canon autobiográfico.

Tanto la noción de autobiografía como la de escritura y la de ficción presentan una complejidad que merece detenimiento. En primer lugar me parece necesario establecer que la teoría psicoanalítica y sus derivaciones en la teoría literaria desde fines de los años sesenta hasta la actualidad, permiten cuestionar la eficacia designativa del término "autobiografía", por el desdoblamiento inherente a la constitución de todo sujeto. $^{210}$ La teoría literaria ha cuestionado sobre todo a partir de 1970 , la certeza respecto del objeto (o el sujeto) designado por el prefijo "auto". Lo que permite abonar la tesis -a la que Bajtín llega por otro camino, el de la exotopía de la posición de autor ${ }^{211}$ _ de que la autobiografía no es ni más ni menos que una biografía. Pero en el texto de Poniatowska esta cuestión es adyacente, puesto que ni Jesusa Palancares es la "autora", ni hay, desde mi perspectiva, novela en el sentido canónico de la palabra. Y aquí entran en juego las nociones de escritura y de ficción. Hasta no verte Jesús mío se puede definir como una producción fuertemente contestataria respecto del sistema textual normativizado por los lectores, la crítica y por la misma producción literaria, al escribir lo que no puede ser escrito, por cuanto propone su texto como la transgresión del límite de lo escribible. ${ }^{212}$ La historia de la escritura -y por lo tanto la historia de la lectura-

\footnotetext{
${ }^{210}$ Aunque es muy amplia la bibliografía que cubre esta cuestión, de gran vigencia en los ámbitos académicos durante las últimas décadas, me parece indispensable citar algunas referencias: Lejeune, Philippe (1971): L'aulobiographie en France, Paris, ed. Armand Colin. Lejeune, Philippe (1975): Le pacte autohiographique, París, ed. du Seuil. De Mann, Paul: "La autobiografía como desfiguración", en: Anthropos No 29, diciembre de 1991. Molloy, Silvia: Acto de presencia. La escritura autobiográfica en Hispanoamérica, México, F.C.E., 1996. Rosa, Nicolás (1990): El arte del olvido, Buenos Aires, Puntosur. ${ }^{211}$ En la teoría de la novela de Bajtín, "el autor en cuanto es un elemento constitutivo de la obra de arte, no coincide jamás con el héroe: son dos" (Bajtín 1938a: 149). Ver además: "Autor y personaje en la actividad estética", especialmente el apartado: "La actitud del autor hacia el héroe" (Bajtín 1977: 13-28).

${ }^{212}$ En su artículo -al que ya hemos hecho referencia- "De la obra al texto", Roland Barthes sostiene que el texto se encuentra en el límite de la legibilidad y de la enunciación, astilla las reglas de la convención literaria y genera un malestar clasificatorio. En sus términos: "el Texto [...] no puede captarse en una jerarquía ni en base a una simple división de géneros. Por el contrario (o precisamente), lo que lo constituye es su fuerza de subversión respecto de las viejas clasificaciones [...] el Texto es lo que llega hasta los límites de las reglas de la enunciación (la racionalidad, la legibilidad, etc.)." (1971: 75). En este sentido sin ninguna duda Hasta no verte Jesús mío es un Texto.
} 
presenta muchas zonas de silencio. El texto recupera una zona de silencio y la convierte en voz; por eso he dicho que este texto es un habla. Lo que acabo de afirmar sólo puede ser comprobado a través de la experiencia lectora, en la producción de los efectos producidos por la voz de Jesusa Palancares:

a) La cadencia propia del habla mexicana de las capas más bajas de la sociedad que evoca incesantemente la narrativa de Rulfo.

b) Su fragmentariedad y falta de conexión, que contrasta con las exigencias de la escritura novelística: Jesusa habla, y en su discurso se yuxtaponen recuerdos y reflexiones que no tienen el "orden" discursivo construido por la expectativa del género novelístico ni por los géneros de la autoficción.

c) El ritmo propio de la oralidad y el orden no sujeto a las normas de la producción escrita son efectos potenciados por el uso de los verbos y las inflexiones del habla: "En la noche cuando estoy solita me pongo a pensar y digo: 'Ay, Señor, dame fuerzas...' [...] ¡Uy no! ¡Si me meto a escarbar puede que ya me hubiera vuelto loca!” (Poniatowska 1969: 14) -cito uno entre infinidad de ejemplos posibles-.

d) Esas modulaciones no se encuentran enmarcadas ni conviven con ninguna otra voz narrativa, ni gravitan dentro de otro centro de enunciación discursiva a la manera de la novela monológica tradicional, que representa las voces y las objetiva. La voz de Jesusa es el único soporte de la enunciación.

Si al mismo tiempo tenemos en cuenta que el acto de leer es un acontecimiento tan productivo como el acto de escribir, la actualización de la voz de Jesusa -la lectura de este texto- borra el artificio y constituye, entonces, el efecto textual; ese efecto (aquí: la voz de Jesusa) es el texto ${ }^{213}$. En otros términos, he hablado de escritura políticamente orientada porque esta producción de Elena Poniatowska reniega de las categorías

\footnotetext{
${ }^{213}$ Estas observaciones y la reflexión subsiguiente se apoyan teóricamente en el escrito de Julia Kristeva, "El texto y su ciencia", primer artículo de Semiótica 1 (1968a: 7-33) y en el trabajo de Roland Barthes citado en la nota precedente: "De la obra al texto" (1971: 73-82).
} 
clásicas de "obra" y de "autor". Esas categorías sólo existen para este caso si consideramos a Hasta no verte... como objeto material y formal, dentro de categorizaciones creadas por un marco disciplinar -los estudios literarios y la crítica- y una industria -la editorial-, pero se desvanecen si atendemos al efecto producido por la lectura. Lo más poderoso en el nivel de la actitud contestataria respecto del sistema textual establecido, es que en Hasta no verte Jesús mío se desdibujan -como en la obra de Pedro Lemebel- dos antiguas parejas: escritura/ literatura, por un lado, y escritura/ oralidad, por otro. Advierto que la barra en cada caso significa una relación diferente. La primera pareja no es una oposición dicotómica, sino dialéctica. Constituye una de las polémicas más interesantes de las últimas décadas en el ámbito de la teoría literaria y se asienta en el cruce de saberes que se han visto profundamente convulsionados en sus presupuestos epistemológicos, tema del que ya me he ocupado en los capítulos anteriores de esta investigación. La serie literaria, como he señalado, es considerada sobre todo a partir de las vanguardias (y en el espacio dado por la discusión teórica, a partir de los años treinta ${ }^{214}$ ) como una controvertida red de producciones que entran y salen de la esfera artística, cuyos límites son permeables. Esa insustancialidad que comienza a contaminar categorías que parecían inconmovibles o por lo menos epistemológicamente sólidas, se advierte en este texto de Elena Poniatowska al problematizar la noción de lo literario y al mismo tiempo la de texto escrito. Hay un trabajo y una voluntad estética de verosimilizar, de parecerse al discurso oral y comunicativo, sin otra "función" que la de testimoniar una experiencia de vida. Pero esa aparente intención testimonial es el vehículo de la orientación política de una escritura que renuncia a los protocolos de la enunciación escrita, de una práctica incuestionablemente literaria que quiere ser discurso oral comunicativo y espontáneo.

\footnotetext{
${ }^{214}$ Me refiero sobre todo a los trabajos de la Escuela de Praga, cuyo principal representante es parte del marco teórico de esta tesis y ha sido citado: Ian Mukařovský.
} 
Por ello Hasta no verte... provoca simultáneamente la reconsideración del objeto "literatura" y del objeto "escritura", precisamente por su oralidad que me atrevo a calificar de radical. Oralidad radical porque es absoluta en términos cuantitativos -no hay una sola línea en el relato que no esté producida en ese registro- y en términos cualitativos dada la fidelidad del texto al habla popular mexicana correspondiente al sujeto, al tiempo y al lugar representados. Cabe señalar que esta actitud contestataria es más eficaz en la medida en que resulta casi imperceptible: su invisibilidad garantiza su eficacia. El cuestionamiento del objeto-escritura no es violento, ni siquiera explícito; simplemente la efectuación de la voz en la escritura es el procedimiento transgresor, realzado por la ausencia absoluta de un "marco" de carácter escriturario -lo que he denominado antes "oralidad radical"- y potenciado por tratarse de una producción que se enmarca en la literatura mexicana de los años sesenta al estar firmada por una autora reconocida por el campo intelectual no sólo en México sino en toda América Latina y en el mundo. El posicionamiento político de esta textualidad opera, pues, en dos niveles: promueve una reconsideración de las categorías que ordenan las relaciones entre la letra y su valor artístico, y al mismo tiempo generan tensión en la frontera entre la letra y la voz. ${ }^{215}$

El caso de esta obra de Poniatowska constituye un punto de inflexión en la historia de la literatura latinoamericana en relación con la tensión oralidad/ escritura, y por eso lo propongo para pensar los cambios y posicionamientos que transforman un sistema textual en un determinado momento de la historia literaria. Resulta productivo concebir dicho sistema como una superficie territorial en la cual las líneas de filiación y los flujos de producción establecen lugares o posiciones discursivas (la de "género

\footnotetext{
${ }^{215}$ Como se verá en las páginas que siguen, mis observaciones tanto en relación con la novela de Poniatowska como respecto de las crónicas de Lemebel, siguen a los más destacados especialistas en el campo de la escritura en vínculo problemático con la oralidad, a saber: Margrit Frenk, Paul Zumthor, Walter Ong y el mexicano Sergio Pérez Cortés.
} 
literario" es aquí una categoría inoperante) cuyo límite no es el desgaste sino el fallo, cuyos pequeños o grandes estallidos determinan re-posicionamientos sobre los bloques dominantes "establecidos", en un equilibrio perpetuamente inestable. ${ }^{216}$ En el marco de este símil puede verse cómo el texto de Elena Poniatowska provoca el fallo en una categoría tan indiscutiblemente establecida como "la escritura"; resulta muy audaz promover una discordancia a ese nivel, teniendo en cuenta el grado de naturalidad que reviste en nuestra economía de convenciones discursivas la calidad de texto escrito, que parece tan claramente distinguible de la de texto oral. Sin embargo, con una actitud tan contestataria como sutil, Poniatowska pone en evidencia la vulnerabilidad de convenciones que parecían de hierro. Por lo dicho, Hasta no verte Jesús mío es fundamental en la constitución de una genealogía en el campo de la oralización de la escritura. Lemebel construye una línea genealógica que llega a Poniatowska para apropiarse de esa actitud contestataria que pone en tensión todas las convenciones discursivas. Como hemos señalado a lo largo de esta investigación, los géneros literarios convencionalmente entendidos resultan categorías inoperantes, abstracciones (géneros “teóricos” los llamó Tzvetan Todorov en su crítica a la taxonomía biologista:

\footnotetext{
${ }^{216}$ En el primer capítulo de su libro: Introducción a la literatura fantástica -titulado "Los géneros literarios"- Tzvetan Todorov elabora una reflexión crítica acerca de la clasificación tradicional de los géneros literarios. La taxonomía convencional toma como modelo el paradigma científico; como sabemos, en el mundo natural el nacimiento de un ejemplar no modifica las condiciones de su especie. En el campo del arte, en cambio, la evolución sigue un ritmo muy diferente: "toda obra modifica el conjunto de las posibilidades; cada nuevo ejemplo modifica la especie. [...] $\mathrm{O}$, dicho en forma más precisa, sólo reconocemos a un texto el derecho de figurar en la historia de la literatura en la medida en que modifique la idea que teníamos hasta ese momento de una u otra actividad" (1968: 12-13). Desde esta perspectiva teórica, la novela de Elena Poniatowska pone en tensión las determinaciones de la serie literaria, como lo he afirmado, y en esa tensión tienen que ser revisados no sólo el concepto de novela (lo que Todorov en el mismo ensayo llama "géneros teóricos") sino también los de escritura, oralidad y literatura. Está claro que cuando la oralidad atraviesa poderosamente la escritura literaria, las clasificaciones colapsan, o al menos resultan insuficientes. De ahí que Paul Zumthor recurra a la teoría literaria (sobre todo a Roland Barthes y Tzvetan Todorov) y aun al psicoanálisis lacaniano (Zumthor 1987: 329) en el último capítulo de su libro La letra y la voz. De la "iteratura" medieval, al que titula con la interrogación: "¿Qué pasa con la literatura?"; allí analiza la problemática de la "novela" medieval, considerada existente a partir del siglo XII y ubicada por el autor en la confluencia de la oralidad con la escritura.
} 
género, especie, tipo, ejemplar) que no reconocen diferencias, y son las diferencias, precisamente, el modo de ser de la literatura. ${ }^{217}$

A continuación realizaré una breve consideración del vínculo entre oralidad y escritura en las sociedades primitivas -en las que predomina la oralidad-y en las sociedades modernas, mayoritariamente letradas. Las sociedades primitivas son orales no porque carezcan de grafismo o de alguna forma de escritura, sino porque ambos sistemas, el gráfico y el fónico, son independientes: hay autonomía entre la escritura y la voz; los signos escritos están conectados pero no subordinados ni ajustados a ella; por eso no la reemplazan ni la representan. En estas sociedades la voz es una resonancia, un signo territorial, heterogéneo respecto del grafismo y siempre en pareja con la audición. Ambos elementos, vocal y gráfico, tienen su propio poder y constituyen dos regímenes de connotación independientes. ${ }^{218}$ Paul Zumthor va más allá y afirma que, en la Edad Media, la escritura era la fiel sirviente de la voz, apoyatura para la palabra ya sabida, conocida por los intérpretes ("la lectura era rumia de algo sabido", Zumthor 1987: 125). Los códices agrupan obras de muy diversos tipos, sin mención de autor, porque es la palabra oral y no la escrita la que vehiculiza la comunicación, dado que "la mentalidad escritural es minoritaria hasta el siglo XVI o XVII" (1987: 172).

Las civilizaciones occidentales modernas son escritas, pero no porque carezcan de voz, sino porque su escritura opera la sustitución de la voz, aplastando el volumen y conjurando la resonancia del régimen de connotación vocal. ${ }^{219}$ Sin duda la poesía es el

\footnotetext{
${ }^{217}$ A propósito recuerdo el lúcido ensayo de Juan José Saer: "La narración-objeto", cuya hipótesis central es que el relato, apartándose de lo "abstracto, unívoco e inteligible" es "una organización singular de atributos particulares" (Saer 1999: 19-20). La narración se estructura "con la autonomía opaca de un objeto y no con la trasparencia conceptual del discurso [...] el objeto narrativo vivifica el eterno presente del relato con la sustancia gruesa de las cosas particulares" (22-23).

${ }^{218}$ Una interesante y muy minuciosa investigación histórica respecto de esta cuestión puede leerse en: Deleuze, Gilles y Félix Guattari, El Anti-Edipo, Capítulo 3: "Salvajes, bárbaros, civilizados" (1972: 143279).

${ }^{219}$ En La letra y la voz Paul Zumthor subrayó el aspecto oral de la poesía del Medievo, el peso de la voz humana sobre la letra. El autor examina las causas y efectos de ese hecho decisivo, atravesando toda la literatura medieval, desde Hispania hasta Germania, en los siglo IX-XV, y analiza tanto el contexto (el
} 
género literario que ha sido más afectado por esta transformación, pero también los géneros narrativo y dramático han sido transfigurados por la evolución de las sociedades orales a las civilizaciones escritas. Tanto la tragedia griega clásica como la epopeya antigua y medieval han perdido una de sus características constitutivas al pasar de su soporte oral y musical al registro escrito. En la escritura lineal el signo se convierte en una máscara, en un doble, sombra sin espesor ni resonancia; la voz ya no surge de un rostro, sino de la letra -letra leída- separándose del cuerpo que la hace audible.

La voz es un signo territorial en la medida en que constituye un "territorio de resonancia", es palabra activa, régimen de connotación. Sostengo que el texto de Elena Poniatowska le restituye a la voz su capacidad territorial, es decir, su potencia de construir un cuerpo de resonancia, independiente de la cultura letrada (no es inocente ni casual el hecho de que Jesusa Palancares sea analfabeta). Hasta no verte... sustrae la voz a la dependencia del sistema gráfico. En un gesto que es político, se opone al movimiento que opaca y cancela la voz, rescatando al lector de su posición "letrada", separada del rostro y de los cuerpos que emiten la voz. Por eso este texto se resiste a tolerar la categoría de autor como causa eficiente, como fuente de su producción, y rechaza la "novela" como lugar de enunciación. Este texto (flujo de escritura reterritorializado) es un habla, es una voz audible porque ha recuperado su naturaleza primitiva. Lemebel toma la decisión de recuperar en sus crónicas los rostros y los cuerpos que emiten la voz, también sus recuerdos y su historia reciente, pero a diferencia de Poniatowska, no necesita destituir la convención novelística, por cuanto no ha sido esa su opción discursiva como escritor. La crónica le ofrece un cuerpo

espacio de la oralidad, los intérpretes, la palabra de la iglesia, la diversidad de voces cultas y populares), como el carácter de la obra (memoria, dicción, armonías de los ritmos, la vocalización del texto, la actuación ante el público y su participación, la plenitud corporal o teatralidad de la manifestación oral). Zumthor defendió un concepto abierto y flexible de la oralidad como paradigma operativo no sólo en las sociedades iletradas (donde tendría el rango de oralidad primaria) sino también en las sociedades letradas o semi-letradas (donde podría ser considerada como oralidad secundaria). 
abierto a textualidades diferentes, un género apto para poner en escena la alteridad y las voces de la calle sin "traducirlas" a un nuevo sistema de comprensión (no tiene el propósito de re-categorizar el margen) y sin convertirlas en "objeto etnológico"220. Elena Poniatowska produce un texto radicalmente oralizado a través de dos operaciones: borrar el soporte de la enunciación escrituraria (la convención novelística) y hacer coincidir el texto mismo con la voz de Jesusa Palancares. La escritura de Lemebel no necesita ese artificio; él es el otro o bien se encuentra en el lugar del otro, esto es, el lugar de los sujetos que no habían tenido nunca el acceso a la palabra (palabra escrita, reconocida, palabra oída, aquella cuya circulación la hace audible).

En "El abismo iletrado de unos sonidos", incluido en Adiós mariquita linda (Lemebel 2004: 91-94), el autor evoca su visita a las ruinas de Chan Chan, cerca de Trujillo, en Perú. En la plaza principal de la ciudad preincaica, se levanta un muro decorado por relieves de peces. A partir de la contemplación de este friso, se despliega una reflexión acerca de los signos, que "hablan otro lenguaje difícil de transferir a la lógica de la escritura"; tal vez sean "voces apresadas en el barro" (2004: 92). Ciertamente, la cultura oral ha perdido la batalla contra la cultura letrada, "el triunfo de la cultura escrita representada por Pizarro, sobre la cultura oral de Atahualpa. Pero eso nos demuestra que leer y escribir son instrumentos de poder más que de conocimiento", y por ello -afirma Lemebel- es posible revertir el proceso: "la oralidad hace uso de la escritura doblando su dominio y apropiándose al mismo tiempo de ella” (2004: 93-94).

El autor es perfectamente consciente de su desafío y lo pone en palabras. Sus crónicas doblan el dominio de la cultura letrada y se apropian de ella para re-

\footnotetext{
${ }^{220}$ La distancia con Jesusa aparece, y Poniatowska la lleva al epígrafe de su relato, en la despedida que le dedica, áspera y con un toque de resentimiento, la protagonista "real" de su historia: Algún día que venga ya no me va a encontrar; se topará nomás con el puro viento. Llegará ese día y cuando llegue, no habrá ni quien le dé una razón. Y pensará que todo ha sido mentira. Es verdad, estamos aqui de a mentiras; lo que cuentan en el radio son mentiras, mentiras las que dicen los vecinos y mentira que me va a sentir. Si ya no le sirvo para nada, ¿qué carajos va a extrañar? Y en el taller tampoco. ¿Quién quiere usted que me extrañe si ni adioses voy a mandar? -Jesusa. (Poniatowska 1969: 11).
} 
territorializar la lengua, rescatarla de su mudez, vocalizarla. El deseo expresado y realizado en esta crónica -y que atraviesa la totalidad de su obra- es desandar el camino de nuestro poderoso "logo egocéntrico" y descubrir la "selva llena de ruidos, como feria clandestina de sabores y olores y raras palabras que siempre están mutando de significado". Mientras habla de las ruinas de Trujillo se refiere también a su propio proyecto: "Más allá del margen de la hoja que se lee, bulle una Babel pagana en voces deslenguadas, ilegibles, constantemente prófugas del sentido que las ficha para la literatura" (Lemebel 2004: 93). Como Poniatowska, elude el lugar prestigioso de la literatura y gana para la literatura aquella Babel de voces deslenguadas. La voz recupera su condición de signo territorial, espacio de resonancia ligada a los cuerpos que hablan.

La voz está unida a la memoria. Un largo proceso fue necesario para que el ojo humano se adaptara a reconocer y comprender los signos escritos sin el auxilio de la vocalización, y solidariamente, hubo que disciplinar el cuerpo para que se mantuviera quieto $y$ en silencio, actitudes que se han arraigado tanto en nuestra cultura contemporánea que las consideramos naturales. Pero son el legado de lectores y escritores silenciosos que desde el Renacimiento se concentraron en sus estudios solitarios y sigilosos. Este sigilo se ha convertido en sinónimo de actitud racional y desde luego en condición indispensable de la erudición y el saber. (Con respecto al ideal ascético que acompañó el nacimiento de la filosofía y determinó su condición desensualizada por siglos, ya hemos citado suficientemente a Friedrich Nietzsche en el marco teórico de esta tesis).

El silencio y la quietud parecen ser connaturales a la lectura y a la escritura, tanto que si sorprendiéramos a alguien que lee vocalizando nos parecería una anomalía o una manera impropia de leer; seguramente la evaluaríamos como menos eficaz y hasta primitiva o primaria. Lectura, escritura, racionalidad, soledad y silencio parecen ir 
siempre de la mano, pero su conjunción no es natural ni necesaria, es el resultado de una larga y asentada costumbre de nuestro orden cultural. Desde luego que $\sin$ esa conjunción la acumulación del saber en nuestra cultura moderna hubiera sido imposible. Pero también es cierto que durante la Antigüedad y la Alta Edad Media la memoria y la voz tenían su propia autoridad, que no entraba en contradicción con las prácticas de la cultura escrita. Ahora bien, sin excluirse, la lectura oral y la escrita tienen diferencias históricas que perviven en el presente. Me voy a detener en algunas de ellas, para retomar luego mi reflexión sobre la obra de Pedro Lemebel.

En su bello libro Entre la voz y el silencio, Margit Frenk (1997) explica cómo se ha dado en nuestra lengua la coexistencia entre la lectura silenciosa -la cual fue abriéndose paso en un mundo no alfabetizado- y diversas formas de la textualidad escrita. La lectura en voz alta no desapareció ni disminuyó con la invención de la imprenta. La hipótesis central del libro sostiene la existencia de una "oralidad de lo escrito" que explicaría la enorme popularidad que tenían en su momento obras escritas que aun hoy consideramos complejas y de altísima calidad literaria (como la obra de Lope de Vega y la del propio Cervantes). La autora presenta abundantes ejemplos y prueba su hipótesis al explicar con su concepto de "oralización" de la escritura cómo las sociedades mayoritariamente analfabetas (ella estudia el fenómeno durante los siglos XV, XVI y XVII) podían disfrutar y comprender "obras tan complejas y sofisticadas, cargadas de mitología antigua y de historia, abundantes en figuras retóricas, llenas de 'conceptos' y, por añadidura, compuestas en verso" (Frenk 5). La clave de esta aparente paradoja reside en una muy desarrollada forma de recepción de la textualidad escrita: la lectura en voz alta (a esta convivencia productiva de la letra y la voz alude el título del volumen). ${ }^{221}$

\footnotetext{
${ }^{221}$ Para Ong existen tres oralidades: la primaria, la residual y la secundaria. Las culturas orales primarias son las que desconocen la escritura. Estas culturas no tienen conocimiento de la escritura: son totalmente
} 
Una consecuencia importante de dicha coexistencia es la comprobación de que la célebre literatura del Siglo de Oro español se desarrolló y extendió en el seno de una cultura híbrida, en la cual la escritura interactuaba con los procesos de oralidad de la comunidad receptora, sobre todo a través de la lectura en voz alta. La transición entre ambas prácticas es objeto de una interesante discusión, pero más allá de las discrepancias entre especialistas, está claro que la cultura oral, las prácticas de la lectura en voz alta y su correspondiente oralización de lo escrito, se mantuvieron mucho tiempo después de la invención de la imprenta. Frenk demuestra una admirable erudición en este tema y cita a numerosas fuentes especializadas. Después de un exhaustivo relevamiento en el que señala algunas imprecisiones, vaguedades y contradicciones, la autora se inclina por los puntos de vista de Gérard Genette y Walter Ong, quienes afirman que el consumo oral del texto escrito no sólo se prolongó más allá de la invención de la imprenta, sino que sólo a partir del siglo XIX se ha venido produciendo "un debilitamiento continuo de los modos auditivos del consumo literario" (Genette 1969: 124) y que la cultura occidental "continuó teniendo residuos orales en gran escala (massive oral residue) hasta el período romántico y aún más allá” (Ong 1982: 41). Margit Frenk cierra esta referencia con un pasaje de Goethe: "Escribir es un mal uso del lenguaje; leer en silencio para uno mismo, un triste sustituto del lenguaje hablado" (en: Poesía y verdad, 1813). "Todo parece indicar-resume la ensayista- que en el mundo de habla española la lectura en voz alta continúa siendo un hábito frecuente hasta entrado el siglo XIX” (Frenk 119).

ágrafas. La oralidad residual se caracteriza por el conocimiento, en alguna medida, de la escritura. Las culturas residualmente orales pueden estar en contacto con una cultura gráfica de alguna manera, y el contacto con tal conocimiento tiene cierta influencia sobre los procesos del pensamiento lingüístico. Finalmente, la oralidad secundaria es un fenómeno que ocurre en la era de las comunicaciones (la radio, la televisión, el teléfono). Esta oralidad, según Ong, "depende de la escritura y la impresión para su existencia" (1982: 11-24). 
Otro autor que, posteriormente, ha estudiado estos fenómenos es el mexicano Sergio Pérez Cortés quien elabora una arqueología de los hábitos intelectuales enfocando en las estrategias de lectura, principalmente desde la Antigüedad hasta la Alta Edad Media. Cito a continuación un fragmento de su último libro, que establece con claridad las diferencias históricas en la interacción autor-lector:

Debido a su soledad, cuando escribe el autor moderno tiene en la mente a un lector anónimo, distante y taciturno que, como él mismo, puede ir y venir por las páginas del libro para verificar la compleja estructura lógica y textual que lo sostiene. Cuando el autor antiguo componía, por el contrario, en su imaginación se presentaba una lectura expresiva, solemne y vigorosa, realizada ante públicos expectantes y a veces bulliciosos. Sus textos estaban compuestos para "sonar". Él sabía que no serían interpretados en el tono relajado del habla cotidiana, sino con la fuerza y el dramatismo que le otorgaba el lector antiguo. Por eso esperaba que en su ejecución vocalizada se reanimarían las mismas emociones y sentimientos que él mismo había sentido en su fuero interno en el momento de la composición, y que serían transmitidos a su auditorio con el resultado, quizá, de que sería su propia voz y no la del lector, la que escucharían sus cercanos. Debido a la lectura en voz alta el autor antiguo y medieval con frecuencia temía más el "juicio del oído" que el veredicto de la lógica. (Pérez Cortés 2006: 51-52).

Este autor también destaca -al igual que Frenk- la coexistencia entre cultura oral y escrita, subrayando el ascenso gradual de la lectura silenciosa, y rechazando la supuesta supremacía de la cultura escrita por sobre la cultural oral. En este sentido, el autor rechaza la idea, muy generalizada, de que las culturas orales sean "protoliterarias o semibárbaras", por cuanto tienen y han tenido producciones intelectuales de alta calidad. De hecho la literatura clásica que hoy admiramos fue compuesta en gran medida "por la voz y por la memoria, por la voz y por el recuerdo"; además las culturas orales han tenido y conservan "sus propias formas, sus valores, e incluso su propia profesionalización". 222

\footnotetext{
${ }^{222}$ A propósito de la cultura oral mexicana Pérez Cortés da una referencia muy significativa para comprender la incidencia de la oralidad en la literatura de su país. Los "pedidores" son hombres que "se
} 
Si bien la lectura en silencio, puramente visual, es una práctica distinta y aun contrapuesta a la lectura oral-auditiva (aquélla claramente intelectual-cognitiva, ligada al conocimiento científico, ésta sensorial-emotiva, ligada al goce), no existe una oposición correlativa entre oralidad y escritura. En efecto, la convivencia de ambos modos en la producción y la transmisión de los textos, las diferencias que se observan en la transición de un sistema al otro según los géneros, las épocas y los países, y la oralización de lo escrito, ha determinado la transmisión literaria de los siglos XVI y XVII particularmente en España y nos permiten concluir que la literatura vocalizada (sea o no impresa) es un fenómeno muy importante, que lejos de ser abolido por la invención de la imprenta pervive claramente hasta el siglo XIX y, desde luego, llega con fuerza hasta nuestros días.

Paul Zumthor en su ineludible Introducción a la poesía oral señala la "función" como el elemento decisivo que define el valor estético de una obra de arte, y por ello analiza el plano de la performance ${ }^{223}$ donde ese valor se realiza. En este sentido señala que el valor estético depende de la competencia social, del consensus que dirige a la vez la producción y la recepción de lo que es calificado como poesía (1983: 82). Según el célebre medievalista, el arte poético asume en la perfomance un carácter instantáneo, tiende a la inmediatez, a la espontaneidad y a la transparencia, dotando de fecundidad y de vida a la palabra. Zumthor vincula la oralidad con la poesía, el poder comunicativo y la performance. Como ya he señalado (ver nota 47), el autor estudia la literatura

pueden parar ante una comunidad y hablar durante tres horas seguidas sin ningún guión escrito". Estas personas desarrollan su actividad en "amusgo", una lengua no completamente estudiada, usada en Oaxaca y Guerrero. El autor detalla que en sus parlamentos ante la comunidad elaboran un discurso secuencial que persigue un objetivo determinado: "pedir una novia para un joven", para lo cual usan "las viejas formas de la retórica aristotélica". La profesión de "pedidor" de los amusgos no es la única que existe pues hay profesionales de la palabra a quienes se paga para que en los funerales hablen bien del muerto.

${ }^{223}$ Zumthor define la performance poética como "la acción compleja por la que un mensaje poético es simultáneamente transmitido y percibido, aquí y ahora. Locutor, destinatario(s), circunstancias [...] se encuentran concretamente confrontados, indiscutibles. En la performance coinciden los dos ejes de la comunicación social: el que une el locutor al autor y aquel por el que se unen situación y tradición". (1983: 33) 
medieval, desde Hispania hasta Germania, en los siglo IX-XV, y analiza el contexto y los rasgos específicos de la obra en este período, poniendo el acento en la actuación ante el público y la teatralidad de la manifestación oral. En sus desarrollos concibe la obra como todo aquello que se comunica poéticamente según las exigencias del "aquí y ahora"; el texto está configurado no sólo por palabras, sino también por sonoridades, ritmos, elementos visuales, esto es, abarca los factores de la performance (1983: 83-84). Para el autor, la estructura poética en régimen de oralidad, opera con la dramatización del discurso y no sólo con los procedimientos verbales, y por lo tanto, el elemento discursivo asume su sentido y sobre todo sus efectos en el espacio dramatizado de la performance. Solas o aisladas, las formas lingüísticas carecen del valor poético y el sentido que asumen en el contexto vocalizado y teatral de su enunciación oral:

Ese texto se convierte en arte, en el seno de un lugar emocional, manifestado en performance, y de donde procede y adonde tiende la totalidad de las energías que constituyen la obra viva. Eso sucede con la performance que, de una comunicación oral, hace un objeto poético, confiriéndole la identidad social en virtud de la cual se percibe y declara como tal. (Zumthor 1983: 84)

Destaco particularmente esta cita del autor porque está en consonancia con mis hipótesis respecto de la obra de Pedro Lemebel, sobre todo teniendo en cuenta el origen de las crónicas del autor chileno: la performance (como he dicho antes, verdadera fragua del discurso lemebeliano) y la oralidad radial, punto de partida de su constitución como autor y de su formación artística. En la presentación de su tercer libro, De perlas y cicatrices, leemos:

Han pasado casi dos años, desde que Raquel Olea y Carolina Rosetti me dieron un lugar en la programación de esta emisora de mujeres para que echara a volar estos textos en el espacio "Cancionero", un microprograma de diez minutos, dos veces al día, de lunes a viernes, donde este puñado de crónicas se hicieron públicas en el goteo oral de su musicalizado relato. [...] El producto de esta 
experiencia no podría contenerlo la documentación letrada que en el paralelismo gráfico de este libro se imprime como muda pauta. (Lemebel 1998: 5). Énfasis mío.

El carácter oral de sus crónicas es un rasgo de toda su obra y constituye una marca original del autor. El texto es escrito para ser leído y su comunicación inmediata lo vincula al presente de la escucha. La crónica de Lemebel enlaza de un modo muy particular el contenido crítico de sus reflexiones con los temas de la vida cotidiana de los oyentes, lo cual provoca que cada texto tenga un engarce particular entre tres momentos: el pasado (a veces es un pasado lejano, como la infancia del cronista, a veces un pasado menos remoto, como los años setenta y ochenta, signado por la dictadura militar), el momento histórico en el que se produce y publica o emite la crónica (a veces ese presente histórico tiene connotaciones políticas, y se alude al gobierno de la Concertación, a veces no), y el presente inmediato o instantáneo, el de cada día y cada hora, ligado a la vida cotidiana y doméstica. Este tercer momento de la crónica lo liga al hic et nunc o "aquí y ahora" propio de la literatura vocalizada. ${ }^{24}$

Traigo a mi análisis de la obra lemebeliana las consideraciones de Paul Zumthor, quien ha estudiado con singular erudición y capacidad de análisis el fenómeno de la poesía oral, porque su precisión y solidez argumentativa echa luz sobre el fenómeno de la oralidad en relación con la función social de la poesía -aunque es obvio que el autor se refiere a la producción medieval, sus conclusiones se ajustan perfectamente a la oralidad de las crónicas que estoy analizando en esta tesis- y también subrayan el carácter "múltiple", abigarrado", sin fronteras precisas del texto oralizado:

[...] esta falta de delimitación externa del poema, lo impreciso de esas fronteras textuales, procede del interior: de la ausencia de "unidad" en todos los sentidos, que daría a ese término una retórica de la escritura.

\footnotetext{
${ }^{224}$ Señala Walter Ong que el propósito de una performancia "nunca es simplemente estético: celebración, educación, [ser un factor] fortalecedor de identidad del grupo, medio de hacer perdurar conocimiento popular, etc." (1987: 156).
} 
El texto oral, la mayoría de las veces, es múltiple, acumulativo, abigarrado, a veces cambiante hasta la contradicción. (Zumthor 1983: 138)

La observación de Zumthor vale para el caso Lemebel: el carácter múltiple y abigarrado de sus crónicas, la musicalidad del texto subrayada por la transmisión radial acompañada de música, se enlaza con la experiencia y la percepción de los oyentes aunando el presente textual (las crónicas realizan un corte sincrónico y enfocan un momento detenido: el "presente" de la enunciación) con el presente inmediato de la transmisión en el aire de la radio. Lemebel es perfectamente consciente de ello:

El resto, la puesta en escena ambiental, el gorgoreo de la emoción, el telón de fondo pintado por bolereados, rockeados o valseados contagios, se dispersó en el aire radial que aspiraron los oyentes. [...] Ahora, la recolección editora enjaula la invisible escritura de ese aire, de ese aliento. (Lemebel 1998: 5-6).

Se da una singular sintonía entre el texto, su vocalización y la percepción de los oyentes. Por ejemplo en "El guante escarlata de Pina Bausch" (Lemebel 2008: 99-107) el lector es sometido al régimen danzante de una prosa que conecta el movimiento de la bailarina, la percepción del cronista en la platea y la visión-audición del lector devenido espectador-oyente:

Y desde el suelo o cielo, una mano triza el aire con un guante escarlata, y parece que vuela la mano paloma, parece que arde el guante diablo, pero no vuela ni se quema, se congela el puño apretado, apenas se encoge arrítmico, conjugándose con otras manos y otros torsos y otras pelvis que rondan el sube y baja de este espejismo carnal. (Lemebel 2008: 99)

A propósito de esta crónica, cito una breve y concentrada observación de Zumthor acerca del ritmo poético en la literatura oral: "en el espacio que engendra el sonido, la imagen sensorialmente percibida se hace objetiva; del ritmo nace y se 
legitima un conocimiento.” (1983: 151. Énfasis mío). La frase integra un apartado en el que se analiza el valor de la recurrencia (también emplea Lemebel este procedimiento) que imprime a la materia sonora una forma que "anima el pensamiento" y es, según el autor, "la fuerza magnética del poema" (1983: 174). Subrayo el nexo que propone Paul Zumthor entre texto, imagen, ritmo, fuerza y pensamiento en la literatura vocalizada, porque da la clave de las relaciones heterogéneas que atraviesan las crónicas de Lemebel y que constituyen el objeto de mi análisis en este capítulo.

La oralidad, la musicalidad y el ritmo de las crónicas de Lemebel se engarzan con el relato de su intimidad, configurando una nueva conexión heterogénea. Lo autobiográfico se da en el marco de una línea de fuerza constitutiva del discurso lemebeliano que ya hemos considerado en esta tesis: las políticas del cuerpo, es decir, la incorporación del deseo y la experiencia particular y menor como configuradores del relato. Narrar desde los márgenes configurando un nuevo mapa social y una intervención en los discursos historiográficos es, como hemos señalado, el proyecto que determina toda su producción; pero a partir del quinto libro: Adiós mariquita linda (2004) ese proyecto se adensa y se personaliza narrando a partir de la construcción de un yo que se desliza hacia la autoficción. Vemos en este libro la atadura indisoluble entre la escritura, la memoria y el deseo, con una estrategia de oralización (Frenk) que materializa sus crónicas -más ligadas a la voz y la audición que a la soledad y el silencio escriturarios- y las convierte en literatura vocalizada.

Memoria y deseo están siempre presentes en cualquier escritura del yo. Ahora bien, en Lemebel esa conjunción se suma a la orientación general de su proyecto creador: se trata de una voz en deriva, cuyo propósito de registro de la experiencia colectiva desde un punto de vista particular y minoritario (el "ojo coliza”) lo vincula a la mejor tradición de la crónica hispanoamericana a través de un sujeto itinerante que le otorga a la ficción 
autobiográfica una marca ex-céntrica. Recordemos a los cronistas de la modernidad latinoamericana, cuyo paseo por las calles de la gran ciudad configura un discurso en travesía. A ella se suma la estrategia de oralización que acabo de señalar y a la que me referiré a continuación.

Los textos de Lemebel, como se ha dicho, inician su recorrido en la oralidad radial y en la performancia. Hemos naturalizado el anglicismo performance sin advertir que es un latinismo travestido. La performancia, como señala Walter Ong, tiene una larga tradición en nuestra lengua y consiste en la creación que se produce en una situación de tipo teatral, representación que suele darse en el ámbito de una fiesta, en la plaza pública, en la calle, siempre colectivamente. Este es un elemento clave en el compuesto discursivo heterogéneo que es la obra de Lemebel: un elemento propio de las culturas orales: el hic et nunc del evento público y colectivo. Al igual que en una cultura plenamente oral, en una cultura oralizada "la comunicación [...] reúne a la gente en grupos" (Ong 1982: 69).

Por lo tanto la oralidad, tributaria de la performancia y la comunicación radial que obran como fragua del registro lemebeliano, le es constitutiva. Digamos, entonces, que el giro autobiográfico en su obra es inseparable de la oralidad y la condición itinerante del sujeto. El registro autobiográfico está compuesto y recorrido por tres sistemas de heterogeneidad: la escritura y la voz (con su modulación oralizada, vocal); la memoria individual y colectiva sin solución de continuidad: lo individual y lo colectivo conviven en las crónicas de Lemebel en un deslizamiento sin bordes; y el silencio y la quietud del registro escriturario con la condición itinerante y el cuerpo en movimiento del paseo lemebeliano, verdadera cartografía deseante de quien recorre la ciudad y camina mirando, en una evocación consciente y me atrevería a afirmar que programática del proyecto baudelaireano del escritor como paseante. 
Como podemos observar, el género autobiográfico, ligado siempre por una tensión constitutiva, a saber: la posibilidad y la imposibilidad de narrar la propia vida, de escribir el yo, encuentra en la prosa lemebeliana el triple indecidible que acabo de bosquejar, complejizando aún más la configuración y la reflexión teórica acerca de este género. A continuación propongo un breve recorrido por algunos procedimientos de su prosa que dan cuenta de lo que acabo de señalar.

En Adiós mariquita linda, sin duda su libro más autobiográfico, observamos un cambio muy evidente en la posición del sujeto respecto de los libros anteriores. En estas historias el sujeto-objeto erotizado pasea por las calles en plan de seducción. El cuerpo conquistado será siempre más temprano que tarde objeto perdido, y su evocación nostálgica recupera todos los géneros populares de una educación sentimental menor (está presente la ideología del bolero y de la canción melódica del primer Serrat, los ritmos del Buena Vista Social Club, la melancolía de Violeta Parra). En la evocación nostálgica de sus amores perdidos, el sujeto que narra no es una "consciencia de sí" captándose en la escritura, desplegándose en el clásico gesto autobiográfico de la indagación interior. La escritura del yo en Lemebel produce un sujeto ex-céntrico, siempre atento a las voces y al acontecer exterior, registrando los ruidos de la calle, las marcas en los rostros, la ingratitud o la soledad en las miradas. La prosa del chileno sabe cartografiar en cada mirada la forma que asumió el último daño. A veces es "un inquieto mirar [...] cesante y peregrino"; a veces un leve matiz expresa el desamparo: “su vocecita huasteca volvió a insistir" (2004: 9); su breve relato sobre su encuentro con “el Wilson” no se aparta nunca del propósito central de su proyecto: historiar lo particular y minoritario. Ese propósito atraviesa sus historias de amor y su más íntima confesión. Todo este libro es una ajustada y original amalgama de experiencia íntima y registro del "duro patiperrear" de la pobreza en el Santiago de la transición. La 
desnudez de los cuerpos amados es también la desnudez de la desposesión y el desamparo de los caídos del régimen social. Pero ese reconocimiento no tiene nada que ver con la "fábula exótica" (de Certeau) de los discursos de la subalternidad. El otroamado no es una identidad subalterna a pesar de la marcada diferencia económica y cultural. Ésta no se encuentra ni borrada ni disimulada en el relato de la crónica, pero tampoco configura un límite que transforma al otro en un objeto etnológico. Lemebel "des-exotiza" la alteridad sin borrarla, sin aplanarla, y sin traducirla en un sistema de comprensión; integra las relaciones -siempre materiales y contingentes- entre discursos, sujetos y prácticas sociales, a sus historias de amor. Baste como ejemplo el bello comienzo de su crónica: "Se llamaba José”:

[...] nada más que José, como si esas cuatro letras hiladas en la baba de la palabra fueran su único equipaje, su peregrina identificación para ir de calle en calle luciendo su esbelto porte de sureño transplantado. $\mathrm{Y}$ es la misma historia de muchos chicos que llegan atraídos por esta luciérnaga de neón, el mismo impulso de José que rumbea la ciudad olfateando la ilusión de una peguita, un pituto, un trabajo, cualquier cosa para no volver al sur derrotado, me dijo cuando lo encontré en el sube y baja de las micros vendiendo maní para salvar al menos la comida. Y sólo entonces vi esos ojos de aguilucho con pena o felino triste, donde aún chispeaba la dignidad de su soberbia. Vivo en la calle, me comentó [...] En él creí ver a una fiera depresiva jugándose sus últimos zarpazos en la riña gatuna de la city. Caminemos, le sugerí con la lengua de arpón que siguió palabreando sus pasos. (Lemebel 2004: 14).

Estos procedimientos son la condición y el límite de su estrategia autobiográfica. Las crónicas de Zanjón de la Aguada ${ }^{225}$ y Adiós mariquita linda se presentan claramente como escrituras del yo, dado que abordan situaciones personales e historias vividas por el autor (lo cual consta en notas incluidas a modo de epílogo, notas al pie, dedicatorias y entrevistas) pero el yo es un vacío activo a través del cual pasan

\footnotetext{
${ }^{225}$ Algunos procedimientos particulares de este libro serán analizados al final de este apartado.
} 
percepciones (voces, texturas, olores) y permiten configurarse como dispositivos de una enunciación colectiva. Por ejemplo, las crónicas agrupadas bajo el título "Todo azul tiene un color", de Adiós mariquita linda (Lemebel 2004: 71-88) se presentan como un relato de viaje. "Cubana de aviación", "La Habana vieja", "Llegando a La Habana" y "El fugado de La Habana" trazan el recorrido desde Santiago de Chile hasta la capital caribeña, respetando la cronología y la cartografía del caso. Lo que encontramos los lectores recorriendo ese trazado es un abigarrado registro de voces, colores, rugosidades, temperaturas, sabores, olores y ritmos:

De trepar esa escalera al cielo, al Caribe, al son, a ese amasado del habla que tiene el pueblo cubano. A esa forma vital de decirse cantando, de cantando la azafata preguntar. Por su pasaje, señor. [...] y sean bienvenidos al vuelo sin fronteras de Cubana de Aviación. (Lemebel 2004: 73. Énfasis mío)

[...] en la ventanilla las nubes son hilachas de pañuelos que te despiden. Y estando en el aire ya no importan las tensiones, ni siquiera la contestación de María Dulce a un pasajero diciéndole: Que su cinturón de seguridad está roto, pues cámbiate de asiento, chico, todo el avión está a tu disposición. Pero casi todos los cinturones están malos, señorita. Entonces, sujétate como puedas, que ya viene el aperitivo de ron. (Lemebel 2004: 73)

Y al segundo trago nadie puede dudar de que la revolución aérea empezó hace rato al ritmo de la salsa que se escucha por los parlantes y que se interrumpe a veces por los tiritones del aparato. (Lemebel 2004: 73)

Se escucha la voz cantante de Asunción María diciendo ya estamos 1legando, que ya volamos sobre el nacarado horizonte del territorio cubano. (Lemebel 2004: 74)

Como vemos, Lemebel registra la música de las palabras, los sabores y colores. Su escritura no es un "derivado" respecto de la palabra hablada, no redobla la voz: la hace audible y sonora, se hace vehículo de su intensidad y su ritmo ("ese amasado del 
habla que tiene el pueblo cubano"). El "ritmo de la salsa que se escucha por los parlantes" está transpuesto en el discurso: es el ritmo de la prosa lemebeliana.

Similar procedimiento se da en el texto “Corazón vudú” (Lemebel 2004: 37-41), al ritmo del Óigame compay del Buena Vista Social Club. El efecto no puede reproducirse aquí; son tres páginas ritmadas por el "Óigame compai”, que funcionan exactamente como en la canción "De camino a la vereda" de la famosa banda cubana: como un leit-motiv musical que se repite y marca el ritmo; Lemebel traslada ese efecto a su prosa que se lee casi cantando, casi bailando. ${ }^{226}$

Una vez más Lemebel elude la coartada del pensamiento binario, y así el relato de su más íntima experiencia amorosa se cruza sin oponerse a la más intensa línea de fuerza de su proyecto autoral: ser la voz y el registro de la experiencia colectiva, a través de una escritura que conjura el silencio y la quietud del registro escriturario.

Serenata cafiola (2008) es un libro escrito en consonancia, literalmente, con las diferentes canciones que evoca ligadas, siempre, a la situación personal o histórica evocada. Está escrito en un doble registro. En principio y como resulta evidente desde el título, todos los textos remiten a una canción, o bien están como tatuados en ella: el ritmo y la letra incluyen la enunciación misma de la crónica. La segunda condición de este "cancionero" es su clave metonímica. El fin de la ilusión democrática se enlaza con

\footnotetext{
${ }^{226} \mathrm{Al}$ analizar el fenómeno de la oralidad, Paul Zumthor parte de un principio no siempre evidente pero decisivo, que es el hecho de que la oralidad no se reduce a la acción de la voz, sino que supone la acción de todo el cuerpo, razón por la cual insiste en el vínculo indisoluble entre oralidad y performance. El autor remite a la tradición histórica para demostrar que fue originariamente la canción la forma por excelencia del discurso de arte verbal: la mayoría de las performances poéticas han sido cantadas, siendo en la voz cantada donde el lenguaje exalta su potencia, donde la palabra se encuentra magnificada, aunque sea al precio de cierto oscurecimiento del sentido, de cierta opacidad del discurso (1983: 186) y subraya que la forma paradigmática en la que se observa este procedimiento es la canción de amor: "La única forma poética que en todos los contextos culturales se presta a ello de forma masiva, inmediatamente accesible a la colectividad es la 'canción de amor' en la diversidad de sus retóricas, fijas y siempre re-inventadas: palabra fuera del tiempo y del espacio, acompasada con fórmulas tranquilizadoras cuyo paradigma es la llamada indecible del deseo; pero también, en todo momento, ruptura y nuevo impulso, voluntad de decir algo nuevo -de nuevo-. Alzada hacia un sujeto desconocido, imprevisible, una escucha vacía, la canción, por esto mismo, alcanza al receptor real, deseado, porvenir virtual del cantor, su Otro". (1983: 171. Énfasis mío)
} 
la pérdida de la madre infantil, configurando un desplazamiento que da la clave semántica del libro: la pérdida de la madre - la pérdida de la patria.

El primer texto del libro, “Tonada pascuera” (Lemebel 2008: 17-19) evoca la muerte de la madre en las vísperas de la Navidad, fecha ligada a su genealogía de escritor. El autor recuerda aquella tarde de comienzos de su adolescencia, cuando la madre le preguntó qué quería como regalo de Navidad:

No quiero juguetes, dije con gravedad, prefiero ese libro, y apunté hacia un gran tomo de láminas sobre la historia del cine. Y ahí comenzó mi carrera literaria, ese fue mi primer libro que marcó el fin de la niñez. Esa noche se murió Santa Claus y supe que la vida me esperaba con la música desafinada de su circo triste. (Lemebel 2008: 18).

La evocación melancólica de la muerte de su madre cierra la primera crónica y atraviesa el libro; el último texto, "Para mi tristeza violeta azul" (Lemebel 2008: 235237), evoca la visita del autor a la tumba de su madre en el Cementerio Metropolitano. El fin de la ilusión infantil y la pérdida de la madre son el punto de partida para narrar el fin de la ilusión democrática en un país que ya ha cumplido -en la fecha de publicación de este libro- dieciocho años de democracia formal, pero en el que aún suena el ritmo trágico de la represión y el manto de olvido sobre las muertes y abusos de la dictadura. Así desfilan por el libro figuras emblemáticas de ese pasado oscuro que permanece como una herida abierta en el presente melancólico de la escritura, como Ana González de Recabarren (“A su linda risa le falta un color”, Lemebel 2008: 69-72) y Víctor Jara (“Quién mató a Víctor Jara" Lemebel 2008: 73-76). Pero también son objeto de la crónica aquellas figuras ambiguas, que tuvieron participación en el sueño setentista apoyando la candidatura y la presidencia de Salvador Allende, pero cedieron a las presiones o a la tentación de "reciclarse" en la escena cultural o televisiva de la dictadura. Es el caso del folclorista Tito Fernández ("Guitarreando con la CNI", 
Lemebel 2008: 81-83) y de uno de los integrantes del famoso conjunto "Los Prisioneros” (“Serenata para un Prisionero”, Lemebel 2008: 169-171).

Podemos decir que este libro se estructura en tres ejes que se cruzan y tienden líneas hacia la obra anterior: 1) la melancólica evocación de un pasado perdido y lejano; en ese pasado se distinguen tres momentos: la infancia, la primera juventud, y un pasado menos remoto, bajo el signo de la ilusión democrática (los años de la Unidad Popular); 2) el recuerdo de la música que acompañó algunos episodios de esa historia evocada con nostalgia, con especial mención a dos grandes figuras de la canción chilena: Violeta Parra y Víctor Jara; 3) las historias particulares de personajes que bajo condiciones de vida muy diversas atravesaron situaciones dolorosas a causa de su homosexualidad, siendo víctimas de la homofobia, la indiferencia o la incomprensión. Una de las secciones del libro, titulada "Cachureo sentimental" (Lemebel 2008: 173193), presenta imágenes vinculadas a algunos textos incluidos en el volumen. Entre ellas, se destaca "Pisagua", fotografía de la performance de Pedro Lemebel que lleva ese título, y que evoca el triste destino de una veintena de detenidos que fueron asesinados en el campo de concentración situado en esa localidad del norte de Chile. ${ }^{227}$

Dos crónicas que integran la sección "Canturreo memorial” integran los aspectos más relevantes del libro que acabo de sintetizar brevemente. La primera es "Quién mató a Víctor Jara" (Lemebel 2008: 73-76). En ella el cronista relata el episodio protagonizado por Isabel Parra, la hija de la célebre poeta, cantante y artista plástica Violeta Parra en un avión de Lan Chile, de regreso a su patria. A punto de aterrizar la nave en el aeropuerto de Pudahuel, Chabela -como la llaman sus amigos- llevó adelante

\footnotetext{
${ }^{227}$ El llamado "Campo de Prisioneros de Pisagua" fue un campo de concentración chileno para prisioneros políticos, creado en septiembre de 1973, poco después del golpe de estado liderado por Augusto Pinochet que derrocó al gobierno de Salvador Allende. Estuvo en funcionamiento hasta octubre de 1974. Entre el 29 de septiembre de 1973 y junio de 1974, fueron ejecutadas 26 personas las cuales se encontraban detenidas en Pisagua. A principios de junio del año 1990 se descubrió una fosa común, y lo que serían los restos de una veintena de seres humanos asesinados y presumiblemente torturados en el lugar.
} 
lo que, según su relato telefónico "fue una performance, una acción de arte o un repentino impulso de bronca que le vino cuando en la ventanilla del avión divisó el imponente merengue congelado de los Andes" (73). La crónica pone en contexto el episodio. En el avión Isabel escucha algunos comentarios que detonan su reacción. Cuando la azafata anuncia la temperatura en la ciudad de Santiago, se escuchan los siguientes comentarios:

Casi un paraíso, casi ideal, tan distinta a la humedad sofocante de Miami, Marichu, escuchó la Isabel a una vieja relamida que conversaba a su lado. Por suerte llegamos temprano para almorzar en el Country, siguió hablando la pituca. Por suerte hay un lindo día para ir después a vitrinear, agregó con el descaro fruncido de su boca cuica. Y ahí la Chabela no pudo más, no aguantó tanta caradura [...]. (Lemebel 2008: 73)

Lo que se observa en el fragmento que voy a transcribir a continuación es un procedimiento que aúna el recuerdo del cantante popular asesinado el mismo día del golpe, la impunidad y el misterio que rodean su asesinato, el ritmo de sus canciones cifrado en la crónica y el efecto de sorpresa, disgusto y confusión que genera en los pasajeros, según su función dentro de la nave, su clase y nacionalidad:

Entonces, parándose del asiento, caminó por el pasillo directo hasta la gran pantalla donde se proyectaba la cordillera azulina en todo su esplendor. QUIÉN MATÓ A VÍCTOR JARA, escribió en el lienzo fosforescente con letra temblorosa, QUIÉN MATÓ A VÍCTOR JARA, lo leían los pasajeros, con un gesto de sorpresa y temor. QUIÉN MATÓ A VÍCTOR JARA, fue la interrogación ausente de signos que la Chabela garabateó en la pantalla nevada del Concord. Así fuera una pregunta implícita, el graffiti de plumón rouge ensangrentó el albor patrio. La letra del gesto rasguñó la nieve al estampar con amor la tersura del nombre. En cada letra iba un verso, en cada entreletra otro nombre, los mil nombres del asesinato y la desaparición. (Lemebel 2008: 74)

Los nombres de Isabel Parra, el de su madre Violeta Parra y el de Víctor Jara danzan en la crónica de Lemebel al ritmo de la pregunta que la joven artista escribió en 
ese lugar prohibido, el lugar donde los chilenos no querían verla: "rayándole los anteojos a la platea aérea, a esa gente chilena que de viaje en viaje le incomoda el crimen rasurado de Víctor Jara" (Lemebel 2008: 74). El episodio está salpicado de humor y de claras referencias al alto nivel económico de los pasajeros chilenos y su ideología de derecha: "Pero no por eso estos terroristas nos van a rayar la tele, pos, oye. Es un atentado en pleno vuelo, Marichu, gritó la pituca [...] Nos van a raptar a Cuba, seguro" (74-75); y devela, una vez más, la profunda brecha que separa al tejido social cuando de los crímenes de la dictadura se trata. Indiferencia, complicidad muda, olvido y silencio. Contra ellos se alza la voz de Lemebel. Aquí aprovecha el "arte-gesto" de Isabel Parra y su confidencia -el narrador refiere el episodio como el producto de una conversación telefónica con su protagonista - para denunciar una vez más la impunidad de los crímenes y la complicidad de cierto sector de la sociedad chilena demasiado cómodo en su desahogada situación económica como para dejarse sobresaltar "por el eco de una impune detonación" (76). Esa detonación, ese crimen, también está relatado en el cuerpo de la crónica:

La Isabel escribió en la pizarra la memoria de un acorde, de un paisaje: calle Segovia, cuatro de la tarde y Víctor llegando acalorado por las agresiones callejeras de los fachos. Otra letra tiza la pizarra eléctrica a estribor, apunta en el silabario la enguindada euforia de la UP. Otra letra, otro paisaje, la calle, la marcha, y su amigo Víctor enamorado de su cantora convicción. (Lemebel 2008: 74)

El procedimiento es complejo en su aparente simplicidad: un relato lleno de dinamismo y notas de color (el gringo despistado, la pituca Marichu y su amiga de boca fruncida; el viejo firulo y el azafato bronceado), narrado por su protagonista, quien es una conocida artista popular, hija de una compositora y cantante venerada por una parte de su pueblo, considerada con recelo por la otra; la intervención de Isabel Parra en la pantalla eléctrica de la aeronave tiene una enorme fuerza visual y sonora, una carga 
emotiva poderosa y expresa un reclamo que exige respuesta ante uno de los crímenes más vergonzosos de la dictadura militar: el asesinato -en circunstancias nunca aclaradas- de un cantante popular, padre de familia, hombre de paz y de trabajo. A todo ello se suma el recuerdo del asesinato, la calle, el día, la hora, el fragor de los primeros momentos del golpe militar de 1973. En el brevísimo tiempo-espacio que duró el gesto artístico de Isabel Parra sobre el espacio aéreo de Santiago, se pusieron de manifiesto todos los elementos del drama político, histórico y jurídico nacional: crímenes impunes, complicidad silenciosa, división social, rechazo a cualquier gesto inocente artístico o político que despierte la memoria y pretenda ponerla a funcionar. ${ }^{228}$

La otra crónica que tiene la virtud de sintetizar los aspectos señalados en este libro, es la que le sigue: "El amargo canto de la extorsión” (Lemebel 2008: 77-80). La historia de Pedro Felipe ${ }^{229}$ destaca uno de los procedimientos más transitados por la prosa de Lemebel: la singularidad de su protagonista. Militante de la izquierda cristiana, luchador a favor de los derechos civiles en plena dictadura, fue perseguido $\mathrm{y}$ secuestrado por el régimen de Pinochet. Resistió la tortura brutal sin dar nombres ni delatar a sus compañeros. Pero la CNI le tenía reservada una trampa aún más escabrosa:

[...] luego de los golpeados interrogatorios, después de escupir sangre y negarse a dar nombres y domicilios. Más allá del escalofrío metálico de la parrilla y luego de quedar tirado en el piso de la celda como un bofe machucado y sin habla. Aún había algo más, todavía faltaba la sedosa telaraña de otra tortura, una garra meliflua que escarbaría en su intimidad homosexual guardada por años, silenciada por su honorable vida de político cristiano y padre de familia. Y allí, en el abandono

\footnotetext{
${ }^{228}$ En 1990 el Informe Rettig determinó que Víctor Jara fue acribillado el 16 de septiembre de 1973 en el Estadio Nacional de Chile. Jamás, ni ese Informe ni el posterior Documento Final, producto de la Mesa de Diálogo del año 2000, le atribuyó el crimen a nadie. Permanece impune.

${ }^{229}$ La crónica no consigna sus apellidos, pero se trata de Pedro Felipe Ramírez Ceballos (nacido en Talca, Chile, el 19 de octubre de 1941), ingeniero y político chileno militante de la Izquierda Cristiana. Fue diputado, ministro de Minería y de Vivienda y Urbanismo durante el gobierno de Salvador Allende. Durante la Dictadura Militar fue detenido y permaneció en varios campos de concentración como la Escuela Militar, la Isla Dawson, Ritoque y Tres Álamos. Se exilió en Venezuela, donde continuó luchando por la recuperación de la democracia. A mediados de los años 80 regresó a Chile, participando en las Jornadas de Protesta Nacional en oposición al régimen de Augusto Pinochet. Tras el fin de la dictadura, se retiró de la política. Forma parte del consejo directivo de la Fundación Salvador Allende.
} 
estropeado de su oscura prisión, en el camastro hediondo de la CNI, una mano de hombre joven hurgando sus amoratadas presas, una boca púber despertando levemente su ansia de tocar, palpar, besar, chupar, acariciar ese cielo de carne adolescente que se le ofrecía como un analgésico entre el sueño y la embriaguez de la tortura. Y Pedro Felipe, colgando en el borde anestesiado de la inconsciencia, a esa sublime tortura no pudo resistirse [...] Sin saber, sin darse cuenta, que una cámara congelaba todas las poses y estertores de ese coito sodomita contratado por la CNI. [...] Entonces comenzó el calvario de Pedro Felipe; allí, ante las fotos que amenazaban destruir su moral al hacerse púlicas, él fue doblemente firme al negarse una y otra vez a dar nombres y delatar a sus compañeros. (Lemebel 2008: 78-79).

No obstante su valentía, su fortaleza y su fidelidad, tanto la familia como el partido le dieron la espalda, en una actitud que Lemebel no vacila en calificar de cómplice: "Ciertamente, la costra moral de esa izquierda cristiana aceptó el reemplazo, complicitándose con la agresión”. Su militancia intachable, su moral inquebrantable, su valentía demostrada antes y después de la tortura no fueron suficiente demostración de nobleza para el partido, ni alcanzaron para "compensar" lo que, en la moral pacata e hipócrita de la izquierda cristiana, es un pecado imperdonable: el de la homosexualidad. Y así, la historia de Pedro Felipe "fue una victoria de la dictadura al quitarle a la izquierda, sin matarlo, uno de sus protagonistas más lúcidos.” (Lemebel 2008: 80).

Pedro Felipe no responde a ninguna de las categorías establecidas de la identidad ni de la "subalternidad". Su historia es singular, sus valores no se adscriben a un espacio previamente determinado en una imaginaria serie de identidades discretas. Lemebel se esmera en rescatar para la historia de Chile una personalidad que se conoce por sus nombres: Pedro Felipe, y por su historia individual, única, signada por la persecución y la exclusión injustas, el olvido, la soledad y la incomprensión. La prosa de Lemebel está sometida a una tensión múltiple que la dinamiza y la hace apta para vehiculizar experiencias particulares y percepciones heterogéneas de diversos sujetos y en distintos espacios y momentos de la historia chilena, una historia plural, irreductible a una única 
línea o a una sola voz. Por ello es tan importante en este libro la canción popular (aludida en el título del volumen y en el de todas las secciones). La canción popular y especialmente la canción de amor es la forma paradigmática en la cual el lenguaje exalta su potencia, donde la palabra se encuentra magnificada, porque multiplica su capacidad comunicativa. Así lo señala Zumthor: "La única forma poética que en todos los contextos culturales se presta a ello [la comunicación] de forma masiva, inmediatamente accesible a la colectividad es la 'canción de amor' en la diversidad de sus retóricas." (1983: 171).

La voz está unida a la memoria, porque se trata de la memoria del cuerpo. No hay memoria de lo abstracto. Ese procedimiento al que llamamos habitualmente "recuerdo" no es una habilidad del pensamiento. Desde luego, también pensamos cuando reconocemos, es decir, rememoramos al poner en funcionamiento la capacidad cognitiva del recuerdo. Pero no es esa la memoria de los acontecimientos que configura la identidad de un individuo ni la de una comunidad. La memoria que nos constituye como sujetos es la memoria del cuerpo. A través del recurso a la poesía, a la voz y a la ficción Lemebel habla desde su memoria personal, le da voz a los actores de sus historias particulares, y esas voces enuncian desde un tiempo y un lugar indisociables de su propia condición. Por ello son posiciones plenas de sentido.

A propósito del vínculo entre memoria, cuerpo y experiencia colectiva, voy a detenerme en un procedimiento que da inicio al libro Zanjón de la aguada, al presentar un singular y productivo cruce de géneros literarios: relato autobiográfico, crónica, teatralidad o discurso teatralizado y cuento de hadas. A partir de 2003 la escritura de Lemebel da un giro autobiográfico. Si bien desde sus primeros libros las crónicas están narradas en primera persona y los episodios tienen con frecuencia al narrador como 
protagonista, es a partir de su cuarto libro donde el relato en primera persona asume un tono personal y a veces íntimo.

La representación del origen ha dado lugar a los más bellos mitos presentes en todas las culturas. Consciente de esta matriz generosa Pedro Lemebel inicia su cuarto volumen de crónicas, Zanjón de la aguada (2003), con un mito de origen que él ha llamado una "arqueología de la pobreza" en su Santiago natal. La sección del libro que incluye este primer texto se titula En el país de nunca jamás. Como lo hará a lo largo de la obra, el autor evoca el universo infantil del cuento de hadas y lo contrapone con el zanjón, “callejón aledaño al fatídico canal que lleva el mismo nombre” (Lemebel 2003: 13). Ahora bien, en una operación que se reitera y ubica al texto en una inestable posición de borde, esa contraposición no es excluyente. Junto a las tablas, las fonolas, los cartones, convive la magia del evocado género literario:

Como por arte de magia aparecía un ranchal en cualquier parte, como si fueran hongos que por milagro brotan después de la lluvia, florecian entre las basuras las precarias casuchas que recibieron el nombre de callampas por la instantánea forma de tomarse un sitio clandestino en el opaco lodazal de la patria. (Lemebel 2003: 14. Énfasis mío).

La abuela compra en el Zanjón "un muro de adobes". Ése será "el frontis de mi primer domicilio", el cual se suma al "techo de fonolas" y al "encatrado de palos", configurando "la arquitectura piñufla de mi palacio infantil" (Lemebel 2003: 15). Observemos la estrategia: una arquitectura de cuento (el muro de adobes se compara en el texto con "una bambalina cinematográfica") para escribir la crónica de una historia minoritaria. Ubicado en un tiempo y un espacio bien determinados, consciente de su objeto de observación y su propósito de registro, también de análisis, el relato le otorga al hecho histórico una dimensión íntima y literaria, incluida en el corazón de la realidad social y política chilena de los años cincuenta. Su arqueología de la pobreza pivotea, 
como veremos enseguida, entre la crónica histórica y el cuento de hadas devenido mito embarrado.

La condición inestable de este texto también se observa en las marcas que tienden a la autodefinición de género. El subtítulo indica: Crónica en tres actos. La alusión al género teatral no se agota allí; en los sucesivos: "Primer acto: La arqueología de la pobreza", "Segundo acto: Mi primer embarazo tubario" y "Tercer acto: Las memorias del Carne Amarga", advertimos que tendrá lugar una representación. Hechos singulares que ponen en escena un carácter, una visión del mundo y un destino. El segundo de los textos mencionados, de apenas dos páginas y media, nos asombra por la intensidad de su efecto y por lo que yo llamaría la trayectoria de su trazado: es una crónica; es un cuento de hadas travestido; es la exposición desnuda de una escena breve, recortada, de la experiencia de la marginalidad en el Zanjón de la Aguada. Pero no se trata solamente de marginalidad social, económica, cultural. El protagonista está al margen de la realidad, su peripecia lo ubica en el borde de cualquier patrón de verosimilitud, de allí que la remisión al cuento de hadas configure con la crónica una heterogeneidad textual armónica, perfectamente amalgamada:

En contraste a este sórdido barrial, el albo flamear de las sábanas y pañales, deslumbrantemente blancos a puro hervido de cloro, confirmaba el refregado pasional de las manos maternas, siempre pálidas, azulosas, sumergidas en lavaza espumante de remojo. Y quizás esa utopía blanqueadora era la única forma como las madres del Zanjón podían simbólicamente despegarse del lodo, y con racimos de chiquillos a cuestas, se encumbraban a las nubes agarradas del fulgor níveo de sus trapos, vaporosamente deshilachados, como banderas de tregua en esa guerra entintada por la supervivencia. (Lemebel 2003: 16).

La situación dramática se ubica desde el comienzo en un eje de contradicción: el sórdido barrial y la "acequia hedionda que corría paralela al rancherío", enmarcan el fulgor níveo de sábanas y pañales que se alzan como banderas de una "utopía 
blanqueadora". En ese cruce se producirá el encantamiento: en el borde de aquella acequia, el niño meterá sus pequeñas manos y sorberá el lodo. La barriguita se hinchará al ritmo de "el tamboreo de la colitis permanente y el dolor abdominal" (Lemebel 2003:

17). El desenlace no puede ser más eficaz:

Así no más llegué a las manos de una doctora con lentes de acuario, quien me vio la panza pobre, pensando en la very tipical desnutrición de los niños africanos. Pero al tantear esa piel tensa de timbal y apoyar en ella su frío estetoscopio, un apagado latido la sobresaltó, retirándose espantada. "No es posible", dijo, mirando a mi madre y escribió nerviosa la receta de un purgante virulento. Esa misma noche se produjo el alumbramiento [...] Y allí, en el negro espejo de la bacinica rebalsante, flotaba el minúsculo cuerpo de un pirigüín detenido en su metamorfosis. Era apenas una cabeza y una colita, pero sobresalían dos patitas verdes que el niño renacuajo había logrado formar en mi vientre desde que me tragué su larva en el micromundo de la vida que, a pesar de todo, se peleaba a codazos el breve espacio de su gestación. (Lemebel 2003: 17-18).

Es necesario observar los puntos de condensación y heterogeneidad en el nivel del lenguaje: "utopía", "alumbramiento" y "niño renacuajo" constituyen nudos de convergencia que dan cuerpo al compuesto textual heterogéneo que estoy describiendo.

El término "utopía", de larga e intensa tradición en los textos históricos y ensayísticos de la Modernidad y posteriores a ella, abroquela en este texto la mirada histórica "global", diríamos con Hayden White, la de los significados completos que le otorgan al discurso "sentido histórico", y la historia minoritaria de un grupo de madres chilenas quienes al borde del Zanjón, en la década de 1950, "podían simbólicamente despegarse del lodo" fregando pañales y sábanas que se despliegan como banderas.

El alumbramiento del niño renacuajo suelda la discontinuidad del verosímil histórico y el ficcional: la receta del purgante virulento y la larva en desarrollo operan del lado del verosímil histórico, absorbidos por el verosímil ficcional que los transfigura en alumbramiento y niño renacuajo, sin hacerles perder su condición de contenido 
histórico; al contrario: esa condición es potenciada por el cuento de hadas que nace y permanece descentrado, fuera de lugar, como he dicho metafóricamente, "embarrado" en la acequia hedionda del Zanjón.

\title{
IV. 4. Tensiones y discontinuidades. El discurso lemebeliano
}

\author{
y la heterogeneidad cultural
}

No hay odio de razas, porque no hay razas. Los pensadores canijos, los pensadores de lámpara, enhebran y recalientan las razas de librería, que el viajero justo y el observador cordial buscan en vano en la justicia de la naturaleza, donde resalta, en el amor victorioso y el apetito turbulento, la identidad universal de hombre. El alma emana, igual y eterna, de los cuerpos diversos de forma y color.

José Martí, "Nuestra América"

Las crónicas de Pedro Lemebel constituyen un régimen de manifestación de un período determinado de la historia reciente de Chile (de complejidad incapturable para el pensamiento y desde luego imposible de enumerar positivamente), y lo expresan siguiendo esa condición diferenciada y no jerarquizable, por cuanto, como hemos señalado a lo largo de la tesis, la identidad fija como "totalidad" es una construcción imaginaria. En otros términos, la heterogeneidad de su discurso, su opción por un género en devenir (el cual, además, presenta en su propia escritura una marca excéntrica, una singularidad irreductible) acompaña la móvil territorialidad de las identidades que expresa, vocaliza, hace audibles, al tiempo que elude el procedimiento y el gesto "representativo" en términos estéticos o ideológicos (sus textos no "representan" los seres minoritarios y las identidades discontinuas que evocan; su figura no es "representativa" de ninguna subalternidad ni se propone incluir, reivindicar, o recategorizar "el margen"). El mismo movimiento (movimiento en sentido 
bergsoniano, ${ }^{230}$ en el que se cruzan sin controlarse ideas, deseos, acontecimientos, cuerpos, sujetos, convicciones y decisiones, lenguajes y silencios) se distribuye en manifestaciones diferenciadas e interviene en la configuración de las sociedades, de los agentes que interactúan en ellas y de los sistemas simbólicos que producen. "La materia fonética y gráfica en expansión accidentada", anti-definición que Severo Sarduy ensaya para pensar el neobarroco, en síntesis conectiva con una deliberada y eficaz revisión de las formas discursivas y los principios epistemológicos de los relatos de la historia, dan cuerpo a un conjunto de textos cuya fuerza está en su dinamismo nómade, lo que hace imposible trazar el diseño o predecir los mecanismos de su producción.

No obstante, valgan las páginas precedentes -me refiero a las de este capítulo IV - como una cartografía de las tensiones que dominan la escritura de un autor que no hace concesiones. Sus textos son resistentes a las convenciones literarias, y eso lo lleva a modificar la norma estética de un género en el que, sin embargo, se inscribe. La operación que acabo de enunciar es una de las condiciones del discurso poético: la poesía opera en el interior de la lengua contra las prohibiciones y las regulaciones normativas de esa lengua; es decir, afirma y niega el sistema en el que se produce, lo asume en un punto presente de su historia para ponerlo en tensión. Esto ocurre también, como he señalado, entre la obra de Lemebel y las convenciones del género crónica. Más allá de su hibridez constitutiva que he justificado y a la que se refiere insistentemente la crítica académica y periodística sobre el género, Lemebel lleva al límite sus condiciones

\footnotetext{
${ }^{230}$ En Duración y simultaneidad (1922), Henri Bergson polemiza con el paradigma filosófico dominante en su época, al elaborar su idea de la duración: no solamente el hombre se percibe a sí mismo como duración (durée réelle), sino que también la realidad entera es duración y élan (movimiento o impulso) vital. Desde su perspectiva, se postula que lo múltiple no puede cuantificarse, sólo puede percibirse una multiplicidad cualitativa dada en una sucesión continua que enlaza el presente con el pasado, y en la que no se descomponen las vivencias, sino que se armonizan entre sí, como sucede, dice Bergson, con las notas de una melodía. Esta insistencia bergsoniana en distinguir entre dos tipos de multiplicidad (una multiplicidad cuantitativa y espacializante, propia de las ciencias físicas y una multiplicidad cualitativa), lo conduce a efectuar un análisis de la noción de número que está en la base de la concepción de la diferencia en el pensamiento de Gilles Deleuze, a la que he aludido reiteradamente en el transcurso de esta investigación.
} 
de posibilidad al investir su escritura de procedimientos poéticos que lo convierten en un género nuevo. Por ello afirmo que el autor chileno produce textos en el sentido dinámico y transgresor que tiene ese término desde mediados de los años sesenta. ${ }^{231}$

Una de las líneas de fuerza de los textos lemebelianos es la asunción del deseo como una poderosa energía social - no solo ni exclusivamente individual o privada- que determina la circulación urbana, los modos de sociabilidad, crea nuevas prácticas y por lo tanto nuevos modos de la subjetividad, nuevos objetos, y desde luego, también nuevos discursos. Esta línea de fuerza determina su poder renovador en todos los campos de la enunciación que hemos analizado: la ficción en relación dialéctica ${ }^{232}$ con la historia, la poesía en relación dialéctica con la crónica, la oralidad en relación dialéctica con la escritura. La crónica de Pedro Lemebel "no es la unidad mitigada de un reposo. Es la intimidad y la violencia de movimientos contrarios que nunca se concilian ni se apaciguan" (Blanchot 1955: 213). La heterogeneidad de su escritura, que hemos relevado en este capítulo, afronta la contradicción y al mismo tiempo atraviesa la línea de sombra de la melancolía, dando lugar a una producción festiva y sonora, cuyos procedimientos poéticos transforman la escritura en materialidad plástica, vocalizada y vibrante, capaz de vehiculizar la abigarrada complejidad de las identidades latinoamericanas sin intentar reponer los dispositivos totalizantes de la racionalidad clásica. Por ello sus crónicas se proponen como "un saber de la caducidad" (Rella); su discurso poético construye otra subjetividad (anti-cartesiana), hace posible un lenguaje para aquello que no ha tenido palabra, y de ese modo propone una nueva relación representativa con su mundo y con la historia reciente de su país: el texto de Lemebel

\footnotetext{
${ }^{231}$ El texto así entendido es para-dójico (Barthes alude a la etimología griega de ese término: estar "al lado" de la opinión general o doxa, de la norma aceptada y reconocida como válida), se ubica en los límites de la enunciación, y por lo tanto está en la frontera de la legibilidad (1971: 73-82).

${ }^{232}$ Empleo aquí el término "dialéctica" (como lo hice durante el trámite de la tesis) en el sentido en que lo emplean Ian Mukařovský y el posestructuralismo francés, es decir, en un sentido post-hegeliano, por cuanto el adjetivo subraya la interacción entre dos términos que se oponen sin resolverse, generando movimientos y transformaciones incesantes en las series en las que se imbrican.
} 
recorre la ciudad y las identidades que la habitan, las cartografía, no con la pretensión de representarlas acabadamente, sino para "decirlas", para hacerlas hablar. 


\section{Conclusiones}

I.

La historia es discurso. Y el discurso es un lugar en el que se ejercen poderes. Durante siglos (por lo menos los tres siglos que Michel Foucault denominaba “época clásica”, es decir: XVII, XVIII y XIX) no se planteó esta cuestión como problema en la escena epistemológica de Occidente. La Historia era considerada el relato de los hechos sucedidos, y sus testigos más valorados eran: el documento, el monumento y el testimonio directo.

El paradigma epistemológico del discurso historiográfico clásico y moderno (lo que Nietzsche llama "historia monumental" y Foucault "historia de los historiadores"; lo que White y Benjamin denominan respectivamente historicismo moderno e historicismo hegeliano) presenta como principios constitutivos la generalización y la construcción de regularidades, necesarias para implementar los cortes con los que procede. Como he señalado en el segundo capítulo, la operación historiográfica implica introducir en el relato de los hechos un principio de inteligibilidad, construido como dispositivo de comprensión. Ahora bien, para introducir ese principio es indispensable una operación previa, a saber: el corte. "El corte es el postulado de la interpretación" (de Certeau 18), y al mismo tiempo su dispositivo dominante. Las divisiones que producen los cortes organizan la representación que debe ser interpretada. En la cultura occidental moderna la inteligibilidad se establece en relación al "otro" (de Certeau), sea el salvaje, el pueblo, el loco, el niño (el origen, la tradición oral, el pasado). La historiografía y 
otras disciplinas que se configuran en los siglos XVII y XVIII elaboran un "saber decir" que interpreta todo lo que el "otro" calla. La medicina moderna nace a partir del momento en que el cuerpo se convierte en un cuadro legible (Foucault 1963), y por lo tanto, en algo que puede escribirse. Así la medicina y la historiografía modernas se construyen como "heterologías" (discursos sobre el "otro"), por cuanto el discurso provoca la separación y protege la distancia que lo separa de su objeto. En las crónicas de Lemebel se opera un trazado que desanda el camino de la separación, diluye la distancia y se propone atravesar el corte. Las consecuencias discursivas más evidentes de ese paradigma son: a) la necesidad del punto de vista neutro, objetivo, que dé la sensación de que los hechos pueden "narrarse solos" (Barthes 1970a); y b) la representación abstracta de los sucesos, orientada a la construcción de una estructura inmanente que totalice el sentido y le otorgue al relato una dimensión providencial, teleológica. Este dispositivo se ajusta a una visión hegemónica del pasado y una pretensión de verdad absoluta, condiciones indispensables para otorgarle a dicha representación imaginaria su dimensión ideal, abstracta y universal, es decir: la ilusión de ser única y lineal, articulada por relaciones de causalidad. La noción de representación está empleada aquí en el sentido que ha subrayado la filosofía contemporánea en la estela del pensamiento nietzscheano, esto es: la representación de un objeto, sujeto o episodio es el resultado de una abstracción que, como tal, procede por generalización, desconociendo o aplanando las diferencias. Además esta representación abstracta cancela cualquier posibilidad de comprender lo acontecido fuera del esquema racional de las causas y sus consecuencias ("la vieja patraña" de la causalidad y la finalidad según el autor de la Genealogía de la moral). Todo ello desconoce las dos fuerzas fundamentales de la historia, según Nietzsche: la voluntad de poder -en la que están implicados los indetenibles poderes de afección, el querer-poder 
nietzscheano es una elaboración del conatus spinoziano- y el azar como fuerza transindividual e ingobernable, fuera del control de la racionalidad.

La escritura de Pedro Lemebel constituye una intervención poderosa en el universo de los discursos oficiales sobre el pasado reciente de Chile, por su condición reactiva a las generalizaciones. Tal como intenté demostrar en el capítulo IV, sus personajes (incluido él mismo cuando narra en primera persona) son sujetos singulares portadores de un saber obtenido en una amplia diversidad de prácticas (identificables pero no reductibles a un "grupo" o "subalternidad" fija ni localizable en ningún sistema previamente concebido de categorías sociales). Esos personajes se encuentran siempre en una relación de resistencia respecto de las dos sujeciones impuestas durante los gobiernos de la Concertación (1990-2010): el olvido y el silencio. A través de ellos las crónicas vehiculizan experiencias particulares, transpuestas al discurso en virtud de procedimientos literarios (narrativos y poéticos).

Como creo haber demostrado en el Capítulo III, Lemebel denuncia las connotaciones continuistas de los gobiernos de la Concertación con respecto al régimen dictatorial y la complicidad con su amnistía. Hemos citado la famosa y polémica frase de Patricio Aylwin: "Realmente, a mi juicio, la transición ya está hecha. En Chile vivimos en democracia", aparecida en El Mercurio el 8 de agosto de 1991. En septiembre de 2005, luego de que se votaran en el Congreso las llamadas "reformas duras", Ricardo Lagos afirmaba al sustituir en la Constitución la firma de Pinochet por la de él: "[Este acto] Marca el término definitivo de la transición. Comenzaron los gobiernos democráticos. Ahora podemos decir que la transición en Chile ha concluido. Ahora tenemos un cuerpo constitucional que está acorde con la tradición histórica de Chile". Ambas frases, con catorce años de diferencia, dan la pauta del marcado continuismo institucional entre los gobiernos de la "Concertación para la Democracia” y 
los designios de la dictadura del General Pinochet. En un arco que va del Informe Rettig (1990) a la Declaración de la mesa de diálogo sobre Derechos Humanos (2000) lo que se observa en una constante: el propósito a medias confesado de pacificar a cualquier precio, y mantener la estabilidad -aunque ello comprometa su plena vigencia- de las instituciones democráticas, habida cuenta del enorme poder que los altos mandos militares conservaron durante esa década. Ambos documentos integran la larga cadena de los esfuerzos realizados por los gobiernos de la Concertación para lograr "consensos" y "reconciliación" en el lastimado tejido social chileno, pero esos esfuerzos concluyeron en altísimos niveles de impunidad, intolerables para quienes han tomado la decisión de mantener viva la memoria.

Por estas razones, rápidamente resumidas aquí y desarrolladas a lo largo de la investigación, he postulado que las crónicas de nuestro autor se producen (se enuncian y se leen) atravesadas por una triple tensión: historia/ ficción, crónica/ poesía y escritura/ oralidad. Esas tensiones están íntimamente asociadas con las transformaciones del paradigma historiográfico. Es decir que el devenir historia de los acontecimientos narrados se produce en virtud de los procedimientos literarios que los configuran. Por ello Hayden White ocupa un lugar preponderante en el marco teórico de mi investigación, habida cuenta de la necesidad de la figuración literaria y de la pluralidad de los puntos de vista en el discurso para transmitir eficazmente un conjunto de experiencias que dé cuenta del acontecer en un punto detenido, en un espacio singularizado de la historia.

II.

El sistema literario es un campo atravesado por fuerzas y tensiones que explican su complejidad y dinamismo. En esas tensiones están y han estado siempre 
comprometidas otras series, a las que Iuri Tinianov, por esta razón, denominó "series vecinas": "el estudio de los géneros es imposible fuera del sistema en el cual y con el cual están en correlación. [...] En rigor, no se consideran jamás los fenómenos literarios fuera de sus correlaciones" (1927: 91; 95). Las demandas de la serie social intervienen en la evolución literaria, provocan la búsqueda de nuevas funciones para los elementos formales existentes, o bien exigen la constitución de formas nuevas. Por esta razón la potencia renovadora de una obra se mide por su relación diferencial con la serie literaria a la que pertenece. En el caso de las crónicas de Pedro Lemebel, esta diferencia está dada por la respuesta que ofrece su escritura a las demandas de la serie social: hacer audibles las voces silenciadas para recuperar la memoria colectiva; hacer hablar al cuerpo que calla a fin de integrar el deseo en la agenda literaria, política y social de su país. Ahora bien, esa demanda exige una enorme transformación del orden discursivo vigente, tanto en la serie literaria como en la historiográfica.

Los procedimientos literarios actúan sobre el cuerpo. En términos de Artaud "la poesía de los sentidos tiende un lazo a los órganos, penetra en la sensibilidad". Lo que he denominado "la economía de los cuerpos" o -siguiendo a Kristeva- "el orden pulsional" se encuentra en interacción dialéctica, es decir, en una tensión que no se resuelve, esto es, en devenir con el orden del discurso. Por ello Michel de Certeau también ocupa junto a Hayden White un lugar central en el marco teórico de esta tesis. Ambos autores -referencias ineludibles en el campo problemático que nos ocupa- se inscriben en la posición epistemológica inaugurada por Friedrich Nietzsche y Sigmund Freud, a quienes Paul Ricoeur denominara con justicia los "padres de la sospecha". Un sujeto de conocimiento ajeno a la voluntad, al dolor, al tiempo (ajeno al deseo como fuerza social) no será nunca el sujeto de un saber. El saber es necesariamente el resultado de un sujeto "en perspectiva", de un "ojo direccionado": 
Existe únicamente un ver perspectivista, únicamente un "conocer" perspectivista; y cuanto mayor sea el número de afectos a los que permitamos decir su palabra sobre una cosa, cuanto mayor sea el número de ojos, de ojos distintos que sepamos emplear para ver una misma cosa, tanto más completo será nuestro 'concepto' de ella, tanto más completa será nuestra "objetividad". (Nietzsche 1887: 154-155. Énfasis y comillas en el original).

La concepción perspectivista de todo sujeto de conocimiento, y la valoración de la sensualidad como vehículo del saber, ideas de cuño nietzscheano, justifican filosófica y gnoseológicamente el punto de vista adoptado en mi lectura de las crónicas del autor chileno. La historia particular, contada por un único "sujeto puro de conocimiento", será siempre una abstracción. Historiar el suceso exige la multiplicidad del punto de vista, lo cual permite la expresión de una vivencia fragmentaria, postulada como "menor" porque elude la pretensión de verdad absoluta y el afán totalizador. También exige el registro poético, porque la experiencia no puede ser representada, sino transpuesta de un orden pulsional a otro: del orden material de las voces y los cuerpos, al orden discursivo que puede dar cuenta de él: el registro poético.

Recordemos lo sostenido por Hayden White a lo largo de su extensa y productiva trayectoria académica: los acontecimientos ocurren, y de hecho son atestiguados por los registros documentales y los monumentos o sus rastros; "los hechos son construidos conceptualmente en el pensamiento y/o figurativamente en la imaginación" (2003: 53), ése es su espacio y su condición de posibilidad.

Los textos de Lemebel solo pueden ser producidos y comprendidos actualizando las tensiones que acabo de referir brevemente. Lemebel genera en su escritura una composición discursiva múltiple y heterogénea: el registro de la crónica es afectado (o territorializado) por el registro poético. Su carácter escriturario (individual y silencioso) es atravesado por la oralidad (colectiva y sonora) que la convierte en literatura 
vocalizada (el término es empleado por todos los teóricos que hemos citado en el capítulo IV y cuyos desarrollos iluminaron nuestra lectura de la oralidad en las crónicas lemebelianas: Walter Ong, Margrit Frenk y Paul Zumthor) y hace oír las voces de identidades minoritarias, silenciadas durante décadas. Las crónicas del autor chileno hacen audibles una multitud diferenciada de voces que no tenían discurso. En su libro Entre la voz y el silencio (citado y analizado en el Capítulo IV) Margrit Frenk explica cómo se ha dado en nuestra lengua la coexistencia entre la lectura silenciosa y diversas formas de la textualidad escrita, por cuanto la lectura en voz alta no desapareció ni disminuyó con la invención de la imprenta. La hipótesis central del libro sostiene la existencia de una "oralidad de lo escrito" que explicaría la enorme popularidad que tenían en su momento Lope de Vega y Cervantes. La autora prueba su hipótesis al explicar -con su concepto de "oralización" de la escritura- cómo las sociedades mayoritariamente analfabetas de los siglos XV, XVI y XVII podían disfrutar y comprender "obras tan complejas y sofisticadas, cargadas de mitología antigua y de historia, abundantes en figuras retóricas, llenas de 'conceptos' y, por añadidura, compuestas en verso" (Frenk 5). La clave de esta aparente paradoja reside en una muy desarrollada forma de recepción de la textualidad escrita: la lectura en voz alta (a esta convivencia productiva de la letra y la voz alude el título del volumen). La literatura vocalizada (sea o no impresa) es un fenómeno muy importante, que lejos de ser abolido por la invención de la imprenta pervive hasta el siglo XIX y llega con fuerza hasta nuestros días. Paul Zumthor, por su parte, concibe la literatura vocalizada como todo aquello que se comunica poéticamente según las exigencias del "aquí y ahora"; la obra está configurada no sólo por palabras, sino también por sonoridades, ritmos, elementos visuales, esto es, abarca los factores de la performance (1983: 83-84). Para el autor, la estructura poética en régimen de oralidad opera con la dramatización del discurso y no 
sólo con los procedimientos verbales, por lo tanto el elemento discursivo asume su sentido y sobre todo sus efectos en el espacio dramatizado de la performance. Solas o aisladas, las formas lingüísticas carecen del valor poético y el sentido que asumen en el contexto vocalizado y teatral de su enunciación oral. En las crónicas de Lemebel la voz recupera su condición de signo territorial, espacio de resonancia ligada a los cuerpos que hablan.

III.

La diferencia cualitativa de las crónicas de Lemebel está dada -además de los aspectos ya considerados- por la ausencia total de la distancia letrada en las descripciones de la vida cotidiana de sus contemporáneos. Lemebel es "el otro" que toma la palabra. Los personajes de sus crónicas (siempre marcados por un índice de singularidad irreductible a cualquier posición fija, es decir, a las categorizaciones frecuentes en los "discursos de la subalternidad") hablan y manifiestan su propia visión del mundo, su íntima comprensión de la realidad que los circunda. Lemebel no los hace ocupar el lugar del "compareciente"; del mismo modo su escritura no repone las alternativas de la "fábula exótica" que representa al sujeto configurado como "otro": salvaje, indio, iletrado, loca, marica, travesti, mestizo, pobre o proleta, portador o infectado, desaparecido o ex-convicto. El otro (el sujeto caído del régimen social que lo expulsa, lo excluye, lo persigue, lo silencia o lo desconoce) no es en la escritura de Lemebel una identidad subalterna. Su diferencia no se encuentra borrada ni disimulada, pero tampoco configura un límite que lo transforma en un objeto etnológico. El discurso lemebeliano "des-exotiza" la alteridad sin escamotearla y sin traducirla a un nuevo sistema de comprensión (no tiene el propósito de re-categorizar el margen). Simplemente no se percibe en su escritura la distancia entre el sujeto del enunciado y el 
sujeto de la enunciación. Elena Poniatowska en la novela que hemos analizado, Hasta no verte Jesús mío, alcanza esta identificación a través de dos operaciones: borrar minuciosamente el soporte de la enunciación escrituraria (la convención novelística) y hacer coincidir el texto mismo con la voz de Jesusa Palancares. La escritura de Lemebel no necesita ese artificio; él es el otro o bien se encuentra en el lugar del otro, esto es, el lugar de los sujetos que no habían tenido nunca el acceso a la palabra (palabra escrita, reconocida, palabra oída, aquella cuya circulación la hace audible): el joven ex-convicto de "Solos en la madrugada"; las madres y esposas, los familiares y amigos de los detenidos desaparecidos por la dictadura militar; el infectado que rechaza la falsa piedad de la garra mediática y la hipocresía del mercado que explota el Sida para su beneficio; la loca perseguida y golpeada o excluida; asesinada o negada como sujeto social; el homosexual que esconde su identidad por miedo a la persecución y el rechazo; el muchacho del bloque, excluido del horizonte de la "utopía social", entre muchos otros.

Cuando, a partir de 1991, comienzan a hacerse oír en Chile las voces de aquellos grupos excluidos o silenciados durante la dictadura, habitualmente calificados como "minoritarios", se produce un fenómeno que no es advertido ni por el conjunto de la comunidad ni por los intelectuales: las reivindicaciones sectoriales ajustan la sensación de homogeneidad cultural blanca (en ese adjetivo actúan implícitamente otras determinaciones: heterosexual, clase media bienpensante, burguesía en ascenso o con pretensiones de ascenso social. Todo esto configuraría la "identidad chilena"). Lemebel arremete contra ese postulado cultural: denuncia la falsa "normalidad blanca" chilena. Sus textos manifiestan que la identidad mestiza se oculta bajo la máscara de lo homogéneo, se niega. Y en la señalización del otro se disimula más aún. Como lo señala Sonia Montecino en su artículo "El mundo indígena en el Chile de hoy": 
Así, la alegoría indígena es cuerpo social, cultural y biológico que expresa lo "otro" de un "uno" que se piensa como blanco. Desde esos paradigmas de lo blanco y lo no blanco la cultura mestiza chilena construye una identidad en donde lo "mismo" -la blanquidad - no se cuestiona, pues ni siquiera se piensa como diferencia frente a los "otros" blancos, los del primer mundo, los del desarrollo, los de la cultura de la palabra. (Montecino 114).

Por lo tanto, aunque parezca contradictorio, los reclamos sectoriales ajustaron la sensación de homogeneidad, al subrayar las diferencias como identidades fijas y absolutas, comprendidas en el marco del pensamiento binario. Recordemos que la oposición binaria siempre es excluyente y jerárquica: uno de los polos de la dicotomía está devaluado, negado o excluido. Desactivar esa exclusión no se logra optando por uno de los términos, cualquiera sea, sino deconstruyendo la dicotomía. Por ello Lemebel afirma radicalmente la heterogeneidad ontológica y opta por los devenires minoritarios. Por ejemplo, cuando comprende que una niña de 12 años con síndrome de Dawn puede darle una lección: "lo minoritario" como concepto filosófico es analizado por el autor bajo una nueva luz, producto del encuentro casual con esa niña que tiene en el cuerpo las marcas del rechazo. La crónica no se limita a denunciar esa exclusión, sino que toma a su protagonista como sujeto de un saber, capaz de revisar una noción tomada del espacio prestigioso de la filosofía, de poner en tensión un concepto producido por la catedral cultural.

IV.

Las crónicas de Pedro Lemebel postulan al tiempo que construyen (exigen y configuran) un sujeto de percepción. Quien lee/escribe estas crónicas participa de la mirada que tensa el espacio intersticial inaugurado en "Anacondas en el parque"; mira desde dentro la exposición y la cercanía de la muerte en la oscuridad de la esquina que protege y escamotea a los muchachos del bloque; cartografía la red de silencios y 
complicidades que expulsa del territorio ocupado (metáfora del Chile democrático) a la primera exiliada en democracia, la Babilonia de Horcón; observa el pliegue de la doble moral del macho-jefe de familia clase media en el interior del cine Nagasaki; advierte la distancia entre el sistema social real y el sistema legal oficial, ilegible para el censo colonial, invisibilizada en el censo contemporáneo; es testigo de la ominosa masacre llevada a cabo por las fuerzas de seguridad de Pinochet, la "Operación Albania", aquella "noche de lobos y cuchillos"; acompaña la mirada del niño al descubrir los tres cuerpos sin vida que yacen en el basural la mañana del doce, y en esa mirada se fija la imagen que narra la historia con una eficacia mayor que la del discurso histórico. El régimen de lectura de las crónicas lemebelianas apela a los sentidos a fin de instaurar la visión y la audición de los hechos narrados de un modo intransferible a otro registro.

En "Las amapolas también tienen espinas", crónica que cierra la primera colección, el crimen de un homosexual es presentado a través de un texto vertiginoso cuya densa materialidad y tensión narrativa envía a las consideraciones de Severo Sarduy en sus ensayos sobre Barroco y Neobarroco: los procedimientos contorsionan el lenguaje, lo complejizan hasta exasperar la sintaxis y lograr el efecto de "salirse de sí" señalado por Sarduy como finalidad del trabajo poético sobre la lengua. En ese texto, además, predomina un procedimiento barroco que he analizado en el desarrollo del Capítulo III: el desplazamiento del foco. Los cuerpos aparecen retaceados, dando la imagen de cuerpos fragmentarios, de objetos parciales. También en la crónica "El proyecto nombres", de Loco afán, el Quilt (paño o tejido) que los familiares, parejas o amigos tejen con las prendas del "deudo sidado" efectúa una poderosa operación barroca que consiste en materializar el acontecimiento inmaterial por excelencia, la muerte, dando cuerpo y textura al sudario que se ubica en el lugar exacto en que el deseo y la muerte se imbrican; allí se escribe el saludo imposible, el mensaje 
inescribible. El Quilt es la metáfora de una presencia borrada, y por ello es también el soporte de la proliferación indefinida (como sucede en "Los mil nombres de María Camaleón”).

La palabra en la escritura de Lemebel es materialidad espesa, cuerpo opaco, textura, imagen, olor, sabor, temperatura; la palabra afectada o territorializada por los procedimientos barrocos es vehículo de sensación: "el barroco teje, más que un texto significante, un entretejido de alusiones y contracciones rizomáticas, que transforman la lengua en textura, sábana bordada que reposa en la materialidad de su peso" (Perlongher 1997: 95).

En la multiplicidad y la proliferación indefinida, en el deslizamiento, la sustitución o el disfraz, procedimientos de altísima recurrencia en su obra, se lee también la opción de Lemebel por la estética neobarroca. La primera crítica académica que aborda la obra del autor, Soledad Bianchi, a mediados del año 1997, contextualiza su producción -en ese contexto nombra a Lezama Lima, a Sarduy y a Perlongher- y describe sus vínculos intertextuales con metáforas móviles, sensoriales e indeterminadas (red, raicilla, nudos, espejos y reflejos, ecos) subrayando así los deslizamientos y las resonancias que conectan esas escrituras: "todos espejeando, reflejando y haciendo reflejar, provocando y acogiendo ecos, deslizándose desde Cuba, La Habana-París, a Buenos Aires y, en su navegación, atracar con las santiaguinas orillas del Mapocho" (PP). ${ }^{233}$ También Carlos Monsiváis considera a Lemebel un neobarroco, habida cuenta de lo que él llama la "intencionalidad barroca": describir "las reverberaciones de lo prohibido en lo permitido exactamente en el momento en que los absolutos se desintegran" (PP). ${ }^{234}$ Subrayo mi coincidencia con esta afirmación de Monsiváis, en

\footnotetext{
${ }^{233}$ Proyecto Patrimonio: http://www.letras.s5.com/archivolemebel.htm También disponible en: http://web.uchile.cl/publicaciones/cyber/03/textos/SBIANCHI.HTML

${ }^{234}$ Carlos Monsiváis prologa en 2001 la reedición de La esquina es mi corazón, primer libro de Lemebel, originalmente publicado en 1995. Este fragmento está extraído de ese prólogo, que se titula "El amargo,
} 
cuanto a las operaciones lemebelianas que deconstruyen oposiciones binarias y jerárquicas pero no para reinsertar "el margen" o la categoría periférica considerada en una supuesta centralidad, sino para proclamar la condición itinerante y en deriva de toda identidad sexual, étnica, ideológica o social. Con el objetivo de probar tal hipótesis han sido cartografiadas las operaciones deconstructivas a las que acabo de hacer referencia en el desarrollo de los capítulos específicos que toman como objeto el corpus de crónicas de Pedro Lemebel (Capítulo III y Capítulo IV).

V.

La experiencia erótica - de la que está saturada su escritura- se produce en la materialidad textual deconstruyendo sistemáticamente los lugares sociales atribuidos a esa práctica y aceptados por el orden burgués. Como he dicho en repetidas oportunidades a lo largo de la tesis, Lemebel rechaza las identidades fijas y propone una identidad sexual nómade, itinerante, en devenir. De ahí la necesidad de plantear en nuestro estudio el aporte de las teorías queer, sobre todo aquellas que han demostrado su eficacia para pensar las diferencias entre géneros más allá del “cuadriculado" social que las determina y paraliza. En esto Lemebel sigue al poeta argentino Néstor Perlongher, quien ha descrito en sus ensayos la pulsión nómade que gobierna la errancia "de los muchachos de la noche" (1997: 45) y, por lo tanto, lo impropio de la denominación "gueto gay" para lo que él considera un territorio móvil, una red de tránsitos. Perlongher lo afirma con claridad:

Es preciso evitar la tentación de pensarlos en tanto "identidades", para verlos en cambio como puntos de calcificación de las redes de flujos (de las trayectorias y los devenires del margen). Las

relamido y brillante frenesí", leído por Monsiváis en la presentación oficial del libro, la cual tuvo lugar el 2 de noviembre de 2001 en el marco de la XXI Feria Internacional del Libro de Santiago, celebrada en la Estación Mapocho. La idea que comento aquí fue retomada por el propio Monsiváis en 2007 en su artículo: "Lemebel o el barroco desclosetado", comentado en el Capítulo I de esta tesis. 
nomenclaturas se inscriben en la trama de los cuerpos -que nunca se encuentran totalmente donde ellas los marcan, de ahí que las asociaciones nominativas proliferen y estallen trastornando la transcripción sociológica. Los nombres -señas de pasaje, antes que bautismos ontológicos- en uso cargan un dejo de carnalidad insultante: bicha bofe, michê, travesti, gay, boy, tía, garoto, maricona, mona, oko, eré, monoko, oko mati, oko odara y sus sucesivas combinaciones y reformulaciones $^{235}$ (Perlongher 1997: 47).

La proliferación de nombres que "barroquizan", según Perlongher, el sistema clasificatorio de la oferta de prostitución masculina en los suburbios de San Pablo, encuentra su correlato en la obra de Lemebel en la crónica que hemos analizado: "Los mil nombres de María Camaleón” (1996: 57-61). La similitud entre la concepción perlogheriana de los flujos de deseo y la de Lemebel es evidente:

Como nubes nacaradas de gestos, desprecios y sonrojos, el zoológico gay pareciera fugarse continuamente de la identidad. No tener un solo nombre ni una geografía precisa donde enmarcar su deseo, su pasión, su clandestina errancia por el calendario callejero donde se encuentran casualmente; donde saludan siempre inventando chapas y sobrenombres que relatan pequeñas crueldades, caricaturas zoomorfas y chistosas ocurrencias. Una colección de apodos que ocultan el rostro bautismal. (Lemebel 1996: 57)

Vemos cómo la multiplicidad forma parte de la "máquina textual"236 que ha sabido construir Lemebel, mostrando que las fuerzas de la historia no obedecen a un destino ni a una finalidad primordial, sino que se juegan, como quería Nietzsche, en el azar de la lucha. Su escritura transformadora, incapturable para la pulsión clasificatoria de la razón moderna, su punto de vista móvil, la discontinuidad de los sucesos narrados desde una experiencia del cuerpo (incluso del cuerpo enfermo), parecen demostrar la formulación de Foucault: "El saber no ha sido hecho para comprender, ha sido hecho

\footnotetext{
${ }^{235}$ En nota al pie Perlongher explica el significado de cada una de las expresiones consignadas. Ver 1997: 47 nota 3.

${ }^{236}$ Utilizo esta terminología con el fin de poner el acento en la condición productiva, fabril de la obra del chileno, en contraste con el propósito representativo-descriptivo-comprensivo del hacer historiográfico y etnográfico convencional.
} 
para hacer tajos" (1979: 20). La metáfora foucaultiana pone en evidencia la íntima relación entre saber y experiencia, entre el orden discursivo y el orden físico, emotivo, pulsional. En el caso de Lemebel podemos agregar: entre la literatura, la historia, las voces y los cuerpos.

Estas son, brevemente consignadas, las dominantes en la prosa del chileno: transgredir la norma representativa del relato, poner en jaque la concepción unitaria y fija de la identidad, la sucesión temporal ordenada y totalizadora, la atribución paralizante de los espacios sociales, subjetivos y discursivos. Lemebel deconstruye esas simbolizaciones -que garantizan el marco representativo de la historia- a través de múltiples procedimientos. Voy a puntualizar los más radicales y transgresores:

1) La disolución del tiempo cronológico (lo que Aníbal González ha llamado "temporalidad sincrónica") hace que el relato escape a la economía del tiempo histórico, el Cronos de la historia monumental (Nietzsche). Gasto y pérdida que se introducen como polizones en el discurso de la crónica y pervierten su condición representativa para agenciarle el tiempo del deseo, el de la economía libidinal. Este tratamiento de la temporalidad permitirá que el relato sea vehículo de experiencia más que de representación de la historia narrada y lo hace apto para expresar la voz de las identidades excluidas de los discursos aceptados o legitimiados, esto es: que circulan como "verdaderos".

$2^{\circ}$ ) El tratamiento del sujeto que enuncia está ordenado también a la comunicación de una experiencia. Esa comunicación se produce en virtud de distintas estrategias. Una es la construcción de un punto de vista móvil que produce el efecto cinematográfico de la cámara subjetiva: el sujeto de la enunciación es un ojo (también oído, boca, piel, en suma: percepción), un punto de observación y percepción que narra. 
Otra estrategia es la condensación del tiempo-espacio de la enunciación ${ }^{237}$ cuyo efecto es singularizar la situación narrativa, hacerla única y al mismo tiempo perceptible, material. El espacio y el tiempo así tratados no son marco, escenario ni paisaje en las crónicas de Lemebel, son fuerzas configuradoras de los sujetos que actúan en ellas; permean las consciencias y le permiten al lector acceder a una experiencia de los sucesos narrados y no a su conocimiento abstracto. La condensación del tiempo-espacio es también, por lo tanto, lo que permite que el acontecimiento sea recuperado para la memoria, por cuanto la memoria es sensorial, perceptiva. Los personajes de las crónicas lemebelianas viven e interactúan como conciencias independientes y despliegan sus acciones y pasiones en el espacio y el tiempo a los que pertenecen y que comparten con los lectores.

$3^{\circ}$ ) La oralidad. En sus textos, la voz es un signo territorial porque constituye, como ya lo hemos señalado, un "territorio de resonancia": palabra activa, régimen de connotación. La literatura vocalizada de Lemebel sustrae la voz a la dependencia del sistema gráfico. En un gesto que es político, intenta rescatar al lector de su posición letrada, es decir separada del rostro y de los cuerpos que emiten la voz. Por ello el "canturreo memorial" de Lemebel es un discurso en presencia. En él la voz está unida a las bocas (húmedas), a los rostros (siempre curtidos) que la emiten, y a la memoria del cuerpo.

$4^{\circ}$ ) La poesía. Las crónicas de Lemebel más que representar, actualizan el acontecimiento. Esto es propio del género poético. Al postular que en la obra de Pedro Lemebel se produce una composición discursiva, es decir, un agenciamiento entre

\footnotetext{
${ }^{237}$ Por ello hemos enviado reiteradamente a las teorizaciones de Mijaíl Bajtín, puesto que el tratamiento del espacio y el tiempo narrativos en la prosa de Pedro Lemebel se ajusta al procedimiento literario que el teórico ruso denominó cronotopo. En las crónicas del autor chileno vemos, percibimos, palpamos la situación que se singulariza progresivamente; el evento se hace carne y voz en la materia narrativa. Como dice Bajtín: "el cronotopo hace que los eventos narrativos se concreticen, los encarna, hace que la sangre corra por sus venas". (1938a: 250; 84-85).
} 
naturalezas discursivas heterogéneas, me propuse demostrar la condición poética de su relato histórico, la cual posibilita la expresión del deseo -individual y colectivo- y la comunicación de una experiencia. Esa "alianza", original y profundamente renovadora de las series en las que interviene, hace de su obra un dispositivo eficaz para narrar la historia reciente con la mirada y la voz de los que no habían sido oídos.

$5^{\circ}$ ) La ficción. La fuerza del texto lemebeliano, su potencia, está dada por procedimientos literarios que permiten historiar el suceso, encarnado por personajes que, dada su singularidad, no pueden ser percibidos como "tipos", no son portadores de una categoría social. Ese chico de "risa púber" de la crónica analizada en el Capítulo IV, “Solos en la madrugada (o el pequeño deliencuente que soñaba ser feliz"), "apenas un jovenzuelo de ojos mosquitos" -aunque dispuesto a "hacer de cogote" a su víctima- es sujeto de contradicción: inocente y culpable, víctima y victimario, libre de toda sujeción y condenado a la marginación. El texto de Lemebel lo singulariza y hace oír su voz, vehículo de un saber; la crónica lo hace portador de una posición plena de sentido, de una visión particular de su mundo; dichas condiciones constituyen su verosimilitud y lo salvan de la objetivación totalizante, ideal e imaginaria propia del estereotipo. Del mismo modo la prosa lemebeliana des-exotiza al portador de HIV, a la loca, travesti, marica o coliza, a los muchachos del bloque, a los indios o mestizos, a los ciudadanos que no aceptan la reconciliación forzada ni la ambigüedad del falso perdón oficial, salvándolos de la "subalternidad" que homogeneiza y aplana diferencias.

De lo dicho en los párrafos precedentes, se desprende la necesidad del procedimiento literario para el relato de la historia, y más aún, la necesidad del procedimiento poético. La memoria está unida a la experiencia sensorial. No hay memoria de lo abstracto. A través del recurso a la poesía, a la oralidad y a la ficción, Lemebel pone en tensión el discurso de la crónica que envía a situaciones históricas del 
pasado reciente, las recupera desde su memoria personal y -a través de procedimientos estrictamente literarios como la condensación del espacio y el tiempo narrativos, la pluralidad de puntos de vista (móviles o itinerantes) y la materialidad plástica y musical de sus imágenes- hace hablar a los cuerpos que permanecían silenciados, sin reestablecer falsas y anacrónicas categorías de la marginalidad. Nuestro autor apuesta a un procedimiento inaugurado en las vanguardias: la singularización cuyo propósito es generar la visión y no el reconocimiento del objeto o sujeto evocado. Víktor Shklovsky teorizó este procedimiento en su artículo, ya comentado, "El arte como artificio", en el que problematiza la herencia de la escuela simbolista, según la cual el arte sería pensamiento por medio de imágenes. Distanciándose de esa hipótesis, el teórico ruso sostiene que la imagen poética no se dirige a la comprensión (no es un sujeto constante para predicados variables) sino que procede por singularización creando "una percepción particular del objeto" y generando "una impresión máxima" (Shklovsky 1917: 57).

El texto es escritura poética y vocalizada que condensa todos los planos del relato a fin de hacer visible, audible, palpable una multitud de historias particulares. ${ }^{238}$ La voz del cronista, lejos de la distancia que objetiva y regula el verosímil de la descripción etnográfica convencional (la "retórica de representación positivista" en términos de Yanko González), construye su relato en clave afectiva. En la dedicatoria de su crónica a los muchachos del bloque, el autor afirma: "Yo me fumo esos vapores en un suspiro de amor por su exilio rebelde. Un brindis de yodo por su imaginario corroído por la droga [...] expuestos y dispuestos a las acrobacias de su trapecio proletario" (Lemebel 1995: 15). De este modo construye el punto de emisión de la voz desde la mirada y la experiencia vital de los protagonistas. Otro tanto sucede con las

\footnotetext{
${ }^{238}$ Este propósito está señalado por el epígrafe de Néstor Perlongher a su primer libro de crónicas, $L a$ esquina es mi corazón: "Errar es un sumergimiento en los olores y los sabores, en las sensaciones de la ciudad. El cuerpo que yerra 'conoce' en/con su desplazamiento."
} 
historias del travestismo callejero, de los detenidos desaparecidos y sus familiares y amigos sin respuesta, del perro quiltra abandonado, "sin amo y sin amor". He postulado y creo haber demostrado en el desarrollo argumentativo de mi tesis, que en la escritura de Pedro Lemebel se producen múltiples devenires minoritarios. El adjetivo, en este contexto, no pretende determinar un "modo de ser" de la literatura, menos aún pretende calificar a ciertas obras literarias, tampoco a determinados autores, sino a las condiciones de una escritura que traza -en un movimiento que es político- una línea de heterogeneidad en un sistema mayor, al que pertenece y al que desequilibra a la vez. A ese trazado denominé - con Gilles Deleuze- movimiento de desterritorialización.

La heterogeneidad de la escritura de Pedro Lemebel es radical: imbrica géneros literarios y discursivos diferentes, satura la crónica de procedimientos literarios (narrativos y poéticos) y hace hablar a los cuerpos que callan -parafraseando a Michel de Certeau- porque enuncia sus historias desde el punto de vista de muchos y muy diversos individuos que no tenían acceso a ningún discurso legitimado, seres "in-

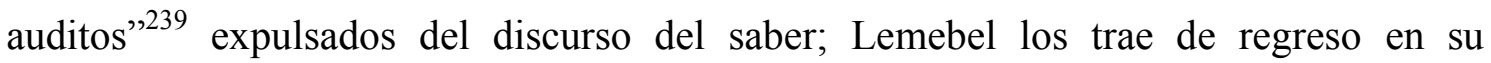
escritura sonora, vibrante y erotizada.

\footnotetext{
${ }^{239}$ Michel de Certeau (223) emplea intencionadamente este término cuya morfología remite tanto a la falta o fracaso de la audición -desde el punto de vista de quien habla o enuncia- como a la condición extraña, no reconocida del sujeto de esa enunciación.
} 


\section{Bibliografía}

\section{Bibliografía de y sobre Pedro Lemebel:}

\subsection{Libros del autor:}

Sum.

Lemebel, Pedro (1986): Incontables (Relatos), Santiago de Chile, Editorial Ergo

Lemebel, Pedro (1995): La esquina es mi corazón, Santiago de Chile, Editorial Cuarto Propio. [Reedición: Santiago de Chile, Seix-Barral, 2004.]

Lemebel, Pedro (1996): Loco afán. Crónicas de Sidario, Santiago de Chile, LOM Ediciones. [Reedición: Barcelona, Anagrama, 2000.]

Lemebel, Pedro (1998): De perlas y cicatrices, Santiago de Chile, LOM Ediciones. [Reedición: Santiago de Chile, Seix-Barral, 2010.] Barral.

Lemebel, Pedro (2001): Tengo miedo, torero (novela), Santiago de Chile, Seix

Lemebel, Pedro (2003): Zanjón de la aguada, Santiago de Chile, Seix Barral.

Lemebel, Pedro (2005): Adiós mariquita linda, Santiago de Chile, Seix Barral.

Lemebel, Pedro y otros (2007): Diagonal sur, Buenos Aires, Edhasa.

Lemebel, Pedro (2008): Serenata cafiola, Santiago de Chile, Seix Barral.

Lemebel, Pedro (2012): Háblame de amores, Santiago de Chile, Seix Barral.

\subsection{Crónicas del autor no recogidas originalmente en libro:}

Lemebel, Pedro: "Homoeróticas urbanas (o apuntes prófugos de un pétalo coliflor)", en: Rocinante, Santiago de Chile, agosto de 1999. [Incluido en la reedición de Loco afán. Crónicas de Sidario, Barcelona, Anagrama, 2000.]

--- "-- El malentendido del unicornio", Suplemento $C(x)$. Cultura y Nación. Clarín, Buenos Aires, sábado 16 de noviembre de 2002, pág. 3. Recogido posteriormente en: Zanjón de la aguada (2003), texto citado.

--- --- $\quad$ "Ojo de loca no se equivoca: Un extraño en el paraíso", Santiago de Chile, La Nación, domingo 24 de julio de 2005.

--- --- "Ojo de loca no se equivoca: Qué pena que no me duela tu nombre ahora", Santiago de Chile, La Nación, domingo 31 de julio de 2005. 
--- "-- $\quad$ "Ojo de loca no se equivoca: Se remata lindo país", Santiago de Chile, La Nación, domingo 18 de diciembre de 2005.

--- --- $\quad$ "El celofán estropeado de un ala colibrí,, Santiago de Chile, $L a$ Nación, domingo 5 de febrero de 2006.

--- "-- "Las andadas cacheras de un playero veranear", Santiago de Chile, Diario La Nación, domingo 22 de enero de 2006.

--- --- "Bienaventuranzas para la creatividad nacional", texto leído en el Festival de las Ideas, Universidad Arcis, 21 de abril de 2006. Reproducido en La Nación, domingo 23 de abril 2006.

--- -- De nuevo la búsqueda, otra vez la decepción”, Santiago de Chile, La Nación, domingo 30 de abril de 2006.

"Ojo de loca no se equivoca. Recuerdos de Pelotillehue", Santiago de Chile, La Nación, domingo 27 de agosto de 2006.

--- ---

"Ojo de loca no se equivoca. Siga participando", Santiago de Chile, La Nación, domingo 15 de abril de 2007.

\subsection{Bibliografía sobre la obra de Pedro Lemebel:}

Aguirre, Andrés: "Tengo miedo torero", Santiago de Chile, El Mercurio, 28 de abril de 2001.

Amado, Ana (2002): "Memoria, boleros y sexo malandra. Una lectura de sus famosas Crónicas de Sidario y de Tengo miedo, torero, su primer libro de ficción", en: Suplemento $C(x)$. Cultura y Nación. Clarín, Buenos Aires, sábado 16 de noviembre de 2002, pág. 2.

Barradas, Efraín (2008): "Para travestirte mejor: Pedro Lemebel y las lecturas políticas desde los márgenes", en: Revista Iberoamericana. Nueva época. Vol. 9, N 33 , 2008, págs. 69-82.

Bianchi, Soledad (1997): "Un guante de áspero terciopelo. La escritura de Pedro Lemebel", trabajo leído en la Mesa Redonda: "Travestismo: la infidelidad del disfraz", en el marco del Ciclo de Género, Educación y Cultura: Conjurando lo perverso. Lo femenino: presencia, supervivencia, realizado los días 19 y 29 de junio de 1997 en la Universidad Metropolitana de Ciencias de la Educación, Departamento de Literatura, Universidad de Chile. Disponible online: http://www.letras.s5.com/archivolemebel.htm También en: http://web.uchile.cl/publicaciones/cyber/03/textos/SBIANCHI.HTML

Billard, Henri (2010): “Los tajos del 'cuerpo deseante' en Loco afán. Crónicas de Sidario de Pedro Lemebel”, en: Recherches, num. 4, printemps 2010, págs. 39-48.

--- --- (2012): "Y la mariquita le dijo al torero... Pedro Lemebel, figura de resistencia cultural", en: Semilla Durán, María A. (comp.): L'écriture de Pedro Lemebel. Nouvelles pratiques identitaires et scripturales. La escritura de Pedro Lemebel. Nuevas prácticas identitarias y escriturales, Publications de l'Université de Saint-Étienne, págs. 15-25.

(2012): "Las cicatrices del margen: resistencia cultural y lucha identitaria en las crónicas urbanas de Pedro Lemebel”, en: Éste que ves, engaño colorido, Literarias, culturas y sujetos alternos en América Latina, sous la direction de 
Chiara Bolognese, Fernanda Bustamante, Mauricio Zabalgoitia, Barcelona, Icaria, págs. 311-318.

--- --- (2012): "La pluma entre las plumas: La presencia de los pájaros en las crónicas urbanas de Pedro Lemebel”, en: Confluencia. Revista Hispánica de Cultura y Literatura, Volume 28, Number 1, University of Northern Colorado, Greeley, USA, págs. 14-19.

Blanco, Fernando y Juan G. Gelpí (1997): "El desliz que desafía otros recorridos. Entrevista con Pedro Lemebel", Nómada, No 3, San Juan de Puerto Rico, junio de 1997, pp. 93-99.

--- --- (comp.): Reinas de otro cielo: Modernidad y autoritarismo en la obra de Pedro Lemebel, Santiago de Chile, LOM, 2004.

---.- "Ciudad sitiada. Ciudad sidada. Notas de lectura para Tengo miedo, torero, de Pedro Lemebel", Revista de la Facultad de Filosofía y Humanidades, Universidad de Chile.

--- --- 2007): "La crónica urbana de Pedro Lemebel: Discurso cultural y construcción de lazo social en los modelos neoliberales", Revista Casa de las Américas, Año XLVII, enero-marzo 2007, pp. 88-94.

Budassi, Sonia (2006): Pedro Lemebel. "Me interesa el clandestinaje", en: Suplemento Cultura Perfil, Buenos Aires, domingo 27 de agosto de 2006, pág. 7.

Cárcamo-Huechante, Luis (2007): "Las perlas de los 'mercados persas' o la poética del mercadeo popular en las crónicas de Pedro Lemebel", Revista Casa de las Américas, Año XLVII, enero-marzo 2007, pp. 95-102.

(2003) "Hacia una trama localizada del mercado. Crónica urbana y economía barrial en Pedro Lemebel”, en: Más allá de la ciudad letrada: crónicas y espacios urbanos, Boris Muñoz y Silvia Spitta (eds.), Instituto Internacional de Literatura Iberoamericana, Pittsburgh University, 2003.

Castillo R., Rodrigo: "Si a los chilenos les basta con la televisión, este es un pobre país", Santiago de Chile, Las Últimas Noticias, lunes 21 de julio de 2003.

Costa, Flavia (2004): "La rabia es la tinta de mi escritura", Suplemento $\tilde{N}$ del Diario Clarín de Buenos Aires, sábado 14 de agosto de 2004, pp. 6-9.

Donoso, Fernanda: "Adiós mariquita linda, de Pedro Lemebel. Por suerte no vine con tacos altos", Santiago de Chile, La Nación, lunes 26 de setiembre de 2005.

Dracos, Carolina Andonie: "El Gusto por la Otredad", Santiago de Chile, El Mercurio, 14 abril 2001. Fuente: letras.s5.com

Espinosa-Mendoza, Norge: "Puig, Paz, Lemebel: la sexualidad como revolución”, Revista Casa de las Américas, Año XLVII, enero-marzo 2007, pp. 80-87.

Espinoza, Patricia (1998): "Un mapa de la denuncia", en: Rocinante, Santiago de Chile, diciembre de 1998. Fuente: letras.s5.com

Extremera, Devy y Mavy Padrón: "Lemebel: el derecho a la diferencia", $L a$ Ventana, Portal informativo de Casa de las Américas.

Ezquerro, Milagros (2012): "De la chronique au roman: dévoiler les sexes", en: Semilla Durán, María A. (comp.): L'écriture de Pedro Lemebel. Nouvelles pratiques 
identitaires et scripturales. La escritura de Pedro Lemebel. Nuevas prácticas identitarias y escriturales, Publications de l'Université de Saint-Étienne, págs. 43-49.

Fornet, Jorge (2007): "Un escritor que se expone", Revista Casa de las Américas, Año XLVII, enero-marzo 2007, pp. 67-68.

Franco, Jean: (1996): "Género y sexo en la transición hacia la modernidad", en: Nomadías, Santiago de Chile, Programa Género y Cultura en América Latina, Universidad de Chile, $\mathrm{N}^{\circ}$ 1. (Acerca de la Instalación "Las dos Fridas", del colectivo de arte Las Yeguas del Apocalipsis).

(2002): "Pedro Lemebel, en cuerpo y alma. ¿Y esa peluca rosa debajo de la cama?", en: Suplemento C $(x)$. Cultura y Nación. Clarín, Buenos Aires, sábado 16 de noviembre de 2002, pág. 2.

González, Yanko (1997): "Loco afán: Una bella etnografía sobre el dolor marica", en: Alpha, $\mathrm{N}^{\circ}$ 13, Universidad de Los Lagos, Osorno, pp. 155-168. [Inhallable]

--- (2005): "Lemebel o el poder cognitivo de la metáfora", presentación del libro de Pedro Lemebel: Adiós mariquita linda, en la Universidad ARCIS, Santiago de Chile, 14 de setiembre de 2005.

--- --- (2007): "Etnografía persistente: Pedro Lemebel o el poder cognitivo de la metáfora", en: Atenea $\mathrm{N}^{\circ}$ 496, Concepción, Segundo Semestre 2007, pp. 161-165.

Gorodischer, Julián: "Pedro Lemebel. 'Escritor, cronista y performer' y sus escritos sobre ciudades sin calma", Buenos Aires, Página 12, jueves 31 de agosto de 2006.

Guerra, Lucía (2000): "La ciudad neoliberal y los devenires de la homosexualidad en la crónica de Pedro Lemebel", en: Revista Chilena de Literatura $\mathrm{N}^{\circ}$ 56, abril de 2000, págs. 71-92.

Guerrero del Río, Eduardo: "Lemebel. Oreja y Rabo", Santiago de Chile, Revista Cultura Urbana, agosto de 2001. Fuente: letras.s5.com

Huby, Anne-Claire (2012): "Tengo miedo torero, de Pedro Lemebel: Variations", en: Semilla Durán, María A. (comp.): L'écriture de Pedro Lemebel. Nouvelles pratiques identitaires et scripturales. La escritura de Pedro Lemebel. Nuevas prácticas identitarias y escriturales, Publications de l'Université de Saint-Étienne, págs. 111-118.

Jeftanovic, Andrea (2000): "Pedro Lemebel: El Cronista de los Márgenes", en: Revista Lucero, California, Berkeley University, 2000. Fuente: letras.s5.com

Livshin, Julia: "Pedro Lemebel: Tengo Miedo Torero. Loca y País", San Francisco Chronicle, domingo 15 de febrero de 2004. Traducción de Omar Pérez Santiago. Escritores de la Guerra, Foro Nórdico, 2004.

Lojo, Martín (2010): "Mi escritura es un género bastardo", ADN Cultura. Revista cultural del diario La Nación, Buenos Aires, sábado 13 de marzo de 2010, págs. $10-11$.

López García, Isabelle (2012): “Culture populaire et 'neobarrocho' dans l'écriture lémébélienne", en: Semilla Durán, María A. (comp.): L'écriture de Pedro Lemebel. Nouvelles pratiques identitaires et scripturales. La escritura de Pedro 
Lemebel. Nuevas prácticas identitarias y escriturales, Publications de l'Université de Saint-Étienne, págs. 27-41.

Mateo del Pino, Ángeles (1998a): "Chile mar y cueca... arréglate Juana Rosa que llega Pedro Lemebel", en: Espejo de paciencia. Revista de literatura y arte de la Universidad de Las Palmas de Gran Canaria. $\mathrm{N}^{\circ}$ 4, pp. 91-95.

--- --- (1998b): "Chile, una loca geografía o las crónicas de Pedro Lemebel”, Hispamérica Revista de Literatura, Año XXVII, N 80-81, pp. 17-28.

--- -- (2001): "Cronista y malabarista. Entrevista a Pedro Lemebel”, en: Cyber Humanitatis $\mathrm{N}^{\circ} 20$, primavera 2001. Disponible en línea.

(2004): "Descorriéndole un telón al corazón: Pedro Lemebel: De perlas y cicatrices”, Revista Chilena de Literatura $\mathrm{N}^{\circ}$ 64, pp. 131-143.

(2009): "Reflotando odiosidades. Compromiso y denuncia en las crónicas de Pedro Lemebel". Disponible en línea: http://acceda.ulpgc.es/bitstream/10553/1200/1/5478.pdf Documento de los Autores. Digitalización realizada por la ULPGC. Biblioteca Universitaria, 2009.

(2012): "Ética y estética de la pasión. Pedro Lemebel camino del sidario", en: Semilla Durán, María A. (comp.): L'écriture de Pedro Lemebel. Nouvelles pratiques identitaires et scripturales. La escritura de Pedro Lemebel. Nuevas prácticas identitarias y escriturales, Publications de l’Université de Saint-Étienne, págs. 63-77.

--- --- (comp.) (2013): Trazos neobarroc-s-ch-os en las poéticas latinoamericanas, Buenos Aires, Ediciones Katatay.

--- (2013): "Performatividad homobarrocha: Las Yeguas del Apocalipsis", en: Mateo del Pino, Ángeles (editora): Trazos neobarroc-s-ch-os en las poéticas latinoamericanas, Buenos Aires, Ediciones Katatay, págs. 337-385.

Matos, Orlando: "Chileno golpea la homofobia", 11 de diciembre de 2006 (www.lapatriaenlinea.com/content/view/17572/26).

Monsiváis, Carlos (2001): “El amargo, relamido y brillante frenesí”, Prólogo a la reedición de La esquina es mi corazón, Santiago de Chile, Seix Barral.

--- (2007):“El Barroco desclosetado”, en: Revista de la Universidad de México, UNAM, Número 42.

Montesinos, Elisa: "Lemebel es la reina de la Feria del Libro", Santiago de Chile, El Mercurio, domingo 28 de octubre de 2001.

Moreno, Fernando (2012): "Bordar la Historia desde los bordes: Tengo miedo torero", en: Semilla Durán, María A. (comp.): L'écriture de Pedro Lemebel. Nouvelles pratiques identitaires et scripturales. La escritura de Pedro Lemebel. Nuevas prácticas identitarias y escriturales, Publications de l'Université de Saint-Étienne, págs. 119-128.

Moure, Clelia (2008): "Retazos de la historia. Acerca de las crónicas de Pedro Lemebel”, en: Piña, Cristina (ed.). Literatura y (pos)modernidad. Teorías y lecturas críticas, Buenos Aires, Biblos.

(2008): "Crónicas neobarrocas: la construcción de una experiencia de la historia", en: Revista de crítica literaria latinoamericana, LimaHanover, NH, $\mathrm{N}^{\circ} 68$, pp. 165-181. 
Nachon, Andi (2003): “La rabia", en: Página 12, Buenos Aires, 25 de octubre 2003.

Neyret, Juan Pablo (2006): "Postal de La Habana: lugares y no lugares en Adiós mariquita linda de Pedro Lemebel", Espéculo. Revista de estudios literarios, Madrid, Universidad Complutense (www.ucm.es/info/especulo/numero34/lemebel.html).

--- -- "Los ojos de Karin Eitel. Panóptico mediático lemebélico", II Congreso Interoceánico de Estudios Latinoamericanos: Sujeto y utopía. El lugar de América Latina, Facultad de Filosofía y Letras, Unviersidad Nacional de Cuyo, Mendoza, 11 al 13 de setiembre de 2003.

Ostrov, Andrea (2003): "Las crónicas de Pedro Lemebel: un mapa de las diferencias", en: La fugitiva contemporaneidad. Narrativa latinoamericana 1990-2000, Buenos Aires, Corregidor, pp. 99-119.

Palaversich, Diana (2002): "The Wounded Body of Proletarian Homosexuality in Pedro Lemebel's Loco afán", Latin American Perspectives No 29, "Gender, Sexualty, and Same-Sex Desire in Latin America", pp. 263-282.

Parys, Jody (2007): "La creación de (com)unidad mediante la hibridez" en: Memoria histórica, Género e Interdisciplinariedad: Los Estudios Culturales Hispánicos en el siglo XXI. Santiago Juan-Navarro and Joan Torres-Pou Eds., Madrid, Biblioteca Nueva.

Piña, Juan Andrés, Reseña a Zanjón de la aguada, Revista Caras, Año 16, N ${ }^{\circ}$ 401, 14 de agosto de 2003.

Poblete, Juan (2003): "La crónica, el espacio urbano y la representación de la violencia en la obra de Pedro Lemebel", en: Muñoz, Boris y Silvia Spitta (comp.): Más allá de la ciudad letrada: crónicas y espacios urbanos, Pittsburgh, Instituto Internacional de Literatura Latinoamericana, Biblioteca de América, 2003.

Promis, José: "Desenfado, irreverencia, agresividad. Derrida en el arrabal", Santiago de Chile, El Mercurio, 2 de agosto de 2003.

Richard, Nelly (1998): "Género, valores y diferencia(s)", en: Residuos y metáforas. Ensayos de crítica cultural sobre el Chile de la Transición. 1998.

Rivera, Angélica: "El largo bolero de Pedro Lemebel”, Santiago de Chile, Las Últimas Noticias, viernes 13 de abril de 2001.

Rojas, Carolina (2012): "Esta lengua tiene sus costos". Entrevista a Pedro Lemebel. Suplemento $\tilde{N}$ del Diario Clarín de Buenos Aires, 15 de diciembre de 2012, pp. 20-22.

Ruffinelli, Jorge (2007): "Lemebel después de Lemebel”, Revista Casa de las Américas, Año XLVII, enero-marzo 2007, pp. 73-79.

Santa Cruz, Guadalupe: "La Santiago Travesti", en el en el marco del Ciclo de Género, Educación y Cultura: Conjurando lo perverso. Lo femenino: presencia, supervivencia, realizado los días 19 y 29 de junio de 1997 en la Universidad Metropolitana de Ciencias de la Educación, Departamento de Literatura, Universidad de Chile. (Conferencia no editada).

Schaffer, Maureen (1998): "La Yegua silenciada", en Revista HOY, No 1.072, Santiago de Chile, 9 al 15 de febrero de 1998. 
Semilla Durán, María A. (comp.) (2012): L'écriture de Pedro Lemebel. Nouvelles pratiques identitaires et scripturales. La escritura de Pedro Lemebel. Nuevas prácticas identitarias y escriturales, Publications de l'Université de Saint-Étienne.

--- --- 2012): "Las travesías del imaginario: la poética del des-borde en la obra de Pedro Lemebel", en: Semilla Durán, María A. (comp.): L'écriture de Pedro Lemebel. Nouvelles pratiques identitaires et scripturales. La escritura de Pedro Lemebel. Nuevas prácticas identitarias y escriturales, Publications de l'Université de Saint-Étienne, págs. 93-108.

Zambra, Alejandro (2003): "El unicornio de Pedro Lemebel", en Las Últimas noticias, Santiago de Chile, miércoles 30 de julio de 2003.

Zerán, Faride: "Pedro Lemebel y la loca del Frente", Santiago de Chile, Rocinante $\mathrm{N}^{\circ} 30$, abril de 2001.

Zurbano, Roberto (2007): "Pedro Lemebel o el triángulo del deseo iletrado", Revista Casa de las Américas, Año XLVII, enero-marzo 2007, pp. 103-107.

\section{Cronistas de Indias, modernistas y contemporáneos:}

AA.VV. Escritores de Indias, Selección, estudio y notas por Manuel Ballesteros, Zaragoza, Ebro, 1961.

AA.VV. Biblioteca virtual Cervantes. Disponible online:

\section{http://www.cervantesvirtual.com}

Barnet, Miguel (1966): Biografía de un cimarrón, Buenos Aires, Galerna, 1968.

Cabrera de Córdoba, L. (1611): De historia para entenderla y escribirla, edición, estudio preliminar y notas de S. Moreno Díaz, Madrid, Instituto de Estudios Políticos, 1948.

Colón, Cristóbal: Diario de a bordo, Madrid, Globus, 1994.

--- --- Textos y documentos completos: relaciones de viajes, cartas y memoriales. Edición, prólogo y notas de Consuelo Varela, Madrid, Alianza, 1982.

Cortés, Hernán: Cartas de relación, Barcelona, Instituto Gallach, Editorial Océano, 1986.

Cristoff, María Sonia (comp.): Idea crónica. Literatura de no ficción iberoamericana, Buenos Aires, Beatriz Viterbo, 2006.

Díaz del Castillo, Bernal: Historia verdadera de la conquista de la Nueva España, Buenos Aires, Eudeba, 1964.

de las Casas, Bartolomé: Brevísima relación de la destrucción de las Indias, Barcelona, Ediciones Orbis, 1986.

del Casal, Julián: Crónicas habaneras. Las Villas, Universidad Central de Las Villas, 1963.

Fernández de Oviedo, Gonzalo: Historia general y natural de las Indias, islas y tierra-firme del mar océano. Reproducción digital de la edición de Madrid, Imprenta de la Real Academia de la Historia, 1851. Disponible online: 
http://www.cervantesvirtual.com/obra/historia-general-y-natural-de-las-indias-islas-ytierrafirme-del-mar-oceano

Gutiérrez Nájera, Manuel: Obras, México, UNAM, 1959.

--- --- C C C C C C Cóntos $\quad 1940$.

Herrera, Antonio de: Historia general de los hechos de los castellanos, en las islas y tierra-firme de el Mar Océano. Prólogo de J. Natalicio González. X volúmenes. Buenos Aires, Guarania, 1945-1947.

León-Portilla, Miguel (1959): Visión de los vencidos, México, UNAM, 1984.

Lezama Lima, José: La Habana, Madrid, Ed. Verbum, 1991.

Martí, José: Obras completas (27 vols.), La Habana, Editora Nacional, 19631973.

Martí, José: Prosa y poesía, Buenos Aires, Kapelusz, 1968.

Monsiváis, Carlos (1970): Días de guardar, México, Ediciones Era, 1991.

Ediciones Era, 1993.

(1976): A ustedes les consta: antología de la crónica en México,

(1978): Amor perdido

--- -- (1979): Antología de la crónica en México, México, UNAM.

--- --- (1995): Los rituales del caos, México, Ediciones Era, 1996. 1977.

Palma, Ricardo: Cien tradiciones peruanas, Caracas, Biblioteca Ayacucho,

Perlongher, Néstor: Prosa plebeya, Buenos Aires, Colihue, 1997.

--- : Papeles insumisos, Edición de A. Cangi y R. Jiménez, Buenos Aires, Santiago Arcos Editor, 2004. 1984.

Poniatowska, Elena (1969): Hasta no verte Jesús mío, México, Alianza / Era,

--- -- (1971): La noche de Tlatelolco, México, Ediciones Era, 1991.

--- --- (1980): Fuerte es el silencio, México, Ediciones Era, 1983.

Rodríguez Juliá, Edgardo (1986): Una noche con Iris Chacón, Río Piedras, Editorial Antillana.

Viterbo.

--- (2009): La nave del olvido. Antología personal, Rosario, Beatriz

Rodó, José Enrique: Obras completas. Prólogo, introducción y notas de Emir Rodríguez Monegal, Madrid, Aguilar, 1977.

Scherer García, Julio y Carlos Monsiváis: Parte de guerra: Tlatelolco 68, México, Aguilar, 1999.

Sahagún, Fray Bernardino de: Historia general de las cosas de Nueva España, Ed. Miguel Acosta Saignes, 3 Tomos, México, Alfa, 1955.

Silva, José Asunción: Obra completa, Medellín, Bedout, 1980.

--- --- Obras completas, Buenos Aires, Plus Ultra, 1968. 
Vespucio, Américo: El nuevo mundo: cartas relativas a sus viajes $y$ descubrimientos. Estudio preliminar de Roberto Orillier, Buenos Aires, Nova, 1951.

\section{Bibliografía crítica y teórica sobre crónicas, géneros no ficcionales y narrativa latinoamericana.}

AA.VV. Historiadores primitivos de Indias, Colección dirigida por Enrique de Vedia, Madrid, B.A.E., 1946.

AA.VV. Julián del Casal: Estudios críticos sobre su obra, Esperanza Figueroa (comp.), Miami, Ediciones Universal, 1974.

Abeyta, Michael (2000): "Un cuadro sincrónico del cuerpo en La noche de Tlatelolco y en Visión de los vencidos", Revista Relaciones, № 82, Vol. XXI, México, Primavera 2000, pp. 175-198.

Amar Sánchez, Ana María (1992): El relato de los hechos. Rodolfo Walsh: testimonio y escritura, Rosario, Beatriz Viterbo.

Anderson Imbert, Enrique (1954): Historia de la literatura hispanoamericana I, México, Fondo de Cultura Económica, 1974.

Avelar, Idelber (2000): Alegorías de la derrota: La ficción posdictatorial y el trabajo del duelo, Santiago de Chile, Cuarto Propio.

Bernabé, Mónica (2006): "Prólogo", en: Cristoff, María Sonia (comp.): Idea crónica. Literatura de no ficción iberoamericana, Buenos Aires, Beatriz Viterbo, 2006. Págs. 7-25.

Cerdán, Francis (1985): "La oración fúnebre del Siglo de Oro. Entre sermón evangélico y panegírico poético sobre fondo de teatro", en: Criticón, Toulouse, $\mathrm{N}^{\circ} 50$, 1985, pp. 79-103.

Chiampi, Ildemar (1993): "La historia tejida por la imagen" en: Lezama Lima, José (1969): La expresión americana, México, F.C.E., 1993. Págs. 9-33.

Contardo, Oscar y Macarena García (2005): La era ochentera. Tevé, pop y under en el Chile de los ochenta, Santiago de Chile, Ediciones B.

D'Allemand, Patricia (1996) “Angel Rama: el discurso de la transculturación", en: Nuevo Texto Crítico, VIII, 16/17, pp. 133-151.

Darío, Rubén: Los raros, en: Obras Completas, Vol. VI, Madrid, Ed. Mundo Latino, 1905.

Egan, Linda. Carlos Monsiváis: Culture and Chronicle in Contemporary Mexico. Tucson, AZ: University of Arizona Press, 2001. 276 pp.

Eltit, Diamela (2000): Emergencias. Escritos sobre literatura, arte y politica, Santiago de Chile, Planeta/Ariel.

Esteve Barba, F. (1964): Historiografia indiana, Madrid, Gredos.

García Canclini, Néstor (1993): El consumo cultural en México, México, CNCA, 1993. 
(1995): "Narrar la multiculturalidad", en: Revista de crítica literaria latinoamericana, Año XXI, No 42, Lima-Berkeley, 2do. semestre de 1995, pp. 9-20.

--- (1989): Culturas híbridas; estrategias para entrar y salir de la modernidad, México, Grijalbo.

--- (1995): Consumidores y ciudadanos, conflictos multiculturales de la globalización. México, Grijalbo.

Gelpí, Juan G. (1997): "Paseo por la crónica urbana: Carlos Monsiváis y José Joaquín Blanco", Nómada, No 3, San Juan de Puerto Rico, junio de 1997, pp. 83-88.

González, Aníbal (1983): La crónica modernista hispanoamericana, Madrid, Ediciones José Porrúa Turanzas.

González Echevarría, Roberto (2000): Mito y archivo. Una teoría de la narrativa en Latinoamérica, México, Fondo de Cultura Económica.

Gusmán, Luis (2005): Epitafios. El derecho a la muerte escrita, Buenos Aires, Norma.

Gutiérrez, José Ismael: "La crónica, género de transición. La confluencia periodismo literatura", en: Manuel Gutiérrez Nájera y sus cuentos. De la crónica periodística al relato de ficción, Peter Lang Publishing, New York, 1999, pp. 91-92

Gutiérrez Girardot, Rafael (1987): "La literatura hispanoamericana de fin de siglo", en: Del neoclasicismo al modernismo. Historia de la literatura hispanoamericana, Tomo II. L. Íñigo Madrigal (comp.), Madrid, Cátedra.

--- (1983): Modernismo, Barcelona, Montesinos.

Henríquez Ureña, Max (1954): Breve historia del modernismo, México, Fondo de Cultura Económica.

Henríquez Ureña, Pedro (1947): Historia de la cultura en la América Hispánica, México, Fondo de Cultura Económica.

Jiménez, José Ovidio: "El ensayo y la crónica del modernismo", en: Del neoclasicismo al modernismo. Historia de la literatura hispanoamericana, Tomo II. L. Íñigo Madrigal (comp.), Madrid, Cátedra.

Manzano Manzano, Juan (1950): Historia de las recopilaciones de Indias, Vol. I: Siglo XVI. Vol. II: Siglo XVII. Madrid, Cultura Hispánica.

Mateo del Pino, Ángeles (2001): “Crónica y fin de siglo en Hispanoamérica (del siglo XIX al XXI)", en: Revista Chilena de Literatura $\mathrm{N}^{\circ}$ 59, Noviembre de 2001, pp. $13-40$.

Martín Barbero, Jesús (1987): De los Medios a las mediaciones: comunicación, cultura y hegemonía. México, Gustavo Gili.

(2001): “Globalización e integración desde la perspectiva cultural", en: Lasarte Valcárcel, Javier (coord.). Territorios intelectuales. Pensamiento y cultura en América Latina. Caracas: Fondo Editorial La Nave Va, pp. 35-48.

Menéndez Pelayo, Marcelino (1941): "De los historiadores de Colón”, en: Estudios y discursos de crítica histórica y literaria, Madrid, Espasa-Calpe. Tomo VII.

Menéndez Pidal, Ramón (1942): La lengua de Cristóbal Colón, Madrid, Austral. 
Mignolo, Walter (1987): “Cartas, crónicas y relaciones del descubrimiento y la conquista", en: Del neoclasicismo al modernismo. Historia de la literatura hispanoamericana, Tomo I. L. Íñigo Madrigal (comp.), Madrid, Cátedra.

Moraña, Mabel: "Documentalismo y ficción: testimonio y narrativa testimonial hispanoamericana en el siglo XX", en: Políticas de la escritura en América Latina. De la Colonia a la Modernidad, Caracas, Ediciones Escultura, 1997.

Muñoz, Boris y Spitta, Silvia (comps.): Mas allá de la ciudad letrada: crónicas y espacios urbanos, Pittsburgh, Instituto Internacional de Literatura Iberoamericana, Biblioteca de América, 2003.

Pastor, Beatriz (1983): Discurso narrativo de la conquista de América, La Habana, Ediciones Casa de las Américas.

Paz, Octavio (1974): Los hijos del limo. Del Romanticismo a las vanguardias, Barcelona, Seix Barral.

Poniatowska, Elena (2012): "Manifestar lo oculto", en: Julián Gorodischer: "El rol de la crónica en América Latina", Suplemento N, 20 de octubre de 2012, p. 18.

Rama, Ángel (1970) Rubén Dario y el Modernismo: circunstancias socioeconómicas de un arte americano. Caracas, Ediciones de la Universidad Central de Venezuela.

Rico.

--- --- (1974): Estudios martianos, Río Piedras, Universidad de Puerto

(1980): El escritor y la industria cultural: el camino hacia la profesionalización, Buenos Aires, CEAL.

--- ---

(1982): Transculturación Narrativa en América Latina, México,

Siglo XXI, 1985.

--- --- (1984): La ciudad letrada, Hanover, Ediciones del Norte.

Ramos, Julio (1989): Desencuentros de la modernidad en América Latina, México, F.C.E.

Richard, Nelly (1998): Residuos y metáforas; ensayos de crítica cultural sobre el Chile de la Transición, Santiago de Chile, Cuarto Propio.

---- (2002): “Saberes académicos y reflexión crítica en América Latina" (Postfacio), en: Daniel Mato (coord.): Estudios y otras prácticas intelectuales latinoamericanas en Cultura y Poder. Caracas, Consejo Latinoamericano de Ciencias Sociales (CLACSO) y CEAP, FACES, Universidad Central de Venezuela, pp:363-372.

--- --- (2005): “Globalización académica, estudios culturales y crítica latinoamericana”, en: Daniel Mato (comp.). Cultura, política y sociedad. Perspectivas latinoamericanas. Consejo Latinoamericano de Ciencias Sociales, Buenos Aires, pp. 455-470.

--- (2008): Debates críticos en América Latina: 36 números de la Revista de Crítica Cultural (1990-2008). Volúmenes 1 y 2. Santiago de Chile, Arcis/ Cuarto Propio/ Revista de Crítica Cultural.

Rotker, Susana (1989): Fundación de una escritura: las crónicas de José Martí, La Habana, Casa de las Américas, 1992.

(1993): “Prólogo”, en: Crónicas. José Martí, Madrid, Alianza. 
Sociedad.

--- --- (2000): Ciudadanías del miedo, Caracas, Editorial Nueva

--- --- 2005): La invención de la crónica, México, F.C.E.

Saer, Juan José (1999): La naración-objeto, Buenos Aires, Planeta-Seix Barral.

Sarlo, Beatriz (1997): "Los estudios culturales y la crítica literaria en la encrucijada valorativa", en Revista de Crítica Cultural $\mathrm{N}^{\circ} 15$, Santiago de Chile, Noviembre.

--- (2005): Tiempo pasado. Cultura de la memoria y giro subjetivo. Una discusión, Buenos Aires, Siglo XXI.

Schulman, Iván A. (1968): "Reflexiones en torno a la definición del modernismo", en: Estudios críticos sobre el modernismo. Introducción y selección de Homero Castillo, Madrid, Gredos.

Weingarten, Marc (2010): The Gang That Wouldn't Write Straight, New York, Three Rivers Press.

Wolfe, Tom (1976): El nuevo periodismo, Barcelona, Anagrama.

Zanetti, Susana (2002): La dorada garra de la lectura. Lectoras y lectores de novela en América Latina, Buenos Aires, Beatriz Viterbo.

\section{Bibliografía sobre la historia reciente de Chile}

Aylwin, Patricio: El reencuentro de los demócratas. Del golpe al triunfo del NO, Grupo Zeta Editor, 1998.

Edwards, Jorge (1991): "La relectura creativa", en: Garretón, Manuel y otros: Cultura, autoritarismo y redemocratización en Chile, Santiago de Chile, Fondo de Cultura Económica, 1993, pp. 49-56.

Garretón, Manuel y otros (1993): Cultura, autoritarismo y redemocratización en Chile, Santiago de Chile, Fondo de Cultura Económica.

Informe Rettig. Informe de la Comisión Nacional de Verdad y Reconciliación, La Nación y Ediciones del Ornitorrinco, Santiago de Chile, 1991.

Montecino, Sonia (1991): "El mundo indígena en el Chile de hoy: temor y tensión de una presencia", en: Garretón, Manuel y otros: Cultura, autoritarismo y redemocratización en Chile, Santiago de Chile, Fondo de Cultura Económica, 1993, pp. 113-120.

Moulian, Tomás (1997): Chile actual. Anatomía de un mito, Santiago de Chile, LOM-Universidad ARCIS.

Portales, Felipe (2005): "La inexistencia de la democracia en Chile", en: Polis Revista Latinoamericana, $\mathrm{N}^{\circ}$ 10, Año 2005, Puesto en línea el 10 noviembre 2012, URL: http://polis.revues.org/7493. Disponible en www.revistapolis.cl

Richard, Nelly (1991): "En torno a las diferencias", en: Garretón, Manuel y otros (1993): Cultura, autoritarismo y redemocratización en Chile, Santiago de Chile, Fondo de Cultura Económica, pp. 39-46. 
--- (2004): Utopía(s) 1973-2003. Revisar el pasado, criticar el presente, imaginar el futuro, Santiago de Chile, Unviersidad ARCIS.

Rojo, Grinor (1991): “Casi veinte años de literatura chilena: 1973-1991”, en: Garretón, Manuel y otros (1993): Cultura, autoritarismo y redemocratización en Chile, Santiago de Chile, Fondo de Cultura Económica, pp. 57-70.

Tironi, Eugenio (1991): "Las políticas de comunicación en la transición y la transición en los medios de comunicación. Cuatro reflexiones", en: Garretón, Manuel y otros: Cultura, autoritarismo y redemocratización en Chile, Santiago de Chile, Fondo de Cultura Económica, 1993, pp. 235-247.

Zalaquett, José (2000): "La Mesa de Diálogo sobre derechos humanos y el proceso de transición política en Chile", Estudios Públicos, N 79 (invierno 2000), Centro de Estudios Públicos (CEP), Santiago de Chile. Disponible online:

http://bibliotecadigital.indh.cl/handle/123456789/182 )

\section{Bibliografía sobre cuestiones de género}

Amícola, José (2000): Camp y posvanguardia. Manifestaciones culturales de un siglo fenecido, Buenos Aires, Paidós. Anthropos.

Amorós, Celia (1991). Hacia una crítica de la razón patriarcal, Barcelona,

--- --- (coord.), (1994): Historia de la teoría feminista, Madrid, Instituto de Investigaciones Feministas de la Unversidad Complutense de Madrid.

Blanco, Fernando: "Políticas de la ciudadanía sexual y la memoria en la escritura de Pedro Lemebel", en: Dieter Ingenschay (ed.), Desde aceras opuestas: literatura/cultura gay y lesbiana en Latinoamérica. Madrid, Iberoamericana, 2006.

Burín, Mabel: "Género y psicoanálisis: subjetividades femeninas vulnerables", en: Actualidad psicológica, año XIX, número 210, Junio de 1994, 2-8.

Butler, Judith (1990): “Gender Trouble, Feminist Theory, and Psychoanalytic Discourse" en: Feminist/Postmodernism, Linda Nicholson ed., New York and London, Routledge. Versión cast.: "Problemas de los géneros, teoría feminista y discurso psicoanalítico", en: Linda Nicholson (comp.) Feminismo/Posmodernismo, Buenos Aires, Feminaria Editora, 1992. Págs. 75-95.

Epps, Brad: "Retos, riesgos, pautas y promesas de la teoría queer", en: Revista Iberoamericana. Dossier: "Los estudios lésbico-gays y queer latinoamericanos", Vol. LXXIV, Núm.225, Octubre-Diciembre 2008, 897-920.

Fernández, Ana María (1994): La mujer de la ilusión. Pactos y contratos entre hombres y mujeres, Buenos Aires, Paidós.

(1993): "Los pies de la ley en el deseo femenino", en: Las mujeres en la imaginación colectiva. Una historia de discriminación y resistencias, Buenos Aires, Paidós. Págs. 136-146.

Kaminsky, Amy: "Hacia un verbo queer", en: Revista Iberoamericana. Dossier: "Los estudios lésbico-gays y queer latinoamericanos", Vol. LXXIV, Núm.225, Octubre-Diciembre 2008, 879-895. Seuil.

Kristeva, Julia (1977): "La femme, ce n’est jamais ça”, en: Polylogue, París, 
Fundamentos, 1980.

(1969): "Poesía y negatividad", en: Semiótica 2, Madrid,

Martínez, Luciano: "Transformación y renovación: Los estudios lésbico-gays y queer latinoamericanos", en: Revista Iberoamericana. Dossier: "Los estudios lésbicogays y queer latinoamericanos", Vol. LXXIV, Núm.225, Octubre-Diciembre 2008, 861876.

Negroni, María (2000): “Alejandra Pizarnik: melancolía y cadáver textual”, Revista del INTI, número 52-53, pág. 175.

Piña, Cristina (1997): "Las mujeres y la escritura: el gato de Cheshire", en: Mujeres que escriben sobre mujeres (que escriben), Buenos Aires, Biblos. Págs. 15-48.

Richard, Nelly (1993): Masculino/Femenino. Prácticas de la diferencia y cultura democrática, Santiago de Chile, Francisco Zegers Editor.

Showalter, Elaine (1981): "Feminist Criticism in the Wilderness", en: Critical Inquiry, VIII, 2, invierno de 1981. Versión cast.: "La crítica feminista en el desierto", en: Otramente: lectura y escritura feministas, México, Fondo de Cultura Económica, 1999, pp. 75-111.

Sinfield, Alan (1994): Cultural Politics. Queer Reading, Londres, Routledge.

Sontag, Susan (1964): "Notes on camp", en: Against Interpretation, Nueva York, Doubleday, 1990.

\section{Bibliografía teórica:}

Artaud, Antonin (1938): El teatro y su doble, Buenos Aires, Sudamericana, 2005 .

--- --- (1947): Van Gogh, el suicidado por la sociedad, traducción y notas de Aldo Pellegrini, Buenos Aires, Argonauta, 1987.

Auerbach, Erich (1942): Mimesis. La representación de la realidad en la literatura occidental, México, Fondo de Cultura Económica, 1950.

Bachelard, Gastón (1957): La poética del espacio, México, FCE, 1991.

Bajtín, Mijail (1938a): "Las formas del tiempo y del cronotopo en la novela. Ensayos de poética histórica”, en: Teoría y estética de la novela, Madrid, Taurus, 1981.

--- --- (1938b): La cultura popular en la Edad Media y el Renacimiento. El contexto de François Rabelais, Alianza, Madrid, 1987.

--- --- (1963): Problemas de la poética de Dostoievski, Buenos Aires, Fondo de Cultura Económica, 1993.

--- --- (1977): Estética de la creación verbal, México, Siglo XXI, 1982.

Barthes, Roland (1966): Crítica y verdad, Trad. de José Bianco, Bs. As., Siglo XXI, 1976.

--- --- (1970a): "El discurso de la historia", en: Estructuralismo y literatura. Buenos Aires, Nueva Visión. 
--- (1970b): "Escribir la lectura", en: El susurro de la lengua, Barcelona, Paidós, 1991. Págs. 35-38.

--- (1971): "De la obra al texto", en: El susurro de la lengua, Barcelona, Paidós, 1991. Págs. 73-82.

--- (1972). El grado cero de la escritura, Trad. de Nicolás Rosa, Buenos Aires, Siglo XXI, 1986.

Benjamin, Walter: Para una crítica de la violencia y otros ensayos. (Iluminaciones IV). Trad. de Roberto Blatt, selección e introducción de Eduardo Subirats, Madrid, Taurus, 1991.

Taurus, 1975 .

(1934): El autor como productor, Trad. de Jesús Aguirre, Madrid,

(1936): La obra de arte en la época de su reproductibilidad técnica, Trad. de Jesús Aguirre, Madrid, Taurus, 1973.

(1938): “Tesis sobre filosofía de la historia", en: Ensayos escogidos. Trad. de H. A. Murena, Buenos Aires, Sur, 1967.

------

Iluminaciones I. Prólogo, trad. y notas de Jesús Aguirre, Madrid,

Taurus, 1971.

--- --- París capital del siglo XIX (Iluminaciones II). Prólogo y trad. de Jesús Aguirre, Taurus Madrid, 1972.

--- --- La dialéctica en suspenso. Fragmentos sobre la historia. Trad., introducción y notas de Pablo Oyarzún Robles, Santiago de Chile, Arcis y Lom Ediciones, 1996.

2005 .

--- --- $\quad$ Libro de los pasajes, Edición de Rolf Tiedemann, Madrid, Akal,

Bergson, Henri (1922): Duración y simultaneidad (a propósito de la teoría de Einstein), Buenos Aires, Ediciones del Signo, 2004.

Blanchot, Maurice (1955): El espacio literario, Barcelona, Paidós, 1992.

--- -- (1959): Le livre à venir, París. Gallimard.

--- --- (1969): El diálogo inconcluso, Caracas, Monte Ávila, 1974.

--- (1973): Le pas au-delà, París, Gallimard, 1973. (Versión castellana: El paso (no) más allá, Barcelona, Paidós, 1984).

textos, 1988.

(1986): Michel Foucault tal y como yo lo imagino, Valencia, Pre-

Bourdieu, Pierre: (1966) Campo del poder y campo intelectual, Trad. de Ma. Teresa Gramuglio, Buenos Aires, Folios, 1983.

-- --- "Campo intelectual y proyecto creador", en: Pouillon, Jean y otros: Problemas del estructuralismo, México, Siglo XXI, 1967.

Chartier, Roger (1995): Escribir las prácticas. Foucault, de Certeau, Marin, Buenos Aires, Manantial, 2001.

Collingwood, R. G. (1946): Idea de la historia, México, Fondo de Cultura Económica, 1979. 
De Certeau, Michel (1978): La escritura de la historia, México, Universidad Iberoamericana, 1993.

Deleuze, Gilles (1967): Nietzsche y la filosofía, Barcelona, Anagrama, 1986.

--- --- (1968): Diferencia y repetición. Madrid, Júcar, 1988.

--- --- (1969): Lógica del sentido. Barcelona, Paidós, 1989.

2004.

(1972): El Anti-Edipo, Barcelona, Paidós, 1985.

--- --- (1981): Spinoza: Filosofía práctica, Buenos Aires, Tusquets,

--- --- 2004): En medio de Spinoza, Buenos Aires, Cactus.

--- --- (1988): El pliegue. Leibniz y el barroco, Barcelona, Paidós, 1989.

Deleuze, Gilles y Félix Guattari (1972). El Anti-Edipo. Barcelona, Paidós, 1985.

--- (1975): Kafka. Por una literatura menor. Versión de Jorge Aguilar Mora. México, Ed. Era, 1990.

--- --- ～～１1976): Rizoma (Introducción). Valencia, Pre-textos, 1977.

--- --- ～～１1980): Mil mesetas. Valencia, Pre-textos, 1988.

--- (1991): ¿Qué es la filosofía? Barcelona, Anagrama, 1997.

Descartes, René. Discurso del método y meditaciones metafísicas. Traducción y notas de Manuel G. Morente. Bs.As., Espasa-Calpe, 1950.

Dilthey, Wilhelm (1856): Introducción a las Ciencias del Espíritu. Prólogo de José Ortega y Gasset, Traducción de Julián Marías, Madrid, Revista de Occidente, 1956. 1944.

Dilthey, Wilhelm: El mundo histórico, México, Fondo de Cultura Económica,

Foucault, Michel (1963): El nacimiento de la clínica, Buenos Aires, Siglo XXI, 2004.

(1966): Las palabras y las cosas. Una arqueología de las ciencias humanas, Barcelona, Planeta, 1984.

--- -- (1969): La arqueología del saber, México, Siglo XXI, 1978.

(1970): El orden del discurso, trad. de A. González Troyano, Barcelona, Tusquets, 1987.

--- ---

(1976) Historia de la sexualidad, 1: La voluntad de saber. Bs.As.,

Siglo XXI, 1990.

Siglo XXI, 1983.

(1975): Vigilar y castigar. Nacimiento de la prisión, México, Fernando Álvarez-Uría, Madrid, La piqueta.

(1979): Microfisica del poder, edición y trad. de Julia Varela y --- --- (1994): De lenguaje y de literatura. Barcelona, Paidós, 1996.

Frenk, Margit (1997): Entre la voz y el silencio. (La lectura en tiempos de Cervantes). Alcalá de Henares, Centro de Estudios Cervantinos. 
Freud, Sigmund (1921): Psicología de las masas, en: Obras completas, Buenos Aires, Siglo XXI, 2013. Vol. 19. Págs. 2563-2603.

(1927): El porvenir de una ilusión, en: Obras completas, Buenos Aires, Siglo XXI, 2013. Vol. 22. Págs. 2961-2988. 2000.

Galimberti, Umberto (1983): Il corpo, Milano, Giangiacomo Feltrinelli Editore,

Gauthier, X. y otros (1973): Artaud, Valencia, Pre-textos, 1977.

González, Fernando M. (1991): Ilusión y grupalidad. Acerca del claro oscuro objeto de los grupos, México, Siglo XXI.

Hegel, Georg (1831): Lecciones sobre la filosofía de la historia universal. Traducción de José Gaos. Madrid, Revista de Occidente, 1974.

Iggers, Georg (1995): La ciencia histórica en el siglo xx. Las tendencias actuales. Una visión panorámica y crítica del debate internacional. Presentación, adaptación y revisión científica de Fernando Sánchez Marcos, Barcelona, Labor.

Jameson, Fredric (1998): El giro cultural. Escritos seleccionados sobre el posmodernismo 1983-1998, Bs. As, Manatial, 1999.

Kristeva, Julia (1966): "La palabra, el diálogo, la novela" en: Semiótica 1. Madrid, Fundamentos, 1981. Págs. 187-225.

--- --- (1967): "Una productividad denominada texto" en: Semiótica 2. Madrid, Fundamentos, 1981. Págs. 7-54.

(1968a): "El texto y su ciencia" en: Semiótica 1. Madrid, Fundamentos, 1981. Págs. 7-33. Fundamentos, 1981. Págs. 55-93.

(1968b): "Poesía y negatividad", en: Semiótica 2. Madrid,

(1972): "El sujeto en proceso", en: Gauthier, X. y otros: Artaud, Valencia, Pre-textos, 1977. Págs. 35-94.

--- (1980): Poderes de la perversión. Buenos Aires, Catálogos, 1988.

Lacan, Jacques (1955) "La cosa freudiana o sentido del retorno a Freud en psicoanálisis”, en: Escritos I, Buenos Aires, Siglo XXI, 1987.

--- -- (1963): Seminario 10. La Angustia, Buenos Aires, Paidós, 2005.

--- (1965): Seminario 11. Cuatro conceptos fundamentales del psicoanálisis, Buenos Aires, Paidós, 1990.

--- (1966): Escritos I. Buenos Aires, Siglo XXI, 1987.

--- -- $\quad$ Escritos II, Buenos Aires, Siglo XXI, 1988.

Le Galliot, Jean (1977). Psicoanálisis y lenguajes literarios, Bs.As., Hachette, 1981.

Le Goff, Jacques y Nora Pierre, editores (1974): Hacer la historia. Tomo I: Nuevos problemas, Barcelona, Laia, 1985.

Lezama Lima, José (1969): La expresión americana, Prólogo y edición crítica de Ildemar Chiampi, México, F.C.E., 1993. 
Lotman, Iuri (1969): La structure du texte artistique, París, Gallimard. (Ed. cast.: Estructura del texto artístico, Madrid, Fundamentos, 1988).

--- --- $\quad$ (1984): Semiósfera. Semiótica de la cultura y del texto, edición de Desiderio Navarro, Tomos I y II, Madrid, Cátedra, 1998.

Mignolo, Walter (1986): “Comprensión hermenéutica y comprensión teórica", en: Teoría del texto e interpretación de textos, México, UNAM.

Mukařovský, Ian (1936): "Función, norma y valor estéticos como hechos sociales", en: Escritos de estética y semiótica del arte, Barcelona, Gustavo Gili Editor, 1977.

Muschietti, Delfina (1989): "El sujeto como cuerpo en dos poetas de vanguardia (César Vallejo, Oliverio Girondo)”, en: Filología XXIII, 1, págs. 127-149.

Nietzsche, Friedrich (1873): Sobre verdad y mentira en sentido extramoral y otros fragmentos de filosofia del conocimiento, ed. de M. Garrido Giménez, Madrid, Tecnos, 2010.

--- --- (1887): La genealogía de la moral, ed. crítica Andrés Sánchez Pascual, Madrid, Alianza Editorial, 2000.

--- --- (1888): Crepúsculo de los ídolos, ed. crítica Andrés Sánchez Pascual, Madrid, Alianza Editorial, 2000.

--- (1873-1876): Segunda consideración intempestiva, Buenos Aires, Libros del Zorzal, 2006.

--- -- (1886). Más allá del bien y del mal. Madrid, EDAF, 1981.

Ong, Walter (1982): Oralidad y escritura. Tecnologías de la palabra, México, F.C.E., 1992.

Pérez Cortés, Sergio (2006): La travesía de la escritura. De la cultura oral a la cultura escrita, México, Taurus.

Rella, Franco (1992): El silencio y las palabras, Barcelona, Paidós.

Ricoeur, Paul (1965): Freud. Una interpretación de la cultura, México, Siglo XXI, 1990.

Rosa, Nicolás (1990): El arte del olvido, Buenos Aires, Puntosur.

--- --- (1997): Tratados sobre Néstor Perlongher, Buenos Aires, Ars.

Sánchez Pascual, Andrés (2000): "Introducción" a: Nietzsche, Friedrich: La genealogía de la moral, Madrid, Alianza.

Sarduy, Severo (1987). Ensayos generales sobre el Barroco. Bs.As., Fondo de Cultura Económica.

Aires, Sudamericana.

(1965): Escrito sobre un cuerpo. Ensayos de crítica, Buenos

Scavino, Dardo (1991): Nomadología. (Una lectura de Deleuze), Buenos Aires, Ediciones del fresno/l.

Shklovski, Viktor: (1917) "El arte como artificio", en: en: Todorov, T. (comp.): Teoría de la literatura de los formalistas rusos, México, Siglo XXI, 1987. 
Spinoza, Baruch: Ética demostrada según el orden geométrico, Introducción, trad. y notas de Vital Peña, Madrid, Editora Nacional, 1980.

Tinianov, Iuri (1927): "Sobre la evolución literaria", en: Todorov, T. (comp.): Teoría de la literatura de los formalistas rusos, México, Siglo XXI, 2004.

Todorov, Tzvetan (1968): "Los géneros literarios", en: Introducción a la literatura fantástica, Barcelona, Ed. Buenos Aires, 1982. Págs. 9-32.

Siglo XXI, 2004.

(1970a): Teoría de la literatura de los formalistas rusos, México,

--- --- (1970b): “Introducción", en: Lo verosímil, Revista Comunicaciones $\mathrm{N}^{\circ}$ 11, Buenos Aires, Ed. Tiempo Contemporáneo. Págs. 11-15.

--- --- (1970c): "Las categorías del relato literario", en: Barthes, Roland, y otros: Análisis estructural del relato, Revista Comunicaciones $\mathrm{N}^{\circ} 8$, Buenos Aires, Editorial Tiempo Contemporáneo. Págs. 155-192.

Touraine, Alain. Crítica de la modernidad, México, FCE, 1994.

Tozzi, Verónica (2003): “Introducción”, en: White, Hayden: El texto histórico como artefacto literario y otros escritos, Barcelona, Paidós. Págs. 9-42.

Vattimo, Gianni (1985). El fin de la modernidad, Barcelona, Gedisa, 1987.

------ (1989). La sociedad transparente. Barcelona, Paidós, 1994.

White, Hayden (1973): Metahistoria. La imaginación histórica en la Europa del siglo XIX, México, Fondo de Cultura Económica, 1992.

White, Hayden (1987): El contenido de la forma. Narrativa, discurso y representación histórica, Barcelona, Paidós, 1992.

White, Hayden (2003): El texto histórico como artefacto literario y otros escritos, Barcelona, Paidós.

Zumthor, Paul (1983): Introducción a la poesía oral, Madrid, Taurus, 1991.

Cátedra, 1990.

(1987): La letra y la voz. De la "literatura" medieval, Madrid, 